\title{
DESEMPENHO DE SISTEMAS DE DUPLA FILTRAÇÃO NO TRATAMENTO DE ÁGUA COM TURBIDEZ ELEVADA
}

\author{
Angela S. Di Bernardo \\ ORIENTADOR: Prof. Dr. J urandyr Povinelli
}

Tese apresentada à Escola de Engenharia de São Carlos, da Universidade de São Paulo, como parte dos requisitos para obtenção do título de Doutor em Hidráulica e Saneamento

São Carlos

2004 
Ficha catalográfica preparada pela Seção de Tratamento da Informação do Serviço de Biblioteca - EESC/USP

D544d

Di Bernardo, Angela S.

Desempenho de sistemas de dupla filtração no

tratamento de água com turbidez elevada / Angela S. Di Bernardo. - - São Carlos, 2004.

Tese (Doutorado) - - Escola de Engenharia de São Carlos-Universidade de São Paulo, 2004.

Área: Hidráulica e Saneamento

Orientador: Prof. Dr. Jurandyr Povinelli.

1. Filtração direta. 2. Dupla filtração.

3. Turbidez elevada. 4. Filtração ascendente.

5. Filtração descendente. I. Título. 


\section{FOLHA DE JULGAMENTO}

Candidata: Engenheira ANGELA SILVA DI BERNARDO

Tese defendida e julgada em 08-07-2904 perante a Comissão Julgadora:

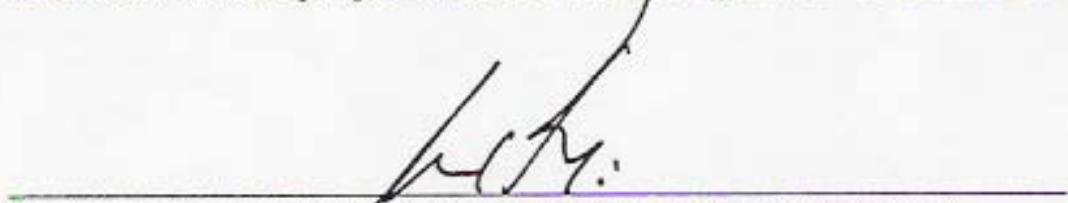

ApRovdsA

Prof. Titular JURAXTYR POVINELLI (Orientador)

(Escola de Engenharia de São Carlos/USP)
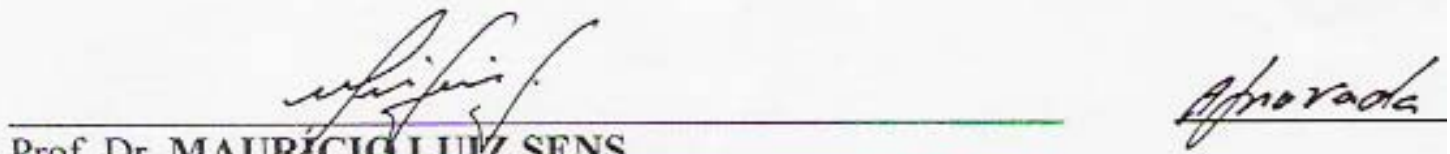

Prof. Dr. MAURICIO LUIZ SENS

(Universidade Federal de Sanfa Catarina/UFSC)

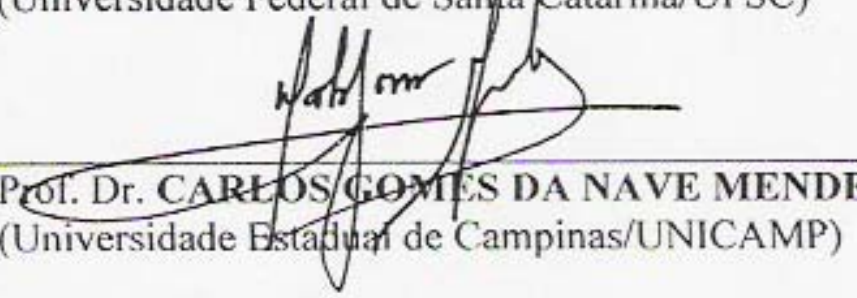

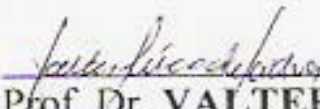

Prof. Dr. VALTER LÚCIO DE PÁDUA

Aprovadu

(Universidade Federal de Minas Gerais/UFMG)

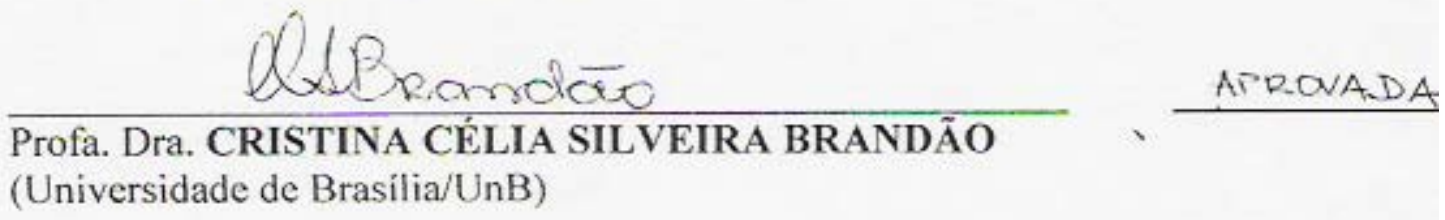

(Universidade de Brasilia/UnB)

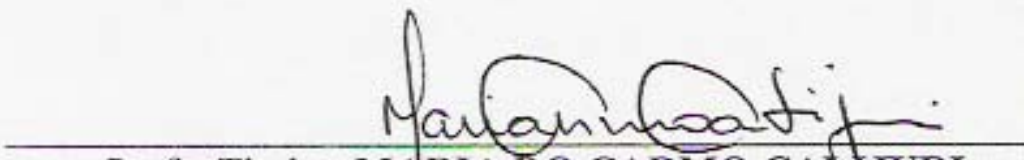

Profa. Titular MARIA DO CARMO CAAJJURI

Coordenadora do Programa de Pós-Graduação em

Engenharia (Hidráulica e Saneamento) e

Presidente da Comissão de Pós-Graduação 


\section{DEDICATÓRIA}

Ao meu filho, motivo de muita alegria, ao meu marido, que eu amo muito, e aos meus pais, que sempre me apoiaram em tudo. 


\section{AGRADECIMENTOS}

Ao Prof. Jurandyr Povinelli pela orientação.

Aos meus pais Luiz e Costancia, pelo incentivo e apoio durante a realização deste trabalho. Ao meu marido, Frederico, pelo amor e companheirismo.

Ao meu filho Henrique, pela alegria e inspiração para finalizar este trabalho.

Aos meus irmãos Bruno, Mario e Laura pelo apoio.

A minha sogra Marta pelo carinho.

Aos colegas Emília K. Kuroda e Alexandre Botari, pela colaboração na realização deste trabalho.

Aos Professores do Departamento de Hidráulica e Saneamento da Escola de Engenharia de São Carlos pelos ensinamentos adquiridos. Aos Funcionários deste departamento e, em especial, ao Francisco Bergamin pela montagem da Instalação Piloto.

À Fundação de Amparo à Pesquisa do Estado de São Paulo - FAPESP pela concessão de bolsa de doutorado (Proc. 00/00591-9).

Aos colegas e às amizades que me acompanharam nestes anos e a todos aqueles que direta ou indiretamente contribuíram para a realização deste trabalho. 
1. INTRODUÇÃO .................................................................................................. 1

2. OBJETIVOS ..................................................................................................... 5

3. REVISÃO DA LITERATURA....................................................................... 6

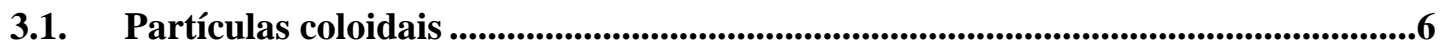

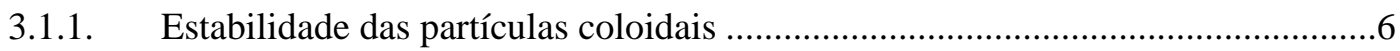

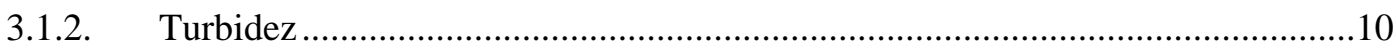

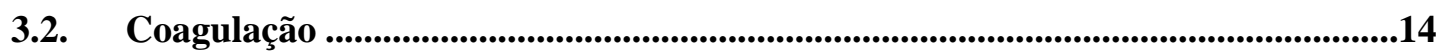

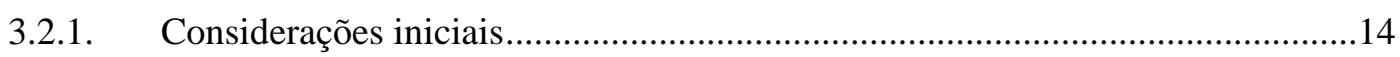

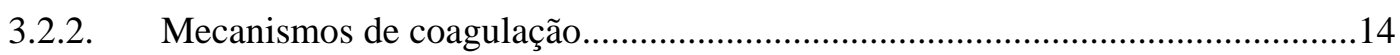

3.2.3. Coagulação com sulfato de alumínio para remoção de turbidez...........................21

3.2.4. Influência da coagulação na filtração direta ........................................................36

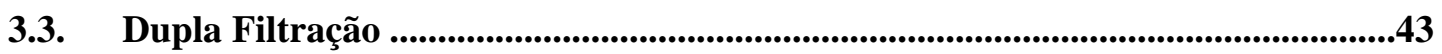

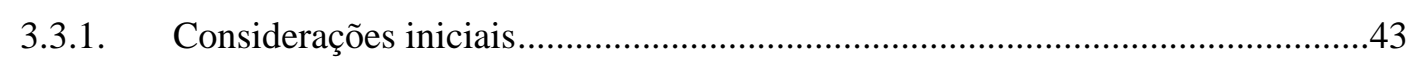

3.3.2. Dupla filtração para remoção de turbidez .........................................................46

3.4. Considerações finais sobre a revisão da literatura ..............................................54

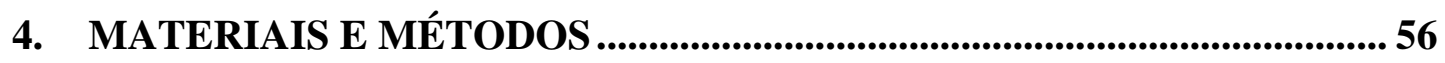

4.1. Fluxograma da metodologia...........................................................................56

4.2. Descrição geral da instalação piloto de dupla filtração ..........................................56

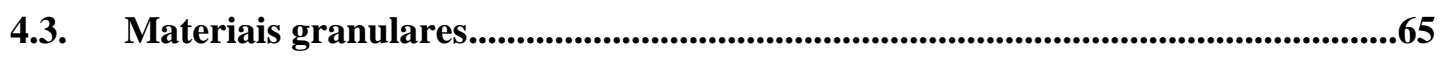

4.4. Preparação e caracterização da caulinita .............................................................68

4.4.1. Ensaio de sedimentação .................................................................................68

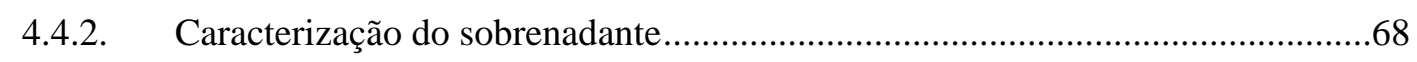




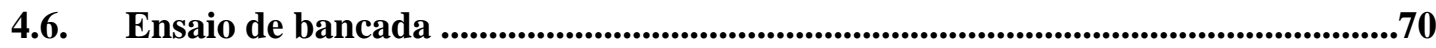

4.6.1. Série I: Condições de coagulação ........................................................................70

4.6.2. Série II: Verificação do tipo de areia dos FLAs.....................................................71

4.6.3. Série III: Verificação das condições de mistura rápida........................................72

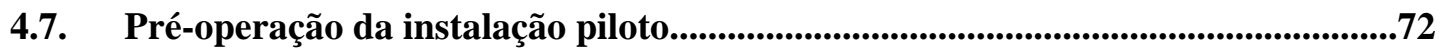

4.7.1. Verificação da composição do meio filtrante ......................................................73

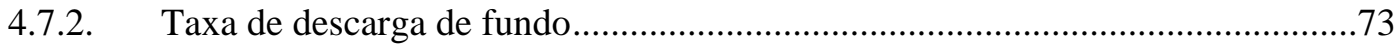

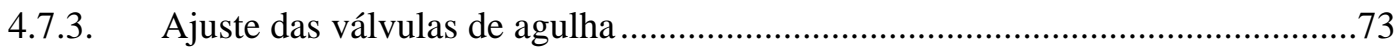

4.7.4. Comparação dos resultados obtidos com a perda de carga calculada pela equação de FAIR et al. (1968).............................................................................................74

4.8. Ensaios de Dupla Filtração _...................................................................................75

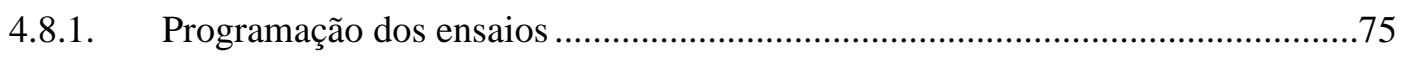

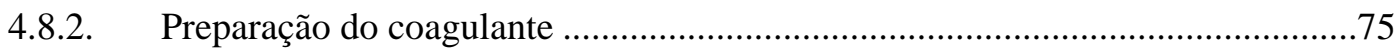

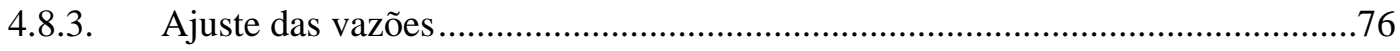

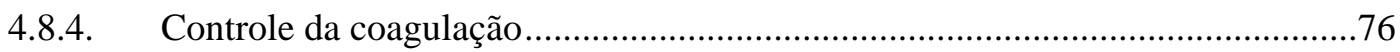

4.8.5. Parâmetros de controle e freqüência ......................................................................77

4.8.6. Encerramento de uma carreira de filtração .............................................................78

4.8.7. Execução de descarga de fundo intermediária....................................................78

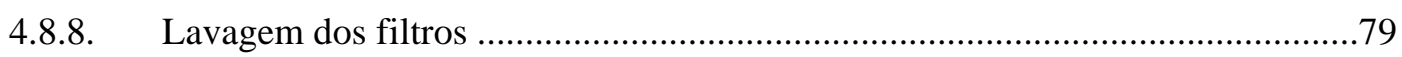

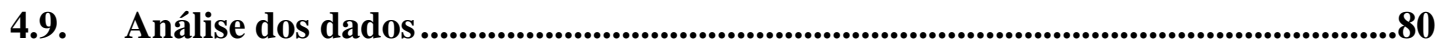

4.9.1. Correção da perda de carga em função da temperatura .........................................80

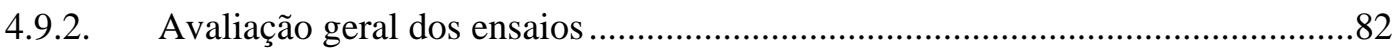

4.9.3. Avaliação da retenção de sólidos ao longo dos filtros ascendentes ......................84

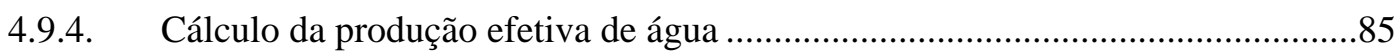

5. RESULTADOS E DISCUSSÃO..................................................................91

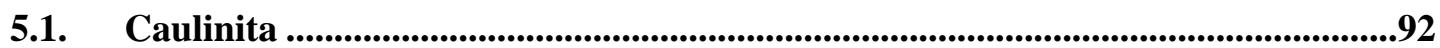

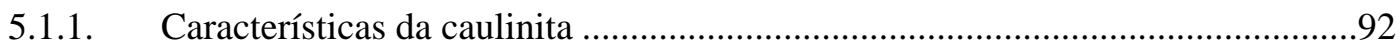

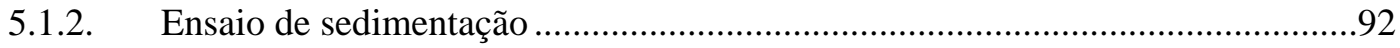

5.1.3. Ensaio de caracterização do sobrenadante da caulinita.......................................94 


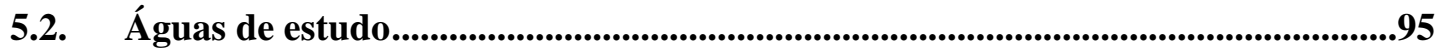

5.3. Ensaios de bancada.................................................................................................96

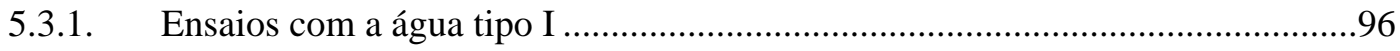

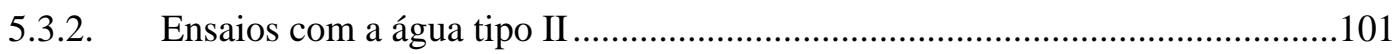

5.3.3. Resumo dos resultados obtidos nos ensaios de bancada ....................................104

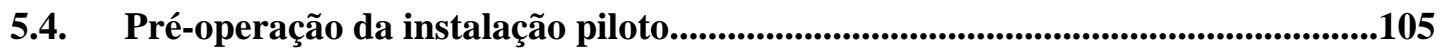

5.4.1. Verificação da composição do meio filtrante do filtro ascendente de areia grossa (sistema 1) e comparação com os valores de perda de carga calculados pela equação de

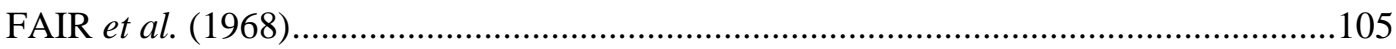

5.4.2. Verificação da composição do meio filtrante do filtro ascendente de pedregulho (sistema 2) e comparação com os valores de perda de carga calculados pela equação de

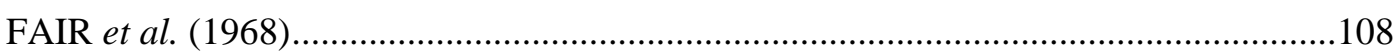

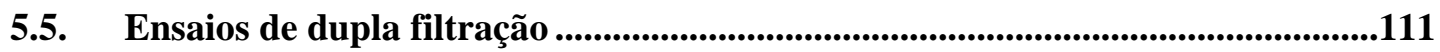

6. CONCLUSÕES E RECOMENDAÇÕES ................................................... 145

7. REFERÊNCIAS BIBLIOGRÁFICAS ...................................................... 275 


\section{LISTA DE FIGURAS}

Figura 3.1 - Estabilidade de partículas coloidais em meio aquoso Fonte: (FAUST \& ALY, 1998)

Figura 3.2 - Representação esquemática da dupla camada elétrica nas vizinhanças de uma interface sólido-líquido - Fonte: WILLIAMS (1994) ............................................................ Figura 3.3 - Configuração esquemática da dupla camada elétrica - Fonte: AWWA (1990)...9 Figura 3.4 - Distribuição de tamanhos de partículas na água - Fonte: AWWA (1990).........11 Figura 3.5 - Representação esquemática de uma partícula de argila - Fonte: OLPHEN (1977)

Figura 3.6 - Distribuição de tamanho dos grãos em material predominantemente argiloso Fonte: KURODA (2002)

Figura 3.7 - Efeito de íons de cargas contrárias no potencial zeta - Fonte: (FAUST \& ALY, 1998).....

Figura 3.8 - Coagulação de partículas de poliestireno-látex no mecanismo de compressão da dupla camada elétrica - Fonte: DI BERNARDO (2001).

Figura 3.9 - Curvas de turbidez residual em função da concentração molar de quatro tipos de coagulantes. Ensaio de coagulação, floculação e sedimentação - Fonte: O’MELIA (1978)..18 Figura 3.10 - Caminhos para a coagulação por adsorção-neutralização de carga e por varredura utilizando sulfato de alumínio - Fonte: AMIRTHARAJAH \& MILLS (1982).....20 Figura 3.11 - Diagrama de coagulação do sulfato de alumínio e sua relação com o potencial zeta - Fonte: ARMITHARAJAH \& MILLS (1982).

Figura 3.12 - Potencial zeta de uma suspensão de alumina em função do $\mathrm{pH}\left(\mathrm{t}=25^{0} \mathrm{C}\right)$ Fonte:YOKOSAWA (2001) .

Figura 3.13 - Potencial zeta de uma suspensão de alumina em função do pH para diferentes forças iônicas $\left(\mathrm{t}=25^{\circ} \mathrm{C}\right)$ - Fonte:YOKOSAWA (2001). 26

Figura 3.14 - Coagulação de águas sintéticas com sulfato de alumínio - Fonte: BLACK \& HANNAH (1961)

Figura 3.15 - Influência das condições da mistura rápida e do mecanismo de coagulação na remoção de turbidez por sedimentação - Fonte: AMIRTHARAJAH \& MILLS (1982).........30 Figura 3.16 - Turbidez remanescente em função da dosagem de sulfato de alumínio e do pH de coagulação (Água com turbidez elevada) - Fonte: MENDES (1989) .32 
Figura 3.17 - Diagrama de coagulação do alumínio - Mobilidade eletroforética em função da dosagem de sulfato de alumínio e do pH de coagulação (Água com turbidez elevada) - Fonte: MENDES (1989)

Figura 3.18 - Diagrama de coagulação do alumínio - Turbidez remanescente em função da dosagem de sulfato de alumínio e do pH - Fonte: MENDES (1989) ..

Figura 3.19 - Diagrama de coagulação de água natural utilizando sulfato de alumínio (mecanismo de varredura) - Fonte: MENDES (1989)

Figura 3.20 - Variação do potencial zeta em função da dosagem de sulfato de alumínio para dois valores constantes do pH de coagulação - Fonte: WILLIAMS (1965) .36

Figura 3.21 - Turbidez da água filtrada em função do pH para as dosagens de 5 e 8 mg/L de sulfato de alumínio - Fonte: AMIRTHARAJAH (1989).....

Figura 3.22 - Desempenho da FDHP em função da dosagem de coagulante Turbidez inicial $=200 \mathrm{uT}, \mathrm{pH}=8,1$, Comprimento do FDHP $=8 \mathrm{~m}$ e Taxa de filtração $=120$ $\mathrm{m}^{3} / \mathrm{m}^{2}$.d Adaptado de AHSAN et al. (1996a).

Figura 3.23 - Desempenho da FDHP em função do $\mathrm{pH}$ de coagulação Turbidez inicial $=200 \mathrm{uT}$, Dosagem de $\mathrm{Al}^{+3}=1 \mathrm{mg} / \mathrm{L}$, Comprimento do FDHP $=8 \mathrm{~m}$ e Taxa e filtração $=120 \mathrm{~m}^{3} / \mathrm{m}^{2} . \mathrm{d}$ - Adaptado de AHSAN et al. (1996a).

Figura 3.24 - Filtro de laboratório de areia

Figura 3.25 - Distribuição de ETAs operadas pelas CESB, por tipo de tecnologia - Fonte: DI BERNARDO et al. (2003)...

Figura 3.26 - Fluxogramas esquemáticos dos sistemas de filtração direta - Fonte: DI BERNARDO et al. (2003)...

Figura 3.27 - Simulação do pico de turbidez da água afluente a instalação piloto de dupla filtração - Fonte: KURODA (2002).

Figura 3.28 - Fotos das camadas do meio granular do FAP e detalhes da unidade de Dupla Filtração utilizada por KURODA (2002) - Fonte: KURODA (2002). .50

Figura 3.29 - Detalhes da unidade de Dupla Filtração utilizada por DE PAULA (2003) Fonte: DE PAULA (2003)... .54

Figura 4.1 - Fluxograma do trabalho experimental ................................................................57

Figura 4.2 - Caixa de homogeneização ……………...............................................................58

Figura 4.3 - Esquema geral da instalação piloto ....................................................................60

Figura 4.4 - Detalhe da entrada de água coagulada, aplicação de água na interface, distribuição do ar e água durante lavagem do filtro ascendente do sistema 1

Figura 4.5- Detalhe da entrada de água coagulada, e da distribuição do ar e água durante lavagem do filtro ascendente do sistema 2 
Figura 4.6 - Detalhe das caixas de nível constante e mistura rápida.

Figura 4.7 - Foto das caixas de nível constante e mistura rápida.

Figura 4.8 - Cortes da instalação piloto - Sistema 1 e Sistema 2 ............................................63

Figura 4.9 - Planta da instalação piloto - Sistema 1 e Sistema 2 2.............................................64

Figura 4.10 - Corte do filtro rápido descendente - Sistema 1..................................................64

Figura 4.11 - Curva granulométrica do meio filtrante do filtro ascendente do sistema 1 ......66

Figura 4.12 - Subcamadas do filtro ascendente de pedregulho - Detalhe do tamanho dos grãos

Figura 4.13 - Curva granulométrica do filtro descendente dos sistemas 1 e 2 .

Figura 4.14 - Equipamento de jarteste e kit de FLA.

Figura 4.15 - Régua graduada colocada no FLA para leitura de perda de carga durante os ensaios de bancada .72

Figura 4.16 - Detalhe da coleta de amostras ao longo dos filtros ascendentes dos sistemas 1 e 2

Figura 4.17 - Uso do FLA no início dos ensaios de dupla filtração para controle da coagulação .77

Figura 4.18 - Massa específica da água em função da temperatura .. .82

Figura 4.19 - Viscosidade absoluta da água em função da temperatura .82

Figura 4.20 - Gráfico típico 1 para avaliação geral dos ensaios de dupla filtração. .83

Figura 4.21 - Gráfico típico 2 para avaliação geral dos ensaios de dupla filtração

Figura 4.22 - Gráfico típico 1 para avaliação da retenção de sólidos ao longo dos filtros ascendentes

Figura 4.23 - Gráfico típico 2 para avaliação da retenção de sólidos ao longo dos filtros ascendentes .85

Figura 4.24 - Critérios de encerramento dos ensaios de dupla filtração .86 Figura 5.1 - Turbidez do sobrenadante e volume de sedimento resultante no ensaio de sedimentação com a caulinita .93

Figura 5.2 - Contagem de partículas das águas de estudo. .95 Figura 5.3 - Resultados de dosagem de coagulante, pH de coagulação e turbidez do filtrado obtidos nos ensaios de bancada de filtração direta para definição das condições de coagulação da água tipo I.

Figura 5.4 - Resultados obtidos nos ensaios de bancada de filtração direta com a água tipo I no diagrama de solubilidade do alumínio

Figura 5.5 - Turbidez da água filtrada em função do tempo de coleta na filtração e do tipo de areia do FLA utilizado - resultados com a água tipo I 
Figura 5.6 - Perda de carga em função do tempo de coleta na filtração e do tipo de areia do FLA utilizado - resultados com a água tipo I.

Figura 5.7 - Turbidez da água filtrada em função do tempo de mistura e do gradiente de velocidade médio na mistura rápida - resultados com a água tipo I.

Figura 5.8 - Resultados de dosagem de coagulante, pH de coagulação e turbidez do filtrado obtidos nos ensaios de bancada de filtração direta para definição das condições de coagulação da água tipo II

Figura 5.9 - Resultados obtidos nos ensaios de bancada de filtração direta com a água tipo II no diagrama de solubilidade do alumínio

Figura 5.10 - Turbidez da água filtrada em função do tempo de mistura e do gradiente de velocidade médio na mistura rápida - resultados com a água tipo II .104

Figura 5.11 - Perda de carga nas câmaras do filtro ascendente de areia grossa durante o ensaio de pré-operação com taxa de filtração de $115 \mathrm{~m}^{3} / \mathrm{m}^{2}$. d. 105

Figura 5.12 - Perda de carga nas câmaras do filtro ascendente de areia grossa durante o ensaio de pré-operação com taxa de filtração de $172 \mathrm{~m}^{3} / \mathrm{m}^{2}$. d. 106

Figura 5.13 - Perda de carga nas câmaras do filtro ascendente de areia grossa durante o ensaio de pré-operação com taxa de filtração de $240 \mathrm{~m}^{3} / \mathrm{m}^{2}$.d. 106

Figura 5.14 - Perda de carga nas câmaras do filtro ascendente de pedregulho durante o ensaio de pré-operação com taxa de filtração de $120 \mathrm{~m}^{3} / \mathrm{m}^{2}$.d.

Figura 5.15 - Perda de carga nas câmaras do filtro ascendente de pedregulho durante o ensaio de pré-operação com taxa de filtração de $175 \mathrm{~m}^{3} / \mathrm{m}^{2}$. d.

Figura 5.16 - Perda de carga nas câmaras do filtro ascendente de pedregulho durante o ensaio de pré-operação com taxa de filtração de $220 \mathrm{~m}^{3} / \mathrm{m}^{2}$.d.

Figura 5.17 - Detalhe do FRD no início do transpasse - 17 h após o início do ensaio 2 .....116 Figura 5.18 - Detalhe da camada suporte do FAAG-C1 após 10 h do início do ensaio 2 ....117 Figura 5.19 - Arraste de flocos e formação de manta no topo do meio filtrante do FAAG-C1 após 14 h do início do ensaio 2

Figura 5.20 - Turbidímetros de escoamento contínuo - Início do transpasse no FAAG após 11 h do início do ensaio 2

Figura 5.21 - Arraste de flocos e formação de manta no topo do meio filtrante do FAAG-C1 após 20 h do início do ensaio $3 .$.

Figura 5.22- Desprendimento de flocos após execução da 5 a DFI na câmara 1 do FAAG ..119 Figura 5.23- Turbidímetros de escoamento contínuo - Início do transpasse no FAAG após 19,5 h do início do ensaio 4 120

Figura 5.24 - Início do transpasse no FAAG-C1 após 19,5 h do início do ensaio 4. .121 
Figura 5.25 - Arraste de flocos e formação de manta no topo do meio filtrante do FAAG-C1 após 27 h do início do ensaio 4

Figura 5.26 - Início do transpasse no FAAG-C1 após 10,8 h do início do ensaio 6 - Arraste gradual de flocos

Figura 5.27 - Arraste de flocos e formação de manta no topo do meio filtrante do FAAG-C1 após 15 h do início do ensaio 6

Figura 5.28 - Detalhe das câmaras 1 e 2 do FAAG após 13,5 h do início do ensaio 6.........123

Figura 5.29 - Detalhe da camada suporte do FAAG-C2 após 15 h do início do ensaio 6 ....124

Figura 5.30 - Manto de lodo no FAAG após 22 h do início do ensaio 8. .126

Figura 5.31 - Detalhe do manto de lodo no FAAG-C1 após 27 h do início do ensaio 8 ......126

Figura 5.32 - Manto de lodo no FAAG após 27 h do início do ensaio 8 . 127

Figura 5.33 - Camada suporte do FAAG-C1 antes e depois da execução da 5 ${ }^{\text {a }}$ DFI.............128

Figura 5.34 - Detalhe do FAAG após 25 h do início do ensaio 9 ...........................................129

Figura 5.35- Manto de lodo no FAP-C1 após 21 h do início do ensaio 10...........................130

Figura 5.36- Manto de lodo no FAP-C1 no final do ensaio 10 (34,5 h) ..............................130

Figura 5.37 - Detalhe da subcamada 1 do FAP-C1 após 2 h e 24 h do início do ensaio 10.131

Figura 5.38 - Subcamada 1 do FAP-C1 antes e após a execução da $3^{\mathrm{a}}$ DFI..........................132

Figura 5.39 - Detalhe da subcamada 1 do FAP-C1 antes e após a execução da $3^{\text {a }}$ DFI .......133

Figura 5.40 - Início do transpasse no FAP-C1 após 4 h do início do ensaio 12 de dupla filtração

Figura 5.41 - Arraste de flocos no FAP-C1 após 10 h do início do ensaio 12 de dupla filtração 134

Figura 5.42 - Manto de lodo no FAP-C2 após 10 h do início do ensaio 14 de dupla filtração 136

Figura 5.43 - Detalhe da subcamada 1 do FAP-C1 antes e após a execução da $5{ }^{\text {a }}$ DFI ........138

Figura 5.44 - Lavagem simultânea com ar e água no FAAG-C1 ………………................142

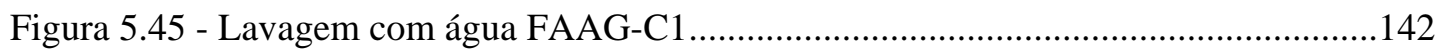

Figura 5.46- Descarga de fundo final no FAP-C1 após término do ensaio 14 de dupla filtração 143

Figura 5.47 - Lavagem com água no FRD após término do ensaio de dupla filtração .144 


\section{LISTA DE TABELAS}

Tabela 1.1 - Parâmetros de qualidade da água bruta, de projeto e operação recomendados para o emprego das tecnologias de FDA, FAAG - FRD e FAP - FRD, Fonte: Adaptada de DI BERNARDO \& ISAAC (2001) e DI BERNARDO et al. (2003).......4 Tabela 3.1 - Características principais das argilas - Fonte: OLPHEN (1977) ........................12 Tabela 3.2 - Características de partículas de poliestireno-látex com grupo sulfato - Fonte: DI BERNARDO (2001).

Tabela 3.3 - Valores do potencial zeta das amostras de água bruta de diferentes mananciais e após coagulação com 40 mg/L de sulfato de alumínio - Fonte: WILLIAMS (1965)

Tabela 3.4 - Desempenho da FDHP em função da dosagem de coagulante Turbidez inicial $=200 \mathrm{uT}, \mathrm{pH}=8,1$, Comprimento do FDHP $=8 \mathrm{~m}$ e Taxa de filtração $=120$ $\mathrm{m}^{3} / \mathrm{m}^{2}$.d Adaptada de AHSAN et al. (1996a) 39

Tabela 3.5 - Desempenho da FDHP em função do $\mathrm{pH}$ de coagulação Turbidez inicial $=200 \mathrm{uT}$, Dosagem $\mathrm{Al}^{+3}=1,0 \mathrm{mg} / \mathrm{L}$; Comprimento do FDHP $=8 \mathrm{~m}$ e Taxa de filtração $=120 \mathrm{~m}^{3} / \mathrm{m}^{2}$.d - Adaptada de AHSAN et al. (1996a).

Tabela 3.6 - Resumo dos resultados de filtração em filtro de laboratório com areia de diferentes granulometrias - Fonte: (DI BERNARDO et al., 2002a).

Tabela 3.7 - Características do material granular utilizado por KURODA (2002) - Fonte: Kuroda (2002)

Tabela 3.8 - Características do meio granular utilizado por DE PAULA (2003) - Fonte: DE PAULA (2003) .53

Tabela 4.1 - Meio filtrante e camada suporte do filtro ascendente do sistema 1 .65

Tabela 4.2 - Meio filtrante do filtro ascendente do sistema 2 e meio filtrante utilizado por KURODA (2002)

Tabela 4.3 - Equipamentos utilizados na caracterização das águas de estudo .69

Tabela 4.4 - Características dos ensaios de dupla filtração .75

Tabela 4.5 - Massa específica e viscosidade absoluta da água em função da temperatura ....81

Tabela 5.1 - Características da caulinita.

Tabela 5.2 - Turbidez do sobrenadante e volume de sedimento resultante no ensaio de sedimentação com a caulinita

Tabela 5.3 - Volumes dos sobrenadantes da caulinita para preparação das águas de estudo em diferentes condições 
Tabela 5.4 - Contagem de partículas das águas de estudo .95

Tabela 5.5 - Características das águas tipo I e tipo II ..... . .96

Tabela 5.6 - Parâmetros determinados nos ensaios de bancada. 104

Tabela 5.7 - Comparação dos valores de perda de carga calculados e medidos nos filtros ascendentes de areia grossa. 107

Tabela 5.8 - Comparação dos valores de perda de carga calculados e medidos nos filtros ascendentes de pedregulho 111

Tabela 5.9 - Produção efetiva de água filtrada nos ensaios de dupla filtração. 114

Tabela 5.10 - Resumo dos resultados dos ensaios de dupla filtração no sistema 1 .139

Tabela 5.11 - Resumo dos resultados dos ensaios de dupla filtração no sistema 2 .140 


\section{LISTA DE ABREVIATURAS E SIGLAS}

\begin{tabular}{|c|c|}
\hline AF & - água filtrada \\
\hline APF & - água pré-filtrada \\
\hline CC & - camada compacta \\
\hline CD & - camada difusa \\
\hline CESB & - companhias estaduais de saneamento básico \\
\hline DCE & - dupla camada elétrica \\
\hline DFF & - descarga de fundo final \\
\hline DFI & - descarga de fundo intermediária \\
\hline DLVO & - Derjaguin, Landau, Verwey e Overbeek \\
\hline ETA & - estação de tratamento de água \\
\hline ETASC & - estação de tratamento de água de São Carlos \\
\hline FA & - filtro ascendente \\
\hline FD & - filtração direta \\
\hline FDA & - filtração direta ascendente \\
\hline FAAG & - filtro ascendente de areia grossa \\
\hline FAAG-C1 & - câmara de filtração 1 do filtro ascendente de areia grossa \\
\hline FAAG-C2 & - câmara de filtração 2 do filtro ascendente de areia grossa \\
\hline FAP & - filtro ascendente de pedregulho \\
\hline FAP-C1 & - câmara de filtração 1 do filtro ascendente de pedregulho \\
\hline FAP-C2 & - câmara de filtração 2 do filtro ascendente de pedregulho \\
\hline FDHP & - filtração direta em pedregulho com escoamento horizontal \\
\hline FLA & - filtro de laboratório de areia \\
\hline FLP & - filtro de laboratório de papel \\
\hline FRD & - filtro rápido descendente \\
\hline PFHD & - pré-filtração em pedregulho com escoamento horizontal \\
\hline PROSAB & - programa de pesquisa em saneamento básico \\
\hline PIZ & - ponto isoelétrico \\
\hline PCZ & - ponto de carga zero \\
\hline ТВ & - turbidímetro de bancada \\
\hline TEC & - turbidímetro de escoamento contínuo \\
\hline
\end{tabular}




\section{LISTA DE SÍMBOLOS}

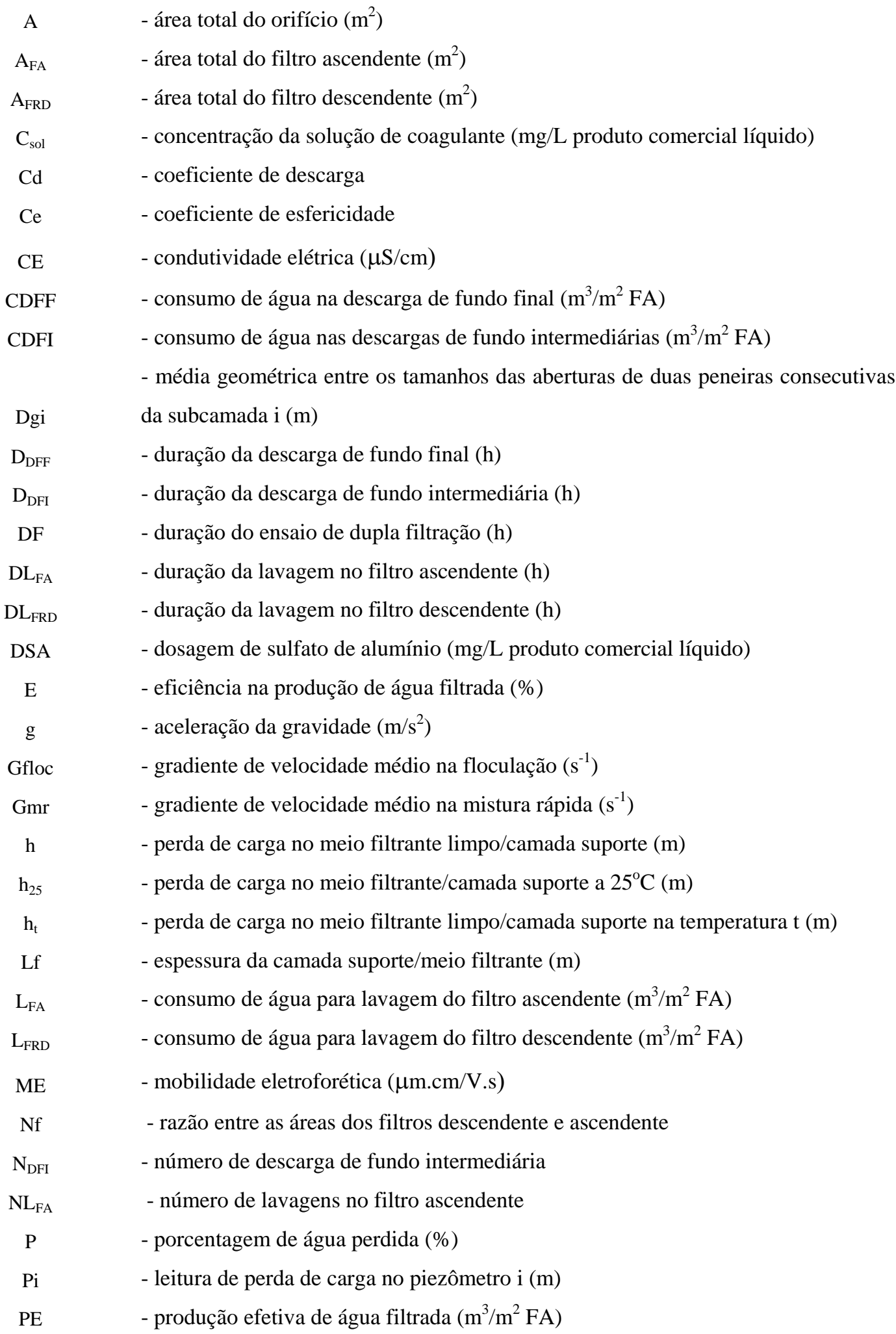




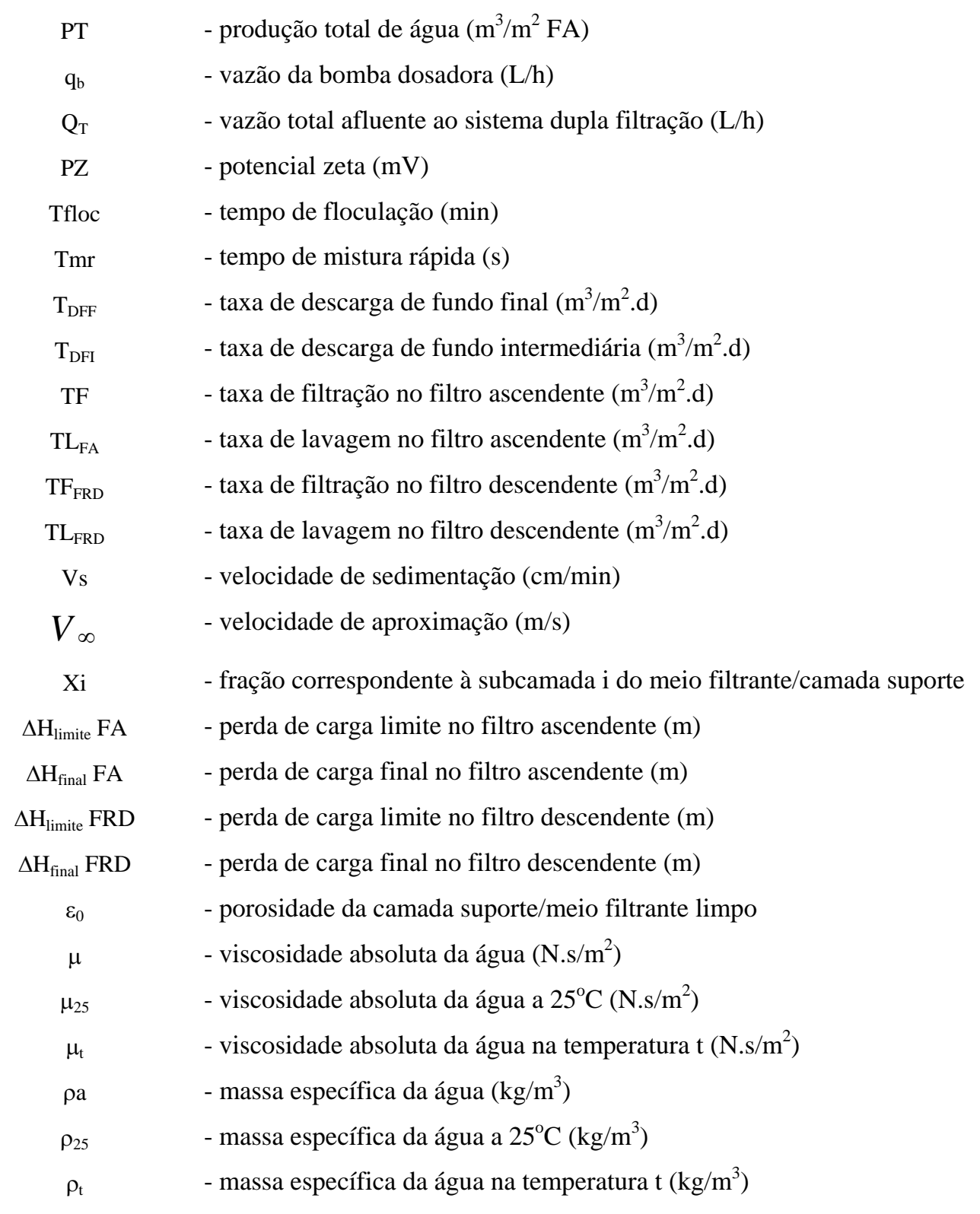




\section{RESUMO}

DI BERNARDO, A. S. (2004). Desempenho de Sistemas de Dupla Filtração no Tratamento de Água com Turbidez Elevada. São Carlos, 2004. 281p. Tese (Doutorado) - Escola de Engenharia de São Carlos, Universidade de São Paulo.

A dupla filtração pode ser considerada como uma das mais promissoras tecnologias para tratamento de água, estimando-se que grande parte das necessidades de tratamento poderiam ser satisfeitas com o uso desta tecnologia. Alguns aspectos ainda não devidamente esclarecidos até o presente sobre esta tecnologia estão relacionados ao tratamento de água com turbidez elevada. Com a montagem e operação de uma instalação piloto, constituída de dois sistemas de dupla filtração (sistema 1: filtro ascendente de areia grossa e filtro descendente de areia e sistema 2: filtro ascendente de pedregulho e filtro descendente de areia), foi realizada uma investigação experimental com águas de estudo preparadas com caulinita (água tipo I com turbidez em torno de 100 uT e água tipo II com turbidez em torno de 300 uT). A coagulação foi realizada com o sulfato de alumínio, sem o uso de alcalinizante ou de acidificante, para que resultasse potencial zeta próximo de zero. A operação de ambos os sistemas foi efetuada com e sem descargas de fundo intermediárias nos filtros ascendentes, e foram variadas as taxas de filtração em ambos os filtros (de 120 a 240 $\mathrm{m}^{3} / \mathrm{m}^{2} . \mathrm{d}$ nos filtros ascendentes e de 180 a $300 \mathrm{~m}^{3} / \mathrm{m}^{2} . \mathrm{d}$ nos filtros descendentes). Concluiuse principalmente que os dois sistemas foram capazes de produzir água filtrada com turbidez consistentemente menor que 0,5 uT e que a produção efetiva de água depende da turbidez da água de estudo, das taxas de filtração, da execução das descargas de fundo intermediárias e da carga hidráulica disponível para retenção de sólidos.

Palavras-chave: filtração direta, dupla filtração, turbidez elevada, filtração ascendente, filtração descendente. 


\begin{abstract}
DI BERNARDO, A. S. (2004). Evaluation of double filtration systems for high turbidity water treatment. São Carlos, 2004. 281p. Tese (Doutorado) - Escola de Engenharia de São Carlos, Universidade de São Paulo.
\end{abstract}

Double filtration may be considered one of the most important technologies for water treatment. It has been estimated that most of water treatment can be efficiently achieved with the use of this technology, although some design and operational aspects related to the high turbidity of the influent water have not been fully studied until the present time.

A pilot plant was built comprising two double filtration systems (system 1 with an upflow coarse sand filter followed by a downflow fine sand filter; system 2 with an upflow gravel filter followed by a downflow filter identical to that used in system 1). The experimental investigation was carried out using influent waters prepared with kaolin (water type I with turbidity of approximately 100 NTU and water type II with turbidity of approximately $300 \mathrm{NTU}$ ). Coagulation was accomplished by using aluminum sulfate (no acid or alkaline products) so that the zeta potential resulted approximately zero. The operation of both systems was carried out with and without intermediate down flushes during the runs. Filtration rates in the filters of both systems varied from 120 to $240 \mathrm{~m}^{3} / \mathrm{m}^{2} . \mathrm{d}$ in the upflow filters and from 180 to $300 \mathrm{~m}^{3} / \mathrm{m}^{2}$.d in downflow filters. It was mainly concluded that both systems resulted capable to produce filtered water with turbidity consistently lower than $0.5 \mathrm{NTU}$ and that the net production was related to the influent water turbidity, filtration rates, execution of intermediate down flushes and the hydraulic head provided for solids retention in both filter of each double filtration system.

Keywords: direct filtration, double filtration, high turbidity, upflow filtration, downflow filtration. 


\section{INTRODUÇÃO}

A filtração direta pode ser considerada como uma das principais tecnologias de tratamento de água para abastecimento público, sendo utilizada com sucesso em diversos países, inclusive no Brasil. De acordo com DI BERNARDO et al. (2003), estima-se que entre 300 e 350 instalações desse tipo estejam em funcionamento no país. Essa condição foi conquistada a partir do aperfeiçoamento constante da tecnologia desde as suas primeiras utilizações no século passado.

A filtração direta ascendente destaca-se por: a) possibilitar a filtração no sentido do maior grão para o menor, resultando em menores valores de perda de carga durante a filtração devido à remoção de quantidade substancial de impurezas na porção do meio filtrante de maior granulometria; como conseqüência, há um aumento da duração da carreira de filtração, além de permitir a utilização da altura total do meio filtrante para retenção de impurezas (ação de profundidade); b) empregar menor quantidade de coagulante por $\mathrm{m}^{3}$ de água tratada quando comparado com estações de tratamento de água (ETAs) de ciclo completo, com coagulação, floculação, sedimentação ou flotação e filtração descendente, pois como a floculação ocorre na camada suporte, onde fica retida grande parte das impurezas, não há necessidade da formação prévia de flocos grandes e densos; c) requerer menores áreas e custo para implantação da estação pela eliminação das unidades de floculação e decantação; d) resultar em custos de operação e manutenção significativamente menores quando comparados ao de uma instalação na qual são usadas a coagulação, floculação, decantação e filtração, devido à redução do consumo de energia e da produção de lodo (DI BERNARDO et al., 2003).

Apesar das vantagens apresentadas, a filtração direta ascendente possui limitações relativas à qualidade microbiológica e físico-química da água bruta, especificamente para valores de turbidez, cor verdadeira ou concentração algal temporariamente elevados, sendo neste caso recomendado o tratamento complementar com filtro rápido descendente, compondo assim o sistema de dupla filtração. Além de dispor das vantagens relacionadas à filtração direta ascendente, a dupla filtração permite o tratamento de água de pior qualidade, possibilita o uso de taxas de filtração mais elevadas, oferece maior segurança com relação às variações bruscas de qualidade da água bruta, apresenta maior remoção global de microrganismos e pode dispensar o descarte de água pré-filtrada no início da carreira de filtração. 
AZEVEDO NETTO (1973) publicou no Brasil os principais parâmetros de projeto da filtração direta ascendente baseando-se, principalmente, na experiência soviética e inglesa. Posteriormente, diversos trabalhos de pesquisa, de mestrado e de doutorado foram realizados na Escola de Engenharia de São Carlos - USP, destacando-se (em ordem cronológica): MENDES (1985) Estudo das influências das dosagens de produtos químicos na filtração direta ascendente (Mestrado); PATERNIANI (1986) Estudo da influência de descarga de fundo na eficiência da remoção de microrganismos em sistemas de filtração direta ascendente (Mestrado); TEIXEIRA (1986) Influência das características da camada suporte e da areia na eficiência da filtração direta ascendente (Mestrado); FERNANDES (1987) Influência das características da camada suporte e dos métodos de descargas de fundo intermediárias no desempenho de sistemas de filtração direta ascendente.(Mestrado); CRUZ VELEZ (1993) Filtração direta ascendente com alta taxa (Mestrado); LARA PINTO (1994) Influência das descargas de fundo intermediárias na filtração direta ascendente de alta taxa (Mestrado); CASTILLA MIRANDA (1997) Influência da mistura dos grãos de areia no desempenho da filtração direta ascendente (Mestrado); ISAAC (1997) Influência da disposição inicial dos grãos de areia na eficiência da filtração direta ascendente (Doutorado); MEGDA (1999) Filtração direta ascendente em pedregulho como prétratamento à filtração rápida descendente (Mestrado); GUSMÃO (2001) Utilização da filtração direta ascendente como pré-tratamento para o tratamento de água de abastecimento (Doutorado); SALDANHA (2002) Avaliação do desempenho de uma estação de tratamento de água com sistema de dupla filtração, em escala real (Mestrado); KURODA (2002) Avaliação da Filtração Direta Ascendente em Pedregulho como Prétratamento em sistemas de Dupla Filtração (Mestrado); DE PAULA (2003) Avaliação da Dupla Filtração para Tratamento de Água de Superficial utilizando Filtro Ascendente de Areia Grossa (Mestrado) e BENINI (2003) Remoção de substâncias húmicas na Dupla Filtração com Filtro Ascendente de Pedregulho (Mestrado).

Na Tabela 1.1 são apresentados os valores limites dos parâmetros de qualidade da água bruta e de projeto e operação, recomendados para o emprego das tecnologias de filtração direta ascendente (FDA) e os sistemas de dupla filtração compostos por filtração ascendente em areia grossa seguida da filtração rápida descendente (FAAG - FRD) e filtração ascendente em pedregulho seguida da filtração rápida descendente (FAP - FRD), segundo resultados de pesquisas realizadas nos últimos 30 anos na Escola de Engenharia de São Carlos - USP.

Apesar dos valores máximos de turbidez recomendados para FAAG - FRD e FAP FRD por DI BERNARDO \& ISAAC (2001) e DI BERNARDO et al. (2003) - células em 
destaque na Tabela 1.1, resultados de trabalhos recentes, KURODA (2002) e DE PAULA (2003), indicam o potencial do uso da dupla filtração no tratamento de água com turbidez mais elevada que os limites apresentados.

Os profissionais que se dedicam a pesquisas relacionadas ao tratamento de água para abastecimento público estão sempre almejando o aperfeiçoamento dos processos e operações unitárias existentes ou o desenvolvimento de novas tecnologias, visando reduzir custos e aumentar a eficiência do tratamento. O objetivo primordial é assegurar a potabilidade da água distribuída à população. Contudo, é importante buscar alternativas de baixo custo que atendam a esse objetivo para viabilizar a universalização do acesso de água em quantidade e com a qualidade necessária para satisfazer os fins a que se destina. Neste sentido, DI BERNARDO et al. (2003) publicaram um livro de tratamento de água para abastecimento por filtração direta com base em pesquisas da rede PROSAB (Programa de Pesquisas em Saneamento Básico, tema 1, edital 3) e demais trabalhos citados anteriormente. Os autores destacaram o uso da dupla filtração como uma das mais promissoras tecnologias para tratamento de água, estimando-se que grande parte das necessidades de tratamento poderiam ser satisfeitas com o uso desta tecnologia.

Dentre alguns aspectos ainda não devidamente esclarecidos até o presente, destacam-se aqueles relacionados ao tratamento de água com turbidez elevada em sistemas de dupla filtração: a) qual o valor máximo de turbidez da água bruta recomendado? b) quais os valores máximos recomendados de taxas de filtração nos filtros ascendente e descendente para otimização do sistema? c) qual é a granulometria do filtro ascendente mais adequada? d) qual a carga hidráulica que deve ser prevista e o método de operação dos filtros ascendentes (com ou sem descargas de fundo intermediárias) que otimizam a dupla filtração no tratamento de água com turbidez elevada? Neste sentido, foi proposto o presente trabalho para avaliação de uma instalação piloto constituída de dois sistemas de dupla filtração (sistema 1: filtro ascendente de areia grossa e filtro descendente de areia e sistema 2: filtro ascendente de pedregulho e filtro descendente de areia), no tratamento de água com turbidez elevada (valores em torno de $100 \mathrm{uT}$ e $300 \mathrm{uT}$ ). 
Tabela 1.1 - Parâmetros de qualidade da água bruta, de projeto e operação recomendados para o emprego das tecnologias de FDA, FAAG - FRD e FAP - FRD,

Fonte: Adaptada de DI BERNARDO \& ISAAC (2001) e DI BERNARDO et al. (2003)

\begin{tabular}{|c|c|c|c|c|}
\hline \multicolumn{2}{|c|}{ Parâmetros } & FDA & FAAG - FRD & FAP - FRD \\
\hline \multirow{3}{*}{ Turbidez (uT) } & $90 \%$ do tempo $\leq$ & 25 & 50 & 100 \\
\hline & $95 \%$ do tempo $\leq$ & 50 & 100 & 150 \\
\hline & $100 \%$ do tempo $\leq$ & 100 & 150 & 200 \\
\hline \multirow[t]{3}{*}{ Cor verdadeira (uH) } & $90 \%$ do tempo $\leq$ & 20 & 50 & 100 \\
\hline & $95 \%$ do tempo $\leq$ & 50 & 100 & 150 \\
\hline & $100 \%$ do tempo $\leq$ & 100 & 150 & 200 \\
\hline \multicolumn{2}{|c|}{$\begin{array}{c}\mathrm{DBO}_{5} \\
(\mathrm{mg} / \mathrm{L})\end{array}$} & 5 & 10 & 10 \\
\hline \multicolumn{2}{|c|}{$\begin{array}{c}\text { COT } \\
(\mathrm{mg} / \mathrm{L})\end{array}$} & 2 & 5 & 5 \\
\hline \multicolumn{2}{|c|}{$\begin{array}{l}\text { Concentração de algas } \\
\text { (UPA/mL) }\end{array}$} & 500 & 2000 & 2500 \\
\hline \multicolumn{2}{|c|}{$\begin{array}{c}\text { E.Coli } \\
(\mathrm{NMP} / 100 \mathrm{~mL})\end{array}$} & 1000 & 5000 & 5000 \\
\hline \multicolumn{2}{|c|}{$\begin{array}{l}\text { Coliformes totais } \\
(\mathrm{NMP} / 100 \mathrm{~mL})\end{array}$} & 5000 & 20000 & 20000 \\
\hline \multicolumn{2}{|c|}{$\begin{array}{l}\text { Taxa filtração ascendente } \\
\qquad\left(\mathrm{m}^{3} / \mathrm{m}^{2} . \mathrm{d}\right)\end{array}$} & 120 a 240 & 120 a 240 & 24 a 144 \\
\hline \multicolumn{2}{|c|}{$\begin{array}{l}\text { Taxa filtração descendente } \\
\qquad\left(\mathrm{m}^{3} / \mathrm{m}^{2} \cdot \mathrm{d}\right)\end{array}$} & - & 200 a 400 & 200 a 400 \\
\hline \multicolumn{2}{|c|}{$\begin{array}{l}\text { Número de descargas de fundo intermediárias no } \\
\text { filtro ascendente durante a carreira }\end{array}$} & $\geq 1$ & $\geq 4$ & $\geq 4$ \\
\hline \multicolumn{2}{|c|}{$\begin{array}{l}\text { Taxa de aplicação de água na interface pedregulho- } \\
\text { areia durante a descarga }\left(\mathrm{m}^{3} / \mathrm{m}^{2} . \mathrm{d}\right)\end{array}$} & $\geq 600$ & $\geq 600$ & - \\
\hline
\end{tabular}




\section{OBJETIVOS}

A montagem e operação de uma instalação piloto, constituída de dois sistemas de dupla filtração (sistema 1: filtro ascendente de areia grossa e filtro descendente de areia e sistema 2: filtro ascendente de pedregulho e filtro descendente de areia), com o fim de avaliar o seu desempenho para o tratamento de duas águas de estudo (água tipo I com turbidez em torno de 100 uT e água tipo II com turbidez em torno de 300 uT), constitui o objetivo geral do presente trabalho.

Os objetivos específicos foram:

- avaliar a eficiência dos dois sistemas em termos de remoção de turbidez das águas filtrada e pré-fitrada, duração da carreira e produção efetiva de água filtrada, para diferentes taxas de filtração nos filtros ascendente e descendente, com e sem a execução de descargas de fundo intermediárias nos filtros ascendentes;

- avaliar a retenção de sólidos ao longo dos filtros ascendentes de areia grossa e de pedregulho. 


\section{REVISÃO DA LITERATURA}

Este capítulo contempla os fundamentos envolvidos e a revisão dos estudos realizados sobre o tema proposto. Foram abordados diferentes assuntos, quais sejam: propriedades das partículas coloidais, mecanismos e influência da coagulação na filtração direta e apresentação e discussão dos principais trabalhos realizados sobre a Dupla Filtração.

\subsection{Partículas coloidais}

\subsubsection{Estabilidade das partículas coloidais}

Em tratamento de água, é comum referir-se aos colóides como hidrofílicos quando os mesmos apresentam afinidade com a água e hidrofóbicos quando estes repelem a água. Os colóides hidrofílicos são estabilizados em meio aquoso por meio da formação de uma camada de moléculas de água orientadas ao redor da partícula. Exemplo típico de um sistema coloidal hidrofílico é o da cola em contato com a água, com formação instantânea de uma “solução coloidal”. Os colóides hidrofóbicos são estabilizados por repulsão eletrostática entre as partículas; estas forças de repulsão são decorrentes dos íons presentes no sistema que são atraídos à superfície da partícula (FAUST \& ALY, 1998). Na Figura 3.1 são mostradas as principais forças envolvidas na estabilização dos colóides em meio aquoso.

São duas as formas de estabilidade das partículas: estabilidade eletrostática e estabilidade estérica. Para cada condição de estabilidade são considerados dois aspectos: estrutura da interface sólido-líquido e forças entre duas interfaces quando próximas entre si.

Segundo FAUST \& ALY (1998), os colóides são estáveis em sistemas aquosos devido a sua capacidade de hidratação ou devido à carga eletrostática em sua superfície. Ambos fenômenos dependem essencialmente da estrutura química e da composição da superfície da partícula na interface com a água.

A maior parte das partículas possui superfície carregada eletricamente, usualmente negativa e decorrente de três fenômenos (estabilidade eletrostática): a) Grupos presentes na superfície sólida podem, ao reagir com a água, receber ou doar prótons; b) Grupos superficiais podem reagir na água com outros solutos além de prótons; c) Imperfeições na estrutura da partícula (substituição isomórfica) são responsáveis por parcela substancial da carga das argilas minerais; tipicamente, plaquetas de sílica tetraédrica são cruzadas por plaquetas de alumina octaédrica de modo que, se um átomo de silício é substituído por um de 
alumínio durante a formação da plaqueta, resulta carga superficial negativa (DI BERNARDO, 2003).

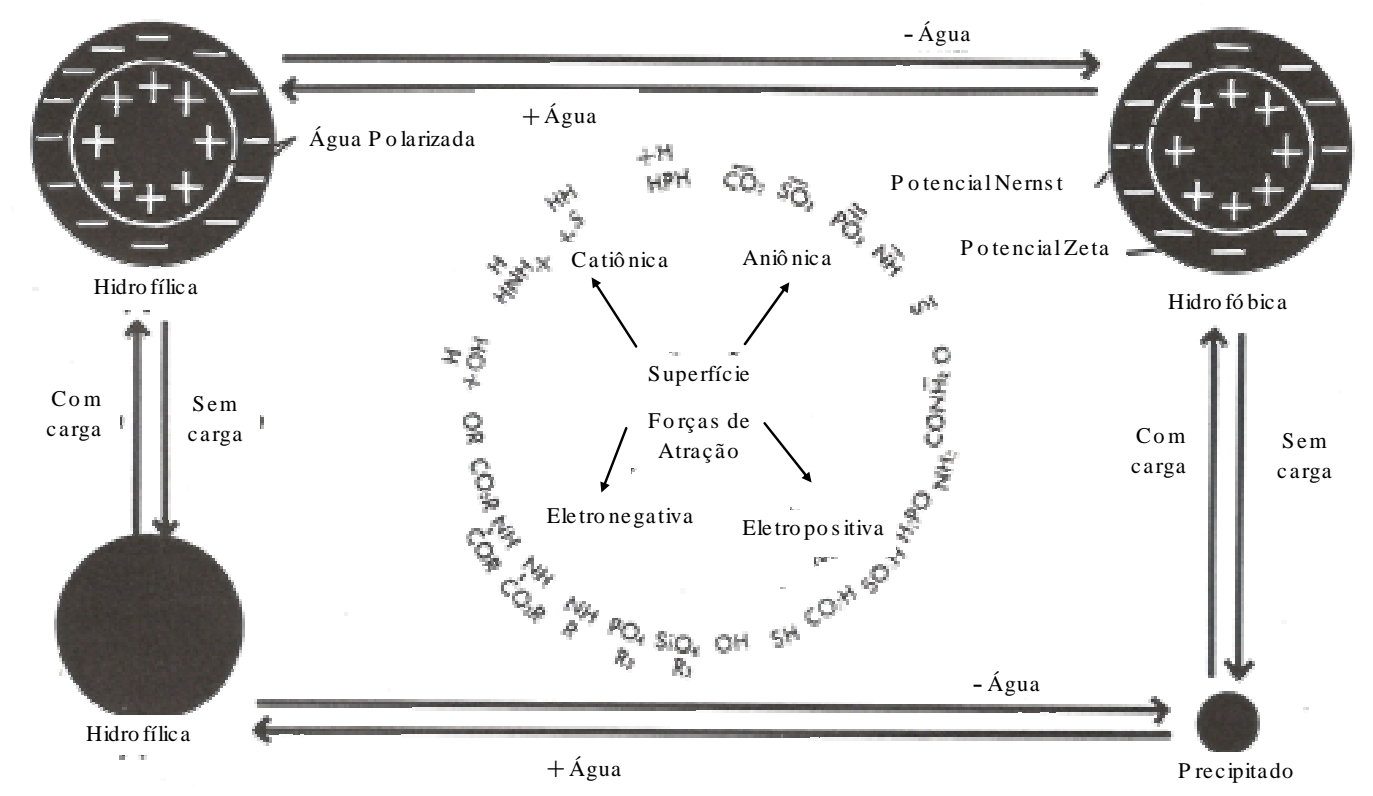

Figura 3.1 - Estabilidade de partículas coloidais em meio aquoso

Fonte: (FAUST \& ALY, 1998)

Devido aos três fenômenos, através dos quais os colóides se apresentam com carga superficial negativa, ocorre um balanço com íons de carga contrária presentes na água e, por isso, um sistema coloidal não apresenta carga elétrica "líquida”. WILLIAMS (1994) comenta que a carga superficial, juntamente com a movimentação Browniana, conduz à formação da Dupla Camada Elétrica (DCE), formada pelas cargas superficiais e pelo excesso de íons com carga oposta (contra-íons) adsorvidos na partícula, deixando o meio circundante eletricamente neutro e mais distante da superfície, e por co-íons (íons de mesma carga) distribuídos de uma maneira difusa no meio polar (ver Figura 3.2). 


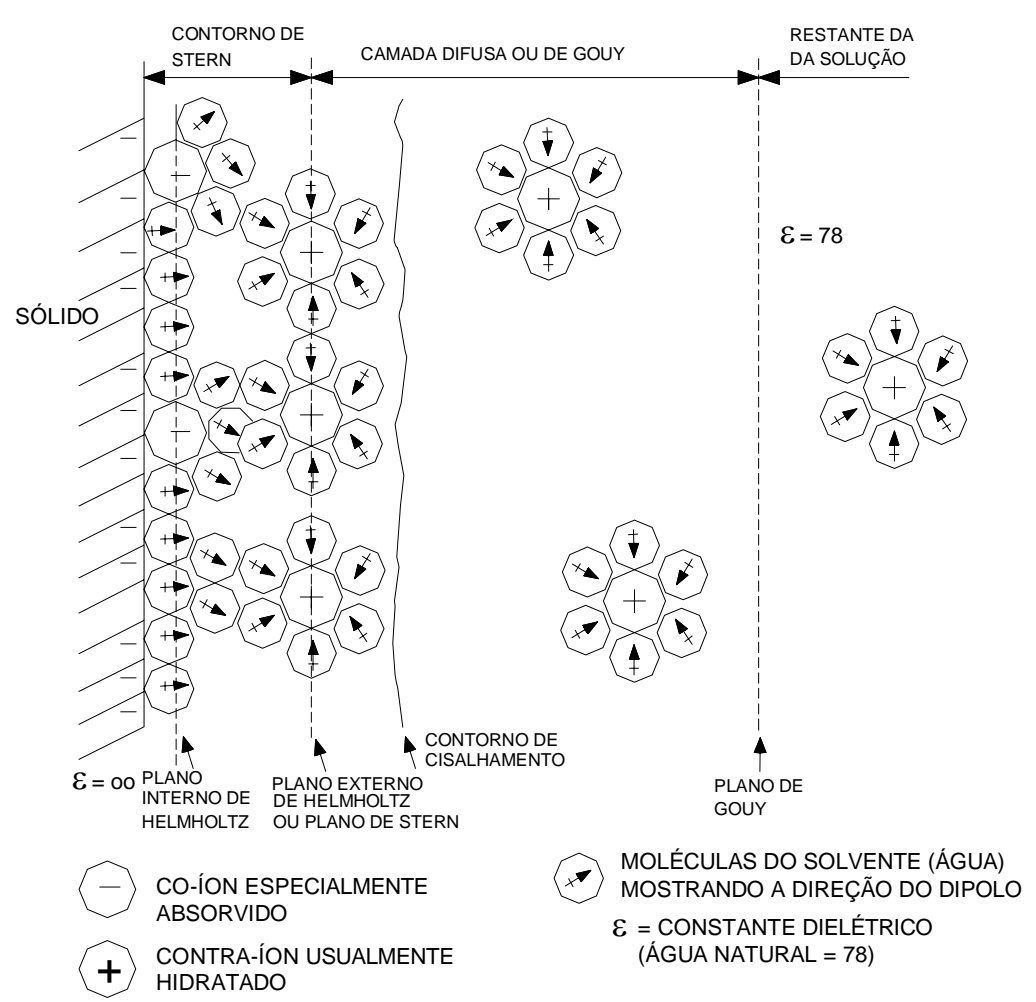

Figura 3.2 - Representação esquemática da dupla camada elétrica nas vizinhanças de uma interface sólido-líquido - Fonte: WILLIAMS (1994)

O modelo mais simples sobre a DCE considera a interface como um dispositivo armazenador de carga, análogo a um capacitor de placa paralela. Um modelo mais realista envolve a divisão da dupla camada em duas regiões, Camada Compacta (CC) e Camada Difusa (CD), conforme mostrado na Figura 3.3. Em sendo negativa a superfície da partícula, há acúmulo de íons positivos na região da interface sólido-líquido, formando, juntamente com a carga negativa da partícula, a DCE, também denominada camada compacta. Íons negativos aproximam-se da CC e atraindo íons positivos, formam a camada difusa, que engloba a primeira; a CD resulta, na realidade, da atração de íons positivos, repulsão eletrostática de íons negativos e difusão térmica (AWWA, 1990). A idéia da DCE foi proposta por Helmotz que desenvolveu o conceito de um sistema contendo cargas distribuídas em dois planos paralelos. Porém, com a movimentação térmica dos íons na água, ocorre um certo grau de desordem, fazendo com que os íons sejam espalhados fora da região da superfície carregada. 


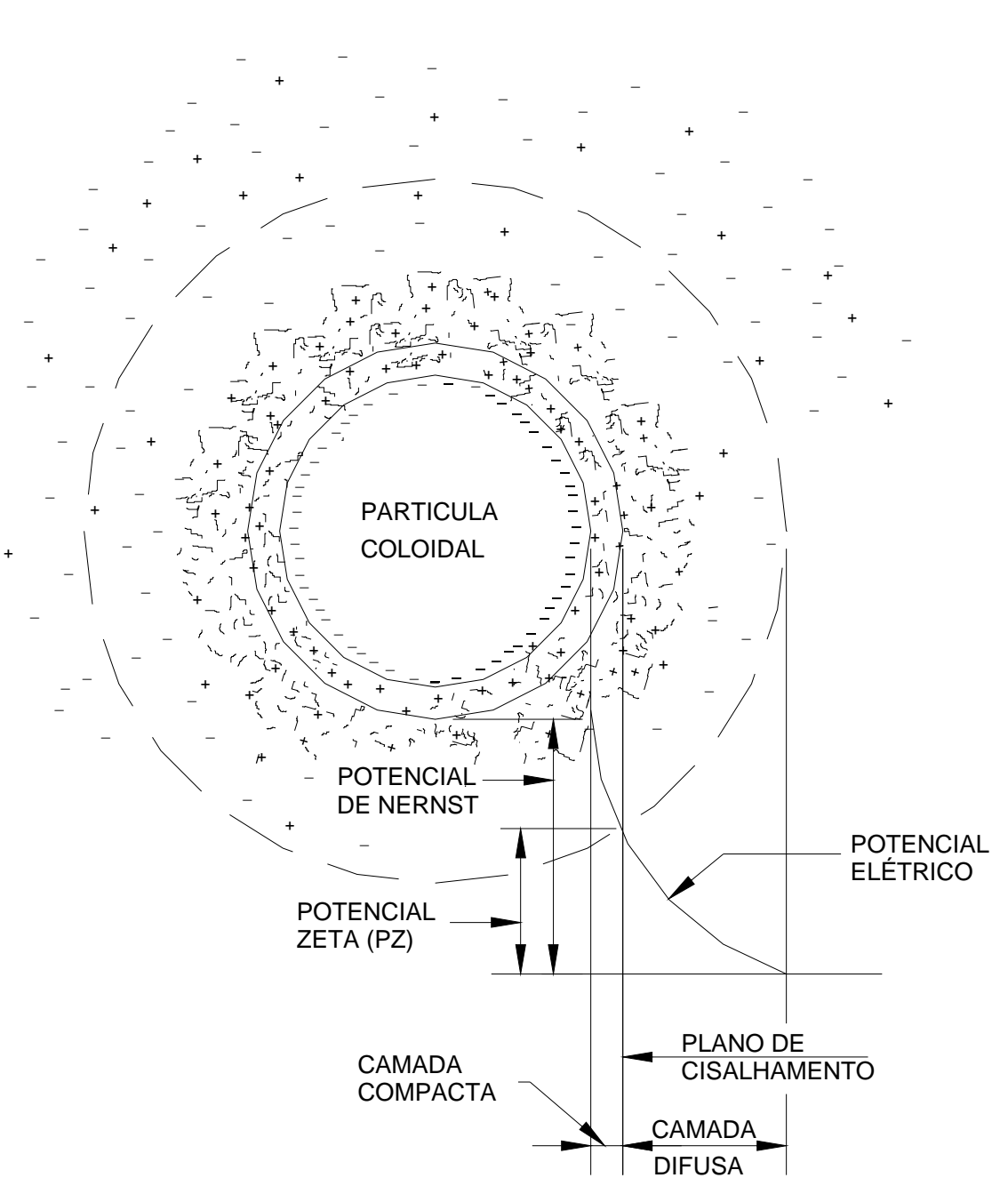

Figura 3.3 - Configuração esquemática da dupla camada elétrica - Fonte: AWWA (1990)

A região com elevada concentração de íons positivos próximos à superfície do colóide é denominada Camada de Stern, a partir da qual se forma a camada difusa, onde a concentração de íons é menor. O potencial elétrico criado pela presença do colóide na água diminui com a distância, a partir da superfície do mesmo, onde é denominado Potencial de Nernst. Stern afirmou que existe uma distância mínima entre a superfície do colóide e os íons de carga contrária, no qual o potencial elétrico decresce linearmente; em seguida, a diminuição resulta exponencial, passando pela fronteira das camadas compacta e difusa, região em que o potencial elétrico, segundo LYKLEMA (1978), é chamado de Potencial Zeta - PZ. O conceito deste potencial está associado à aplicação da diferença de potencial em uma amostra de água contendo colóides negativos de tal forma que certa porção do meio, em torno de partícula, caminha junto com esta ao eletrodo positivo, caracterizando o Plano de Cisalhamento. 
Não existe um meio experimental direto de medida do potencial de Stern, embora seja possível medir o PZ. Porém, o PZ não é necessariamente uma boa indicação do potencial superficial, pois é possível que ocorra adsorção específica de íons no plano de Stern, o que pode até alterar a magnitude do potencial de Stern e do potencial de superfície. Em vista disso, deve-se tomar cuidado na interpretação das medidas de $\mathrm{PZ}$, a menos que o eletrólito usado seja classificado como indiferente, o que pode ser verificado avaliando a dependência do pH com o PZ. De acordo com WILLIAMS (1994) se o pH no qual o PZ é zero (ponto isoelétrico - PIZ) e independe da concentração de eletrólito, então, o eletrólito é denominado eletrólito indiferente e o ponto isoelétrico pode ser seguramente vinculado ao ponto de carga zero - PCZ. O PCZ é, geralmente, uma característica própria da superfície sólida, e a sua variação pode ser tomada como evidência de adsorção específica do eletrólito na superfície.

\subsubsection{Turbidez}

A turbidez vem progressivamente consolidando-se como um dos principais parâmetros na avaliação do desempenho das estações de tratamento. A Portaria 518 estabelece para águas de consumo humano limite máximo permissível de 1,0 uT para a água filtrada, recomendando valores inferiores a 0,5 uT em $95 \%$ das amostras mensais (BRASIL, 2004). A turbidez, juntamente com a contagem de partículas, são parâmetros que podem indicar a presença de organismos como giardia e criptosporídio. Estes organismos representam alto risco sanitário, são de difícil detecção, quantificação e remoção nos filtros de ETAs, e apresentam elevada resistência aos métodos tradicionais de desinfecção. Neste contexto, as normas mundiais para água de consumo têm-se tornado progressivamente mais restritivas para os limites da turbidez da água filtrada.

A turbidez das águas é devida à presença de partículas em estado coloidal, em suspensão, matéria orgânica e inorgânica finamente dividida, plâncton e outros organismos microscópicos. O comportamento dessas partículas no meio dispersante está intimamente ligado às suas dimensões, distinguindo-se três fenomenologias distintas conforme se tenham soluções, dispersões coloidais ou suspensões.

Nas soluções, o fracionamento das partículas ocorre a nível de moléculas ou átomos. Já nas dispersões coloidais, as partículas são finamente divididas e não sedimentam em um intervalo de tempo razoável. E por último, as suspensões, nas quais a separação de fases é conseguida por simples decantação em um tempo relativamente curto. A distinção entre dispersão coloidal e suspensão é arbitrária, porém tem sido adotado o tamanho de uma esfera 
de $1 \mu \mathrm{m}$. Na Figura 3.4 é mostrada a distribuição de tamanho das partículas e moléculas presentes nas águas.

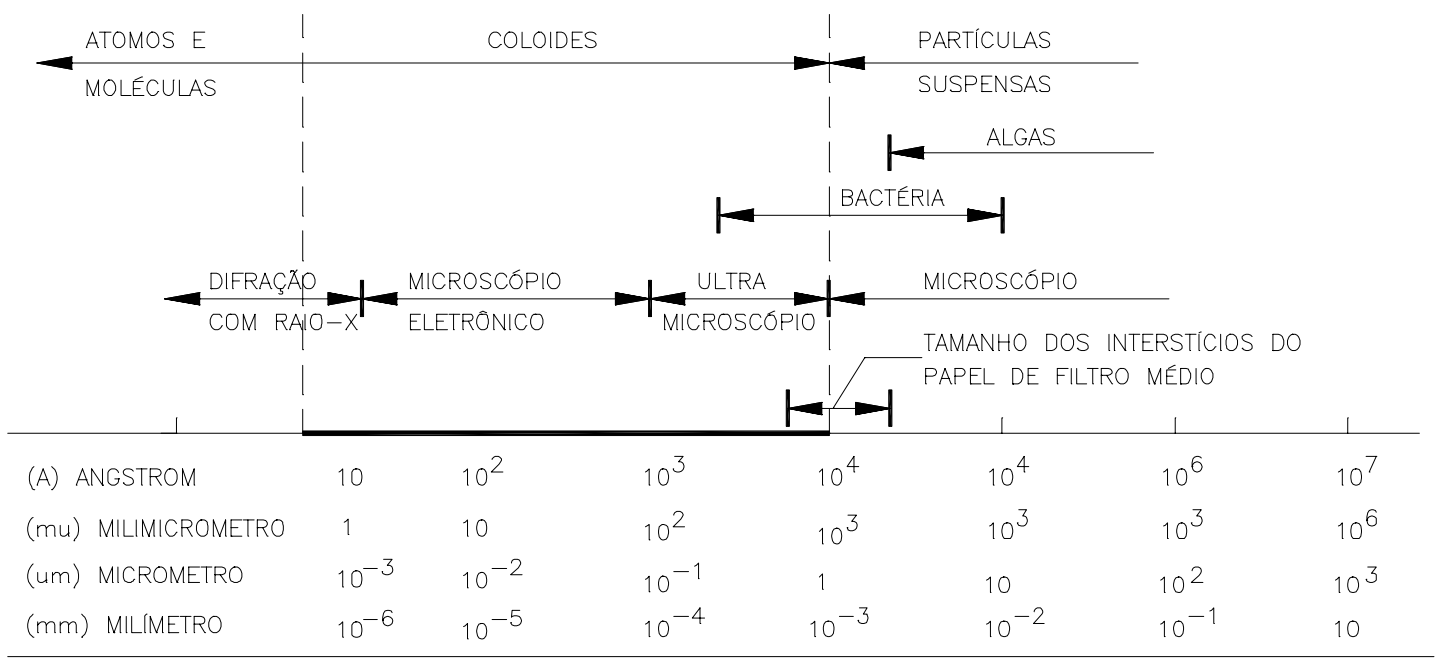

Figura 3.4 - Distribuição de tamanhos de partículas na água - Fonte: AWWA (1990)

Nos sistemas coloidais hidrofóbicos, as propriedades das superfícies das partículas são muito importantes, principalmente nas águas naturais, que podem conter diversos tipos de argila. As águas superficiais contêm sólidos em suspensão e em estado coloidal. Em lagos, a maior parte da turbidez é devida à matéria coloidal ou à partículas extremamente pequenas. Já cursos d’água correntes, onde há maior turbulência, a turbidez é devida, principalmente, a partículas em suspensão. As argilas comumente encontradas são: caulinita, bentonita, ilita e muscovita (DI BERNARDO, 2003).

As argilas são constituídas por partículas extremamente pequenas: argilominerais, matéria orgânica, partículas de quartzo, mica, pirita, calcita e outros materiais residuais, podendo conter também minerais não cristalizados ou amorfos. O pequeno tamanho de suas partículas faz com que as argilas tenham propriedades coloidais. Segundo OLPHEN (1977), morfologicamente as partículas de argila apresentam-se em forma de plaquetas compostas por lâminas muito finas (Figura 3.5). 


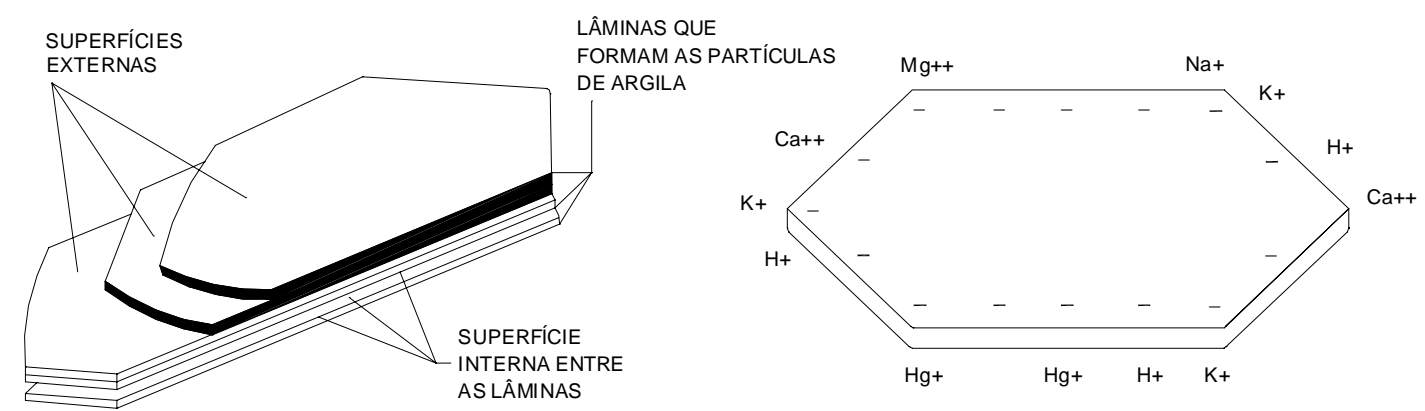

Figura 3.5 - Representação esquemática de uma partícula de argila - Fonte: OLPHEN (1977)

Observações microscópicas e análise das argilas através de raio $\mathrm{X}$ feitas por OLPHEN (1977), possibilitaram classificá-las segundo a estrutura do cristal; seus principais elementos são alumínio, silício, magnésio, potássio, oxigênio e hidrogênio, combinados conforme o tipo das mesmas. Na Tabela 3.1 têm-se algumas características de três tipos de argilas e, na Figura 3.6, a curva de distribuição granulométrica de um solo predominantemente argiloso feita por KURODA (2002).

Tabela 3.1 - Características principais das argilas - Fonte: OLPHEN (1977)

\begin{tabular}{|c|c|c|c|c|}
\hline Tipo de Argila & Estrutura & $\begin{array}{c}\text { Superfície } \\
\text { Específica } \\
\left(\mathrm{m}^{2} / \mathrm{g}\right)\end{array}$ & $\begin{array}{c}\text { Massa } \\
\text { Específica } \\
\left(\mathrm{kg} / \mathrm{m}^{3}\right)\end{array}$ & $\begin{array}{c}\text { Umidade } \\
\text { (\%) }\end{array}$ \\
\hline \multirow[t]{2}{*}{ Montmorilonita } & \multirow[t]{2}{*}{$\mathrm{Al}\{\mathrm{Mg}\}\left(\mathrm{Si}_{8} \mathrm{O}_{20}\right)(\mathrm{OH})_{4} \times \mathrm{H}_{2} \mathrm{O}$} & \multirow[t]{2}{*}{15,5} & 2348 & 46 \\
\hline & & & 1772 & 0 \\
\hline \multirow{2}{*}{$\begin{array}{c}\text { Caulinita } \\
\text { (diâmetro médio } \\
0,3 \mu \mathrm{m} \text { ) }\end{array}$} & \multirow[t]{2}{*}{$\begin{array}{l}\mathrm{Al}_{4}\left(\mathrm{Si}_{4} \mathrm{O}_{10}\right)(\mathrm{OH})_{8} \\
\mathrm{Al}_{4}\left(\mathrm{Si}_{4} \mathrm{O}_{6}\right)(\mathrm{OH})_{16}\end{array}$} & \multirow[t]{2}{*}{15,5} & 2667 & 6,5 \\
\hline & & & 2467 & 0 \\
\hline \multirow{2}{*}{$\begin{array}{c}\text { Ilita } \\
\text { (diâmetro médio } \\
0,3 \mu \mathrm{m} \text { ) }\end{array}$} & \multirow[t]{2}{*}{$\mathrm{K}_{\mathrm{y}} \mathrm{Al}_{4}\left\{\mathrm{Fe}_{4} \mathrm{Mg}_{16}\right\}\left(\mathrm{Si}_{8} \mathrm{yAl}_{\mathrm{y}}\right) \mathrm{O}_{20}$} & \multirow[t]{2}{*}{97,1} & 2642 & 0 \\
\hline & & & 2128 & 18 \\
\hline
\end{tabular}




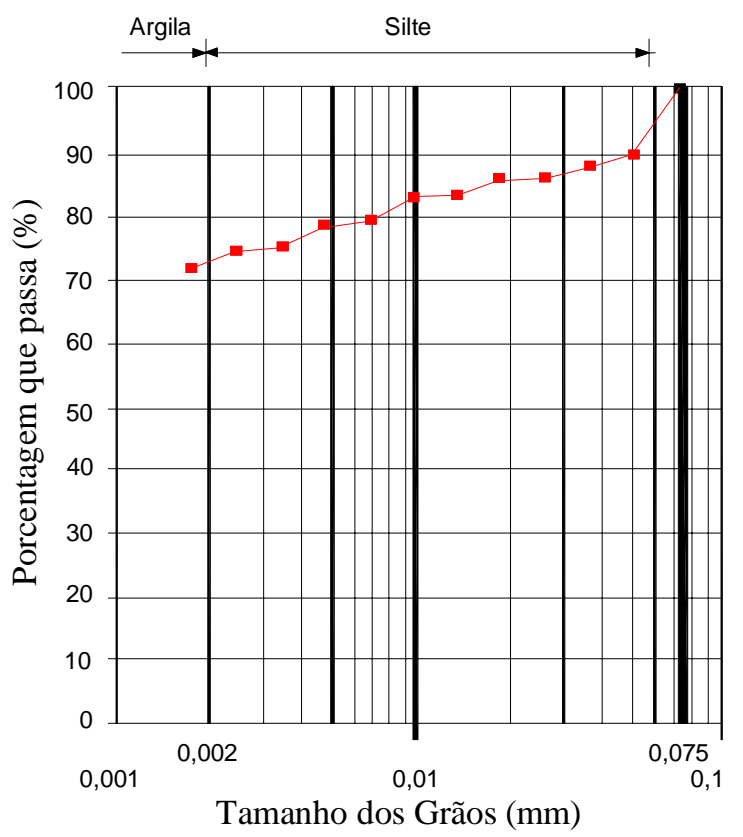

Figura 3.6 - Distribuição de tamanho dos grãos em material predominantemente argiloso Fonte: KURODA (2002)

A propriedade óptica expressa como turbidez pode ser considerada como a interação entre a luz e as partículas em suspensão na água. Em amostras contendo partículas em suspensão, a maneira como a água interfere na transmissão de luz está relacionada com as características destas partículas (tamanho, forma e composição) e com o comprimento de onda da luz incidente.

Um fator importante a ser considerado em trabalhos nos quais a turbidez é o principal parâmetro de controle, é a diferença que existe entre os diversos equipamentos de medida de turbidez. O princípio básico do funcionamento dos equipamentos de determinação nefelométrica de turbidez consiste em um detector disposto a um determinado ângulo em relação ao raio de luz incidente, que mede a reflexão da luz pelas partículas. Para o ângulo de $90^{\circ}$, o equipamento denomina-se nefelômetro ou turbidímetro (HACH et al., 1989).

Vários fatores podem afetar os valores de turbidez medidos por diferentes equipamentos, tais como o tipo de lâmpada, as lentes, as células para amostragem, a mencionada orientação da fonte de luz e do detector, o número de detectores, a limpeza interna do medidor, a deterioração da fonte de luz, a susceptibilidade a vibrações e a interferências eletrônicas, e a capacidade de fornecer estabilidade nas leituras (TEIXEIRA et al., 2004). 
Neste sentido, TEIXEIRA et al. (2004) realizaram um estudo sobre a confiabilidade analítica, em termos de turbidez, dos efluentes de duas unidades de filtração em escala piloto. Foram realizadas determinações deste parâmetro com equipamentos de bancada e de escoamento contínuo, e a partir dos resultados experimentais, foram efetuados testes de confiabilidade e de validade, considerando o turbidímetro de bancada como padrão. Os resultados da análise estatística comprovaram que as determinações de turbidez estão condicionadas aos distintos princípios de funcionamento dos equipamentos.

\subsection{Coagulação}

\subsubsection{Considerações iniciais}

A água pode conter uma variedade de impurezas, destacando-se partículas coloidais, substâncias húmicas e organismos em geral. Conforme dito anteriormente, tais impurezas apresentam carga superficial negativa, impedindo que as mesmas aproximem-se uma das outras, permanecendo no meio líquido se suas características não forem alteradas. Para que as impurezas possam ser removidas, é preciso alterar-se algumas características da água e, conseqüentemente, das impurezas, através da coagulação, floculação, sedimentação (ou flotação) e filtração.

A coagulação depende fundamentalmente das características da água e das impurezas presentes, conhecidas através de parâmetros tais como $\mathrm{pH}$, alcalinidade, cor verdadeira, turbidez, temperatura, potencial zeta, condutividade elétrica, tamanho e distribuição de tamanhos das partículas em estado coloidal e em suspensão, etc. A coagulação, pré-tratamento químico para a desestabilização de partículas, constitui o fator mais importante para a produção de água filtrada de boa qualidade, principalmente quando se aplica uma das técnicas de filtração direta. O pré-tratamento quando feito de maneira inadequada pode acarretar a produção de efluente de má qualidade, mesmo para baixas taxas de filtração. Já no tratamento em ciclo completo, a floculação também pode resultar ineficiente, comprometendo o desempenho da sedimentação e da filtração (DI BERNARDO, 1993a).

\subsubsection{Mecanismos de coagulação}

Atualmente, considera-se a coagulação como o resultado individual ou combinado da ação de quatro mecanismos distintos: a) compressão da dupla camada elétrica; b) adsorção e neutralização; c) varredura; d) adsorção e formação de pontes. 


\section{a) Compressão da dupla camada elétrica}

Sabe-se, desde o final do século XIX, que um sistema coloidal pode ser desestabilizado pela adição de íons de carga contrária à das partículas coloidais. Sais simples, como cloreto de sódio, são considerados eletrólitos indiferentes e não têm características de hidrólise ou de adsorção, como ocorre com sais de alumínio ou de ferro. Schulze e Hardy, por volta de 1900, utilizando a teoria desenvolvida por Derjaguin, Landau, Verwey e Overbeek (denominada DLVO), mostraram que a desestabilização de um colóide por um eletrólito indiferente ocorre devido a interações eletrostáticas: íons de mesma carga são repelidos e de carga contrária são atraídos pelos colóides; quanto maior a carga do íon positivo, menor a quantidade requerida para a coagulação. No caso do sódio, cálcio e alumínio, as concentrações molares desses metais para causar a desestabilização de um colóide negativo variam, aproximadamente, na proporção de $1: 10^{-2}: 10^{-3}$. A introdução de um eletrólito num sistema coloidal irá causar um aumento na densidade de cargas na camada difusa e diminuir a "esfera” de influência das partículas, ocorrendo a coagulação por compressão da dupla camada difusa. Concentrações elevadas de íons positivos e negativos (força iônica grande) na água acarreta um acréscimo do número de íons na camada difusa que, para manter-se eletricamente neutra, necessariamente, passam a ter seu volume reduzido (diminuição da espessura), de forma que as forças de Van der Waals tornam-se dominantes, eliminando a estabilização eletrostática; exemplo típico desse mecanismo ocorre quando águas doces com força iônica pequena misturam-se à água do mar, promovendo a formação de depósitos nas desembocaduras (DI BERNARDO, 2003).

Na Figura 3.7a é representada uma partícula coloidal negativa em um meio com baixa concentração de íons monovalentes; conforme aumenta essa concentração de íons (Figuras 3.7b e 3.7c), mais íons positivos entram na dupla camada e há redução do potencial zeta. Na Figura 3.7d íons positivos trivalentes entraram na dupla camada, reduzindo o potencial zeta, ocorrendo a coagulação por compressão da dupla camada elétrica. 

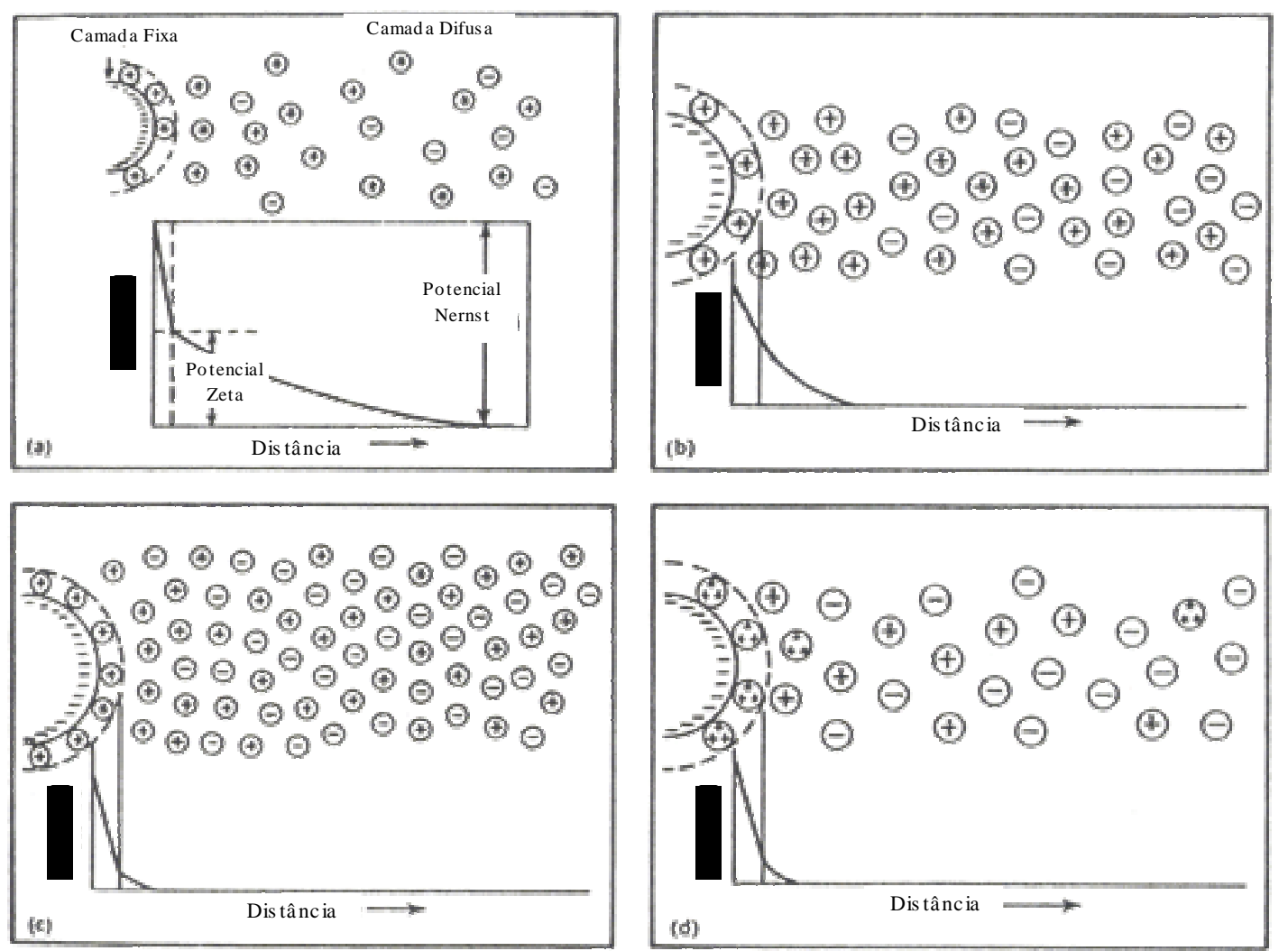

Figura 3.7 - Efeito de íons de cargas contrárias no potencial zeta - Fonte: (FAUST \& ALY, 1998)

Vale destacar dois aspectos interessantes sobre esse mecanismo de coagulação: a) a quantidade de eletrólitos para conseguir-se a coagulação é, praticamente, independente da concentração de colóides na água; b) para qualquer quantidade adicionada de eletrólitos é impossível causar a reestabilização das partículas coloidais, ou seja, a reversão de carga das mesmas, que passa a ser positiva.

Na Figura 3.8 têm-se dados de um estudo realizado por DI BERNARDO (2001) utilizando partículas hidrofóbicas de poliestireno-látex, cujas características são apresentadas na Tabela 6.2. Foi usado cloreto de cálcio como coagulante em água deionizada contendo 4,5 x $10^{5}$ partículas/mL, turbidez de $10 \mathrm{uT}$, potencial zeta de $-40 \mathrm{mV}, \mathrm{pH}=7,58$ e temperatura de $25{ }^{\circ} \mathrm{C}$. Observa-se que o $\mathrm{pH}$ permaneceu praticamente constante e a condutividade elétrica aumentou em função do aumento da dosagem de cloreto de cálcio. Como houve diminuição do potencial zeta de $-40 \mathrm{mV}$ para cerca de $-5 \mathrm{mV}$ com dosagem de $5 \mathrm{~g} / \mathrm{L}$ do eletrólito indiferente, pode-se considerar que o mecanismo de coagulação resultou da compressão da dupla camada elétrica. 
Tabela 3.2 - Características de partículas de poliestireno-látex com grupo sulfato - Fonte: DI

BERNARDO (2001)

\begin{tabular}{|c|c|}
\hline Características & Valor \\
\hline Diâmetro Médio $(\mu \mathrm{m})$ & 2.9 \\
\hline Concentração de Sólidos $(\mathrm{g} / 100 \mathrm{~mL})$ & 8,3 \\
\hline Número de Partículas em Água Deionizada $(\# / \mathrm{mL})$ & $6,2 \times 10^{9}$ \\
\hline Superfície Específica $\left(\mathrm{cm}^{2} / \mathrm{g}\right)$ & $2 \times 10^{4}$ \\
\hline Massa Específica das Partículas a $20^{\circ} \mathrm{C}\left(\mathrm{g} / \mathrm{cm}^{3)}\right.$ & 1.055 \\
\hline Densidade de Carga Superficial $\left(\mu \mathrm{C} / \mathrm{cm}^{2}\right)$ & 8,4 \\
\hline
\end{tabular}

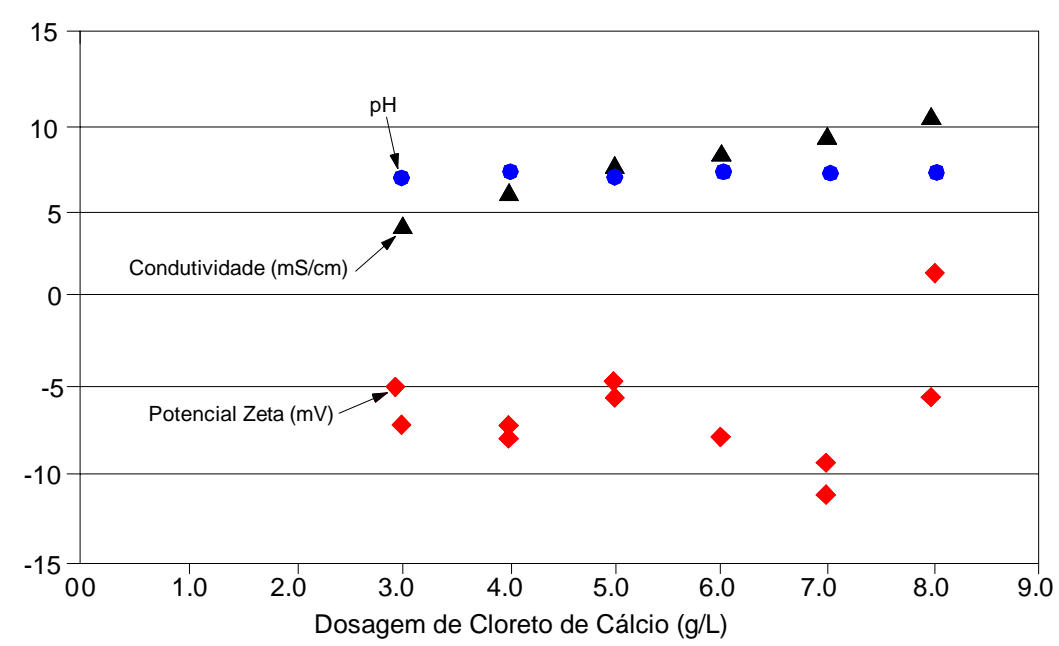

Figura 3.8 - Coagulação de partículas de poliestireno-látex no mecanismo de compressão da dupla camada elétrica - Fonte: DI BERNARDO (2001)

Ao utilizar dois tipos de água com concentrações distintas de partículas de poliestireno-látex, iguais a $4,5 \times 10^{5}$ e $1,2 \times 10^{6}$ part./mL (turbidez de 10 uT e 38 uT, respectivamente), DI BERNARDO (2001) comprovou que, independentemente da concentração de partículas, não houve alteração da dosagem de cloreto de cálcio necessária para que o potencial zeta se aproximasse de zero.

Na Figura 3.9a, têm-se os resultados da coagulação realizada com $\mathrm{Na}^{+}, \mathrm{Ca}^{2+}, \mathrm{Al}^{3+}$, obtidos em ensaios de coagulação, floculação e sedimentação, os quais estão coerentes com a teoria DLVO e a regra empírica de Schulze-Hardy. Entretanto, os coagulantes geralmente usados em tratamento de água, não são eletrólitos indiferentes, indicando que, além da compressão da dupla camada, poderão ocorrer outros fenômenos. Por exemplo, é muito menor a concentração de dodecilamina (amina de longa cadeia orgânica) necessária para causar o mesmo efeito do $\mathrm{Na}^{+}$(ver Figura 3.9b). 


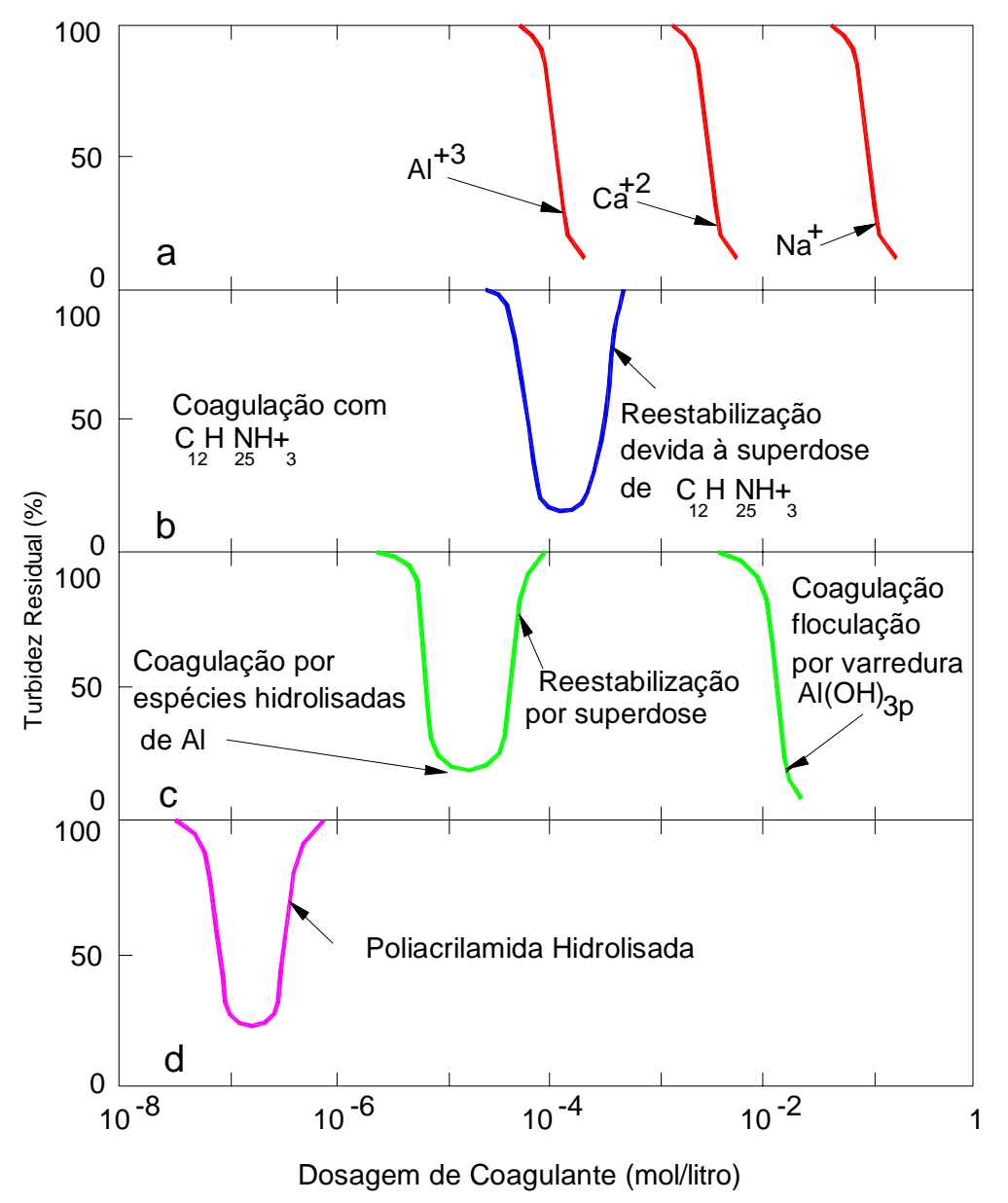

Figura 3.9 - Curvas de turbidez residual em função da concentração molar de quatro tipos de coagulantes. Ensaio de coagulação, floculação e sedimentação - Fonte: O’MELIA (1978)

\section{b) Adsorção e Neutralização de Cargas}

A desestabilização de uma dispersão coloidal consiste nas interações entre coagulante-colóide, coagulante-solvente e colóide-solvente. Uma amina orgânica, como a $\mathrm{C}_{12} \mathrm{H}_{25} \mathrm{NH}_{3}{ }^{+}$(ver Figura 3.9b) é uma substância ativa na superfície dos colóides, que se acumula nas interfaces, e os grupos $\mathrm{CH}_{2}$ nas cadeias alifáticas das moléculas que não interagem com a água. Em contraposição, sódio e cálcio interagem fortemente com as moléculas de água e não são ativos na superfície dos colóides. Duas diferenças importantes são evidentes quando se compara $\mathrm{C}_{12} \mathrm{H}_{25} \mathrm{NH}_{3}{ }^{+}$com Na ${ }^{+}$. Primeiramente, os íons de sódio somente são efetivos como coagulante para dosagens da ordem de $0,1 \mathrm{M}$, enquanto a amina orgânica, com carga idêntica, causa a desestabilização do colóide com dosagens da ordem de $6 \times 10^{-5} \mathrm{M}$. Em segundo lugar, para dosagens de amina acima de aproximadamente $4 \times 10-^{4}$ M, ocorre a reestabilização dos colóides, fenômeno também conhecido como reversão de cargas, isto é, os colóides tornam-se carregados positivamente, pelo excesso de íons de 
amina que têm carga +1 . O mesmo não acontece com o sódio. Conforme os dados apresentados na Figura 3.9b, é provável que as interações coagulante-solvente (amina-água) sejam responsáveis pela adsorção do coagulante na interface colóide-água. No caso de espécies hidrolisadas de alumínio ou de ferro ou de polímeros sintéticos catiônicos, é comum ocorrer a adsorção específica, causada pela interação entre coagulante e colóide. Como o fenômeno de adsorção é dominante, nota-se que, em parte, são semelhantes às Figuras 3.9c e 3.9d com a 3.9b. O mecanismo de adsorção-neutralização de carga é muito importante quando o tratamento é realizado através de uma das tecnologias da filtração direta, pois não há necessidade da produção de flocos para posterior sedimentação ou flotação, mas de partículas desestabilizadas que serão retidas no meio granular dos filtros - DI BERNARDO (2003).

\section{c) Varredura}

De acordo com DI BERNARDO (2003), dependendo da quantidade adicionada de sal (coagulante), do pH da mistura e da concentração de alguns tipos de íons na água, poderá ocorrer a formação de precipitados. As partículas coloidais presentes comportam-se como núcleos de condensação para estes precipitados e, desta forma, são removidas por sedimentação. Com sais de ferro e alumínio, podem ser formados os precipitados $\mathrm{Al}(\mathrm{OH})_{3}(\mathrm{p})$ e $\mathrm{Fe}(\mathrm{OH})_{3}(\mathrm{p})$.

O mecanismo da varredura é intensivamente utilizado nas estações de tratamento de água em que se tem a floculação e a sedimentação (ou flotação) antecedendo a filtração rápida. Em geral, os flocos obtidos com esse mecanismo são maiores e sedimentam ou flotam mais facilmente que os flocos obtidos com a coagulação realizada no mecanismo de adsorção e neutralização de cargas.

Segundo AMIRTHARAJAH \& MILLS (1982) os mecanismos de coagulação por adsorção e neutralização de cargas e por varredura, quando é utilizado o sulfato de alumínio, podem ocorrer segundo os caminhos indicados na Figura 3.10. 


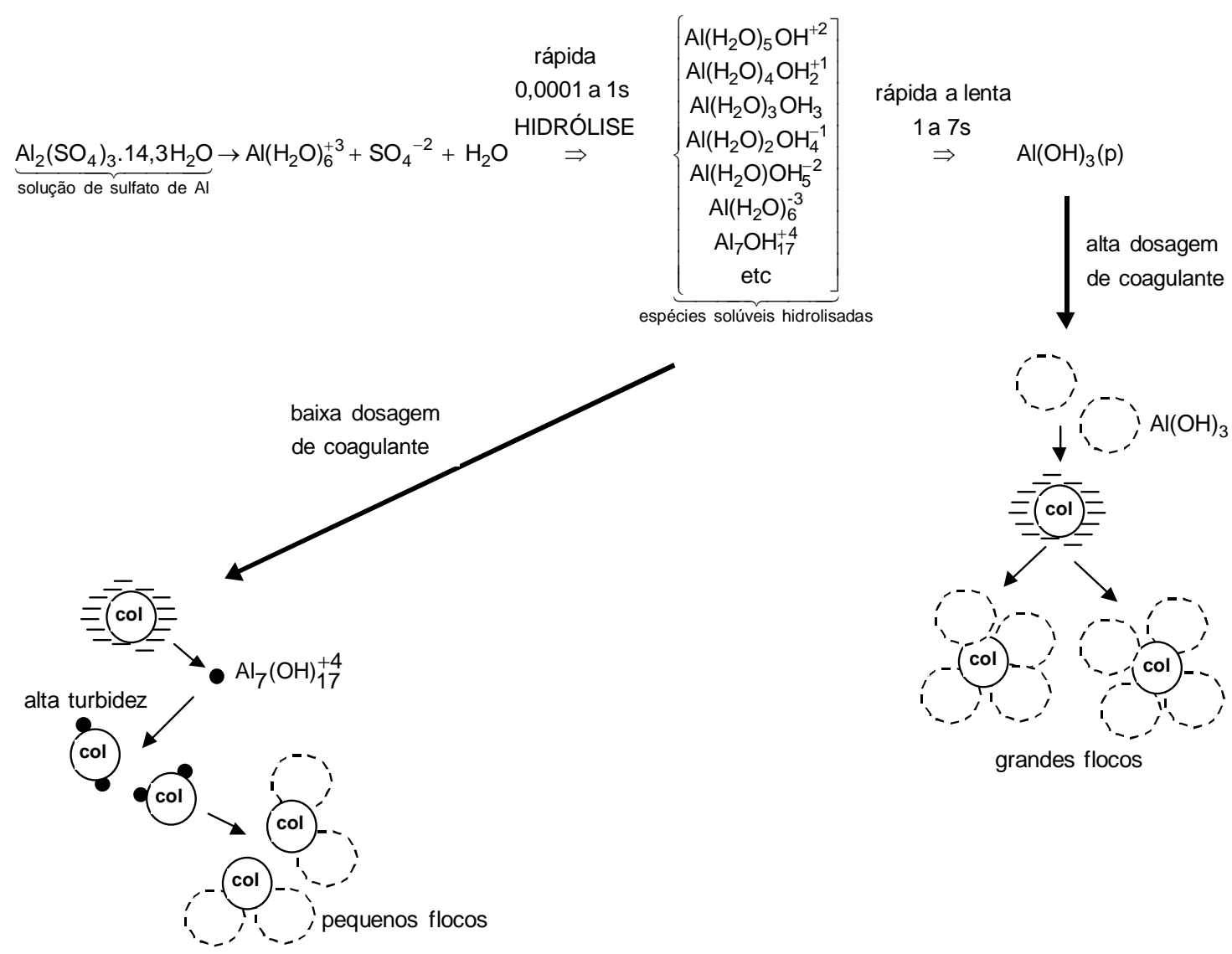

Figura 3.10 - Caminhos para a coagulação por adsorção-neutralização de carga e por varredura utilizando sulfato de alumínio - Fonte: AMIRTHARAJAH \& MILLS (1982)

Ao estudarem água com cor verdadeira alta (100 uH) em relação a turbidez (5 uT), e outra com cor verdadeira baixa (5 uH) em relação a turbidez (200 uT), com alcalinidade de 30 a $40 \mathrm{mg} / \mathrm{L}$ de $\mathrm{CaCO}_{3}$, respectivamente, coaguladas nos mecanismos de adsorçãoneutralização e da varredura, DI BERNARDO et al. (1987) concluíram: a região de adsorção é caracterizada por valores de $\mathrm{pH}$ e dosagens de coagulante bem menores que os da região da varredura; a faixa de valores de dosagem de coagulante e $\mathrm{pH}$ final que produz resultados satisfatórios é bem mais estreita no mecanismo de adsorção-neutralização, em comparação ao da varredura; as condições de mistura rápida e de floculação não são necessariamente as mesmas quando são diferentes os mecanismos de coagulação.

Observa-se na varredura, que o potencial zeta mínimo não corresponde às regiões ótimas de coagulação, dado que o processo em pauta independe da neutralização das cargas superficiais. 


\section{d) Adsorção e formação de pontes}

Existe uma grande variedade de compostos naturais e sintéticos, caracterizados por grande cadeia molecular (massa molar $>10^{6}$ ), com a propriedade de apresentarem grupos com carga ao longo da cadeia e capazes de agirem como coagulantes eficientes. Tais compostos, denominados polieletrólitos, podem ser classificados como aniônicos, catiônicos, anfolíticos e não-iônicos, dependendo da característica do grupo com carga que apresentam. Pesquisas do comportamento destes compostos têm mostrado que é possível a desestabilização de colóides carregados negativamente por ambos tipos de polímeros, catiônico e aniônico. Desta forma, nem o modelo de compressão da camada difusa e nem o da neutralização-adsorção podem ser considerados para caracterizar este mecanismo. A teoria desenvolvida para explicar o comportamento dos polímeros como coagulantes, é baseada na adsorção dos mesmos à superfície das partículas coloidais, seguida ou pela redução da carga ou pelo "entrelaçamento" das partículas pelos polímeros - LYKLEMA (1978).

\subsubsection{Coagulação com sulfato de alumínio para remoção de turbidez}

Os trabalhos realizados por BLACK \& WILLEMS (1961), BLACK \& HANNAH (1961), BLACK \& CHRISTMAN (1963), O’MELIA (1978), RUBIN (1974), STUMM \& O’MELIA (1968), TAMBO \& WATANABE (1979a), TAMBO \& WATANABE (1979b), TAMBO \& WATANABE (1979c) e TAMBO \& MISCHNICK (1979), contribuíram consideravelmente para que, na década de oitenta, AMIRTHARAJAH \& MILLS (1982) propusessem uma forma mais simples de se estudar a coagulação, baseada nos diagramas de solubilidade do alumínio e do ferro.

ARMITHARAJAH \& MILLS (1982) desenvolveram o diagrama de coagulação (Figura 3.11), com base no diagrama de solubilidade do alumínio e das condições de coagulação, dosagem de $\mathrm{Al}_{2}\left(\mathrm{SO}_{4}\right)_{3}$ x 14,3 $\mathrm{H}_{2} \mathrm{O}$ e pH da mistura, no tratamento de águas sintéticas e naturais, com turbidez relativamente alta se comparada à cor verdadeira. Neste diagrama, além das curvas das espécies hidrolisadas do alumínio, há a delimitação das regiões nas quais predominam os diferentes mecanismos de coagulação, e também são mostradas a variação do potencial zeta da dispersão coloidal estabilizada e a variação do potencial zeta resultante da interação entre os colóides da dispersão com as espécies hidrolisadas.

Segundo os autores, o procedimento por eles adotado possibilitou a "generalização" das condições de pH e dosagem de coagulante, no caso o sulfato de alumínio, para a efetiva desestabilização de partículas através dos diferentes mecanismos de coagulação. Uma vez 
que a reversão de cargas ocorre no limite da zona de reestabilização, deveria ser evidente que a área de carga zero estaria localizada ao lado de fora desse limite. Sendo assim, uma coagulação muito boa deveria ocorrer ao longo de uma seção estreita deste limite, com o mecanismo sendo predominantemente adsorção-desestabilização. A localização precisa da linha correspondente à mobilidade eletroforética nula é também dependente da quantidade de espécies hidrolisadas de alumínio necessária para a neutralização de cargas, bem como da presença de ânions.

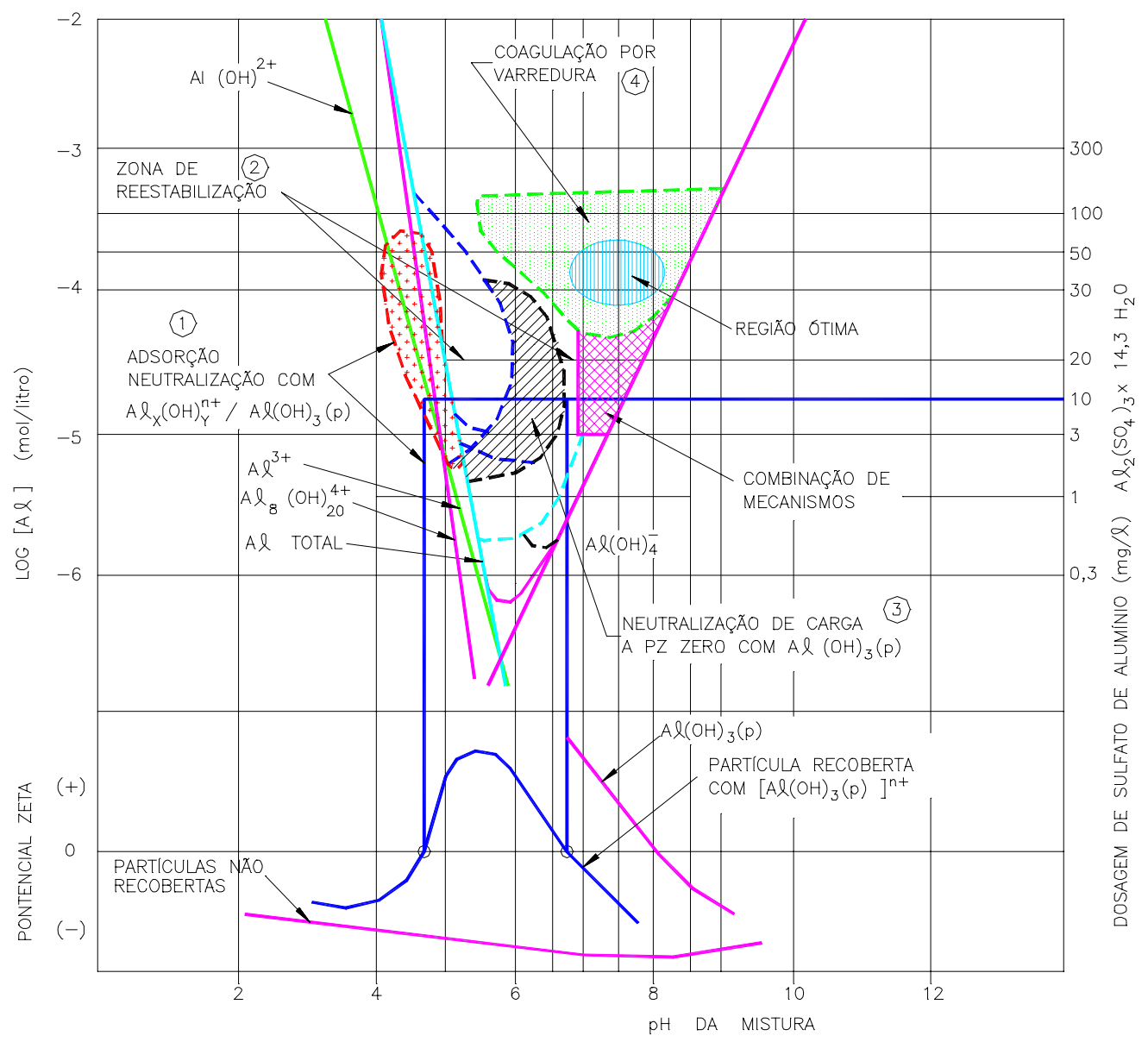

Figura 3.11 - Diagrama de coagulação do sulfato de alumínio e sua relação com o potencial zeta Fonte: ARMITHARAJAH \& MILLS (1982)

Na Figura 3.11 existem quatro regiões distintas, caracterizadas pelos pares de valores dosagem de coagulante $\mathrm{x} \mathrm{pH}$ da mistura, que distinguem os diferentes mecanismos de coagulação e a reestabilização das partículas coloidais - ARMITHARAJAH \& MILLS (1982), quais sejam:

Região 1: ocorre a neutralização de carga das partículas coloidais pelas espécies hidrolisadas positivas de alumínio, que são adsorvidas na superfície dos colóides. Da 
interação entre tais espécies de alumínio, positivas, e os colóides, negativos, resulta uma curva em que o potencial zeta (negativo) se aproxima de zero, num valor de $\mathrm{pH}$ da ordem de 4,8, caracterizando o ponto isoelétrico dos colóides recobertos com espécies do alumínio. É evidente que, se for mantido constante o pH de 4,8, a dosagem de sulfato de alumínio poderá variar de aproximadamente 3 a $70 \mathrm{mg} / \mathrm{L}$;

Região 2: seja, por exemplo, a dosagem de sulfato de alumínio naquela faixa mencionada e $\mathrm{pH}$ igual a 4,8. Se o $\mathrm{pH}$ diminuísse, as partículas recobertas apresentariam PZ negativo, permanecendo estabilizada a dispersão coloidal. Mas, com o aumento do pH (maior que 4,8), o PZ se torna positivo, e também os colóides se tornam positivos, caracterizando o fenômeno da reestabilização. Para um valor de $\mathrm{pH}$ fixo, igual a 6, por exemplo, existe uma relação estequiométrica entre a concentração da dispersão coloidal e a dosagem de sulfato de alumínio, que delimitam a parte inferior da região de reestabilização. A desestabilização, que causa o aparecimento da delimitação superior da região de reestabilização, tem sido creditada à presença de íons $\mathrm{SO}_{4}^{-2}$ e ao aprisionamento dos colóides reestabilizados em complexos de sulfato do tipo $\mathrm{Al}\left(\mathrm{H}_{2} \mathrm{O}\right) \mathrm{SO}_{4}{ }^{+}$;

Região 3: considerando, na Figura 3.11, uma dosagem de sulfato de alumínio igual a $10 \mathrm{mg} / \mathrm{L}$ nota-se que, a partir do $\mathrm{pH}=4,8$, a curva resultante da interação entre as espécies hidrolisadas positivas de alumínio e as partículas coloidais, atinge um valor de PZ máximo (reestabilização) e diminui com o aumento do $\mathrm{pH}$, até que o ponto isoelétrico seja novamente atingido, em um valor de pH em torno de 6,8 (para a dispersão coloidal considerada). Isto é devido à presença de hidróxido de alumínio com carga positiva. Para dosagens de sulfato de alumínio compreendidas entre cerca de 3 e $30 \mathrm{mg} / \mathrm{L}$, existe uma região conhecida por “corona”, na qual o mecanismo de coagulação é devido à neutralização de carga pelo hidróxido de alumínio positivo. Essa região é considerada ideal para a coagulação quando se tem uma das tecnologias de filtração direta;

Região 4: geralmente, para valores de $\mathrm{pH}$ entre 6 e 8, com dosagens superiores a cerca de $30 \mathrm{mg} / \mathrm{L}$, tende a ocorrer a formação excessiva de precipitados (hidróxido de alumínio), de forma que as partículas coloidais são aprisionadas nos mesmos, caracterizando o mecanismo da varredura (do inglês, “sweep coagulation”), cuja região, delimitada pelos pares de valores dosagem de coagulante x pH de coagulação, é relativamente ampla para uma mesma eficiência de remoção de turbidez. A coagulação realizada nesse mecanismo é a recomendada quando se tem tratamento em ciclo completo, com coagulação, floculação e sedimentação antes da filtração, pois os flocos obtidos são facilmente removidos nos decantadores. Esse mecanismo de coagulação também tem sido adotado quando se tem a flotação em lugar da sedimentação para a clarificação da água. 
Este procedimento tem sido intensivamente utilizado no Brasil durante as duas últimas décadas por DI BERNARDO (1983, 1985), DI BERNARDO et al. (1987, 2000), MENDES (1989), MARINELLI (1999), DI BERNARDO (2000) e PAVANELLI (2001), dentre outros.

Com respeito ao diagrama de coagulação com alumínio para remoção de turbidez, algumas considerações importantes foram feitas por FAUST \& ALY (1998) e DI BERNARDO (2003), destacando-se:

- a região de reestabilização depende da superfície específica das partículas coloidais e foi delimitada por dosagens de sulfato de alumínio entre 2 e $30 \mathrm{mg} / \mathrm{L}$ e $\mathrm{pH}$ de coagulação entre 5,0 e 6,8, limites aplicáveis para águas com concentração relativamente baixa de partículas coloidais, o que geralmente ocorre com águas superficiais utilizadas como fonte de abastecimento. Para elevada concentração de colóides, são necessárias altas dosagens de coagulante, podendo desaparecer a região de reestabilização;

- concentrações relativamente altas de ânions, como fosfato $\left(\mathrm{PO}_{4}^{-3}\right)$, silicato $\left(\mathrm{SiO}(\mathrm{OH})_{3}{ }^{-3}\right)$, ou sulfato $\left(\mathrm{SO}_{4}^{-2}\right)$ podem suprimir a reversão de carga e a reestabilização; em águas naturais, concentrações do íon sulfato da ordem de 12 mg/L (como sulfato) têm causado tal fenômeno;

- concentração elevada de substâncias húmicas podem controlar o processo da coagulação, alterando as regiões delimitadas no diagrama;

- existe uma região no diagrama em que a coagulação é devida à combinação dos mecanismos de neutralização de carga pelo precipitado e varredura;

- não existe dosagem ótima de coagulante e tampouco pH ótimo de coagulação, termos geralmente usados na prática. Na verdade, existe um par de valores "dosagem de coagulante x pH de coagulação” considerado apropriado, que é selecionado levandose em conta alguns aspectos, tais como a não necessidade do uso de alcalinizante ou de acidificante, a turbidez remanescente, os custos com produtos químicos, etc. Para que isso fique realmente claro, considere-se a dosagem de sulfato de alumínio, igual a 10 mg/L; ao se variar o pH de coagulação de 7,5 para 6,2 e em seguida para 4,8, há alteração significativa no mecanismo de coagulação predominante, combinação de mecanismos, neutralização de cargas pelo precipitado e adsorção - neutralização de cargas, respectivamente. O mesmo pode-se dizer a respeito do $\mathrm{pH}$; considerando-se pH de coagulação constante e igual à cerca de 6,5, o mecanismo de coagulação dominante será o de neutralização de carga pelo precipitado para a dosagem de 
coagulante igual a $10 \mathrm{mg} / \mathrm{L}$, e da varredura para a dosagem de coagulante compreendida entre aproximadamente 30 e $100 \mathrm{mg} / \mathrm{L}$.

Evidentemente, o diagrama da Figura 3.11 corresponde a uma situação particular que ilustra o uso do diagrama de solubilidade do alumínio, pois as linhas que delimitam as diferentes regiões se alteram com as características da água. Com a relação à parte inferior da Figura 3.11, são fundamentais alguns esclarecimentos. O ponto isoelétrico (PIZ) para o hidróxido de alumínio encontra-se na faixa de $\mathrm{pH}$ compreendida entre 7 e 9, dependendo dos íons presentes na água (principalmente os ânions). Nessa Figura, foi admitido um valor de pH igual a 8 para o PIZ do hidróxido de alumínio, de forma que o precipitado se torna positivo ou negativo para valores de $\mathrm{pH}$ inferiores ou superiores a 8 , respectivamente.

Embora o comportamento do hidróxido de alumínio não possa ser considerado exatamente igual ao óxido de alumínio, os estudos de YOKOSAWA (2001) mostraram que o valor do PIZ desse óxido ocorre para $\mathrm{pH}$ igual a 8; a carga resultante pode ser positiva ou negativa para valores do $\mathrm{pH}$ inferiores ou superiores ao do $\mathrm{pH}$ do PIZ, respectivamente. A pesquisadora ressalta ainda que quando se tem somente alumina na água, o potencial zeta pode ser relacionado com a carga superficial “líquida” do óxido. Na Figura 3.12 é mostrada a variação do potencial zeta com o pH para o óxido de alumínio. No entanto, quando um eletrólito indiferente, como o cloreto de sódio é adicionado à água, há aumento da força iônica ocorrendo interações entre os íons do eletrólito e as superfícies do óxido de alumínio que contém sítios positivos, negativos e neutros e redução do $\mathrm{pH}$ para o ponto isoelétrico (ver Figura 3.13).

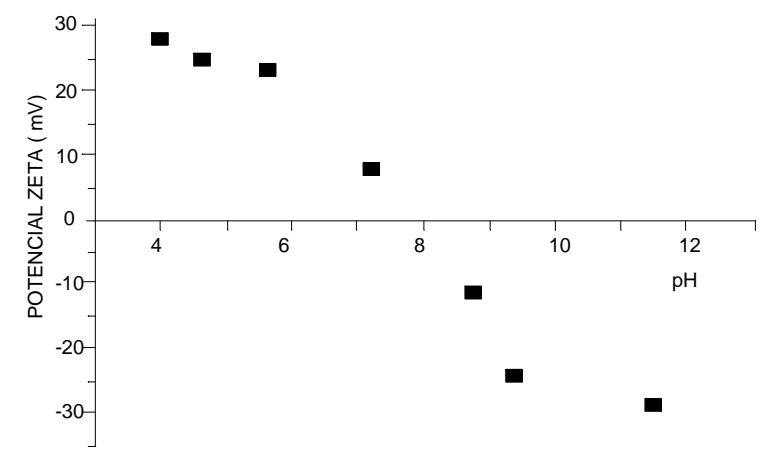

Figura 3.12 - Potencial zeta de uma suspensão de alumina em função do $\mathrm{pH}\left(\mathrm{t}=25{ }^{0} \mathrm{C}\right)$ -

Fonte:YOKOSAWA (2001) 


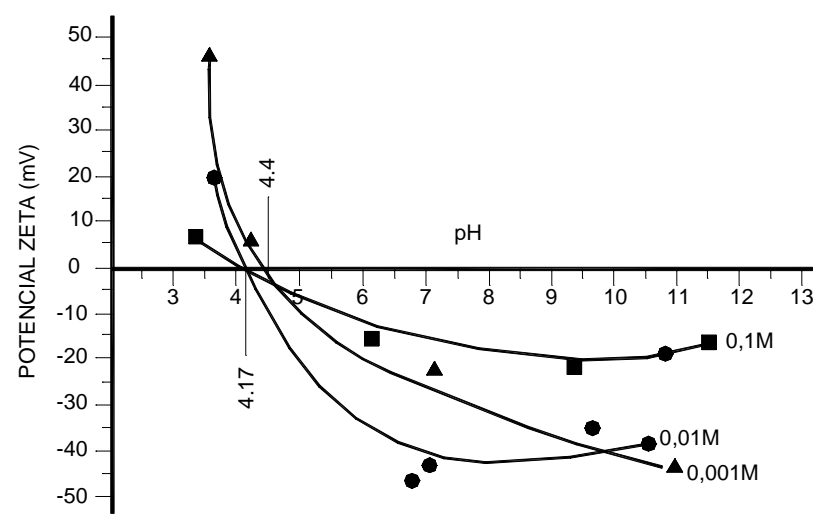

Figura 3.13 - Potencial zeta de uma suspensão de alumina em função do pH para diferentes forças iônicas ( $\left.\mathrm{t}=25^{0} \mathrm{C}\right)$ - Fonte:YOKOSAWA (2001)

Os principais resultados do trabalho realizado por BLACK \& HANNAH (1961) sobre a coagulação de águas sintéticas preparadas a partir de argilas minerais, são mostrados nos gráficos da Figura 3.14. Como mencionado anteriormente, a caulinita, a ilita e a montmorilonita são representantes das três maiores classes das argilas minerais. Elas apresentam carga negativa quando em meio aquoso, conforme ilustrado na Figura 3.14a; independente do $\mathrm{pH}$ estudado $(3,3<\mathrm{pH}<10)$, as águas apresentaram mobilidade eletroforética negativa.

$\mathrm{O}$ efeito da coagulação com $5 \mathrm{mg} / \mathrm{L}$ de sulfato de alumínio $\left(\mathrm{Al}_{2}(\mathrm{SO} 4)_{3} \times 14,3 \mathrm{H}_{2} \mathrm{O}\right)$ em função do pH na remoção de turbidez e na variação da mobilidade eletroforética das três águas estudadas são mostrados na Figura 3.14b. Os dados indicaram que uma pequena quantidade de sulfato de alumínio é suficiente para reverter a carga da caulinita para o pH de aproximadamente 5, enquanto que os flocos formados pelas outras duas argilas continuaram com carga negativa. Percebe-se na Figura 3.14c, que com a dosagem de $15 \mathrm{mg} / \mathrm{L}$ de sulfato de alumínio, houve reversão de cargas somente com a caulinita e com a ilita. Nas Figuras 3.14b e 3.14c observa-se também a faixa de $\mathrm{pH}$ em que ocorre a desestabilização. As três argilas coagularam na faixa de $\mathrm{pH}$ de 3,5 a 4,5 (partículas ligeiramente negativas). Com o aumento do $\mathrm{pH}$, houve reversão de cargas com a caulinita e com a ilita, região definida pela não formação de flocos. Por fim, os dados indicam que a região em que ocorre a melhor coagulação para as três argilas está compreendida na faixa de pH de 7,4 a 8,2.

Com $100 \mathrm{mg} / \mathrm{L}$ de sulfato de alumínio, dosagem para formação de flocos na varredura, ocorreu a desestabilização na faixa de $\mathrm{pH}$ de 3,5 a 4,5 (Figura 3.14d); com o aumento do $\mathrm{pH}$, houve reversão de cargas para valores positivos e posterior reestabilização 
para valores de pH entre 4,5 e 5,5. Com o aumento do pH, houve nova desestabilização para as três argilas, resultando os menores valores de turbidez residual até pH de 8,5.

Estes estudos demonstram que a neutralização de cargas não é o único fenômeno responsável pela eficiência da coagulação com o sulfato de alumínio para três argilas. Isto fica evidente na Figura 3.14c, onde os melhores resultados de remoção de turbidez foram obtidos para valores de $\mathrm{pH}$ entre 7,5 e 8,5, região em que a mobilidade eletroforética é negativa. Outra importante observação é o fato de serem necessários $100 \mathrm{mg} / \mathrm{L}$ de sulfato de alumínio para que houvesse a reversão de carga na montmorilonita (Figura 3.14d), enquanto que 15 mg/L foram suficientes para que ocorresse uma boa coagulação (Figura 3.14c).

Uma das primeiras aplicações do diagrama de coagulação do alumínio (Figura 3.11), após coagulação, floculação e sedimentação, foi realizada por AMIRTHARAJAH \& MILLS (1982) para estudar a influência das condições da mistura rápida na remoção de turbidez, utilizando água preparada com caulinita (turbidez $=17$ a $27 \mathrm{uT}$; alcalinidade $=80 \mathrm{mg}$ $\mathrm{CaCO}_{3} / \mathrm{L}$ ) e coagulando a água com sulfato de alumínio PA, $\mathrm{Al}_{2}(\mathrm{SO} 4)_{3} \times 16 \mathrm{H}_{2} \mathrm{O}$ (dosagens compreendidas entre 1 e $40 \mathrm{mg} / \mathrm{L}$ e valores do $\mathrm{pH}_{\text {coag }}$ entre 4 e 9), procurando, dessa forma, cobrir as diferentes regiões do diagrama da Figura 3.11. Foram testadas três condições diferentes de mistura rápida: a) agitador de lâmina plana com gradiente de velocidade médio (Gmr) de $300 \mathrm{~s}^{-1}$ e tempo de mistura rápida (Tmr) igual a $60 \mathrm{~s}$; b) agitador de hélice com $\mathrm{Gmr}=1.000 \mathrm{~s}^{-1}$ e Tmr $=20 \mathrm{~s}$; c) um misturador tipo hélice helicoidal com Gmr $\cong 16.000 \mathrm{~s}^{-1}$ e tempo $T m r=1 \mathrm{~s}$. Após a mistura rápida, a água coagulada era floculada com gradiente de velocidade médio de floculação (Gfloc) igual a $25 \mathrm{~s}^{-1}$ e tempo de floculação (Tfloc) de 20 min, sendo a turbidez do sobrenadante medida em intervalos de 15 min por um período de 2 h. Na Figura 3.15 são mostrados os principais resultados do trabalho realizado, nas quais, além da turbidez remanescente em função do tempo de sedimentação para as três condições de mistura rápida, são apresentados os valores do $\mathrm{pH}$ de coagulação, da dosagem de sulfato de alumínio e da mobilidade eletroforética (ME) ou velocidade de eletroforese (VE), a partir da qual se pode calcular o potencial zeta (existe relação direta entre a ME ou VE e o PZ). 

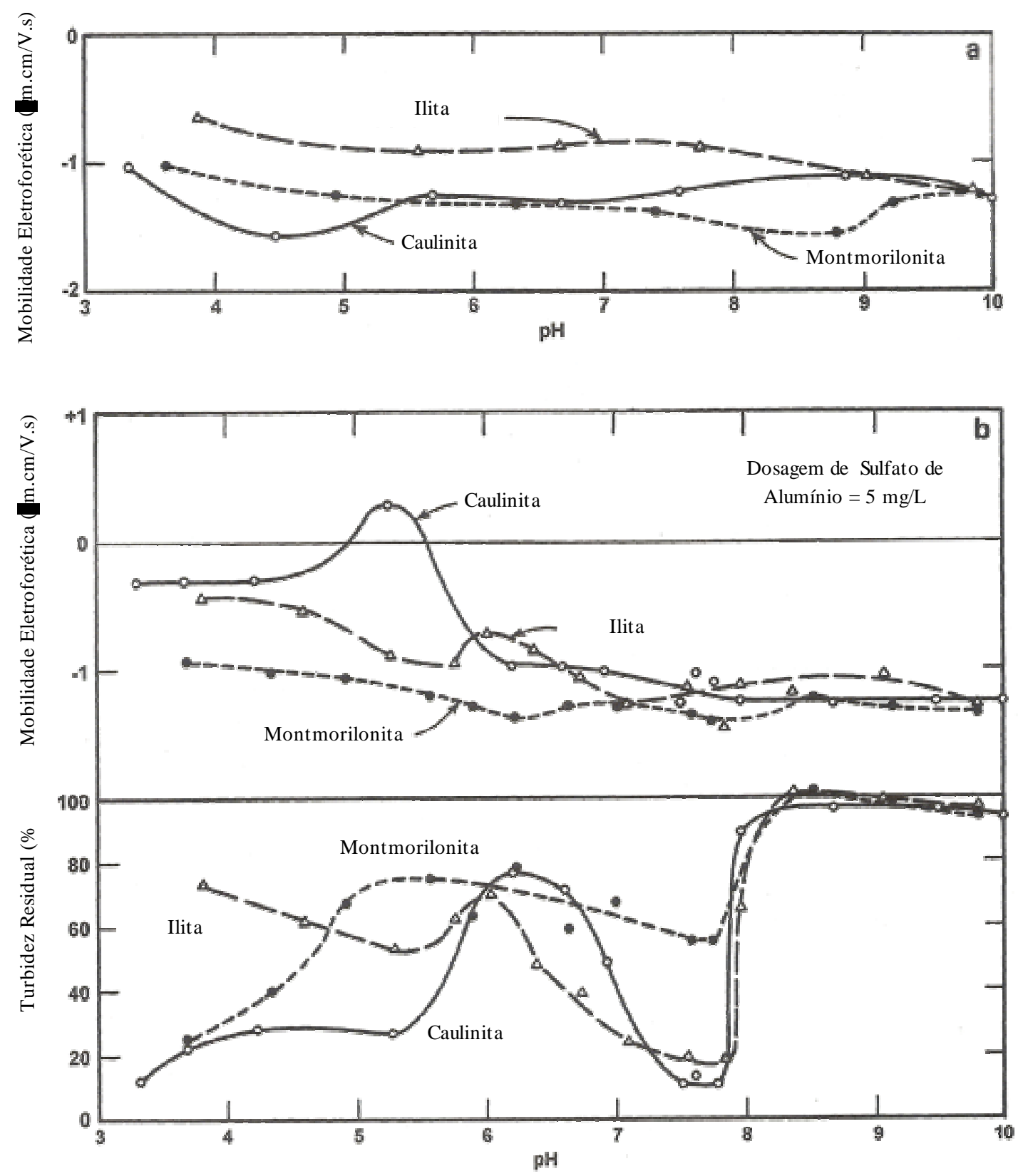

Figura 3.14 - Coagulação de águas sintéticas com sulfato de alumínio - Fonte: BLACK \& HANNAH (1961) 

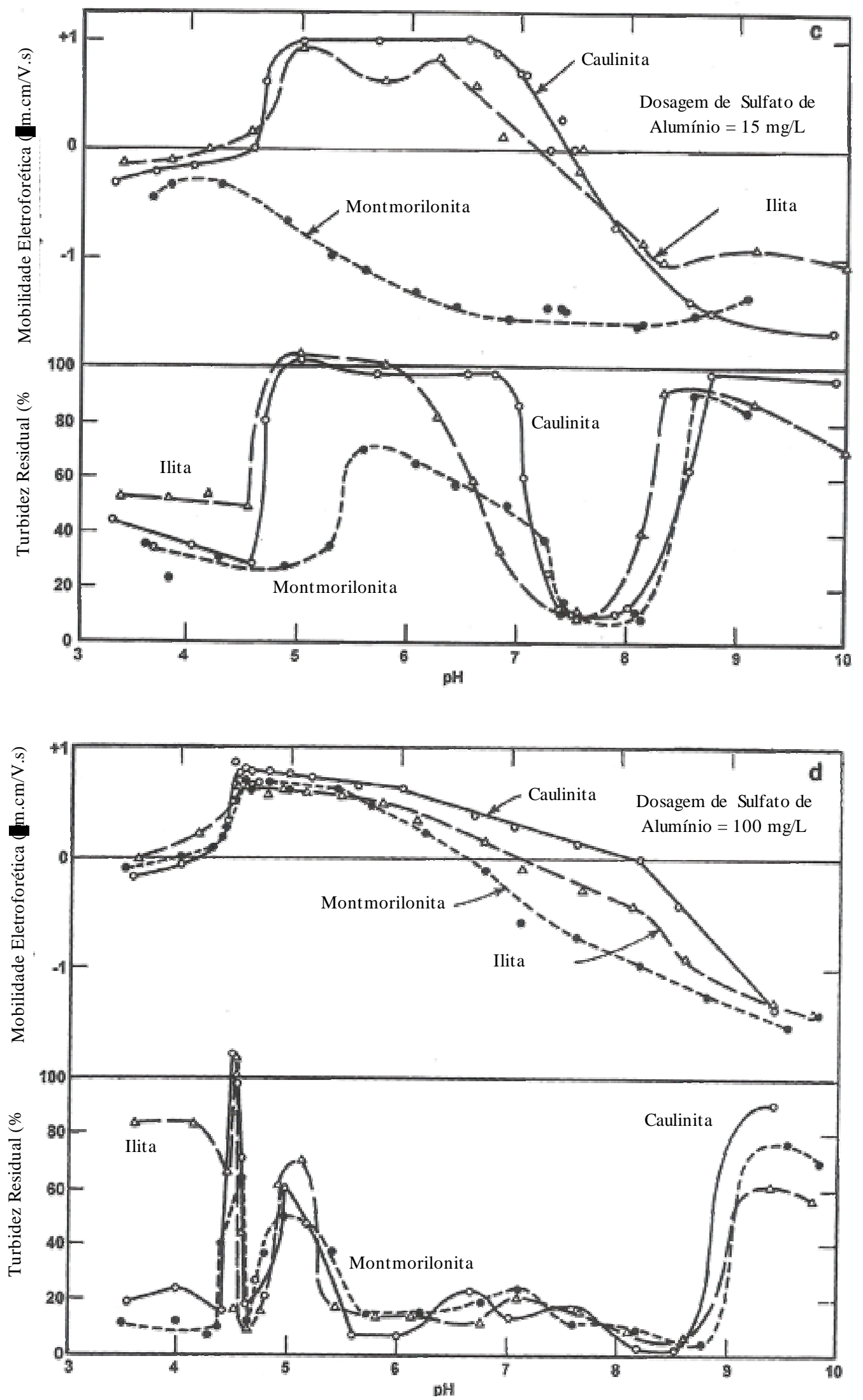

Figura 3.14 - Continuação 


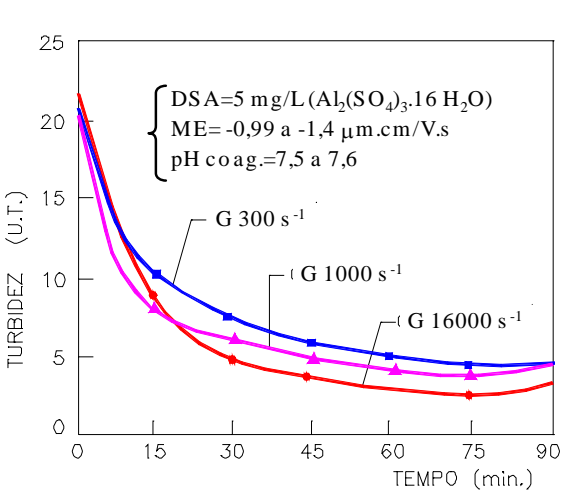

A - NEUTRALIZAÇÃO + VARREDURA

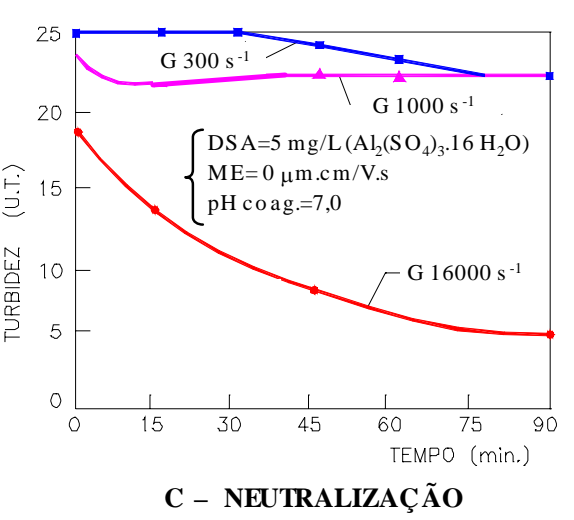

C - NEUTRALIZAÇ ÃO

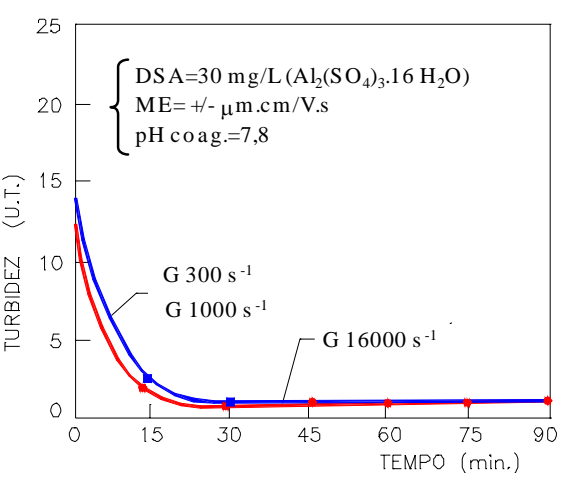

E- VARREDURA

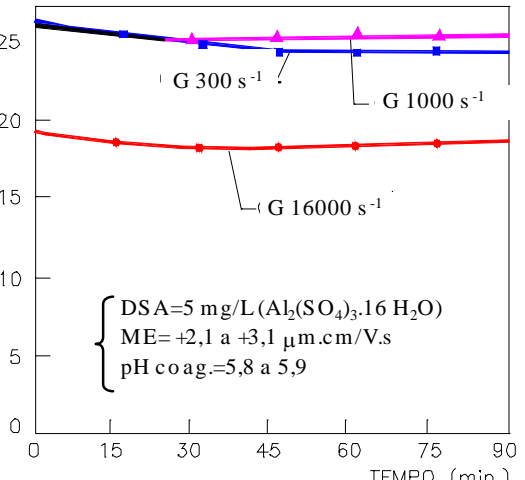

B - REESTABILIZAÇ Ão

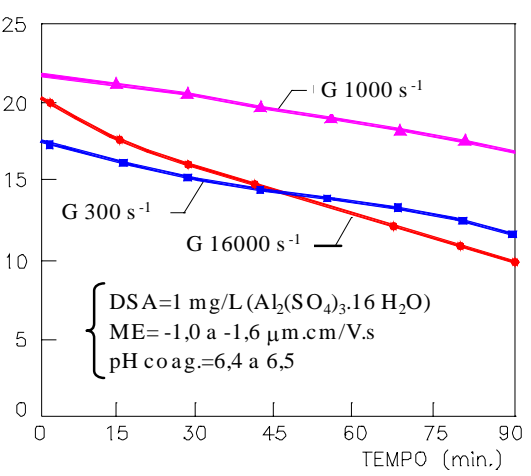

D - NEUTRALIZAÇÃo

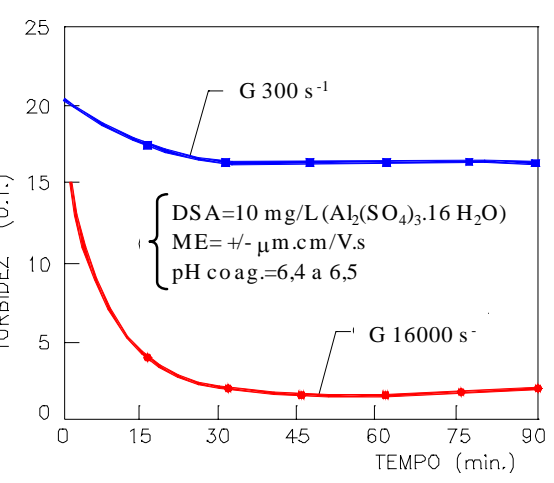

F - NEUTRALIZAÇÃo

Figura 3.15 - Influência das condições da mistura rápida e do mecanismo de coagulação na remoção de turbidez por sedimentação - Fonte: AMIRTHARAJAH \& MILLS (1982)

Dentre as principais conclusões do trabalho realizado por AMIRTHARAJAH \& MILLS (1982), destacam-se:

- tanto na região de coagulação com predomínio do mecanismo de varredura (Figura 3.15E) quanto da combinação (Figura 3.15A), houve pouca influência de Gmr, 
embora a turbidez final resultasse menor para coagulação no mecanismo de varredura;

- a elevada intensidade de mistura rápida $\left(\mathrm{Gmr}=16000 \mathrm{~s}^{-1}\right.$, Tmr $\left.=1 \mathrm{~s}\right)$ resultou em significativa diferença, somente na região corona ao redor da zona de reestabilização, onde predomina o mecanismo de neutralização (Figura 3.15C e 3.15F);

- na região de reestabilização (Figura 3.15B), não houve diferenças substanciais na coagulação, associadas às condições de mistura rápida;

- pela Figura 3.14D, observa-se que na região de neutralização abaixo da zona de reestabilização, caracterizada pelas baixas dosagens de $\mathrm{Al}_{2}(\mathrm{SO} 4)_{3} \times 16 \mathrm{H}_{2} \mathrm{O}$;

- a remoção de turbidez por coagulação pela varredura é consideravelmente maior que a coagulação por neutralização de cargas, após floculação e sedimentação, evidenciando a intrínseca relação entre o mecanismo de coagulação e o tipo de tecnologia de tratamento; uma vez mais é possível verificar que a coagulação pela varredura conduz à formação de flocos que sedimentam com maior velocidade que aqueles obtidos com a coagulação realizada no mecanismo de neutralização de cargas.

Na Figura 3.16 tem-se o diagrama de coagulação para remoção de turbidez por coagulação, floculação e sedimentação em equipamento de jarteste, em que o sulfato de alumínio utilizado encontrava-se na forma $\mathrm{Al}_{2}\left(\mathrm{SO}_{4}\right)_{3}$ x $18 \mathrm{H}_{2} \mathrm{O}$. A água de estudo, preparada em laboratório com água destilada, substâncias húmicas e caulinita, apresentava as seguintes características: turbidez $=200 \mathrm{uT}$; cor verdadeira $=5 \mathrm{uH}$; alcalinidade $=30 \mathrm{mg} \mathrm{CaCO}_{3} / \mathrm{L}$; temperatura $=20{ }^{\circ} \mathrm{C}$; condutividade elétrica $=72 \mu \mathrm{S} / \mathrm{cm} ; \mathrm{pH}=7,5$. Para proporcionar a variação do pH de coagulação foi usado ácido clorídrico ou hidróxido de sódio. No diagrama de solubilidade do alumínio foram marcados os pontos de mesma turbidez remanescente correspondente a cada par de valores dosagem de sulfato de alumínio x pH de coagulação (DSA x pHcoag), após mistura rápida (Gmr $=900 \mathrm{~s}^{-1}, \mathrm{Tmr}=2 \mathrm{~s}$ ), floculação (Gfloc $=30 \mathrm{~s}^{-1}$, Tfloc= $20 \mathrm{~min}$ ) e sedimentação (Vs $=2 \mathrm{~cm} / \mathrm{min}$ ). Por meio de interpolação gráfica, foram traçadas as curvas de mesma turbidez remanescente, expressas em porcentagem da turbidez inicial (MENDES, 1989).

É evidente na Figura 3.16, a existência de duas regiões distintas em que foram conseguidos resultados satisfatórios: região A, com remoção de turbidez superior a $80 \%$, para valores de pHcoag entre 4,6 e 5,0 e dosagens de sulfato de alumínio entre 8 e $12 \mathrm{mg} / \mathrm{L}$, em que há predominância de espécies hidrolisadas de alumínio com carga positiva; Região B, com remoção de turbidez superior a $95 \%$, para valores de pHcoag entre 6,4 e 7,8 e 
dosagens de sulfato de alumínio entre 40 e 80 mg/L, com predominância do precipitado de alumínio. Na região A, pode-se dizer que o mecanismo de adsorção e neutralização de carga foi o principal mecanismo de coagulação, enquanto, na região B, a coagulação ocorreu devido ao mecanismo da varredura.

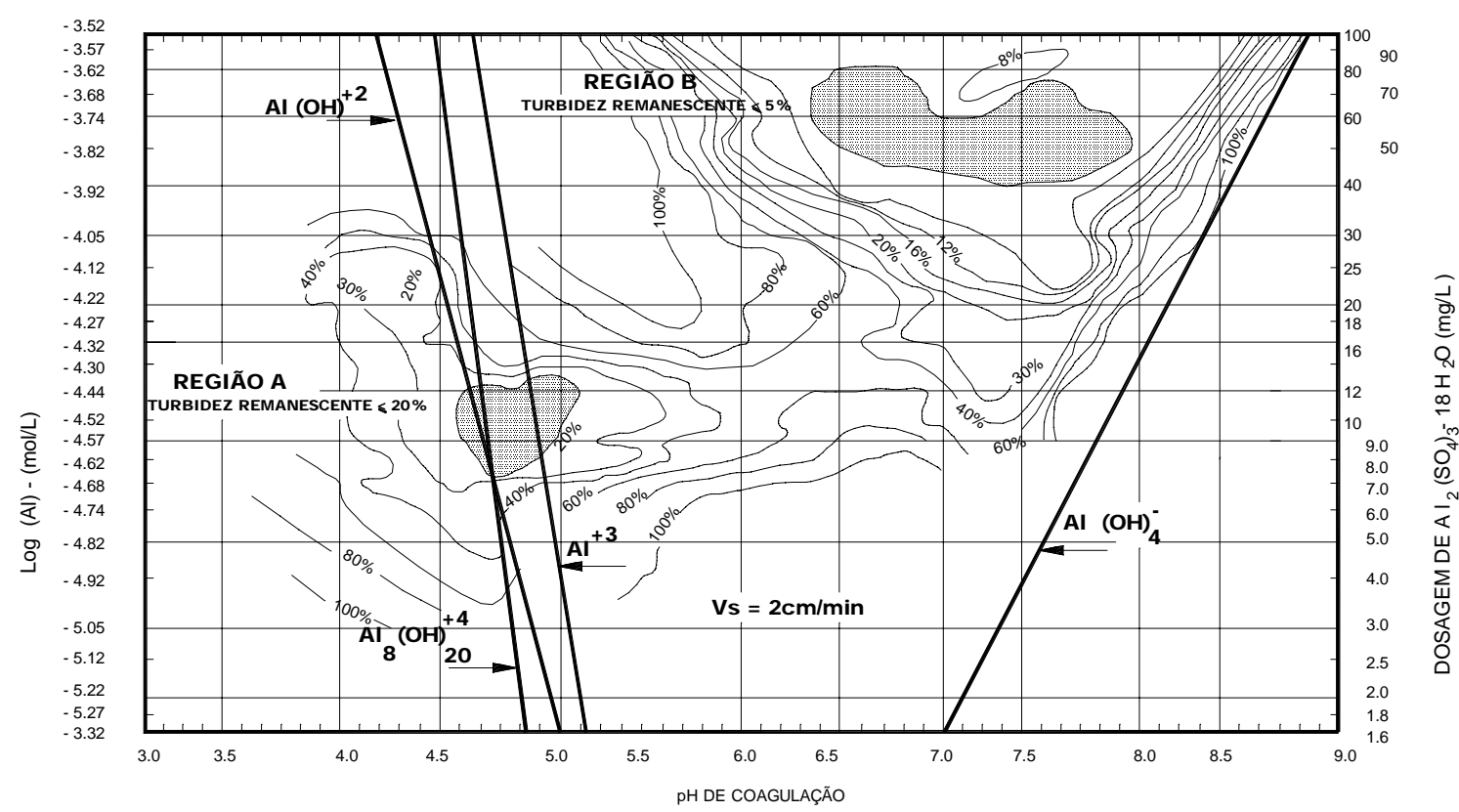

Figura 3.16 - Turbidez remanescente em função da dosagem de sulfato de alumínio e do pH de coagulação (Água com turbidez elevada) - Fonte: MENDES (1989)

Quando a coagulação é realizada para posterior floculação e remoção de flocos por sedimentação ou flotação, o mecanismo da varredura é, sem dúvida, o mais apropriado, pois a remoção é significativamente maior que aquela obtida com o mecanismo de adsorção e neutralização de carga. Com amostras da água coagulada sob diferentes condições (coletadas imediatamente após a mistura rápida), foi observado, em equipamento especial, que a ME resultava positiva ou negativa, o que permitiu a construção da Figura 3.17. Nota-se que as regiões de coagulação A e B da Figura 3.16 passam pela curva dos pontos isoelétricos mostrada na Figura 5.17 (MENDES, 1989). 


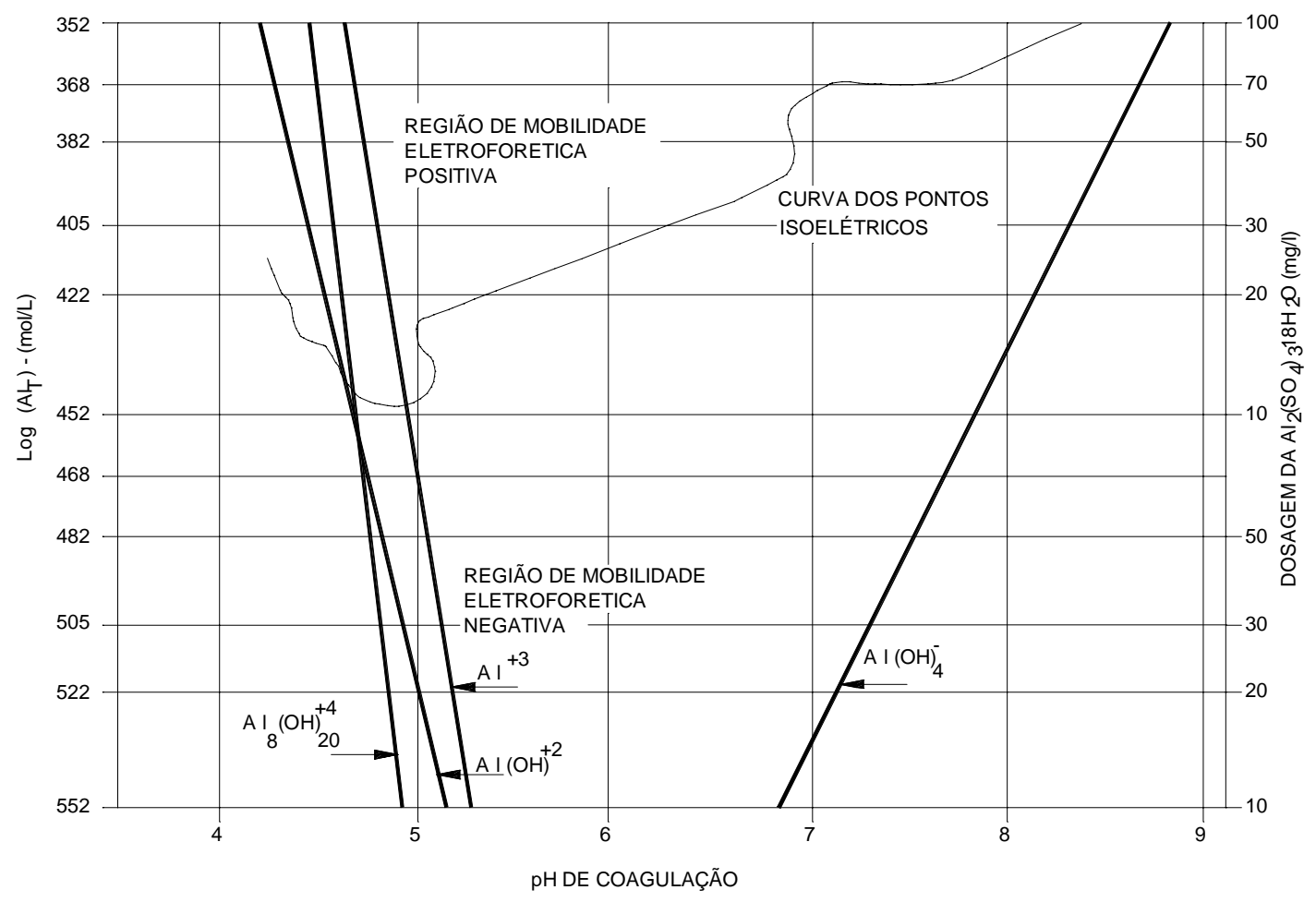

Figura 3.17 - Diagrama de coagulação do alumínio - Mobilidade eletroforética em função da dosagem de sulfato de alumínio e do pH de coagulação (Água com turbidez elevada) - Fonte: MENDES (1989)

Diagramas de coagulação semelhantes ao da Figura 3.16 são obtidos sempre que a turbidez seja relativamente alta se comparada à cor verdadeira, como mostrado na Figura 3.18, para água preparada em laboratório, com as seguintes características: $\mathrm{pH}=7,0$; turbidez $=50 \mathrm{uT}$; cor verdadeira $=20 \mathrm{uH}$; cor aparente $=340 \mathrm{uH}$; alcalinidade $=30 \mathrm{mg}$ $\mathrm{CaCO}_{3} / \mathrm{L}$ (MENDES, 1989).

Na Figura 3.19 tem-se o diagrama de coagulação de água natural com as seguintes características: $\mathrm{pH}=6,8$; turbidez $=160 \mathrm{uT}$; cor verdadeira $=30 \mathrm{uH}$; alcalinidade $=15 \mathrm{mg}$ $\mathrm{CaCO}_{3} / \mathrm{L}$. Como foi usado sulfato de alumínio sólido comercial, sem se conhecer o teor de alumina, não foram traçadas as linhas que representam as espécies hidrolisadas de alumínio. Observa-se que apenas se obteve a região de coagulação por varredura, por tratar-se de água bruta afluente a uma estação de tratamento em ciclo completo que, geralmente, apresenta turbidez superior a 30 uT (MENDES, 1989). 


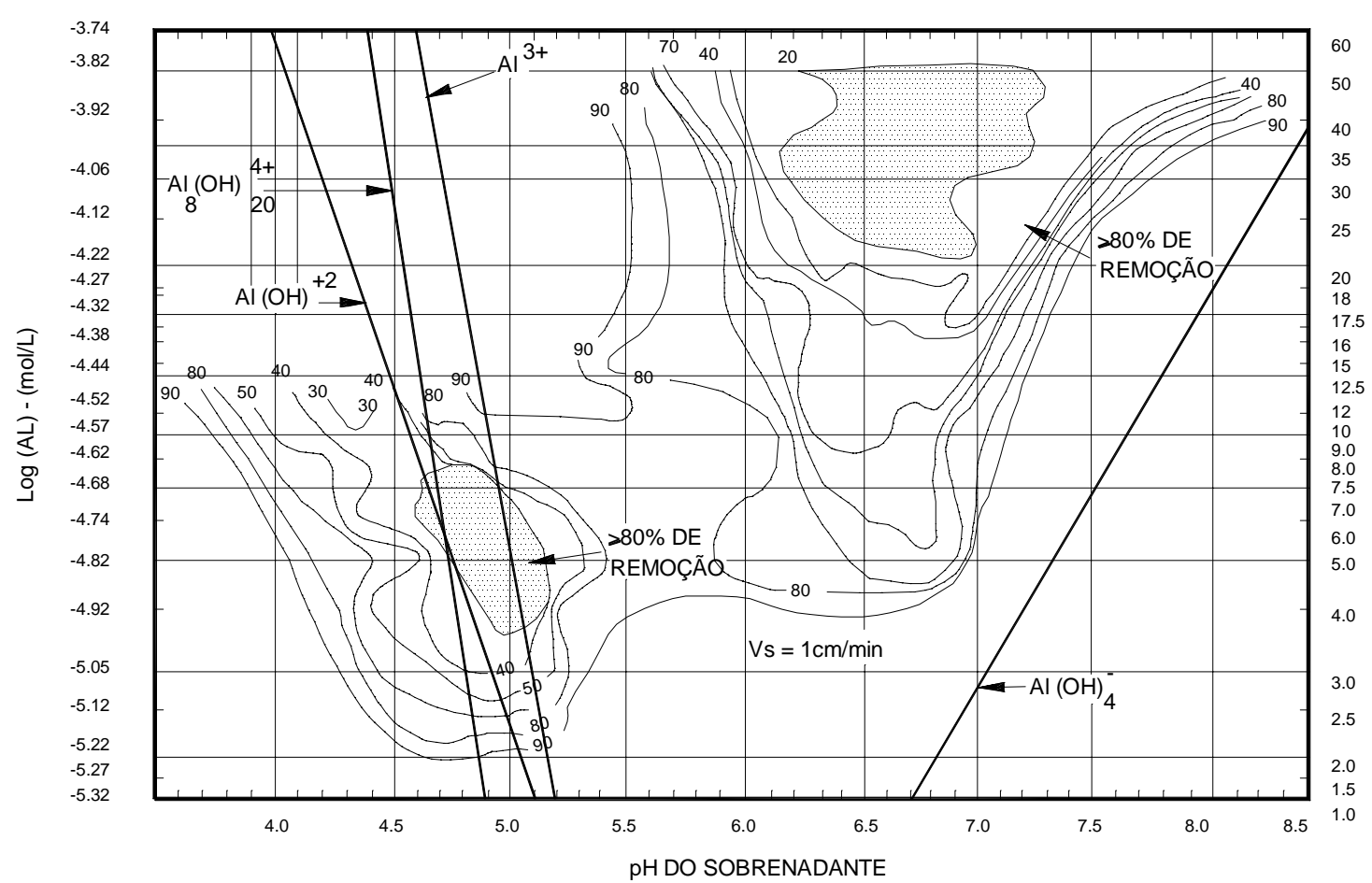

Figura 3.18 - Diagrama de coagulação do alumínio - Turbidez remanescente em função da dosagem de sulfato de alumínio e do pH - Fonte: MENDES (1989)

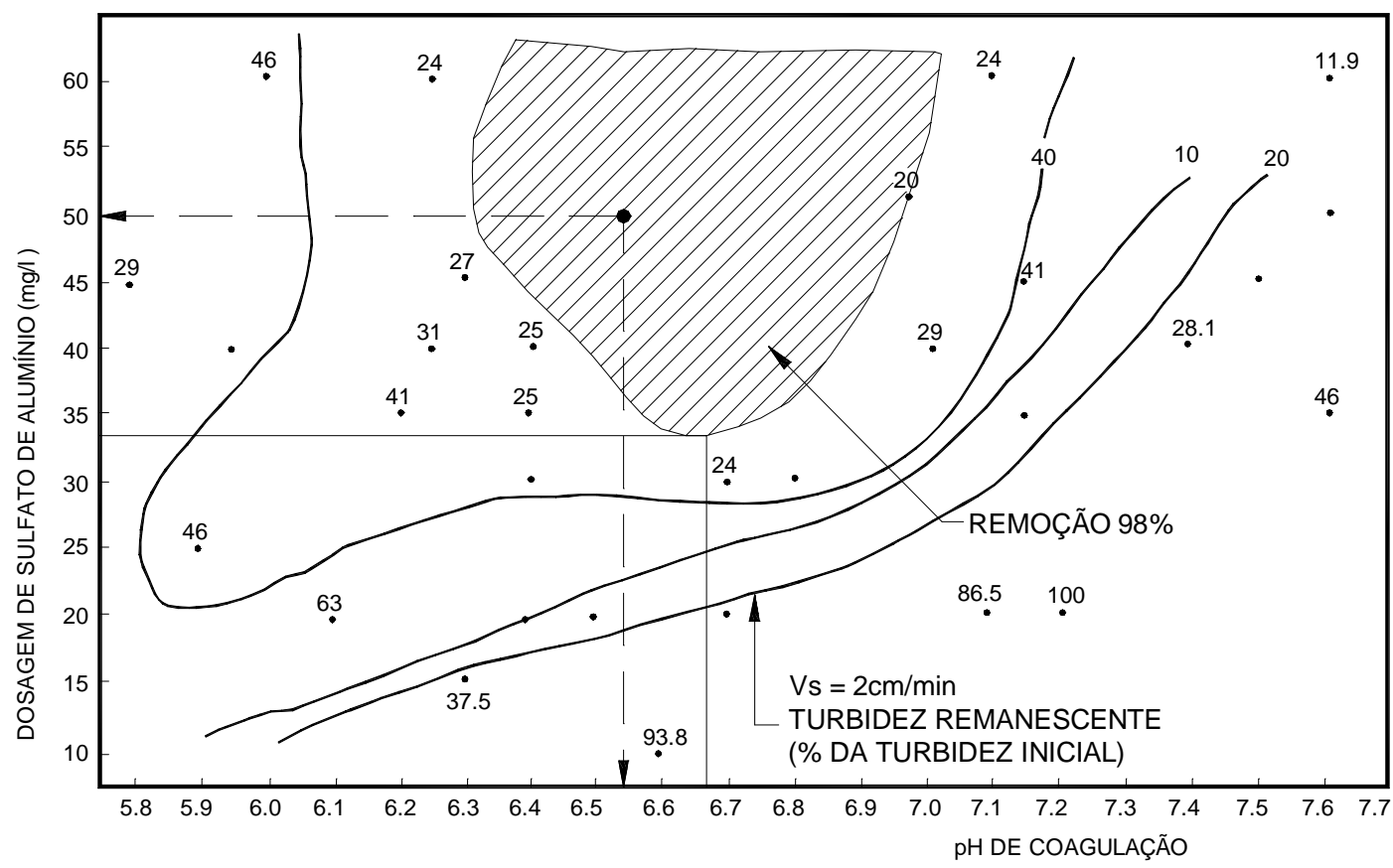

Figura 3.19 - Diagrama de coagulação de água natural utilizando sulfato de alumínio (mecanismo de varredura) - Fonte: MENDES (1989) 
Na Tabela 3.3 são apresentados dados do trabalho realizado por WILLIAMS (1965) com 12 amostras de água de diferentes mananciais, submetidas à mesma dosagem de sulfato de alumínio, de aproximadamente $40 \mathrm{mg} / \mathrm{L}\left(\mathrm{Al}_{2}(\mathrm{SO} 4)_{3} \times 14,3 \mathrm{H}_{2} \mathrm{O}\right)$. Como se pode observar na Tabela 3.3, algumas amostras de água coaguladas apresentaram potencial zeta negativo e outras positivo, de forma que é difícil afirmar que a coagulação necessariamente precisa ser efetuada com potencial zeta próximo de zero. Ademais, com as amostras 8 e 9, as águas coaguladas correspondentes tiveram seu potencial zeta pouco alterado pela adição de sulfato de alumínio, o que deve ter contribuído para a produção de água filtrada com turbidez relativamente alta.

Tabela 3.3 - Valores do potencial zeta das amostras de água bruta de diferentes mananciais e após coagulação com 40 mg/L de sulfato de alumínio - Fonte: WILLIAMS (1965)

\begin{tabular}{|c|c|c|c|c|c|c|c|c|c|}
\hline \multirow[t]{2}{*}{ Amostra } & \multicolumn{5}{|c|}{ Água Bruta } & \multicolumn{3}{|c|}{ Água Coagulada } & \multirow{2}{*}{$\begin{array}{c}\text { Água } \\
\text { Filtrada } \\
\text { Turbidez } \\
\text { (uT) }\end{array}$} \\
\hline & $\mathrm{pH}$ & $\begin{array}{c}\text { CE } \\
(\mu \mathrm{S} / \mathrm{cm})\end{array}$ & $\begin{array}{c}\text { Turbidez } \\
\text { (uT) }\end{array}$ & $\begin{array}{c}\mathrm{ME} \\
(\mu \mathrm{m} . \mathrm{cm} / \mathrm{sV})\end{array}$ & $\begin{array}{c}\mathrm{PZ} \\
(\mathrm{mV})\end{array}$ & $\begin{array}{c}\mathrm{ME} \\
(\mu \mathrm{m} . \mathrm{cm} / \mathrm{sV})\end{array}$ & $\begin{array}{c}\mathrm{PZ} \\
(\mathrm{mV})\end{array}$ & $\mathrm{pH}$ & \\
\hline 1 & 7,9 & 71,4 & 10 & $-1,55$ & $-18,9$ & $+1,09$ & $+14,0$ & 6,9 & 0,5 \\
\hline 2 & 7,8 & 92,6 & 10 & $-1,47$ & $-19,1$ & $+1,14$ & $+14,8$ & 6,7 & 0,8 \\
\hline 3 & 7,7 & 78,7 & 12 & $-1,32$ & $-17,2$ & $+1,03$ & $+13,4$ & 6,6 & 0,5 \\
\hline 4 & 7,7 & 83,3 & 10 & $-1,04$ & $-13,5$ & $+1,16$ & $+14,1$ & 6,5 & 0,5 \\
\hline 5 & 8,2 & 250,0 & 20 & $-1,32$ & $-17,2$ & $-0,37$ & $-4,8$ & 7,1 & 0,5 \\
\hline 6 & 8,5 & 357,1 & 10 & $-1,41$ & $-18,3$ & $-0,47$ & $-6,1$ & 7,2 & 0,1 \\
\hline 7 & 8,0 & 156,2 & 8 & $-1,36$ & $-17,7$ & $-0,29$ & $-3,8$ & 7,1 & 0,5 \\
\hline 8 & 7,6 & 285,7 & 8 & $-1,43$ & $-18,6$ & $-1,14$ & $-14,8$ & 7,1 & 1,5 \\
\hline 9 & 7,4 & 294,1 & 12 & $-1,57$ & $-20,4$ & $-1,53$ & $-19,9$ & 7,1 & 2,5 \\
\hline 10 & 7,5 & 94,3 & 10 & $-1,70$ & $-22,1$ & $+0,85$ & $+11,0$ & 6,6 & 0,5 \\
\hline 11 & 7,9 & 133,3 & 6 & $-2,09$ & $-27,2$ & $+0,68$ & $+8,8$ & 6,7 & 0,5 \\
\hline 12 & 8,6 & 357,1 & 8 & $-1,53$ & $-18,9$ & $-0,80$ & $-10,4$ & 7,3 & 0,1 \\
\hline
\end{tabular}

Além do potencial zeta da água bruta, outras características podem afetar a coagulação, destacando-se a condutividade elétrica, o pH, a temperatura, etc. A influência do pH de coagulação no potencial zeta pode ser visto na Figura 3.20, na qual se tem o potencial zeta em função da dosagem de sulfato de alumínio, mantendo-se constante, mediante o uso de hidróxido de sódio ou de ácido clorídrico, o pH de coagulação em 8,2 ou 6,0.

Observa-se, para uma mesma dosagem de sulfato de alumínio, por exemplo, igual a $25 \mathrm{mg} / \mathrm{L}$, que para o pH de coagulação igual a 6,0, o valor de $\mathrm{PZ}$ resulta ligeiramente positivo, enquanto, para o pH de coagulação igual 8,2, o valor de PZ resulta aproximadamente $-12 \mathrm{mV}$. Esse comportamento é decorrente da predominância de espécie 
hidrolisada $\mathrm{Al}(\mathrm{OH})_{4}^{-}$em valores maiores do $\mathrm{pH}$ de coagulação, concorrendo para que a coagulação resulte ineficiente. Também, não se deve esquecer do mecanismo de coagulação, o qual deve ser selecionado em função da tecnologia de tratamento, pois, como visto na Figura 3.11, para a mesma dosagem de coagulante, obtém-se PZ próximo de zero em dois valores distintos do $\mathrm{pH}$ de coagulação.

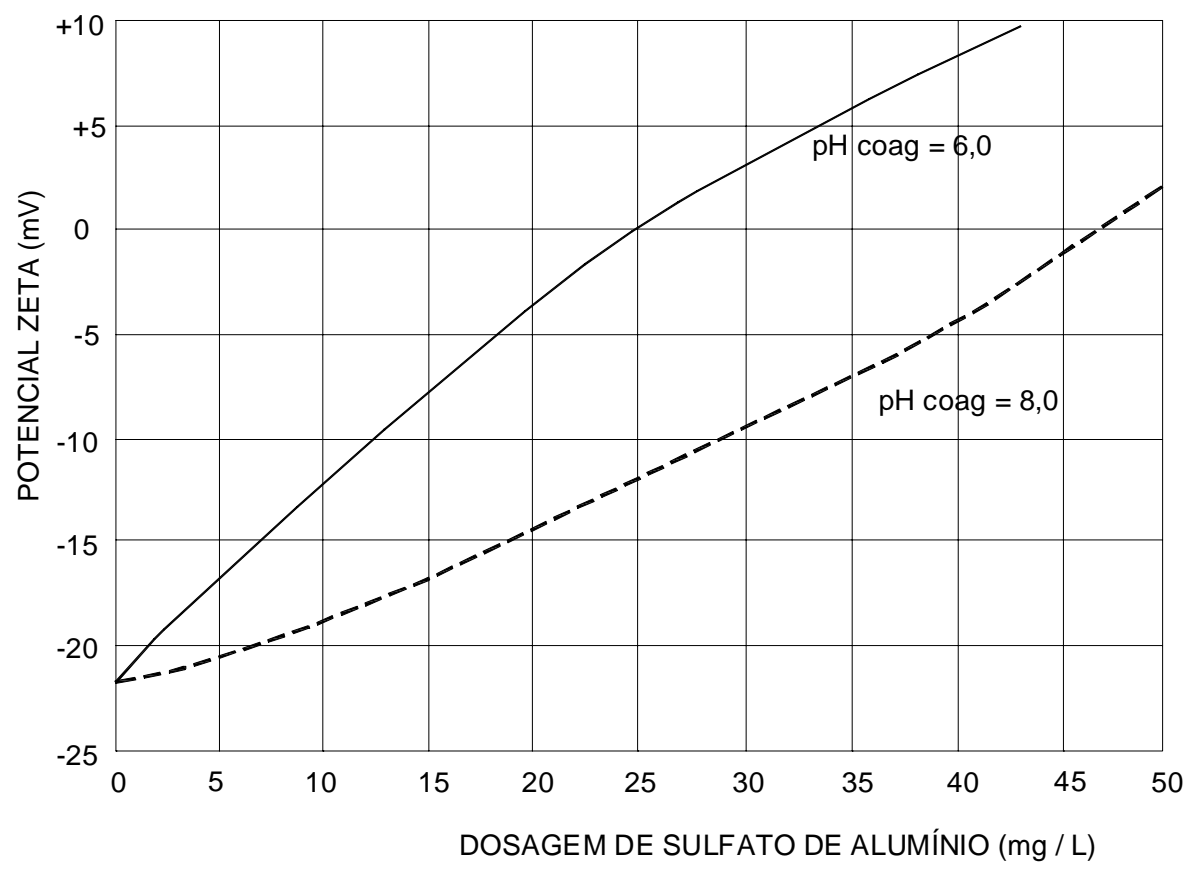

Figura 3.20 - Variação do potencial zeta em função da dosagem de sulfato de alumínio para dois valores constantes do pH de coagulação - Fonte: WILLIAMS (1965)

\subsubsection{Influência da coagulação na filtração direta}

WAGNER \& HUDSON (1982), ao avaliar dados operacionais de diversas estações de filtração direta de vários países, inclusive do Brasil, detectaram o enorme potencial de se trabalhar com baixas dosagens de coagulante na filtração direta ascendente. Aqueles pesquisadores julgaram que os resultados práticos por eles levantados, particularmente quanto à efetiva desestabilização de partículas com dosagens baixas de sulfato de alumínio, pareciam consistentes com o diagrama de coagulação, apresentado por AMIRTHARAJAH \& MILLS (1982).

Uma importante contribuição dada por WAGNER \& HUDSON (1982) foi a apresentação de um ensaio simples de bancada utilizando o aparelho de jarteste para uma avaliação rápida da potencialidade de determinada água ser tratada por filtração direta descendente. Os resultados assim obtidos foram compatíveis com os obtidos em estudos em escala piloto e protótipos, com economia de tempo e de recursos. O teste de bancada é 
aplicado para identificar as dosagens mínimas necessárias para a coagulação de forma a produzir uma água com baixa turbidez após a mesma ser filtrada em filtro de papel padrão de laboratório (Whatman 40). No entanto, o melhor coagulante, o polímero mais efetivo, a dosagem ótima, a seqüência de aplicação, a intensidade e tempo de mistura ideais devem ser obtidos em instalação piloto de escoamento contínuo. A técnica recomendada pelos autores dura de 2 a 3 minutos, e o papel deve ser usado apenas uma vez e descartado. Segundo os autores, quando a dosagem requerida para obter água filtrada com baixa turbidez é inferior a 6 ou 7 mg/L com adição de pequena dosagem de polímero, então a água bruta tem o potencial de ser tratada por filtração direta descendente.

DI BERNARDO (1985), com base no trabalho de WAGNER \& HUDSON (1982), procurou avaliar a potencialidade do emprego da filtração direta ascendente para água proveniente de represa, cujas características favoreciam a aplicação da técnica. Foram realizados testes de bancada com a filtração em filtro de papel Whatman 40 e também ensaios em instalação piloto. Os resultados mostraram que havia uma consistência dos dados quando se comparava a turbidez da água filtrada obtida pelos dois métodos, sendo que, após decorridos cerca de 30 minutos de filtração na instalação piloto, os resultados obtidos eram melhores ou iguais àqueles em filtro de papel.

Num trabalho de campo realizado na estação de tratamento de água de São Carlos ETASC, MENDES (1985), utilizando instalação piloto de filtração direta ascendente, comprovou o melhor desempenho dos filtros quando se aplicava uma dosagem de sulfato de alumínio menor do que aquela adotada em escala real em ciclo completo. Foram operados dois filtros em paralelo, e, num deles, era realizada a filtração com a aplicação de água coagulada na ETASC, e no outro, era usada água coagulada com dosagem menor de sulfato de alumínio (redução de 25, 50 e 75\% na dosagem da ETASC). As principais conclusões foram: a) a duração das carreiras era inversamente proporcional à dosagem de sulfato de alumínio utilizada; b) as dosagens utilizadas em estações de tratamento convencionais não são ideais para o tratamento de filtração direta ascendente, pois as carreiras de filtração resultam muito reduzidas, devido à ocorrência prematura do transpasse de sólidos; c) o valor do pH de coagulação que otimiza a eficiência do sistema estudado é inferior ao comumente utilizado para condições ótimas de coagulação em sistemas convencionais, podendo-se, em função da alcalinidade da água bruta, eliminar a utilização de cal no processo de coagulação.

AMIRTHARAJAH (1989) apresentou resultados obtidos num estudo em escala piloto, no qual, mais uma vez, comprovou a validade do uso do diagrama de coagulação como ferramenta para obtenção das condições ideais de $\mathrm{pH}$ e dosagem de sulfato de alumínio em estações de filtração direta descendente. A instalação, com filtro de camada dupla, foi 
operada com taxa de $320 \mathrm{~m}^{3} / \mathrm{m}^{2}$.d. Os resultados estão apresentados na Figura 3.21 para dosagens de sulfato de alumínio iguais a 5 e $8 \mathrm{mg} / \mathrm{L}$. As profundidades indicadas são aquelas em que foram coletadas amostras da água ao longo do filtro. As variáveis pesquisadas foram o pH e a dosagem. A turbidez indicada é a da água filtrada após 7 horas de funcionamento. Na referida figura também foram colocadas faixas do diagrama de coagulação do sulfato de alumínio, delimitando as regiões de neutralização de cargas e de reestabilização correspondentes a cada dosagem específica utilizada. Na Figura 3.21a é mostrado que a maior eficiência na filtração para a dosagem de 5 mg/L ocorreu para pH entre 6,9 e 7,0, correspondente à região corona de neutralização de cargas. Verifica-se na Figura 3.21b que, para uma dosagem maior (8 mg/L), a região de maior eficiência na filtração ampliou-se para a faixa de pH de 6,9 a 7,1, mas permaneceu coincidente com a região de neutralização de cargas. O autor verificou também, a partir de dados relatados na literatura, que a maioria das estações de filtração direta operavam com dosagens de sulfato de alumínio na faixa de 2 a 20 mg/L e pH entre 6,5 e 7,5, caindo no domínio que corresponde à região de neutralização de cargas com adsorção das espécies hidrolisadas de alumínio às partículas.

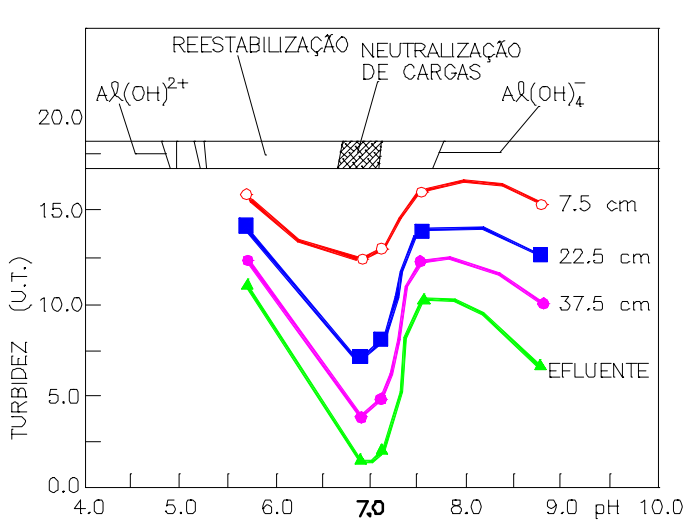

a) $\mathrm{DSA}=5 \mathrm{mg} / \mathrm{L}$

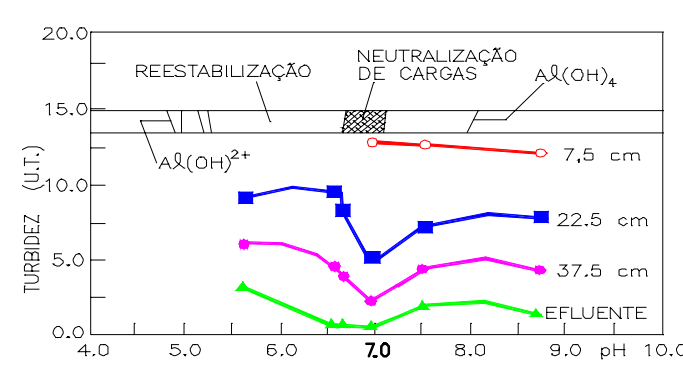

b) $\mathrm{DSA}=8 \mathrm{mg} / \mathrm{L}$

Figura 3.21 - Turbidez da água filtrada em função do pH para as dosagens de 5 e 8 mg/L de sulfato de alumínio - Fonte: AMIRTHARAJAH (1989)

Para superar algumas das limitações da pré-filtração em pedregulho com escoamento horizontal - PFHP, para tratamento posterior com filtração lenta ou rápida, e torná-la mais adequada à aplicação urbana, AHSAN et al. (1996a) investigaram, em instalação piloto, a aplicação de coagulante químico antecedendo a PFHP. Esse processo modificado é denominado de filtração direta em pedregulho com escoamento horizontal - FDHP. Os autores realizaram ensaios em jarteste para obtenção de um diagrama de coagulação similar ao apresentado por AMIRTHARAJAH \& MILLS (1982), porém para água com turbidez elevada (200 uT). 
Na Tabela 3.4 e Figura 3.22 são apresentados os resultados dos ensaios de FDHP (taxa de filtração de $120 \mathrm{~m}^{3} / \mathrm{m}^{3}$.d e comprimento do FDHP de 8,0 m) em que foi variada a dosagem de coagulante para o pH de 8,1. Na Tabela 3.5 e Figura 3.23 são apresentados os resultados dos ensaios de FDHP (taxa de filtração de $120 \mathrm{~m}^{3} / \mathrm{m}^{3}$.d e comprimento do FDHP de 8,0 m) em que foi variado o pH de coagulação para a dosagem de alumínio de $1 \mathrm{mg} / \mathrm{L}$.

Com base no diagrama de coagulação obtido por AHSAN et al. (1996a) e na Figura 3.11, os mesmos concluíram que para a dosagem de $2 \mathrm{mg} / \mathrm{L} \mathrm{de} \mathrm{Al}^{+3}$, o mecanismo predominante foi o de varredura, e ocorreu uma excelente remoção de partículas. Para a dosagem de $1 \mathrm{mg} / \mathrm{L}$ de $\mathrm{Al}^{+3}$ a turbidez do efluente foi mais alta (2 a $6 \mathrm{uT}$ ) e houve provavelmente uma combinação dos mecanismos de neutralização de cargas e varredura, e para $0,5 \mathrm{mg} / \mathrm{L}$ de $\mathrm{Al}^{+3}$ as partículas foram insuficientemente desestabilizadas e resultaram em menor eficiência.

Tabela 3.4 - Desempenho da FDHP em função da dosagem de coagulante Turbidez inicial $=200 \mathrm{uT}, \mathrm{pH}=8,1$, Comprimento do FDHP $=8 \mathrm{~m}$ e Taxa de filtração $=120 \mathrm{~m}^{3} / \mathrm{m}^{2} \cdot \mathrm{d}$ Adaptada de AHSAN et al. (1996a)

\begin{tabular}{|c|c|c|c|c|}
\hline $\begin{array}{c}\text { Dosagem } \mathrm{Al}^{+3} \\
(\mathrm{mg} / \mathrm{L})\end{array}$ & $\begin{array}{c}\text { Amadurecimento } \\
\text { do Filtro } \\
(\mathrm{h})\end{array}$ & $\begin{array}{c}\text { Duração carreira } \\
\text { de filtração (h) }\end{array}$ & $\begin{array}{c}\text { Perda de Carga } \\
\text { Total } \\
(\mathrm{cm})\end{array}$ & $\begin{array}{c}\text { Turbidez } \\
\text { Efluente } \\
(\mathrm{uT})\end{array}$ \\
\hline 0,5 & 10 & 86 & 13,7 & 6,0 \\
\hline 1,0 & 5 & 90 & 16,5 & 2,0 \\
\hline 2,0 & 2 & 60 & 15,9 & 0,3 \\
\hline 4,0 & $<1$ & 24 & 10,1 & 0,2 \\
\hline
\end{tabular}




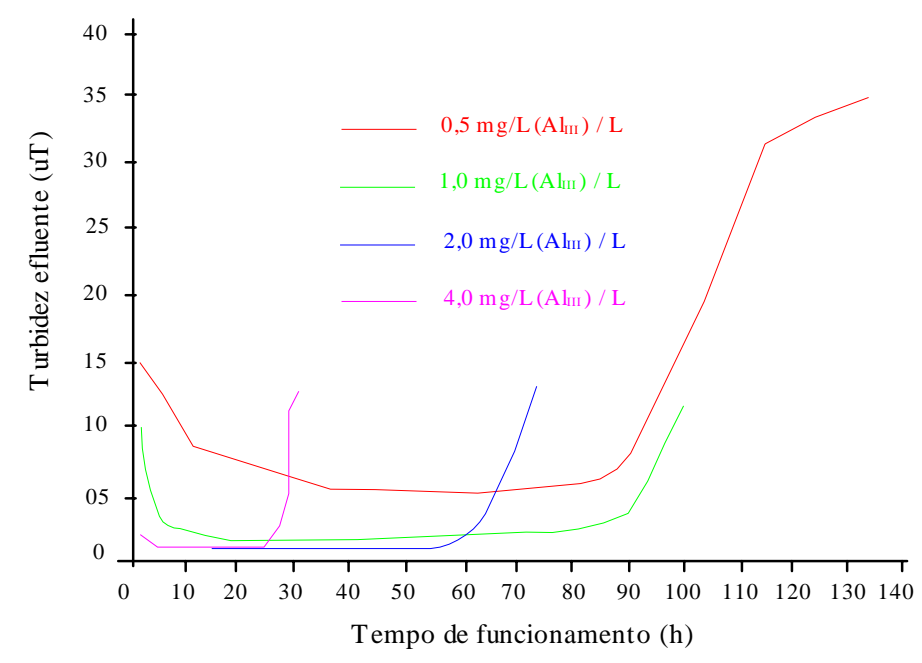

Figura 3.22 - Desempenho da FDHP em função da dosagem de coagulante

Turbidez inicial $=200 \mathrm{uT}, \mathrm{pH}=8,1$, Comprimento do FDHP $=8 \mathrm{~m}$ e Taxa de filtração $=120 \mathrm{~m}^{3} / \mathrm{m}^{2} \cdot \mathrm{d}$ Adaptado de AHSAN et al. (1996a)

As dosagens empregadas sugerem que o mecanismo de coagulação mais apropriado para a FDHP consiste na combinação da varredura e neutralização, mostrando-se similares às utilizadas na filtração direta (entre 0,5 e $1,5 \mathrm{mg} / \mathrm{L}$ de $\mathrm{Al}^{+3}$ ) para este tipo de água, tendo sido efetivos para ampla faixa de variação do pH (entre 6,5 e 8,5) - Figura 3.23 e Tabela 3.5.

Tabela 3.5 - Desempenho da FDHP em função do pH de coagulação Turbidez inicial $=200 \mathrm{uT}$, Dosagem $\mathrm{Al}^{+3}=1,0 \mathrm{mg} / \mathrm{L}$; Comprimento do FDHP $=8 \mathrm{~m}$ e Taxa de filtração $=120 \mathrm{~m}^{3} / \mathrm{m}^{2} \cdot \mathrm{d}$ - Adaptada de AHSAN et al. (1996a)

\begin{tabular}{|c|c|c|c|c|}
\hline pH de Coagulação & $\begin{array}{c}\text { Amadurecimento } \\
\text { do Filtro } \\
\text { (h) }\end{array}$ & $\begin{array}{c}\text { Duração carreira } \\
\text { de filtração (h) }\end{array}$ & $\begin{array}{c}\text { Perda de Carga } \\
\text { Total } \\
(\mathrm{cm})\end{array}$ & $\begin{array}{c}\text { Turbidez } \\
\text { Efluente } \\
\text { (uT) }\end{array}$ \\
\hline 6,0 & 3 & 58 & 10,7 & 6,0 \\
\hline 7,0 & 5 & 74 & 19,0 & 1,3 \\
\hline 7,8 & 5 & 95 & 17,2 & 2,1 \\
\hline 8,1 & 5 & 90 & 16,5 & 2,0 \\
\hline
\end{tabular}




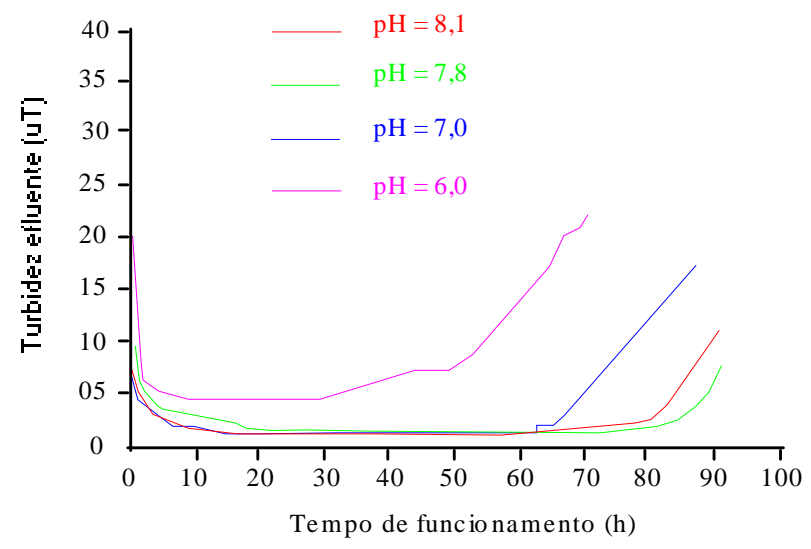

Figura 3.23 - Desempenho da FDHP em função do pH de coagulação

Turbidez inicial $=200 \mathrm{uT}$, Dosagem de $\mathrm{Al}^{+3}=1 \mathrm{mg} / \mathrm{L}$, Comprimento do FDHP $=8 \mathrm{~m}$ e Taxa e filtração $=120 \mathrm{~m}^{3} / \mathrm{m}^{2} . \mathrm{d}$ - Adaptado de AHSAN et al. (1996a)

Segundo DI BERNARDO et al. (2000), a avaliação preliminar da potencialidade do emprego da filtração direta descendente ou da filtração direta ascendente pode ser realizada através da determinação da dosagem de coagulante, requerida para o tratamento de águas dos mananciais em estudo, na época de chuvas, utilizando FLP (Whatman 40), desde que os valores máximos de alguns parâmetros não superem os sugeridos a seguir: turbidez $=25$ uT, cor verdadeira $=50 \mathrm{uH}$, algas filamentosas ou concentração total de algas $=100$ ind. $/ \mathrm{mL}$, concentração protozoários, rotíferos e metazoários $=500$ ind./L. Caso contrário, os resultados produzidos utilizando o FLP (Whatman 40), podem diferir daqueles que conduzem aos melhores resultados nos meios filtrantes usualmente empregados para esta tecnologia.

Na maioria dos estudos realizados, é difícil detectar, após coagulação, floculação e sedimentação, a região de coagulação denominada “corona”, na qual se tem a coagulação no mecanismo de neutralização de carga pelo precipitado com carga positiva. Durante algum tempo foi usado o filtro de papel Whatman 40, o qual possui abertura média igual a 8,4 $\mu \mathrm{m}$, para determinar a dosagem de coagulante e o pH de coagulação correspondentes àquele mecanismo, porém, quando a turbidez excede um determinado valor, ocorre colmatação do filtro de papel, dificultando a observação das condições de coagulação apropriadas para a filtração direta. Na Figura 3.21 viu-se que os melhores resultados na filtração são obtidos naquela região mencionada, o que tem sido confirmado quando são usados filtros de laboratório, acoplados a equipamento de jarteste (ver Figura 3.24). Após a coagulação nos diferentes jarros do equipamento, é executada a filtração, medindo-se a turbidez do filtrado de amostras coletadas em diferentes tempos de filtração (entre 10 e 40 min). 
Em função da turbidez da água de estudo, DI BERNARDO et al. (2002a) comprovaram que há necessidade de utilizar areias com diferentes granulometrias como meio filtrante para determinar as condições de coagulação (dosagem de coagulante x pH de coagulação), como mostrado na Tabela 3.6. Procedimentos detalhados a respeito da execução de ensaios em filtros de laboratório podem ser encontrados em livro específico sobre ensaios de tratabilidade (DI BERNARDO et al., 2002a).

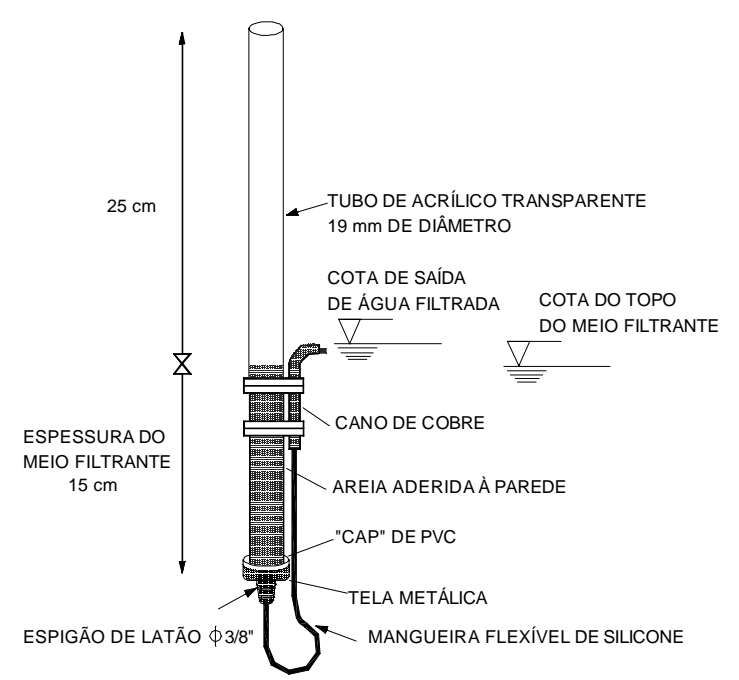

Figura 3.24 - Filtro de laboratório de areia

Tabela 3.6 - Resumo dos resultados de filtração em filtro de laboratório com areia de diferentes granulometrias - Fonte: (DI BERNARDO et al., 2002a).

\begin{tabular}{|c|c|c|c|c|c|c|c|}
\hline $\begin{array}{c}\text { Turbidez } \\
\text { da Água } \\
\text { de Estudo } \\
(\mathrm{uT})\end{array}$ & $\begin{array}{c}\text { Tamanho dos } \\
\text { Grãos de }\end{array}$ & \multicolumn{2}{|c|}{ Dosagens (mg/L) } & \multicolumn{4}{|c|}{ Valores obtidos } \\
\cline { 3 - 8 } & $(\mathrm{mm})$ & $\begin{array}{c}\text { Sulfato } \\
\text { de } \\
\text { Alumínio }\end{array}$ & $\begin{array}{c}\text { Carbonato de } \\
\text { Sódio } \\
(\mathrm{mg} / \mathrm{L})\end{array}$ & $\begin{array}{c}\text { Sulfato } \\
\text { de } \\
\text { Alumínio } \\
(\mathrm{mg} / \mathrm{L})\end{array}$ & $\begin{array}{c}\text { Carbonato } \\
\text { de Sódio } \\
(\mathrm{mg} / \mathrm{L})\end{array}$ & $\begin{array}{c}\mathrm{pH} \\
\text { de Coag. }\end{array}$ & $\begin{array}{c}\text { Turbidez } \\
\text { Filtrado } \\
\text { Coleta a } \\
20 \text { min } \\
\text { (uT) }\end{array}$ \\
\hline 15,3 & 0,3 a 0,59 & 4 a 11 & 0 & 7,5 & 0 & 6,38 & 0,32 \\
\hline 25 & 0,3 a 0,59 & 2,5 a 11 & 0 & 9,3 & 0 & 5,64 & 0,29 \\
\hline 63,5 & 0,42 a 0,84 & 12 a 21 & 0 a 9 & 17 & 8 & 6,34 & 0,25 \\
\hline 85,5 & 0,42 a 0,84 & 17 a 30 & 7 a 15 & 17 & 8 & 6,59 & 0,22 \\
\hline 160 & 0,59 a 1,41 & 17 a 25 & 6 a 12 & 17 & 8 & 6,57 & 0,37 \\
\hline 236 & 0,59 a 1,41 & 17 a 30 & 8 a 15 & 21 & 10 & 6,56 & 0,3 \\
\hline 351 & 0,59 a 1,41 & 21 a 34 & 10 a 17 & 25 & 12 & 6,37 & 0,32 \\
\hline
\end{tabular}


No trabalho realizado por KURODA (2002) em instalação piloto de dupla filtração composta por filtração direta ascendente em pedregulho seguida da filtração rápida descendente, a determinação das condições de coagulação em função da qualidade do filtrado em filtro de laboratório de papel (FLP) e ou filtro de laboratório de areia (FLA) resultaram, para alguns ensaios, em água coagulada com valores negativos de potencial zeta, produzindo porém, ótimos resultados com relação à qualidade dos efluentes filtrados e duração da carreira. Este fato sugere que a escolha dos parâmetros de coagulação baseada somente no critério da medida do potencial zeta da água coagulada próxima de zero apresenta restrições, sendo fundamental a realização de ensaios de filtração direta em FLP ou FLA, adequados às características da água bruta em questão. KURODA (2002) também concluiu que a utilização do FLA nos ensaios de laboratório para determinação das condições de coagulação química, produziu resultados satisfatórios, especialmente nos ensaios que apresentaram maior sensibilidade às variações das condições de coagulação e da qualidade da água, comparado ao FLP.

\subsection{Dupla Filtração}

\subsubsection{Considerações iniciais}

Na Pesquisa Nacional de Saneamento Básico realizada pelo IBGE (2000), as tecnologias de tratamento de águas para abastecimento são classificadas como convencionais, que incluem todas as etapas tradicionais do processo (coagulação, floculação, decantação e filtração) e não-convencionais, incluindo nesta última a filtração direta ascendente e descendente, a dupla filtração e filtração lenta.

Atualmente, estima-se em 300 a 350 o número de instalações de filtração direta ascendente para tratamento de água destinada ao consumo humano, em funcionamento no Brasil, construídas em concreto, chapa de aço ou em fibra, com capacidade de 5 a $2000 \mathrm{~L} / \mathrm{s}$, para remoção principalmente de cor, turbidez e ferro (DI BERNARDO et al., 2003).

Segundo pesquisa realizada com as diversas Companhias Estaduais de Saneamento Básico (CESB) atuantes no país, pelo Sistema Nacional de Informações sobre Saneamento, em publicação no ano de 1999, foi constatado que apesar da maior difusão atual das tecnologias de tratamento não-convencionais, o tratamento convencional (ou de ciclo completo) ainda é o mais utilizado em nosso país, com especial destaque nos estados de Minas Gerais, Rio Grande do Sul e Paraná, conforme mostrado na Figura 3.25. Tem-se observado maior tendência de utilização do tratamento de ciclo completo nos estados do Sul e Sudeste, provavelmente devido às variações mais significativas da qualidade da água ao 
longo do ano, com aumentos acentuados de turbidez nos períodos chuvosos. Na região Nordeste, por outro lado, onde há diversas captações em açudes, que funcionam como decantadores naturais, a qualidade da água bruta parece favorecer o emprego da filtração direta.

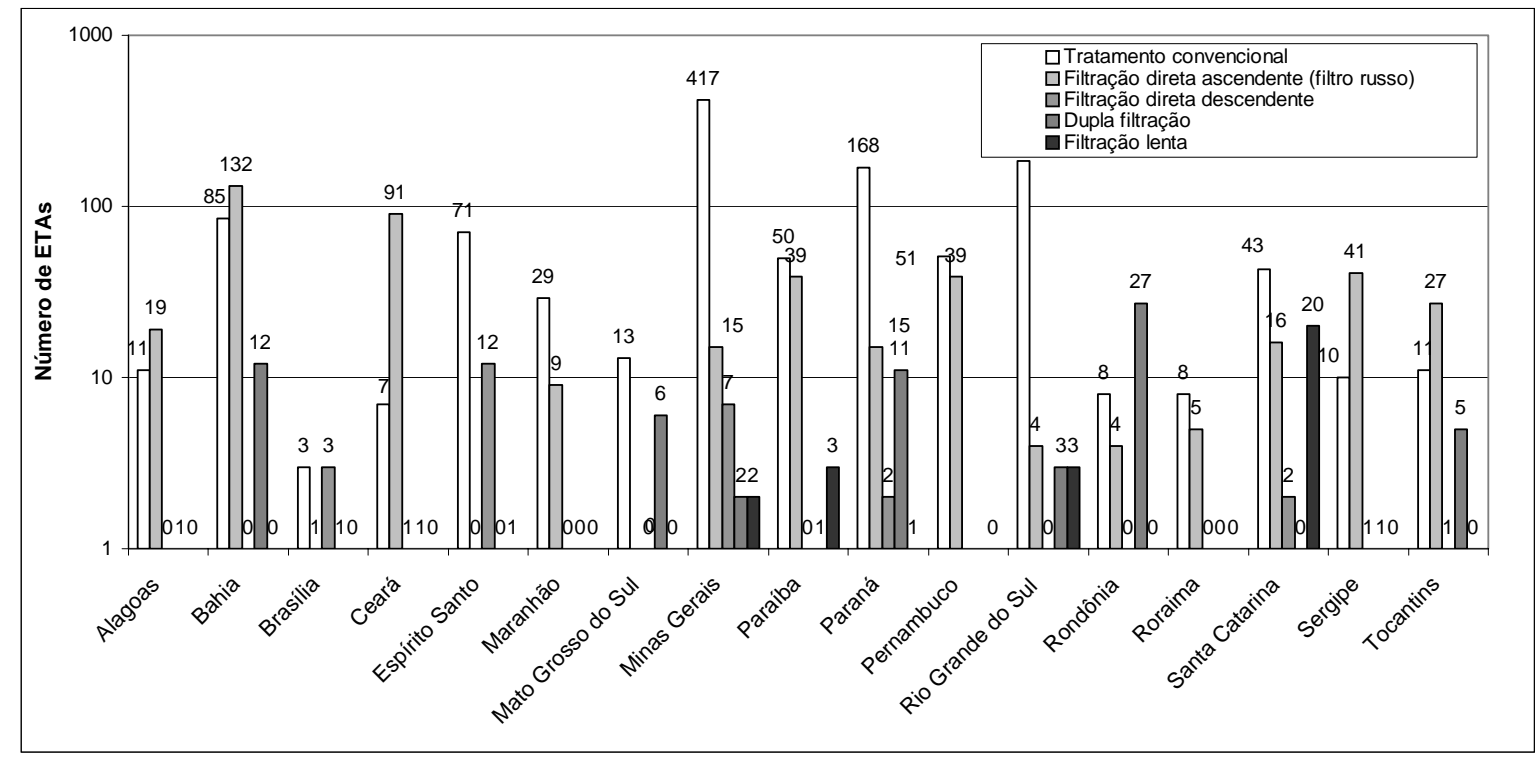

Figura 3.25 - Distribuição de ETAs operadas pelas CESB, por tipo de tecnologia - Fonte: DI BERNARDO et al. (2003)

Como mencionado anteriormente, a filtração direta ascendente apresenta diversas vantagens diante do tratamento convencional. A primeira delas é o fato de requerer menores área e custo para implantação da estação devido a eliminação das unidades de floculação e decantação; outra vantagem é o menor consumo de produtos químicos durante o processo de tratamento. Essas vantagens, além de trazerem facilidade de operação e manutenção, levam também a uma grande economia de recursos, já que haverá uma infra-estrutura mais simples a ser construída e mantida, e menor quantidade de produtos químicos a serem adquiridos e menor geração de lodo.

Apesar das vantagens apresentadas, a filtração direta ascendente possui limitações relativas à qualidade microbiológica e físico-química da água bruta, especificamente para valores de turbidez, cor verdadeira ou concentração algal temporariamente elevados, sendo neste caso recomendado o tratamento complementar com filtro rápido descendente, compondo assim o sistema de dupla filtração.

Assim, o desconhecimento das características da água bruta e de sua variação sazonal pode levar a erros na escolha da tecnologia de tratamento. Ressalta-se, contudo, que os resultados que foram obtidos no âmbito do PROSAB indicam que os limites de 
aplicabilidade da filtração direta em relação à qualidade da água bruta, especialmente da dupla filtração, são mais amplos do que normalmente é reportado na literatura, conforme pode ser observado em DI BERNARDO et al. (2003). É conveniente que ajustes operacionais e a possibilidade de emprego da dupla filtração sejam considerados como opções antes de transformar as ETAs de filtração direta ascendente e descendente em ETAs de ciclo completo, uma vez que esta tecnologia implica em maiores custos de construção e de operação, muito embora seja a opção mais apropriada em alguns casos.

A filtração direta pode ser empregada para o tratamento de águas para abastecimento em três configurações básicas distintas, apresentadas de forma esquemática na Figura 3.26.

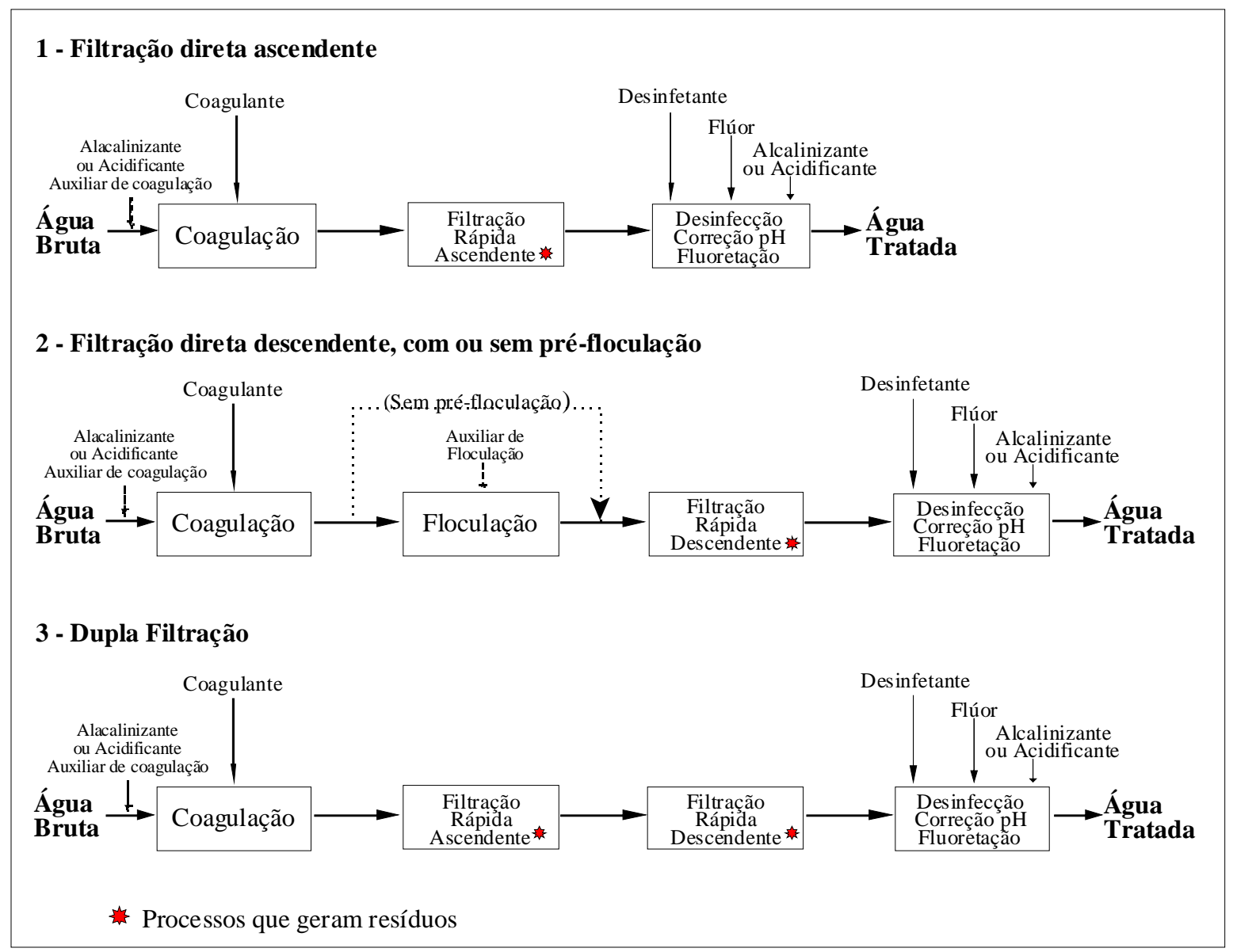

Figura 3.26 - Fluxogramas esquemáticos dos sistemas de filtração direta - Fonte: DI BERNARDO et

$$
\text { al. (2003) }
$$

A dupla filtração é caracterizada pelo uso da filtração direta ascendente como prétratamento para filtração descendente. A água coagulada passa inicialmente pelo filtro ascendente, com material granular tendo granulometria apropriada para que seja produzida água filtrada com turbidez consistentemente inferior a 10 uT. As principais vantagens da dupla filtração em relação à filtração direta ascendente são: a) permite o tratamento de água 
com qualidade pior; b) possibilita o uso de taxas de filtração mais elevadas; c) oferece maior segurança do ponto de vista operacional com relação às variações bruscas de qualidade da água bruta; d) é maior a remoção global de microrganismos, aumentando a segurança com relação à desinfecção final; e) não há necessidade de descartar água filtrada no filtro ascendente no início da carreira de filtração, pois esta água será filtrada no filtro descendente.

Dependendo do arranjo de alimentação das unidades filtrantes, tanto a filtração ascendente como a descendente podem funcionar com taxa constante ou com taxa declinante. A instalação pode possuir um conjunto de filtros ascendentes, seguido de outro conjunto de filtros descendentes ou ter diversas unidades de dupla filtração, cada uma delas constituída de um filtro ascendente e de um descendente (DI BERNARDO et al., 2003).

A dupla filtração utilizando filtro ascendente de areia grossa ou de pedregulho tem sido pesquisada de forma mais sistemática na América Latina, particularmente no Brasil. Contribuições importantes sobre a filtração de água coagulada em areia grossa e em pedregulho resultaram dos trabalhos realizados por AHSAN (1995), AHSAN et al. (1996a), AHSAN et al. (1996b), WEGELIN et al. (1996), CRUZ VELEZ et al. (1998), MEGDA (1999), CEZAR et al. (2000), GUSMÃO (2001), AMARAL et al. (2001), KURODA (2002), SILVA (2003), DE PAULA (2003) e demais trabalhos realizados no âmbito do Prosab.

\subsubsection{Dupla filtração para remoção de turbidez}

AHSAN (1995), AHSAN et al. (1996a), AHSAN et al. (1996b) estudaram a filtração com escoamento horizontal em uma unidade contendo dois compartimentos, o primeiro com pedregulho de tamanho médio de $20 \mathrm{~mm}$, e o segundo, com pedregulho de tamanho médio igual a $8 \mathrm{~mm}$. O afluente foi preparado com água de torneira e caulinita, de modo que a turbidez resultasse entre 160 e 500 uT e sulfato de alumínio foi o coagulante utilizado. As principais conclusões do estudo experimental foram as seguintes: a) para taxas de filtração compreendidas entre 72 e $168 \mathrm{~m}^{3} / \mathrm{m}^{2}$.d, foi obtido efluente com turbidez continuamente menor ou igual a 2 uT; b) o primeiro compartimento atuou como um sedimentador, removendo aglomerados maiores, enquanto no segundo, predominou o efeito da filtração com ação de profundidade, removendo partículas de menor tamanho; c) a duração da carreira de filtração foi função da turbidez do afluente e da taxa de filtração, e variou de algumas horas até 20 dias. O autor, em função dos dados obtidos, procurou modelar o funcionamento desse tipo de unidade com respeito à remoção das partículas, e estudou a influência de diversos aspectos operacionais no desempenho da unidade, tais como 
mecanismo de coagulação, características da mistura rápida, qualidade do afluente, limpeza do meio granular, etc.

WEGELIN et al. (1996) realizaram estudos em uma instalação de Filtração em Múltiplas Etapas localizada na Bolívia, alterando o funcionamento do pré-filtro de escoamento horizontal para filtração ascendente em pedregulho e coagulando a água bruta, de modo a adequar a qualidade do afluente aos filtros lentos. Mesmo com valores elevados de turbidez (300 a $600 \mathrm{uT}$ ) e ferro total (3,0 a 15,0 mg/L) da água bruta, os autores obtiveram consistentemente efluente com turbidez menor ou igual a 5 uT, comprovando a aplicabilidade da filtração direta ascendente em pedregulho.

CRUZ VELEZ et al. (1998) estudaram a filtração direta ascendente em pedregulho para tratamento do efluente de uma unidade de pré-filtração dinâmica. Para uma perda de carga máxima de 0,4 m no meio granular, devido a retenção de impurezas, tratando afluente com turbidez por volta de $200 \mathrm{uT}$, foi produzido efluente com turbidez menor que $5 \mathrm{uT}$ e carreiras de filtração com duração de 74 h para taxa de filtração de $268 \mathrm{~m}^{3} / \mathrm{m}^{2}$.d, 144 h para taxa de filtração de $144 \mathrm{~m}^{3} / \mathrm{m}^{2}$.d e, depois de $168 \mathrm{~h}$, a perda de carga no meio granular era somente de $0,18 \mathrm{~m}$ para a taxa de filtração de $72 \mathrm{~m}^{3} / \mathrm{m}^{2}$.d. Tais trabalhos possibilitaram, na EESC-USP, que MEGDA (1999) e GUSMÃO (2000) estudassem o desempenho da dupla filtração, utilizando filtro ascendente de pedregulho e de areia grossa como pré-tratamento à filtração rápida descendente.

MEGDA (1999) trabalhou com água bruta proveniente de manancial superficial, com turbidez consistentemente inferior a 71 uT e empregou taxas no filtro ascendente variando entre 12 e $115 \mathrm{~m}^{3} / \mathrm{m}^{2}$.d, e de $250 \mathrm{~m}^{3} / \mathrm{m}^{2}$.d no filtro descendente de areia. As principais conclusões obtidas foram as seguintes: a) o filtro ascendente de pedregulho apresentou capacidade de amortecimento de picos de turbidez de até $70 \mathrm{uT}$; b) a taxa de filtração no filtro ascendente influenciou a duração da carreira e a qualidade do efluente produzido nesta unidade - quanto menor a taxa de filtração mais longa resultou a duração da carreira e menor foi a turbidez do efluente; c) a duração da carreira de filtração do filtro descendente foi influenciada pelo desempenho do filtro ascendente - quanto maior a turbidez do efluente do filtro ascendente, mais curta foi a duração da carreira no filtro descendente; d) a eficiência global da instalação de dupla filtração foi relativamente alta quanto à remoção de turbidez, cor aparente, ferro e coliformes totais - em geral, a turbidez do efluente final foi sempre inferior a $1 \mathrm{uT}$, a cor aparente menor que $5 \mathrm{uH}$, o teor de ferro inferior a $0,1 \mathrm{mg} / \mathrm{L}$ e o NMP de coliformes totais sempre menor que 5 ufc/100 mL.

GUSMÃO (2001) estudou a dupla filtração, comparando a filtração ascendente em pedregulho com a de areia grossa, como pré-tratamento à filtração rápida descendente. 
Utilizando taxas de filtração de até $480 \mathrm{~m}^{3} / \mathrm{m}^{2}$.d nas duas unidades (ascendente e descendente) e tratando água proveniente de manancial superficial com turbidez alcançando até 100 uT, o pesquisador concluiu, principalmente, que: a) para taxas de filtração no filtro ascendente de pedregulho inferiores a $120 \mathrm{~m}^{3} / \mathrm{m}^{2}$.d, ocorria retenção substancial de impurezas nesta unidade, porém, a carreira de filtração era encerrada sempre por perda de carga limite no filtro descendente; b) para taxas de filtração no filtro ascendente de areia inferiores a $300 \mathrm{~m}^{3} / \mathrm{m}^{2}$.d, ocorria retenção substancial de impurezas nesta unidade (em relação à descendente) com a carreira de filtração sendo encerrada sempre por perda de carga limite; c) para taxas de filtração de 120 a $180 \mathrm{~m}^{3} / \mathrm{m}^{2}$.d no filtro ascendente de pedregulho, o desprendimento de impurezas era muito grande, causando a colmatação rápida do filtro descendente; d) para taxas de filtração maiores que $300 \mathrm{~m}^{3} / \mathrm{m}^{2}$.d no filtro ascendente de areia, o desprendimento de impurezas fazia com que o filtro descendente também contribuísse para a retenção global de impurezas. Segundo GUSMÃO (2001), deve existir uma granulometria do material granular intermediária (entre a de pedregulho e a de areia grossa) no filtro ascendente e uma combinação de taxa de filtração nos filtros ascendente e descendente, em função da qualidade da água bruta, que otimiza o desempenho global da instalação.

SALDANHA (2002) avaliou um sistema de dupla filtração em escala real (ETA2) do serviço autônomo de água de São Carlos - SP, a qual trata água bruta retirada do Ribeirão do Feijão. Primeiramente foram levantadas as três unidades de dupla filtração que compõe a ETA, caracterizado o material filtrante e verificada as condições operacionais. Posteriormente, foi levantada a situação geral da ETA através de diversos parâmetros, definindo-se e acompanhando-se os principais problemas. Após isso foi realizada uma comparação da ETA2 com uma instalação piloto de dupla filtração. Os resultados mostraram que a estação teve uma baixa produção efetiva e qualidade do efluente muitas vezes insatisfatória decorrente principalmente da existência de caminhos preferenciais e falta de material filtrante, confirmando, portanto, a importância da distribuição e dosagem adequada de coagulante, bem como, a necessidade da qualificação de operadores para evitar a ocorrência de problemas operacionais.

KURODA (2002) avaliou o sistema de dupla filtração composto por filtração direta ascendente em pedregulho seguida da filtração rápida descendente em instalação piloto, variando-se a taxa de filtração no filtro ascendente (60 a $240 \mathrm{~m}^{3} / \mathrm{m}^{2}$.d) e descendente (100 a $240 \mathrm{~m}^{3} / \mathrm{m}^{2}$.d) com e sem execução de descargas de fundo intermediárias no ascendente. A água bruta era proveniente de um manancial superficial com pH entre 6,5 a 7,5, valores de turbidez compreendidos entre 8,5 e $21 \mathrm{uT}$, cor verdadeira entre 19 e $50 \mathrm{uH}$ e alcalinidade 
entre 6,7 e $10 \mathrm{mg} \mathrm{CaCO}_{3} / \mathrm{L}$. KURODA(2002) verificou também o comportamento da instalação para uma condição simulada de ocorrência de pico de turbidez de 380 uT, com curta duração (Figura 3.27).

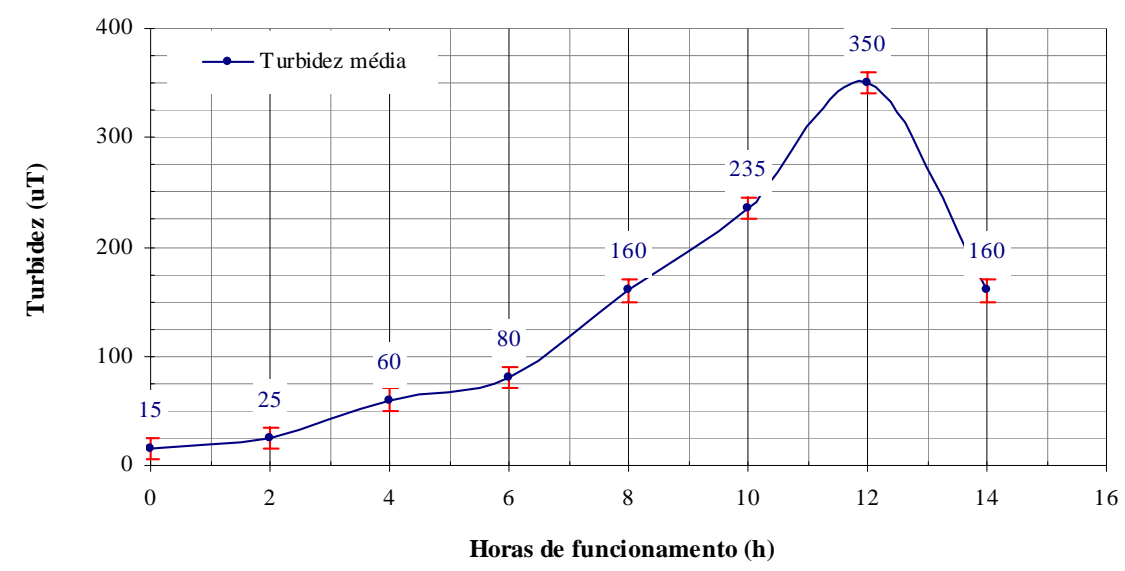

Figura 3.27 - Simulação do pico de turbidez da água afluente a instalação piloto de dupla filtração Fonte: KURODA (2002)

Na Tabela 3.7 e Figura 3.28 são apresentadas as características do meio granular dos filtros ascendente e descendente utilizado por KURODA (2002).

Tabela 3.7 - Características do material granular utilizado por KURODA (2002) - Fonte: Kuroda (2002)

\begin{tabular}{|c|c|c|c|}
\hline & \multicolumn{2}{|c|}{ Ascendente (FAP) } & Descendente (FRD) \\
\hline Camada & $\begin{array}{c}\text { Tamanho dos } \\
\text { grãos (mm) }\end{array}$ & $\begin{array}{l}\text { Espessura da } \\
\text { Subcam. (mm) }\end{array}$ & Tamanho dos grãos $=0,3$ a $1,41 \mathrm{~mm}$ \\
\hline 1 & 19,0 a 25,4 & 300 & Tamanho efetivo $=0,42$ a $0,45 \mathrm{~mm}$ \\
\hline 2 & 9,6 a 15,9 & 300 & Coef. de desuniformidade $=1,7$ \\
\hline 3 & 3,2 a 6,4 & 300 & Coef. de esfericidade $=0,75$ a 0,8 \\
\hline 4 & 1,41 a 2,4 & 300 & Espessura da camada $=0,7 \mathrm{~m}$ \\
\hline
\end{tabular}




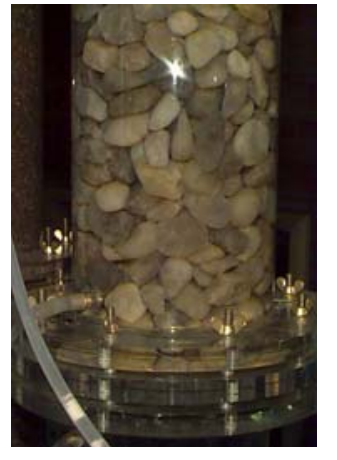

a) $1^{\mathrm{a}}$. Camada:

19,0 a $25,4 \mathrm{~mm}$

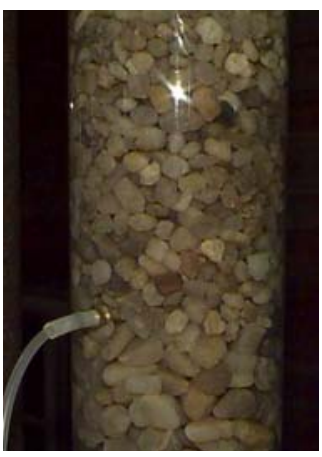

b) $2^{a}$. Camada:

9,6 a 15,9 mm

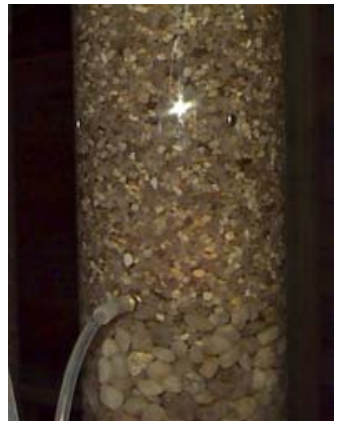

c) $3^{\mathrm{a}}$. Camada:

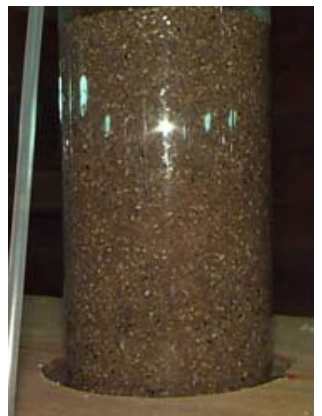

d) 4a . Camada:

3,2 a $6,4 \mathrm{~mm}$

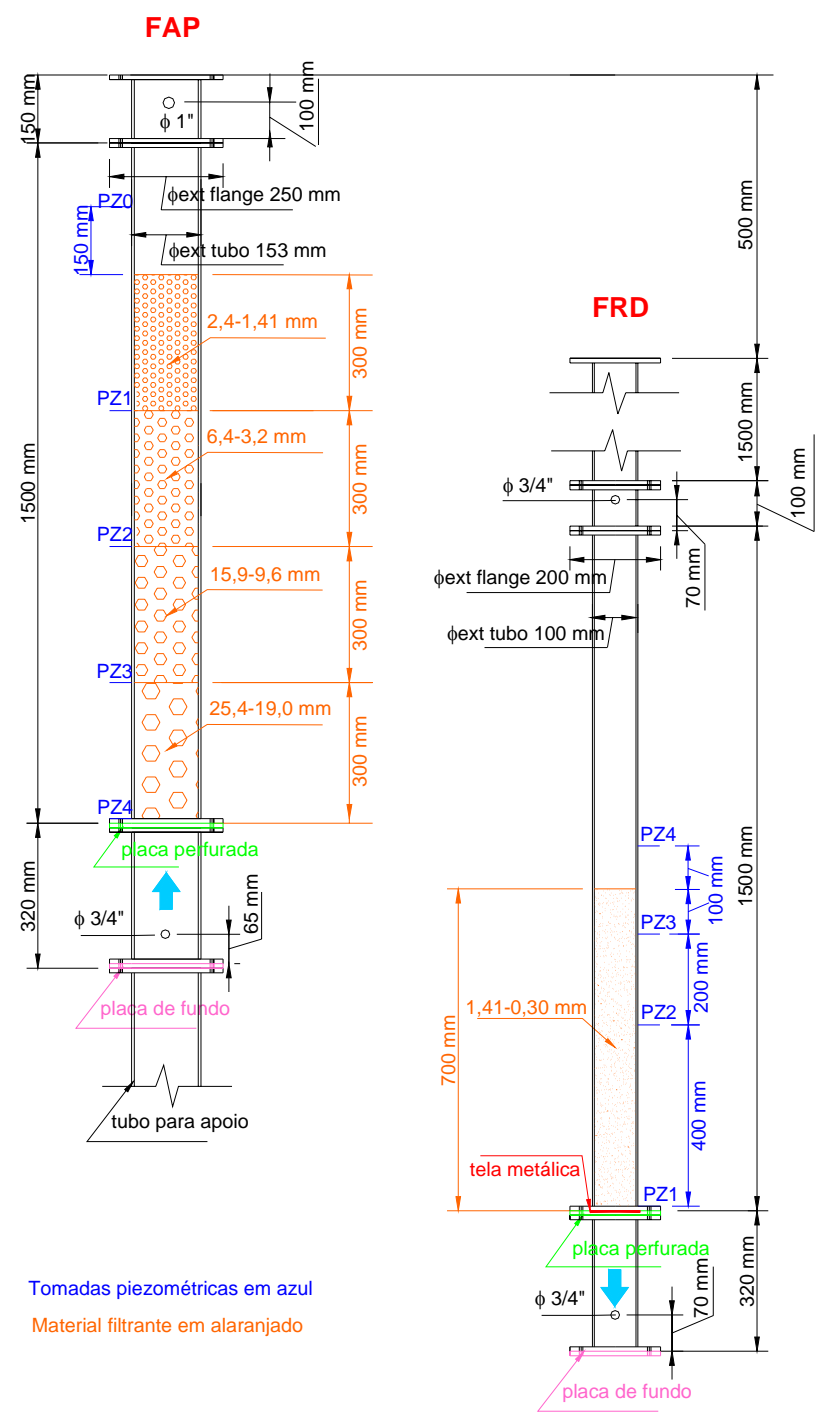

Figura 3.28 - Fotos das camadas do meio granular do FAP e detalhes da unidade de Dupla Filtração utilizada por KURODA (2002) - Fonte: KURODA (2002)

As principais conclusões do trabalho foram: a) No ensaio de simulação do pico, a aplicação das condições de coagulação, obtidas nos ensaios de laboratório por coagulação em jarteste e de filtração direta em FLAs, produziu ótimos resultados, tendo, o filtro ascendente de pedregulho (FAP) com taxa de filtração de $120 \mathrm{~m}^{3} / \mathrm{m}^{2}$.d, sido capaz de absorver o pico de turbidez de 380 uT, produzindo efluente pré-filtrado com valores de 
turbidez entre 0,3 e 5,7 uT, e o FRD com taxa de filtração de $180 \mathrm{~m}^{3} / \mathrm{m}^{2}$.d, produzido efluente final com valores consistentemente menores que $1 \mathrm{uT}$, e na maior parte do tempo menores que 0,1 uT; b) em geral, foi observada a ocorrência de desprendimentos de flocos para todas as taxas de filtração empregadas, sendo variável o tempo de operação de início da ocorrência deste fenômeno, em função da taxa de filtração empregada, do grau de colmatação do FAP, da dosagem de coagulante empregada e qualidade da água bruta; c) o método de execução de descarga de fundo intermediária (DFI) empregado (com esvaziamento total do filtro), apresentou recuperação de carga hidráulica e qualidade dos efluentes logo após a DFI, superiores ao método com esvaziamento até o topo do meio granular; d) nos ensaios realizados com execução de 3 e 4 DFIs e taxas de filtração de 180 $\mathrm{m}^{3} / \mathrm{m}^{2}$.d e $240 \mathrm{~m}^{3} / \mathrm{m}^{2}$.d, respectivamente, os números de DFIs executadas no FAP mostraram-se insuficientes, devido à ocorrência de carreamento contínuo de flocos antecedendo a execução de cada DFI. Entretanto, mesmo com o número de DFIs menor que o requerido, foi constatado que a qualidade do efluente produzido resultou significativamente superior, a ocorrência de desprendimentos de flocos e os valores dos picos de turbidez decorrentes desses desprendimentos foram significativamente reduzidos, as durações das carreiras do FAP resultaram mais longas, apresentando somas das cargas hidráulicas parciais recuperadas com a execução de 3 e 4 DFIs, iguais a 56,9 cm e 70,4 cm, respectivamente, valores que correspondem em até 1,4 vezes, a carga hidráulica disponível $(50 \mathrm{~cm})$ estabelecida para o FAP, as durações das carreiras do FRD resultaram mais longas, devido à qualidade dos efluentes pré-filtrados, os índices de produção efetiva de água resultaram superiores aos obtidos nos ensaios sem a execução de DFIs, devido principalmente, à produção de carreiras de durações mais longas; d) nos ensaios sem execução de DFIs, o FAP foi capaz de produzir efluentes com valores de turbidez adequados ao tratamento complementar com a FRD, para taxas de filtração iguais ou inferiores a $180 \mathrm{~m}^{3} / \mathrm{m}^{2}$.d, tendo resultado em carreiras de durações entre 38 e 83 h; e) embora o filtro FRD tenha sido capaz de absorver os picos de turbidez decorrentes do carreamento e desprendimento de flocos no filtro FAP, nos ensaios sem execução de DFIs e taxa de filtração de $240 \mathrm{~m}^{3} / \mathrm{m}^{2}$.d, o seu desempenho foi considerado insatisfatório; f) a eficiência global do sistema de Dupla Filtração com FAP foi satisfatória tendo o efluente final apresentado turbidez durante a maior parte do tempo inferior a 0,1 uT e cor verdadeira inferior a $1 \mathrm{uH}$ independentemente da qualidade da água bruta e da taxa empregada; o FRD foi capaz de absorver as variações da qualidade de água pré-filtrada devido às execuções das DFIs, lavagens e ocorrências de desprendimentos de flocos; g) de maneira geral, o FRD garantiu a produção de efluente final com qualidade condizente com o padrão de potabilidade, inclusive atendendo ao valor de 
turbidez (0,5 uT), enfaticamente, recomendado quando o tratamento é realizado por filtração direta; h) a distribuição da perda de carga nas camadas do meio granular do FAP foi similar para os ensaios realizados, independentemente das taxas de filtração empregadas e da execução ou não de DFIs. As duas camadas inferiores do FAP (de maiores granulometrias) camadas 1 e 2, totalizando $60 \mathrm{~cm}$ de espessura, foram responsáveis por apenas 2,6 a 7,8 \% da perda de carga total; a camada 3, com espessura de $30 \mathrm{~cm}$, por 27,9 a 38,1\% e a camada 4 (de menor granulometria) com espessura de $30 \mathrm{~cm}$, por cerca de 58,9 a 76,8 \% da perda de carga total. Com relação ao FRD, observou-se que cerca de 70,5 a 92,5 \% da perda de carga total foi associada à camada superior (de menor granulometria) com apenas $10 \mathrm{~cm}$ de espessura. Por outro lado, o FRD foi capaz de absorver as variações de qualidade da água pré-filtrada devido às execuções das DFIs, lavagens e ocorrências de carreamento e de desprendimentos de flocos, tendo resultado em durações satisfatórias das carreiras de filtração.

DE PAULA (2003) realizaram estudos sobre a dupla filtração, em uma instalação piloto, para o tratamento de água para abastecimento, utilizando filtração ascendente em areia grossa como pré-tratamento à filtração rápida descendente em areia. Foram empregadas combinações de taxas nos filtros, que variaram de 120 a $360 \mathrm{~m}^{3} / \mathrm{m}^{2}$.d no ascendente e de 200 a $400 \mathrm{~m}^{3} / \mathrm{m}^{2}$.d no descendente e execução de descargas de fundo intermediárias na unidade de filtração ascendente, com significativa recuperação da carga hidráulica disponível. A água bruta era proveniente de um manancial superficial com $\mathrm{pH}$ entre 6,5 a 7,5, valores de turbidez compreendidos entre 8,5 e $21 \mathrm{uT}$, cor verdadeira entre 19 e $50 \mathrm{uH}$ e alcalinidade entre 6,7 e $10 \mathrm{mg} \mathrm{CaCO}_{3} / \mathrm{L}$. Foi simulado também, pico de turbidez de curta duração da ordem de 380 uT, a fim acompanhar o desempenho do sistema (Figura 3.27). Na Tabela 3.8 e Figura 3.29 são apresentadas as características do meio granular dos filtros ascendente e descendente utilizado por DE PAULA (2003).

As principais conclusões do trabalho foram: a) a distribuição da perda de carga nas camadas do meio granular do filtro ascendente de areia grossa (FAAG) não apresentou diferenças significativas para as variadas taxas de filtração e modo de operação (com e sem execução de DFIs), tendo a camada suporte sido responsável por 10,8 a 21,3 \% da perda de carga total e a camada filtrante, por 79 a 89,2 \%. No FRD, cerca de 63,3 a 79,1 \% da perda de carga total foi associada à subcamada superior (de menor granulometria) com apenas 10 cm de espessura, porém, considerando a função de polimento e barreira bacteriológica dessa unidade de filtração, concluiu-se que a granulometria utilizada foi adequada para este fim; b) de maneira geral em todos os ensaios foram obtidos resultados condizentes ao padrão de Potabilidade (Portaria 518); tanto no efluente do FAAG quanto no FRD, a turbidez 
manteve-se sempre abaixo de 0,7 uT e 0,5 uT, respectivamente. Em alguns ensaios, a turbidez do efluente do FAAG, resultou relativamente alta no início da carreira ou devido à execução das DFIs, que foram no entanto amortecidos pelo FRD; c) com o uso de taxas de filtração inferiores a $240 \mathrm{~m}^{3} / \mathrm{m}^{2}$.d no FAAG e $300 \mathrm{~m}^{3} / \mathrm{m}^{2}$.d no FRD, foi observada retenção substancial de impurezas no FAAG, resultando no encerramento da carreira sempre por perda de carga limite de 2,2 m neste filtro; d) com o uso de taxas de filtração maiores que $240 \mathrm{~m}^{3} / \mathrm{m}^{2} \mathrm{~d}$ no FAAG, o desprendimento de impurezas fazia com que o filtro descendente também contribuísse para a retenção global de impurezas.

Tabela 3.8 - Características do meio granular utilizado por DE PAULA (2003) - Fonte: DE PAULA (2003)

\begin{tabular}{|c|c|c|c|c|}
\hline Filtro & Material & Subcamada & Tamanho dos grãos (mm) & Espessura $(\mathrm{cm})$ \\
\hline \multirow{7}{*}{$\begin{array}{l}\text { Ascendente } \\
\text { (FAAG) }\end{array}$} & \multirow{6}{*}{$\begin{array}{l}\text { Pedregulho } \\
\text { (Suporte) }\end{array}$} & Fundo & $25,4-19,0$ & 10 \\
\hline & & Primeira & $12,7-19,0$ & 10 \\
\hline & & Segunda & $6,4-12,7$ & 10 \\
\hline & & Terceira & $3,2-6,4$ & 15 \\
\hline & & Quarta & $6,4-12,7$ & 7,5 \\
\hline & & Superior & $12,7-19,0$ & 7,5 \\
\hline & Areia & Tamanho dos grãos: $1,0-2,4$ mm & Tamanho efetivo: $1,4 \mathrm{~mm}$ & $\begin{array}{c}\text { Espessura da camada } \\
1,6 \mathrm{~m}\end{array}$ \\
\hline $\begin{array}{l}\text { Descendente } \\
\text { (FRD) }\end{array}$ & Areia & Tamanho dos grãos: 0,30 - 1,41 mm & Tamanho efetivo: 0,43 mm & $\begin{array}{c}\text { Espessura da camada } \\
0,7 \mathrm{~m}\end{array}$ \\
\hline
\end{tabular}




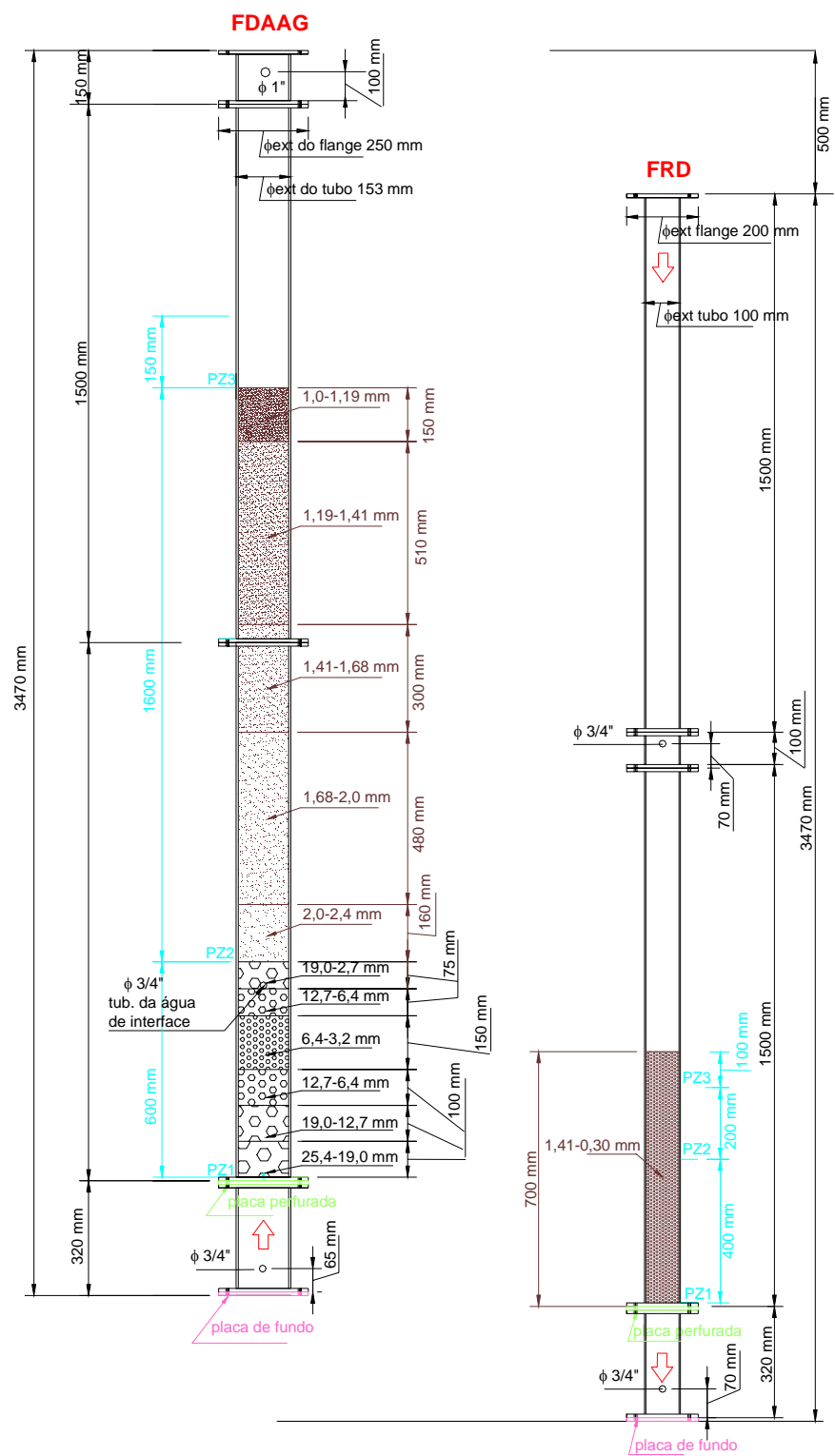

Figura 3.29 - Detalhes da unidade de Dupla Filtração utilizada por DE PAULA (2003) - Fonte: DE PAULA (2003)

\subsection{Considerações finais sobre a revisão da literatura}

Os resultados das investigações recentes realizadas sobre a dupla filtração revelam o grande potencial que esta tecnologia possui, uma vez que é considerada mais viável econômica e operacionalmente que o tratamento em ciclo completo. DI BERNARDO et al. (2003) destacaram o uso da dupla filtração como uma das mais promissoras tecnologias para tratamento de água, estimando-se que grande parte das necessidades de tratamento poderiam ser satisfeitas com o uso desta tecnologia. 
Apesar dos valores máximos de turbidez recomendados por DI BERNARDO \& ISAAC (2001) e DI BERNARDO et al. (2003), os trabalhos de KURODA (2002) e DE PAULA (2003), indicam o potencial do uso da dupla filtração no tratamento de água com turbidez mais elevada que os limites apresentados.

Neste sentido, foi proposto o presente trabalho, visando esclarecer os limites máximos de turbidez para uso da dupla filtração com filtro ascendente de areia grossa (sistema 1) e filtro ascendente de pedregulho (sistema 2). Para elaboração da metodologia e discussão dos dados obtidos neste trabalho, foram utilizados os fundamentos, as conclusões e recomendações de vários trabalhos e publicações, sendo os principais apresentados a seguir:

- AWWA (1990), WILLIAMS (1994), FAUST \& ALY (1998) explicam a forças envolvidas na estabilidade das partículas coloidais em meio aquoso e as principais características quando ocorre a desestabilização dos mesmos.

- Os trabalhos de HACH et al. (1989) e TEIXEIRA et al. (2004) esclarecem que as determinações de turbidez estão condicionadas aos distintos princípios de funcionamento dos equipamentos disponíveis no mercado.

- BLACK \& HANNAH (1961) demonstraram que a neutralização de cargas não é o único fenômeno responsável pela eficiência da coagulação com o sulfato de alumínio para águas preparadas a partir de três tipos de argila (ilita, caulinita e montmorilonita).

- Os trabalhos realizados por BLACK \& WILLEMS (1961), BLACK \& HANNAH (1961), BLACK \& CHRISTMAN (1963), O’MELIA (1978), RUBIN (1974), STUMM \& O’MELIA (1968), TAMBO \& WATANABE (1979a), TAMBO \& WATANABE (1979b), TAMBO \& WATANABE (1979c) e TAMBO \& MISCHNICK (1979), contribuíram consideravelmente para que, na década de oitenta, AMIRTHARAJAH \& MILLS (1982) propusessem uma forma mais simples de se estudar a coagulação, baseada nos diagramas de solubilidade do alumínio e do ferro. Este procedimento tem sido intensivamente utilizado no Brasil durante as duas últimas décadas por DI BERNARDO (1983, 1985), DI BERNARDO et al. (1987, 2000), MENDES (1989), MARINELLI (1999), DI BERNARDO (2000) e PAVANELLI (2001), dentre outros.

- AHSAN (1995), AHSAN et al. (1996a), AHSAN et al. (1996b), WEGELIN et al. (1996), CRUZ VELEZ et al. (1998), MEGDA (1999), CEZAR et al. (2000), GUSMÃO (2001), AMARAL et al. (2001), KURODA (2002), SILVA (2003), DE PAULA (2003) e DI BERNARDO et al. (2003) são as principais referências sobre os avanços da tecnologia de dupla filtração. 


\section{MATERIAIS E MÉTODOS}

Neste capítulo são apresentados o fluxograma do trabalho experimental, a descrição e funcionamento da instalação piloto de dupla filtração, a descrição das atividades realizadas nas fases de pré-operação, ensaios em bancada e ensaios na instalação piloto, incluindo as dificuldades encontradas e adaptações efetuadas. É apresentada também a forma de análise dos dados e cálculo da produção efetiva de água para posterior avaliação dos resultados obtidos.

\subsection{Fluxograma da metodologia}

Na Figura 4.1 é apresentado um fluxograma da metodologia empregada para a realização do trabalho experimental. No total foram realizados 15 ensaios de dupla filtração na instalação piloto.

\subsection{Descrição geral da instalação piloto de dupla filtração}

A instalação piloto foi montada no Laboratório de Instalações Piloto - LIP, próximo ao Departamento de Hidráulica e Saneamento da EESC-USP. Foram aproveitadas diversos componentes das instalações utilizadas por MEGDA (1999) e GUSMÃO (2001), adaptandoas para a execução do presente trabalho.

Basicamente, a instalação foi constituída por um tanque de $20 \mathrm{~m}^{3}$ para preparação e armazenamento da água de estudo, bomba para recalque da água bruta, caixas de plástico de 1500 L para preparação da dispersão de caulinita, bomba para recalque da dispersão de caulinita, caixa de homogeneização da água de estudo com agitador (Figura 4.2); caixa de nível constante para regularizar a vazão de entrada nos filtros, caixa de mistura rápida provida de agitador para mistura do coagulante, tanque de solução de coagulante e bomba dosadora, tubulações individuais para alimentação dos sistemas de dupla filtração, medidor de vazão do tipo magnético, dois sistemas de dupla filtração, cada um deles com filtro ascendente possuindo material granular específico (sistema 1: filtro ascendente de areia grossa e filtro rápido descendente de areia - FAAG-FRD e sistema 2: filtro ascendente de pedregulho e filtro rápido descendente de areia - FAP-FRD), rotâmetros de água e ar, compressor para lavagem com ar, turbidímetros de escoamento contínuo para medida de turbidez da água de estudo, água pré-filtrada e água filtrada, placa de aquisição de dados para registro dos turbidímetros de escoamento contínuo e monitoramento da vazão, e piezômetros 
para medida de perda de carga ao longo dos meios granulares dos filtros ascendentes e descendentes.

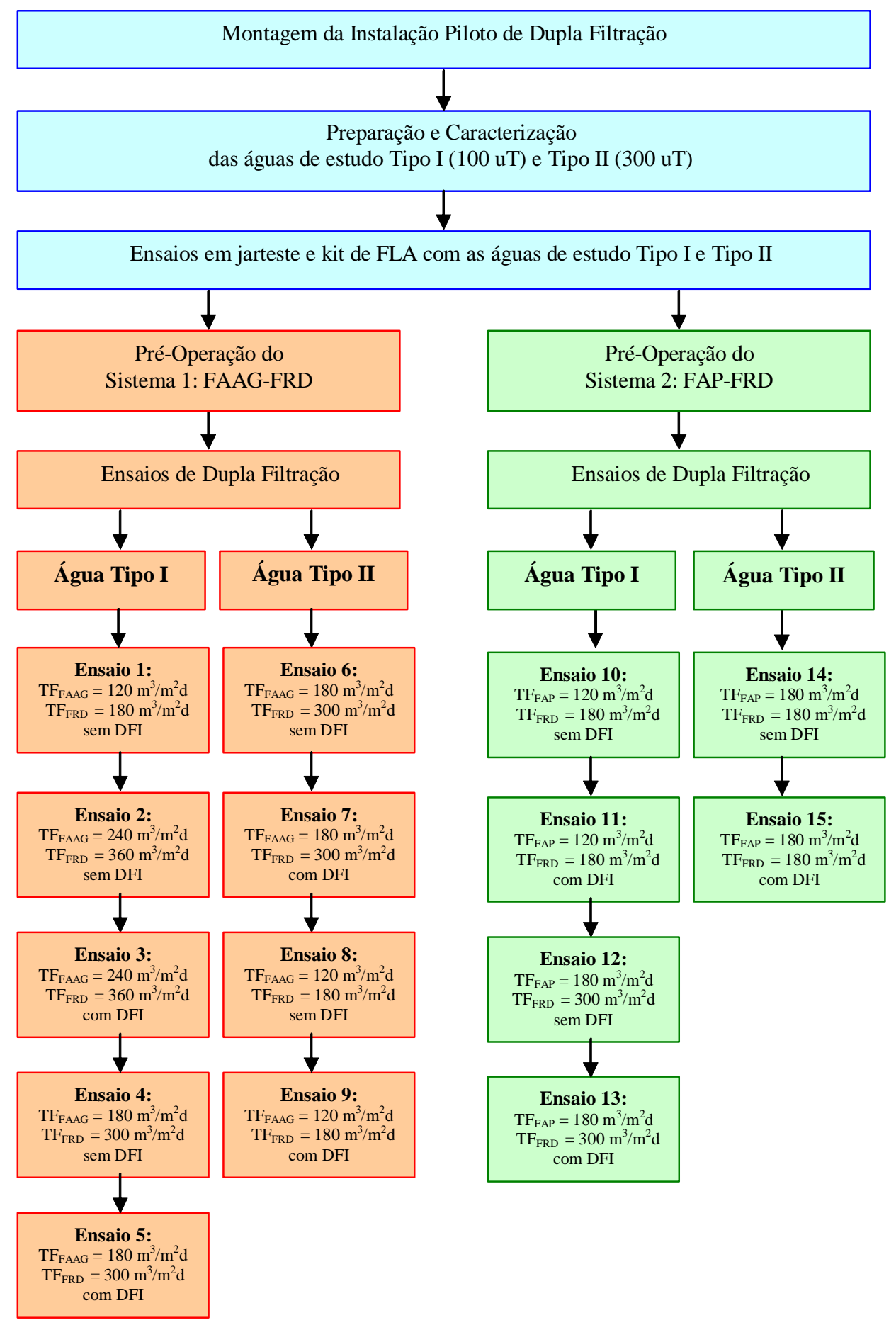

Figura 4.1 - Fluxograma do trabalho experimental 


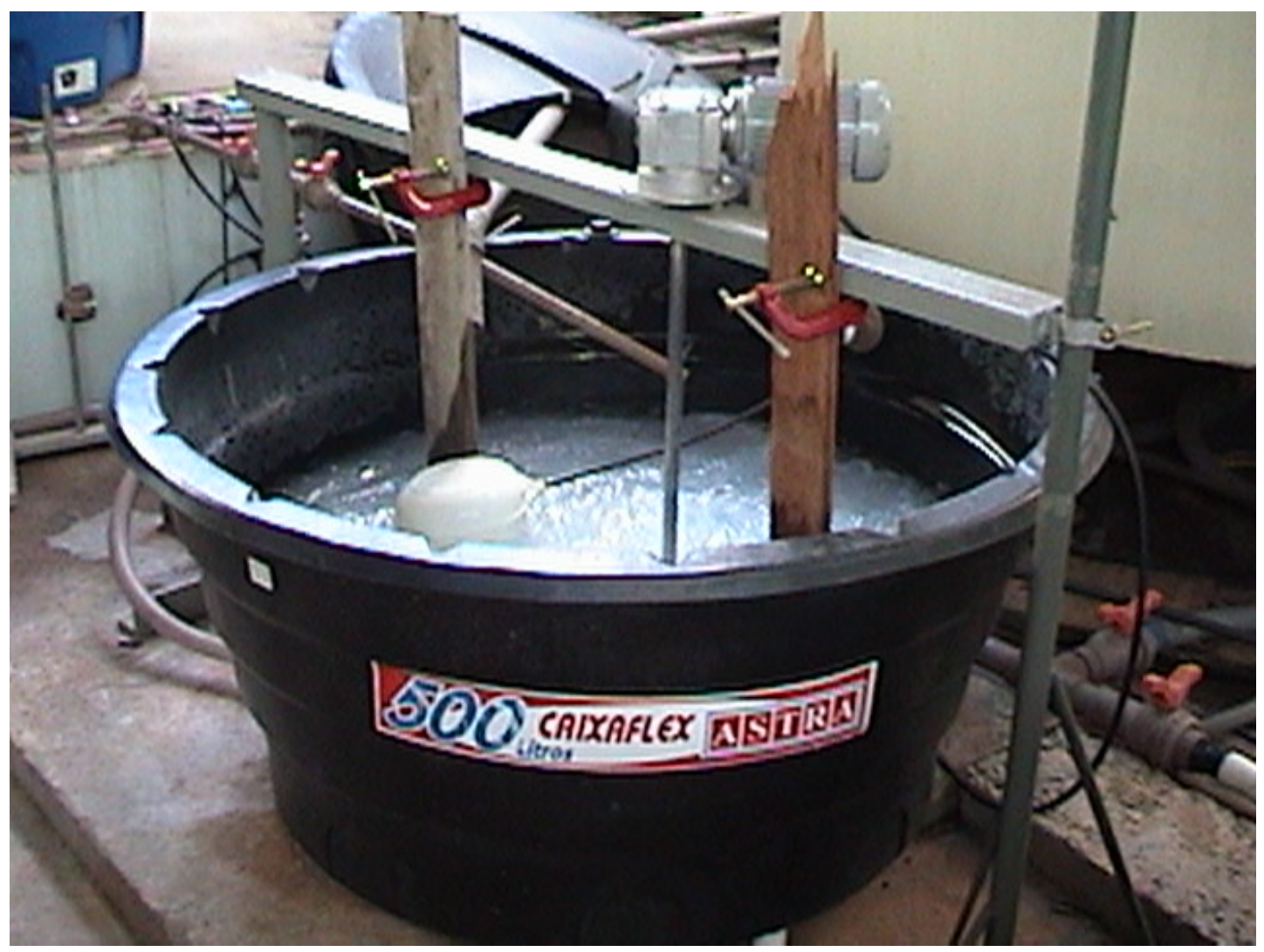

Figura 4.2 - Caixa de homogeneização

Na Figura 4.3 é mostrado um esquema geral da instalação piloto.

Na Figura 4.4 são apresentadas as tubulações de entrada de água coagulada, de aplicação de água na interface pedregulho-areia e de distribuição do ar e água para lavagem nas duas câmaras do filtro ascendente do sistema 1. Na Figura 4.5 são apresentadas as tubulações de entrada de água coagulada e de distribuição do ar e água para lavagem nas duas câmaras do filtro ascendente do sistema 2. A água para aplicação na interface e a água para lavagem eram provenientes da rede existente no laboratório de instalação piloto. $\mathrm{O}$ ar para lavagem foi proveniente de soprador.

As águas de estudo foram preparadas a partir da água do poço da EESC-USP (sem cloro) com adição da dispersão de caulinita. Antes de adicionar a caulinita, a água do poço, reservada no tanque de $20 \mathrm{~m}^{3}$, era recirculada, passando da caixa de homogeneização com agitador ao tanque, até que seu $\mathrm{pH}$ estabilizasse, ou seja, até que fosse atingido o equilíbrio, com parte do $\mathrm{CO}_{2}$ dissolvido liberado. Após a estabilização do $\mathrm{pH}$, era bombeada a dispersão de caulinita até que resultasse a turbidez desejada da água de estudo. A água de estudo passava então dos tanques para a caixa de homogeneização e era bombeada para a caixa de nível constante, onde fixada a vazão total desejada, o cap com orifício era posicionado na altura necessária (detalhe Figura 4.6 e foto na Figura 4.7). O excesso da água de estudo 
retornava para a caixa de homogeneização. A água que passava no orifício do cap entrava na câmara de mistura rápida, onde recebia a solução de coagulante. A água coagulada vertia para uma terceira câmara, da qual partia uma tubulação de alimentação dos sistemas de dupla filtração. Cada sistema de dupla filtração possuía o filtro ascendente constituído por duas câmaras com diâmetro interno de $91 \mathrm{~mm}$, e o filtro descendente, de diâmetro interno de 91 mm no sistema 1 e de 63 mm no sistema 2, todos construídos em acrílico transparente.

Os sistemas de dupla filtração (sistema 1: FAAG-FRD e sistema 2: FAP-FRD) não foram operados em paralelo em vista da dificuldade da realização simultânea das coletas ao longo das câmaras dos filtros ascendentes de areia grossa e de pedregulho. Neste sentido, para assegurar a qualidade do trabalho, cuidado extra foi tomado na preparação das águas de estudo, de modo que fosse possível a comparação dos dois sistemas.

Nas Figuras 4.8 a 4.10 são apresentadas a planta e os cortes da instalação piloto. 
Tanque de Prepáas das Águas de Estudo

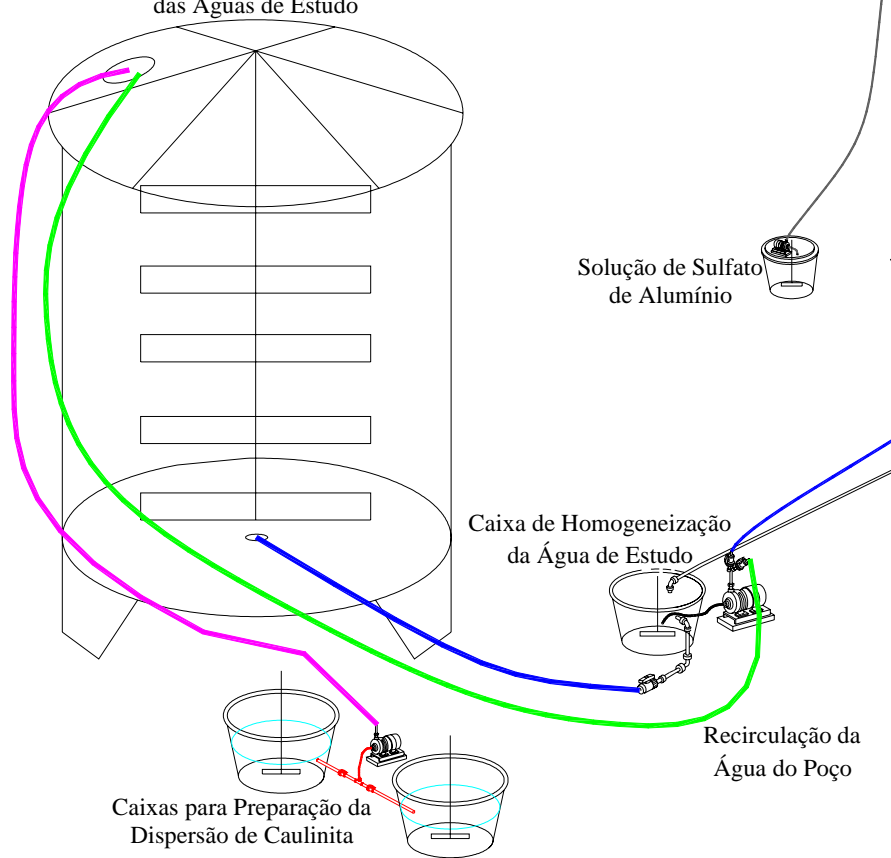

Constante

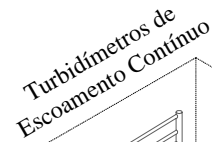

orif cio 1 Entrada de

Caixa de Mistura

Rápida
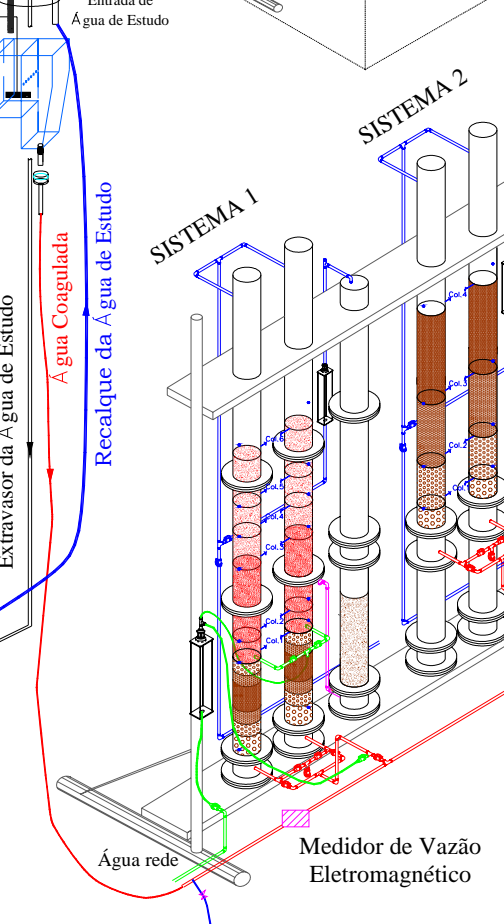

FLA

Figura 4.3 - Esquema geral da instalação piloto 


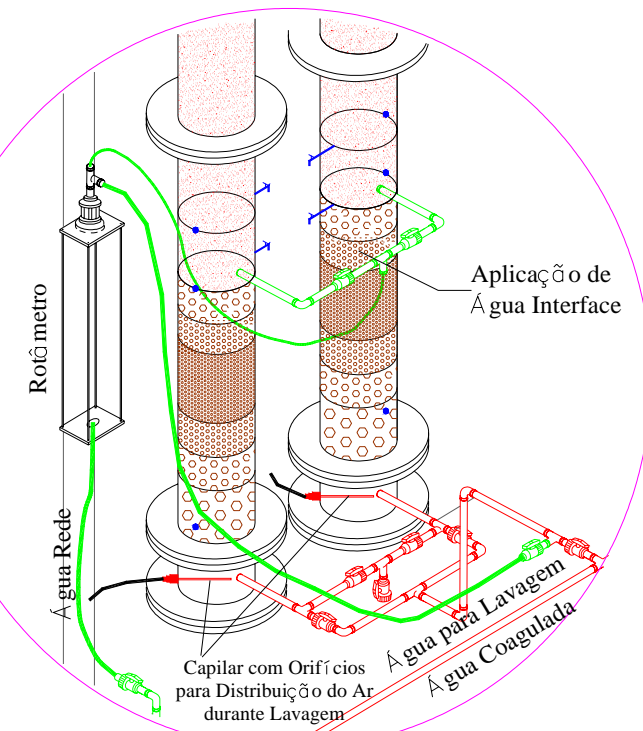

Figura 4.4 - Detalhe da entrada de água coagulada, aplicação de água na interface, distribuição do ar e água durante lavagem do filtro ascendente do sistema 1

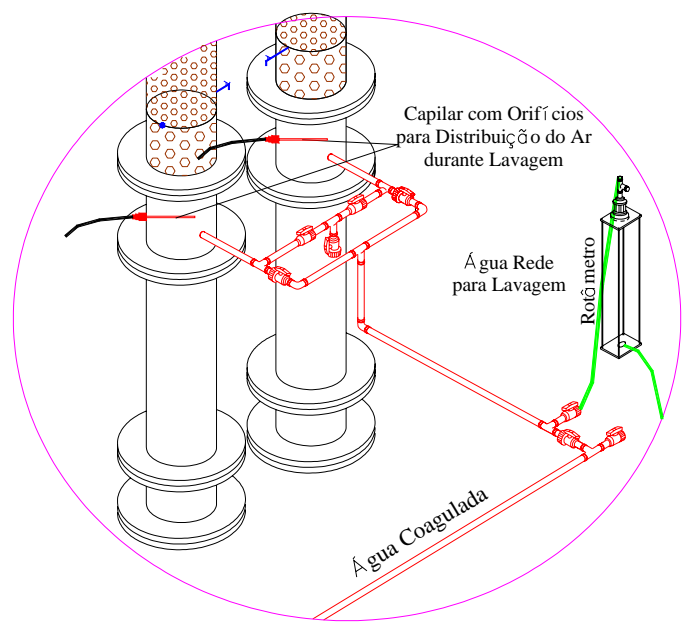

Figura 4.5- Detalhe da entrada de água coagulada, e da distribuição do ar e água durante lavagem do filtro ascendente do sistema 2

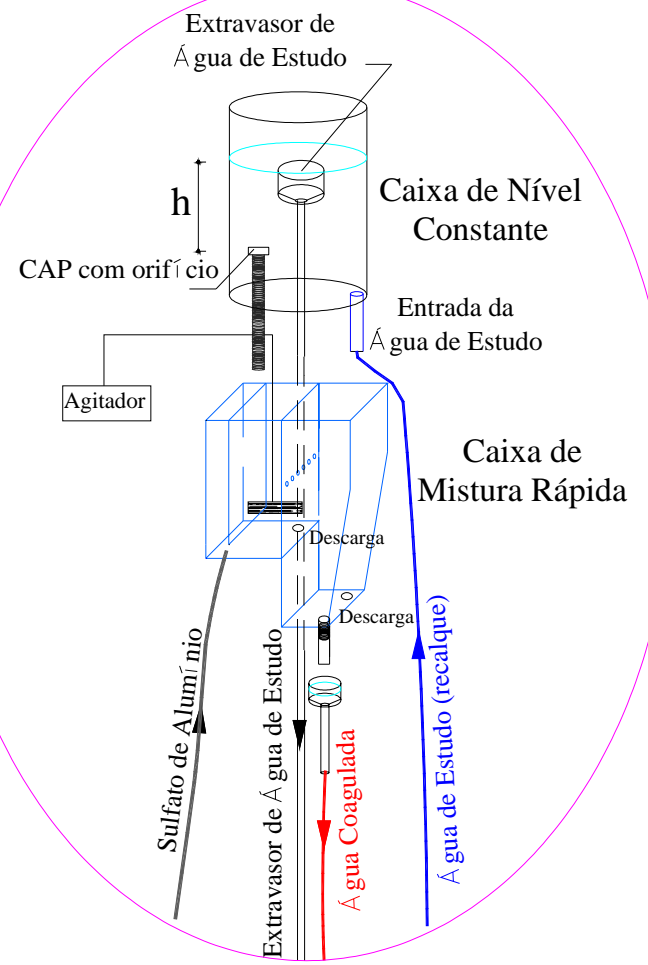

Figura 4.6 - Detalhe das caixas de nível constante e mistura rápida 


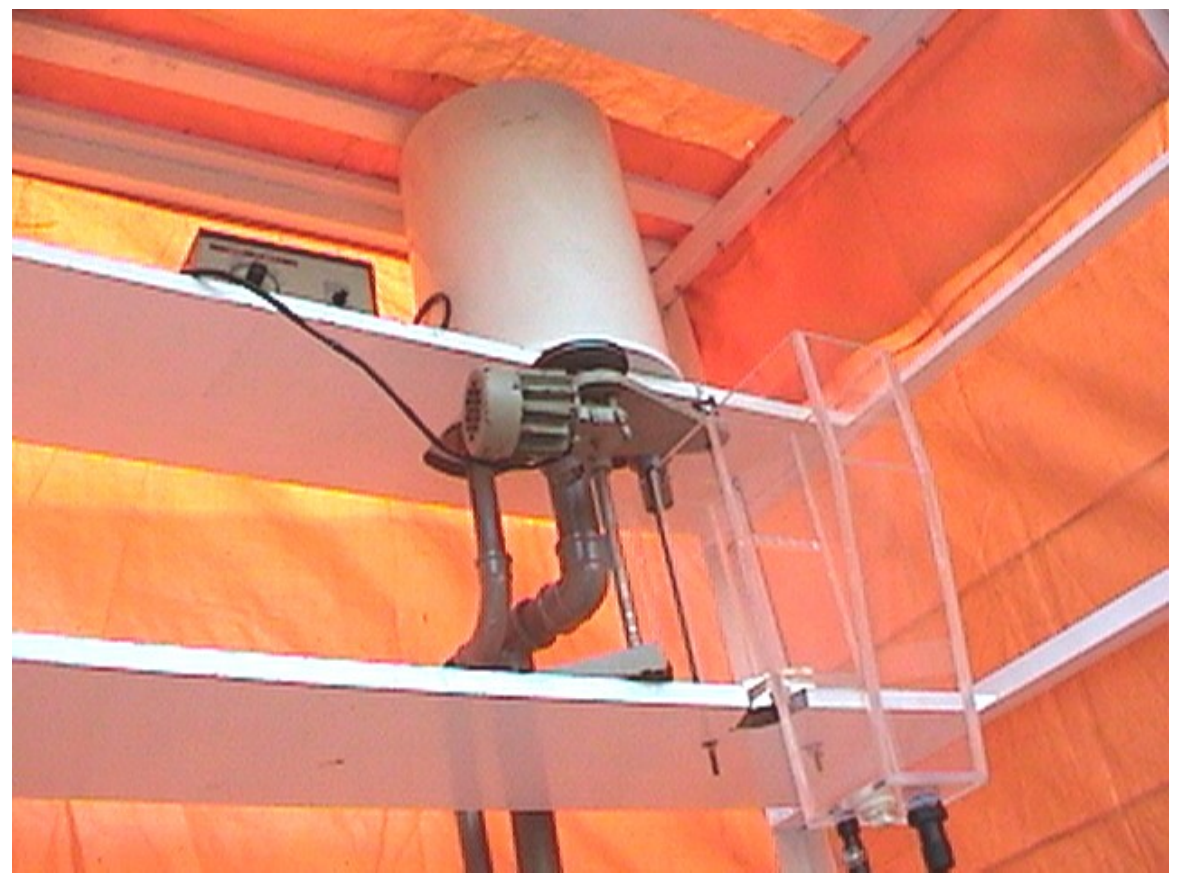

Figura 4.7 - Foto das caixas de nível constante e mistura rápida

A tubulação de alimentação dos filtros ascendentes possuía um desvio para que fossem efetuados ajustes na dosagem de coagulante, e conseqüentemente do $\mathrm{pH}$ de coagulação, por meio do uso do filtro de areia de laboratório (FLA). Uma vez ajustada a condição desejável de coagulação, a água coagulada era desviada para a parte inferior do filtro ascendente e a água clarificada, coletada na parte superior, era conduzida para o filtro descendente. Foram coletadas amostras de 3 em 3 horas ao longo do filtro ascendente por meio de um capilar perfurado no topo de cada subcamada e válvulas de agulha, de modo que a vazão de coleta não interferisse no funcionamento do filtro. O filtro ascendente do sistema 1 possuía entrada na interface pedregulho-areia para injeção de água por ocasião da execução de descargas de fundo intermediárias. A saída de água filtrada dos filtros descendentes dos dois sistemas foram posicionadas $10 \mathrm{~cm}$ acima da cota do topo do meio filtrante. As lavagens eram realizadas com água da rede e as respectivas vazões de água de lavagem eram controladas por meio de rotâmetros ou pela expansão do meio filtrante. A vazão de ar para lavagem era proveniente de um soprador e regulada por meio de um rotâmetro de ar. 


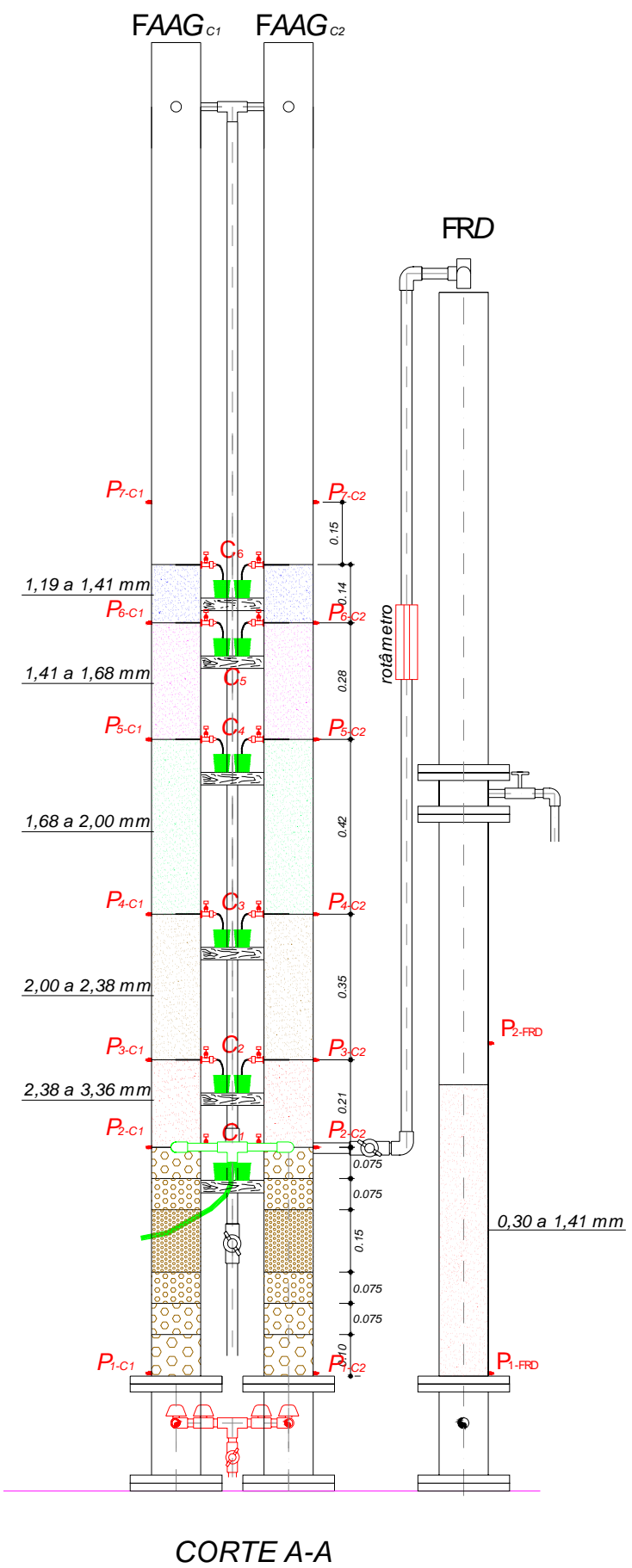

SISTEMA 1

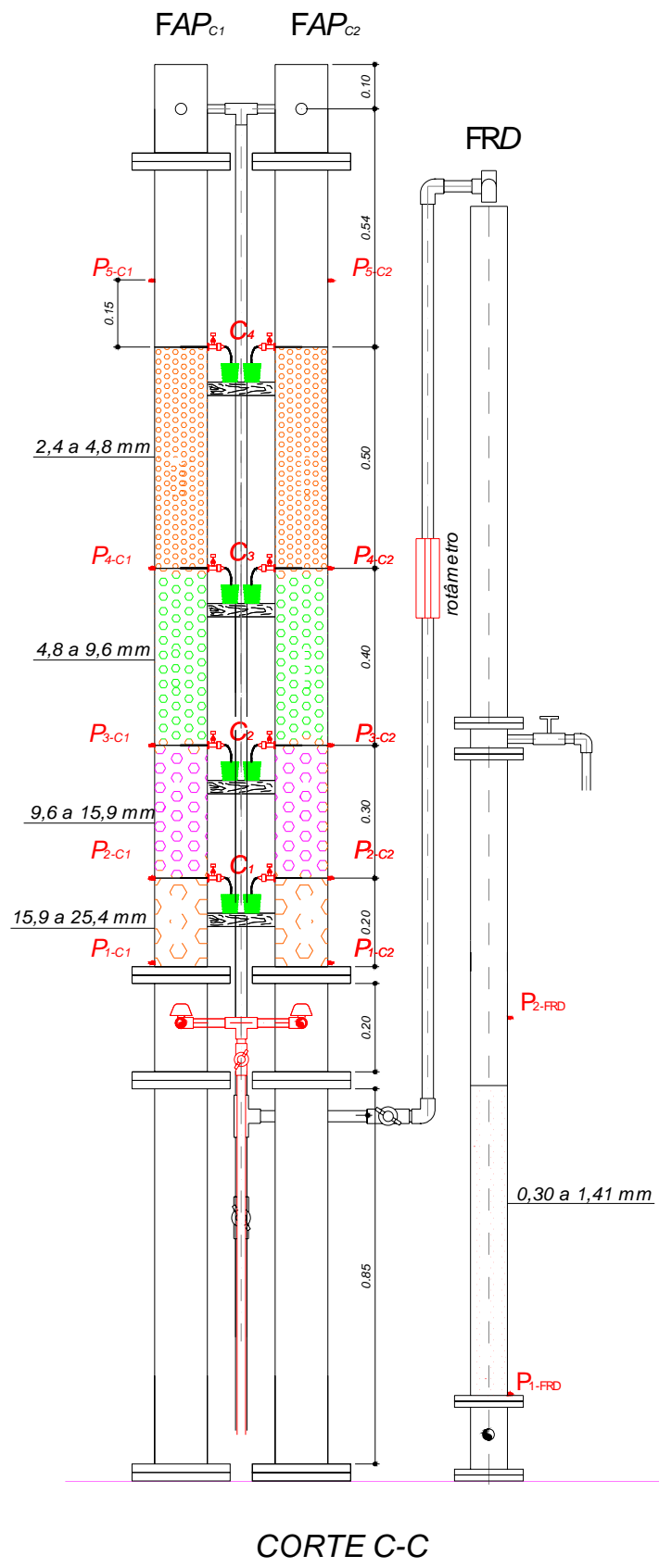

SISTEMA 2

Figura 4.8 - Cortes da instalação piloto - Sistema 1 e Sistema 2 


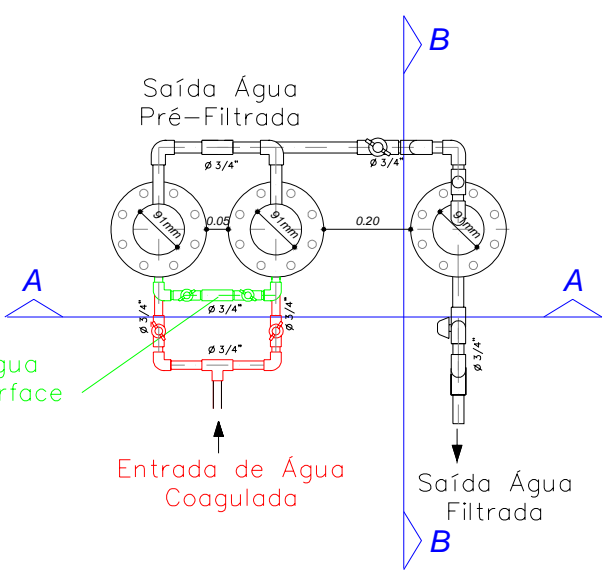

SISTEMA 1

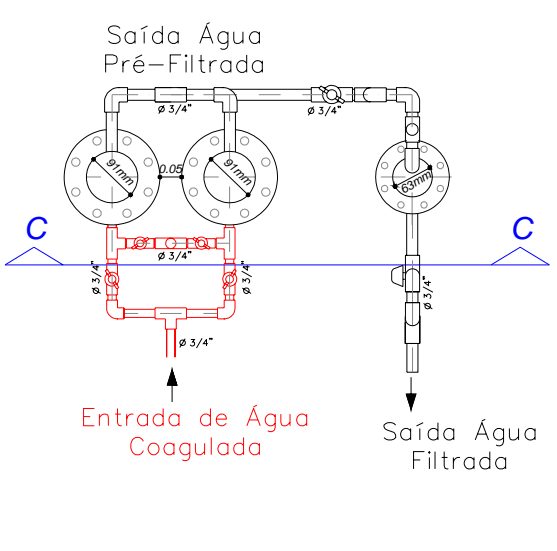

SISTEMA 2

Figura 4.9 - Planta da instalação piloto - Sistema 1 e Sistema 2

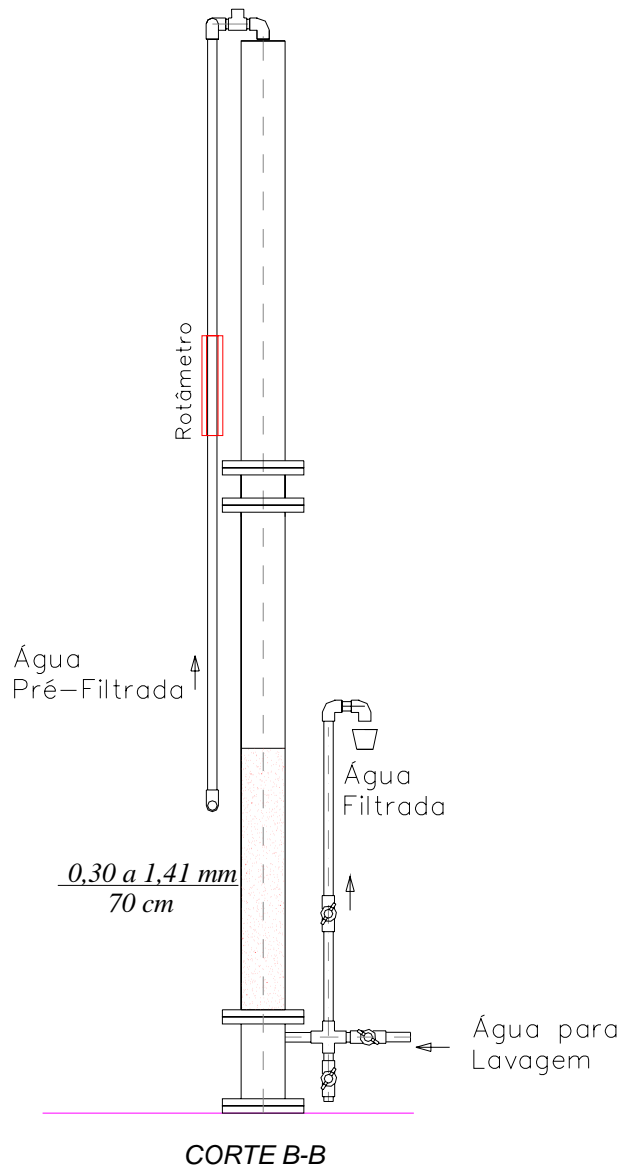

Figura 4.10 - Corte do filtro rápido descendente - Sistema 1 


\subsection{Materiais granulares}

Devido a distribuição desigual de perda de carga no meio granular do FAAG (camada suporte: 10,8 a 21,3 \% da perda de carga total e camada filtrante: 79 a 89,2 \% da perda de carga total), DE PAULA (2003) sugeriu o aumento da granulometria e a diminuição da espessura da camada filtrante, sendo neste trabalho adotada a composição para o filtro ascendente do sistema 1 conforme valores da Tabela 4.1.

Tabela 4.1 - Meio filtrante e camada suporte do filtro ascendente do sistema 1

\begin{tabular}{|c|c|c|}
\hline Subcamadas do Meio Filtrante & Tamanho $(\mathrm{mm})$ & Espessura (cm) \\
\hline 5 (topo) & 1,19 a 1,41 & 28,0 \\
4 & 1,41 a 1,68 & 42,0 \\
3 & 1,68 a 2,00 & 35,0 \\
2 & 2,00 a 2,38 & 21,0 \\
1 & 2,38 a 3,36 & Espessura (cm) \\
\hline Camada Suporte & Tamanho (mm) & 7,5 \\
\hline 6 & 12,7 a 19,0 & 7,5 \\
3 & 6,4 a 12,7 & 15,0 \\
2 & 3,36 a 6,4 & 7,5 \\
1 (fundo) & 6,4 a 12,7 & 7,5 \\
\hline
\end{tabular}

As características da areia grossa eram: tamanho dos grãos de 1,19 a 3,36 mm, tamanho efetivo $\left(\mathrm{D}_{10}\right)$ de $1,41 \mathrm{~mm}, \mathrm{D}_{60}$ de $2,00 \mathrm{~mm}$, coeficiente de desuniformidade igual a 1,42 e espessura da camada de 1,40 m. Na Figura 4.11 é apresentada a curva granulométrica do meio filtrante. Observa-se na Tabela 4.1 e na Figura 4.11, que a granulometria adotada é mais grossa que aquela utilizada por DE PAULA (2003), que foi de 1,00 a 2,38 mm. 


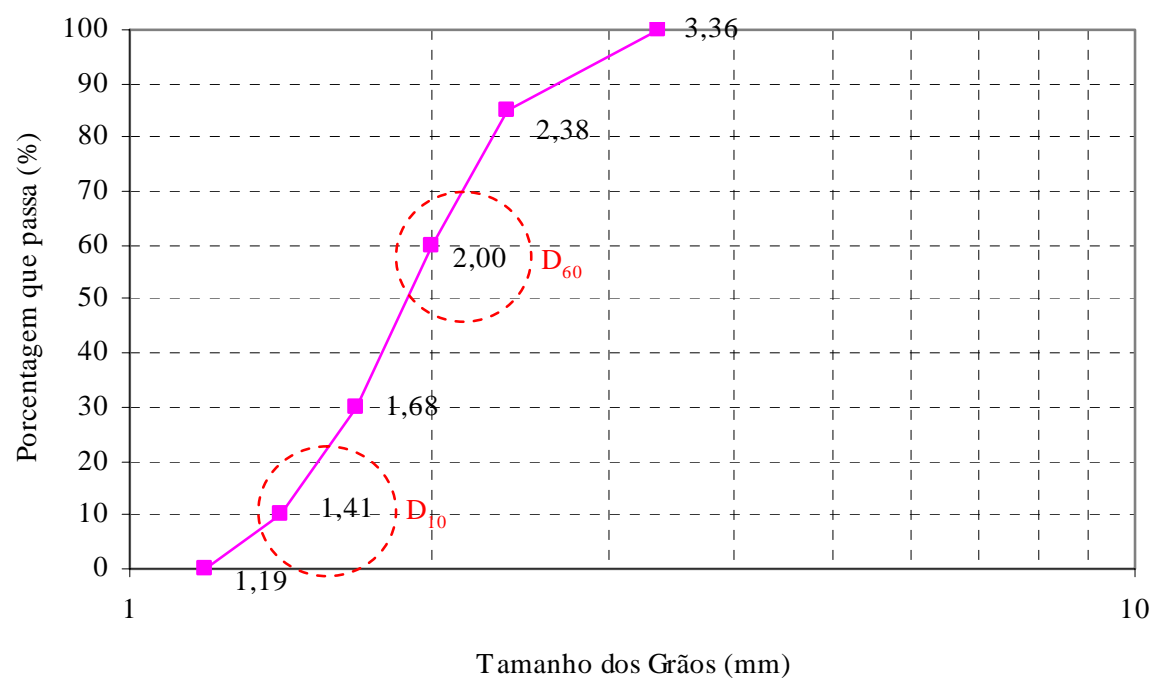

Figura 4.11 - Curva granulométrica do meio filtrante do filtro ascendente do sistema 1

Devido a distribuição desigual de perda de carga nas camadas do meio granular do FAP, KURODA (2002) sugeriu o aumento da espessura e da granulometria da última camada do FAP, sendo neste trabalho adotada a composição para o filtro ascendente do sistema 2 conforme valores da Tabela 4.2 e foto da Figura 4.12. A espessura da camada foi de $1,40 \mathrm{~m}$.

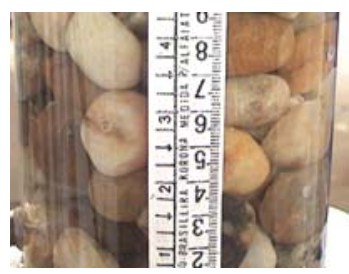

Subcamada 1

$(15,9$ a $25,4 \mathrm{~mm})$

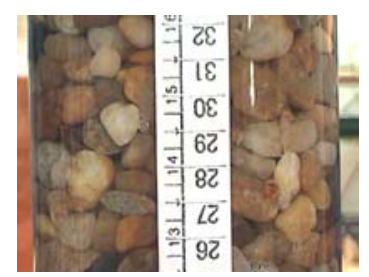

Subcamada 2

$(9,6$ a $15,9 \mathrm{~mm})$

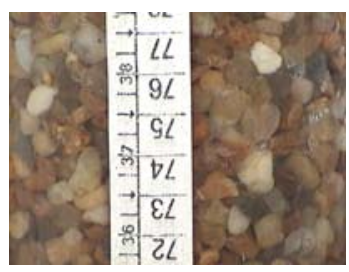

Subcamada 3

$(4,8$ a $9,6 \mathrm{~mm})$

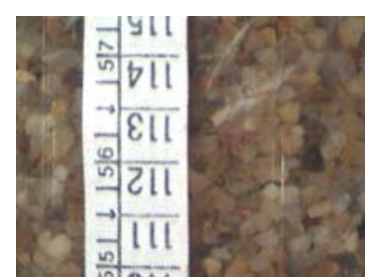

Subcamada 4

$(2,4$ a $4,8 \mathrm{~mm})$

Figura 4.12 - Subcamadas do filtro ascendente de pedregulho - Detalhe do tamanho dos grãos

Os filtros descendentes possuíam placa perfurada no fundo, sobre a qual foi disposta tela metálica ou de plástico, de forma que o material filtrante foi disposto diretamente sobre a mesma. O meio filtrante foi constituído unicamente de areia com as seguintes características: espessura da camada de $0,70 \mathrm{~m}$; tamanho dos grãos de 0,30 a $1,41 \mathrm{~mm}$; tamanho efetivo $\left(\mathrm{D}_{10}\right)$ de $0,42 \mathrm{~mm} ; \mathrm{D}_{60}$ de $0,71 \mathrm{~mm}$ e coeficiente de desuniformidade igual a 1,69. Estas características foram adotadas com base nos resultados obtidos por KURODA (2002) e DE PAULA (2003), onde os autores concluíram que o FRD foi capaz de absorver as variações 
da qualidade de água pré-filtrada devido às execuções das DFIs, lavagens e ocorrências de desprendimentos de flocos.

Tabela 4.2 - Meio filtrante do filtro ascendente do sistema 2 e meio filtrante utilizado por

KURODA (2002)

\begin{tabular}{|c|c|c|c|c|}
\hline $\begin{array}{c}\text { Subcamadas do Meio } \\
\text { Filtrante }\end{array}$ & $\begin{array}{c}\text { Tamanho } \\
(\mathrm{mm})\end{array}$ & $\begin{array}{c}\text { Espessura da } \\
\text { Subcamada (cm) }\end{array}$ & $\begin{array}{c}\text { Tamanho } \\
(\mathrm{mm}) \\
\text { KURODA (2002) }\end{array}$ & $\begin{array}{c}\text { Espessura da } \\
\text { Subcamada (cm) } \\
\text { KURODA (2002) }\end{array}$ \\
\hline 4 (topo) & 2,4 a 4,8 & 50 & 1,41 a 2,4 & 30 \\
3 & 4,8 a 9,6 & 40 & 3,2 a 6,4 & 30 \\
2 & 9,6 a 15,9 & 30 & 9,6 a 15,9 & 30 \\
1 & 15,9 a 25,4 & 20 & 19,0 a 25,4 & 30 \\
\hline
\end{tabular}

Na Figura 4.13 é apresentada a curva granulométrica do meio filtrante do filtro descendente, igual nos dois sistemas de dupla filtração.

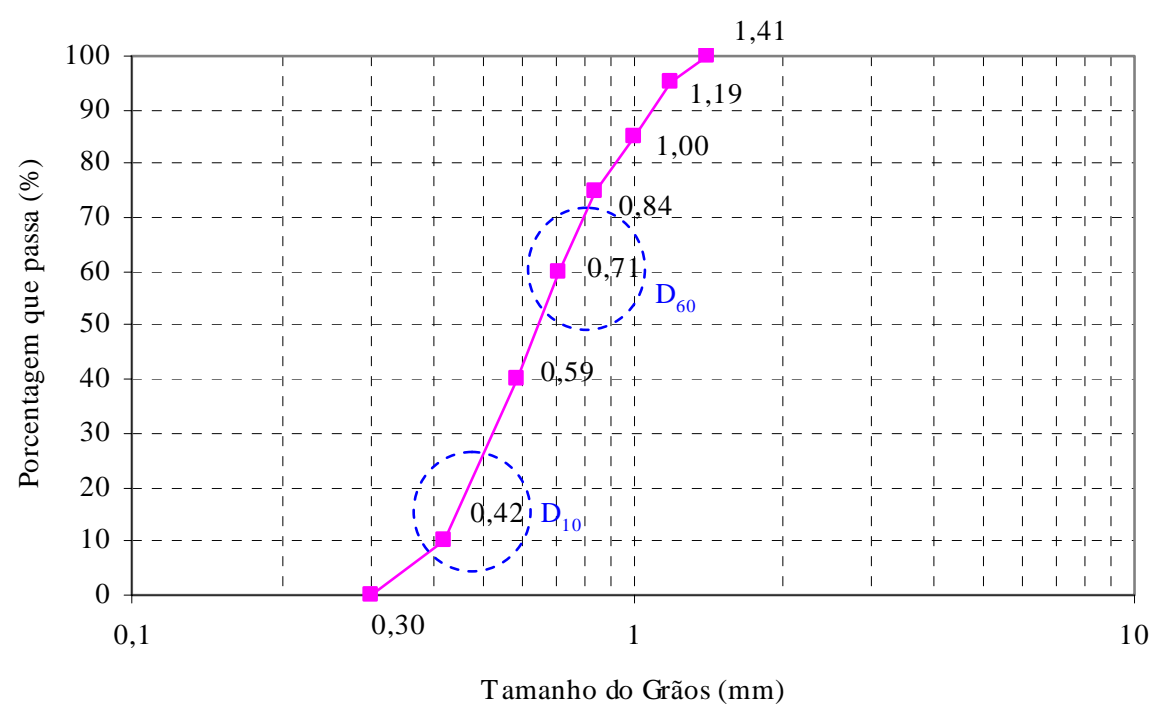

Figura 4.13 - Curva granulométrica do filtro descendente dos sistemas 1 e 2 


\subsection{Preparação e caracterização da caulinita}

Foram realizados dois tipos de ensaio para avaliar o método de preparação e as características da caulinita que foi utilizada para conferir turbidez às águas de estudo.

\subsubsection{Ensaio de sedimentação}

Foi realizado um ensaio em cone Imhoff para verificação do comportamento do sobrenadante da caulinita, também denominado de dispersão-mãe, em função do tempo de sedimentação após agitação de 21,5g de caulinita em 1L de água destilada - procedimento descrito por CAMPOS (1980). Visando o melhor aproveitamento do produto, também foi testada a sua reutilização.

Primeira agitação da caulinita: foram pesados 21,5g da caulinita e adicionados em $1 \mathrm{~L}$ de água do poço. Após 2 horas de agitação em jarteste com gradiente de velocidade médio da ordem de $200 \mathrm{~s}^{-1}$, a dispersão foi transferida para o Cone Imnhoff. Foram feitas leituras de turbidez e volume de sedimento em função do tempo.

Segunda agitação da caulinita: o sedimento do caulim resultante do primeiro ensaio foi retirado do cone e o volume completado com 1L de água do poço. Após 2 horas de agitação em jarteste com gradiente de velocidade médio da ordem de $200 \mathrm{~s}^{-1}$, a nova dispersão foi transferida para o cone Imnhoff. Foram feitas leituras de turbidez e volume de sedimento em função do tempo.

\subsubsection{Caracterização do sobrenadante}

Este ensaio foi realizado para verificar o número e o tamanho de partículas presentes nos sobrenadantes resultantes da primeira e segunda agitação da caulinita. Para tal, foram preparadas duas águas com turbidez igual a $100 \mathrm{uT}$, sendo na primeira utilizada somente o sobrenadante da primeira agitação (água tipo Ia), e na segunda o sobrenadante das duas (água tipo Ib), simulando o que poderia acontecer na preparação das águas de estudo durante os ensaios de dupla filtração. A caracterização também foi feita para a água com turbidez de 300 uT preparada com caulinita somente da primeira agitação - água tipo IIa.

Para a preparação dos sobrenadantes, foi utilizado o procedimento descrito anteriormente: agitação de 21,5g de caulinita em $1 \mathrm{~L}$ de água do poço por 2 horas e coleta do sobrenadante 1 após 10 horas de repouso; agitação do sedimento da primeira agitação em $1 \mathrm{~L}$ de água do poço por 2 horas e coleta do sobrenadante 2 após 10 horas de repouso. 


\subsection{Preparação e caracterização das águas de estudo}

As águas de estudo tipo I e tipo II foram preparadas a partir da mistura da água do poço da EESC-USP com sobrenadante da caulinita (características e modo de preparação no item 4.4), de modo que a turbidez final resultasse em torno de 100 uT e de 300 uT, respectivamente. Como mencionado anteriormente, antes da adição da caulinita na água do poço, esta foi recirculada até que o pH ficasse estável.

A caracterização das águas foi feita no laboratório de saneamento da EESC-USP, e os seguintes parâmetros foram medidos: turbidez, alcalinidade, $\mathrm{pH}$, temperatura, cor aparente, cor verdadeira, contagem de partículas, condutividade elétrica, potencial zeta, carbono orgânico dissolvido, sólidos totais suspensos e dissolvidos, absorvância a 254 nm e oxigênio consumido.

Na Tabela 4.3 são listados os equipamentos e os métodos utilizados na caracterização das águas de estudo.

Tabela 4.3 - Equipamentos utilizados na caracterização das águas de estudo

\begin{tabular}{|c|c|c|}
\hline Equipamento & Parâmetro & Método \\
\hline Turbidímetro HACH, modelo $210 \mathrm{P}$ & turbidez & nefelométrico \\
\hline Potenciômetro DIGIMED, modelo DM 20 & $\mathrm{pH}$ & potenciométrico \\
\hline $\begin{array}{c}\text { Zetâmetro MALVERN, modelo Zetamaster particle } \\
\text { eletrophoresis analyser }\end{array}$ & potencial zeta & $\begin{array}{l}\text { espectroscopia de correlação } \\
\text { de fotos }\end{array}$ \\
\hline Potenciômetro DIGIMED, modelo DM 20 & alcalinidade & titulação potenciométrica \\
\hline $\begin{array}{l}\text { Espectrofotômetro de leitura direta, HACH, } \\
\qquad \mathrm{DR} / 4000\end{array}$ & cor aparente & espectrofotométrico \\
\hline $\begin{array}{l}\text { Espectrofotômetro de leitura direta, HACH, } \\
\qquad \text { DR/4000 } \\
\text { Bomba de vácuo MARCONI, modelo MA057 }\end{array}$ & cor verdadeira & $\begin{array}{c}\text { filtração em membrana } \\
\text { espectrofotométrico }\end{array}$ \\
\hline $\begin{array}{c}\text { Total Organic Carbon Analyzer, SHIMADZU, } \\
\text { modelo TOC } 5000 \text { A }\end{array}$ & $\begin{array}{l}\text { carbono orgânico } \\
\text { dissolvido }\end{array}$ & $\begin{array}{c}\text { combustão a alta } \\
\text { tempereratura }\end{array}$ \\
\hline $\begin{array}{l}\text { Balança analítica METTLER, modelo AT } 261 \\
\text { Bomba de vácuo MARCONI, modelo MA057 } \\
\text { Estufa FABBE } \\
\text { Mufla EDG Equipamentos, modelo EDGCON SP }\end{array}$ & $\begin{array}{c}\text { sólidos totais suspensos e } \\
\text { dissolvidos }\end{array}$ & filtração em membrana \\
\hline $\begin{array}{l}\text { Espectrofotômetro UV-Visível SHIMADZU, } \\
\text { modelo UV-160 A }\end{array}$ & absorvância a $254 \mathrm{~nm}$ & absorção ultravioleta \\
\hline Chapa de aquecimento QUIMIS, modelo Q-313F22 & oxigênio consumido & $\begin{array}{l}\text { Oxidação e titulação com } \\
\mathrm{KMnO}_{4}\end{array}$ \\
\hline $\begin{array}{l}\text { Amostrador HIAC/ROYCO, modelo } 3000 \text { A } \\
\text { Contador HIAC/ROYCO, modelo } 8000 \text { A }\end{array}$ & partículas & $\begin{array}{l}\text { extinção de luz gerado por } \\
\text { diodo a laser }\end{array}$ \\
\hline
\end{tabular}


Durante a realização dos ensaios de dupla filtração, a água de estudo foi armazenada no tanque de $20 \mathrm{~m}^{3}$ e foi feito monitoramento constante das características da água para assegurar a qualidade dos resultados.

\subsection{Ensaio de bancada}

Foram realizados ensaios de bancada com as águas de estudo, utilizando-se equipamento de jarteste e kit de filtros de laboratório de areia - FLA, conforme descrição detalhada na referência DI BERNARDO et al. (2002b) (ver Figura 4.14).

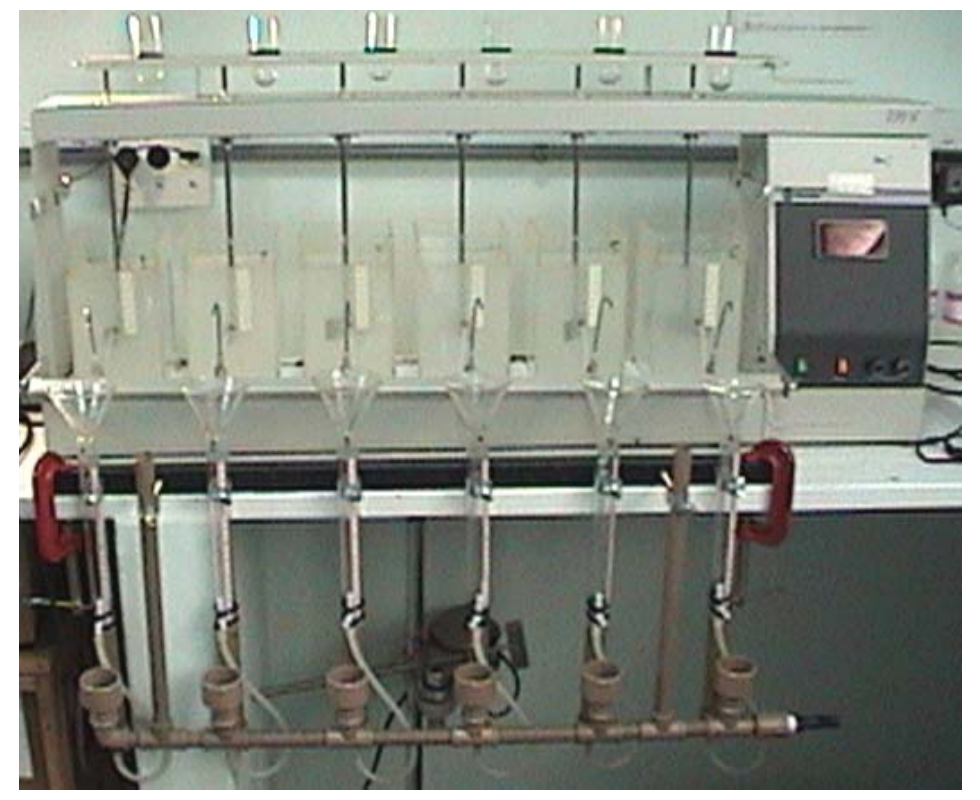

Figura 4.14 - Equipamento de jarteste e kit de FLA

Os produtos químicos utilizados nos ensaios foram o sulfato de alumínio, produto comercial líquido com 7,2 \% $\mathrm{Al}_{2} \mathrm{O}_{3}$, como coagulante, ácido clorídrico como acidificante e carbonato de sódio como alcalinizante.

Foram realizadas três séries de ensaios de filtração direta (coagulação em jarteste e filtração em FLAs), com as duas águas de estudo, conforme descrição a seguir. Antes de cada ensaio, as principais características das águas de estudo (turbidez, $\mathrm{pH}$, temperatura e alcalinidade) eram verificadas de modo a assegurar a comparação dos diversos ensaios.

\subsubsection{Série I: Condições de coagulação}

Foram realizados ensaios de filtração direta variando-se a dosagem de sulfato de alumínio e o pH de coagulação por meio da adição de carbonato de sódio ou ácido clorídrico, objetivando a determinação do par de valores dosagem de sulfato $\mathrm{x}$ pH de coagulação que eliminasse a necessidade do uso de acidificante/alcalinizante e cuja eficiência fosse 
considerada satisfatória. Para escolha deste ponto foram construídos gráficos, nos quais se tem curvas de mesma turbidez em função do pH de coagulação (abscissa) e dosagem de sulfato de alumínio (ordenada).

As características dos ensaios foram as seguintes: mistura rápida: tempo de $30 \mathrm{~s}$, gradiente de velocidade médio de $1000 \mathrm{~s}^{-1}$, coletas nos FLAs após 10, 20 e 30 min de filtração, areia FLA tipo 2 para a água tipo I e areia FLA tipo 3 para a água tipo II (ver especificação na Série II) e parâmetros de controle: pH de coagulação, potencial zeta e turbidez do filtrado (equipamentos utilizados - ver Tabela 4.3).

\subsubsection{Série II: Verificação do tipo de areia dos FLAs}

Foram realizados ensaios de filtração direta com a dosagem de sulfato de alumínio fixada na série I, objetivando a determinação do tipo de areia dos FLAs que proporcionasse os melhores resultados em termos de remoção de turbidez e evolução da perda de carga. Os tipos de areia estudados foram:

- Areia tipo 1: grãos entre 0,30 e 0,59 mm e $\mathrm{D}_{10}=0,42 \mathrm{~mm}$;

- Areia tipo 2: grãos entre 0,42 e 0,84 mm e $D_{10}=0,59 \mathrm{~mm}$;

- Areia tipo 3: grãos entre 0,59 e 1,41 mm e $\mathrm{D}_{10}=0,71 \mathrm{~mm}$.

As características dos ensaios foram as seguintes: mistura rápida: tempo de $30 \mathrm{~s}$, gradiente de velocidade médio de $1000 \mathrm{~s}^{-1}$, coletas nos FLAs após 10, 20, 30, 40, 50 e 60 min de filtração, parâmetros de controle: pH de coagulação, turbidez do filtrado (equipamentos utilizados - ver Tabela 4.3) e perda de carga nos FLAs por meio de régua graduada disposta conforme mostrado na Figura 4.15. 


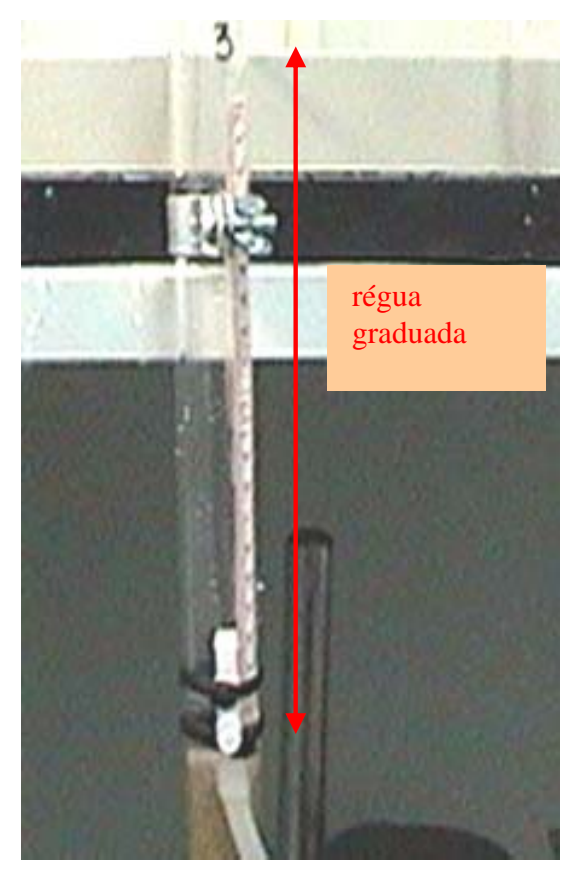

Figura 4.15 - Régua graduada colocada no FLA para leitura de perda de carga durante os ensaios de bancada

\subsubsection{Série III: Verificação das condições de mistura rápida}

Foram realizados ensaios de filtração direta com a dosagem de sulfato de alumínio fixada na série I e com o tipo de areia do FLA determinado na série II, variando-se o tempo e o gradiente de velocidade médio da mistura rápida, objetivando a determinação do gradiente com o qual a variação do tempo de mistura não influenciasse a eficiência da coagulação-filtração. Como a caixa de mistura rápida na instalação piloto é idêntica a um jarro do jarteste, a determinação deste gradiente permitiu que para diferentes taxas de filtração adotadas nos ensaios na instalação piloto, a eficiência do sistema não fosse influenciada pelo aumento ou redução do tempo de mistura.

As características dos ensaios foram as seguintes: mistura rápida: tempos: 20, 60, 100, 140, 180 e 220 s (tempo fixados em função das taxas de filtração que foram estudadas e considerando-se o efeito de curto circuito no escoamento contínuo), gradiente de velocidade médio: 400, 600, 800 e $1000 \mathrm{~s}^{-1}$, coletas nos FLAs após 10, 20 e 30 min de filtração, parâmetros de controle: pH de coagulação e turbidez do filtrado (equipamentos utilizados ver Tabela 4.3).

\subsection{Pré-operação da instalação piloto}

Nesta fase foram realizados ensaios preliminares com água do poço da EESC-USP na instalação piloto de dupla filtração, objetivando verificar a composição do meio filtrante 
das duas câmaras do filtro ascendente de areia grossa e das duas câmaras do filtro ascendente de pedregulho, ajustar as válvulas de agulha ao longo dos mesmos, calibrar os turbidímetros de escoamento contínuo e o software para aquisição dos dados, aferir os rotâmetros de água e bomba dosadora, e determinar a posição dos registros de descarga das duas câmaras dos filtros ascendentes dos sistemas 1 e 2 para obtenção das taxas de descarga fixadas.

\subsubsection{Verificação da composição do meio filtrante}

Para assegurar que as duas câmaras dos filtros ascendentes dos sistemas 1 e 2 estivessem com o mesmo meio filtrante, foram realizados ensaios com a água do poço (turbidez menor que $1 \mathrm{uT}$ ), sem coagulação, de modo que a vazão total passasse somente por uma câmara de filtração de cada vez. Para tal foram fechados os registros de entrada da câmara que não estava sendo estudada. Foram feitas leituras nos piezômetros localizados ao longo do filtro para diferentes taxas de filtração $\left(115,172\right.$ e $240 \mathrm{~m}^{3} / \mathrm{m}^{2}$.d para o sistema 1 e 120, 175 e $220 \mathrm{~m}^{3} / \mathrm{m}^{2}$.d para o sistema 2).

\subsubsection{Taxa de descarga de fundo}

Foram realizados ensaios para ajustar a posição dos registros de descarga dos filtros ascendentes dos sistemas 1 e 2, de modo que as taxas de descargas durante a realização das descargas de fundo intermediárias resultassem em torno de 800 e de $700 \mathrm{~m}^{3} / \mathrm{m}^{2}$.d, respectivamente.

No sistema 1, a descarga foi efetuada com aplicação simultânea de água (água da rede) na interface pedregulho-areia, com vazão ajustada por meio de rotâmetro (taxa de aplicação de $800 \mathrm{~m}^{3} / \mathrm{m}^{2}$.d), e a posição dos registros das câmaras 1 e 2 foi fixada quando não houve alteração do nível de água no interior do filtro, ou seja, taxa de descarga igualou a taxa de aplicação de água na interface.

No sistema 2, a descarga foi efetuada com esvaziamento total do filtro e a posição dos registros de descarga foi fixada de modo que o volume descartado em 2 min resultasse taxa de descarga média de $700 \mathrm{~m}^{3} / \mathrm{m}^{2}$.d.

\subsubsection{Ajuste das válvulas de agulha}

Foram realizados ensaios com diferentes taxas de filtração com a água do poço, sem coagulação, para ajustar a posição das válvulas de agulha na ocasião da coleta das amostras ao longo dos filtros ascendentes (detalhe Figura 4.16). As válvulas foram ajustadas de modo que a vazão que estava sendo coletada não ultrapassasse 10 \% da vazão total, assegurando desta maneira que não houvesse interferência no funcionamento dos filtros. 


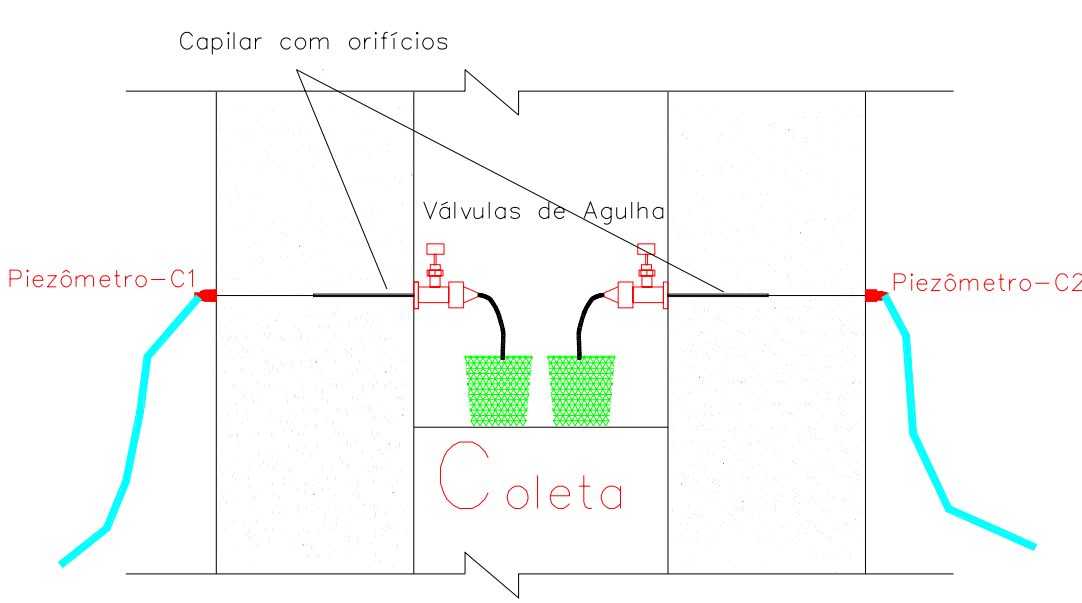

Figura 4.16 - Detalhe da coleta de amostras ao longo dos filtros ascendentes dos sistemas 1 e 2

\subsubsection{Comparação dos resultados obtidos com a perda de carga calculada pela equação de FAIR et al. (1968)}

Os resultados de perda de carga obtidos na pré-operação foram comparados com os valores de perda de carga calculados pela equação proposta por FAIR et al. (1968), válida para taxas de filtração menores que $500 \mathrm{~m}^{3} / \mathrm{m}^{2}$.d e para o meio filtrante limpo.

$$
h=\frac{150 \times \mu \times V_{\infty} \times\left(1-\varepsilon_{0}\right)^{2}}{g \times \rho_{a} \times \varepsilon_{0}{ }^{3} \times C e^{2}} \times L_{f} \times \sum \frac{X i}{(D g i)^{2}}
$$

em que:

h (m): perda de carga no meio filtrante limpo;

$\mu\left(\mathrm{N} . \mathrm{s} / \mathrm{m}^{2}\right)$ : viscosidade absoluta da água;

$\rho$ a $\left(\mathrm{kg} / \mathrm{m}^{3}\right)$ : massa específica da água;

Ce: coeficiente de esfericidade;

$\varepsilon_{0}$ : porosidade da camada suporte limpa;

$V_{\infty}(\mathrm{m} / \mathrm{s})$ : velocidade de aproximação;

$\mathrm{g}\left(\mathrm{m} / \mathrm{s}^{2}\right)$ : aceleração da gravidade;

Lf (m): espessura da camada suporte;

Xi: fração correspondente a subcamada i;

Dgi (m): média geométrica entre os tamanhos das aberturas de duas peneiras consecutivas da subcamada i; 


\subsection{Ensaios de Dupla Filtração}

\subsubsection{Programação dos ensaios}

Na Tabela 4.4 são apresentados os valores das taxas de filtração e as demais características dos ensaios de dupla filtração na instalação piloto.

Tabela 4.4 - Características dos ensaios de dupla filtração

\begin{tabular}{|c|c|c|c|c|c|}
\hline $\begin{array}{l}\text { Água } \\
\text { Estudo }\end{array}$ & $\begin{array}{c}\text { Sistema de } \\
\text { Dupla Filtração }\end{array}$ & $\begin{array}{c}\text { Taxa de Filtração no } \\
\text { Filtro Ascendente } \\
\left(\mathrm{m}^{3} / \mathrm{m}^{2} \cdot \mathrm{d}\right)\end{array}$ & $\begin{array}{c}\text { Taxa de Filtração no } \\
\text { Filtro Descendente } \\
\qquad\left(\mathrm{m}^{3} / \mathrm{m}^{2} . \mathrm{d}\right)\end{array}$ & $\begin{array}{c}\text { Execução de } \\
\text { Descargas de Fundo } \\
\text { Intermediárias }\end{array}$ & $\begin{array}{l}\text { Número } \\
\text { do Ensaio }\end{array}$ \\
\hline Tipo I & 1 & 120 & 180 & Não & 1 \\
\hline Tipo I & 1 & 240 & 360 & Não & 2 \\
\hline Tipo I & 1 & 240 & 360 & Sim & 3 \\
\hline Tipo I & 1 & 180 & 300 & Não & 4 \\
\hline Tipo I & 1 & 180 & 300 & Sim & 5 \\
\hline Tipo II & 1 & 180 & 300 & Não & 6 \\
\hline Tipo II & 1 & 180 & 300 & Sim & 7 \\
\hline Tipo II & 1 & 120 & 180 & Não & 8 \\
\hline Tipo II & 1 & 120 & 180 & Sim & 9 \\
\hline Tipo I & 2 & 120 & 180 & Não & 10 \\
\hline Tipo I & 2 & 120 & 180 & Sim & 11 \\
\hline Tipo I & 2 & 180 & 300 & Não & 12 \\
\hline Tipo I & 2 & 180 & 300 & Sim & 13 \\
\hline Tipo II & 2 & 180 & 180 & Não & 14 \\
\hline Tipo II & 2 & 180 & 180 & Sim & 15 \\
\hline
\end{tabular}

\subsubsection{Preparação do coagulante}

O coagulante utilizado foi o sulfato de alumínio. Foi adquirida a solução concentrada do produto, com teor de $\mathrm{Al}_{2} \mathrm{O}_{3}$ de 7,2 \% e diluída em um bombona de $50 \mathrm{~L}$ provida de agitador e bomba dosadora.

O cálculo da vazão da bomba dosadora foi realizado utilizando-se o conceito de balanço de massa:

$$
C_{s o l} \times q_{b}=D S A \times\left(q_{b}+Q_{T}\right)
$$

em que:

$\mathrm{C}_{\text {sol }}$ (mg/L produto comercial): concentração da solução de coagulante; 
$\mathrm{q}_{\mathrm{b}}(\mathrm{L} / \mathrm{h})$ : vazão da bomba dosadora;

DSA (mg/L produto comercial): dosagem de coagulante;

$\mathrm{Q}_{\mathrm{T}}(\mathrm{L} / \mathrm{h})$ : vazão total de água de estudo recalcada.

\subsubsection{Ajuste das vazões}

A vazão total afluente ao sistema de dupla filtração foi verificada por meio de medidor eletromagnético instalado na tubulação a montante da entrada dos filtros ascendentes. O ajuste dessa vazão foi realizado pela altura h (carga hidráulica sobre o orifício) e pelo diâmetro do orifício no cap na caixa de nível constante (ver detalhe Figura 4.5). A equação de perda de carga em orifício é dada por:

$$
Q_{T}=C d \cdot A \cdot \sqrt{2 \cdot g \cdot h}
$$

Equação 4.3

em que:

$\mathrm{Q}_{\mathrm{T}}\left(\mathrm{m}^{3} / \mathrm{s}\right)$ : vazão total de água de estudo recalcada;

A $\left(\mathrm{m}^{2}\right)$ : área do orifício;

$\mathrm{g}\left(\mathrm{m} / \mathrm{s}^{2}\right)$ : aceleração da gravidade;

$\mathrm{h}(\mathrm{m})$ : perda de carga;

Cd: coeficiente de descarga.

Uma parte da vazão de água pré-filtrada foi direcionada ao filtro descendente e foi verificada por meio de rotâmetro e a outra parcela da água foi direcionada ao turbidímetro de escoamento contínuo para leitura da turbidez da água pré-filtrada, cuja faixa de vazão varia de 15 a $45 \mathrm{~L} / \mathrm{h}$.

\subsubsection{Controle da coagulação}

Foi utilizado o FLA com características idênticas àquelas utilizadas nos ensaios de bancada para controle e ajuste, quando necessário, da coagulação com sulfato de alumínio. No início de cada ensaio de dupla filtração, a água coagulada era desviada e o ajuste da condição ótima de coagulação era obtido por meio da variação da vazão da bomba dosadora, uso do FLA (ver Figura 4.17) e leitura do potencial zeta da água coagulada. Assim que a turbidez no FLA resultasse inferior a 1 uT e o potencial zeta se aproximasse de zero, o desvio era fechado e a água era direcionada ao filtro ascendente. Vale ressaltar que a dosagem inicial de sulfato de alumínio utilizada nos ensaios foi aquela determinada nos ensaios de bancada. Nesta etapa foi feito apenas um ajuste. 


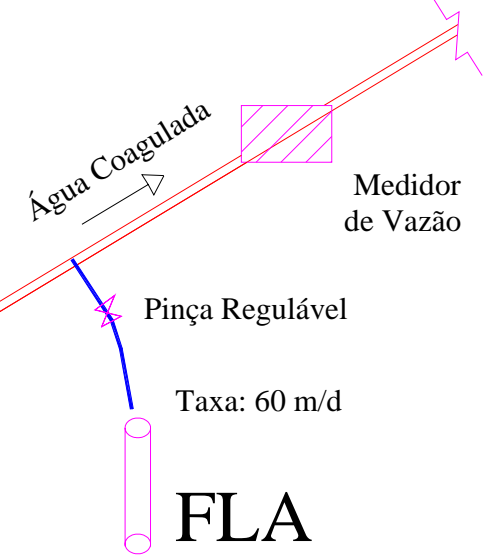

Figura 4.17 - Uso do FLA no início dos ensaios de dupla filtração para controle da coagulação

\subsubsection{Parâmetros de controle e freqüência}

Os principais parâmetros de controle nos ensaios de dupla filtração foram:

- Perda de carga: foram instaladas tomadas de pressão ao longo dos meios granulares dos filtros ascendentes para realização de leituras piezométricas. A freqüência de leituras piezométricas foi realizada de 3 em 3 horas. Nos filtros descendentes foram instaladas tomadas de pressão para medida da perda de carga total na camada de areia;

- Vazão: a vazão total afluente ao sistema de filtração foi medida continuamente pelo medidor de vazão eletromagnético localizado na tubulação a montante da entrada do filtro ascendente e registrada na placa de aquisição de dados a cada 5 min; a vazão afluente ao filtro descendente foi monitorada a cada $1 \mathrm{~h}$ por meio da leitura do rotâmetro;

- Turbidez: além da medida e registro contínuo de turbidez da água de estudo e dos efluentes dos filtros ascendente e descendente (equipamento: turbidímetros de escoamento contínuo da HACH, modelo 1720 C), foram coletadas amostras dos efluentes dos filtros ascendente e descendente, da água de estudo, e da água préfiltrada no final de cada subcamada a cada 3 horas (equipamento: tubidímetro de bancada da HACH, modelo $2100 \mathrm{P}$ );

- Potencial zeta: o potencial zeta da água coagulada foi medido no início de cada ensaio de dupla filtração;

- Alcalinidade: a alcalinidade da água de estudo era medida no início de cada ensaio;

- pH: o pH da água de estudo e da água coagulada foram medidos a cada 6 horas;

- Temperatura: a temperatura da água de estudo foi medida de 3 em 3 horas. 


\subsubsection{Encerramento de uma carreira de filtração}

O encerramento de uma carreira de filtração foi considerado quando:

- fosse alcançada a perda de carga limite no meio granular, fixada em 1,80 m nos filtros descendentes;

- a turbidez do efluente do filtro descendente superasse $1 \mathrm{uT}$;

- a duração da carreira atingisse $72 \mathrm{~h}$.

\subsubsection{Execução de descarga de fundo intermediária}

Devido aos resultados obtidos com o ensaio sem descarga de fundo correspondente (mesmas taxas nos filtros ascendente e descendente), a programação das descargas de fundo intermediárias foi feita em função do tempo (intervalos de 4,5 a 6 horas, dependendo das taxas de filtração e da água de estudo).

As descargas de fundo intermediárias no filtro ascendente de areia grossa foram realizadas nas duas câmaras de filtração simultaneamente, de acordo com o procedimento descrito a seguir.

- colocar as pinças nos piezômetros para evitar acúmulo de caulinita nos mesmo;

- fechar os registros de entrada de água coagulada no filtro ascendente e abrir registro de desvio da água coagulada;

- fechar o registro de água pré-filtrada na tubulação de entrada no filtro descendente e abrir o registro de desvio de água pré-filtrada;

- fechar o registro de saída de água filtrada;

- abrir os registros de descarga na posição determinada na pré-operação e simultaneamente abrir registro de água para aplicação na interface (água proveniente da rede) com taxa de aplicação de $800 \mathrm{~m}^{3} / \mathrm{m}^{2}$.d (vazão ajustada por meio de rotâmetro), de modo que o nível de água no filtro não fosse alterado;

- duração da descarga de fundo de 2 minutos;

- fechar os registros de descarga e de água para aplicação na interface;

- abrir os registros de entrada de água coagulada no filtro ascendente e fechar o registro de desvio da água coagulada;

- abrir o registro de água pré-filtrada na tubulação de entrada no filtro descendente e fechar o registro de desvio de água pré-filtrada;

- abrir o registro de saída de água filtrada;

- tirar as pinças dos piezômetros. 
As descargas de fundo intermediárias no filtro ascendente de pedregulho foram realizadas nas duas câmaras de filtração simultaneamente, de acordo com o procedimento descrito a seguir.

- colocar as pinças nos piezômetros para evitar acúmulo de caulinita nos mesmo;

- fechar os registros de entrada de água coagulada no filtro ascendente e abrir registro de desvio da água coagulada;

- fechar o registro de água pré-filtrada na tubulação de entrada no filtro descendente e abrir o registro de desvio de água pré-filtrada;

- fechar o registro de saída de água filtrada;

- abrir os registros de descarga na posição determinada na pré-operação (taxa de descarga de aproximadamente $700 \mathrm{~m}^{3} / \mathrm{m}^{2}$.d), com esvaziamento total do filtro;

- duração da descarga de fundo de aproximadamente 2 minutos (volume descartado de aproximadamente $13 \mathrm{~L}$ );

- fechar os registros de descarga;

- abrir os registros de entrada de água coagulada no filtro ascendente e fechar o registro de desvio da água coagulada;

- abrir o registro de água pré-filtrada na tubulação de entrada no filtro descendente e fechar o registro de desvio de água pré-filtrada;

- abrir o registro de saída de água filtrada;

- tirar as pinças dos piezômetros.

Para a caracterização dos picos de turbidez no reinício de operação dos ensaios realizados nos dois sistemas, após a execução de uma descarga de fundo, foi feito o controle da turbidez da água pré-filtrada e filtrada de minuto em minuto, até que o sistema entrasse em equilíbrio novamente.

\subsubsection{Lavagem dos filtros}

A lavagem dos filtros descendentes foi efetuada por meio de insuflação de ar durante 3 min, com taxa de aplicação da ordem de $15 \mathrm{~L} / \mathrm{s} \cdot \mathrm{m}^{2}$, seguida de água para promover expansão de $30 \%$ na camada de areia (velocidade ascensional de $0,80 \mathrm{~m} / \mathrm{min}$ ) durante cerca de $10 \mathrm{~min}$.

No filtro ascendente de areia grossa, a limpeza foi efetuada primeiramente com execução de descarga de fundo com esvaziamento total do filtro (registros de descarga totalmente abertos resultando taxa da ordem de $960 \mathrm{~m}^{3} / \mathrm{m}^{2}$.d e duração de $1,5 \mathrm{~min}$ ), seguida da introdução simultânea de ar com taxa de aplicação da ordem de 5 a 7 L/s.m² e água com 
velocidade ascensional da ordem de $0,5 \mathrm{~m} / \mathrm{min}$ durante $5 \mathrm{~min}$; a operação foi finalizada com aplicação de água com velocidade ascensional de $1,5 \mathrm{~m} / \mathrm{min}$ por $10 \mathrm{~min}$.

No filtro ascendente de pedregulho, a limpeza foi efetuada primeiramente com execução de descarga de fundo com esvaziamento total do filtro (registros de descarga totalmente abertos resultando taxa da ordem de $960 \mathrm{~m}^{3} / \mathrm{m}^{2}$.d e duração de $1,5 \mathrm{~min}$ ), seguida da introdução simultânea de ar com taxa de aplicação da ordem de 5 a 7 L/s.m² e água com velocidade ascensional da ordem de $0,5 \mathrm{~m} / \mathrm{min}$ durante $3 \mathrm{~min}$; a operação foi finalizada com aplicação de água com velocidade ascensional de $1,5 \mathrm{~m} / \mathrm{min}$ por $5 \mathrm{~min}$.

A perda de carga total limite no meio granular dos filtros ascendentes de areia grossa e pedregulho foram, respectivamente, fixadas em 1,20 m e 0,80 m. Quando atingidas, deveria ser realizada a lavagem do filtro ascendente.

A perda de carga total limite fixada para o meio granular dos filtros descendentes foi de 1,80 m. A lavagem destes filtros durante as carreiras de filtração deveria ser realizada somente quando a perda de carga limite fosse alcançada e ainda não tivesse ocorrido o transpasse nos filtros ascendentes.

Para lavagem dos filtros, a água era proveniente da rede existente no laboratório IP e a vazão desejada ajustada por meio de rotâmetro. O ar para lavagem era proveniente de soprador e a vazão desejada ajustada também por meio de rotâmetro.

\subsection{Análise dos dados}

\subsubsection{Correção da perda de carga em função da temperatura}

Para análise da evolução da perda de carga nos filtros durante os ensaios de dupla filtração, a variação da temperatura foi considerada mediante a utilização da equação 4.1. Percebe-se na equação 4.1, que os únicos parâmetros que variam em função da temperatura são a massa específica e a viscosidade absoluta da água, sendo a correção da perda de carga realizada segundo a equação 4.4. Vale ressaltar que os valores de perda de carga foram corrigidos para a temperatura de $25^{\circ} \mathrm{C}$, que foi a temperatura predominante nos 15 ensaios realizados.

$$
h_{25}=\frac{h_{t} \times \rho_{t} \times \mu_{25}}{\rho_{25} \times \mu_{t}}
$$

Equação 4.4

em que: 
$\mu_{25}\left(\mathrm{~N} . \mathrm{s} / \mathrm{m}^{2}\right)$ : viscosidade absoluta da água a $25^{\circ} \mathrm{C}$;

$\rho_{25}\left(\mathrm{~kg} / \mathrm{m}^{3}\right)$ : massa específica da água a $25^{\circ} \mathrm{C}$;

$\mu_{\mathrm{t}}\left(\mathrm{N} . \mathrm{s} / \mathrm{m}^{2}\right)$ : viscosidade absoluta da água na temperatura t;

$\rho_{\mathrm{t}}\left(\mathrm{kg} / \mathrm{m}^{3}\right)$ : massa específica da água na temperatura $\mathrm{t}$;

$\mathrm{h}_{25}(\mathrm{~m})$ : perda de carga corrigida (temperatura de $25^{\circ} \mathrm{C}$ );

$h_{t}(m)$ : perda de carga na temperatura t.

Na Tabela 4.5 são mostradas as variações da massa específica e da viscosidade absoluta da água em função da temperatura.

Tabela 4.5 - Massa específica e viscosidade absoluta da água em função da temperatura

\begin{tabular}{|c|c|c|}
\hline $\begin{array}{c}\text { Temperatura } \\
\left({ }^{\circ} \mathrm{C}\right)\end{array}$ & $\begin{array}{l}\text { Massa Específica } \\
\qquad\left(\mathrm{kg} / \mathrm{m}^{3}\right)\end{array}$ & $\begin{array}{c}\text { Viscosidade Absoluta } \\
10^{-3}\left(\mathrm{~N} . \mathrm{s} / \mathrm{m}^{2}\right)\end{array}$ \\
\hline 10 & 999,702 & 1,308 \\
\hline 11 & 999,607 & 1,271 \\
\hline 12 & 999,500 & 1,236 \\
\hline 13 & 999,379 & 1,203 \\
\hline 14 & 999,246 & 1,171 \\
\hline 15 & 999,102 & 1,140 \\
\hline 16 & 998,945 & 1,111 \\
\hline 17 & 998,777 & 1,083 \\
\hline 18 & 998,598 & 1,056 \\
\hline 19 & 998,407 & 1,030 \\
\hline 20 & 998,206 & 1,005 \\
\hline 21 & 997,995 & 0,981 \\
\hline 22 & 997,773 & 0,958 \\
\hline 23 & 997,541 & 0,936 \\
\hline 24 & 997,299 & 0,914 \\
\hline 25 & 997,048 & 0,894 \\
\hline 26 & 996,787 & 0,874 \\
\hline 27 & 996,517 & 0,855 \\
\hline 28 & 996,237 & 0,836 \\
\hline 29 & 995,949 & 0,818 \\
\hline 30 & 995,651 & 0,801 \\
\hline
\end{tabular}

Com os dados da Tabela 4.5, foram ajustadas curvas relacionando a temperatura com a massa específica e com a viscosidade absoluta, conforme mostrado nas Figuras 4.18 e 4.19, respectivamente. Para facilitar a correção da perda de carga, as equações apresentadas nas Figuras 4.18 e 4.19 foram utilizadas para cálculo dos parâmetros $\mu_{\mathrm{t}} \mathrm{e} \rho_{\mathrm{t}}$, respectivamente. 


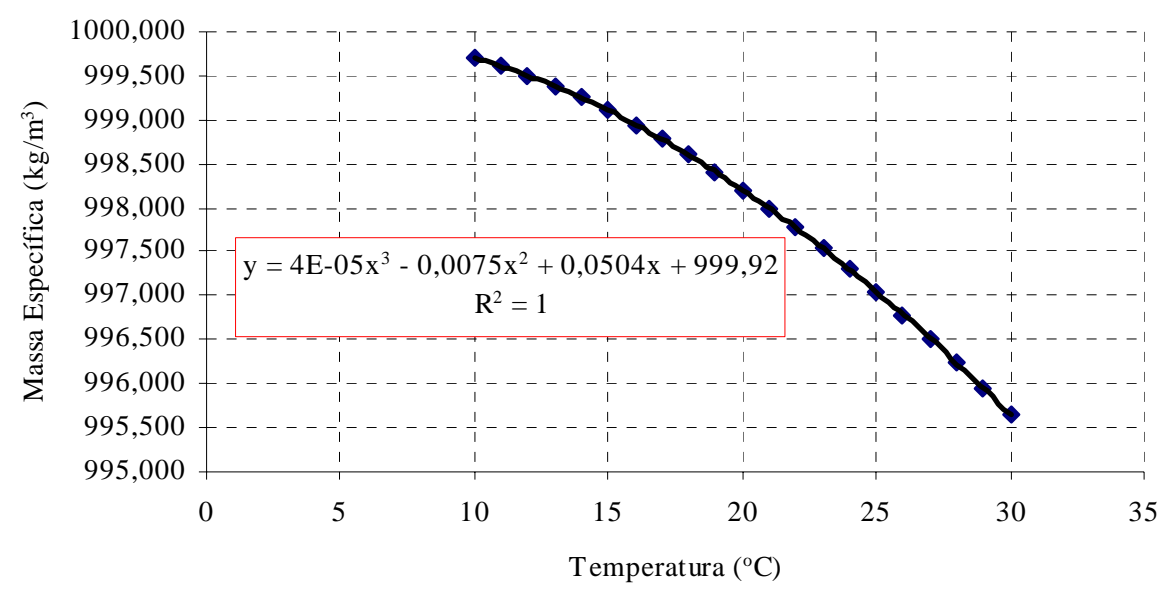

Figura 4.18 - Massa específica da água em função da temperatura

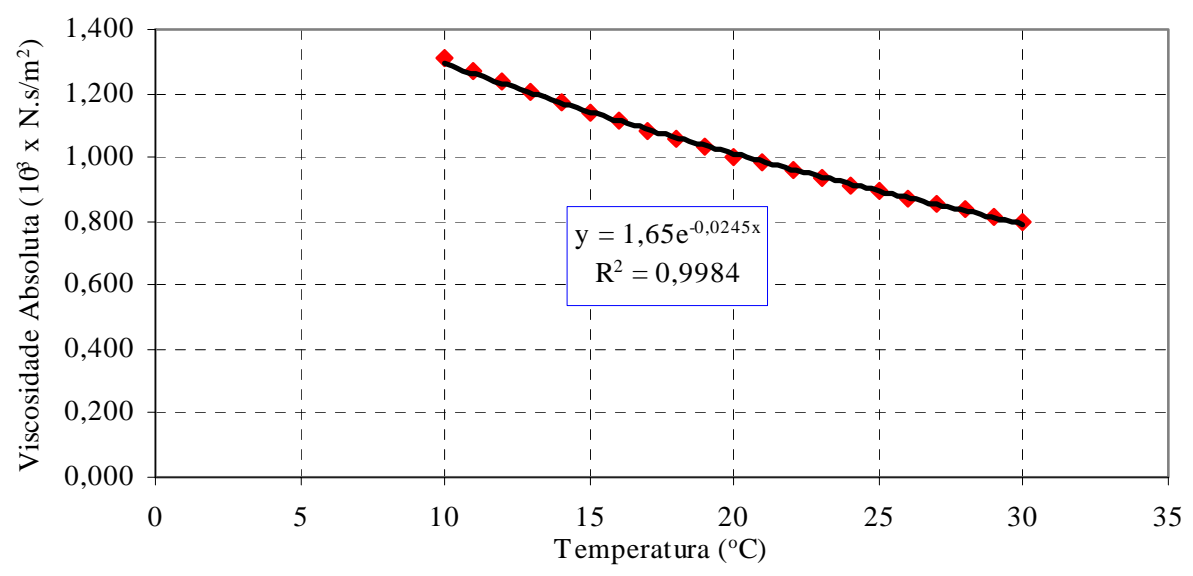

Figura 4.19 - Viscosidade absoluta da água em função da temperatura

\subsubsection{Avaliação geral dos ensaios}

Para a avaliação geral dos ensaios de dupla filtração nos sistemas 1 e 2, foram construídos dois tipos de gráficos. O primeiro contendo os valores de turbidez das águas de estudo, pré-filtrada e filtrada, obtidos nos turbidímetros de escoamento contínuo, e a vazão total de entrada no filtro ascendente, medida no medidor de vazão eletromagnético, em função do tempo de ensaio (duração da carreira de filtração); esses dados foram registrados no computador por meio de placa de aquisição de dados e software específico. O segundo contendo as evoluções das perdas de carga totais (corrigidas para a temperatura de $25^{\circ} \mathrm{C}$ ) nos filtros ascendente e descendente em função do tempo de ensaio; a perda de carga foi medida por meio da leitura de piezômetros localizados ao longo do meio filtrante dos filtros. 
Por meio destes gráficos é possível avaliar a influência das taxas de filtração e da execução das descargas de fundo intermediárias nos filtros ascendentes na eficiência dos sistemas de dupla filtração.

Nas Figuras 4.20 e 4.21 são mostrados os gráficos típicos construídos para avaliação geral dos ensaios de dupla filtração.

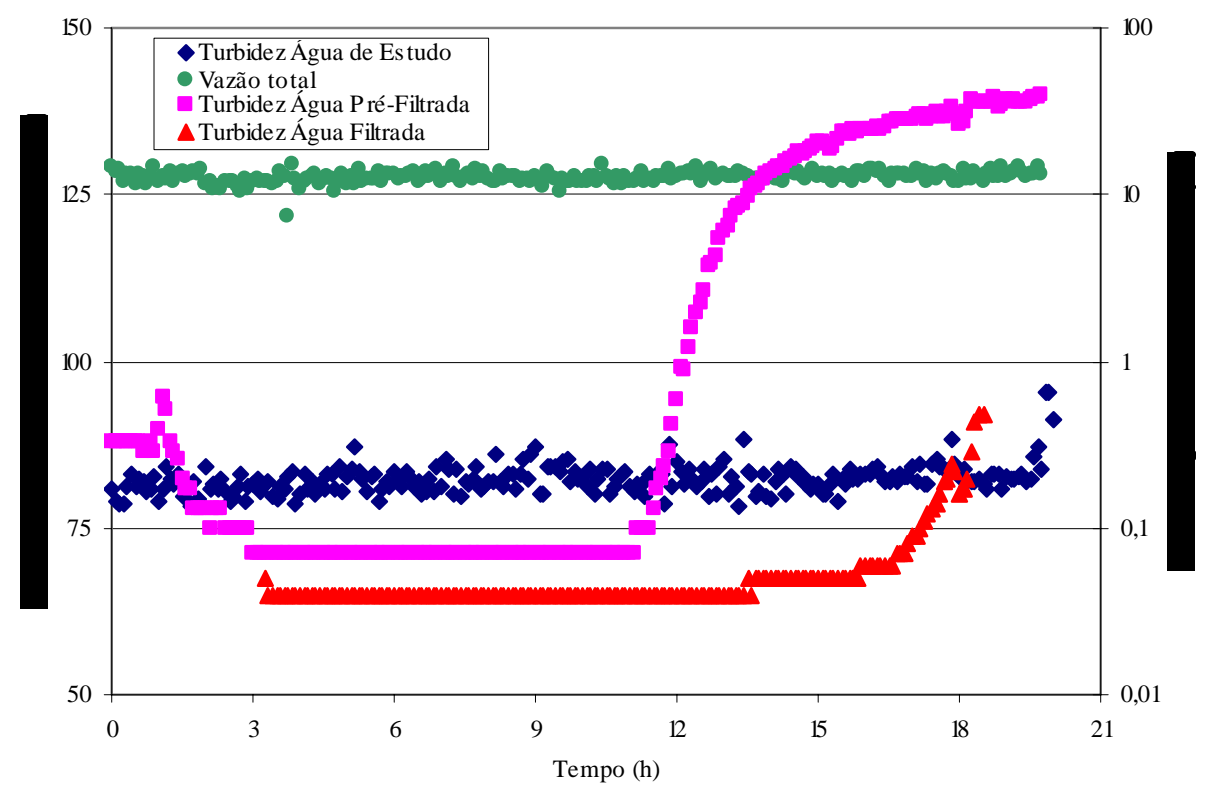

Figura 4.20 - Gráfico típico 1 para avaliação geral dos ensaios de dupla filtração

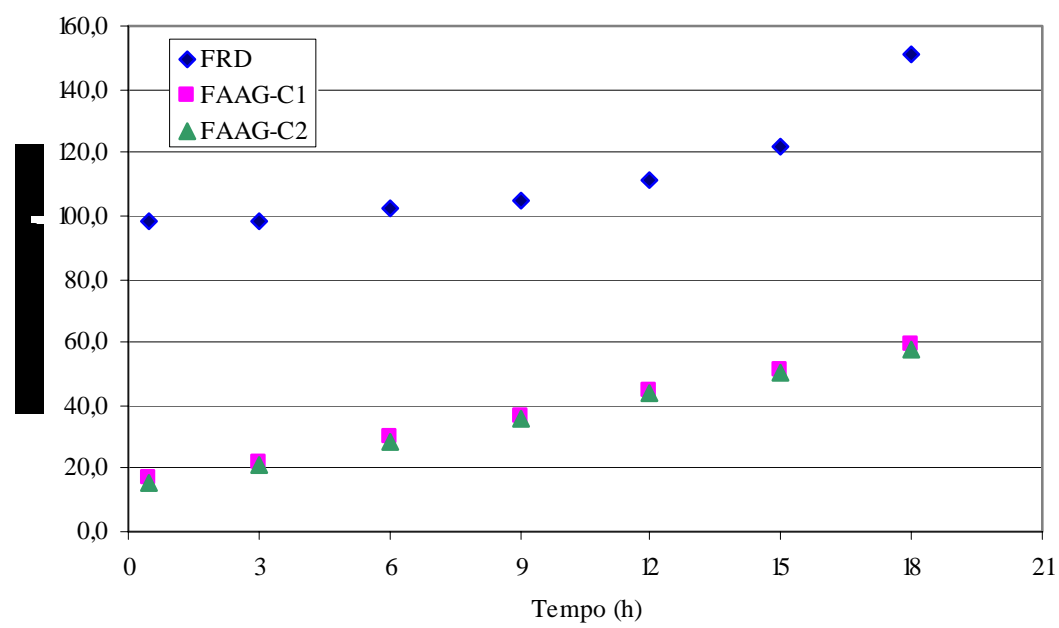

Figura 4.21 - Gráfico típico 2 para avaliação geral dos ensaios de dupla filtração 


\subsubsection{Avaliação da retenção de sólidos ao longo dos filtros ascendentes}

Para a avaliação da retenção de sólidos nas subcamadas dos filtros ascendentes dos sistemas 1 e 2, foram construídos dois tipos de gráficos. O primeiro contendo os valores de turbidez das amostras coletadas no final de cada subcamada (coletas realizadas de 3 em 3 horas e turbidez lida no turbidímetro de bancada) em função do tempo de ensaio. O segundo contendo as evoluções das perdas de carga em cada subcamada dos filtros ascendentes (corrigidas para a temperatura de $25^{\circ} \mathrm{C}$ ) em função do tempo de ensaio; a perda de carga foi medida por meio da leitura de piezômetros localizados ao longo do meio filtrante dos filtros ascendentes dos sistemas 1 e 2 .

Nas Figuras 4.22 e 4.23 são mostrados os gráficos típicos construídos para avaliação da retenção de sólidos ao longo dos filtros ascendentes.

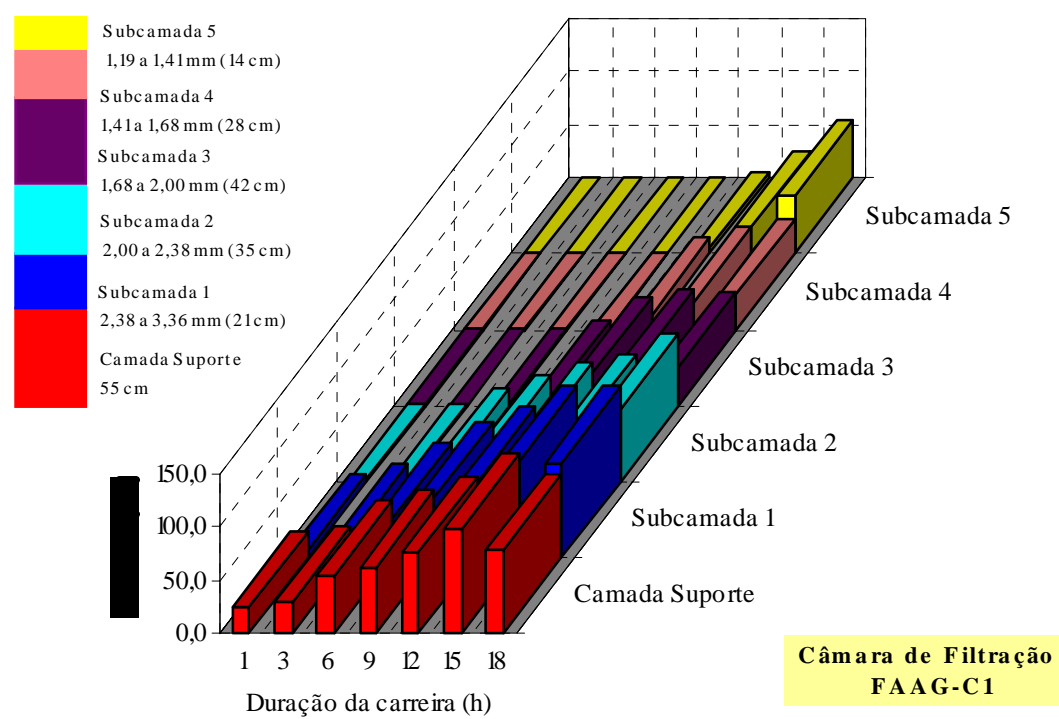

Figura 4.22 - Gráfico típico 1 para avaliação da retenção de sólidos ao longo dos filtros ascendentes 


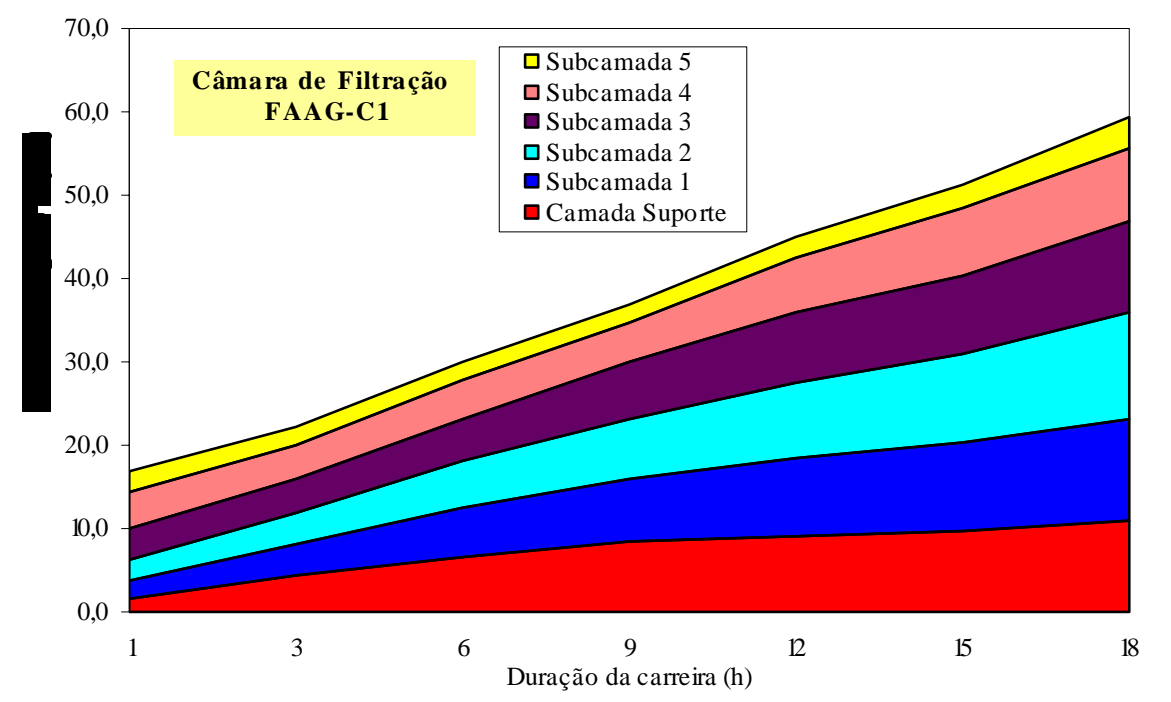

Figura 4.23 - Gráfico típico 2 para avaliação da retenção de sólidos ao longo dos filtros ascendentes

\subsubsection{Cálculo da produção efetiva de água}

A duração do ensaio de dupla filtração foi ditada por um dos três critérios mencionados no item 4.8.6. Para comparação da produção efetiva de água nos ensaios de dupla filtração, foi adotado o tempo máximo de duração da carreira de três dias como referência, ou seja, mesmo que a duração de uma carreira fosse inferior a esse tempo, a produção total de água, bem como as lavagens e descargas de fundo foram multiplicadas por um coeficiente para que resultasse a produção efetiva de água em 72 horas.

A produção efetiva de água foi calculada pela equação 4.5 .

$$
P E=P T-L_{F A}-C D F F-C D F I-L_{F R D}
$$

em que:

$\mathrm{PE}\left(\mathrm{m}^{3} / \mathrm{m}^{2} \mathrm{FA}\right)$ : produção efetiva de água filtrada;

$\mathrm{PT}\left(\mathrm{m}^{3} / \mathrm{m}^{2} \mathrm{FA}\right)$ : produção total de água filtrada;

$\mathrm{L}_{\mathrm{FA}}\left(\mathrm{m}^{3} / \mathrm{m}^{2} \mathrm{FA}\right)$ :consumo de água para lavagem do filtro ascendente;

$\mathrm{CDFF}\left(\mathrm{m}^{3} / \mathrm{m}^{2} \mathrm{FA}\right)$ :consumo de água na descarga de fundo final;

CDFI ( $\left.\mathrm{m}^{3} / \mathrm{m}^{2} \mathrm{FA}\right)$ :consumo de água utilizada para as descargas de fundo intermediárias;

$\mathrm{L}_{\mathrm{FRD}}\left(\mathrm{m}^{3} / \mathrm{m}^{2} \mathrm{FA}\right)$ :consumo de água para lavagem do filtro descendente. 
Neste trabalho a produção efetiva foi calculada com base na área do filtro ascendente (unidade $\mathrm{m}^{3} / \mathrm{m}^{2} \mathrm{FA}$ ). Para tal, o termo $\mathrm{L}_{\mathrm{FRD}}$ teve que ser multiplicado por um fator $\mathrm{Nf}$, que considera a razão entre as áreas dos filtros descendente e ascendente.

Os termos da equação 4.5 foram calculados de diferentes maneiras, de acordo com o critério de encerramento e a situação do filtro ascendente. Na Figura 4.24 são mostradas as possíveis situações dos filtros ascendente e descendente na ocasião do término do ensaio.
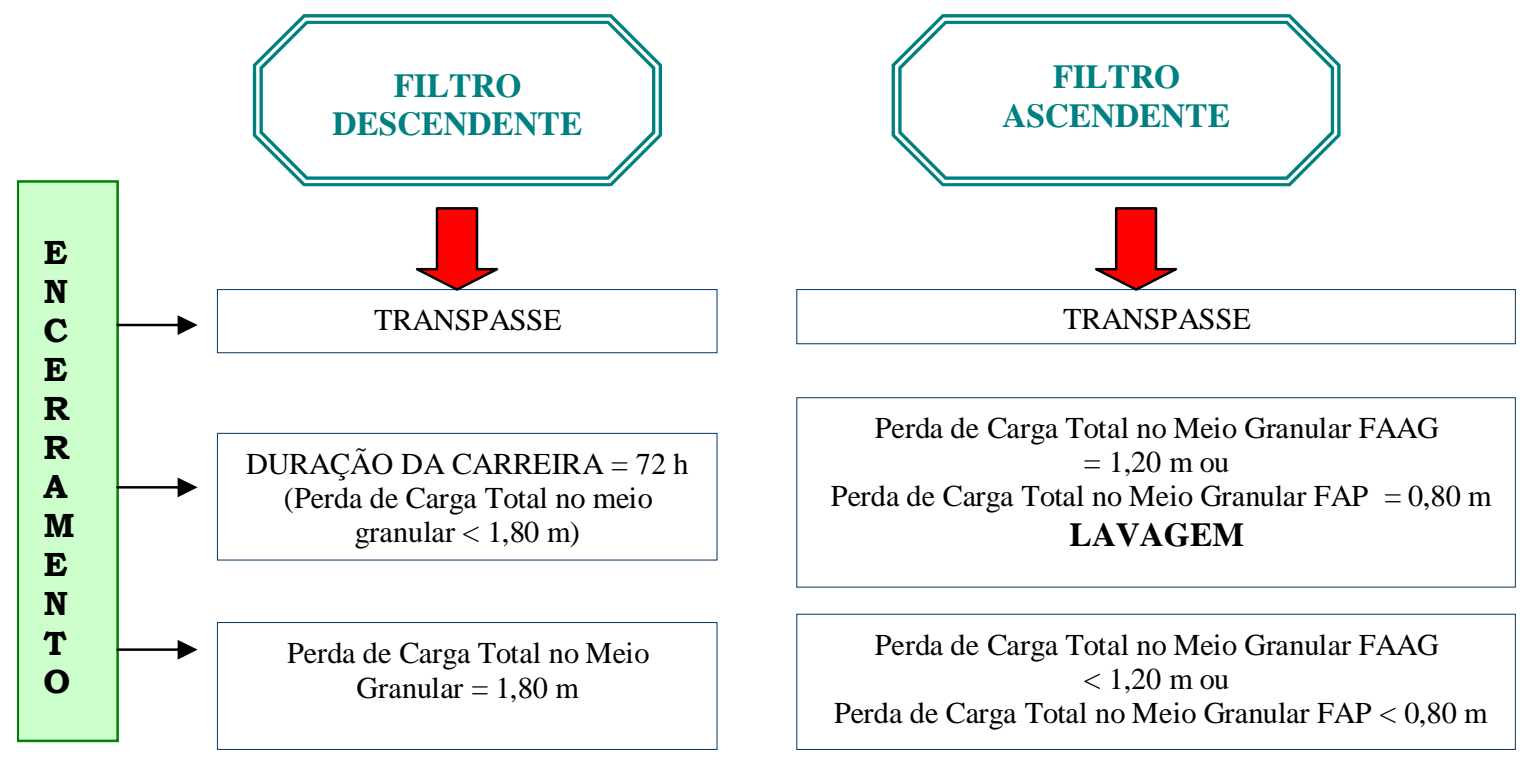

Figura 4.24 - Critérios de encerramento dos ensaios de dupla filtração

A seguir são apresentadas as combinações prováveis de ocorrência nos ensaios de dupla filtração e a respectiva equação para cálculo da produção efetiva de água.

\section{a) Encerramento do ensaio por ocorrência de transpasse no FRD}

Foi assumido que essa situação ocorreria quando acontecesse o transpasse no filtro ascendente, uma vez que para absorver os picos de turbidez do efluente do filtro ascendente, o filtro descendente seria provavelmente colmatado mais rapidamente. Assim, tem-se que:

Produção total de água: $\mathrm{PT}=\mathrm{TF} \times \mathrm{Tr}$

em que: $\mathrm{TF}=$ taxa de filtração do $\mathrm{FA}\left(\mathrm{m}^{3} / \mathrm{m}^{2}\right.$.d), $\mathrm{Tr}=$ tempo de referência $(\operatorname{Tr}=3$ dias $)$.

Lavagem do Filtro Ascendente: $\mathrm{L}_{\mathrm{FA}}=\mathrm{TL}_{\mathrm{FA}} \times \mathrm{DL}_{\mathrm{FA}} \times \mathrm{Tr} / \mathrm{DF}$

em que: $\mathrm{TL}_{\mathrm{FA}}=$ taxa de água para lavagem do $\mathrm{FA}\left(\mathrm{m}^{3} / \mathrm{m}^{2} . \mathrm{d}\right)$; $\mathrm{DL}_{\mathrm{FA}}=$ duração da lavagem do FA (d), DF = duração da carreira de filtração (d), $\operatorname{Tr}=$ tempo de referência $(\operatorname{Tr}=3$ dias). 
Descarga de Fundo Final $: \mathrm{CDFF}=\mathrm{T}_{\mathrm{DFF}} \mathrm{x} \mathrm{D}_{\mathrm{DFF}} \mathrm{x} \mathrm{Tr} / \mathrm{DF}$

em que: $T_{\mathrm{DFF}}=$ taxa de descarga de fundo $\left(\mathrm{m}^{3} / \mathrm{m}^{2} . \mathrm{d}\right)$; $\mathrm{D}_{\mathrm{DFF}}=$ duração da descarga de fundo (d), DF = duração da carreira de filtração (d), $\operatorname{Tr}=$ tempo de referência $(\operatorname{Tr}=3$ dias).

Descarga de Fundo Intermediária: $\mathrm{CDFI}=\mathrm{N}_{\mathrm{DFI}} \times \mathrm{T}_{\mathrm{DFI}} \times \mathrm{D}_{\mathrm{DFI}}$

em que: $\mathrm{N}_{\mathrm{DFI}}=$ número de DFI que seriam executadas no FA em 72 horas; $\mathrm{T}_{\mathrm{DFI}}=$ taxa de descarga de fundo $\left(\mathrm{m}^{3} / \mathrm{m}^{2}\right.$.d); $\mathrm{D}_{\mathrm{DFI}}=$ duração da descarga de fundo (d), DF = duração da carreira de filtração (d), $\operatorname{Tr}=$ tempo de referência $(\operatorname{Tr}=3$ dias).

Lavagem do Filtro Descendente: $\mathrm{L}_{\mathrm{FRD}}=\mathrm{TL}_{\mathrm{FRD}} \times \mathrm{DL}_{\mathrm{FRD}} \times \mathrm{Nf} \times \mathrm{Tr} / \mathrm{DF}$

em que: $\mathrm{TL}_{\mathrm{FRD}}=$ taxa de água para lavagem do $\mathrm{FRD}\left(\mathrm{m}^{3} / \mathrm{m}^{2}\right.$.d); $\mathrm{DL}_{\mathrm{FRD}}=$ duração da lavagem do FRD (d), $\mathrm{Nf}=\mathrm{A}_{\mathrm{FRD}} / \mathrm{A}_{\mathrm{FA}}$ e $\mathrm{A}_{\mathrm{FA}}=$ área do $\mathrm{FA}\left(\mathrm{m}^{2}\right), \mathrm{A}_{\mathrm{FRD}}=$ área do $\mathrm{FRD}\left(\mathrm{m}^{2}\right), \mathrm{DF}=$ duração da carreira de filtração (d), $\operatorname{Tr}=$ tempo de referência ( $\operatorname{Tr}=3$ dias).

\section{b) Duração da carreira atingir $72 \mathrm{~h}$}

b.1) Ocorrência de transpasse FA

Produção total de água: $\mathrm{PT}=\mathrm{TF} \times \mathrm{DF}$

em que: TF = taxa de filtração do FA $\left(\mathrm{m}^{3} / \mathrm{m}^{2} . \mathrm{d}\right), \mathrm{DF}=$ duração da carreira de filtração (= 3d).

Lavagem do Filtro Ascendente: $\mathrm{L}_{\mathrm{FA}}=\mathrm{TL}_{\mathrm{FA}} \times \mathrm{DL}_{\mathrm{FA}}$

em que: $\mathrm{TL}_{\mathrm{FA}}=$ taxa de água para lavagem do $\mathrm{FA}\left(\mathrm{m}^{3} / \mathrm{m}^{2} \cdot \mathrm{d}\right) ; \mathrm{DL}_{\mathrm{FA}}=$ duração da lavagem do FA (d).

Descarga de Fundo Final: $\mathrm{CDFF}=\mathrm{T}_{\mathrm{DFF}} \times \mathrm{D}_{\mathrm{DFF}}$

em que: $\mathrm{T}_{\mathrm{DFF}}=$ taxa de descarga de fundo $\left(\mathrm{m}^{3} / \mathrm{m}^{2} . \mathrm{d}\right) ; \mathrm{D}_{\mathrm{DFF}}=$ duração da descarga de fundo (d).

Descarga de Fundo Intermediária: $\mathrm{CDFI}=\mathrm{N}_{\mathrm{DFI}} \times \mathrm{T}_{\mathrm{DFI}} \times \mathrm{D}_{\mathrm{DFI}}$

em que: $\mathrm{N}_{\mathrm{DFI}}=$ número de DFI executadas no FA em 72 horas; $\mathrm{T}_{\mathrm{DFI}}=$ taxa de descarga de fundo $\left(\mathrm{m}^{3} / \mathrm{m}^{2} . \mathrm{d}\right) ; \mathrm{D}_{\mathrm{DFI}}=$ duração da descarga de fundo (d).

Lavagem do Filtro Descendente: $\mathrm{L}_{\mathrm{FRD}}=\mathrm{TL}_{\mathrm{FRD}} \times \mathrm{DL}_{\mathrm{FRD}} \times \mathrm{Nf} \times\left(\Delta \mathrm{H}_{\text {final }} \mathrm{FRD} / \Delta \mathrm{H}_{\text {limite }} \mathrm{FRD}\right)$ em que: $\mathrm{TL}_{\mathrm{FRD}}=$ taxa de água para lavagem do $\mathrm{FRD}\left(\mathrm{m}^{3} / \mathrm{m}^{2} . \mathrm{d}\right)$; $\mathrm{DL}_{\mathrm{FRD}}=$ duração da lavagem do FRD (d), $\mathrm{Nf}=\mathrm{A}_{\mathrm{FRD}} / \mathrm{A}_{\mathrm{FA}}$ e $\mathrm{A}_{\mathrm{FA}}=$ área do $\mathrm{FA}\left(\mathrm{m}^{2}\right), \mathrm{A}_{\mathrm{FRD}}=$ área do $\mathrm{FRD}\left(\mathrm{m}^{2}\right) ; \Delta \mathrm{H}_{\text {final }} \mathrm{FRD}$ = perda de carga final no FRD (m); $\Delta \mathrm{H}_{\text {limite }} \mathrm{FRD}$ = perda de carga prevista no FRD (1,80 m). 
b.2) Sem ocorrência de transpasse FA

Produção total de água: $\mathrm{PT}=\mathrm{TF}$ x DF

em que: $\mathrm{TF}=$ taxa de filtração do $\mathrm{FA}\left(\mathrm{m}^{3} / \mathrm{m}^{2} . \mathrm{d}\right), \mathrm{DF}=$ duração da carreira de filtração $(=3 \mathrm{~d})$.

Lavagem do Filtro Ascendente: $\mathrm{L}_{\mathrm{FA}}=\mathrm{TL}_{\mathrm{FA}} \times \mathrm{DL}_{\mathrm{FA}} \mathrm{x}\left(\mathrm{NL}_{\mathrm{FA}}+\Delta \mathrm{H}_{\text {final }} \mathrm{FA} / \Delta \mathrm{H}_{\text {limite }} \mathrm{FA}\right)$

em que: $\mathrm{TL}_{\mathrm{FA}}=$ taxa de água para lavagem do $\mathrm{FA}\left(\mathrm{m}^{3} / \mathrm{m}^{2} . \mathrm{d}\right)$; $\mathrm{DL}_{\mathrm{FA}}=$ duração da lavagem do FA (d), $N L_{F A}=$ número de lavagens do FA (será diferente de 0 caso a perda de carga limite no FA seja alcançada durante o ensaio); $\Delta \mathrm{H}_{\text {final }} \mathrm{FA}=$ perda de carga final no FA (m); $\Delta \mathrm{H}_{\text {limite }}$ FA= perda de carga prevista no FA (1,0 m para FAAG e 0,80 para FAP).

Descarga de Fundo Final: $\mathrm{CDFF}=\mathrm{T}_{\mathrm{DFF}} \mathrm{x} \mathrm{D}_{\mathrm{DFF}} \mathrm{x}\left(\mathrm{NL}_{\mathrm{FA}}+\Delta \mathrm{H}_{\text {final }} \mathrm{FA} / \Delta \mathrm{H}_{\text {limite }} \mathrm{FA}\right)$

em que: $\mathrm{T}_{\mathrm{DFF}}=$ taxa de descarga de fundo $\left(\mathrm{m}^{3} / \mathrm{m}^{2} . \mathrm{d}\right)$; $\mathrm{D}_{\mathrm{DFF}}=$ duração da descarga de fundo (d), $\mathrm{NL}_{\mathrm{FA}}=$ número de lavagens do $\mathrm{FA}$ (será diferente de 0 caso a perda de carga limite no FA seja alcançada durante o ensaio); $\Delta \mathrm{H}_{\text {final }} \mathrm{FA}=$ perda de carga final no $\mathrm{FA}(\mathrm{m}) ; \Delta \mathrm{H}_{\text {limite }}$ FA= perda de carga prevista no FA (1,0 m para FAAG e 0,80 para FAP).

Descarga de Fundo Intermediária: $\mathrm{CDFI}=\mathrm{N}_{\mathrm{DFI}} \times \mathrm{T}_{\mathrm{DFI}} \times \mathrm{D}_{\mathrm{DFI}}$ em que: $\mathrm{N}_{\mathrm{DFI}}=$ número de DFI executadas no FA em 72 horas; $\mathrm{T}_{\mathrm{DFI}}=$ taxa de descarga de fundo $\left(\mathrm{m}^{3} / \mathrm{m}^{2}\right.$.d); $\mathrm{D}_{\mathrm{DFI}}=$ duração da descarga de fundo (d).

Lavagem do Filtro Descendente: $\mathrm{L}_{\mathrm{FRD}}=\mathrm{TL}_{\mathrm{FRD}} \times \mathrm{DL}_{\mathrm{FRD}} \times \mathrm{Nf} \times\left(\Delta \mathrm{H}_{\text {final }} \mathrm{FRD} / \Delta \mathrm{H}_{\text {limite }} \mathrm{FRD}\right)$ em que: $\mathrm{TL}_{\mathrm{FRD}}=$ taxa de água para lavagem do $\mathrm{FRD}\left(\mathrm{m}^{3} / \mathrm{m}^{2}\right.$.d); $\mathrm{DL}_{\mathrm{FRD}}=$ duração da lavagem do $\mathrm{FRD}(\mathrm{d}), \mathrm{Nf}=\mathrm{A}_{\mathrm{FRD}} / \mathrm{A}_{\mathrm{FA}}$ e $\mathrm{A}_{\mathrm{FA}}=$ área do $\mathrm{FA}\left(\mathrm{m}^{2}\right), \mathrm{A}_{\mathrm{FRD}}=$ área do $\mathrm{FRD}\left(\mathrm{m}^{2}\right), \Delta \mathrm{H}_{\text {final }} \mathrm{FRD}$ = perda de carga final no FRD; $\Delta \mathrm{H}_{\text {limite }} \mathrm{FRD}=$ perda de carga prevista no $\mathrm{FRD}(1,80 \mathrm{~m})$.

\section{c) Encerramento da carreira por perda de carga limite no FRD}

c.1) Ocorrência de transpasse no FA

Produção total de água: $\mathrm{PT}=\mathrm{TF} \times \mathrm{Tr}$

em que: $\mathrm{TF}=$ taxa de filtração do $\mathrm{FA}\left(\mathrm{m}^{3} / \mathrm{m}^{2}\right.$.d), $\mathrm{Tr}=$ tempo de referência $(\mathrm{Tr}=3$ dias $)$.

Lavagem do Filtro Ascendente: $\mathrm{L}_{\mathrm{FA}}=\mathrm{TL}_{\mathrm{FA}}$ x DL $\mathrm{DA} \times \mathrm{Tr} / \mathrm{DF}$

em que: $\mathrm{TL}_{\mathrm{FA}}=$ taxa de água para lavagem do $\mathrm{FA}\left(\mathrm{m}^{3} / \mathrm{m}^{2}\right.$.d); $\mathrm{DL}_{\mathrm{FA}}=$ duração da lavagem do FA (d) , DF = duração da carreira de filtração $(d), \operatorname{Tr}=$ tempo de referência $(\operatorname{Tr}=3$ dias). 
Descarga de Fundo Final: $\mathrm{CDFF}=\mathrm{T}_{\mathrm{DFF}} \times \mathrm{D}_{\mathrm{DFF}} \mathrm{x} \mathrm{Tr} / \mathrm{DF}$

em que: $T_{D F F}=$ taxa de descarga de fundo $\left(\mathrm{m}^{3} / \mathrm{m}^{2} . \mathrm{d}\right) ; \mathrm{D}_{\mathrm{DFF}}=$ duração da descarga de fundo (d), DF: duração da carreira de filtração (d), $\operatorname{Tr}=$ tempo de referência ( $\operatorname{Tr}=3$ dias).

Descarga de Fundo Intermediária: $\mathrm{CDFI}=\mathrm{N}_{\mathrm{DFI}} \times \mathrm{T}_{\mathrm{DFI}} \times \mathrm{D}_{\mathrm{DFI}}$

em que: $\mathrm{N}_{\mathrm{DFI}}=$ número de DFI que seriam executadas no FA em 72 horas; $\mathrm{T}_{\mathrm{DFI}}=$ taxa de descarga de fundo $\left(\mathrm{m}^{3} / \mathrm{m}^{2} . \mathrm{d}\right)$; $\mathrm{D}_{\mathrm{DFI}}=$ duração da descarga de fundo (d), DF: duração da carreira de filtração (d), $\operatorname{Tr}=$ tempo de referência $(\operatorname{Tr}=3$ dias).

Lavagem do Filtro Descendente: $\mathrm{L}_{\mathrm{FRD}}=\mathrm{TL}_{\mathrm{FRD}} \times \mathrm{DL}_{\mathrm{FRD}} \times \mathrm{Nf} \times \mathrm{Tr} / \mathrm{DF}$

em que: $\mathrm{TL}_{\mathrm{FRD}}=$ taxa de água para lavagem do $\mathrm{FRD}\left(\mathrm{m}^{3} / \mathrm{m}^{2} . \mathrm{d}\right) ; \mathrm{DLR}_{\mathrm{FRD}}=$ duração da lavagem do FRD (d), $\mathrm{Nf}=\mathrm{A}_{\mathrm{FA}} / \mathrm{A}_{\mathrm{FRD}}$ e $\mathrm{A}_{\mathrm{FA}}=$ área do $\mathrm{FA}\left(\mathrm{m}^{2}\right), \mathrm{A}_{\mathrm{FRD}}=$ área do $\mathrm{FRD}\left(\mathrm{m}^{2}\right)$; $\mathrm{DF}=$ duração da carreira de filtração (d), $\operatorname{Tr}=$ tempo de referência ( $\operatorname{Tr}=3$ dias).

c.2) Sem ocorrência de transpasse no FA

Produção total de água: $\mathrm{PT}=\mathrm{TF} \times \mathrm{Tr}$

em que: $\mathrm{TF}=$ taxa de filtração do $\mathrm{FA}\left(\mathrm{m}^{3} / \mathrm{m}^{2}\right.$.d), $\mathrm{Tr}=$ tempo de referência $(\operatorname{Tr}=3$ dias).

Lavagem do Filtro Ascendente: $\mathrm{L}_{\mathrm{FA}}=\mathrm{TL}_{\mathrm{FA}} \times \mathrm{DL}_{\mathrm{FA}} \times\left(\mathrm{NL}_{\mathrm{FA}}+\Delta \mathrm{H}_{\text {final }} \mathrm{FA} / \Delta \mathrm{H}_{\text {limite }} \mathrm{FA}\right) \times \mathrm{Tr} / \mathrm{DF}$ em que: $\mathrm{TL}_{\mathrm{FA}}=$ taxa de água para lavagem do $\mathrm{FA}\left(\mathrm{m}^{3} / \mathrm{m}^{2} . \mathrm{d}\right)$; $\mathrm{DL}_{\mathrm{FA}}=$ duração da lavagem do FA (d), $\mathrm{NL}_{\mathrm{FA}}$ : número de lavagens do FA (será diferente de 0 caso a perda de carga limite no FA seja alcançada durante o ensaio); $\Delta \mathrm{H}_{\text {final }} \mathrm{FA}=$ perda de carga final no FA (m); $\Delta \mathrm{H}_{\text {limite }}$ FA= perda de carga prevista no FA (1,0 m para FAAG e 0,80 para FAP), DF = duração da carreira de filtração (d), $\operatorname{Tr}=$ tempo de referência $(\operatorname{Tr}=3$ dias).

Descarga de Fundo Final: $\mathrm{CDFF}=\mathrm{T}_{\mathrm{DFF}} \mathrm{x} \mathrm{D}_{\mathrm{DFF}} \mathrm{x}\left(\mathrm{NL}_{\mathrm{FA}}+\Delta \mathrm{H}_{\text {final }} \mathrm{FA} / \Delta \mathrm{H}_{\text {limite }} \mathrm{FA}\right) \times \mathrm{Tr} / \mathrm{DF}$ em que: $\mathrm{T}_{\mathrm{DFF}}=$ taxa de descarga de fundo $\left(\mathrm{m}^{3} / \mathrm{m}^{2} . \mathrm{d}\right) ; \mathrm{D}_{\mathrm{DFF}}=$ duração da descarga de fundo (d), NLFA: número de lavagens do FA (será diferente de 0 caso a perda de carga limite no FA seja alcançada durante o ensaio); $\Delta \mathrm{H}_{\text {final }} \mathrm{FA}=$ perda de carga final no $\mathrm{FA}(\mathrm{m}) ; \Delta \mathrm{H}_{\text {limite }} \mathrm{FA}=$ perda de carga prevista no FA (1,0 m para FAAG e 0,80 para FAP), DF = duração da carreira de filtração $(\mathrm{d}), \operatorname{Tr}=$ tempo de referência $(\operatorname{Tr}=3$ dias). 
Descarga de Fundo Intermediária: $\mathrm{CDFI}=\mathrm{N}_{\mathrm{DFI}} \times \mathrm{T}_{\mathrm{DFI}} \times \mathrm{D}_{\mathrm{DFI}}$

em que: $\mathrm{N}_{\mathrm{DFI}}=$ número de DFI que seriam executadas no $\mathrm{FA}$ em 72 horas; $\mathrm{T}_{\mathrm{DFI}}=$ taxa de descarga de fundo $\left(\mathrm{m}^{3} / \mathrm{m}^{2} . \mathrm{d}\right)$; $\mathrm{D}_{\mathrm{DFI}}=$ duração da descarga de fundo (d), DF: duração da carreira de filtração (d), $\operatorname{Tr}=$ tempo de referência ( $\operatorname{Tr}=3$ dias).

Lavagem do Filtro Descendente: $\mathrm{L}_{\mathrm{FRD}}=\mathrm{TL}_{\mathrm{FRD}} \times \mathrm{DL}_{\mathrm{FRD}} \times \mathrm{Nf} \times \mathrm{Tr} / \mathrm{DF}$

em que: $\mathrm{TL}_{\mathrm{FRD}}=$ taxa de água para lavagem do $\mathrm{FRD}\left(\mathrm{m}^{3} / \mathrm{m}^{2} . \mathrm{d}\right)$; $\mathrm{DL}_{\mathrm{FRD}}$ : duração da lavagem do FRD (d), $\mathrm{Nf}=\mathrm{A}_{\mathrm{FRD}} / \mathrm{A}_{\mathrm{FA}}$ e $\mathrm{A}_{\mathrm{FA}}=$ área do $\mathrm{FA}\left(\mathrm{m}^{2}\right), \mathrm{A}_{\mathrm{FRD}}=$ área do $\mathrm{FRD}\left(\mathrm{m}^{2}\right)$; $\mathrm{DF}=$ duração da carreira de filtração (d), $\operatorname{Tr}=$ tempo de referência ( $\operatorname{Tr}=3$ dias). 


\section{RESULTADOS E DISCUSSÃO}

Neste capítulo são apresentados e discutidos os resultados da investigação experimental, sendo os seguintes tópicos abordados: resultados dos ensaios com a caulinita, resultados da caracterização das águas de estudo, resultados dos ensaios de bancada com as águas de estudo, resultados da pré-operação da instalação piloto, resultados e produção efetiva de água dos ensaios de dupla filtração.

Para melhor organização dos dados experimentais, os mesmos foram divididos em anexos, conforme descrição a seguir:

- Anexo A: tabelas com os resultados dos ensaios de bancada com as águas tipo I e tipo II;

- Anexo B: tabelas com os resultados da pré-operação dos sistemas 1 e 2 de dupla filtração;

- Anexo C: tabelas e gráficos com os resultados dos ensaios de dupla filtração nos sistemas 1 e 2;

- Anexo D: tabelas com os cálculos de produção efetiva de água de cada ensaio de dupla filtração. 


\subsection{Caulinita}

\subsubsection{Características da caulinita}

Para conferir turbidez às águas de estudo, foi escolhida a caulinita, uma vez que é uma das principais argilas presentes em águas superficiais. Na Tabela 5.1 são apresentadas as suas principais características, obtidas com o fabricante.

Tabela 5.1 - Características da caulinita

\begin{tabular}{|c|c|}
\hline Propriedades Físicas & \\
\hline Nome comercial & Caulim micronizado \\
\hline Aspecto & Pó fino \\
\hline Cor & Branca \\
\hline Massa Específica do grão $\left(\mathrm{g} / \mathrm{cm}^{3}\right)$ & $2,60 \pm 0,05$ \\
\hline Massa Específica Aparente solta $\left(\mathrm{g} / \mathrm{cm}^{3}\right)$ & $0,47 \pm 0,02$ \\
\hline Massa Específica Aparente compactada (g/cm³) & $0,57 \pm 0,02$ \\
\hline Umidade (\% máxima) & 1,0 \\
\hline pH (solução 5\%) & $7,70 \pm 1,0$ \\
\hline Carbonatos & Isento \\
\hline Composição & Porcentagem expressa em óxidos \\
\hline $\mathrm{SiO}_{2}$ (Dióxido de Silício) & 47,3 \\
\hline $\mathrm{Al}_{2} \mathrm{O}_{3}$ (Óxido de Alumínio) & 36,3 \\
\hline $\mathrm{Fe}_{2} \mathrm{O}_{3}$ (Óxido de Ferro) & 0,63 \\
\hline $\mathrm{TiO}_{2}$ (Dióxido de Titânio) & 0,51 \\
\hline CaO (Óxido de Cálcio) & $<0,05$ \\
\hline MgO (Óxido de Magnésio) & $<0,10$ \\
\hline MnO (Óxido de Manganês) & $<0,01$ \\
\hline $\mathrm{Na}_{2} \mathrm{O}$ (Óxido de Sódio) & 0,52 \\
\hline $\mathrm{K}_{2} \mathrm{O}$ (Óxido de Potássio) & 9,3 \\
\hline
\end{tabular}

Fonte: adaptada de CIA COMERCIAL PROMINÉRIOS (2002)

\subsubsection{Ensaio de sedimentação}

Na Tabela 5.2 e na Figura 5.1 são apresentados os resultados do ensaio de sedimentação realizado com a caulinita, onde foram monitorados a turbidez do sobrenadante e o volume de sedimento resultantes da primeira e segunda agitação da caulinita em função do tempo de sedimentação, conforme descrito no item 4.4.1. 
Tabela 5.2 - Turbidez do sobrenadante e volume de sedimento resultante no ensaio de sedimentação com a caulinita

\begin{tabular}{|c|c|c|c|c|}
\cline { 2 - 5 } \multicolumn{1}{c|}{} & \multicolumn{2}{c|}{ Primeira Agitação } & \multicolumn{2}{c|}{ Segunda Agitação } \\
\hline $\begin{array}{c}\text { Tempo de } \\
\text { Sedimentação (h) }\end{array}$ & $\begin{array}{c}\text { Turbidez } \\
\text { Sobrenadante 1 (uT) }\end{array}$ & $\begin{array}{c}\text { Volume } \\
\text { Sedimento 1 (mL/L) }\end{array}$ & $\begin{array}{c}\text { Turbidez } \\
\text { Sobrenadante 2 (uT) }\end{array}$ & $\begin{array}{c}\text { Volume } \\
\text { Sedimento 2 (mL/L) }\end{array}$ \\
\hline 0,083 & 8000 & 7,0 & - & - \\
\hline 0,5 & 4150 & 14,0 & - & - \\
\hline 2,5 & 3300 & 20,0 & - & - \\
\hline 4 & 2800 & 20,0 & - & 21,0 \\
\hline 6 & 2000 & 20,5 & 245 & 21,5 \\
\hline 8 & 2200 & 21,0 & 330 & 22,0 \\
\hline 10 & 1600 & 21,0 & 410 & 22,5 \\
\hline 12 & 1650 & 21,0 & 345 & 22,5 \\
\hline 14 & 1800 & 21,0 & 325 & 22,5 \\
\hline 16 & 1900 & 21,0 & 280 & 22,5 \\
\hline 18 & 1500 & - & 300 & - \\
\hline 20 & 1500 & - & - & \\
\hline 24 & 650 & 21,5 & & \\
\hline
\end{tabular}

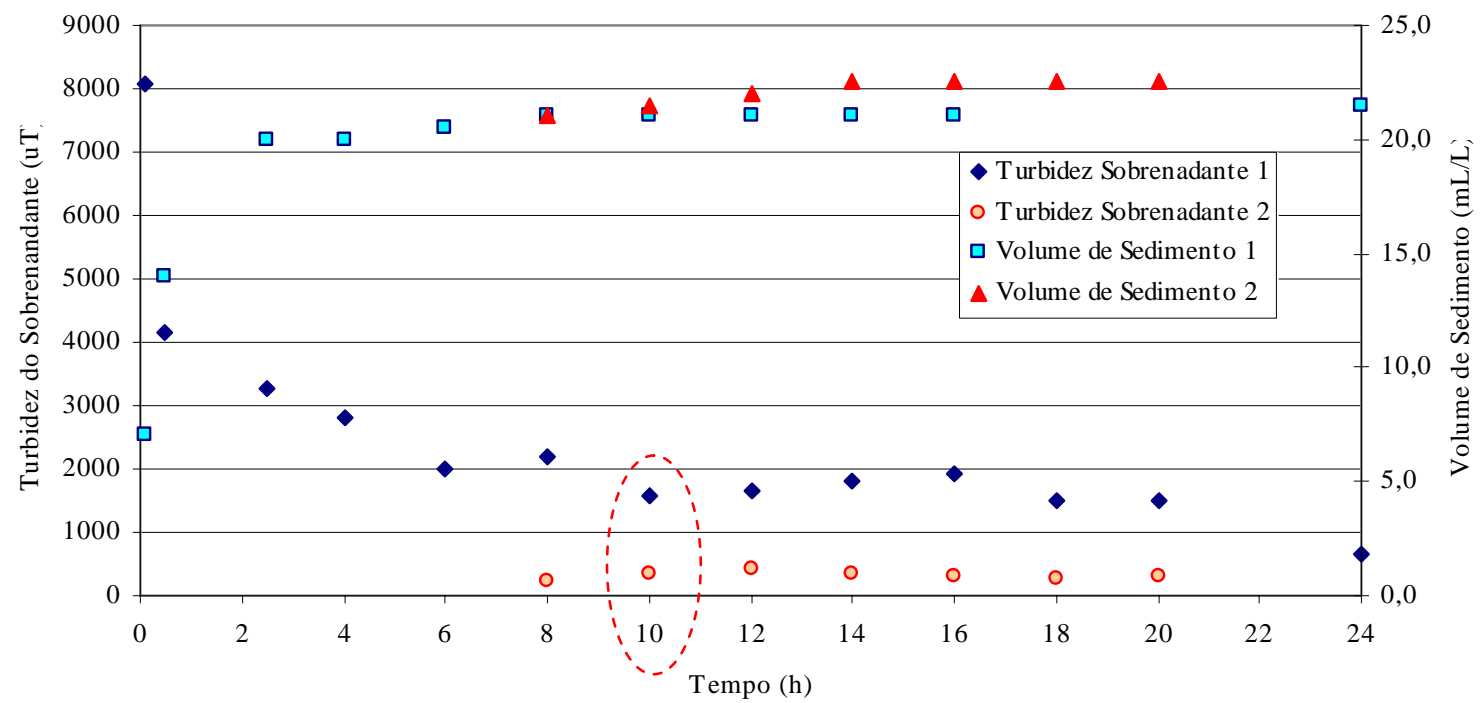

Figura 5.1 - Turbidez do sobrenadante e volume de sedimento resultante no ensaio de sedimentação com a caulinita

Conforme observado na Tabela 5.2 e Figura 5.1, após 10 horas de sedimentação a “dispersão-mãe” (sobrenadante) resultante da primeira agitação tendeu para um valor constante. Vale ressaltar que as oscilações nos valores de turbidez foram decorrentes de erros na diluição das amostras, motivo pelo qual a curva de sedimentação não foi sempre decrescente com o tempo. Para a realização do ensaio de caracterização do sobrenadante 
(item 5.1.3), foi escolhido o tempo de sedimentação de 10 horas para a primeira e segunda agitação da caulinita.

\subsubsection{Ensaio de caracterização do sobrenadante da caulinita}

Na Tabela 5.3 são apresentados os volumes dos sobrenadantes da caulinita necessários para preparação das águas de estudo em diferentes condições. Na Tabela 5.4 e na Figura 5.2 são apresentados os resultados da contagem de partículas das águas de estudo preparadas neste ensaio.

Tabela 5.3 - Volumes dos sobrenadantes da caulinita para preparação das águas de estudo em diferentes condições

\begin{tabular}{|c|c|c|}
\hline & $\begin{array}{c}\text { Volume } \\
\text { Sobrenadante } 1(\mathrm{~mL}) \\
\text { Turbidez 2450uT }\end{array}$ & $\begin{array}{c}\text { Volume } \\
\text { Sobrenadante } 2(\mathrm{~mL}) \\
\text { Turbidez 410uT }\end{array}$ \\
\hline $\begin{array}{c}\text { Água tipo Ia* } \\
\text { (Turbidez } 100 \text { uT) }\end{array}$ & 200 & - \\
\hline $\begin{array}{c}\text { Água tipo Ib* } \\
\text { (Turbidez } 100 \text { uT) }\end{array}$ & 135 & 300 \\
\hline $\begin{array}{c}\text { Água tipo IIa* } \\
\text { (Turbidez } 300 \text { uT) }\end{array}$ & 600 & - \\
\hline
\end{tabular}

A contagem de partículas feita para as águas tipo Ia, tipo Ib e tipo IIa é apresentada na Tabela 5.4 e na Figura 5.2.

Os resultados obtidos neste ensaio indicaram que não houve diferença significativa no tamanho e quantidade de partículas presentes nas águas Ia e Ib, sendo, portanto, viável o uso do sobrenadante da segunda agitação da caulinita para preparação das águas de estudo. Para as águas Ia e Ib houve predominância de partículas com tamanhos entre 2 e $10 \mu \mathrm{m}$ (turbidez de 100 uT). Já para a água IIa, (turbidez de 300 uT) preparada somente a partir do sobrenadante da primeira agitação da caulinita, houve predominância de partículas maiores que as presentes nas águas tipo Ia e Ib, com tamanho variando de 2 a $20 \mu \mathrm{m}$. Este aumento pode ser atribuído a agregação de partículas menores devido a quantidade de $\mathrm{Al}_{2} \mathrm{O}_{3}$ presente na composição da caulinita utilizada. 
Tabela 5.4 - Contagem de partículas das águas de estudo

\begin{tabular}{|c|c|c|c|}
\hline Faixa de Tamanho $(\mu \mathrm{m})$ & $\begin{array}{c}\text { Água tipo Ia } \\
\left(\mathrm{n}^{\mathrm{o}} \text { part./mL }\right)\end{array}$ & $\begin{array}{c}\text { Água tipo Ib } \\
\left(\mathrm{n}^{\mathrm{o}} \text { part./mL }\right)\end{array}$ & $\begin{array}{c}\text { Água tipo IIa } \\
\left(\mathrm{n}^{\mathrm{o}} \text { part./mL }\right)\end{array}$ \\
\hline $2-4$ & 7287,0 & 7034,0 & 4687,0 \\
\hline $4-6$ & 8158,3 & 8105,3 & 6005,7 \\
\hline $6-8$ & 5490,7 & 5886,9 & 6306,1 \\
\hline $8-10$ & 2110,5 & 2422,2 & 5391,1 \\
\hline $10-12$ & 588,80 & 663,53 & 2856,3 \\
\hline $12-14$ & 288,87 & 297,40 & 1326,8 \\
\hline $14-16$ & 191,33 & 191,13 & 450,07 \\
\hline $16-18$ & 136,27 & 139,67 & 244,6 \\
\hline $18-20$ & 80,87 & 86,47 & 351,6 \\
\hline $20-30$ & 111,27 & 119,2 & 27,07 \\
\hline $30-40$ & 12,20 & 15,20 & 5,47 \\
\hline $40-50$ & 4,00 & 5,267 & 2,13 \\
\hline $50-70$ & 4,13 & 2,00 & 0,67 \\
\hline $75-100$ & 2,67 & 1,47 & \\
\hline
\end{tabular}

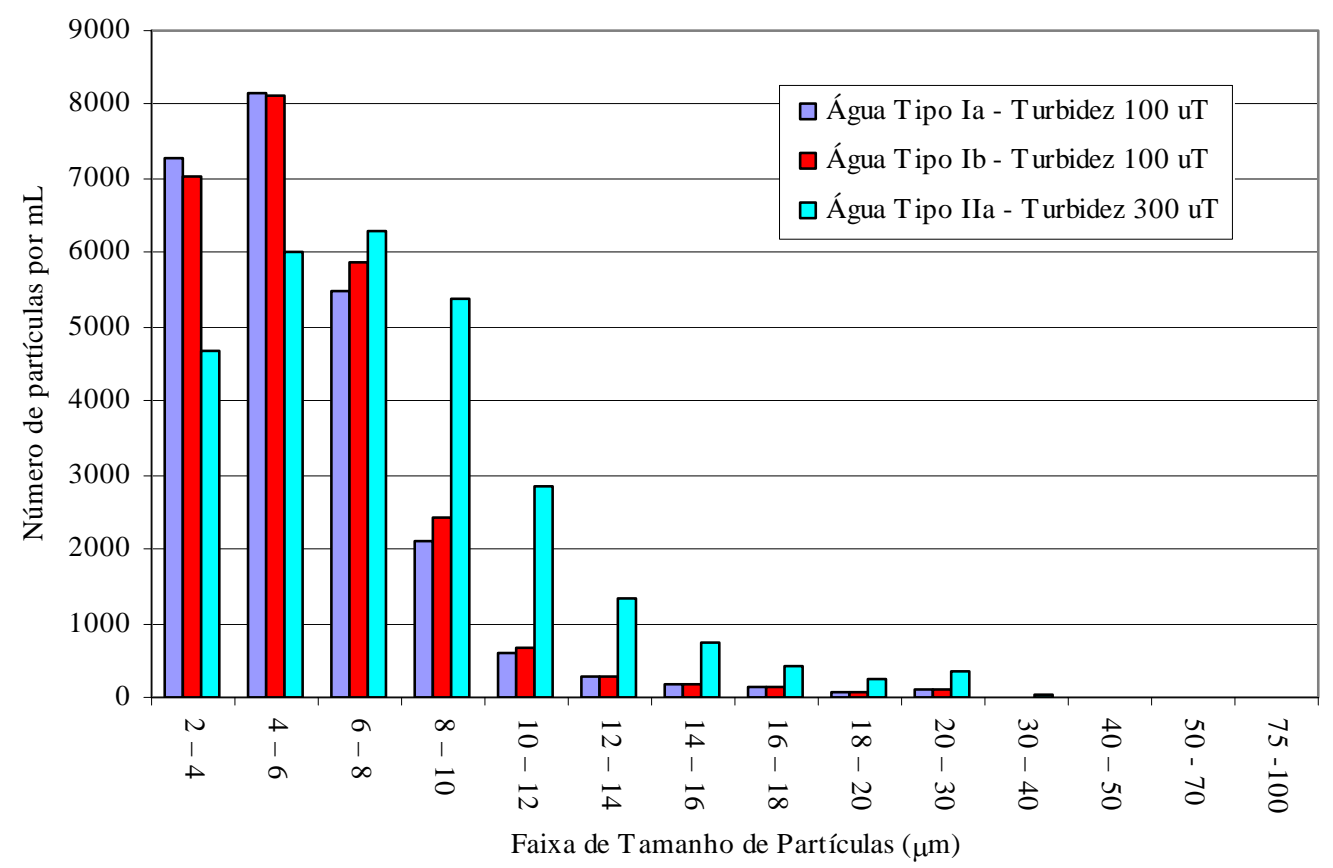

Figura 5.2 - Contagem de partículas das águas de estudo

\section{2. Águas de estudo}

As águas tipo I e tipo II foram preparadas a partir da mistura da água do poço da EESC-USP com sobrenadante da caulinita, de modo que os valores de turbidez final resultassem iguais a $100 \mathrm{uT}$ e $300 \mathrm{uT}$, respectivamente. Apesar dos resultados obtidos no 
item 5.1.3, que indicaram a possibilidade do uso do sobrenadante após a segunda agitação, para a realização dos ensaios de bancada e dos ensaios de dupla filtração, optou-se pela preparação das águas somente com sobrenadante da primeira agitação da caulinita. Na Tabela 5.5 são apresentadas as principais características das águas tipo I e tipo II.

Tabela 5.5 - Características das águas tipo I e tipo II

\begin{tabular}{|c|c|c|}
\hline Parâmetro & Água tipo I & Água tipo II \\
\hline Turbidez (uT) & 95 a 108 & 268 a 310 \\
\hline Alcalinidade $\left(\mathrm{mg} / \mathrm{L} \mathrm{CaCO}_{3}\right)$ & 26,4 a 28,4 & 22,0 a 24,5 \\
\hline Cor Aparente $(\mathrm{uH})$ & 410 a 450 & 1150 a 1380 \\
\hline Cor Verdadeira $(\mathrm{uH})$ & 2 & 2 \\
\hline $\mathrm{pH}$ & 7,52 a 7,77 & 7,60 a 7,88 \\
\hline Condutividade Elétrica $(\mu \mathrm{S} / \mathrm{cm})$ & 47,8 & 57,5 \\
\hline Carbono Orgânico Dissolvido $(\mathrm{mg} / \mathrm{L})$ & 2,596 & 2,160 \\
\hline Absorvância a $254 \mathrm{~nm}$ & 0,002 & 0,004 \\
\hline Oxigênio Consumido $(\mathrm{mg} / \mathrm{L})$ & 0,1 & 0,1 \\
\hline
\end{tabular}

\subsection{Ensaios de bancada}

As tabelas contendo os resultados dos ensaios de bancada são apresentadas no Anexo A. O equipamento de jarteste e o kit de filtros de laboratório de areia (FLAs) utilizados nestes ensaios podem ser vistos em fotos apresentadas na Figura A.1 no Anexo A.

\subsubsection{Ensaios com a água tipo I}

\section{Série I: Condições de coagulação}

Foram realizados dez ensaios de filtração direta em jarteste e kit de FLA para otimização da coagulação da água tipo I (características dos ensaios no item 4.6.1). Na ocasião da realização dos ensaios com a água tipo I, o zetâmetro não estava funcionando, motivo pelo qual não foi lido o potencial zeta da água coagulada. Os ensaios foram realizados com a temperatura variando de 24 a $26^{\circ} \mathrm{C}$. Os resultados são mostrados nas Tabelas A1.1 a A1.10 do Anexo A.

Na Figura 5.3 são apresentados os resultados destes ensaios para definição das condições de coagulação da água tipo I. 


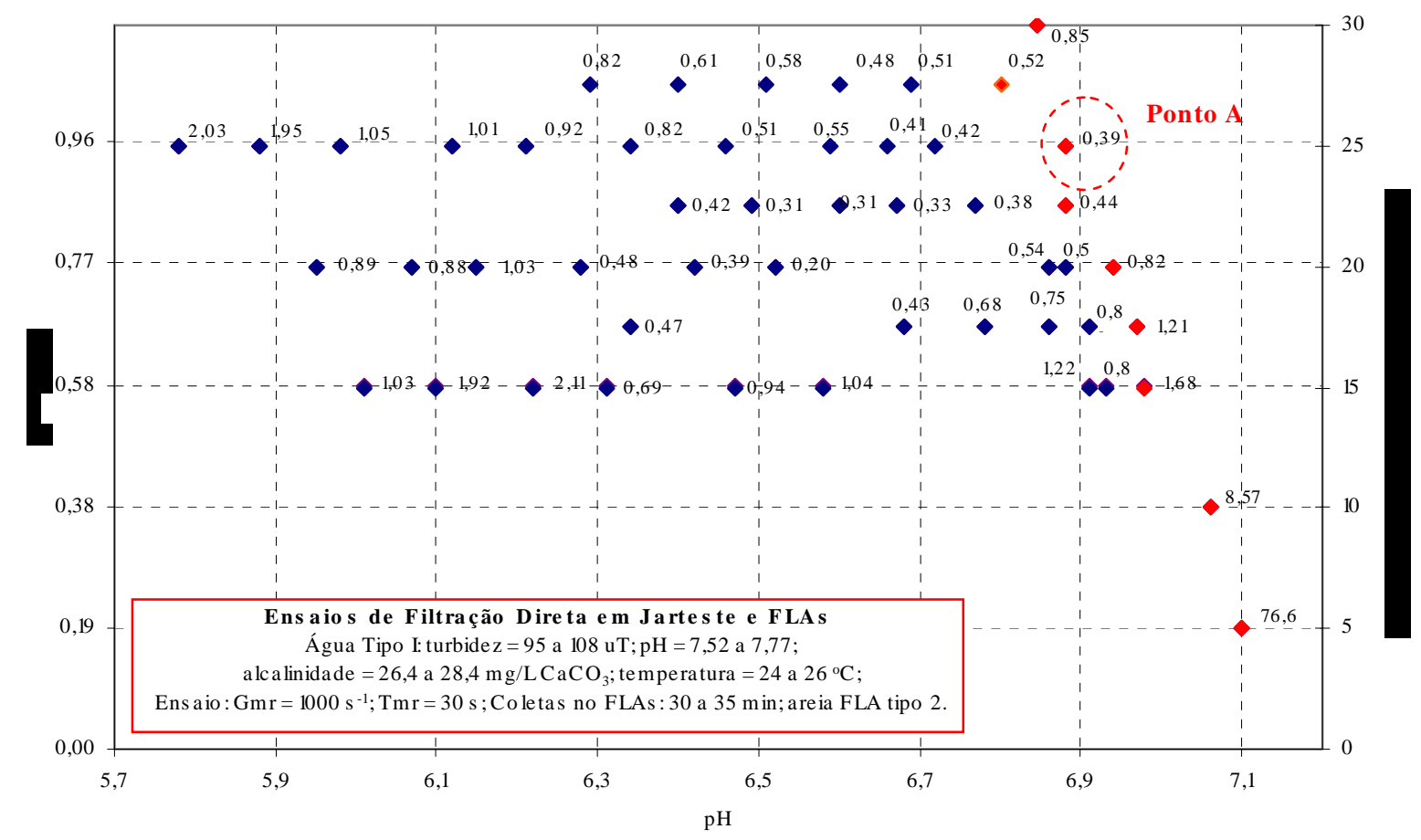

Figura 5.3 - Resultados de dosagem de coagulante, pH de coagulação e turbidez do filtrado obtidos nos ensaios de bancada de filtração direta para definição das condições de coagulação da água tipo I

Observa-se na Figura 5.3 que a região que apresentou os melhores resultados em termos de remoção de turbidez está compreendida na faixa de dosagens de sulfato de alumínio de 22,5 a 27,5 mg/L do produto comercial (0,86 a 1,05 mg/L Al) e pH entre 6,3 e 6,9. Os pontos destacados são aqueles em que não houve a adição de acidificante. Para valores de pH de coagulação menores que 6,3, houve um aumento considerável nos valores de turbidez da água filtrada obtidos para todas as dosagens estudadas.

Com a dosagem de sulfato de alumínio de $25 \mathrm{mg} / \mathrm{L}$ do produto comercial e $\mathrm{pH}$ de coagulação de 6,88 (ponto A), foi obtida turbidez do filtrado de 0,39 uT (coleta com 30 min). Apesar de outros pontos terem resultado valores de turbidez menores, o ponto A foi escolhido para a realização dos demais ensaios de bancada e de dupla filtração com a água tipo I, uma vez que a remoção de turbidez foi considerada satisfatória e não houve a necessidade da utilização de acidificante para ajuste do pH de coagulação.

Na Figura 5.4 é mostrada a localização dos pontos obtidos (pH de coagulação $\mathrm{x}$ dosagem de sulfato de alumínio) no diagrama de solubilidade do alumínio. 


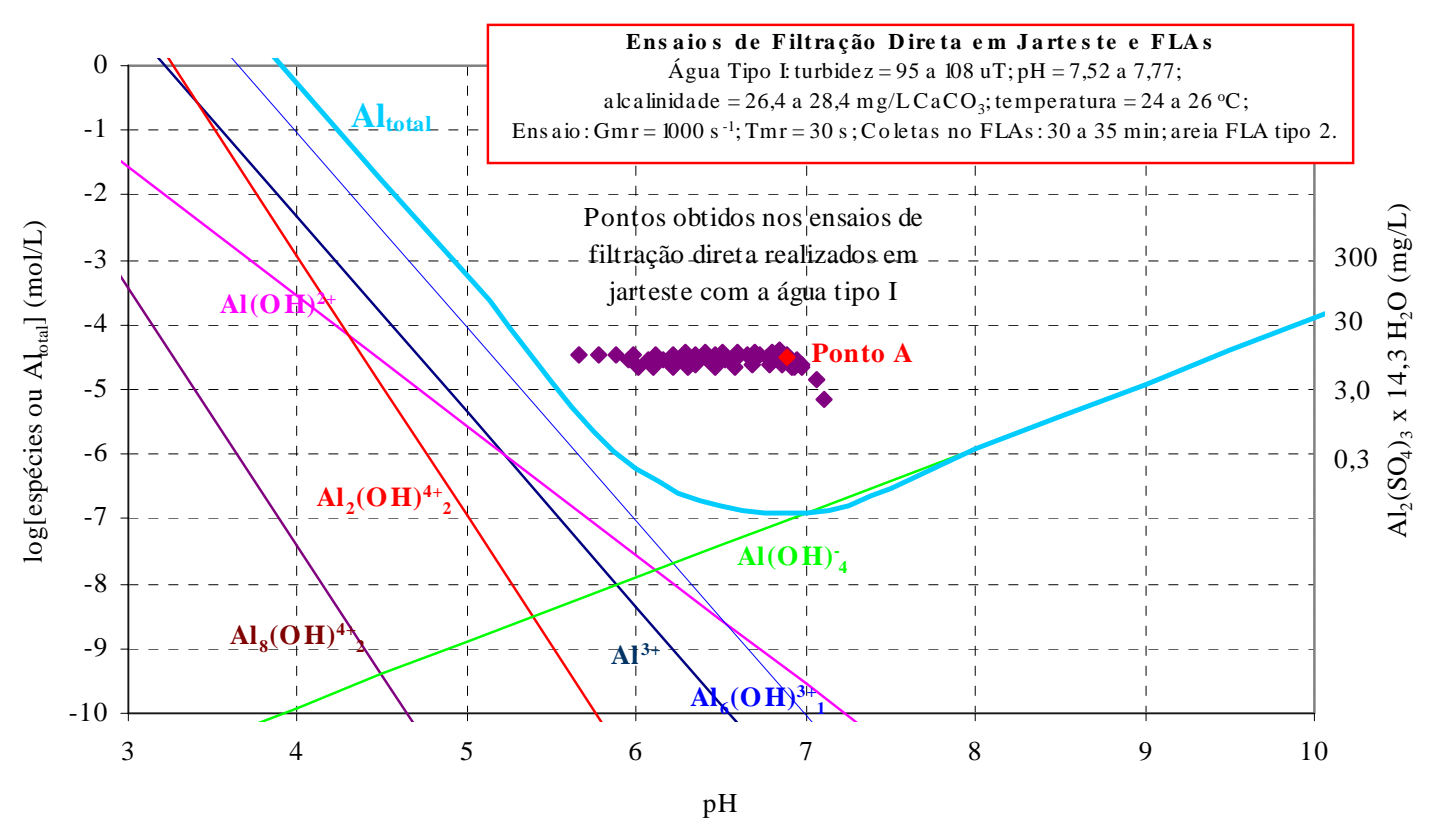

Figura 5.4 - Resultados obtidos nos ensaios de bancada de filtração direta com a água tipo I no diagrama de solubilidade do alumínio

\section{Série II: Verificação da areia dos FLAs}

Foi realizado um ensaio de filtração direta com a água tipo I e dosagem de sulfato de alumínio de 25,0 mg/L (0,96 mg/L Al) em todos os jarros, variando-se apenas o tipo de areia utilizado nos FLAs (as características deste ensaio no item 4.6.2).

Nas Figuras 5.5 e 5.6 são apresentados os resultados deste ensaio para determinação do tipo de areia dos FLAs que proporcionasse os melhores resultados em termos de remoção de turbidez e evolução de perda de carga. Foram feitas réplicas de cada jarro, conforme mostrado nas Figuras 5.5 e 5.6 .

Os resultados são mostrados na Tabela A1.11 no Anexo A. 


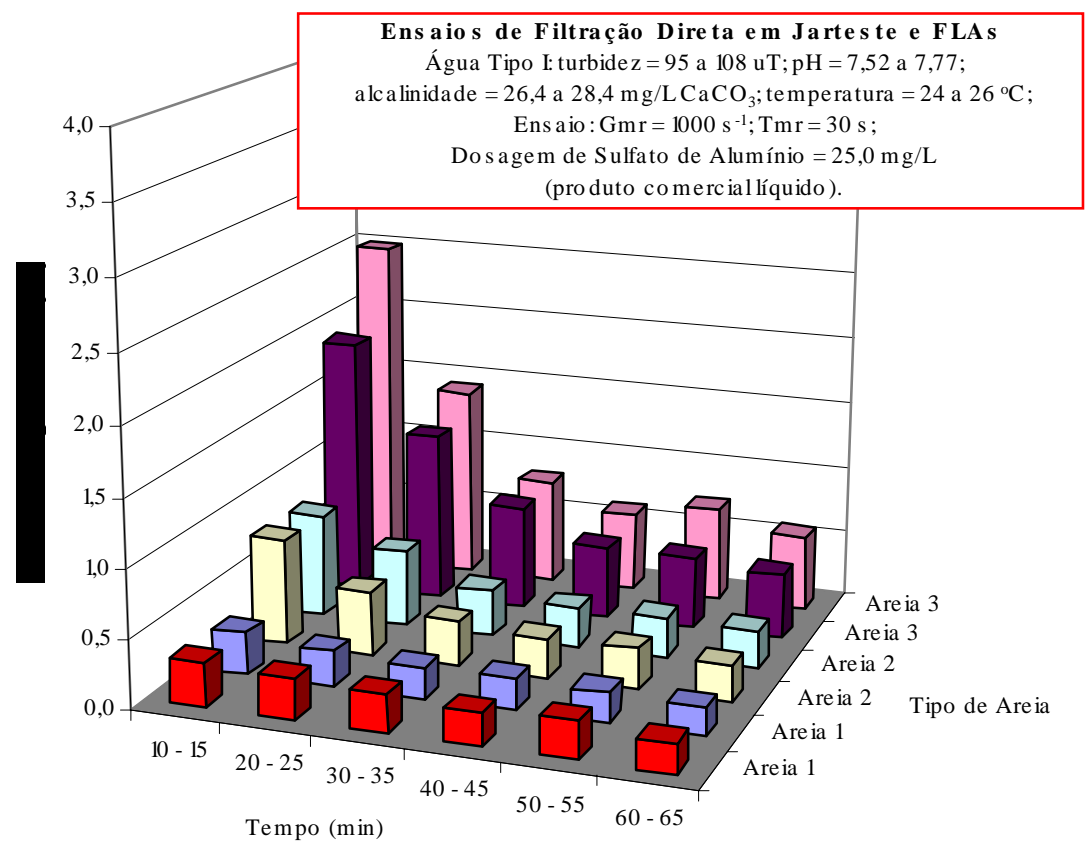

Figura 5.5 - Turbidez da água filtrada em função do tempo de coleta na filtração e do tipo de areia do FLA utilizado - resultados com a água tipo I

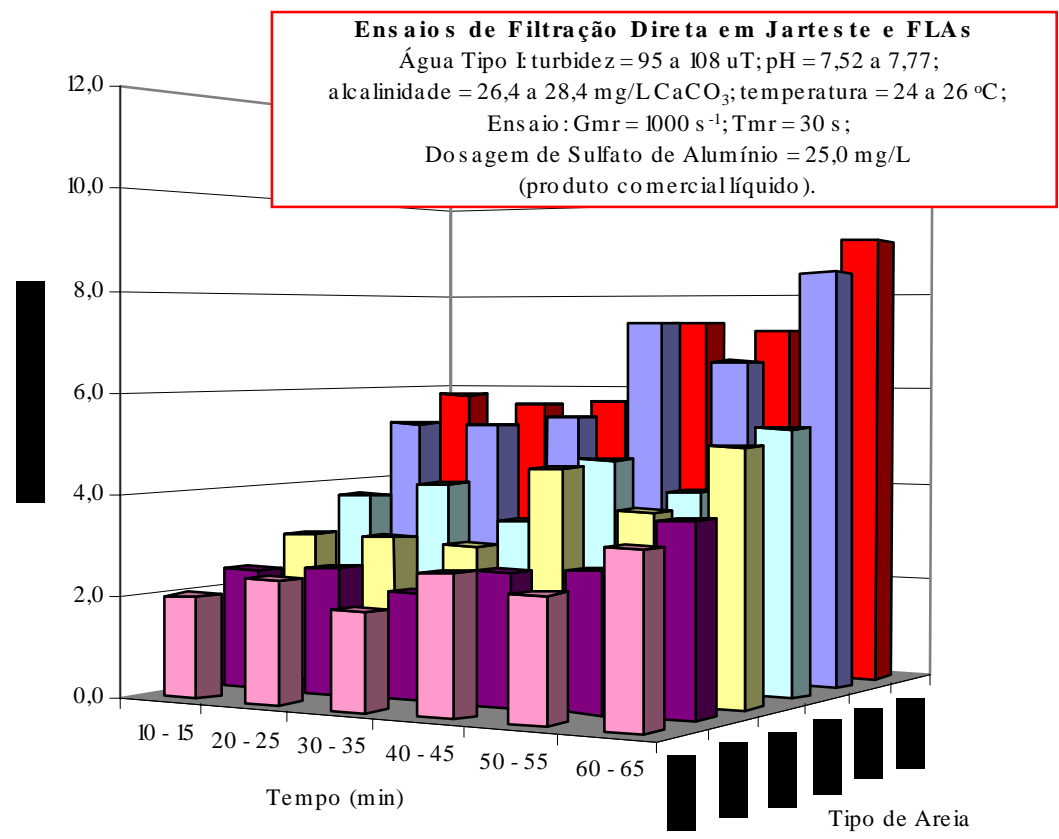

Figura 5.6 - Perda de carga em função do tempo de coleta na filtração e do tipo de areia do FLA utilizado - resultados com a água tipo I

Observa-se na Figura 5.5 que os menores valores de turbidez da água filtrada foram obtidos com o uso da areia tipo 1 , de menor granulometria (0,30 a 0,59 mm), para todas as 
coletas efetuadas (turbidez entre 0,33 e 0,21 uT). Entretanto, a perda de carga medida nos filtros de laboratório de areia - FLA1 e FLA2 foram consideravelmente maiores que os valores obtidos nos demais FLAs (Figura 5.6). Com a areia tipo 3, de maior granulometria (0,59 a 1,41 mm), os valores de turbidez obtidos foram significativamente maiores para todas as coletas realizadas. A partir do tempo de $30 \mathrm{~min}$, a diferença obtida nos valores de turbidez das águas filtradas nos FLA3 e FLA4 (areia tipo 2 - 0,42 e 0,84 mm) e nos FLA1 e FLA2 (areia tipo 1 - 0,30 a 0,59 mm), foi pequena, motivo pelo qual optou-se pelo uso da areia tipo 2 para os ensaios com a água tipo I.

Os resultados obtidos estão de acordo com o trabalho realizado por DI BERNARDO et al. (2002), no qual foi utilizada a areia tipo 2 nos ensaios de filtração direta para água bruta com turbidez entre 63,5 e 85,5 uT, e os valores de turbidez obtidos foram menores que 0,5 uT (Tabela 3.6).

\section{Série III: Verificação das condições de mistura rápida}

Foram realizados quatro ensaios de filtração direta com a dosagem de sulfato de alumínio comercial de 25,0 mg/L e com a areia tipo 2 nos FLAs, variando-se o tempo e o gradiente de velocidade médio da mistura rápida, objetivando a determinação do gradiente com o qual a variação do tempo de mistura não influenciasse na eficiência da coagulaçãofiltração (as características dos ensaios foram descritas no item 4.6.3).

Os resultados são mostrados nas Tabelas A1.12 a A1.15 do Anexo A.

Percebe-se na Figura 5.7, que os melhores resultados foram obtidos com o gradiente de velocidade de $800 \mathrm{~s}^{-1}$. Entretanto, com o gradiente de velocidade de $400 \mathrm{~s}^{-1}$ não significativa a variação nos valores de turbidez da água filtrada em função do tempo de mistura rápida, motivo pelo qual este valor foi adotado para a realização dos ensaios na instalação piloto com a água tipo I. 


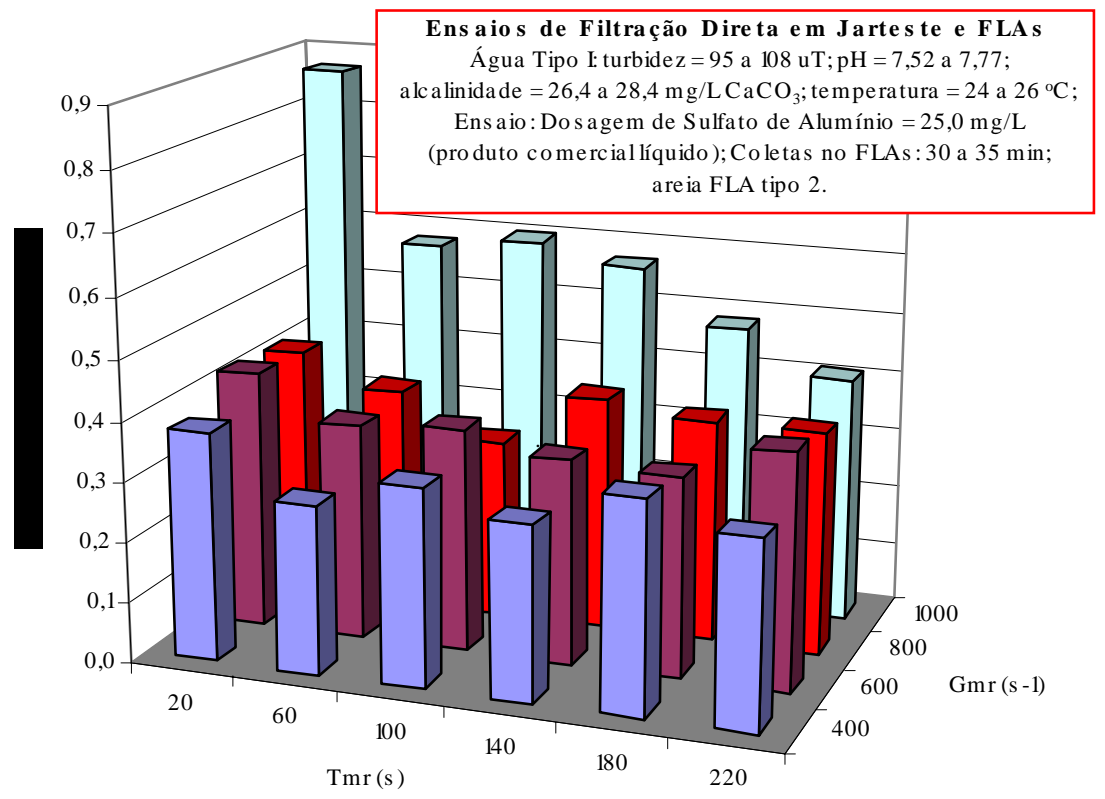

Figura 5.7 - Turbidez da água filtrada em função do tempo de mistura e do gradiente de velocidade médio na mistura rápida - resultados com a água tipo I

\subsubsection{Ensaios com a água tipo II}

\section{Série I: Condições de coagulação}

Foram realizados cinco ensaios de filtração direta em jarteste e kit de FLA para otimização da coagulação da água tipo II (características dos ensaios no item 4.6.1). Na ocasião de realização dos ensaios com a água tipo II, o zetâmetro não estava funcionando, motivo pelo qual não foi lido o potencial zeta da água coagulada.

Os resultados são mostrados nas Tabelas A2.1 a A2.5 do Anexo A.

Na Figura 5.8 são apresentados os resultados dos ensaios destes ensaios para definição das condições de coagulação da água tipo II.

Observa-se na Figura 5.8 que a região que apresentou os melhores resultados em termos de remoção de turbidez está compreendida na faixa de dosagens de sulfato de alumínio de 40,0 a 60,0 mg/L do produto comercial e pH entre aproximadamente 6,7 e 7,1. Os pontos destacados são aqueles em que não houve a adição de alcalinizante ou acidificante. Para valores de $\mathrm{pH}$ de coagulação menores que 6,5, houve um aumento considerável nos valores de turbidez da água filtrada obtidos para todas as dosagens estudadas. Com o uso de alcalinizante para ajuste do $\mathrm{pH}$ de coagulação, foram obtidos os menores valores de turbidez da água filtrada. Com a dosagem de sulfato de alumínio de 55 mg/L do produto comercial e pH de coagulação de 6,68 (ponto B), foi obtida turbidez do filtrado de 0,31 uT (coleta com $30 \mathrm{~min}$ ). Apesar de outros pontos terem resultado valores de 
turbidez menores, o ponto B foi escolhido para a realização dos demais ensaios de bancada e de dupla filtração com a água tipo II, uma vez que a remoção de turbidez foi considerada satisfatória e não houve a necessidade da utilização de alcalinizante para ajuste do pH de coagulação.

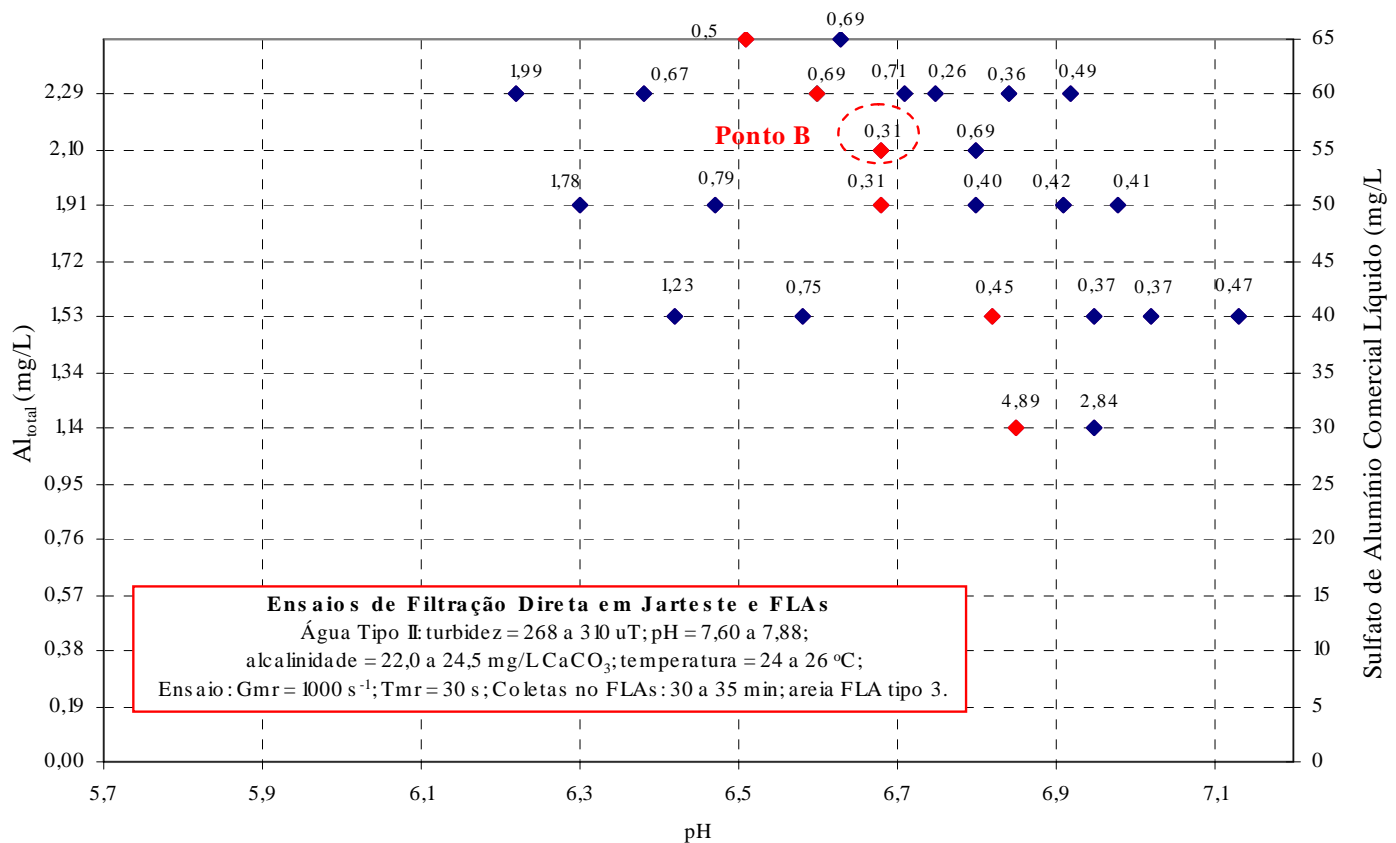

Figura 5.8 - Resultados de dosagem de coagulante, pH de coagulação e turbidez do filtrado obtidos nos ensaios de bancada de filtração direta para definição das condições de coagulação da água tipo II

Na Figura 5.9 é mostrada a localização dos pontos obtidos (pH de coagulação x dosagem de sulfato de alumínio) no diagrama de solubilidade do alumínio. 


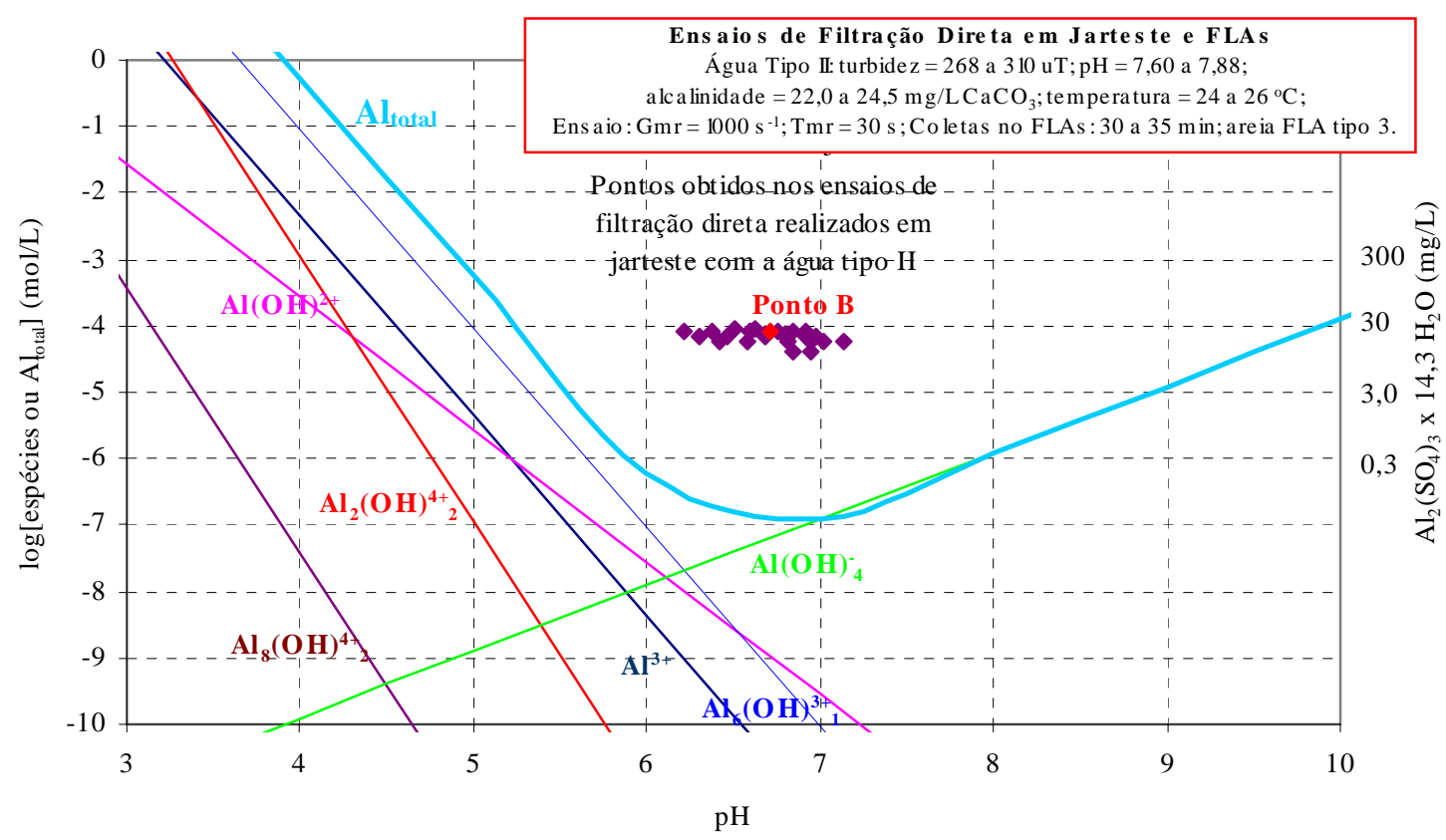

Figura 5.9 - Resultados obtidos nos ensaios de bancada de filtração direta com a água tipo II no diagrama de solubilidade do alumínio

\section{Série II: Verificação da areia dos FLAs}

Não foi necessária a realização deste ensaio, uma vez que os resultados obtidos na série I com a areia tipo 3 foram considerados satisfatórios e coerentes com a literatura consultada. Sendo assim, foi adotada a areia tipo $3(0,59$ a 1,41 $\mathrm{mm})$ para a realização dos demais ensaios com a água tipo II (turbidez de 300 uT).

\section{Série III: Verificação das condições de mistura rápida}

Foram realizados três ensaios de filtração direta com a dosagem de sulfato de alumínio líquido comercial de 55,0 mg/L (2,10 mg/L Al) e com a areia tipo 3, variando-se o tempo e o gradiente de velocidade médio da mistura rápida, objetivando a determinação do gradiente com o qual o a variação do tempo de mistura não influenciasse na eficiência da coagulação-filtração (as características dos ensaios foram descritas no item 4.6.3).

Os resultados são mostrados nas Tabelas A2.6 a A2.8 do Anexo A.

Percebe-se na Figura 5.10, que com o gradiente de velocidade de $600 \mathrm{~s}^{-1}$, não foi significativa a variação nos valores de turbidez da água filtrada em função do tempo de mistura rápida. 


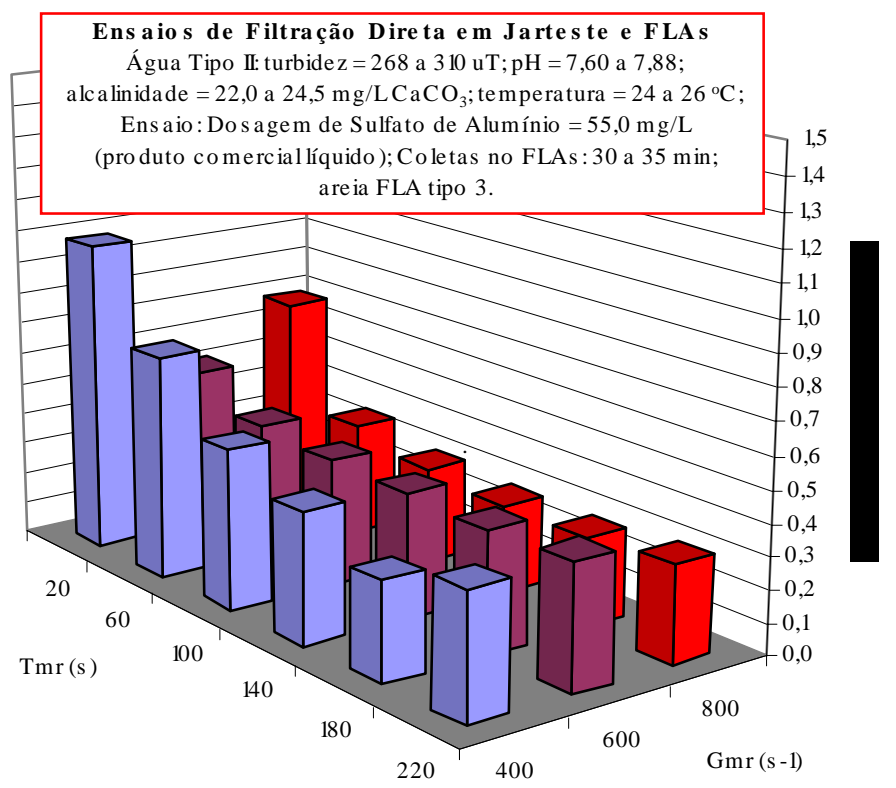

Figura 5.10 - Turbidez da água filtrada em função do tempo de mistura e do gradiente de velocidade médio na mistura rápida - resultados com a água tipo II

Nota-se na Figura 5.10, que os melhores resultados foram obtidos com o gradiente de velocidade de $800 \mathrm{~s}^{-1}$. Entretanto, com o gradiente de velocidade de $600 \mathrm{~s}^{-1}$ não foi significativa a variação nos valores de turbidez da água filtrada em função do tempo de mistura rápida, motivo pelo qual este valor foi adotado para a realização dos ensaios na instalação piloto com a água tipo II.

\subsubsection{Resumo dos resultados obtidos nos ensaios de bancada}

Na Tabela 5.6 são apresentados os parâmetros determinados nas séries de ensaios de filtração direta realizados em jarteste e kit de FLAs e que foram utilizados nos ensaios de dupla filtração na instalação piloto com as águas tipo I e tipo II.

Tabela 5.6 - Parâmetros determinados nos ensaios de bancada

\begin{tabular}{|c|c|c|}
\hline Parâmetro & Água tipo I & Água tipo II \\
\hline $\begin{array}{c}\text { Dosagem de Sulfato de Alumínio } \\
\text { (mg/L produto comercial líquido) }\end{array}$ & 25,0 & 55,0 \\
\hline $\begin{array}{c}\text { Gradiente de Velocidade na } \\
\text { Mistura Rápida }\left(\mathrm{s}^{-1}\right)\end{array}$ & 400 & 600 \\
\hline Areia FLA para controle da coagulação \\
na instalação piloto & tipo 2 & tipo 3 \\
\hline
\end{tabular}




\subsection{Pré-operação da instalação piloto}

\subsubsection{Verificação da composição do meio filtrante do filtro ascendente de areia grossa (sistema 1) e comparação com os valores de perda de carga calculados pela equação de FAIR et al. (1968)}

Os resultados dos ensaios de pré-operação do sistema 1 são mostrados no Anexo B nas Tabelas B1.1 a B1.3. Na ocasião da realização dos ensaios, a temperatura da água do poço era de $25 \pm 1{ }^{\circ} \mathrm{C}$.

Nas Figuras 5.11 a 5.13 são apresentados os resultados das perdas de carga lidas nos piezômetros das duas câmaras do filtro ascendente de areia grossa (FAAG-C1: câmara 1 e FAAG-C2: câmara 2) para as taxas de filtração de 115, 172 e $240 \mathrm{~m}^{3} / \mathrm{m}^{2}$.d, respectivamente, durante 2 horas de ensaio.

Para as três taxas de filtração estudadas, a diferença obtida nos valores de perda de carga lidos foi pequena ( $<10 \%)$, com valores de perda de carga ligeiramente superiores na câmara 2, sendo, portanto, consideradas semelhantes as duas câmaras de filtração do FAAG em termos de composição do meio filtrante.

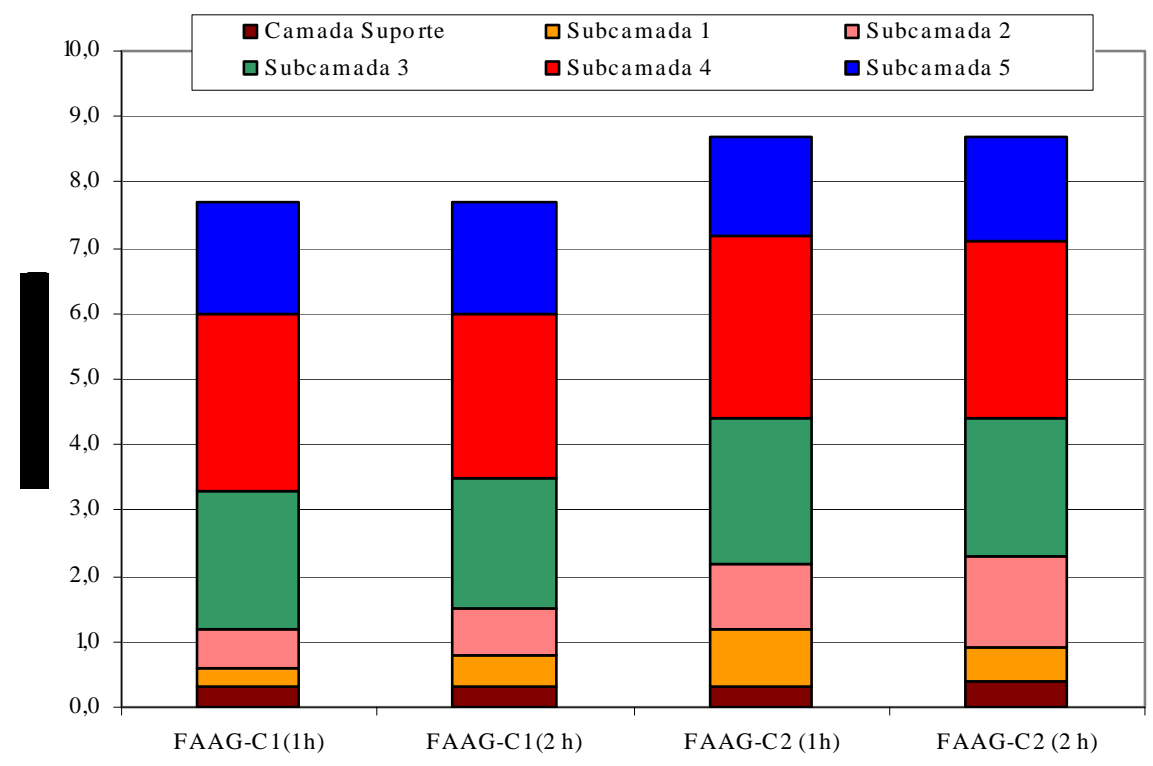

Figura 5.11 - Perda de carga nas câmaras do filtro ascendente de areia grossa durante o ensaio de préoperação com taxa de filtração de $115 \mathrm{~m}^{3} / \mathrm{m}^{2} . d$ 


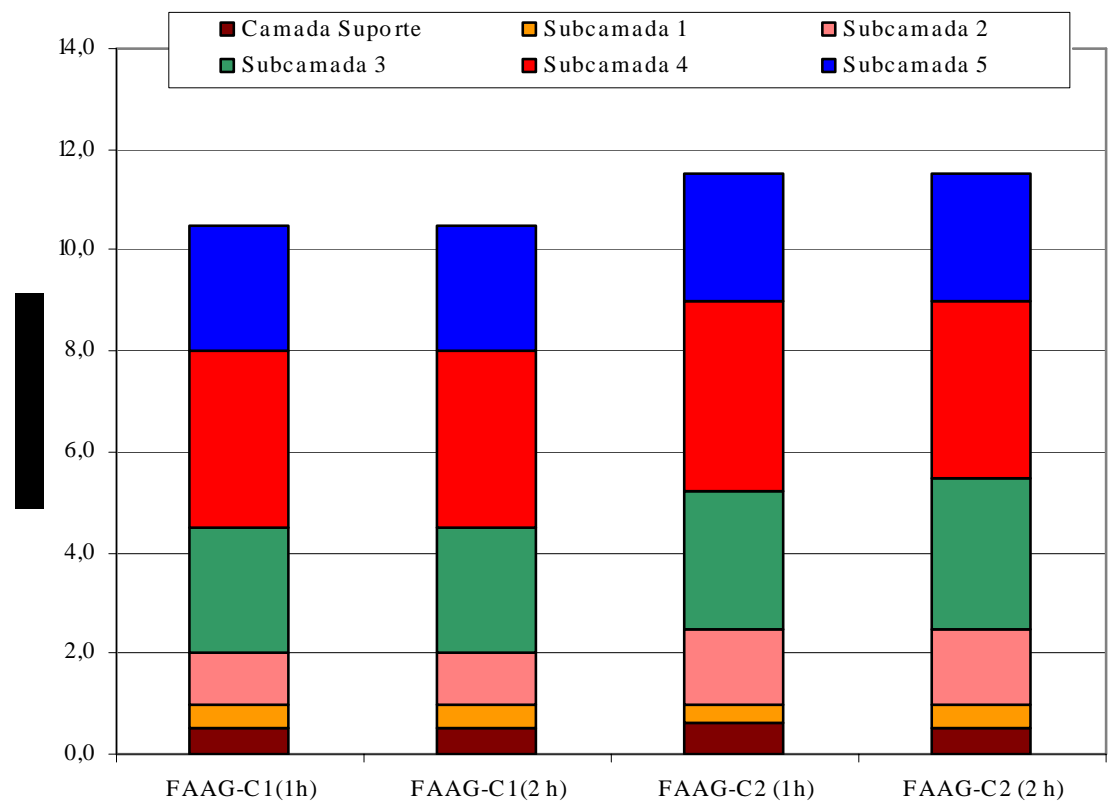

Figura 5.12 - Perda de carga nas câmaras do filtro ascendente de areia grossa durante o ensaio de préoperação com taxa de filtração de $172 \mathrm{~m}^{3} / \mathrm{m}^{2}$.d

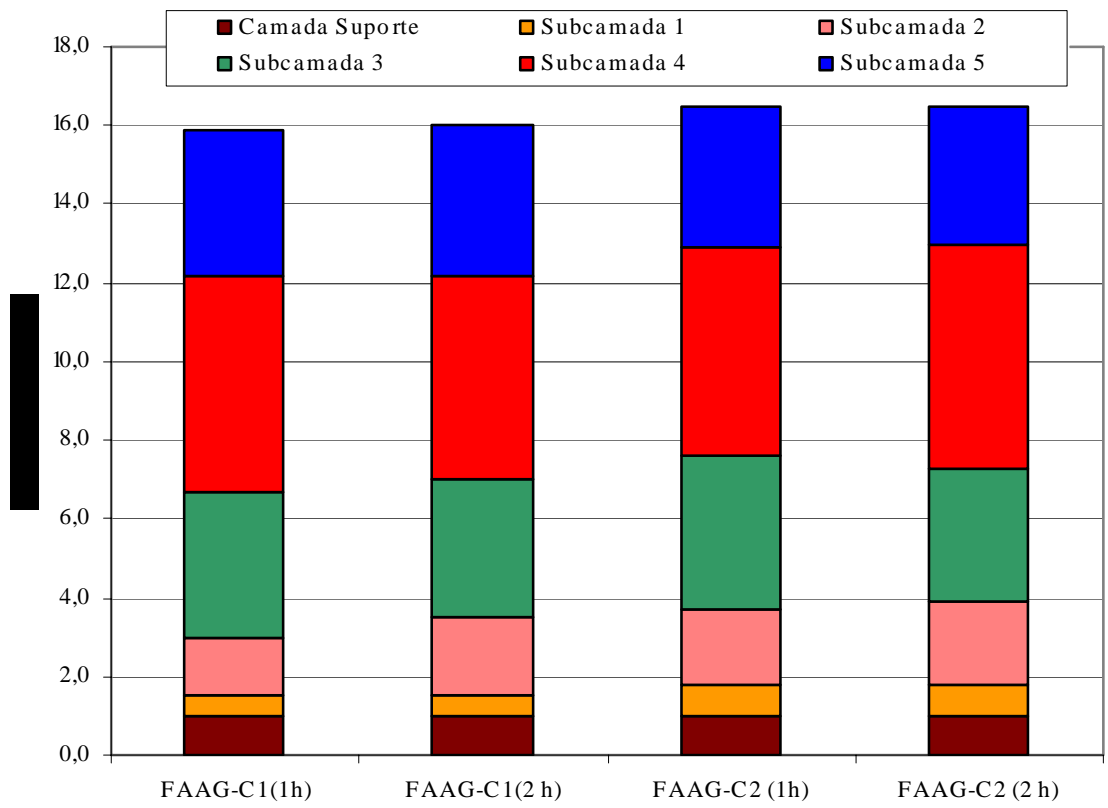

Figura 5.13 - Perda de carga nas câmaras do filtro ascendente de areia grossa durante o ensaio de préoperação com taxa de filtração de $240 \mathrm{~m}^{3} / \mathrm{m}^{2}$.d

Para comparação dos valores de perda de carga obtidos na instalação piloto com a equação de FAIR et al. (1968), foi utilizada a equação 4.1, em que: h (m): perda de carga no meio filtrante limpo/camada suporte limpa; $\mu\left(\mathrm{N} . \mathrm{s} / \mathrm{m}^{2}\right)$ : viscosidade absoluta da água 
$\left(0,894.10^{-3} \mathrm{~N} . \mathrm{s} / \mathrm{m}^{2}\right.$ para $\left.25^{\circ} \mathrm{C}\right)$; pa $\left(\mathrm{kg} / \mathrm{m}^{3}\right)$ : massa específica da água $\left(997,05 \mathrm{~kg} / \mathrm{m}^{3}\right.$ para $\left.25^{\circ} \mathrm{C}\right)$; Ce: coeficiente de esfericidade (0,75 para meio filtrante e 0,70 para camada suporte); $\varepsilon_{0}$ : porosidade da camada suporte limpa (0,40 para meio filtrante e 0,42 para camada suporte); $V_{\infty}(\mathrm{m} / \mathrm{s})$ : velocidade de aproximação; g $\left(\mathrm{m} / \mathrm{s}^{2}\right)$ : aceleração da gravidade $(9,81)$; Lf: espessura da camada suporte (1,40 para meio filtrante e 0,55 para camada suporte); $\sum \frac{X i}{D g i^{2}}$ (ver Tabelas B1.4 e B1.5 no Anexo B).

Para taxa de $115 \mathrm{~m}^{3} / \mathrm{m}^{2}$.d, a perda de carga no meio filtrante limpo a $25^{\circ} \mathrm{C}$ é igual a:

$$
\mathrm{h}_{\mathrm{FAAG}}=\frac{150 \times 0,894 \times 10^{-3} \times 0,00133 \times(1-0,40)^{2}}{9,81 \times 997,05 \times(0,40)^{3} \times(0,75)^{2}} \times 1,40 \times 304593,5=0,078 \mathrm{~m}
$$

Para taxa de $115 \mathrm{~m}^{3} / \mathrm{m}^{2}$.d, a perda de carga na camada suporte limpa a $25^{\circ} \mathrm{C}$ é igual a:

$$
\mathrm{h}_{\mathrm{CS}}=\frac{150 \times 0,894 \times 10^{-3} \times 0,00133 \times(1-0,42)^{2}}{9,81 \times 997,05 \times(0,42)^{3} \times(0,70)^{2}} \times 0,55 \times 17545,02=0,002 \mathrm{~m}
$$

Na Tabela 5.7 são apresentados os valores de perda de carga calculados pela equação 4.1 para as demais taxas estudadas e os resultados obtidos na pré-operação do sistema 1.

Tabela 5.7 - Comparação dos valores de perda de carga calculados e medidos nos filtros ascendentes de areia grossa

\begin{tabular}{|c|c|c|c|c|c|c|}
\hline $\begin{array}{c}\text { Taxa de Filtração } \\
\left(\mathrm{m}^{3} / \mathrm{m}^{2} \cdot \mathrm{d}\right)\end{array}$ & \multicolumn{2}{|c|}{ Perda de carga calculada (cm) } & \multicolumn{3}{|c|}{ Perda de carga medida na instalação piloto FAAG (cm) } \\
& Camada Suporte & Meio Filtrante & \multicolumn{2}{|c|}{$\begin{array}{c}\text { Camada Suporte (P1 - P2) } \\
\text { FAAG-C1 }\end{array}$} & \multicolumn{2}{|c|}{$\begin{array}{c}\text { Meio Filtrante (P2 - P7) } \\
\text { FAG-C2 }\end{array}$} \\
& & & 0,3 & 0,4 & 7,4 & 8,4 \\
\hline 115 & 0,2 & 7,8 & 0,5 & 0,6 & 10,0 & 10,9 \\
\hline 172 & 0,3 & 11,7 & 1,0 & 1,0 & 15,0 & 15,5 \\
\hline
\end{tabular}

Conforme mostrado na Tabela 5.7, para o meio filtrante do FAAG (subcamadas 1 a 5), a diferença entre os valores obtidos na instalação piloto e aqueles calculados pela equação de FAIR et al. (1968) foi considerada satisfatória (< 10 \%, com exceção do valor obtido para a taxa de $172 \mathrm{~m}^{3} / \mathrm{m}^{2}$.d na FAAG-C1). Já para a camada suporte, a diferença foi significativa, 
principalmente para a taxa de filtração de $240 \mathrm{~m}^{3} / \mathrm{m}^{2}$.d, indicando que a equação de FAIR et al. (1968) neste caso não foi adequada para o cálculo exato da perda de carga. Diminuindose a porosidade da camada suporte limpa de 0,42 para 0,30, os valores calculados pela equação se aproximam dos obtidos na instalação piloto. Entretanto, não existe na literatura dados que confirmem este valor de porosidade para o pedregulho. Outra explicação para as diferenças obtidas pode ter sido a baixa relação entre o diâmetro interno do filtro (91 mm) e o tamanho do pedregulho (maior igual a 25,4 mm e menor igual a 2,4 mm), de 3,6 a 38 . LANG et al. (1996) recomenda que esta razão seja maior que 50 para que não ocorra o efeito de parede durante a filtração. Esta relação não foi observada neste trabalho devido as limitações relativas à quantidade de água de estudo a ser preparada.

\subsubsection{Verificação da composição do meio filtrante do filtro ascendente de pedregulho (sistema 2) e comparação com os valores de perda de carga calculados pela equação de FAIR et al. (1968)}

Os resultados dos ensaios de pré-operação do sistema 2 são mostrados no Anexo B nas Tabelas B2.1 a B2.3. Na ocasião da realização dos ensaios, a temperatura da água do poço era de $25 \pm 1{ }^{\circ} \mathrm{C}$.

Nas Figuras 5.14 a 5.16 são apresentados os resultados das perdas de carga lidas nos piezômetros das duas câmaras do filtro ascendente de pedregulho (FAP-C1: câmara 1 e FAPC2: câmara 2) para as taxas de filtração de 120, 175 e $220 \mathrm{~m}^{3} / \mathrm{m}^{2}$.d, respectivamente, durante 2 horas de ensaio.

Para as três taxas de filtração estudadas, a diferença obtida nos valores de perda de carga lidos foi praticamente desprezível (<5\%), sendo, portanto, consideradas semelhantes as duas câmaras de filtração do FAP em termos de composição do meio filtrante. 


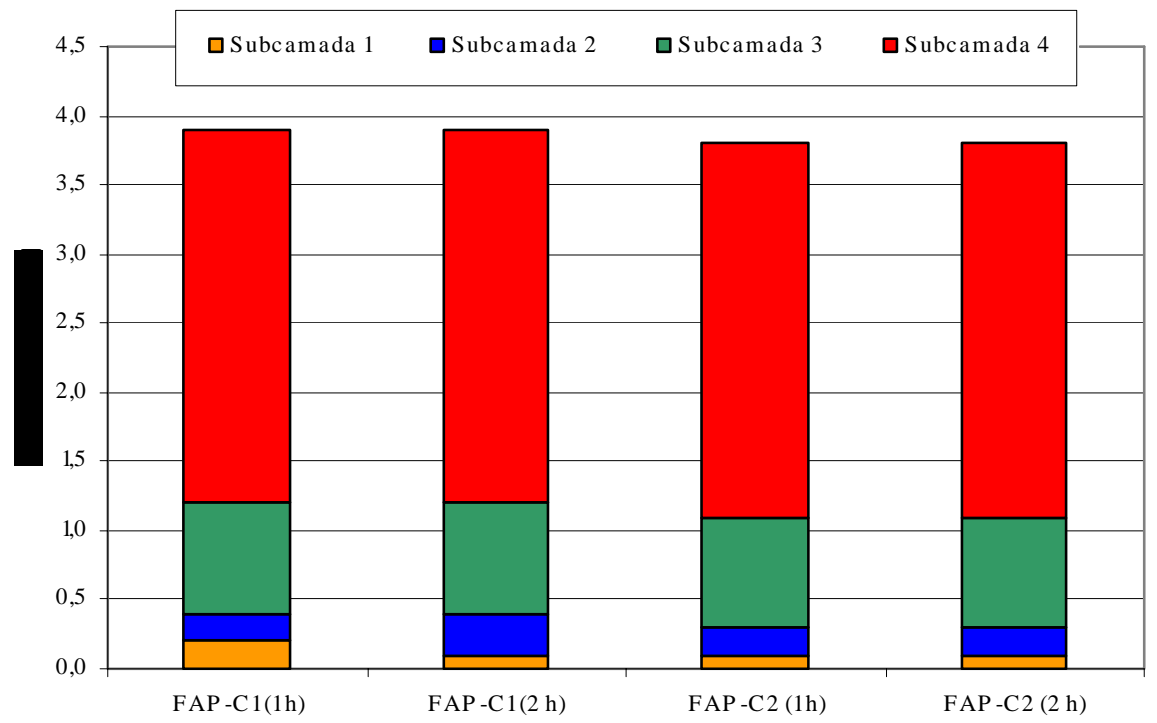

Figura 5.14 - Perda de carga nas câmaras do filtro ascendente de pedregulho durante o ensaio de préoperação com taxa de filtração de $120 \mathrm{~m}^{3} / \mathrm{m}^{2} . d$

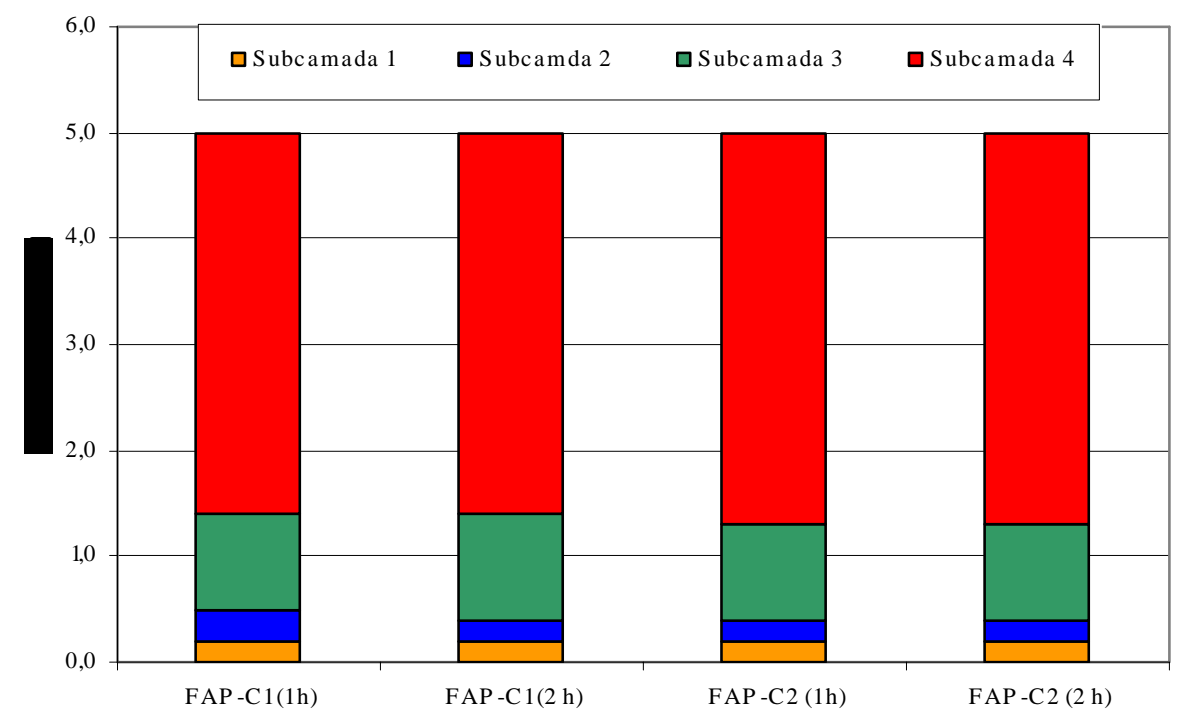

Figura 5.15 - Perda de carga nas câmaras do filtro ascendente de pedregulho durante o ensaio de préoperação com taxa de filtração de $175 \mathrm{~m}^{3} / \mathrm{m}^{2}$.d 


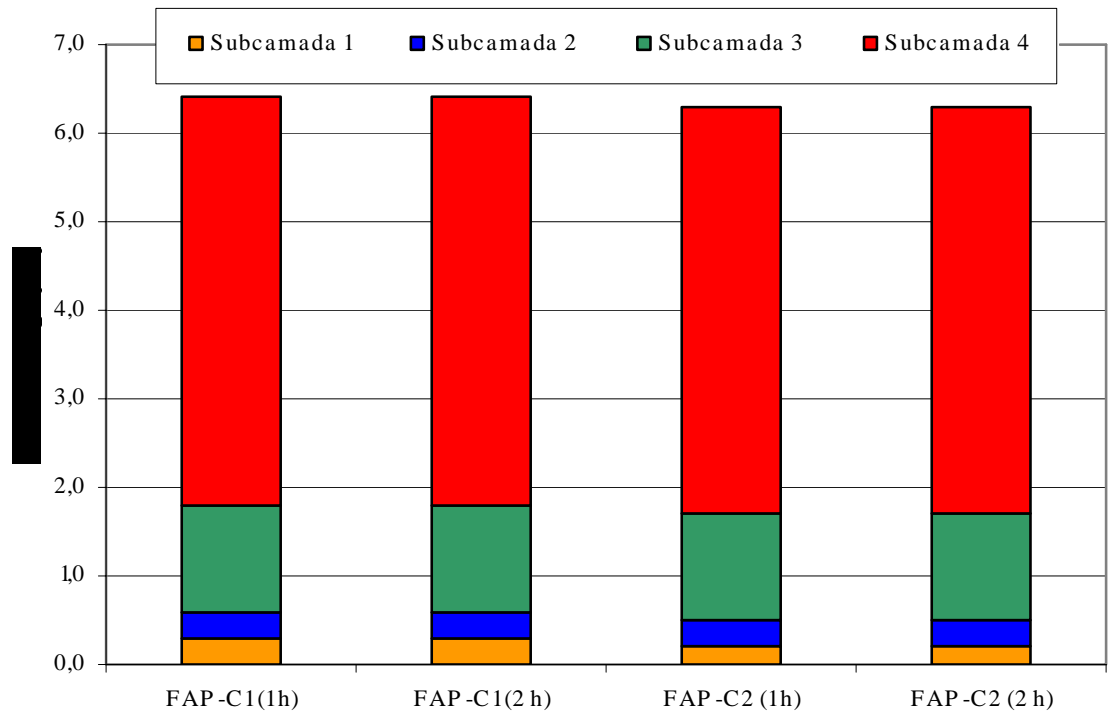

Figura 5.16 - Perda de carga nas câmaras do filtro ascendente de pedregulho durante o ensaio de préoperação com taxa de filtração de $220 \mathrm{~m}^{3} / \mathrm{m}^{2}$.d

Para comparação dos valores de perda de carga obtidos na instalação piloto com a equação de FAIR et al. (1968), a perda de carga no meio filtrante limpo foi calculada pela equação 4.1, em que: $\mathrm{h}(\mathrm{m})$ : perda de carga no meio filtrante limpo; $\mu\left(\mathrm{N} . \mathrm{s} / \mathrm{m}^{2}\right)$ : viscosidade absoluta da água $\left(0,894.10^{-3} \mathrm{~N} . \mathrm{s} / \mathrm{m}^{2}\right.$ para $\left.25^{\circ} \mathrm{C}\right)$; pa $\left(\mathrm{kg} / \mathrm{m}^{3}\right)$ : massa específica da água $\left(997,05 \mathrm{~kg} / \mathrm{m}^{3}\right.$ para $\left.25^{\circ} \mathrm{C}\right)$; Ce: coeficiente de esfericidade $(0,70) ; \varepsilon_{0}$ : porosidade do meio filtrante limpo $(0,42) ; V_{\infty}(\mathrm{m} / \mathrm{s})$ : velocidade de aproximação;g $\left(\mathrm{m} / \mathrm{s}^{2}\right)$ : aceleração da gravidade (9,81); Lf: espessura da camada suporte $(1,40) ; \sum \frac{X i}{D g i^{2}}$ (ver Tabela B2.4 no Anexo B).

Para a taxa de $220 \mathrm{~m}^{3} / \mathrm{m}^{2}$.d, resulta a seguinte perda de carga no meio filtrante limpo a $25^{\circ} \mathrm{C}$ do FAP:

$$
\mathrm{h}_{\mathrm{FAP}}=\frac{150 \times 0,894 \times 10^{-3} \times 0,00255 \times(1-0,42)^{2}}{9,81 \times 997,05 \times(0,42)^{3} \times(0,70)^{2}} \times 1,40 \times 38960,0=0,018 \mathrm{~m}
$$

Na Tabela 5.8 são apresentados os valores de perda de carga calculados pela equação 4.1 para as demais taxas estudadas e os resultados obtidos na pré-operação da instalação piloto 
Tabela 5.8 - Comparação dos valores de perda de carga calculados e medidos nos filtros ascendentes de pedregulho

\begin{tabular}{|c|c|c|c|}
\hline $\begin{array}{c}\text { Taxa de Filtração } \\
\left(\mathrm{m}^{3} / \mathrm{m}^{2} . \mathrm{d}\right)\end{array}$ & $\begin{array}{c}\text { Perda de carga } \\
\text { calculada }(\mathrm{cm})\end{array}$ & \multicolumn{2}{|c|}{$\begin{array}{c}\text { Perda de carga medida na instalação } \\
\text { piloto FAP }(\mathrm{cm})\end{array}$} \\
\hline 220,0 & 1,8 & 6,4 & FAP-C2 \\
\hline 175,4 & 1,4 & 5,0 & 5,3 \\
\hline 120,0 & 1,0 & 3,9 & 3,0 \\
\hline
\end{tabular}

A equação 4.1, proposta por FAIR et al. (1968) foi desenvolvida para cálculo da perda de carga em meios filtrantes de areia, e tem sido utilizada para estimar a perda de carga em meios filtrantes de pedregulho. No entanto, como se observa na Tabela 5.8, os valores calculados são significativamente inferiores àqueles medidos na instalação piloto. Novamente, diminuindo-se a porosidade do meio filtrante de pedregulho limpo de 0,42 para 0,30, os valores calculados pela equação se aproximam dos obtidos na instalação piloto. Entretanto, não existe na literatura dados que confirmem este valor de porosidade para o pedregulho. As mesmas observações relativas ao possível efeito de parede descritas no item 5.4.1 também são pertinentes neste caso.

\subsection{Ensaios de dupla filtração}

No Anexo C são apresentados os resultados dos quinze ensaios de dupla filtração realizados nos sistemas 1 e 2 . Os resultados foram apresentados em forma de tabelas, gráficos e fotos dos fenômenos ocorridos.

Algumas observações são comuns a todos os ensaios, quais sejam:

a) as tabelas iniciais Ci.1 (i é o número do ensaio) apresentam as condições de cada ensaio em relação à água de estudo, a coagulação e taxas de filtração:

- água de estudo: apesar de no ensaio de reutilização da caulinita ter sido constatado que a utilização do sobrenadante da segunda agitação não modificaria as características da água de estudo em termos de tamanho e número de partículas, nos ensaios realizados, as águas de estudo foram preparadas a partir do bombeamento somente do sobrenadante da primeira agitação até que fosse atingida a turbidez desejada. Para a preparação de $18 \mathrm{~m}^{3}$ da água tipo I (turbidez $100 \mathrm{uT}$ ), foram utilizados em média 300 L da dispersão-mãe (sobrenadante após 10 h de repouso). Para a preparação de $18 \mathrm{~m}^{3}$ da água tipo II (turbidez $300 \mathrm{uT}$ ), foram utilizados em média 800 L da dispersão-mãe (sobrenadante após 10 h de repouso); além da 
turbidez, a alcalinidade, o pH e o potencial zeta da água de estudo foram monitorados antes do início do ensaio;

- coagulação: com base nas dosagens de coagulante fixadas nos ensaios de bancada, era preparada a solução de sulfato de alumínio e bombeada a vazão necessária (equação 4.2) para a coagulação das águas tipo I e tipo II; a solução era bombeada à caixa de mistura rápida e misturada a água de estudo por meio de agitação com gradiente de velocidade também determinado nos ensaios de bancada; para controle da coagulação nos ensaio 1 a 5 de dupla filtração, foi utilizado somente o FLA, cuja localização pode ser vista na Figura 4.3 - desvio de água coagulada. A partir do ensaio 6 de dupla filtração, ocasião em que o zetâmetro encontrava-se em funcionamento, além do FLA, foram realizadas medidas do potencial zeta da água coagulada antes do início dos ensaios; em todos os ensaios realizados com a água tipo I, a dosagem de sulfato de alumínio que resultou água filtrada no FLA menor que 0,5 uT ou potencial zeta próximo de zero, variou de 27,5 a $30,0 \mathrm{mg} / \mathrm{L}$ do produto comercial líquido (1,05 a 1,15 mg/L Al); já para a água tipo II, essa dosagem variou de 55,0 a 60,0 mg/L (2,11 a 2,30 mg/L Al); em cada tabela Ci.1 são apresentados a dosagem de sulfato de alumínio utilizada, o valor da turbidez da água filtrada obtida no FLA e o potencial zeta e pH da água coagulada após os ajustes de dosagens.

- taxas de filtração: a vazão afluente aos filtros ascendentes foi controlada por meio de medidor eletromagnético e os valores registrados no computador de 5 em 5 min; com esses valores, foram calculadas as vazões médias e os desvios padrão; para os filtros descendentes, a vazão foi medida em rotâmetro de 3 em 3 horas e calculada a média, conforme pode ser visto nas tabelas Ci.1 do Anexo C;

b) as tabelas Ci.2 (i é o número do ensaio) apresentam as resultados obtidos em cada ensaio em relação a diversos parâmetros:

- vazão total: a vazão medida no medidor eletromagnético foi monitorada de 3 em 3 horas e os valores anotados em caso de problemas com a placa ou com software de aquisição de dados;

- turbidez, pH e temperatura da água de estudo: foram realizadas coletas da água de estudo na caixa de homogeneização de 3 em 3 horas e monitorados os parâmetros citados;

- pH de coagulação: a cada 6 horas foi medido o pH da água coagulada com coleta de amostra no desvio de água coagulada para uso do FLA; 
- turbidez ao longo do meio filtrante dos filtros ascendente e descendente: foram realizadas coletas de 3 em 3 horas ao longo do meio filtrante dos filtros ascendente e descendente, com duração aproximada de 15 min e volume total entre 100 e $150 \mathrm{~mL}$; a vazão de coleta nos registros de agulha localizados no final de cada subcamada do filtro ascendente foi fixada de modo que não houvesse interferência significativa nas taxas de filtração fixadas;

- perda de carga: foram realizadas leituras de perda de carga de 3 em 3 horas nos piezômetros; a perda de carga apresentada nos gráficos do Anexo C foram corrigidas para a temperatura de $25^{\circ} \mathrm{C}$, conforme detalhado no item 4.9.1. Por esse motivo, nos ensaios em que a temperatura da água ficou muito abaixo ou muito acima de $25{ }^{\circ} \mathrm{C}$, a perda de carga final prevista para o FRD $(1,80 \mathrm{~m})$ não é coincidente com aquela apresentada nos gráficos.

- outra observação importante diz respeito aos valores de turbidez apresentados nas tabelas do Anexo C. Segundo HACH et al. (1989), existe uma diferença na turbidez lida em equipamentos com princípios de funcionamento diferentes. No caso deste trabalho, a turbidez da água de estudo, a turbidez das amostras coletadas ao longo do meio filtrante do filtro ascendente e a turbidez das águas pré-filtrada e filtrada foram lidas no turbidímetro de bancada (TB) e apresentadas nas tabelas C1.2; nos turbidímetros de escoamento contínuo (TEC) foram lidas as turbidez das águas de estudo (somente água tipo I devido ao limite de 100 uT do equipamento), pré-filtrada e filtrada, e estes valores foram registrados no computador de 5 em 5 min (valores apresentados nas figuras Ci.1); a comparação dos resultados obtidos evidencia que os valores de turbidez lidos nos turbidímetros de escoamento contínuo são inferiores àqueles lidos no turbidímetro de bancada, sendo essa diferença mais significativa para valores menores que $1 \mathrm{uT}$, conforme já comprovado por TEIXEIRA et al. (2004).

No Anexo D são apresentados os resultados dos cálculos de produção efetiva de água para os ensaios de dupla filtração realizados nos sistemas 1 e 2. Os resultados foram apresentados em forma de tabela e os resultados resumidos na Tabela 5.9. 
Tabela 5.9 - Produção efetiva de água filtrada nos ensaios de dupla filtração

\begin{tabular}{|c|c|c|c|c|c|c|}
\hline Ensaio & $\begin{array}{c}\text { Água } \\
\text { Estudo/ } \\
\text { Sistema de } \\
\text { Dupla } \\
\text { Filtração }\end{array}$ & $\begin{array}{c}\text { Taxa de } \\
\text { Filtração } \\
\text { FA } \\
\left(\mathrm{m}^{3} / \mathrm{m}^{2} \cdot \mathrm{d}\right)\end{array}$ & $\begin{array}{c}\text { Taxa de } \\
\text { Filtração } \\
\text { FRD } \\
\left(\mathrm{m}^{3} / \mathrm{m}^{2} \cdot \mathrm{d}\right)\end{array}$ & $\begin{array}{l}\text { Execução de } \\
\text { Descargas de } \\
\text { Fundo } \\
\text { Intermediárias }\end{array}$ & $\begin{array}{c}\text { Produção } \\
\text { Efetiva de } \\
\text { Água } \\
\left(\mathrm{m}^{3} / \mathrm{m}^{2} \mathrm{FA}\right)\end{array}$ & $\begin{array}{l}\text { Eficiência na } \\
\text { produção de } \\
\text { água filtrada } \\
\text { (\%) }\end{array}$ \\
\hline 1 & Tipo I/ 1 & 120 & 187 & Não & 339 & 94 \\
\hline 2 & Tipo I/ 1 & 236 & 362 & Não & 622 & 88 \\
\hline 3 & Tipo I/ 1 & 239 & 362 & a cada $6 \mathrm{~h}$ & 654 & 91 \\
\hline 4 & Tipo I/ 1 & 176 & 305 & Não & 478 & 91 \\
\hline 5 & Tipo I/ 1 & 180 & 305 & a cada $6 \mathrm{~h}$ & 515 & 96 \\
\hline 6 & Tipo II/ 1 & 179 & 305 & Não & 458 & 85 \\
\hline 7 & Tipo II/ 1 & 178 & 305 & a cada $4,5 \mathrm{~h}$ & 463 & 87 \\
\hline 8 & Tipo II/ 1 & 126 & 179 & Não & $*$ & $*$ \\
\hline 9 & Tipo II/ 1 & 123 & 182 & a cada $4,5 \mathrm{~h}$ & $* *$ & $* *$ \\
\hline 10 & Tipo I/ 2 & 126 & 193 & Não & * & $*$ \\
\hline 11 & Tipo I/ 2 & 126 & 193 & a cada $6 \mathrm{~h}$ & 361 & 96 \\
\hline 12 & Tipo I/ 2 & 180 & 293 & Não & 474 & 88 \\
\hline 13 & Tipo I/ 2 & 181 & 293 & a cada $4,5 \mathrm{~h}$ & 478 & 88 \\
\hline 14 & Tipo II/ 2 & 178 & 185 & Não & * & $*$ \\
\hline 15 & Tipo II/ 2 & 178 & 185 & a cada $4,5 \mathrm{~h}$ & 512 & 96 \\
\hline
\end{tabular}

* ensaios em que houve a formação do manto de lodo no topo do meio filtrante do filtro ascendente não foi calculada a produção efetiva de água filtrada; ** ensaio interrompido com $36 \mathrm{~h}$.

A seguir são discutidos os resultados de cada ensaio.

\section{- Ensaio 1}

Este ensaio foi realizado no sistema 1 com a água tipo I e taxas médias de filtração de $120 \mathrm{~m}^{3} / \mathrm{m}^{2}$.d no FAAG e $187 \mathrm{~m}^{3} / \mathrm{m}^{2}$.d no FRD, sem a execução de descargas de fundo intermediárias.

Na Figura C1.1 do Anexo C é apresentada a variação da turbidez das águas de estudo, pré-filtrada e filtrada ao longo do ensaio 1, valores obtidos nos turbidímetros de escoamento contínuo (TEC). O encerramento do ensaio ocorreu por tempo limite (72 horas). O transpasse no filtro ascendente ocorreu após 50,5 h do início do ensaio e a perda de carga final no FAAG foi de aproximadamente 1,20 m. Após a ocorrência do transpasse no FAAG (pico de 40 uT no TB - na ocasião deste ensaio o software de aquisição de dados não estava registrando valores maiores que 5 uT da água pré-filtrada), a turbidez da água filtrada não ultrapassou 0,04 uT no TEC, indicando que o FRD foi o responsável pela retenção significativa de sólidos nas últimas 20 h do ensaio. A perda de carga final no FRD foi 
estimada em 1,00 m, visto que não foram feitas as últimas leituras de perda de carga (Figura C1.2 - Anexo C).

Nas Figuras C1.3 e C1.5 (Anexo C) são apresentados os valores de turbidez ao longo do meio filtrante das câmaras FAAG-C1 e FAAG-C2, respectivamente, e nas Figuras C1.4 e C1.6, os valores de perda de carga obtidos nos piezômetros das câmaras FAAG-C1 e FAAGC2, respectivamente. Os valores de turbidez apresentados nestas figuras foram lidos no TB. O comportamento das duas câmaras filtrantes foi praticamente o mesmo, revelando que no início do ensaio a remoção significativa de sólidos no FAAG, nas condições do ensaio 1, ocorreu na camada suporte e nas subcamadas 1 (tamanho dos grãos de 2,38 a 3,36 mm) e 2 (tamanho dos grãos de 2,00 a 2,38 mm) do meio filtrante, e com o passar do tempo as demais subcamadas também passaram a reter parte dos sólidos. O aumento da perda de carga devido a retenção de sólidos foi significativo em todo o meio filtrante, com exceção da subcamada 5, cuja perda de carga variou de 1,3 a 6,0 cm. Com o tempo de 24 h houve uma provável falha na medição da perda de carga, decorrente provavelmente de pequena variação da vazão total afluente ao sistema no momento das leituras dos piezômetros (Figuras C1.4 e C1.6).

A produção efetiva de água do ensaio 1 foi calculada com base no item 4.9.4 b1, e resultou valor de $339 \mathrm{~m}^{3} / \mathrm{m}^{2}$ e eficiência de 94 \% na produção de água filtrada.

\section{- $\quad$ Ensaio 2}

Este ensaio foi realizado no sistema 1 com a água tipo I e taxas médias de filtração de $236 \mathrm{~m}^{3} / \mathrm{m}^{2}$.d no FAAG e $362 \mathrm{~m}^{3} / \mathrm{m}^{2}$.d no FRD.

Na Figura C2.1 do Anexo C é apresentada a variação da turbidez das águas de estudo, pré-filtrada e filtrada (valores obtidos no TEC) e a variação da vazão total afluente ao sistema ao longo do ensaio 2. O encerramento do ensaio se deu por ocorrência de transpasse no FRD após 19,5 h do início do ensaio. O transpasse no FAAG ocorreu após 11 h e a perda de carga final foi de aproximadamente 0,60 m. Apesar dos elevados valores de turbidez da água pré-filtrada após a ocorrência do transpasse no FAAG (pico de 40 uT no TEC), a turbidez da água filtrada não ultrapassou 0,10 uT no TEC, indicando que o FRD foi o responsável pela retenção significativa de sólidos nas últimas horas do ensaio (detalhe do FRD na Figura 5.17). A perda de carga final no FRD foi de 1,55 m (Figura C2.2 do Anexo C).

Nas Figuras C2.3 e C2.5 do Anexo C são apresentados os valores de turbidez ao longo do meio filtrante das câmaras FAAG-C1 e FAAG-C2, respectivamente, e nas Figuras C2.4 e C2.6, os valores de perda de carga obtidos nos piezômetros das câmaras FAAG-C1 e FAAG-C2, respectivamente. Os valores de turbidez apresentados nestas figuras foram lidos 
no TB. O comportamento das duas câmaras filtrantes foi praticamente o mesmo. Com o aumento da taxa de filtração no FAAG em relação ao ensaio 1, o caminhamento da frente de impurezas ocorreu de maneira diferente daquele observado no ensaio 1 , sendo que a partir de $15 \mathrm{~h}$ de carreira, houve pequena retenção de sólidos nas subcamadas do meio filtrante devido provavelmente ao elevado grau de colmatação. O aumento da perda de carga devido a retenção de sólidos foi significativo em todo o meio filtrante, com exceção da subcamada 5 , que apresentou perda de carga praticamente constante $(2,5$ a $3,5 \mathrm{~cm})$ e inferior as demais subcamadas.

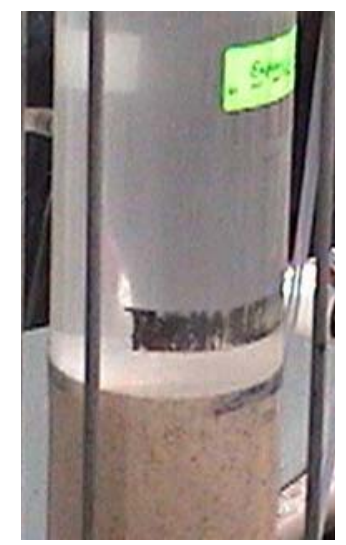

Figura 5.17 - Detalhe do FRD no início do transpasse - 17 h após o início do ensaio 2

Na Figura 5.18 é mostrada uma foto da camada suporte do FAAG-C1 após 10 h do início do ensaio 2. Percebe-se que houve elevado grau de colmatação, indicando a necessidade da execução das descargas de fundo intermediárias para aumento da carreira de filtração.

O aspecto visual do arraste de flocos no FAAG-C1 pode ser visto na Figura 5.19, ressaltando que este fenômeno observado nas duas câmaras.

Na Figura 5.20 são mostradas as fotos tiradas do display do TEC para visualização do aumento gradual da turbidez quando da ocorrência do transpasse no FAAG.

A produção efetiva de água do ensaio 2 foi calculada com base no item 4.9 .4 a, e resultou valor de $622 \mathrm{~m}^{3} / \mathrm{m}^{2}$ e eficiência de 88 \% na produção de água filtrada. A baixa eficiência obtida indica que as taxas estudadas não são adequadas para o tratamento da água tipo I neste tipo de sistema de dupla filtração. 


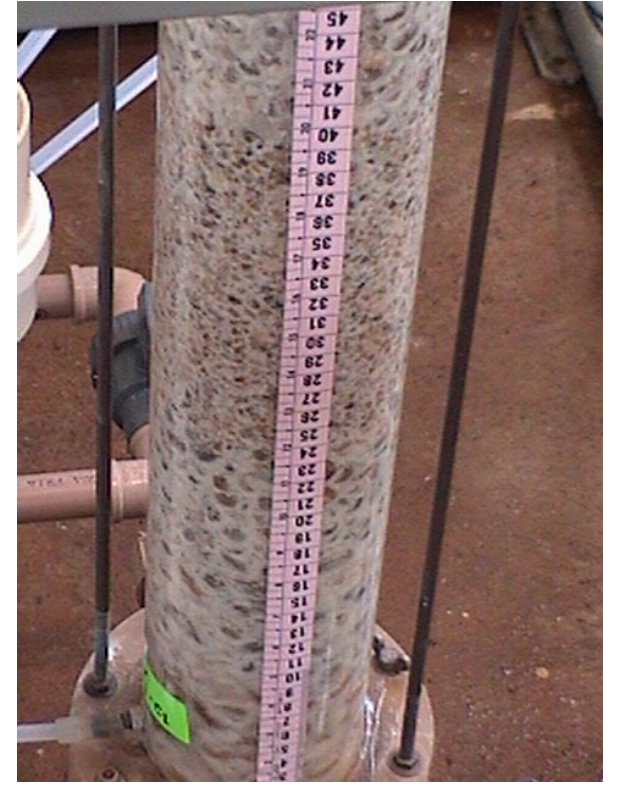

Figura 5.18 - Detalhe da camada suporte do FAAG-C1 após 10 h do início do ensaio 2

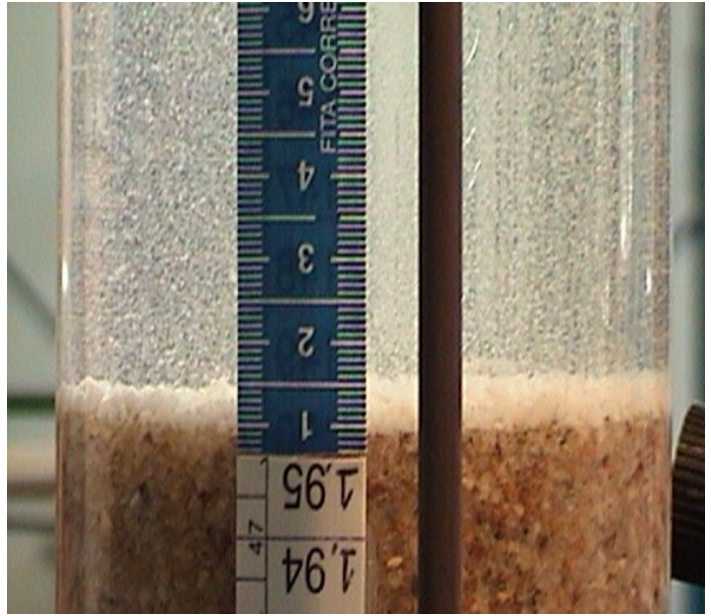

Figura 5.19 - Arraste de flocos e formação de manta no topo do meio filtrante do FAAG-C1 após 14 h do início do ensaio 2

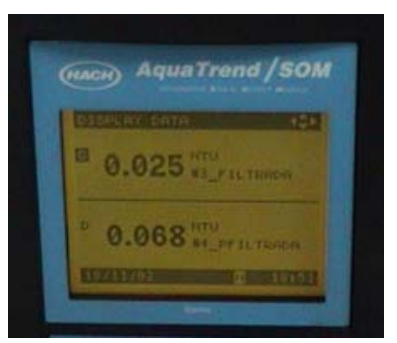

$\Delta \mathrm{t}=2 \mathrm{~h}$

(turbidez: $\mathrm{APF}=0,068 \mathrm{uT}$ e $\mathrm{AF}=$ $0,025 \mathrm{uT}$ )

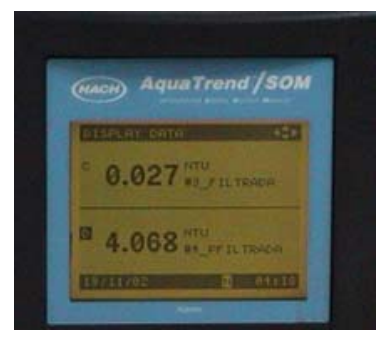

$\Delta \mathrm{t}=11,5 \mathrm{~h}$

(turbidez: $\mathrm{APF}=4,068 \mathrm{uT}$ e $\mathrm{AF}=$

$0,027 \mathrm{uT})$

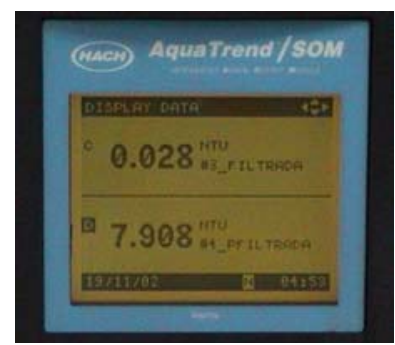

$\Delta \mathrm{t}=12 \mathrm{~h}$

(turbidez: $\mathrm{APF}=7,908 \mathrm{uT}$ e $\mathrm{AF}=$

$0,028 \mathrm{uT}$ )

* APF: água pré-filtrada; AF: água filtrada

Figura 5.20 - Turbidímetros de escoamento contínuo - Início do transpasse no FAAG após 11 h do início do ensaio 2

\section{- Ensaio 3}

Este ensaio foi realizado no sistema 1 com a água tipo I e taxas médias de filtração de $239 \mathrm{~m}^{3} / \mathrm{m}^{2}$.d no FAAG e $362 \mathrm{~m}^{3} / \mathrm{m}^{2}$.d no FRD, com a execução de descargas de fundo intermediárias (DFIs) no FAAG a cada 6 h.

Na Figura C3.1 (Anexo C) é apresentada a variação da turbidez das águas de estudo, pré-filtrada e filtrada (valores obtidos no TEC) e a variação da vazão total afluente ao sistema ao longo do ensaio 3. O encerramento do ensaio se deu por perda de carga limite no 
FRD (1,80 m), após 33 h do início do ensaio. O transpasse nas duas cânaras do FAAG ocorreu aproximadamente após 18 h (detalhe do arraste de flocos na câmara 1 após 20 h na Figura 5.21) e foi verificado o desprendimento de flocos, causando elevados picos de turbidez na água pré-filtrada (pico máximo de 100 uT) após a execução das DFI (total de 5 DFIs) - detalhe na Figura 5.22. A perda de carga final no FAAG foi de aproximadamente 0,30 m, sendo que, com a execução das DFIs, houve recuperação significativa da carga hidráulica (Figura C3.2 - Anexo C). Apesar dos elevados valores de turbidez da água préfiltrada após a execução das DFIs e após a ocorrência do transpasse no FAAG, a turbidez da água filtrada não ultrapassou 0,07 uT no TEC, indicando que o FRD foi o responsável pela retenção significativa de sólidos nas últimas 15 horas do ensaio.

Nas Figuras C3.3 e C3.5 do Anexo C são apresentados os valores de turbidez ao longo do meio filtrante das câmaras FAAG-C1 e FAAG-C2, respectivamente, e nas Figuras C3.4 e C3.6, os valores de perda de carga obtidos nos piezômetros das câmaras FAAG-C1 e FAAG-C2, respectivamente. Os valores de turbidez apresentados nestas figuras foram lidos no TB. O comportamento das duas câmaras filtrantes foi praticamente o mesmo. O caminhamento da frente de impurezas ocorreu de maneira diferente daquele observado no ensaio 2, ocorrendo a limpeza das subcamadas e conseqüente redução nos valores de turbidez das amostras coletadas ao longo do meio filtrante com a execução das DFIs. Até 15 h do início do ensaio, a camada suporte e as subcamadas 1 e 2 foram as responsáveis pela retenção de grande parte dos sólidos. As subcamadas 3 e 4 retiveram parte dos sólidos somente no final do ensaio e a subcamada 5 praticamente não reteve sólidos neste ensaio.

A produção efetiva de água do ensaio 3 foi calculada com base no item 4.9 .4 c1, e resultou valor de $654 \mathrm{~m}^{3} / \mathrm{m}^{2}$ e eficiência de $91 \%$ na produção de água filtrada. Percebe-se que com a execução das DFIs houve um aumento na eficiência (3 \%) em relação ao ensaio 2. Para melhorar ainda mais a eficiência do sistema, as taxas de filtração deveriam ser menores ou talvez pudesse ser aumentado o número das DFIs. 


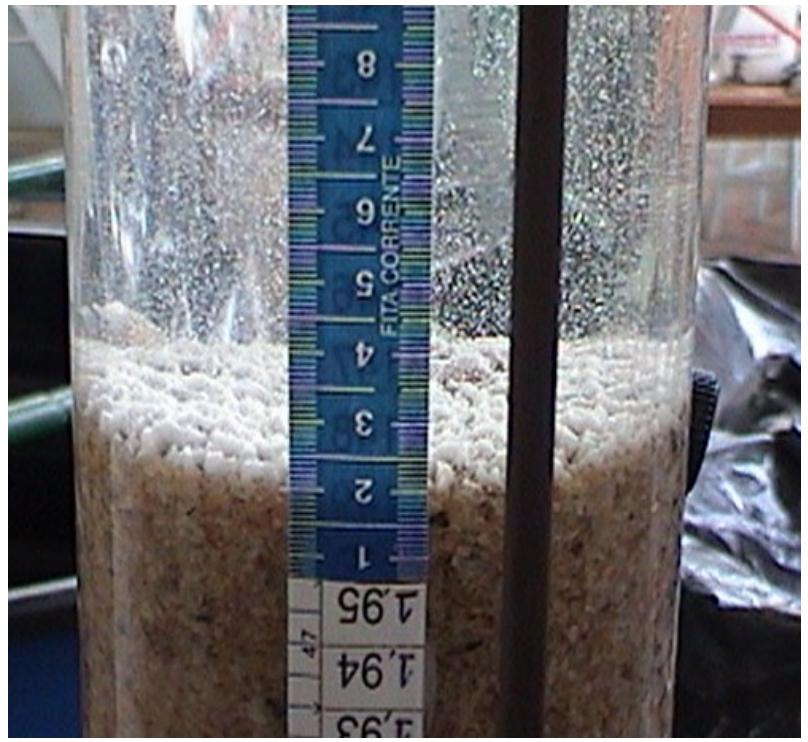

Figura 5.21 - Arraste de flocos e formação de manta no topo do meio filtrante do FAAG-C1 após 20 h do início do ensaio 3

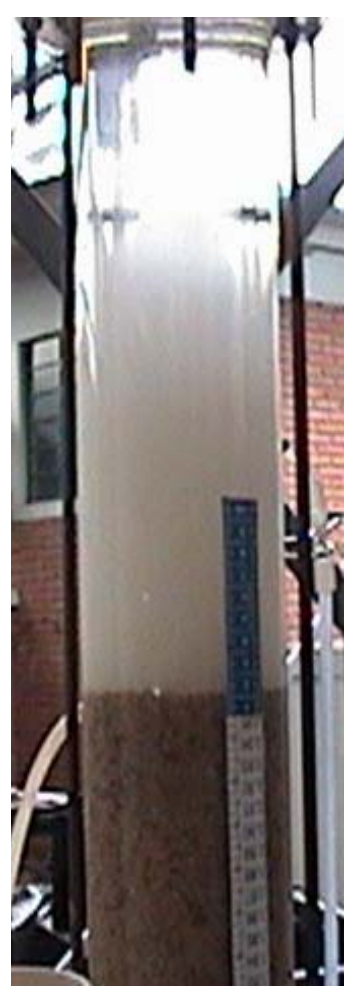

Figura 5.22- Desprendimento de flocos após execução da $5^{\mathrm{a}}$ DFI na câmara 1 do FAAG

\section{- Ensaio 4}

Com os resultados obtidos nos ensaios 2 e 3, optou-se por diminuir as taxas de filtração nos dois filtros, sendo o ensaio 4 realizado no sistema 1 com a água tipo I e taxas médias de filtração de $176 \mathrm{~m}^{3} / \mathrm{m}^{2}$.d no FAAG e $305 \mathrm{~m}^{3} / \mathrm{m}^{2}$.d no FRD. 
Na Figura C4.1 do Anexo C é apresentada a variação da turbidez das águas de estudo, pré-filtrada e filtrada (valores obtidos no TEC) e a variação da vazão total afluente ao sistema ao longo do ensaio 4. O encerramento do ensaio se deu por ocorrência de transpasse no FRD após 33,5 h do início do ensaio. O transpasse no FAAG ocorreu após 19,5 h (Figura 5.23) e a perda de carga final foi de aproximadamente $0,68 \mathrm{~m}$. O FRD foi o responsável pela retenção significativa de sólidos nas últimas horas do ensaio e a perda de carga final neste filtro foi de 1,55 m (Figura C4.2 - Anexo C). Nas Figuras 5.24 e 5.25 é visível o aumento do arraste de flocos na câmara 1 do FAAG no início do transpasse e após 7,5 h do início do mesmo. O mesmo foi observado na câmara 2 do FAAG.

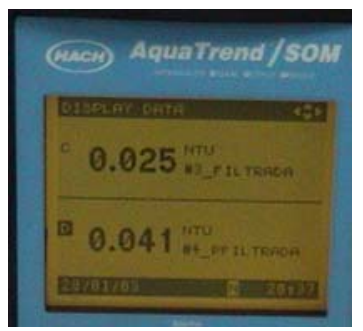

$\Delta \mathrm{t}=10 \mathrm{~h}$

(turbidez: $\mathrm{APF}=0,041 \mathrm{uT}$

e $\mathrm{AF}=0,025 \mathrm{uT}$ )

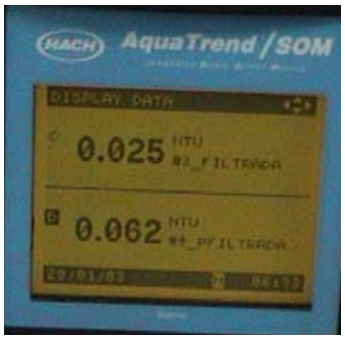

$\Delta \mathrm{t}=19,5$ h - Início

Transpasse

(turbidez: $\mathrm{APF}=0,062 \mathrm{uT}$

e $\mathrm{AF}=0,025 \mathrm{uT}$ )

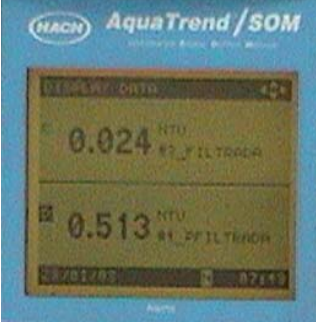

$\Delta \mathrm{t} \sim 21 \mathrm{~h}$

(turbidez: APF $=0,513 \mathrm{uT}$

e $\mathrm{AF}=0,024 \mathrm{uT}$ )

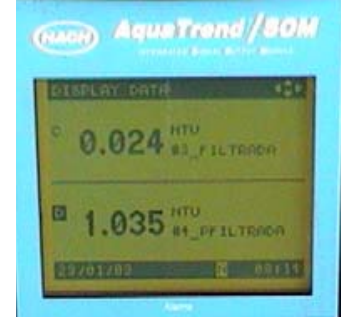

$\Delta \mathrm{t} \sim 22 \mathrm{~h}$

(turbidez: APF $=1,035 \mathrm{uT}$

e $\mathrm{AF}=0,024 \mathrm{uT}$ )

* APF: água pré-filtrada; AF: água filtrada

Figura 5.23- Turbidímetros de escoamento contínuo - Início do transpasse no FAAG após 19,5 h do início do ensaio 4

Nas Figuras C4.3 e C4.5 do Anexo C são apresentados os valores de turbidez ao longo do meio filtrante das câmaras FAAG-C1 e FAAG-C2, respectivamente, e nas Figuras C4.4 e C4.6, os valores de perda de carga obtidos nos piezômetros das câmaras FAAG-C1 e FAAG-C2, respectivamente. Os valores de turbidez apresentados nestas figuras foram lidos no TB. O comportamento das duas câmaras filtrantes foi praticamente o mesmo. A camada suporte e as subcamadas 1, 2 e 3 foram as responsáveis pela retenção de sólidos. Somente após 19 h do início do ensaio a subcamada 4 passou a reter pequena quantidade de sólidos e a subcamada 5 praticamente não reteve sólidos durante todo o ensaio. O aumento significativo da perda de carga devido a retenção de sólidos foi verificado em todas as subcamadas, com exceção da subcamada 5, que apresentou perda de carga inicial de 2,0 cm e final de $4,5 \mathrm{~cm}$.

A produção efetiva de água do ensaio 4 foi calculada com base no item 4.9 .4 a, e resultou valor de $478 \mathrm{~m}^{3} / \mathrm{m}^{2}$ e eficiência de $91 \%$ na produção de água filtrada, ou seja, com 
a diminuição das taxas de filtração de 240 para $180 \mathrm{~m}^{3} / \mathrm{m}^{2}$.d no FAAG e 360 para 300 $\mathrm{m}^{3} / \mathrm{m}^{2}$.d no FRD, houve aumento de $3 \%$ na eficiência.

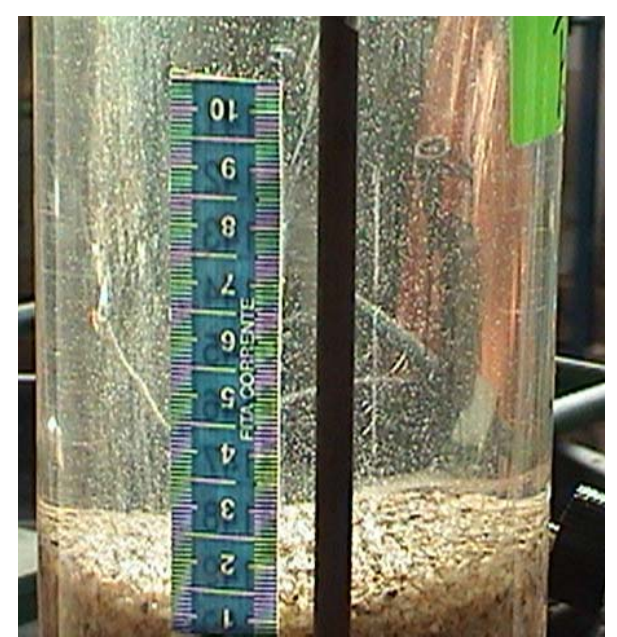

Figura 5.24 - Início do transpasse no FAAG-C1 após 19,5 h do início do ensaio 4

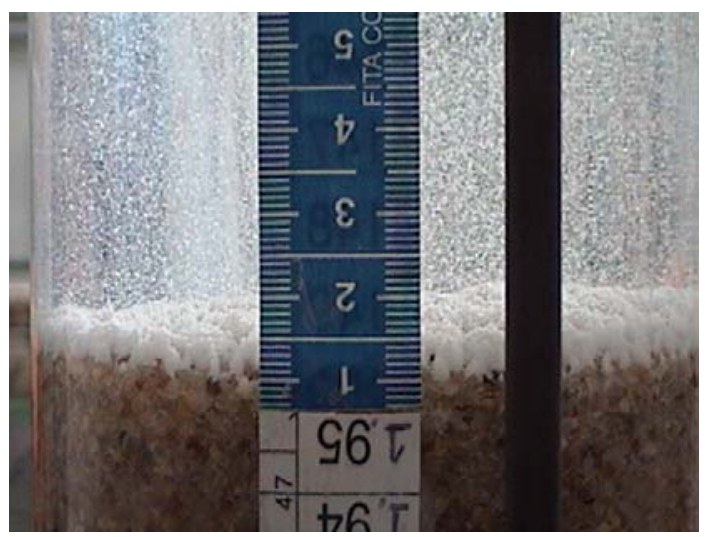

Figura 5.25 - Arraste de flocos e formação de manta no topo do meio filtrante do FAAG-C1 após 27 h do início do ensaio 4

\section{- Ensaio 5}

Este ensaio foi realizado no sistema 1 com a água tipo I e taxas médias de filtração de $180 \mathrm{~m}^{3} / \mathrm{m}^{2}$.d no FAAG e $305 \mathrm{~m}^{3} / \mathrm{m}^{2}$.d no FRD, com a execução de descargas de fundo intermediárias (DFIs) no FAAG a cada 6 h.

Na Figura C5.1 (Anexo C) é apresentada a variação da turbidez das águas de estudo, pré-filtrada e filtrada (valores obtidos no TEC) e a variação da vazão total afluente ao sistema ao longo do ensaio 5. O encerramento do ensaio se deu por perda de carga limite no FRD (1,80 m), após 61 h do início do ensaio. Não ocorreu o transpasse no FAAG, mas foi verificado o desprendimento de flocos durante $30 \mathrm{~min}$, causando elevados picos de turbidez na água pré-filtrada (pico máximo de 100 uT), após a execução das DFI (total de 9 DFIs). A perda de carga final no FAAG foi de aproximadamente 0,35 m, sendo que, com a execução das DFIs, houve recuperação significativa da carga hidráulica (Figura C5.2 - Anexo C). O FRD foi capaz de absorver os picos de turbidez da água pré-filtrada após a execução das DFIs, sendo que a turbidez da água filtrada se manteve praticamente constante $(0,04$ uT no TEC) durante todo o ensaio.

Nas Figuras C5.3 e C5.5 do Anexo C são apresentados os valores de turbidez ao longo do meio filtrante das câmaras FAAG-C1 e FAAG-C2, respectivamente, e nas Figuras C5.4 e C5.6, os valores de perda de carga obtidos nos piezômetros das câmaras FAAG-C1 e FAAG-C2, respectivamente. Os valores de turbidez apresentados nestas figuras foram lidos 
no TB. O comportamento das duas câmaras filtrantes foi praticamente o mesmo. Com a execução das DFIs, ocorreu a limpeza principalmente das camadas suporte e subcamadas 1 e 2 do FAAG e conseqüente redução nos valores de turbidez da água pré-filtrada nas amostras coletadas após as DFIs. Até 9 h do início do ensaio, a camada suporte e as subcamadas 1 e 2 foram as responsáveis pela retenção de grande parte dos sólidos. As subcamadas 3 e 4 retiveram parte dos sólidos somente no final do ensaio e a subcamada 5 praticamente não reteve sólidos neste ensaio.

A produção efetiva de água do ensaio 5 foi calculada com base no item 4.9 .4 c2, e resultou valor de $515 \mathrm{~m}^{3} / \mathrm{m}^{2}$ e eficiência de $96 \%$ na produção de água filtrada. Percebe-se que com a execução das DFIs houve aumento na eficiência de 5 \% em relação ao ensaio 4. As taxas de filtração utilizadas neste ensaio foram consideradas adequadas para o tratamento da água tipo I no sistema I.

\section{- Ensaio 6}

Com base nos resultados obtidos nos ensaios anteriores, foi realizado o ensaio 6 no sistema 1 com a água tipo II e taxas médias de filtração de $179 \mathrm{~m}^{3} / \mathrm{m}^{2}$.d no FAAG e 305 $\mathrm{m}^{3} / \mathrm{m}^{2} . \mathrm{d}$ no FRD.

Na Figura C6.1 do Anexo C é apresentada a variação da turbidez das águas préfiltrada e filtrada (valores obtidos no TEC) e a variação da vazão total afluente ao sistema ao longo do ensaio 6. A turbidez da água de estudo foi monitorada no TB, devido ao limite de 100 uT do TEC (Tabela C6.2 - Anexo C). O encerramento do ensaio se deu por ocorrência de transpasse no FRD após 20,5 h do início do ensaio. O transpasse no FAAG ocorreu após 10,8 h (Figura 5.26) e a perda de carga final foi de aproximadamente $0,90 \mathrm{~m}$. O FRD foi o responsável pela retenção significativa de sólidos nas últimas horas do ensaio e a perda de carga final neste filtro foi de 1,73 m (Figura C6.2 - Anexo C).

Nas Figuras 5.26 e 5.27 é visível o aumento do arraste de flocos na câmara 1 do FAAG no início do transpasse e após 4,2 h do início do mesmo. Na Figura 5.28 são mostradas as duas câmaras do FAAG após 13,5 h do início do ensaio 6 .

Nas Figuras C6.3 e C6.5 do Anexo C são apresentados os valores de turbidez ao longo do meio filtrante das câmaras FAAG-C1 e FAAG-C2, respectivamente, e nas Figuras C6.4 e C6.6, os valores de perda de carga obtidos nos piezômetros das câmaras FAAG-C1 e FAAG-C2, respectivamente. Os valores de turbidez apresentados nestas figuras foram lidos no TB. O comportamento das duas câmaras filtrantes foi praticamente o mesmo. No início do ensaio, a camada suporte e as subcamadas 1, 2 e 3 retiveram sólidos e a partir de aproximadamente $9 \mathrm{~h}$ de carreira, houve retenção de sólidos em todas as subcamadas do 
meio filtrante. Com 15 h de ensaio, a retenção de sólidos foi mínima em todas as subcamadas, evidenciando o alto grau de colmatação do meio filtrante.

A produção efetiva de água do ensaio 6 foi calculada com base no item 4.9.4 a, e resultou valor $458 \mathrm{~m}^{3} / \mathrm{m}^{2}$ e eficiência de $85 \%$ na produção de água filtrada, ou seja, com o aumento da turbidez da água de estudo de 100 uT (ensaio 4) para 300 uT (ensaio 6), houve redução de 6 \% na eficiência do sistema 1.

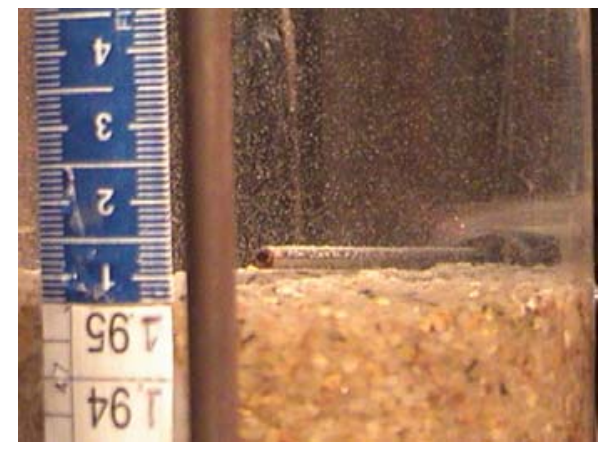

Figura 5.26 - Início do transpasse no FAAG-C1 após 10,8 h do início do ensaio 6 - Arraste gradual de flocos

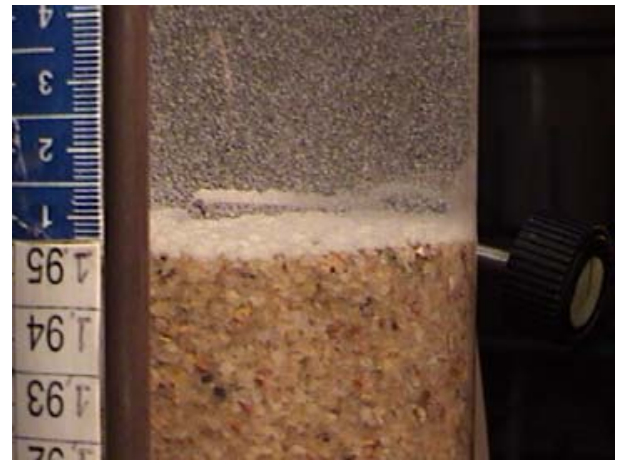

Figura 5.27 - Arraste de flocos e formação de manta no topo do meio filtrante do FAAG-C1 após 15 h do início do ensaio 6

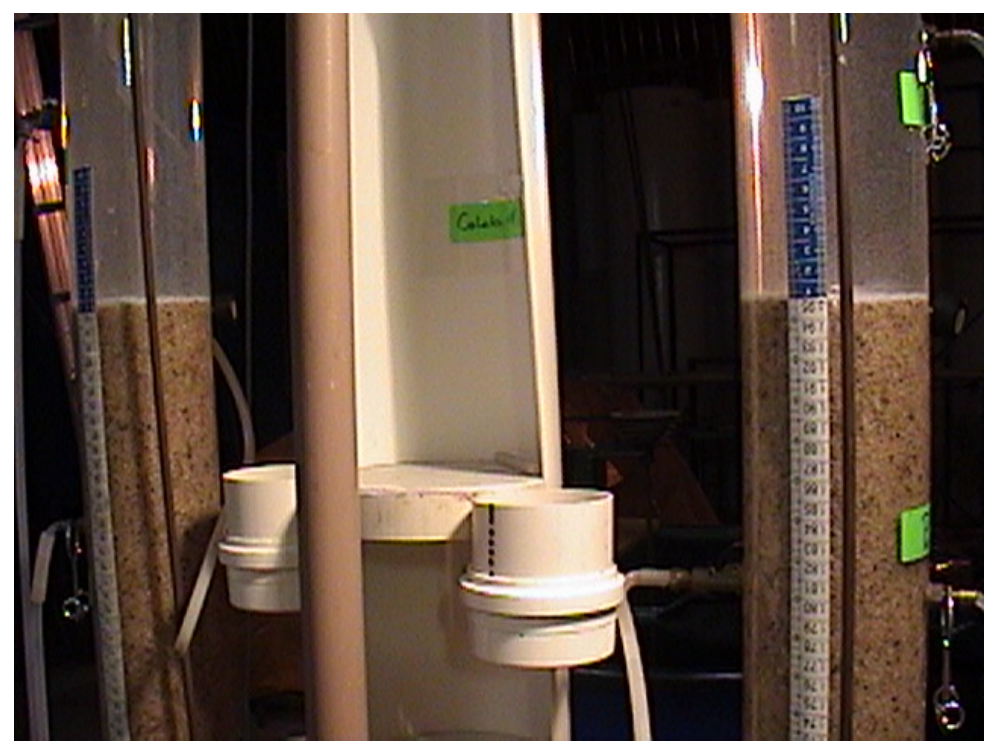

Figura 5.28 - Detalhe das câmaras 1 e 2 do FAAG após 13,5 h do início do ensaio 6

Na Figura 5.28 é mostrada uma foto da camada suporte do FAAG após 15 h de ensaio. Percebe-se que houve colmatação intensa da camada suporte, indicando a 
necessidade da execução das DFIs para melhorar a eficiência do sistema na clarificação da água tipo II.

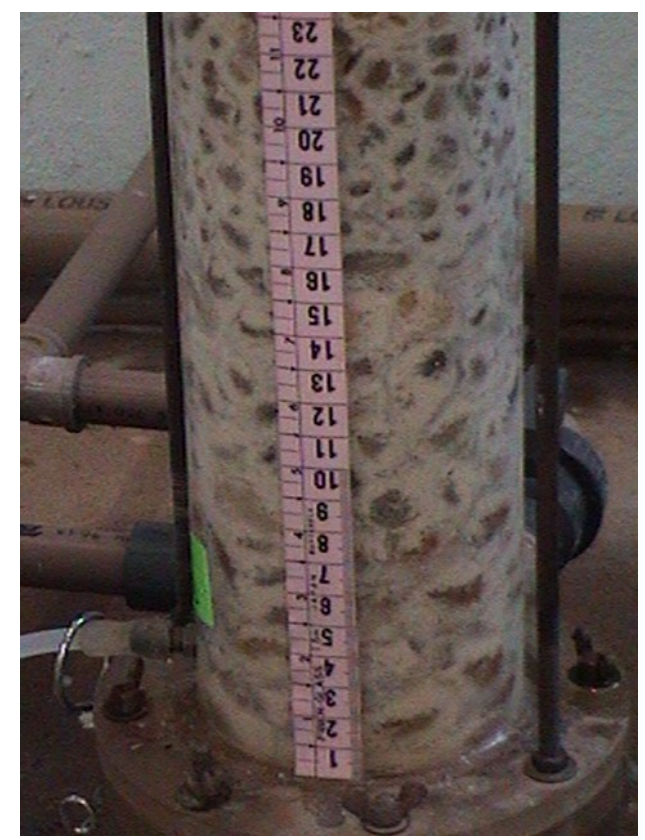

Figura 5.29 - Detalhe da camada suporte do FAAG-C2 após 15 h do início do ensaio 6

\section{- $\quad$ Ensaio 7}

Este ensaio foi realizado no sistema 1 com a água tipo II e taxas médias de filtração de $178 \mathrm{~m}^{3} / \mathrm{m}^{2}$.d no FAAG e $305 \mathrm{~m}^{3} / \mathrm{m}^{2}$.d no FRD, com a execução de descargas de fundo intermediárias (DFIs) no FAAG a cada 4,5 h.

Na Figura C7.1 (Anexo C) é apresentada a variação da turbidez das águas préfiltrada e filtrada (valores obtidos no TEC) e a variação da vazão total afluente ao sistema ao longo do ensaio 7. A turbidez da água de estudo foi monitorada no TB, devido ao limite de 100 uT do TEC (Tabela C7.2 - Anexo C). O encerramento do ensaio se deu por perda de carga limite no FRD (1,80 m), após 30 h do início do ensaio. O transpasse no FAAG ocorreu após aproximadamente $15 \mathrm{~h}$. Foi verificado o desprendimento de flocos durante $30 \mathrm{~min}$, causando elevados picos de turbidez na água pré-filtrada (pico máximo de 210 uT, medido no TB), após a execução de cada DFI (total de 6 DFIs). A perda de carga final no FAAG foi de aproximadamente $0,45 \mathrm{~m}$, sendo que, com a execução das DFIs, houve recuperação significativa da carga hidráulica (Figura C7.2 - Anexo C). O FRD foi capaz de absorver os picos de turbidez da água pré-filtrada após a execução das DFIs e após o transpasse no FAAG, sendo que a turbidez da água filtrada se manteve praticamente constante $(0,04 \mathrm{uT}$ no TEC) durante todo o ensaio. 
Nas Figuras C7.3 e C7.5 do Anexo C são apresentados os valores de turbidez ao longo do meio filtrante das câmaras FAAG-C1 e FAAG-C2, respectivamente, e nas Figuras C7.4 e C7.6, os valores de perda de carga obtidos nos piezômetros das câmaras FAAG-C1 e FAAG-C2, respectivamente. Os valores de turbidez apresentados nestas figuras foram lidos no TB. O comportamento das duas câmaras filtrantes foi praticamente o mesmo. Com a execução das DFIs, ocorreu a limpeza das camadas suporte e subcamadas 1 e 2 do FAAG e conseqüente redução nos valores de turbidez da água pré-filtrada nas amostras coletadas após as DFIs. No início do ensaio, a camada suporte e as subcamadas 1, 2 e 3 retiveram sólidos e a partir de aproximadamente $21 \mathrm{~h}$ de carreira, houve retenção de sólidos em todas as subcamadas do meio filtrante. Com 24 h de ensaio, a retenção de sólidos foi mínima em todas as subcamadas (alto grau de colmatação do meio filtrante), tendo sido constatado um aumento nos valores de turbidez da coleta C5 em relação a coleta C4, fato decorrente da formação de manto de flocos no topo da subcamada 5 - região de coleta C5.

A produção efetiva de água do ensaio 7 foi calculada com base no item 4.9 .4 c1, e resultou valor de $463 \mathrm{~m}^{3} / \mathrm{m}^{2}$ e eficiência de $87 \%$ na produção de água filtrada. Com a execução das DFIs houve um aumento de 2 \% na eficiência de produção de água filtrada. Os resultados indicaram que as taxas de filtração utilizadas não foram adequadas para o tratamento da água tipo II neste sistema de dupla filtração.

\section{- Ensaio 8}

Com base nos resultados obtidos nos ensaios 6 e 7, foi realizado o ensaio 8 no sistema 1 com a água tipo II e taxas médias de filtração de $126 \mathrm{~m}^{3} / \mathrm{m}^{2}$.d no FAAG e 179 $\mathrm{m}^{3} / \mathrm{m}^{2}$.d no FRD.

Na Figura C8.1 do Anexo C é apresentada a variação da turbidez das águas préfiltrada e filtrada (valores obtidos no TEC) e a variação da vazão total afluente ao sistema ao longo do ensaio 8. A turbidez da água de estudo foi monitorada no TB, devido ao limite de 100 uT do TEC (Tabela C8.2 - Anexo C). O transpasse no FAAG ocorreu após 14 h de ensaio, e devido a formação de manto de lodo no topo do meio filtrante do FAAG após $17 \mathrm{~h}$ (foto do manto na Figura 5.30), optou-se pelo encerramento do ensaio com 36 h. A formação do manto de lodo compromete os resultados, uma vez que este passa a ser uma barreira adicional para os sólidos que passam pelo meio filtrante do FAAG. Após 27 h, iniciou-se o desprendimento do manto de lodo, com aumento gradual da turbidez da água pré-filtrada, como pode ser visto na Figura C8.1 do Anexo C e fotos das Figuras 5.31 e 5.32.

Nas Figuras C8.3 e C8.5 do Anexo C são apresentados os valores de turbidez ao longo do meio filtrante das câmaras FAAG-C1 e FAAG-C2, respectivamente, e nas Figuras 
C8.4 e C8.6, os valores de perda de carga obtidos nos piezômetros das câmaras FAAG-C1 e FAAG-C2, respectivamente. Como mencionado anteriormente, a discussão destes dados e o cálculo da produção efetiva de água ficam comprometidos em decorrência da formação do manto de lodo no topo do FAAG com 17 h de ensaio. O fenômeno ocorrido se deu provavelmente porque a quantidade de sólidos na água de estudo era muito grande e a taxa de filtração de $126 \mathrm{~m}^{3} / \mathrm{m}^{2}$.d no FAAG era muito baixa, propiciando a formação do manto (para a taxa de $179 \mathrm{~m}^{3} / \mathrm{m}^{2}$.d - ensaio 6, não houve formação do manto). A execução das DFIs pode ser uma alternativa para este problema.

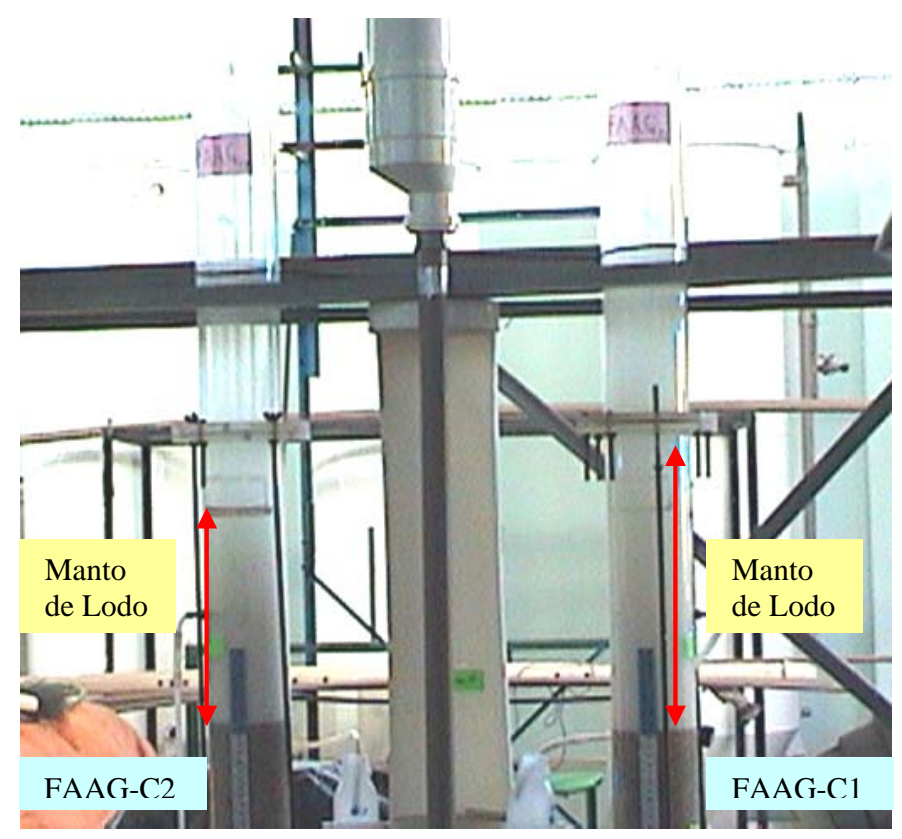

Figura 5.30 - Manto de lodo no FAAG após 22 h do início do ensaio 8

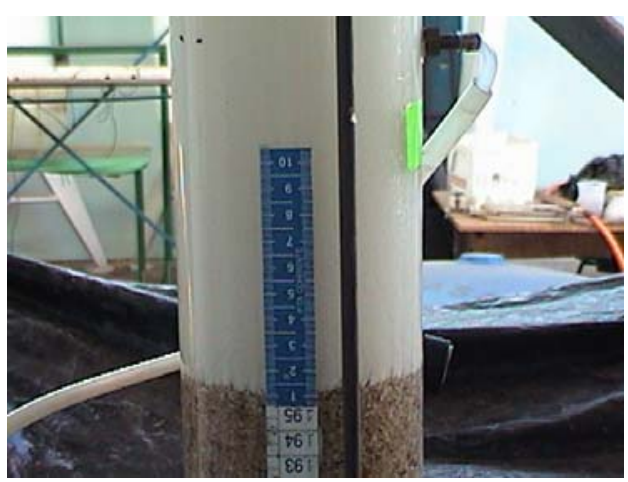

Figura 5.31 - Detalhe do manto de lodo no FAAG-C1 após 27 h do início do ensaio 8 


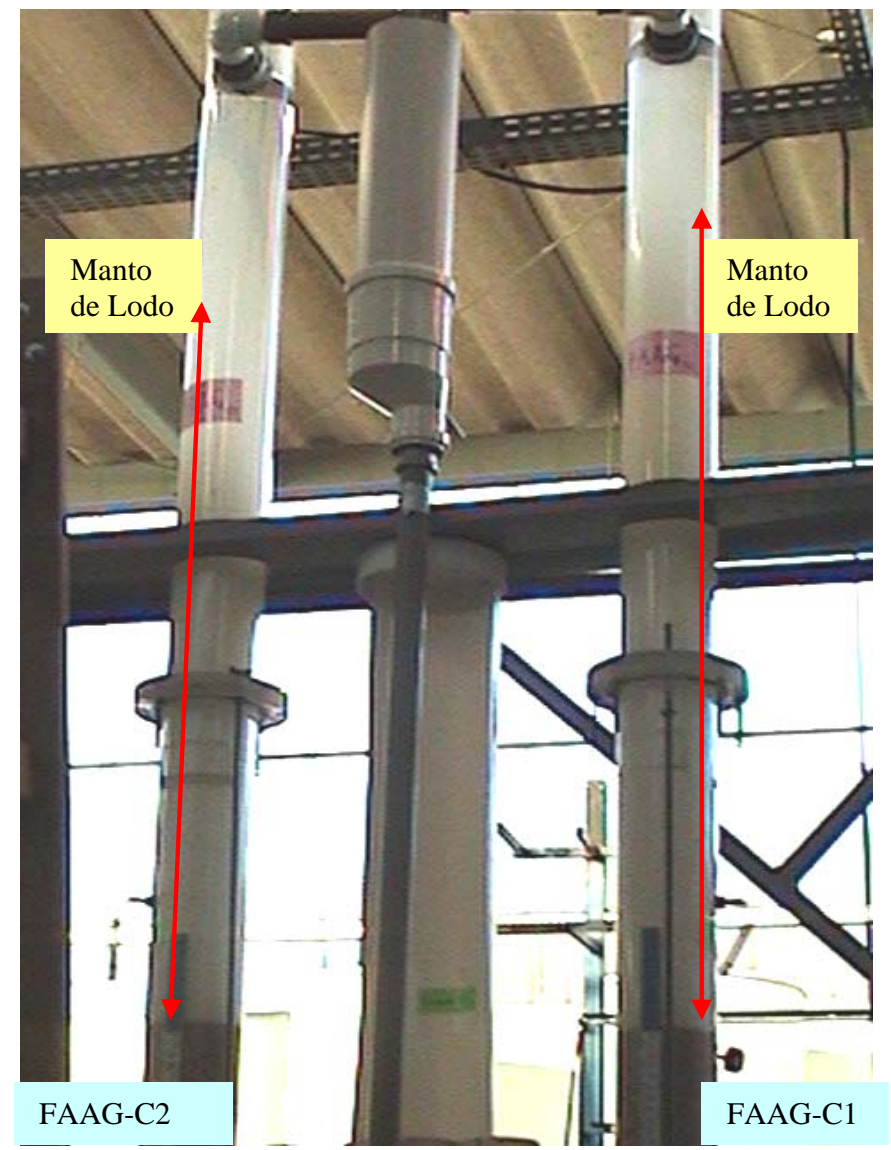

Figura 5.32 - Manto de lodo no FAAG após 27 h do início do ensaio 8

\section{- Ensaio 9}

Este ensaio foi realizado no sistema 1 com a água tipo II e taxas médias de filtração de $123 \mathrm{~m}^{3} / \mathrm{m}^{2}$.d no FAAG e $182 \mathrm{~m}^{3} / \mathrm{m}^{2}$.d no FRD, com a execução de descargas de fundo intermediárias (DFIs) no FAAG a cada 4,5 h.

Na Figura C9.1 (Anexo C) é apresentada a variação da turbidez das águas préfiltrada e filtrada (valores obtidos no TEC) e a variação da vazão total afluente ao sistema ao longo do ensaio 9. A turbidez da água de estudo foi monitorada no TB, devido ao limite de 100 uT do TEC (Tabela C9.2 - Anexo C). O encerramento do ensaio se deu por tempo limite, que neste caso foi de $36 \mathrm{~h}$. Foi verificado o desprendimento de flocos durante $10 \mathrm{~min}$, causando pequenos picos de turbidez na água pré-filtrada (pico máximo de 0,45 uT no TEC), após a execução de cada DFI (total de 7 DFIs). A perda de carga final no FAAG foi de aproximadamente $0,16 \mathrm{~m}$, sendo que, com a execução das DFIs, houve recuperação quase total da carga hidráulica (Figura C9.2 - Anexo C). A turbidez da água filtrada se manteve praticamente constante (0,04 uT no TEC) durante todo o ensaio e a perda de carga final no FRD foi de $0,67 \mathrm{~m}$. Apesar de ter sido interrompida com $36 \mathrm{~h}$, os resultados apresentados 
indicam que a carreira iria se prolongar por mais tempo antes da ocorrência do transpasse ou perda de carga limite no FRD.

Nas Figuras C9.3 e C9.5 do Anexo C são apresentados os valores de turbidez ao longo do meio filtrante das câmaras FAAG-C1 e FAAG-C2, respectivamente, e nas Figuras C9.4 e C9.6, os valores de perda de carga obtidos nos piezômetros das câmaras FAAG-C1 e FAAG-C2, respectivamente. Os valores de turbidez apresentados nestas figuras foram lidos no TB. O comportamento das duas câmaras filtrantes foi praticamente o mesmo. Com a execução das DFIs, ocorreu a limpeza das camadas suporte (detalhe na foto da Figura 5.33) e subcamada 1 do FAAG e conseqüente redução nos valores de turbidez da água pré-filtrada nas amostras coletadas após as DFIs. Foi constatado que as subcamadas 4 e 5 praticamente não retiveram sólidos neste ensaio.

A vantagem da execução das DFIs pode ser vista na Figura 5.34, onde foi constatado que não houve a formação do manto de lodo no topo do FAAG.
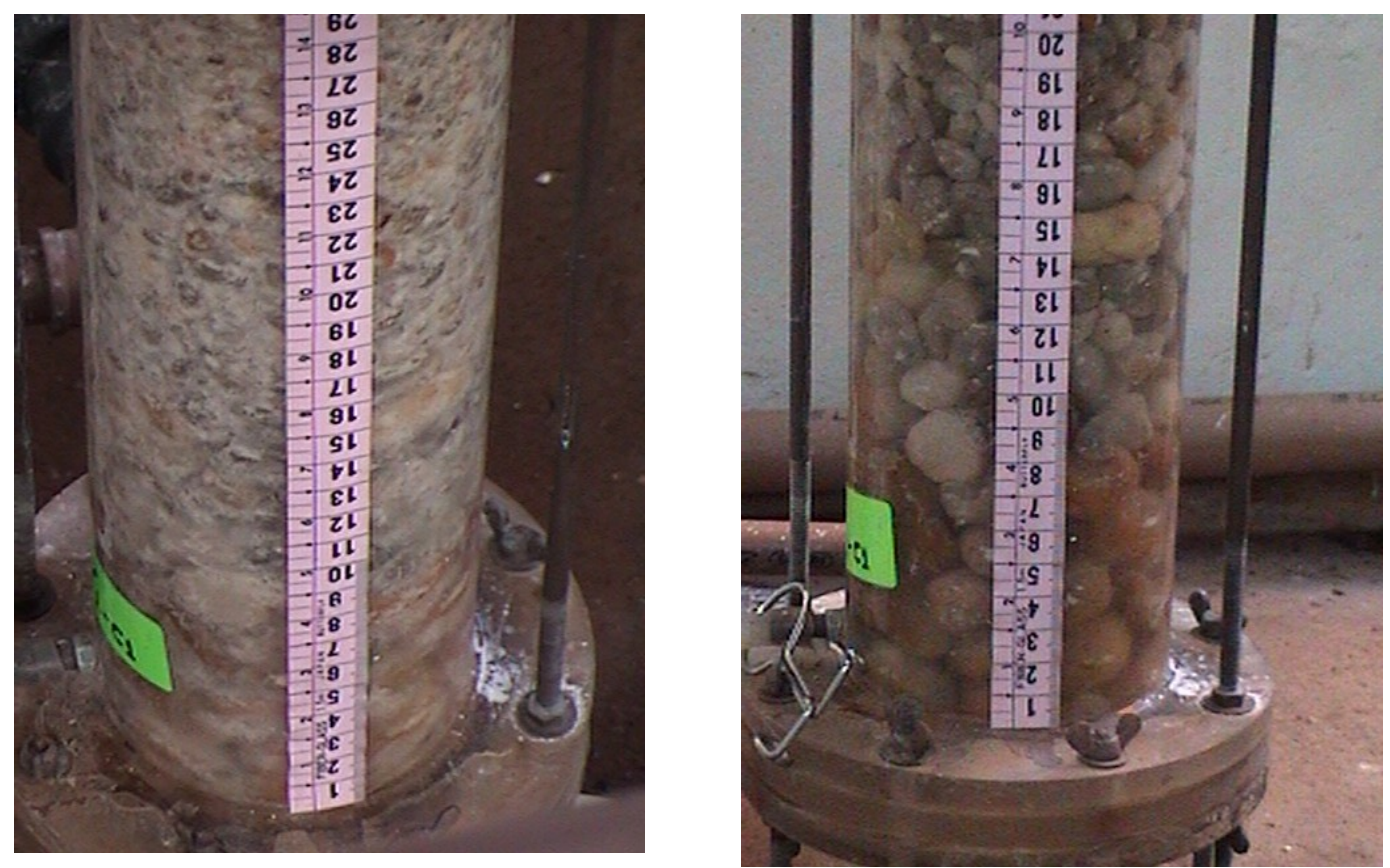

Figura 5.33 - Camada suporte do FAAG-C1 antes e depois da execução da 5ª DFI 

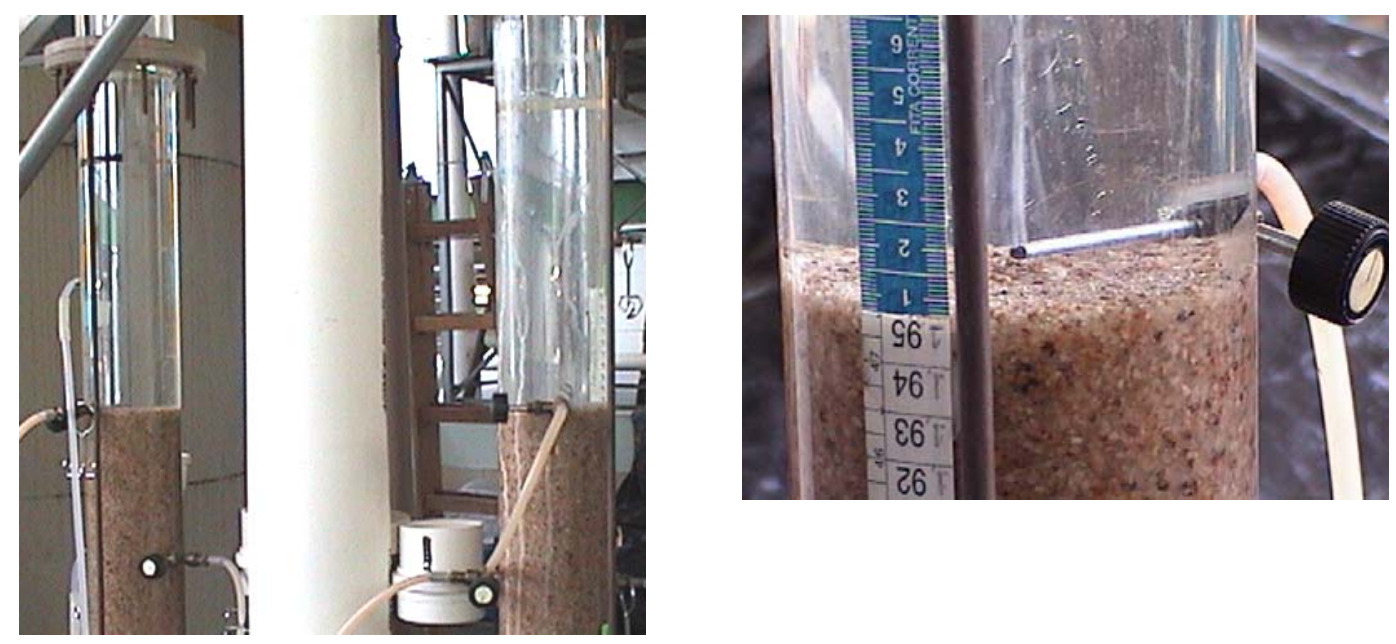

Figura 5.34 - Detalhe do FAAG após 25 h do início do ensaio 9

A produção efetiva de água do ensaio 9 não foi calculada em virtude do ensaio ter sido encerrado com 36 h e o tempo de referência para cálculo da produção efetiva ser de 72 h.

\section{- Ensaio 10}

O ensaio 10 foi realizado no sistema 2 com a água tipo I e taxas médias de filtração de $126 \mathrm{~m}^{3} / \mathrm{m}^{2}$.d no FAP e $193 \mathrm{~m}^{3} / \mathrm{m}^{2}$.d no FRD.

Na Figura C10.1 do Anexo C é apresentada a variação da turbidez das águas de estudo, pré-filtrada e filtrada (valores obtidos no TEC) e a variação da vazão total afluente ao sistema ao longo do ensaio 10. O transpasse no FAP ocorreu após 10 h de ensaio e houve a formação de manto de lodo no topo do meio filtrante do FAP após 21 h (foto do manto na Figura 5.35). Como mencionado anteriormente, a formação do manto de lodo compromete os resultados, uma vez que este passa a ser uma barreira adicional para os sólidos que passam pelo meio filtrante do FAP. Após 27,5 h, iniciou-se o desprendimento do manto de lodo, com aumento gradual da turbidez da água pré-filtrada, como pode ser visto na Figura C10.1 do Anexo C e foto da Figura 5.36. O ensaio foi encerrado com 34,5 h quando foi atingida a perda de carga limite no FRD.

Nas Figuras C10.3 e C10.5 do Anexo C são apresentados os valores de turbidez ao longo do meio filtrante das câmaras FAP-C1 e FAP-C2, respectivamente, e nas Figuras C10.4 e C10.6, os valores de perda de carga obtidos nos piezômetros das câmaras FAP-C1 e FAP-C2, respectivamente. Como mencionado anteriormente, a discussão destes dados e o cálculo da produção efetiva de água ficam comprometidos em decorrência da formação do manto de lodo no topo do FAP com 21 h de ensaio. O fenômeno ocorrido se deu provavelmente porque a quantidade de sólidos na água de estudo era grande e a taxa de 
filtração de $126 \mathrm{~m}^{3} / \mathrm{m}^{2}$.d no FAP era muito baixa, propiciando a formação do manto. A execução das DFIs é vital para o funcionamento adequado do sistema 2.

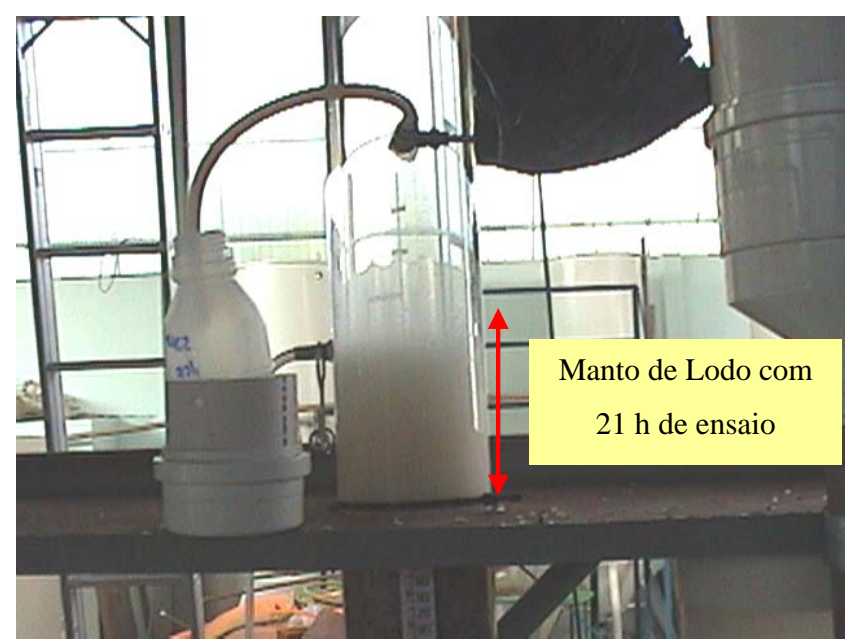

Figura 5.35- Manto de lodo no FAP-C1 após 21 h do início do ensaio 10

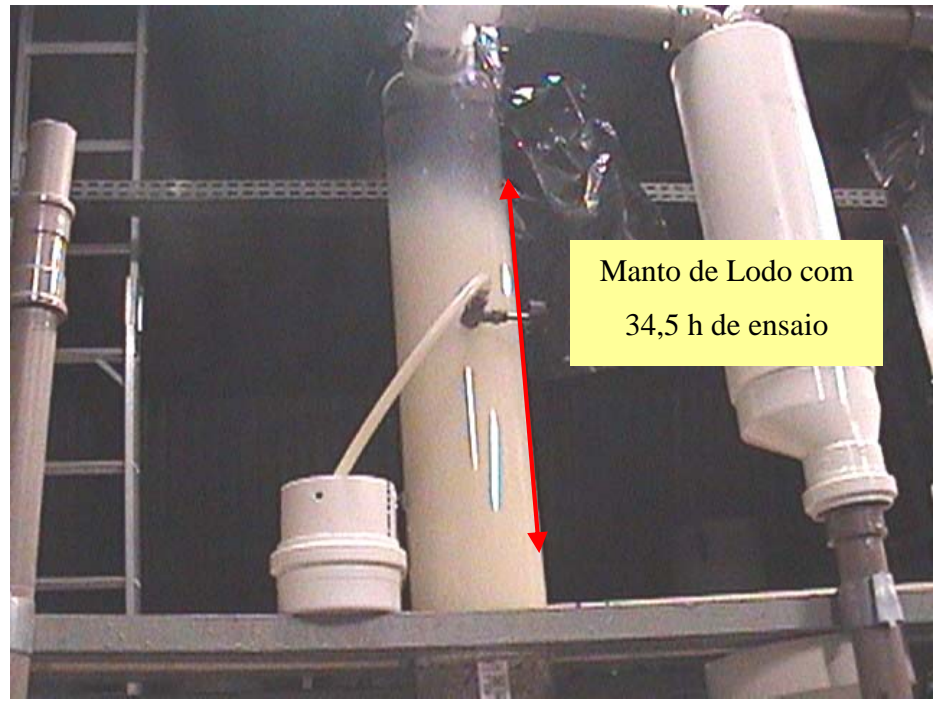

Figura 5.36- Manto de lodo no FAP-C1 no final do ensaio 10 (34,5 h)

A colmatação da subcamada 1 do FAP no decorrer do ensaio 10 pode ser evidenciada na Figura 5.37, onde são mostradas fotos desta subcamada com 2 h e 24 h de ensaio. Mais uma vez fica evidente a importância da execução das DFIs para melhora do funcionamento do sistema 2. 

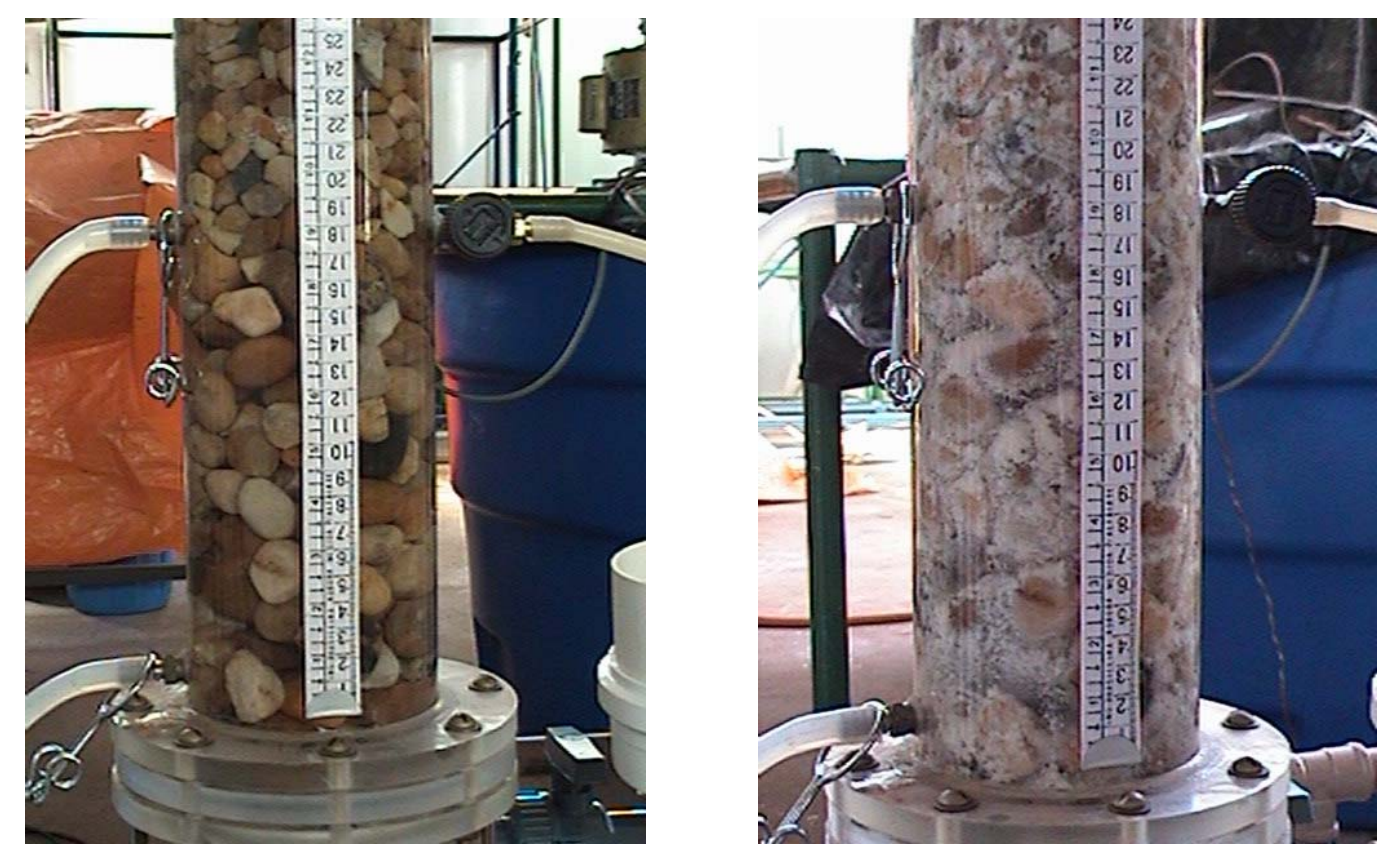

Figura 5.37 - Detalhe da subcamada 1 do FAP-C1 após 2 h e 24 h do início do ensaio 10

\section{- Ensaio 11}

Este ensaio foi realizado no sistema 2 com a água tipo I e taxas médias de filtração de $126 \mathrm{~m}^{3} / \mathrm{m}^{2}$.d no FAP e $193 \mathrm{~m}^{3} / \mathrm{m}^{2}$.d no FRD, com a execução de descargas de fundo intermediárias (DFIs) no FAP a cada 6 h.

Na Figura C11.1 (Anexo C) é apresentada a variação da turbidez das águas de estudo, pré-filtrada e filtrada (valores obtidos no TEC) e a variação da vazão total afluente ao sistema ao longo do ensaio 11 . O encerramento do ensaio se deu por perda de carga limite no FRD após 35,5 h. Foi verificado o desprendimento de flocos durante $30 \mathrm{~min}$, causando pequenos picos de turbidez na água pré-filtrada (pico máximo de 8 uT no TEC), após a execução de cada DFI (total de 5 DFIs). A perda de carga final no FAP foi de aproximadamente $0,06 \mathrm{~m}$, sendo que, com a execução das DFIs, houve recuperação quase total da carga hidráulica (Figura C11.2 - Anexo C). O FRD garantiu a produção de água filtrada com turbidez abaixo de 0,05 uT durante todo o ensaio.

Nas Figuras C11.3 e C11.5 do Anexo C são apresentados os valores de turbidez ao longo do meio filtrante das câmaras FAP-C1 e FAP-C2, respectivamente, e nas Figuras C11.4 e C11.6, os valores de perda de carga obtidos nos piezômetros das câmaras FAP-C1 e FAP-C2, respectivamente. Os valores de turbidez apresentados nestas figuras foram lidos no TB. O comportamento das duas câmaras filtrantes foi praticamente o mesmo. Com a execução das DFIs, ocorreu a limpeza das subcamadas 1 e 2 do FAP (detalhe nas fotos da 
Figura 5.38 e 5.39), e conseqüente redução nos valores de turbidez da água pré-filtrada nas amostras coletadas após as DFIs. Vale ressaltar que esta redução nos valores de turbidez não foi tão significativa quanto àquela evidenciada nos ensaios no sistema 1 em que foram executadas as DFIs. O aumento da perda de carga durante o ensaio foi relativamente pequeno em todas as subcamadas do FAP, apesar da grande quantidade de sólidos retida nas subcamadas 1 e 2, de maior granulometria. A perda de carga na subcamada 4, de menor granulometria, no início, durante e no final do ensaio representou mais de 50\% da perda de carga total no meio filtrante do FAP.

Não ocorreu a formação do manto de lodo no topo do FAP, comprovando a vantagem da execução das DFIs.

A produção efetiva de água do ensaio 11 foi calculada com base no item 4.9.4 c2, e resultou valor de $361 \mathrm{~m}^{3} / \mathrm{m}^{2}$ e eficiência de 96 \% na produção de água filtrada.
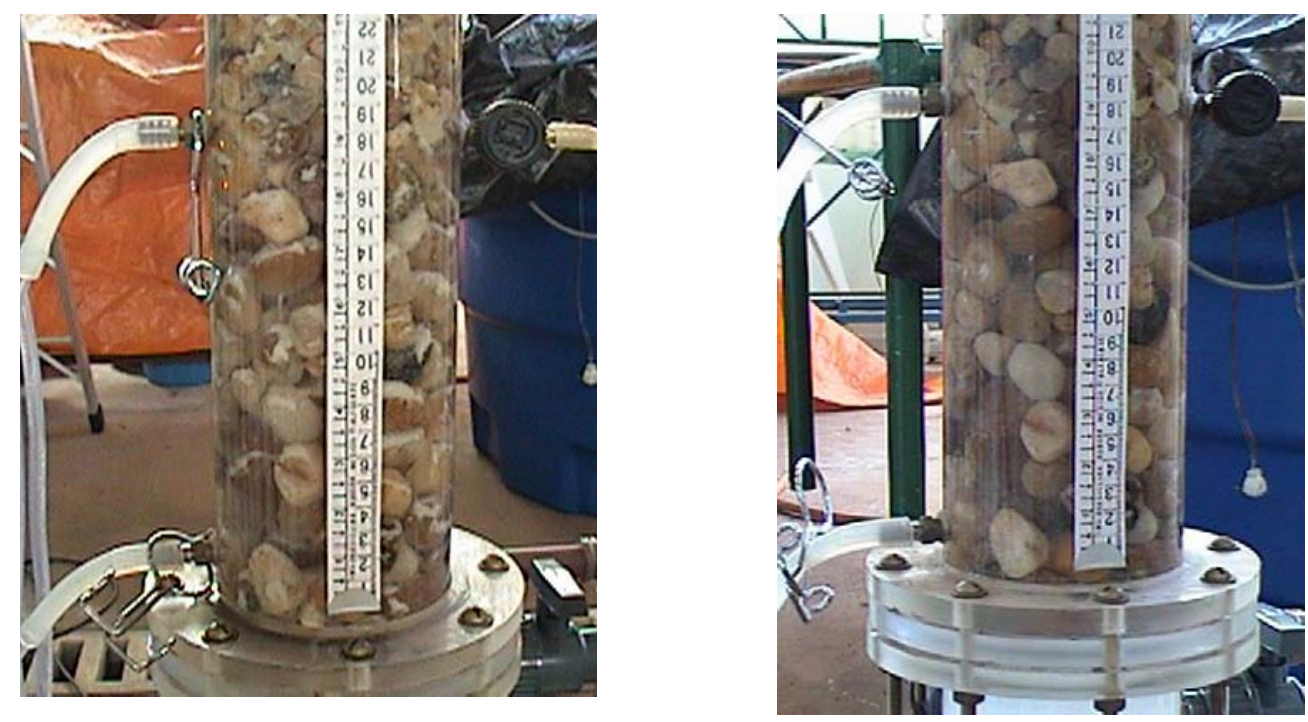

Figura 5.38 - Subcamada 1 do FAP-C1 antes e após a execução da $3^{\mathrm{a}}$ DFI 

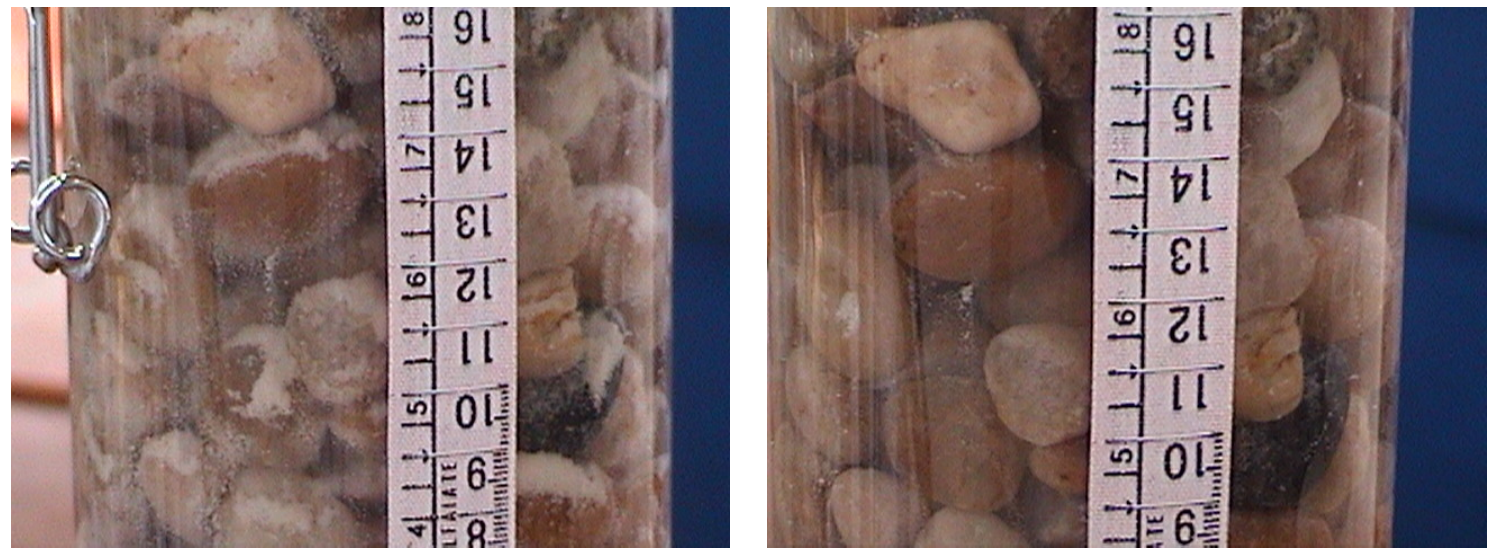

Figura 5.39 - Detalhe da subcamada 1 do FAP-C1 antes e após a execução da $3^{\mathrm{a}}$ DFI

\section{- Ensaio 12}

Com base nos resultados obtidos nos ensaios 10 e 11, foi realizado o ensaio 12 no sistema 2 com a água tipo I e taxas médias de filtração de $180 \mathrm{~m}^{3} / \mathrm{m}^{2}$.d no FAP e 293 $\mathrm{m}^{3} / \mathrm{m}^{2}$.d no FRD.

Na Figura C12.1 do Anexo C é apresentada a variação da turbidez das águas de estudo, pré-filtrada e filtrada (valores obtidos no TEC) e a variação da vazão total afluente ao sistema ao longo do ensaio 12. O encerramento do ensaio se deu por perda de carga limite no FRD após 13 h do início do ensaio. O transpasse no FAP ocorreu após 6 h (Figura 5.40) e a perda de carga final foi de aproximadamente $0,12 \mathrm{~m}$. O FRD foi o responsável pela retenção significativa de sólidos nas últimas horas do ensaio, com produção constante de água filtrada com turbidez menor que 0,05 uT (Figura C12.2 - Anexo C).

Comparando as Figuras 5.40 e 5.41, percebe-se visualmente o aumento do arraste de flocos na FAP no início do transpasse e após 4 h do início do mesmo.

Nas Figuras C12.3 e C12.5 do Anexo C são apresentados os valores de turbidez ao longo do meio filtrante das câmaras FAP-C1 e FAP-C2, respectivamente, e nas Figuras C12.4 e C12.6, os valores de perda de carga obtidos nos piezômetros das câmaras FAP-C1 e FAP-C2, respectivamente. Os valores de turbidez apresentados nestas figuras foram lidos no TB. O comportamento das duas câmaras filtrantes foi praticamente o mesmo. A retenção significativa de sólidos ocorreu em todas as subcamadas do FAP. O aumento da perda de carga foi relativamente pequeno nas subcamadas 1 e 2, de maior granulometria, apesar da grande quantidade de sólidos retida. Nas subcamadas 3 e 4, de menor granulometria, este crescimento foi mais significativo. 
A produção efetiva de água do ensaio 12 foi calculada com base no item 4.9 .4 c1, e resultou valor de $474 \mathrm{~m}^{3} / \mathrm{m}^{2}$ eficiência de $88 \%$ na produção de água filtrada. Os resultados indicam a necessidade de se trabalhar com taxa de filtração no FRD menor que $300 \mathrm{~m}^{3} / \mathrm{m}^{2} . d$.

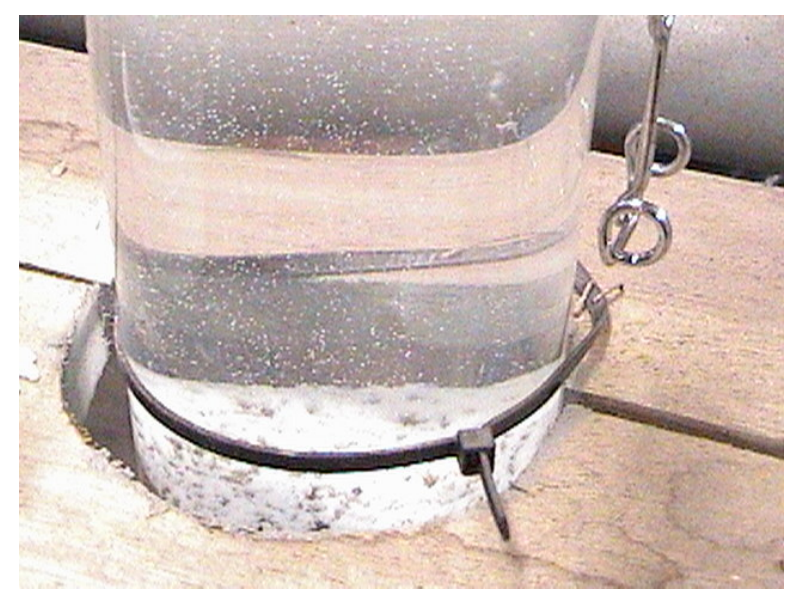

Figura 5.40 - Início do transpasse no FAP-C1 após 4 h do início do ensaio 12 de dupla filtração

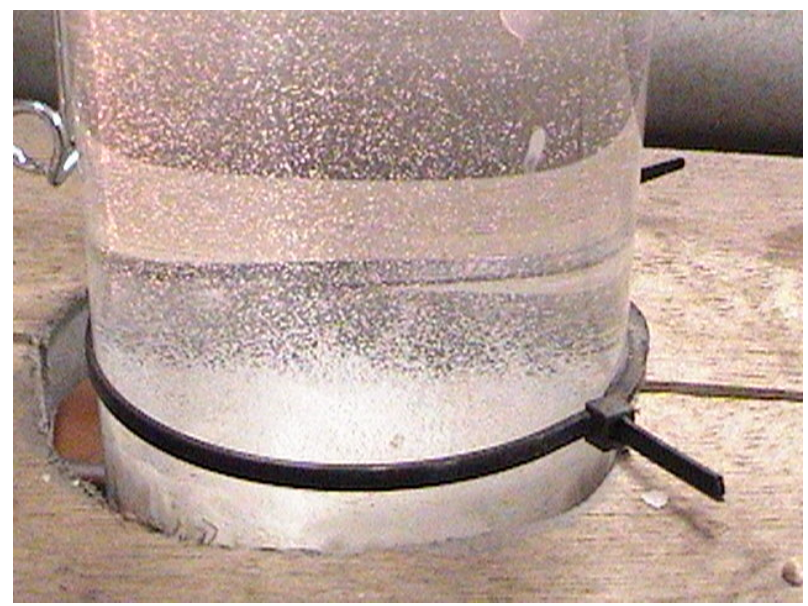

Figura 5.41 - Arraste de flocos no FAP-C1 após 10 h do início do ensaio 12 de dupla filtração

\section{- Ensaio 13}

Este ensaio foi realizado no sistema 2 com a água tipo I e taxas médias de filtração de $181 \mathrm{~m}^{3} / \mathrm{m}^{2}$.d no FAP e $293 \mathrm{~m}^{3} / \mathrm{m}^{2}$.d no FRD, com a execução de descargas de fundo intermediárias (DFIs) no FAP a cada 4,5 h.

Na Figura C13.1 (Anexo C) é apresentada a variação da turbidez das águas de estudo, pré-filtrada e filtrada (valores obtidos no TEC) e a variação da vazão total afluente ao sistema ao longo do ensaio 13. O encerramento do ensaio se deu por perda de carga limite no FRD após 17,5 h. Vale ressaltar que o valor da perda de carga final do FRD apresentada na 
Figura C13.2 é inferior a 1,80 m devido a correção da temperatura realizada, conforme descrito no item 4.9.1. O transpasse no FAP ocorreu com aproximadamente 6 h de ensaio, após a execução da primeira DFI. Foi verificado o desprendimento de flocos durante $30 \mathrm{~min}$, causando pequenos picos de turbidez na água pré-filtrada (pico máximo de 15 uT no TEC), após a execução de cada DFIs (total de 3 DFIs). A perda de carga final no FAP foi de aproximadamente $0,07 \mathrm{~m}$, sendo que com a execução das DFIs houve recuperação quase que total da carga hidráulica (Figura C13.2 - Anexo C). O FRD garantiu a produção de água filtrada com turbidez abaixo de 0,05 uT durante todo o ensaio.

Nas Figuras C13.3 e C13.5 do Anexo C são apresentados os valores de turbidez ao longo do meio filtrante das câmaras FAP-C1 e FAP-C2, respectivamente, e nas Figuras C13.4 e C13.6, os valores de perda de carga obtidos nos piezômetros das câmaras FAP-C1 e FAP-C2, respectivamente. Os valores de turbidez apresentados nestas figuras foram lidos no TB. O comportamento das duas câmaras filtrantes foi praticamente o mesmo. Com a execução das DFIs, ocorreu a limpeza das subcamadas 1 e 2 do FAP e conseqüente redução nos valores de turbidez da água pré-filtrada nas amostras coletadas após as DFIs. Novamente, a redução nos valores de turbidez não foi tão significativa quanto àquela evidenciada nos ensaios no sistema 1 em que foram executadas as DFIs. O aumento da perda de carga durante o ensaio foi relativamente pequeno em todas as subcamadas do FAP, apesar da grande quantidade de sólidos retida nas subcamadas 1 , 2 e 3 . A perda de carga na subcamada 4, de menor granulometria, no início, durante e no final do ensaio representou mais de $50 \%$ da perda de carga total no meio filtrante do FAP.

A produção efetiva de água do ensaio 13 foi calculada com base no item 4.9 .4 c1, e resultou valor de $478 \mathrm{~m}^{3} / \mathrm{m}^{2}$ eficiência de $88 \%$ na produção de água filtrada. Apesar do aumento na duração da carreira de filtração de 13 h para 17,5 h em relação ao ensaio 12, com a execução das DFIs não houve melhora na eficiência de produção de água filtrada. Isto ocorreu porque o volume de água gasto nas DFIs foi elevado em relação a duração da carreira, indicando a necessidade de se trabalhar com taxa de filtração no FRD menor que $300 \mathrm{~m}^{3} / \mathrm{m}^{2}$.d para que a evolução de perda de carga neste filtro seja menor ou diminuir o número de DFIs.

\section{- Ensaio 14}

Com base nos resultados obtidos nos ensaios 10 a 13, foi realizado o ensaio 14 no sistema 2 com a água tipo II e taxas médias de filtração de $178 \mathrm{~m}^{3} / \mathrm{m}^{2}$.d no FAP e 185 $\mathrm{m}^{3} / \mathrm{m}^{2}$.d no FRD. 
Na Figura C14.1 do Anexo C é apresentada a variação da turbidez das águas préfiltrada e filtrada (valores obtidos no TEC) e a variação da vazão total afluente ao sistema ao longo do ensaio 10. A turbidez da água de estudo foi monitorada no TB, devido ao limite de 100 uT do TEC (Tabela C14.2 - Anexo C). O transpasse no FAP ocorreu após 3 h de ensaio e houve a formação de manto de lodo no topo do meio filtrante do FAP após 8 h (foto do manto na Figura 5.42). Após 10 h, iniciou-se o desprendimento do manto de lodo, com aumento gradual da turbidez da água pré-filtrada, como pode ser visto na Figura C14.1 do Anexo C. O ensaio foi encerrado com 19,5 h devido ao transpasse no FRD.

Nas Figuras C14.3 e C14.5 do Anexo C são apresentados os valores de turbidez ao longo do meio filtrante das câmaras FAP-C1 e FAP-C2, respectivamente, e nas Figuras C14.4 e C14.6, os valores de perda de carga obtidos nos piezômetros das câmaras FAP-C1 e FAP-C2, respectivamente. Como mencionado anteriormente, a discussão destes dados e o cálculo da produção efetiva de água ficam comprometidos em decorrência da formação do manto de lodo no topo do FAP com $8 \mathrm{~h}$ de ensaio. O fenômeno ocorrido se deu provavelmente porque a quantidade de sólidos na água de estudo era grande e a taxa de filtração de $178 \mathrm{~m}^{3} / \mathrm{m}^{2}$.d no FAP era muito baixa, propiciando a formação do manto. Mais uma vez, fica claro que a execução das DFIs é vital para o funcionamento adequado do sistema 2.

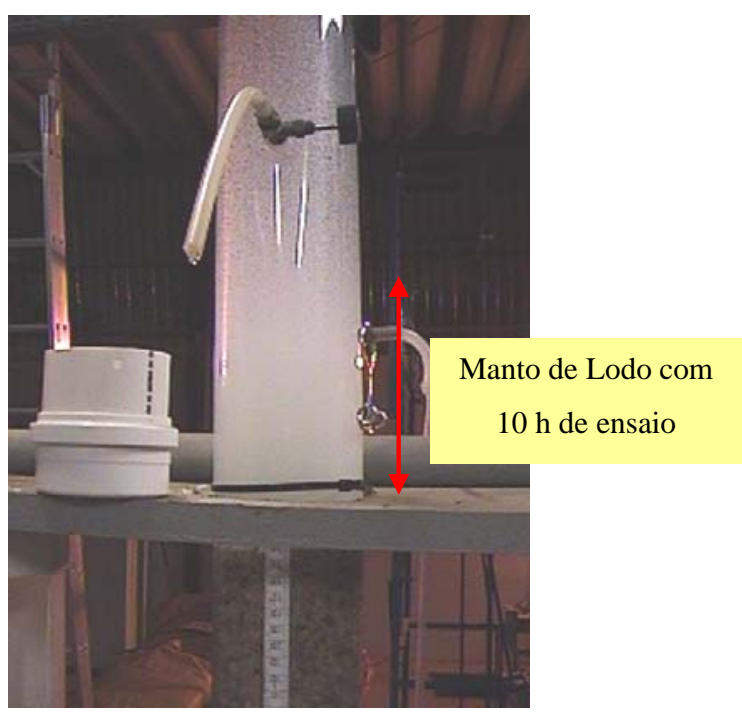

Figura 5.42 - Manto de lodo no FAP-C2 após 10 h do início do ensaio 14 de dupla filtração

\section{- Ensaio 15}

Este ensaio foi realizado no sistema 2 com a água tipo II e taxas médias de filtração de $178 \mathrm{~m}^{3} / \mathrm{m}^{2}$.d no FAP e $185 \mathrm{~m}^{3} / \mathrm{m}^{2}$.d no FRD, com a execução de descargas de fundo intermediárias (DFIs) no FAP a cada 4,5 h. 
Na Figura C15.1 (Anexo C) é apresentada a variação da turbidez das águas préfiltrada e filtrada (valores obtidos no TEC) e a variação da vazão total afluente ao sistema ao longo do ensaio 15. A turbidez da água de estudo foi monitorada no TB, devido ao limite de 100 uT do TEC (Tabela C15.2 - Anexo C). O encerramento do ensaio se deu por perda de carga limite no FRD após 31 h. Vale ressaltar que o valor da perda de carga final do FRD apresentada na Figura C15.2 é inferior a 1,80 m devido a correção da temperatura realizada, conforme descrito no item 4.9.1. Foi verificado o desprendimento de flocos durante $15 \mathrm{~min}$, causando pequenos picos de turbidez na água pré-filtrada (pico máximo de 25 uT no TEC), após a execução de cada DFIs (total de 6 DFIs). A perda de carga final no FAP foi de aproximadamente $0,07 \mathrm{~m}$, sendo que com a execução das DFIs houve recuperação quase que total da carga hidráulica (Figura C15.2 - Anexo C). O FRD garantiu a produção de água filtrada com turbidez abaixo de 0,05 uT durante todo o ensaio.

Nas Figuras C15.3 e C15.5 do Anexo C são apresentados os valores de turbidez ao longo do meio filtrante das câmaras FAP-C1 e FAP-C2, respectivamente, e nas Figuras C15.4 e C15.6, os valores de perda de carga obtidos nos piezômetros das câmaras FAP-C1 e FAP-C2, respectivamente. Os valores de turbidez apresentados nestas figuras foram lidos no TB. O comportamento das duas câmaras filtrantes foi praticamente o mesmo. Com a execução das DFIs, ocorreu a limpeza das subcamadas 1 e 2 do FAP e conseqüente redução nos valores de turbidez da água pré-filtrada nas amostras coletadas após as DFIs (Figura 5.43). Novamente, a redução nos valores de turbidez não foi tão significativa quanto àquela evidenciada nos ensaios no sistema 1 em que foram executadas as DFIs. A retenção de sólidos ocorreu em todo meio filtrante. $\mathrm{O}$ aumento da perda de carga durante o ensaio foi relativamente pequeno em todas as subcamadas do FAP, apesar da grande quantidade de sólidos retida nas subcamadas 1,2 e 3 . A perda de carga na subcamada 4, de menor granulometria, no início, durante e no final do ensaio representou mais de 50\% da perda de carga total no meio filtrante do FAP.

A produção efetiva de água do ensaio 15 foi calculada com base no item 4.9 .4 c2, e resultou valor de $512 \mathrm{~m}^{3} / \mathrm{m}^{2}$ eficiência de 96 \% na produção de água filtrada. 

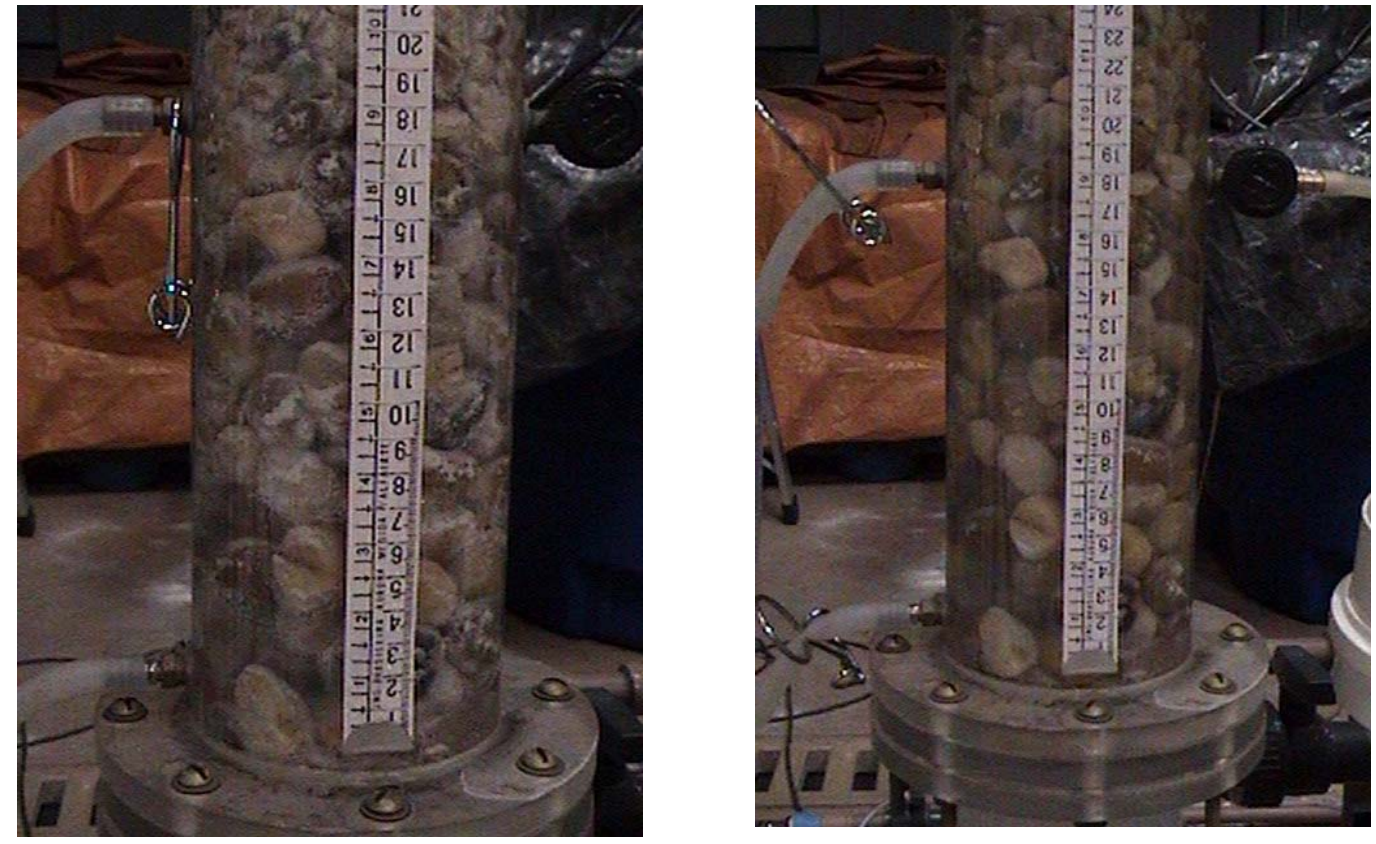

Figura 5.43 - Detalhe da subcamada 1 do FAP-C1 antes e após a execução da $5^{\mathrm{a}}$ DFI

Não ocorreu a formação do manto de lodo no topo do FAP, comprovando a vantagem da execução das DFIs.

Nas Tabelas 5.10 e 5.11 são apresentados os principais resultados dos ensaios de dupla filtração realizados nos sistemas 1 e 2, respectivamente. 
Tabela 5.10 - Resumo dos resultados dos ensaios de dupla filtração no sistema 1

\begin{tabular}{|c|c|c|c|c|c|c|c|}
\hline Ensaio & $\begin{array}{l}\text { TF-FAAG } \\
\left(\mathrm{m}^{3} / \mathrm{m}^{2} \cdot \mathrm{d}\right)\end{array}$ & $\begin{array}{l}\text { TF-FRD } \\
\left(\mathrm{m}^{3} / \mathrm{m}^{2} \cdot \mathrm{d}\right)\end{array}$ & $\begin{array}{l}\text { Execução } \\
\text { de DFIs }\end{array}$ & $\begin{array}{l}\text { Duração } \\
\text { (h) }\end{array}$ & $\begin{array}{c}\mathrm{PE} \\
\left(\mathrm{m}^{3} / \mathrm{m}^{2}\right. \\
\mathrm{FA})\end{array}$ & E (\%) & Características e Fenômenos observados \\
\hline $\begin{array}{l}1 \\
\text { Água } \\
\text { tipo I }\end{array}$ & 120 & 187 & Não & 72 & 339 & 94 & $\begin{array}{l}\text { Encerramento por tempo limite; Transpasse FAAG após 50,5 h; } \Delta \text { PFAAG = 1,20 m, retenção de } \\
\text { sólidos nas camada suporte e subcamadas } 1 \text { e } 2 ; \Delta \text { PFRD = 1,00 m, turbidez água filtrada }<0,04 \text { uT. }\end{array}$ \\
\hline $\begin{array}{l}2 \\
\text { Água } \\
\text { tipo I }\end{array}$ & 236 & 362 & Não & 19,5 & 622 & 88 & $\begin{array}{l}\text { Encerramento por transpasse FRD; Transpasse FAAG após } 11 \mathrm{~h} \text { (colmatação elevada); } \Delta \text { PFAAG }= \\
0,60 \mathrm{~m} ; \Delta \mathrm{PFRD}=1,55 \mathrm{~m} \text {, turbidez água filtrada }<0,10 \mathrm{uT} .\end{array}$ \\
\hline $\begin{array}{l}3 \\
\text { Água } \\
\text { tipo I }\end{array}$ & 239 & 362 & $\begin{array}{l}\text { a cada } \\
6 \mathrm{~h}\end{array}$ & 33 & 654 & 91 & $\begin{array}{l}\text { Encerramento por perda de carga limite FRD; Transpasse FAAG após } 18 \mathrm{~h} ; \Delta \mathrm{PFAAG}=0,30 \mathrm{~m} \text {, } \\
\text { DFIs: recuperação parcial da carga hidráulica e limpeza das subcamadas; } \Delta \mathrm{PFRD}=1,80 \mathrm{~m} \text {, turbidez } \\
\text { água filttrada }<0,07 \mathrm{uT} \text {. }\end{array}$ \\
\hline $\begin{array}{l}4 \\
\text { Água } \\
\text { tipo I }\end{array}$ & 176 & 305 & Não & 33,5 & 478 & 91 & $\begin{array}{l}\text { Encerramento por transpasse FRD; Transpasse FAAG após 19,5 h; } \Delta \text { PFAAG = 0,68 m, retenção de } \\
\text { sólidos em todo o meio filtrante; } \Delta \text { PFRD }=1,35 \mathrm{~m} .\end{array}$ \\
\hline $\begin{array}{l}5 \\
\text { Água } \\
\text { tipo I }\end{array}$ & 180 & 305 & $\begin{array}{l}\text { a cada } \\
6 \mathrm{~h}\end{array}$ & 61 & 515 & 96 & $\begin{array}{l}\text { Encerramento por perda de carga limite FRD; Não houve transpasse FAAG; DFIs: recuperação } \\
\text { parcial da carga hidráulica e limpeza das subcamadas; } \Delta \text { PFRD = } 1,80 \mathrm{~m} \text {, turbidez água filtrada }<0,04 \\
\text { uT. }\end{array}$ \\
\hline $\begin{array}{l}6 \\
\text { Água } \\
\text { tipo II }\end{array}$ & 179 & 305 & Não & 20,5 & 458 & 85 & $\begin{array}{l}\text { Encerramento por transpasse FRD; Transpasse FAAG após 10,8 h (colmatação elevada); } \triangle \text { PFAAG = } \\
\text { 0,90 m, retenção de sólidos nas primeiras subcamadas; } \Delta \text { PFRD = 1,73 m. }\end{array}$ \\
\hline $\begin{array}{l}7 \\
\text { Água } \\
\text { tipo II }\end{array}$ & 178 & 305 & $\begin{array}{l}\text { a cada } \\
6 \mathrm{~h}\end{array}$ & 30 & 463 & 87 & $\begin{array}{l}\text { Encerramento por perda de carga limite FRD; Transpasse FAAG após } 15 \mathrm{~h}, \Delta \mathrm{PFAAG}=0,45 \mathrm{~m} \text {, } \\
\text { DFIs: recuperação parcial da carga hidráulica e limpeza das subcamadas; } \Delta \mathrm{PFRD}=1,80 \mathrm{~m} \text {, turbidez } \\
\text { água filtrada }<0,04 \mathrm{uT} \text {. }\end{array}$ \\
\hline $\begin{array}{l}8 \\
\text { Água } \\
\text { tipo II }\end{array}$ & 126 & 179 & Não & 36 & $*$ & $*$ & $\begin{array}{l}\text { Formação do Manto de Lodo no topo do FAAG após } 17 \text { h; Transpasse FAAG após 14; Após } 27 \text { h } \\
\text { iniciou-se o desprendimento do manto de lodo. }\end{array}$ \\
\hline $\begin{array}{l}9 \\
\text { Água } \\
\text { tipo II }\end{array}$ & 123 & 182 & $\begin{array}{l}\text { a cada } \\
4,5 \mathrm{~h}\end{array}$ & 36 & $* *$ & $* *$ & $\begin{array}{l}\text { Encerramento por tempo limite; Transpasse FAAG após } 15 \text { h, } \triangle \mathrm{PFAAG}=0,16, \mathrm{~m} \text {, DFIs: } \\
\text { recuperação parcial da carga hidráulica e limpeza das subcamadas; } \Delta \mathrm{PFRD}=0.67 \mathrm{~m} \text {, turbidez água } \\
\text { filtrada }<0,04 \text { uT. }\end{array}$ \\
\hline
\end{tabular}

$\triangle$ PFAAG: perda de carga final no FAAG (valor médio das duas câmaras); $\triangle$ PFRD: perda de carga final no FRD. 
Tabela 5.11 - Resumo dos resultados dos ensaios de dupla filtração no sistema 2

\begin{tabular}{|c|c|c|c|c|c|c|c|}
\hline Ensaio & $\begin{array}{l}\text { TF-FAP } \\
\left(\mathrm{m}^{3} / \mathrm{m}^{2} \cdot \mathrm{d}\right)\end{array}$ & $\begin{array}{l}\text { TF-FRD } \\
\left(\mathrm{m}^{3} / \mathrm{m}^{2} \cdot \mathrm{d}\right)\end{array}$ & $\begin{array}{l}\text { Execução } \\
\text { de DFIs }\end{array}$ & $\begin{array}{l}\text { Duração } \\
\text { (h) }\end{array}$ & $\begin{array}{c}\mathrm{PE} \\
\left(\mathrm{m}^{3} / \mathrm{m}^{2}\right. \\
\mathrm{FA})\end{array}$ & $\mathrm{E}(\%)$ & Características e Fenômenos observados \\
\hline $\begin{array}{l}10 \\
\text { Água } \\
\text { tipo I }\end{array}$ & 126 & 193 & Não & 36 & * & $*$ & $\begin{array}{c}\text { Formação do Manto de Lodo no topo do FAP após } 17 \text { h; Transpasse FAP após } 14 \text { h; Após } 27 \text { h } \\
\text { iniciou-se o desprendimento do manto de lodo. }\end{array}$ \\
\hline $\begin{array}{l}11 \\
\text { Água } \\
\text { tipo I }\end{array}$ & 126 & 193 & $\begin{array}{l}\text { a cada } \\
6 \mathrm{~h}\end{array}$ & 35,5 & 361 & 96 & $\begin{array}{c}\text { Encerramento por perda de carga limite FRD; } \triangle \mathrm{PFAP}=0,06 \mathrm{~m} \text {, DFIs: recuperação quase total da } \\
\text { carga hidráulica e limpeza das subcamadas; } \Delta \mathrm{PFRD}=1,80 \mathrm{~m} \text {, turbidez pré-filtrada }<0,6 \mathrm{uT} \text { e } \\
\text { turbidez da água filtrada }<0,05 \mathrm{uT} \text {. }\end{array}$ \\
\hline $\begin{array}{l}12 \\
\text { Água } \\
\text { tipo I }\end{array}$ & 180 & 293 & Não & 13 & 474 & 88 & $\begin{array}{l}\text { Encerramento por perda de carga limite FRD; Transpasse FAP após } 6 \mathrm{~h} ; \Delta \mathrm{PFAP}=0,12 \mathrm{~m} \text {, } \\
\qquad \Delta \mathrm{PFRD}=1,80 \mathrm{~m} \text {, turbidez da água filtrada }<0,05 \mathrm{uT} .\end{array}$ \\
\hline $\begin{array}{l}13 \\
\text { Água } \\
\text { tipo I }\end{array}$ & 181 & 293 & $\begin{array}{l}\text { a cada } \\
4,5 \mathrm{~h}\end{array}$ & 17,5 & 478 & 88 & $\begin{array}{c}\text { Encerramento por perda de carga limite FRD; Transpasse FAP após } 6 \mathrm{~h} ; \Delta \mathrm{PFAP}=0,07 \mathrm{~m}, \Delta \mathrm{PFRD} \\
=1,80 \mathrm{~m} \text {, turbidez da água filtrada }<0,05 \mathrm{uT} .\end{array}$ \\
\hline $\begin{array}{l}14 \\
\text { Água } \\
\text { tipo II }\end{array}$ & 178 & 185 & Não & 36 & $*$ & $*$ & Formação do Manto de Lodo no topo do FAP após 8 h; Transpasse FAP após 3 h. \\
\hline $\begin{array}{l}15 \\
\text { Água } \\
\text { tipo II }\end{array}$ & 178 & 185 & $\begin{array}{l}\text { a cada } \\
4,5 \mathrm{~h}\end{array}$ & 31 & 512 & 96 & $\begin{array}{c}\text { Encerramento por perda de carga limite FRD; } \Delta \mathrm{PFAP}=0,07 \mathrm{~m} \text {, DFIs: recuperação quase total da } \\
\text { carga hidráulica e limpeza das subcamadas } 1 \text { e } 2 ; \Delta \mathrm{PFRD}=1,80 \mathrm{~m} \text {, } \\
\text { turbidez da água filtrada }<0,05 \mathrm{uT} .\end{array}$ \\
\hline
\end{tabular}

* ensaio em que houve a formação do manto de lodo no topo do meio filtrante do FAP

$\triangle$ PFAP: perda de carga final no FAP (valor médio das duas câmaras); $\triangle$ PFRD: perda de carga final no FRD. 


\section{- Considerações sobre a lavagem dos filtros}

No filtro ascendente de areia grossa, a limpeza foi efetuada primeiramente com execução de descarga de fundo com esvaziamento total do filtro (registros de descarga totalmente abertos resultando taxa da ordem de $960 \mathrm{~m}^{3} / \mathrm{m}^{2}$.d e duração de 1,5 min), seguida da introdução simultânea de ar com taxa de aplicação da ordem de 5 a 7 L/s.m² e água com velocidade ascensional da ordem de $0,5 \mathrm{~m} / \mathrm{min}$ durante $5 \mathrm{~min}$; a operação foi finalizada com aplicação de água somente com velocidade ascensional de 1,5 m/min por $10 \mathrm{~min}$.

Como a perda de carga limite no FAAG não foi atingida em nenhum dos ensaios realizados no sistema 1, a lavagem do FAAG durante o ensaio não foi necessária, sendo feita no término da carreira conforme procedimento descrito no anteriormente.

O detalhe do topo do FAAG durante a lavagem com ar e água simultânea pode ser visto na Figura 5.44, onde foi verificado que as taxas empregadas não ocasionaram a mistura dos grãos das subcamadas.

Na Figura 5.45 é mostrada a expansão do meio filtrante do FAAG (em torno de 10 \%) com a lavagem somente com água.

A otimização da lavagem do sistema FAAG-FRD não foi o objetivo deste trabalho, mas o método e as taxas utilizados, visualmente parecem não ter garantido a lavagem eficiente do FAAG, com produção de efluente menor que 5 uT, sendo recomendado que seja feito um estudo com diferentes métodos e taxas de lavagem para esclarecimento deste assunto. 

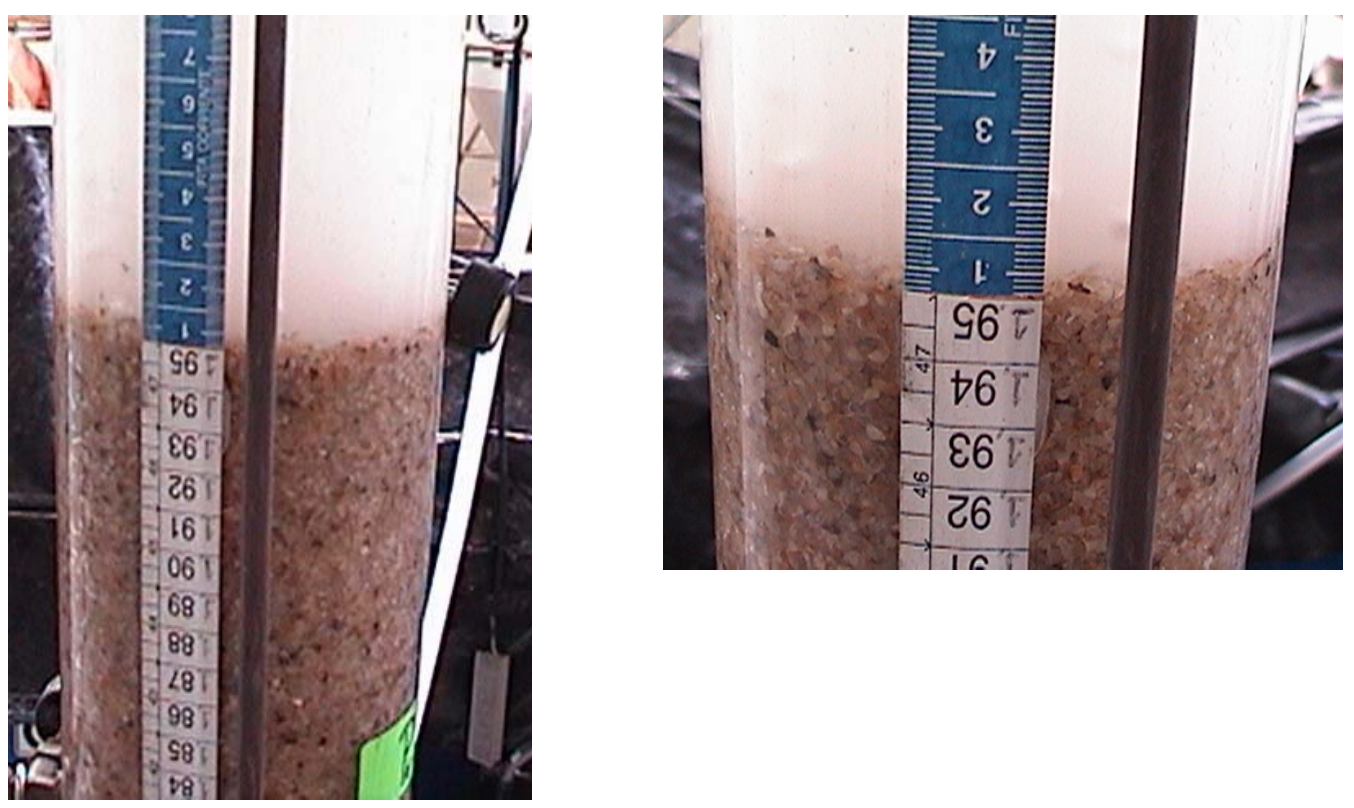

Figura 5.44 - Lavagem simultânea com ar e água no FAAG-C1

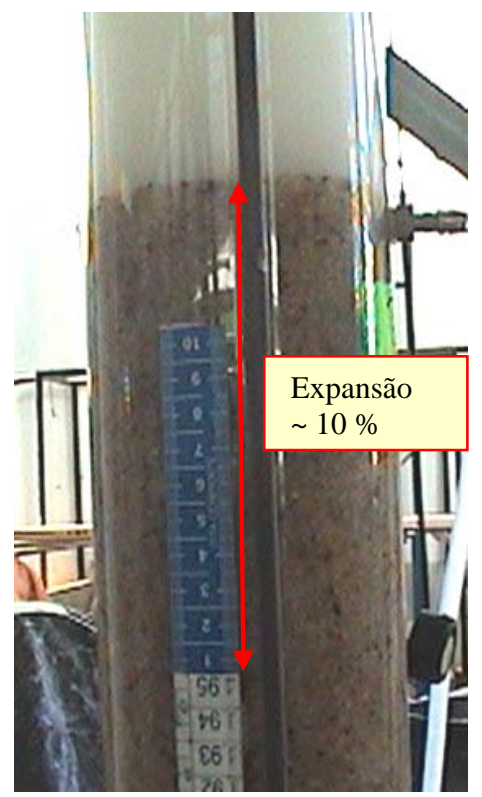

Figura 5.45 - Lavagem com água FAAG-C1

No filtro ascendente de pedregulho, a limpeza foi efetuada primeiramente com execução de descarga de fundo com esvaziamento total do filtro (registros de descarga totalmente abertos resultando taxa da ordem de $960 \mathrm{~m}^{3} / \mathrm{m}^{2}$.d e duração de $1,5 \mathrm{~min}$ ) - Figura 5.46 , seguida da introdução simultânea de ar com taxa de aplicação da ordem de 5 a 7 $\mathrm{L} / \mathrm{s} . \mathrm{m}^{2}$ e água com velocidade ascensional da ordem de $0,5 \mathrm{~m} / \mathrm{min}$ durante $3 \mathrm{~min}$; a operação foi finalizada com aplicação de água com velocidade ascensional de 1,5 m/min por $5 \mathrm{~min}$. 
Como a perda de carga limite no FAP não foi atingida em nenhum dos ensaios realizados no sistema 2, a lavagem deste filtro durante o ensaio não foi necessária, sendo feita no término da carreira conforme procedimento descrito no anteriormente.
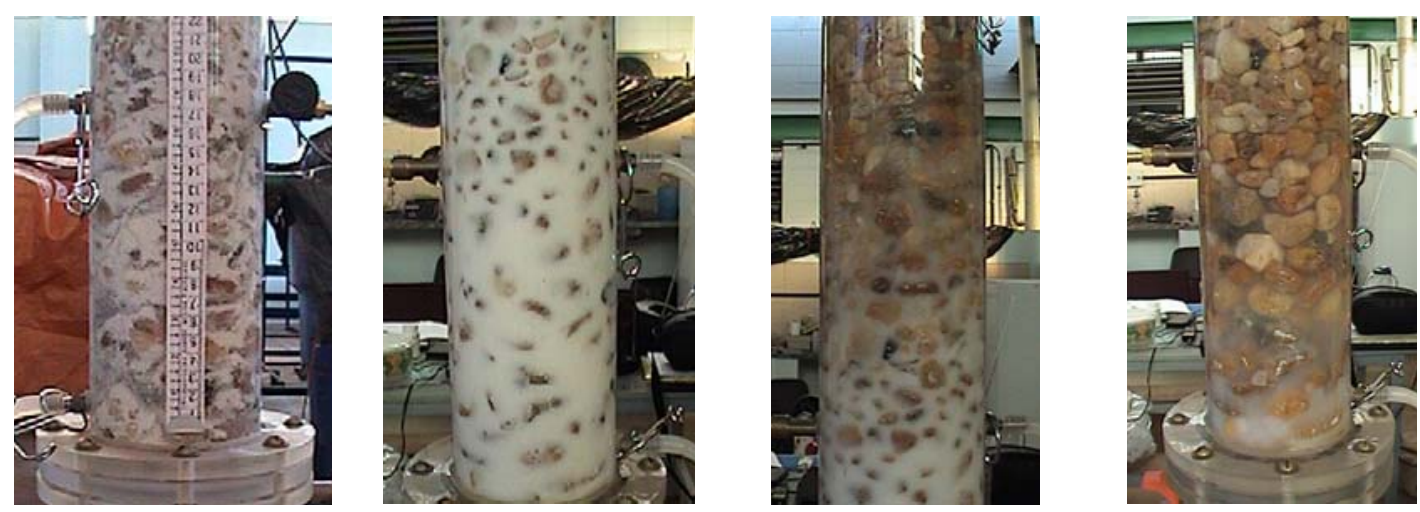

Figura 5.46- Descarga de fundo final no FAP-C1 após término do ensaio 14 de dupla filtração

A otimização da lavagem do sistema FAP-FRD não foi o objetivo deste trabalho, mas o método e as taxas utilizados, visualmente parecem ter garantido a lavagem eficiente do FAP, com produção de efluente menor que 5 uT. Entretanto, recomenda-se que seja feito um estudo com diferentes métodos e taxas de lavagem para esclarecimento deste assunto.

A lavagem dos filtros descendentes dos dois sistemas foi efetuada por meio de insuflação de ar durante $3 \mathrm{~min}$, com taxa de aplicação da ordem de $15 \mathrm{~L} / \mathrm{s} . \mathrm{m}^{2}$, seguida de água para promover expansão de $30 \%$ na camada de areia (velocidade ascensional de 0,80 $\mathrm{m} / \mathrm{min}$ ) durante cerca de $10 \mathrm{~min}$, procedimento semelhante ao adotado por KURODA (2002) e DE PAULA (2003). A lavagem do FRD foi realizada também no final dos ensaios, sendo que os tempos e as taxas de água e de ar propostos foram considerados satisfatórios para a sua limpeza (Figura 5.47). 


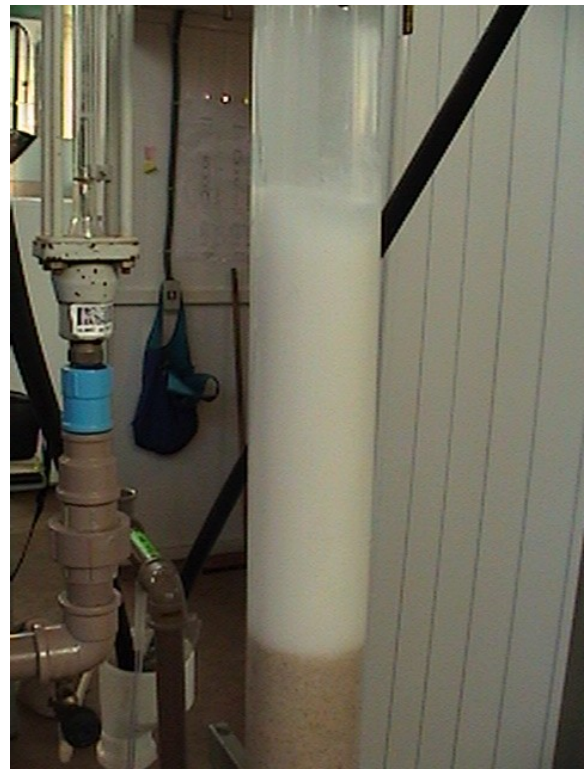

Figura 5.47 - Lavagem com água no FRD após término do ensaio de dupla filtração 


\section{CONCLUSÕES E RECOMENDAÇÕES}

Com base no trabalho realizado, as seguintes conclusões gerais são apresentadas:

a) a realização do ensaio com o filtro de laboratório de areia (FLA) e a medida do potencial zeta da água coagulada mostraram-se ferramentas importantes no controle da coagulação para sistemas de filtração direta;

b) a coagulação das águas de estudo tipo I e tipo II foi realizada com a dosagem mínima de sulfato de alumínio que eliminasse a necessidade do uso de acidificante ou alcalinizante. Foi verificado que nestas condições ocorreu a neutralização de carga das partículas de caulnita, ou seja, o potencial zeta resultou próximo de zero;

c) os valores de turbidez lidos nos turbidímetros de escoamento contínuo (TEC) são inferiores àqueles lidos no turbidímetro de bancada (TB), sendo essa diferença mais significativa para valores menores que $1 \mathrm{uT}$;

d) os dois sistemas de dupla filtração foram capazes de clarificar as águas tipo I e tipo II, em condições distintas, com produção de água filtrada com valores menores que 0,05 uT (medidos na TEC);

e) foi verificada a ocorrência de picos de turbidez na água pré-filtrada após a execução das DFIs nos dois sistemas, com duração de 10 a $30 \mathrm{~min}$, sendo que no sistema 1 esses valores foram superiores àqueles observados no sistema 2;

f) o FRD foi essencial nos dois sistemas para a produção de água filtrada com valores menores que 0,5 uT, valor recomendado pela portaria 518/2004. Devido a eficiência do FAP na retenção de sólidos ter sido menor que aquela observado no FAAG, as taxas de crescimento de perda de carga e de retenção de sólidos foram maiores no FRD do sistema 2 , indicando que neste sistema deveriam ser utilizadas taxas de filtração menores no FRD;

g) a execução das descargas de fundo intermediária (DFIs) nos dois sistemas mostrou-se vantajosa em termos de aumento na duração da carreira de filtração, aumento da eficiência de produção de água filtrada na maior parte dos ensaios, e impedimento da formação do manto de lodo no topo dos filtros ascendentes;

h) em todos ensaios realizados, a perda de carga final foi inferior à 1,20 m no FAAG e inferior a 0,80 m no FAP, resultados que indicam que a carga hidráulica prevista para ambos os filtros poderia ser menor que aquelas recomendadas na literatura; 
i) em todos ensaios realizados com execução de DFIs no FAAG e FAP, o término da carreira de filtração no FRD ocorreu por perda de carga limite de 1,80 m, resultado que indica a necessidade de se trabalhar com carga hidráulica disponível mais elevada nesse filtro;

j) a dupla filtração com filtro ascendente de areia grossa e a dupla filtração com filtro ascendente de pedregulho são indicadas para o tratamento de água com turbidez de até 300 uT; entretanto, é imprescindível que sejam feitos ensaios de bancada e ensaios em instalação piloto antes da aplicação da tecnologia;

Com base no trabalho realizado, as seguintes conclusões específicas para os sistemas 1 e 2 são apresentadas:

a) no sistema 1, os melhores resultados em termos de remoção de sólidos, duração da carreira e produção efetiva de água foram obtidos com taxas de filtração $180 \mathrm{~m}^{3} / \mathrm{m}^{2}$.d no FAAG e $305 \mathrm{~m}^{3} / \mathrm{m}^{2}$.d no FRD, com a execução das DFIs a cada 6 h no ensaio com a água tipo I;

b) no sistema 1, os melhores resultados em termos de remoção de sólidos, duração da carreira e produção efetiva de água foram obtidos com taxas de filtração $178 \mathrm{~m}^{3} / \mathrm{m}^{2}$.d no FAAG e $305 \mathrm{~m}^{3} / \mathrm{m}^{2}$.d no FRD, com a execução das DFIs a cada 4,5 h no ensaio com a água tipo II;

c) para o sistema 1 e água de estudo tipo II, com a taxa de filtração de $126 \mathrm{~m}^{3} / \mathrm{m}^{2}$.d no FAAG, houve a formação de manto de lodo quando o ensaio foi realizado sem a execução das DFIs;

d) nos ensaios realizados no sistema 1 sem a execução das DFIs, a retenção de sólidos no início dos ensaios ocorreu na camada suporte e nas subcamadas 1, 2 e 3 do FAAG, terminando com a retenção de sólidos em todo o meio filtrante;

e) nos ensaios realizados no sistema 1 sem a execução das DFIs, o aumento significativo da perda de carga devido a retenção de sólidos foi verificado em todas as subcamadas, com exceção da subcamada 5, em que a perda de carga se manteve praticamente constante ou com valores finais ligeiramente superiores a perda de carga inicial;

f) nos ensaios realizados no sistema 1 com a execução das DFIs, o aumento da perda de carga devido a retenção de sólidos foi relativamente pequeno em todas as subcamadas do FAAG;

g) no sistema 2, para o tratamento da água tipo I, os melhores resultados em termos de remoção de sólidos, duração da carreira e produção efetiva de água foram obtidos com taxas de filtração $126 \mathrm{~m}^{3} / \mathrm{m}^{2}$.d no FAP e $193 \mathrm{~m}^{3} / \mathrm{m}^{2}$.d no FRD, com a execução das DFIs 
a cada 6 h; já para o tratamento da água tipo II, os melhores resultados foram obtidos com taxas de filtração para $178 \mathrm{~m}^{3} / \mathrm{m}^{2}$.d no FAP e $185 \mathrm{~m}^{3} / \mathrm{m}^{2}$.d no FRD e a execução das DFIs a cada $4,5 \mathrm{~h}$;

h) para o sistema 2, houve a formação do manto de lodo em duas condições: ensaio 10: água tipo I e taxa de $126 \mathrm{~m}^{3} / \mathrm{m}^{2}$.d no FAP e ensaio 14: água tipo II e taxa de $178 \mathrm{~m}^{3} / \mathrm{m}^{2}$.d no FAP, ambos sem a execução das DFIs;

i) nos ensaios realizados no sistema 2, houve retenção de sólidos em todo o meio filtrante do FAP;

j) nos ensaios realizados no sistema 2 sem a execução das DFIs, o aumento da perda de carga foi relativamente pequeno nas subcamadas 1 e 2, de maior granulometria, apesar da grande quantidade de sólidos retida; nas subcamadas 3 e 4, de menor granulometria, este aumento foi mais significativo;

k) nos ensaios realizados no sistema 2 com a execução das DFIs, o aumento da perda de carga foi relativamente pequeno em todas as subcamadas do FAP, apesar da grande quantidade de sólidos retida principalmente nas subcamadas de maior granulometria;

Com base no trabalho realizado, as seguintes recomendações são feitas:

a) a realização de ensaios de bancada e de ensaios em instalação piloto com a água a ser tratada para avaliar a aplicabilidade da dupla filtração;

b) para a escolha da melhor opção de tratamento, a realização de um estudo de custo considerandos os custos de implantação e de operação das duas tecnologias (FAAG-FRD e FAP-FRD), e a avaliação das condições sócio-econômicas da comunidade, visto que a operação da FAP-FRD é mais simples que a operação do FAAG-FRD, embora as duas exijam operação com pessoal qualificado;

c) a realização de ensaios de dupla filtração em instalação piloto visando a otimização do método de lavagem dos filtros ascendentes de areia grossa e pedregulho;

d) a realização de ensaios de dupla filtração em instalação piloto visando a otimização das execução das descargas de fundo intermediárias;

e) a realização de ensaios de dupla filtração em instalação piloto com águas preparadas com outros tipos de argila que não a caulinita;

f) a realização de ensaios de dupla filtração em instalação piloto com água natural com turbidez elevada;

g) a realização de ensaios de dupla filtração em instalação piloto para remoção de algas;

h) a realização de ensaios em instalação piloto obedecendo a relação D/d > 50 (D: diâmetro interno do filtro; d: tamanho do pedregulho); 
i) aumento da espessura da subcamada 5 do FAAG;

j) como a maior parte dos ensaios foi encerrada por perda de carga ou ocorrência de transpasse no FRD, recomenda-se que sejam estudados outros meios filtrantes nesse filtro;

k) medidas in loco da porosidade do meio filtrante para comparação entre a perda de carga calculada pela equação de FAIR et al. (1968) e àquelas obtidas na instalação piloto. 
ANEXO A 
Parte A1

\section{ENSAIOS DE BANCADA COM A ÁGUA DE ESTUDO TIPO I}

\section{Características da Água de Estudo Tipo I durante os ensaios:}

Turbidez: 95 a 108 uT;

pH: 7,52 a 7,77;

Alcalinidade: 26,4 a $28,4 \mathrm{mg} / \mathrm{L} \mathrm{CaCO}_{3}$

Temperatura: 24 a $26{ }^{\circ} \mathrm{C}$

\section{Série I: Condições de Coagulação}

Condições dos ensaios: Mistura Rápida: $\mathrm{Gmr}=1000 \mathrm{~s}^{-1}$ e Tmr $=30$ s; Filtração: coleta nos FLAs após 10, 20 e 30 min e areia FLAs tipo 2.

Tabela A1.1 - Resultados do ensaio de filtração direta 1.1

\begin{tabular}{|c|c|c|c|c|c|c|}
\hline \multirow[t]{2}{*}{ JARRO } & \multicolumn{2}{|c|}{ PRODUTOS QUÍMICOS } & \multirow{2}{*}{$\begin{array}{c}\mathrm{pH} \\
\mathrm{de} \\
\text { Coagulação }\end{array}$} & \multicolumn{3}{|c|}{ TURBIDEZ ÁGUA FILTRADA (uT) } \\
\hline & Outro & $\begin{array}{l}\text { Sulfato de } \\
\text { Alumínio } \\
\text { (mg/L) }\end{array}$ & & 10 a $15 \mathrm{~min}$ & 20 a $25 \mathrm{~min}$ & 30 a $35 \mathrm{~min}$ \\
\hline 1 & & 5,0 & 7,13 & 58,3 & 57,5 & 76,6 \\
\hline 2 & & 10,0 & 7,06 & 14,4 & 10,9 & 8,57 \\
\hline 3 & & 15,0 & 6,99 & 3,97 & 2,12 & 1,68 \\
\hline 4 & & 20,0 & 6,95 & 1,83 & 0,85 & 0,82 \\
\hline 5 & & 25,0 & 6,88 & 1,10 & 0,55 & 0,39 \\
\hline 6 & & 30,0 & 6,85 & 1,28 & 1,01 & 0,85 \\
\hline
\end{tabular}

Tabela A1.2 - Resultados do ensaio de filtração direta 1.2

\begin{tabular}{|c|c|c|c|c|c|c|}
\hline \multirow[t]{2}{*}{ JARRO } & \multicolumn{2}{|c|}{ PRODUTOS QUÍMICOS } & $\mathrm{pH}$ & \multicolumn{3}{|c|}{ TURBIDEZ ÁGUA FILTRADA (uT) } \\
\hline & $\begin{array}{c}\text { Ácido } \\
\text { Clorídrico } \\
\text { (mg/L) }\end{array}$ & $\begin{array}{c}\text { Sulfato de } \\
\text { Alumínio } \\
(\mathrm{mg} / \mathrm{L})\end{array}$ & $\begin{array}{c}\text { de } \\
\text { Coagulação }\end{array}$ & 10 a 15 min & 20 a 25 min & 30 a 35 min \\
\hline 2 & 2,0 & 15,0 & 6,47 & 3,53 & 1,54 & 0,94 \\
\hline 3 & 4,0 & 15,0 & 6,31 & 2,91 & 1,24 & 0,69 \\
\hline 4 & 1,0 & 20,0 & 6,52 & 1,76 & 0,78 & 0,20 \\
\hline
\end{tabular}

Tabela A1.3 - Resultados do ensaio de filtração direta 1.3

\begin{tabular}{|c|c|c|c|c|c|c|}
\hline \multirow[t]{2}{*}{ JARRO } & \multicolumn{2}{|c|}{ PRODUTOS QUÍMICOS } & \multirow{2}{*}{$\begin{array}{c}\mathrm{pH} \\
\text { de } \\
\text { Coagulação }\end{array}$} & \multicolumn{3}{|c|}{ TURBIDEZ ÁGUA FILTRADA (uT) } \\
\hline & $\begin{array}{c}\text { Ácido } \\
\text { Clorídrico } \\
\text { (mg/L) } \\
\end{array}$ & $\begin{array}{c}\text { Sulfato de } \\
\text { Alumínio } \\
(\mathrm{mg} / \mathrm{L})\end{array}$ & & 10 a $15 \mathrm{~min}$ & 20 a 25 min & 30 a $35 \mathrm{~min}$ \\
\hline 2 & 7,0 & 15,0 & 6,10 & 3,66 & 2,54 & 1,92 \\
\hline 3 & 8,0 & 15,0 & 6,01 & 3,04 & 2,24 & 1,03 \\
\hline 4 & 6,0 & 20,0 & 6,15 & 1,97 & 1,72 & 1,03 \\
\hline 6 & 8,0 & 20,0 & 5,95 & 2,39 & 0,98 & 0,89 \\
\hline
\end{tabular}


Tabela A1.4 - Resultados do ensaio de filtração direta 1.4

\begin{tabular}{|c|c|c|c|c|c|c|}
\hline \multirow[t]{2}{*}{ JARRO } & \multicolumn{2}{|c|}{ PRODUTOS QUÍMICOS } & \multirow{2}{*}{$\begin{array}{c}\mathrm{pH} \\
\text { de } \\
\text { Coagulação }\end{array}$} & \multicolumn{3}{|c|}{ TURBIDEZ ÁGUA FILTRADA (uT) } \\
\hline & $\begin{array}{l}\text { Ácido } \\
\text { Clorídrico } \\
\text { (mg/L) }\end{array}$ & $\begin{array}{c}\text { Sulfato de } \\
\text { Alumínio } \\
\text { (mg/L) }\end{array}$ & & 10 a $15 \mathrm{~min}$ & 20 a $25 \mathrm{~min}$ & 30 a $35 \mathrm{~min}$ \\
\hline 2 & 0,50 & 15,0 & 6,91 & 4,00 & 2,10 & 1,22 \\
\hline 3 & & 15,0 & 6,98 & 4,04 & 2,44 & 2,07 \\
\hline 4 & 0,25 & 20,0 & 6,88 & 1,52 & 0,83 & 0,59 \\
\hline
\end{tabular}

Tabela A1.5 - Resultados do ensaio de filtração direta 1.5

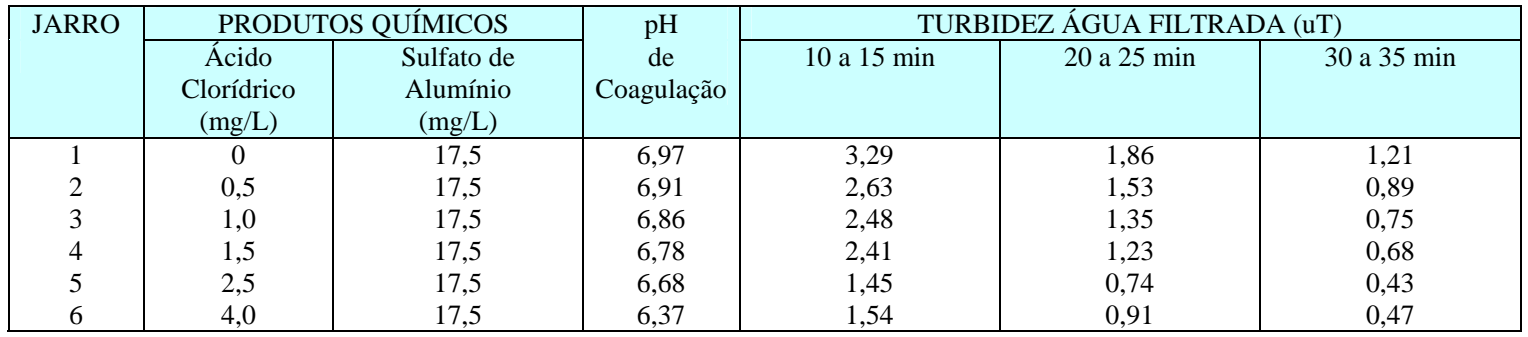

Tabela A1.6 - Resultados do ensaio de filtração direta 1.6

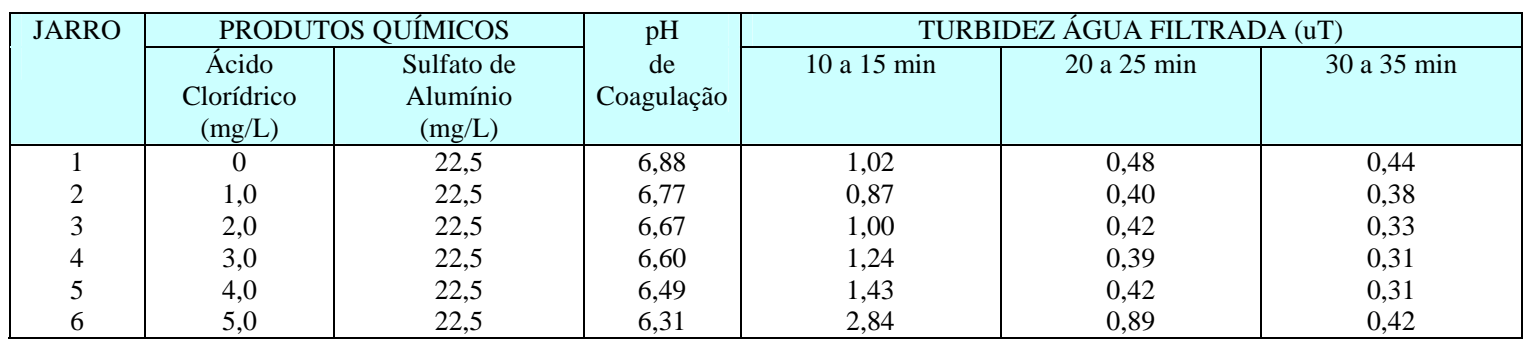

Tabela A1.7 - Resultados do ensaio de filtração direta 1.7

\begin{tabular}{|c|c|c|c|c|c|c|}
\hline \multirow[t]{2}{*}{ JARRO } & \multicolumn{2}{|c|}{ PRODUTOS QUÍMICOS } & \multirow{2}{*}{$\begin{array}{c}\mathrm{pH} \\
\text { de } \\
\text { Coagulação }\end{array}$} & \multicolumn{3}{|c|}{ TURBIDEZ ÁGUA FILTRADA (uT) } \\
\hline & $\begin{array}{c}\text { Ácido } \\
\text { Clorídrico } \\
(\mathrm{mg} / \mathrm{L})\end{array}$ & $\begin{array}{c}\text { Sulfato de } \\
\text { Alumínio } \\
(\mathrm{mg} / \mathrm{L})\end{array}$ & & 10 a $15 \mathrm{~min}$ & 20 a 25 min & 30 a $35 \mathrm{~min}$ \\
\hline 2 & 0,5 & 25,0 & 6,72 & 0,87 & 0,55 & 0,42 \\
\hline 3 & 1,0 & 25,0 & 6,66 & 1,13 & 0,54 & 0,41 \\
\hline 4 & 2,0 & 25,0 & 6,59 & 1,44 & 0,70 & 0,55 \\
\hline 6 & 4,0 & 25,0 & 6,34 & 1,58 & 0,64 & 0,82 \\
\hline
\end{tabular}


Tabela A1.8 - Resultados do ensaio de filtração direta 1.8

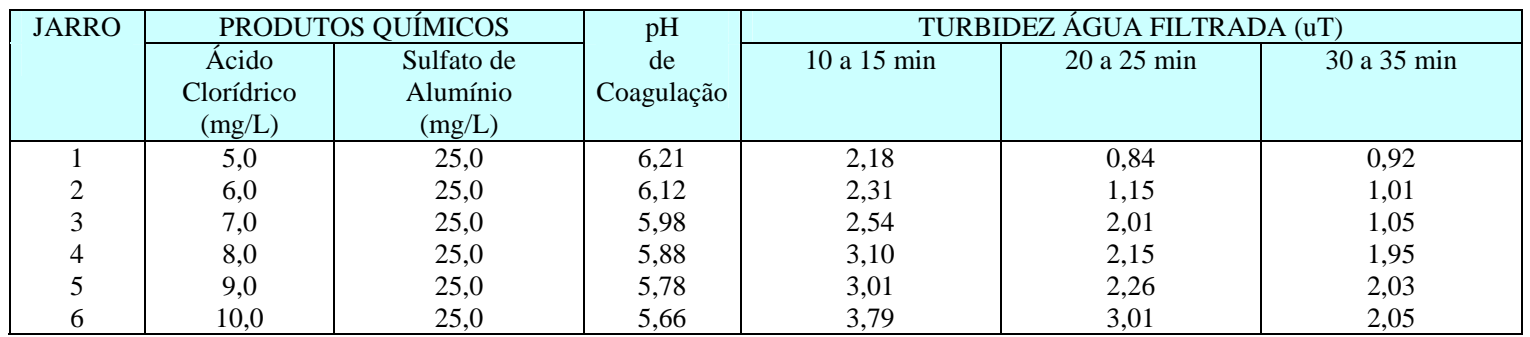

Tabela A1.9 - Resultados do ensaio de filtração direta 1.9

\begin{tabular}{|c|c|c|c|c|c|c|}
\hline \multirow[t]{2}{*}{ JARRO } & \multicolumn{2}{|c|}{ PRODUTOS QUÍMICOS } & $\mathrm{pH}$ & \multicolumn{3}{|c|}{ TURBIDEZ ÁGUA FILTRADA (uT) } \\
\hline & $\begin{array}{l}\text { Ácido } \\
\text { Clorídrico } \\
\text { (mg/L) }\end{array}$ & $\begin{array}{l}\text { Sulfato de } \\
\text { Alumínio } \\
\text { (mg/L) }\end{array}$ & $\begin{array}{c}\text { de } \\
\text { Coagulaçã } \\
\text { o }\end{array}$ & 10 a $15 \mathrm{~min}$ & 20 a $25 \mathrm{~min}$ & 30 a $35 \mathrm{~min}$ \\
\hline 1 & 0 & 20,0 & 6,99 & 1,93 & 0,94 & 0,75 \\
\hline 2 & 1,0 & 20,0 & 6,86 & 1,06 & 0,73 & 0,47 \\
\hline 3 & 2,0 & 20,0 & 6,77 & 1,92 & 0,84 & 1,47 \\
\hline 4 & 0 & 15,0 & 7,11 & 8,03 & 6,79 & 6,54 \\
\hline 5 & 1,0 & 15,0 & 6,85 & 3,80 & 1,92 & 1,71 \\
\hline 6 & 1,0 & 22,5 & 6,83 & 1,28 & 0,58 & 0,38 \\
\hline
\end{tabular}

Tabela A1.10 - Resultados do ensaio de filtração direta 1.10

\begin{tabular}{|c|c|c|c|c|c|c|}
\hline \multirow[t]{2}{*}{ JARRO } & \multicolumn{2}{|c|}{ PRODUTOS QUÍMICOS } & $\mathrm{pH}$ & \multicolumn{3}{|c|}{ TURBIDEZ ÁGUA FILTRADA (uT) } \\
\hline & $\begin{array}{c}\text { Ácido } \\
\text { Clorídrico } \\
(\mathrm{mg} / \mathrm{L})\end{array}$ & $\begin{array}{c}\text { Sulfato de } \\
\text { Alumínio } \\
(\mathrm{mg} / \mathrm{L})\end{array}$ & $\begin{array}{c}\text { de } \\
\text { Coagulação }\end{array}$ & 10 a $15 \mathrm{~min}$ & 20 a 25 min & 30 a $35 \mathrm{~min}$ \\
\hline 2 & 0,5 & 27,5 & 6,69 & 1,09 & 0,85 & 0,51 \\
\hline 3 & 1,0 & 27,5 & 6,60 & 1,13 & 0,74 & 0,48 \\
\hline 4 & 2,0 & 27,5 & 6,51 & 1,21 & 0,60 & 0,58 \\
\hline 6 & 4,0 & 27,5 & 6,29 & 1,81 & 0,83 & 0,82 \\
\hline
\end{tabular}

\section{Série II: Verificação da areia dos FLAs}

Condições dos ensaios: Mistura Rápida: $\mathrm{Gmr}=1000 \mathrm{~s}^{-1}$, Tmr $=30 \mathrm{~s}$ e Dosagem de Sulfato de Alumínio: 25 mg/L do produto comercial líquido; Filtração: coleta e leitura de perda de carga nos FLAs após 10, 20, 30, 40, 50 e 60 min.

Tabela A1.11 - Resultados do ensaio de filtração direta 1.11

\begin{tabular}{|c|c|c|c|c|c|c|c|c|c|c|c|c|c|c|c|c|}
\hline \multirow{3}{*}{$\begin{array}{c}\text { JAR } \\
\text { RO }\end{array}$} & \multirow{2}{*}{\multicolumn{2}{|c|}{$\begin{array}{l}\text { PRODUTOS } \\
\text { QUÍMICOS }\end{array}$}} & \multirow{3}{*}{$\begin{array}{l}\mathrm{pH} \text { de } \\
\text { Coag. }\end{array}$} & \multirow{3}{*}{$\begin{array}{l}\text { Tipo } \\
\text { Areia }\end{array}$} & \multicolumn{12}{|c|}{ ÁGUA FILTRADA (uT) } \\
\hline & & & & & \multicolumn{2}{|c|}{10 a $15 \min$} & \multicolumn{2}{|c|}{20 a $25 \min$} & \multicolumn{2}{|c|}{30 a $35 \mathrm{~min}$} & \multicolumn{2}{|c|}{40 a $45 \mathrm{~min}$} & \multicolumn{2}{|c|}{50 a 55 min } & \multicolumn{2}{|c|}{60 a $65 \min$} \\
\hline & $\begin{array}{c}\text { Ácido } \\
\text { Clorídrico } \\
\text { (mg/L) }\end{array}$ & $\begin{array}{c}\text { Sulfato de } \\
\text { Alumínio } \\
\text { (mg/L) }\end{array}$ & & & $\begin{array}{l}\text { Turb. } \\
\text { (uT) }\end{array}$ & $\begin{array}{l}\text { Perda } \\
\text { Carga } \\
(\mathrm{cm})\end{array}$ & $\begin{array}{l}\text { Turb. } \\
\text { (uT) }\end{array}$ & $\begin{array}{l}\text { Perda } \\
\text { Carga } \\
\text { (cm) }\end{array}$ & $\begin{array}{l}\text { Turb. } \\
\text { (uT) }\end{array}$ & $\begin{array}{l}\text { Perda } \\
\text { Carga } \\
\text { (cm) }\end{array}$ & $\begin{array}{l}\text { Turb. } \\
\text { (uT) }\end{array}$ & $\begin{array}{l}\text { Perda } \\
\text { Carga } \\
(\mathrm{cm})\end{array}$ & $\begin{array}{l}\text { Turb. } \\
\text { (uT) }\end{array}$ & $\begin{array}{l}\text { Perda } \\
\text { Carga } \\
(\mathrm{cm})\end{array}$ & $\begin{array}{l}\text { Turb. } \\
\text { (uT) }\end{array}$ & $\begin{array}{l}\text { Perda } \\
\text { Carga } \\
\text { (cm) }\end{array}$ \\
\hline 1 & 0 & 25,0 & 6,88 & 1 & 0,33 & 5,2 & 0,30 & 5,2 & 0,27 & 5,4 & 0,24 & 7,4 & 0,27 & 6,6 & 0,21 & 8,4 \\
\hline 2 & 0 & 25,0 & 6,85 & 1 & 0,31 & 5,8 & 0,26 & 5,6 & 0,23 & 5,7 & 0,24 & 7,4 & 0,22 & 7,2 & 0,21 & 9,1 \\
\hline 3 & 0 & 25,0 & 6,88 & 2 & 0,78 & 3,0 & 0,47 & 3,0 & 0,33 & 2,9 & 0,29 & 4,5 & 0,30 & 3,7 & 0,27 & 5,0 \\
\hline 4 & 0 & 25,0 & 6,91 & 2 & 0,76 & 3,7 & 0,56 & 4,0 & 0,34 & 3,3 & 0,29 & 4,6 & 0,30 & 4,0 & 0,28 & 5,3 \\
\hline 5 & 0 & 25,0 & 6,90 & 3 & 1,91 & 2,0 & 1,25 & 2,4 & 0,77 & 1,9 & 0,54 & 2,7 & 0,53 & 2,4 & 0,48 & 3,3 \\
\hline 6 & 0 & 25,0 & 6,90 & 3 & 2,50 & 2,4 & 1,42 & 2,5 & 0,78 & 2,1 & 0,59 & 2,6 & 0,70 & 2,7 & 0,56 & 3,7 \\
\hline
\end{tabular}




\section{Série III: Verificação das condições de mistura rápida}

Condições dos ensaios: Dosagem de Sulfato de Alumínio = 25,0 mg/L do produto comercial líquido;

Filtração: coleta nos FLAs após 10, 20 e 30 min e areia FLAs tipo 2.

Tabela A1.12 - Resultados do ensaio de filtração direta1.12 - Gmr $=400 \mathrm{~s}^{-1}$

\begin{tabular}{|c|c|c|c|c|c|c|c|}
\hline \multirow[t]{2}{*}{ JARRO } & \multicolumn{2}{|c|}{ PRODUTOS QUÍMICOS } & \multirow{2}{*}{$\begin{array}{c}\text { pH de } \\
\text { Coagulação }\end{array}$} & \multirow{2}{*}{$\begin{array}{c}\text { Tempo } \\
\text { de Mistura } \\
\text { Rápida (s) }\end{array}$} & \multicolumn{3}{|c|}{ TURBIDEZ ÁGUA FILTRADA (uT) } \\
\hline & Outro & $\begin{array}{c}\text { Sulfato de } \\
\text { Alumínio } \\
(\mathrm{mg} / \mathrm{L})\end{array}$ & & & 10 a $15 \mathrm{~min}$ & 20 a 25 min & 30 a $35 \mathrm{~min}$ \\
\hline 1 & - & 25,0 & 6,92 & 20 & 0,68 & 0,58 & 0,38 \\
\hline 2 & - & 25,0 & 6,88 & 60 & 0,42 & 0,32 & 0,28 \\
\hline 3 & - & 25,0 & 6,91 & 100 & 0,50 & 0,38 & 0,33 \\
\hline 4 & - & 25,0 & 6,94 & 140 & 0,47 & 0,31 & 0,29 \\
\hline 5 & - & 25,0 & 6,95 & 180 & 0,36 & 0,30 & 0,35 \\
\hline 6 & - & 25,0 & 6,95 & 220 & 0,39 & 0,30 & 0,31 \\
\hline
\end{tabular}

Tabela A1.13 - Resultados do ensaio de filtração direta $1.13-\mathrm{Gmr}=600 \mathrm{~s}^{-1}$

\begin{tabular}{|c|c|c|c|c|c|c|c|}
\hline \multirow[t]{2}{*}{ JARRO } & \multicolumn{2}{|c|}{ PRODUTOS QUÍMICOS } & \multirow{2}{*}{$\begin{array}{c}\text { pH de } \\
\text { Coagulação }\end{array}$} & \multirow{2}{*}{$\begin{array}{c}\text { Tempo } \\
\text { de Mistura } \\
\text { Rápida (s) }\end{array}$} & \multicolumn{3}{|c|}{ TURBIDEZ ÁGUA FILTRADA (uT) } \\
\hline & Outro & $\begin{array}{c}\text { Sulfato de } \\
\text { Alumínio } \\
\text { (mg/L) }\end{array}$ & & & 10 a 15 min & 20 a 25 min & 30 a 35 min \\
\hline 1 & - & 25,0 & 6,92 & 20 & 1,08 & 0,58 & 0,43 \\
\hline 2 & - & 25,0 & 6,77 & 60 & 0,59 & 0,40 & 0,36 \\
\hline 3 & - & 25,0 & 6,85 & 100 & 0,64 & 0,63 & 0,37 \\
\hline 4 & - & 25,0 & 6,87 & 140 & 0,41 & 0,35 & 0,34 \\
\hline 5 & - & 25,0 & 6,90 & 180 & 0,48 & 0,30 & 0,33 \\
\hline 6 & - & 25,0 & 6,91 & 220 & 0,60 & 0,39 & 0,39 \\
\hline
\end{tabular}

Tabela A1.14 - Resultados do ensaio de filtração direta $1.14-\mathrm{Gmr}=800 \mathrm{~s}^{-1}$

\begin{tabular}{|c|c|c|c|c|c|c|c|}
\hline \multirow{2}{*}{ JARRO } & \multicolumn{2}{|c|}{ PRODUTOS QUÍMICOS } & \multirow{2}{*}{$\begin{array}{c}\text { pH de } \\
\text { Coagulação }\end{array}$} & \multirow{2}{*}{$\begin{array}{c}\text { Tempo } \\
\text { de Mistura } \\
\text { Rápida (s) }\end{array}$} & \multicolumn{3}{|c|}{ TURBIDEZ ÁGUA FILTRADA (uT) } \\
\hline & Outro & $\begin{array}{c}\text { Sulfato de } \\
\text { Alumínio } \\
(\mathrm{mg} / \mathrm{L})\end{array}$ & & & 10 a 15 min & 20 a 25 min & 30 a $35 \mathrm{~min}$ \\
\hline 2 & - & 25,0 & 6,84 & 60 & 0,60 & 0,44 & 0,37 \\
\hline 3 & - & 25,0 & 6,83 & 100 & 0,50 & 0,33 & 0,30 \\
\hline 4 & - & 25,0 & 6,97 & 140 & 0,45 & 0,35 & 0,39 \\
\hline
\end{tabular}

Tabela A1.15 - Resultados do ensaio de filtração direta 1.15 - Gmr $=1000 \mathrm{~s}^{-1}$

\begin{tabular}{|c|c|c|c|c|c|c|c|}
\hline \multirow[t]{2}{*}{ JARRO } & \multicolumn{2}{|c|}{ PRODUTOS QUÍMICOS } & \multirow{2}{*}{$\begin{array}{c}\text { pH de } \\
\text { Coagulação }\end{array}$} & \multirow{2}{*}{$\begin{array}{c}\text { Tempo } \\
\text { de Mistura } \\
\text { Rápida (s) }\end{array}$} & \multicolumn{3}{|c|}{ TURBIDEZ ÁGUA FILTRADA (uT) } \\
\hline & Outro & $\begin{array}{c}\text { Sulfato de } \\
\text { Alumínio } \\
\text { (mg/L) }\end{array}$ & & & 10 a $15 \mathrm{~min}$ & 20 a $25 \mathrm{~min}$ & 30 a $35 \mathrm{~min}$ \\
\hline 2 & - & 25,0 & 6,80 & 60 & 0,84 & 0,68 & 0,58 \\
\hline 3 & - & 25,0 & 6,79 & 100 & 0,82 & 0,62 & 0,60 \\
\hline 4 & - & 25,0 & 6,88 & 140 & 0,68 & 0,63 & 0,57 \\
\hline
\end{tabular}


Parte A2

\section{ENSAIOS DE BANCADA COM A ÁGUA DE ESTUDO TIPO II}

\section{Características da Água de Estudo Tipo II durante os ensaios:}

Turbidez: 268 a 310 uT;

pH: 7,60 a 7,88;

Alcalinidade: 22,0 a 24,5 mg/L $\mathrm{CaCO}_{3}$

Temperatura: 24 a $26{ }^{\circ} \mathrm{C}$

\section{Série I: Condições de Coagulação}

Condições dos ensaios: Mistura Rápida: $\mathrm{Gmr}=1000 \mathrm{~s}^{-1}$ e Tmr = 30 s; Filtração: coleta nos FLAs após 10, 20 e 30 min e areia FLAs tipo 3.

Tabela A2.1 - Resultados do ensaio de filtração direta 2.1

\begin{tabular}{|c|c|c|c|c|c|c|}
\hline \multirow[t]{2}{*}{ JARRO } & \multicolumn{2}{|c|}{ PRODUTOS QUÍMICOS } & \multirow{2}{*}{$\begin{array}{c}\mathrm{pH} \\
\text { de } \\
\text { Coagula } \\
\text { ção }\end{array}$} & \multicolumn{3}{|c|}{ TURBIDEZ ÁGUA FILTRADA (uT) } \\
\hline & $\begin{array}{c}\text { Carbonato de } \\
\text { Sódio } \\
(\mathrm{mg} / \mathrm{L})\end{array}$ & $\begin{array}{l}\text { Sulfato de } \\
\text { Alumínio } \\
(\mathrm{mg} / \mathrm{L})\end{array}$ & & 10 a 15 min & 20 a 25 min & 30 a $35 \mathrm{~min}$ \\
\hline 1 & 0 & 40,0 & 6,82 & 0,61 & 0,48 & 0,45 \\
\hline 2 & 0 & 50,0 & 6,68 & 0,64 & 0,39 & 0,31 \\
\hline 3 & 0 & 60,0 & 6,60 & 0,82 & 0,76 & 0,79 \\
\hline 4 & 4,0 & 40,0 & 6,95 & 0,63 & 0,44 & 0,37 \\
\hline 5 & 4,0 & 50,0 & 6,80 & 0,46 & 0,36 & 0,40 \\
\hline 6 & 4,0 & 60,0 & 6,75 & 0,58 & 0,32 & 0,26 \\
\hline
\end{tabular}

Tabela A2.2 - Resultados do ensaio de filtração direta 2.2

\begin{tabular}{|c|c|c|c|c|c|c|}
\hline \multirow[t]{2}{*}{ JARRO } & \multicolumn{2}{|c|}{ PRODUTOS QUÍMICOS } & \multirow{2}{*}{$\begin{array}{c}\mathrm{pH} \\
\text { de } \\
\text { Coagula } \\
\text { ção }\end{array}$} & \multicolumn{3}{|c|}{ TURBIDEZ ÁGUA FILTRADA (uT) } \\
\hline & $\begin{array}{c}\text { Ácido } \\
\text { Clorídrico } \\
\text { (mg/L) }\end{array}$ & $\begin{array}{c}\text { Sulfato de } \\
\text { Alumínio } \\
(\mathrm{mg} / \mathrm{L})\end{array}$ & & 10 a $15 \mathrm{~min}$ & 20 a 25 min & 30 a $35 \mathrm{~min}$ \\
\hline 1 & 1,5 & 40,0 & 6,58 & 1,03 & 0,95 & 0,75 \\
\hline 2 & 1,5 & 50,0 & 6,47 & 1,01 & 0,89 & 0,79 \\
\hline 3 & 1,5 & 60,0 & 6,38 & 0,89 & 0,78 & 0,67 \\
\hline 4 & 3,0 & 40,0 & 6,42 & 2,11 & 1,71 & 1,23 \\
\hline 5 & 3,0 & 50,0 & 6,30 & 2,09 & 1,98 & 1,78 \\
\hline 6 & 3,0 & 60,0 & 6,22 & 2,27 & 1,76 & 1,99 \\
\hline
\end{tabular}

Tabela A2.3 - Resultados do ensaio de filtração direta 2.3

\begin{tabular}{|c|c|c|c|c|c|c|}
\hline \multirow[t]{2}{*}{ JARRO } & \multicolumn{2}{|c|}{ PRODUTOS QUÍMICOS } & \multirow{2}{*}{$\begin{array}{c}\mathrm{pH} \\
\text { de } \\
\text { Coagula } \\
\text { ção }\end{array}$} & \multicolumn{3}{|c|}{ TURBIDEZ ÁGUA FILTRADA (uT) } \\
\hline & $\begin{array}{c}\text { Carbonato de } \\
\text { Sódio } \\
(\mathrm{mg} / \mathrm{L})\end{array}$ & $\begin{array}{c}\text { Sulfato de } \\
\text { Alumínio } \\
(\mathrm{mg} / \mathrm{L})\end{array}$ & & 10 a 15 min & 20 a $25 \mathrm{~min}$ & 30 a 35 min \\
\hline 1 & 6,0 & 40,0 & 7,02 & 0,61 & 0,48 & 0,37 \\
\hline 2 & 6,0 & 50,0 & 6,91 & 0,63 & 0,49 & 0,42 \\
\hline 3 & 6,0 & 60,0 & 6,84 & 0,51 & 0,56 & 0,36 \\
\hline 4 & 8,0 & 40,0 & 7,13 & 0,63 & 0,57 & 0,47 \\
\hline 5 & 8,0 & 50,0 & 6,98 & 0,66 & 0,50 & 0,41 \\
\hline 6 & 8,0 & 60,0 & 6,92 & 0,68 & 0,51 & 0,49 \\
\hline
\end{tabular}


Tabela A2.4 - Resultados do ensaio de filtração direta 2.4

\begin{tabular}{|c|c|c|c|c|c|c|}
\hline \multirow[t]{2}{*}{ JARRO } & \multicolumn{2}{|c|}{ PRODUTOS QUÍMICOS } & \multirow{2}{*}{$\begin{array}{c}\mathrm{pH} \\
\text { de } \\
\text { Coagula } \\
\text { ção }\end{array}$} & \multicolumn{3}{|c|}{ TURBIDEZ ÁGUA FILTRADA (uT) } \\
\hline & $\begin{array}{c}\text { Carbonato de } \\
\text { Sódio } \\
(\mathrm{mg} / \mathrm{L})\end{array}$ & $\begin{array}{c}\text { Sulfato de } \\
\text { Alumínio } \\
(\mathrm{mg} / \mathrm{L})\end{array}$ & & 10 a $15 \mathrm{~min}$ & 20 a $25 \mathrm{~min}$ & 30 a $35 \mathrm{~min}$ \\
\hline 1 & 0 & 30,0 & 6,85 & 5,48 & 5,18 & 4,89 \\
\hline 2 & 5,0 & 30,0 & 6,95 & 2,63 & 2,84 & 2,84 \\
\hline
\end{tabular}

Tabela A2.5 - Resultados do ensaio de filtração direta 2.5

\begin{tabular}{|c|c|c|c|c|c|c|}
\hline \multirow[t]{2}{*}{ JARRO } & \multicolumn{2}{|c|}{ PRODUTOS QUÍMICOS } & \multirow{2}{*}{$\begin{array}{c}\mathrm{pH} \\
\text { de } \\
\text { Coagula } \\
\text { ção }\end{array}$} & \multicolumn{3}{|c|}{ TURBIDEZ ÁGUA FILTRADA (uT) } \\
\hline & $\begin{array}{c}\text { Carbonato de } \\
\text { Sódio } \\
(\mathrm{mg} / \mathrm{L})\end{array}$ & $\begin{array}{c}\text { Sulfato de } \\
\text { Alumínio } \\
(\mathrm{mg} / \mathrm{L})\end{array}$ & & 10 a $15 \mathrm{~min}$ & 20 a $25 \mathrm{~min}$ & 30 a $35 \mathrm{~min}$ \\
\hline 1 & 0 & 55,0 & 6,68 & 0,54 & 0,49 & 0,31 \\
\hline 2 & 0 & 60,0 & 6,60 & 0,92 & 0,77 & 0,69 \\
\hline 3 & 0 & 65,0 & 6,51 & 1,01 & 0,89 & 0,52 \\
\hline 4 & 4,0 & 55,0 & 6,80 & 1,12 & 0,67 & 0,69 \\
\hline 5 & 4,0 & 60,0 & 6,71 & 1,18 & 0,89 & 0,71 \\
\hline 6 & 4,0 & 65,0 & 6,63 & 1,29 & 0,93 & 0,69 \\
\hline
\end{tabular}

\section{Série III: Verificação das condições de mistura rápida}

Condições dos ensaios: Dosagem de Sulfato de Alumínio = 55,0 mg/L do produto comercial líquido; Filtração: coleta nos FLAs após 10, 20 e 30 min e areia FLAs tipo 3.

Tabela A2.6 - Resultados do ensaio de filtração direta $2.6-\mathrm{Gmr}=400 \mathrm{~s}^{-1}$

\begin{tabular}{|c|c|c|c|c|c|c|c|}
\hline \multirow[t]{2}{*}{ JARRO } & \multicolumn{2}{|c|}{ PRODUTOS QUÍMICOS } & \multirow{2}{*}{$\begin{array}{c}\text { pH de } \\
\text { Coagulação }\end{array}$} & \multirow{2}{*}{$\begin{array}{c}\text { Tempo } \\
\text { de Mistura } \\
\text { Rápida (s) }\end{array}$} & \multicolumn{3}{|c|}{ TURBIDEZ ÁGUA FILTRADA (uT) } \\
\hline & Outro & $\begin{array}{c}\text { Sulfato de } \\
\text { Alumínio } \\
(\mathrm{mg} / \mathrm{L})\end{array}$ & & & 10 a $15 \mathrm{~min}$ & 20 a 25 min & 30 a $35 \mathrm{~min}$ \\
\hline 1 & - & 55,0 & 6,68 & 20 & 1,01 & 0,91 & 0,98 \\
\hline 2 & - & 55,0 & 6,65 & 60 & 0,87 & 0,74 & 0,70 \\
\hline 3 & - & 55,0 & 6,71 & 100 & 0,55 & 0,50 & 0,50 \\
\hline 4 & - & 55,0 & 6,77 & 140 & 0,48 & 0,45 & 0,41 \\
\hline 5 & - & 55,0 & 6,77 & 180 & 0,58 & 0,57 & 0,31 \\
\hline 6 & - & 55,0 & 6,77 & 220 & 0,57 & 0,50 & 0,39 \\
\hline
\end{tabular}

Tabela A2.7 - Resultados do ensaio de filtração direta 2.7 - Gmr $=600 \mathrm{~s}^{-1}$

\begin{tabular}{|c|c|c|c|c|c|c|c|}
\hline \multirow[t]{2}{*}{ JARRO } & \multicolumn{2}{|c|}{ PRODUTOS QUÍMICOS } & \multirow{2}{*}{$\begin{array}{c}\text { pH de } \\
\text { Coagulação }\end{array}$} & \multirow{2}{*}{$\begin{array}{c}\text { Tempo } \\
\text { de Mistura } \\
\text { Rápida (s) }\end{array}$} & \multicolumn{3}{|c|}{ TURBIDEZ ÁGUA FILTRADA (uT) } \\
\hline & Outro & $\begin{array}{l}\text { Sulfato de } \\
\text { Alumínio } \\
(\mathrm{mg} / \mathrm{L})\end{array}$ & & & 10 a 15 min & 20 a 25 min & 30 a $35 \mathrm{~min}$ \\
\hline 1 & - & 55,0 & 6,71 & 20 & 0,95 & 0,55 & 0,51 \\
\hline 2 & - & 55,0 & 6,70 & 60 & 0,64 & 0,48 & 0,42 \\
\hline 3 & - & 55,0 & 6,70 & 100 & 0,61 & 0,42 & 0,40 \\
\hline 4 & - & 55,0 & 6,69 & 140 & 0,68 & 0,41 & 0,39 \\
\hline 5 & - & 55,0 & 6,74 & 180 & 0,69 & 0,47 & 0,38 \\
\hline 6 & - & 55,0 & 6,75 & 220 & 0,71 & 0,40 & 0,39 \\
\hline
\end{tabular}


Tabela A2.8 - Resultados do ensaio de filtração direta 2.8 - Gmr $=800 \mathrm{~s}^{-1}$

\begin{tabular}{|c|c|c|c|c|c|c|c|}
\hline \multirow[t]{2}{*}{ JARRO } & \multicolumn{2}{|c|}{ PRODUTOS QUÍMICOS } & \multirow{2}{*}{$\begin{array}{c}\text { pH de } \\
\text { Coagulação }\end{array}$} & \multirow{2}{*}{$\begin{array}{c}\text { Tempo } \\
\text { de Mistura } \\
\text { Rápida (s) }\end{array}$} & \multicolumn{3}{|c|}{ TURBIDEZ ÁGUA FILTRADA (uT) } \\
\hline & Outro & $\begin{array}{c}\text { Sulfato de } \\
\text { Alumínio } \\
(\mathrm{mg} / \mathrm{L})\end{array}$ & & & 10 a 15 min & 20 a 25 min & 30 a $35 \mathrm{~min}$ \\
\hline 1 & - & 55,0 & 6,71 & 20 & 0,71 & 0,70 & 0,68 \\
\hline 2 & - & 55,0 & 6,74 & 60 & 0,58 & 0,41 & 0,35 \\
\hline 3 & - & 55,0 & 6,74 & 100 & 0,41 & 0,30 & 0,30 \\
\hline 4 & - & 55,0 & 6,78 & 140 & 0,35 & 0,30 & 0,28 \\
\hline 5 & - & 55,0 & 6,75 & 180 & 0,39 & 0,28 & 0,28 \\
\hline 6 & - & 55,0 & 6,75 & 220 & 0,45 & 0,37 & 0,30 \\
\hline
\end{tabular}

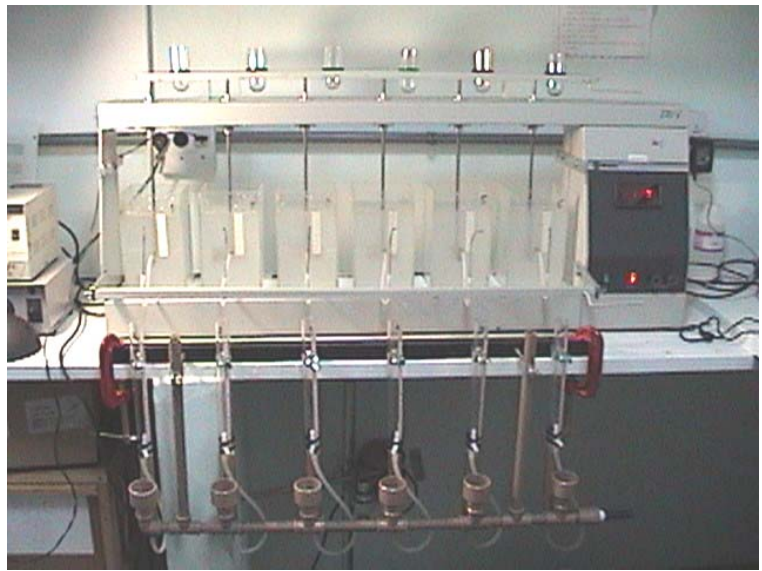

Jarteste e kit de FLAs

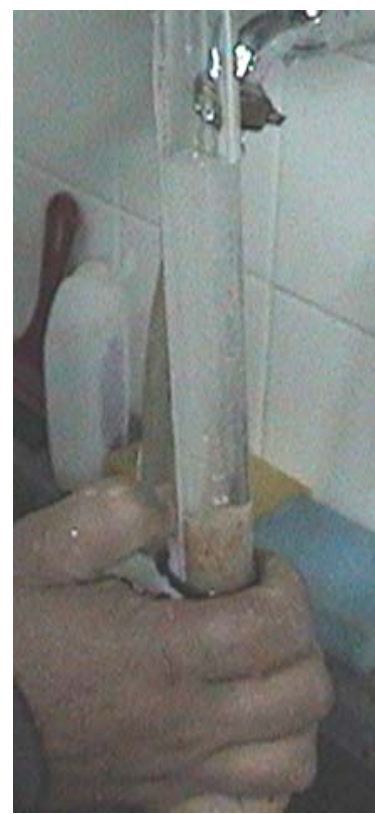

Lavagem de um FLA - Início

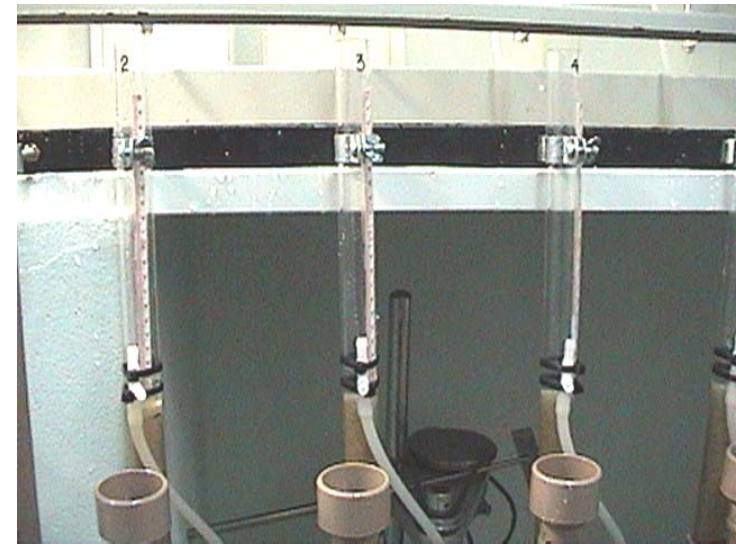

Detalhe dos FLAs

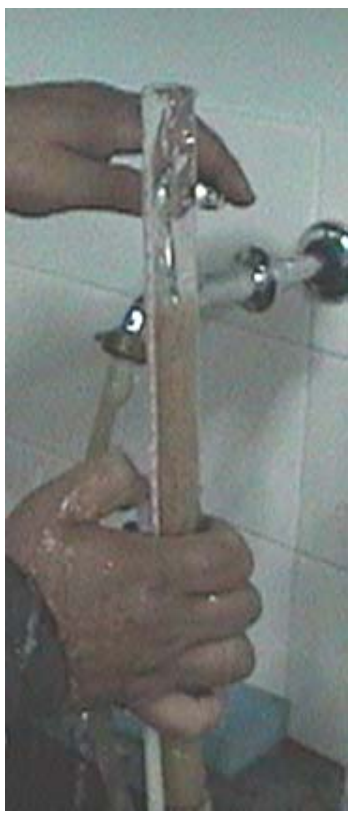

Lavagem de um FLA - Fim

Figura A.1 - Jarteste e kit de FLAs utilizados nos ensaios de bancada com as águas de estudo tipo I e tipo II 
ANEXO B 


\section{Parte B1}

\section{PRÉ-OPERAÇÃO DO SISTEMA DE DUPLA FILTRAÇÃO 1}

\section{FILTRO ASCENDENTE DE AREIA GROSSA - FILTRO RÁPIDO DESCENDENTE}

Tabela B1.1 - Perda de Carga nos piezômetros das câmaras 1 e 2 do FAAG Taxa FAAG $=115 \mathrm{~m}^{3} / \mathrm{m}^{2} \cdot \mathrm{d}$

\begin{tabular}{|c|c|c|c|c|c|c|c|c|}
\hline $\begin{array}{c}\text { Câmara } \\
\text { FAAG }\end{array}$ & $\begin{array}{c}\text { Tempo } \\
(\mathrm{h})\end{array}$ & $\begin{array}{c}\text { P1 } \\
(\mathrm{cm})\end{array}$ & $\begin{array}{c}\text { P2 } \\
(\mathrm{cm})\end{array}$ & $\begin{array}{c}\text { P3 } \\
(\mathrm{cm})\end{array}$ & $\begin{array}{c}\text { P4 } \\
(\mathrm{cm})\end{array}$ & $\begin{array}{c}\text { P5 } \\
(\mathrm{cm})\end{array}$ & $\begin{array}{c}\text { P6 } \\
(\mathrm{cm})\end{array}$ & $\begin{array}{c}\text { P7 } \\
(\mathrm{cm})\end{array}$ \\
\hline 1 & 0 & 256,5 & 256,2 & 255,9 & 255,3 & 253,2 & 250,5 & 248,8 \\
1 & 1 & 256,5 & 256,2 & 255,7 & 255,0 & 253,0 & 250,5 & 248,8 \\
2 & 0 & 256,2 & 255,9 & 255 & 254 & 251,8 & 249,0 & 247,5 \\
2 & 1 & 256,2 & 255,8 & 255,3 & 253,9 & 251,8 & 249,1 & 247,5 \\
\hline
\end{tabular}

Tabela B1.2 - Perda de Carga nos piezômetros das câmaras 1 e 2 do FAAG Taxa FAAG $=172 \mathrm{~m}^{3} / \mathrm{m}^{2} . \mathrm{d}$

\begin{tabular}{|c|c|c|c|c|c|c|c|c|}
\hline Câmara & $\begin{array}{c}\text { Tempo } \\
\text { FAAG }\end{array}$ & $\begin{array}{c}\text { P1 } \\
(\mathrm{c})\end{array}$ & $\begin{array}{c}\text { P2 } \\
(\mathrm{cm})\end{array}$ & $\begin{array}{c}\text { P3 } \\
(\mathrm{cm})\end{array}$ & $\begin{array}{c}\text { P4 } \\
(\mathrm{cm})\end{array}$ & $\begin{array}{c}\text { P5 } \\
(\mathrm{cm})\end{array}$ & $\begin{array}{c}\text { P6 } \\
(\mathrm{cm})\end{array}$ & $\begin{array}{c}\text { P7 } \\
(\mathrm{cm})\end{array}$ \\
\hline 1 & 0 & 259,5 & 259,0 & 258,5 & 257,5 & 255,0 & 251,5 & 249,0 \\
1 & 1 & 259,5 & 259,0 & 258,5 & 257,5 & 255,0 & 251,5 & 249,0 \\
2 & 0 & 259,0 & 258,4 & 258,0 & 256,5 & 253,8 & 250,0 & 247,5 \\
2 & 1 & 259,0 & 258,5 & 258,0 & 256,5 & 253,5 & 250,0 & 247,5 \\
\hline
\end{tabular}

Tabela B1.3 - Perda de Carga nos piezômetros das câmaras 1 e 2 do FAAG Taxa FAAG $=240 \mathrm{~m}^{3} / \mathrm{m}^{2} . \mathrm{d}$

\begin{tabular}{|c|c|c|c|c|c|c|c|c|}
\hline $\begin{array}{c}\text { Câmara } \\
\text { FAAG }\end{array}$ & $\begin{array}{c}\text { Tempo } \\
(\mathrm{h})\end{array}$ & $\begin{array}{c}\text { P1 } \\
(\mathrm{cm})\end{array}$ & $\begin{array}{c}\text { P2 } \\
(\mathrm{cm})\end{array}$ & $\begin{array}{c}\text { P3 } \\
(\mathrm{cm})\end{array}$ & $\begin{array}{c}\text { P4 } \\
(\mathrm{cm})\end{array}$ & $\begin{array}{c}\text { P5 } \\
(\mathrm{cm})\end{array}$ & $\begin{array}{c}\text { P6 } \\
(\mathrm{cm})\end{array}$ & $\begin{array}{c}\text { P7 } \\
(\mathrm{cm})\end{array}$ \\
\hline 1 & 0 & 265,0 & 264,0 & 263,5 & 262,0 & 258,3 & 252,8 & 249,1 \\
1 & 1 & 265,0 & 264,0 & 263,5 & 261,5 & 258,0 & 252,8 & 249,0 \\
2 & 0 & 264,0 & 263,0 & 262,2 & 260,3 & 256,4 & 251,1 & 247,5 \\
2 & 1 & 264,0 & 263,0 & 262,2 & 260,1 & 256,7 & 251,0 & 247,5 \\
\hline
\end{tabular}

Tabela B1.4 - Valores de $\sum \frac{X i}{D g i^{2}}$ para o meio filtrante do FAAG

\begin{tabular}{|c|c|c|c|c|c|}
\hline \multicolumn{2}{|c|}{ Tamanho (mm) } & Dgi (mm) & Espessura (m) & Xi & Xi/Dgi ${ }^{2}\left(\mathrm{~m}^{-2}\right)$ \\
\hline 1,19 & 1,41 & 1,30 & 0,14 & 0,10 & 59598,3 \\
1,41 & 1,68 & 1,54 & 0,28 & 0,20 & 84430,9 \\
1,68 & 2,00 & 1,83 & 0,42 & 0,30 & 8925 \\
2,00 & 2,38 & 2,18 & 0,35 & 0,15 & 52521,0 \\
2,38 & 3,36 & 2,83 & 0,21 & 1,00 & 30457,5 \\
\hline$\Sigma$ & & 1,40 & & 3045 \\
\hline
\end{tabular}


Tabela B1.5 - Valores de $\sum \frac{X i}{D g i^{2}}$ para a camada suporte do FAAG

\begin{tabular}{|c|c|c|c|c|c|}
\hline \multicolumn{2}{|c|}{ Tamanho (mm) } & Dgi $(\mathrm{mm})$ & Espessura (m) & Xi & Xi/Dgi $^{2}\left(\mathrm{~m}^{-2}\right)$ \\
\hline 12,70 & 19,00 & 15,53 & 0,075 & 0,14 & 565,12 \\
6,40 & 12,70 & 9,02 & 0,075 & 0,14 & 1677,70 \\
3,36 & 6,40 & 4,64 & 0,150 & 0,27 & 12682,63 \\
6,40 & 12,70 & 9,02 & 0,075 & 0,14 & 1677,70 \\
12,70 & 19,00 & 15,53 & 0,075 & 0,14 & 565,12 \\
19,00 & 25,40 & 21,97 & 0,100 & 0,18 & 376,75 \\
\hline$\Sigma$ & & & 0,55 & 1,00 & 17545,02 \\
\hline
\end{tabular}

Parte B2

PRÉ-OPERAÇÃO DO SISTEMA DE DUPLA FILTRAÇÃO 2 FILTRO ASCENDENTE DE PEDREGULHO - FILTRO RÁPIDO DESCENDENTE

Tabela B2.1 - Perda de Carga nos piezômetros das câmaras 1 e 2 do FAP

Taxa FAP $=120,0 \mathrm{~m}^{3} / \mathrm{m}^{2} . \mathrm{d}$

\begin{tabular}{|c|c|c|c|c|c|c|}
\hline $\begin{array}{c}\text { Câmara } \\
\text { FAP }\end{array}$ & $\begin{array}{c}\text { Tempo } \\
\text { (h) }\end{array}$ & $\begin{array}{c}\mathrm{P} 1 \\
(\mathrm{~cm})\end{array}$ & $\begin{array}{c}\mathrm{P} 2 \\
(\mathrm{~cm})\end{array}$ & $\begin{array}{c}\text { P3 } \\
(\mathrm{cm})\end{array}$ & $\begin{array}{c}\mathrm{P} 4 \\
(\mathrm{~cm})\end{array}$ & $\begin{array}{c}\text { P5 } \\
(\mathrm{cm})\end{array}$ \\
\hline $\begin{array}{l}1 \\
1 \\
2 \\
2\end{array}$ & $\begin{array}{l}0 \\
1 \\
0 \\
1\end{array}$ & $\begin{array}{l}247,3 \\
247,3 \\
247,2 \\
247,2\end{array}$ & $\begin{array}{l}247,1 \\
247,2 \\
247,1 \\
247,1\end{array}$ & $\begin{array}{l}246,9 \\
246,9 \\
246,9 \\
246,9\end{array}$ & $\begin{array}{l}246,1 \\
246,1 \\
246,1 \\
246,1\end{array}$ & $\begin{array}{l}243,4 \\
243,4 \\
243,4 \\
243,4\end{array}$ \\
\hline
\end{tabular}

Tabela B2.2 - Perda de Carga nos piezômetros das câmaras 1 e 2 do FAP

Taxa FAP $=175,4 \mathrm{~m}^{3} / \mathrm{m}^{2} . \mathrm{d}$

\begin{tabular}{|c|c|c|c|c|c|c|}
\hline $\begin{array}{c}\text { Câmara } \\
\text { FAP }\end{array}$ & $\begin{array}{c}\text { Tempo } \\
\text { (h) }\end{array}$ & $\begin{array}{c}\text { P1 } \\
(\mathrm{cm})\end{array}$ & $\begin{array}{c}\text { P2 } \\
(\mathrm{cm})\end{array}$ & $\begin{array}{c}\text { P3 } \\
(\mathrm{cm})\end{array}$ & $\begin{array}{c}\text { P4 } \\
(\mathrm{cm})\end{array}$ & \\
\hline 1 & 0 & 248,5 & 248,3 & 248,0 & 247,1 & 243,5 \\
$(\mathrm{~cm})$
\end{tabular}

Tabela B2.3 - Perda de Carga nos piezômetros das câmaras 1 e 2 do FAP

Taxa FAP $=220,0 \mathrm{~m}^{3} / \mathrm{m}^{2} . \mathrm{d}$

\begin{tabular}{|c|c|c|c|c|c|c|}
\hline $\begin{array}{c}\text { Câmara } \\
\text { FAP }\end{array}$ & $\begin{array}{c}\text { Tempo } \\
\text { (h) }\end{array}$ & $\begin{array}{c}\text { P1 } \\
(\mathrm{cm})\end{array}$ & $\begin{array}{c}\text { P2 } \\
(\mathrm{cm})\end{array}$ & $\begin{array}{c}\text { P3 } \\
(\mathrm{cm})\end{array}$ & $\begin{array}{c}\text { P4 } \\
(\mathrm{cm})\end{array}$ & \\
\hline 1 & & & & 249,2 & 248,0 & 243,4 \\
$(\mathrm{~cm})$
\end{tabular}


Tabela B2.4- Valores de $\sum \frac{X i}{D g i^{2}}$ para o meio filtrante do FAP

\begin{tabular}{|c|c|c|c|c|c|}
\hline \multicolumn{2}{|c|}{ Tamanho (mm) } & Dgi $(\mathrm{mm})$ & Espessura $(\mathrm{m})$ & $\mathrm{Xi}$ & $\mathrm{Xi}^{-D_{g i}{ }^{2}\left(\mathrm{~m}^{-2}\right)}$ \\
\hline 2,40 & 4,80 & 3,39 & 0,50 & 0,357 & 31002,0 \\
4,80 & 9,60 & 6,79 & 0,40 & 0,286 & 6200,4 \\
9,60 & 15,90 & 12,35 & 0,30 & 0,214 & 1403,9 \\
15,90 & 25,40 & 20,10 & 0,20 & 0,143 & 353,7 \\
\hline$\Sigma$ & & 1,40 & 1,000 & 38960,0 \\
\hline
\end{tabular}


ANEXO C 


\section{ENSAIO 1 DE DUPLA FILTRAÇÃO}

Tabela C1.1 - Condições do ensaio 1 de dupla filtração, Sistema 1 e Água de estudo Tipo I

\begin{tabular}{|c|c|c|}
\hline \multicolumn{3}{|c|}{ Água de Estudo } \\
\hline Turbidez (uT) & & 74,8 a 92,6 \\
\hline $\mathrm{pH}$ & & 7,65 a 8,04 \\
\hline Alcalinidade $(\mathrm{mg} / \mathrm{L} \mathrm{CaCO}$ ) & & 24,0 \\
\hline Temperatura $\left({ }^{\circ} \mathrm{C}\right)$ & & 26,0 a 31,5 \\
\hline Potencial Zeta (mV) & & - \\
\hline \multicolumn{3}{|c|}{ Coagulação } \\
\hline Dosagem sulfato de alumínio (mg/L AL) & & 1,05 \\
\hline Dosagem sulfato de alumínio (mg/L produto comercial líquido) & & 27,5 \\
\hline pH de coagulação & & 7,05 a 7,34 \\
\hline Potencial Zeta $(\mathrm{mV})$ & & - \\
\hline FLA (areia tipo 2) - Turbidez após 30 min de filtração & & 0,35 \\
\hline Gradiente de velocidade na mistura rápida $\left(\mathrm{s}^{-1}\right)$ & & 400 \\
\hline \multicolumn{3}{|c|}{ Taxas de Filtração } \\
\hline CAP com orifício de & média & desvio padrão \\
\hline Vazão Total (L/h) - medidor eletromagnético & 65 & - \\
\hline Taxa de Filtração FAAG $\left(\mathrm{m}^{3} / \mathrm{m}^{2} . \mathrm{d}\right)$ & 120 & - \\
\hline Vazão FRD (L/h) - rotâmetro & 50,7 & - \\
\hline Taxa de Filtração FRD $\left(\mathrm{m}^{3} / \mathrm{m}^{2} . \mathrm{d}\right)$ & 187,2 & - \\
\hline
\end{tabular}


Tabela C1.2 - Resultados do ensaio 1 de dupla filtração - Sistema 1 e Água de estudo Tipo I

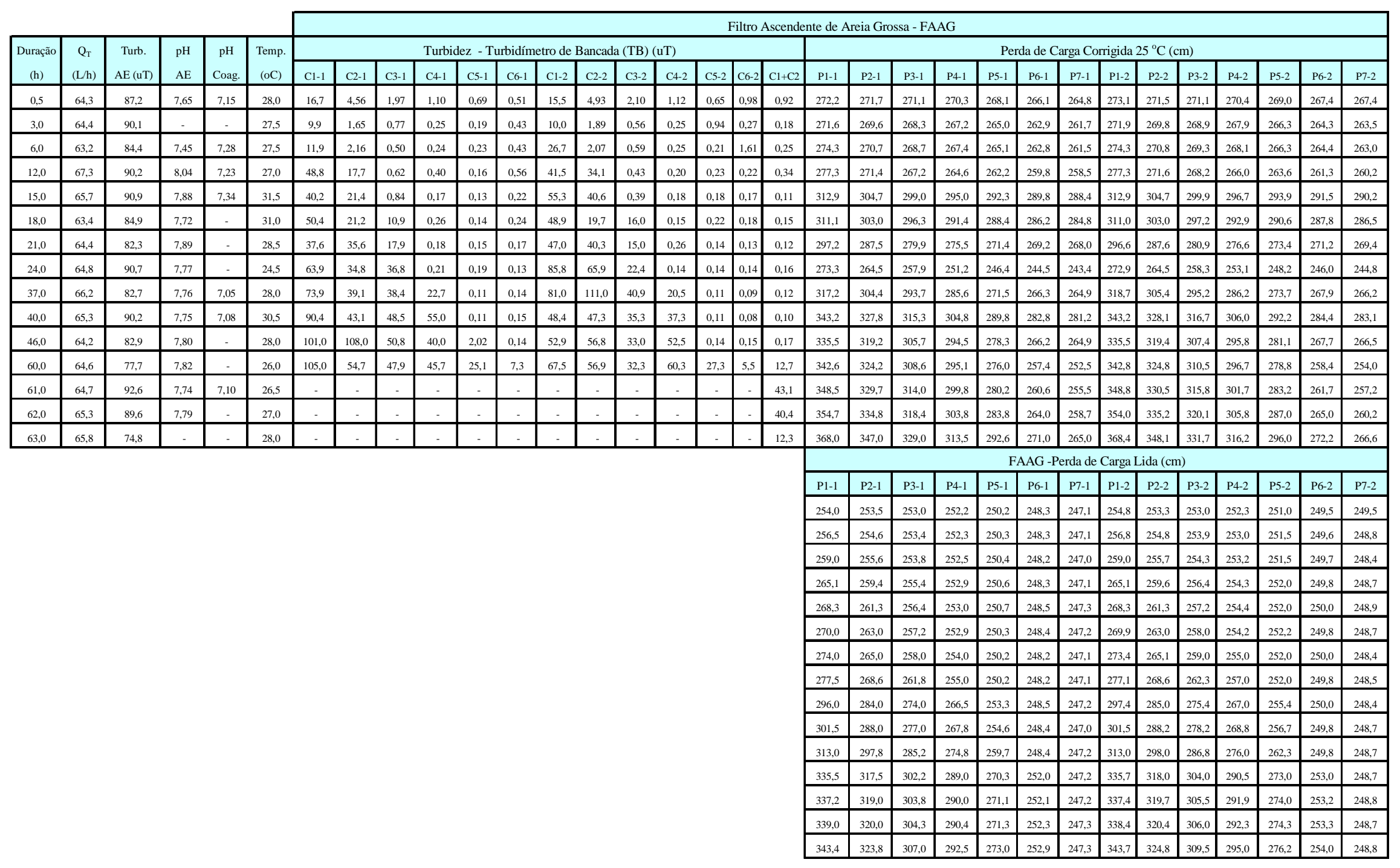


Tabela C1.2 - Continuação

\begin{tabular}{|c|c|c|c|c|c|c|c|}
\hline \multirow{3}{*}{$\begin{array}{l}\text { Duração } \\
\text { (h) }\end{array}$} & \multirow{3}{*}{$\begin{array}{l}\text { Temp. } \\
(\mathrm{oC})\end{array}$} & \multicolumn{6}{|c|}{ Filtro Rápido Descendente - FRD } \\
\hline & & \multirow{2}{*}{$\begin{array}{l}\text { Qfd } \\
(\mathrm{L} / \mathrm{h})\end{array}$} & \multirow{2}{*}{$\begin{array}{c}\text { Turbidez - TB (uT) } \\
\text { AF }\end{array}$} & \multicolumn{2}{|c|}{ Perda de Carga Corrigida $25^{\circ} \mathrm{C}(\mathrm{cm})$} & \multicolumn{2}{|c|}{ Perda de Carga Lida (cm) } \\
\hline & & & & P1 & P2 & P1 & P2 \\
\hline 0,5 & 28,0 & 50,0 & 1,40 & 27,7 & 70,2 & 25,8 & 65,5 \\
\hline 3,0 & 27,5 & 50,5 & 0,10 & 27,5 & 74,1 & 26,0 & 70,0 \\
\hline 6,0 & 27,5 & 54,0 & 0,11 & 26,9 & 78,4 & 25,4 & 74,0 \\
\hline 12,0 & 27,0 & 54,0 & 0,10 & 27,2 & 81,3 & 26,0 & 77,7 \\
\hline 15,0 & 31,5 & 50,0 & 0,09 & 30,4 & 85,5 & 26,1 & 73,3 \\
\hline 18,0 & 31,0 & 50,0 & 0,11 & 30,0 & 81,1 & 26,0 & 70,4 \\
\hline 21,0 & 28,5 & 51,0 & 0,12 & 27,6 & 79,0 & 25,4 & 72,8 \\
\hline 24,0 & 24,5 & 50,0 & 0,13 & 24,1 & 74,4 & 24,5 & 75,5 \\
\hline 37,0 & 28,0 & 50,0 & 0,10 & 25,9 & 78,2 & 24,2 & 73,0 \\
\hline 40,0 & 30,5 & 50,0 & 0,08 & 27,7 & 80,3 & 24,3 & 70,5 \\
\hline 46,0 & 28,0 & 50,0 & 0,16 & 26,4 & 76,4 & 24,6 & 71,3 \\
\hline 60,0 & 26,0 & 50,0 & 0,16 & 25,2 & 87,9 & 24,7 & 86,1 \\
\hline 61,0 & 26,5 & 50,0 & 0,21 & 25,4 & 90,4 & 24,6 & 87,5 \\
\hline 62,0 & 27,0 & 50,0 & 0,20 & 25,7 & 92,6 & 24,6 & 88,5 \\
\hline 63,0 & 28,0 & 51,0 & 0,22 & 26,4 & 99,9 & 24,6 & 93,2 \\
\hline
\end{tabular}

$\mathrm{Q}_{\mathrm{T}}$ : vazão total afluente ao Sistema de Dupla Filtração (medidor de vazão eletromagnético);

Turb. AE: turbidez da água de estudo (turbidímetro de bancada);

pH AE: pH da água de estudo;

pH Coag.: pH de coagulação;

Ci-1: amostra coletada no final da subcamada i do meio filtrante da câmara de filtração 1 do FAAG;

Ci-2: amostra coletada no final da subcamada i do meio filtrante da câmara de filtração 2 do FAAG;

C1+C2: amostra de água pré-filtrada global (efluentes das câmaras de filtração 1 e 2 da FAAG);

Pi-1: piezômetro i localizado na câmara de filtração 1 do FAAG;

Pi-2: piezômetro i localizado na câmara de filtração 2 do FAAG;

Q

Turb. AF: turbidez da água filtrada (turbidímetro de bancada);

P1 e P2: piezômetros localizados no início e no final do FRD, respectivamente.

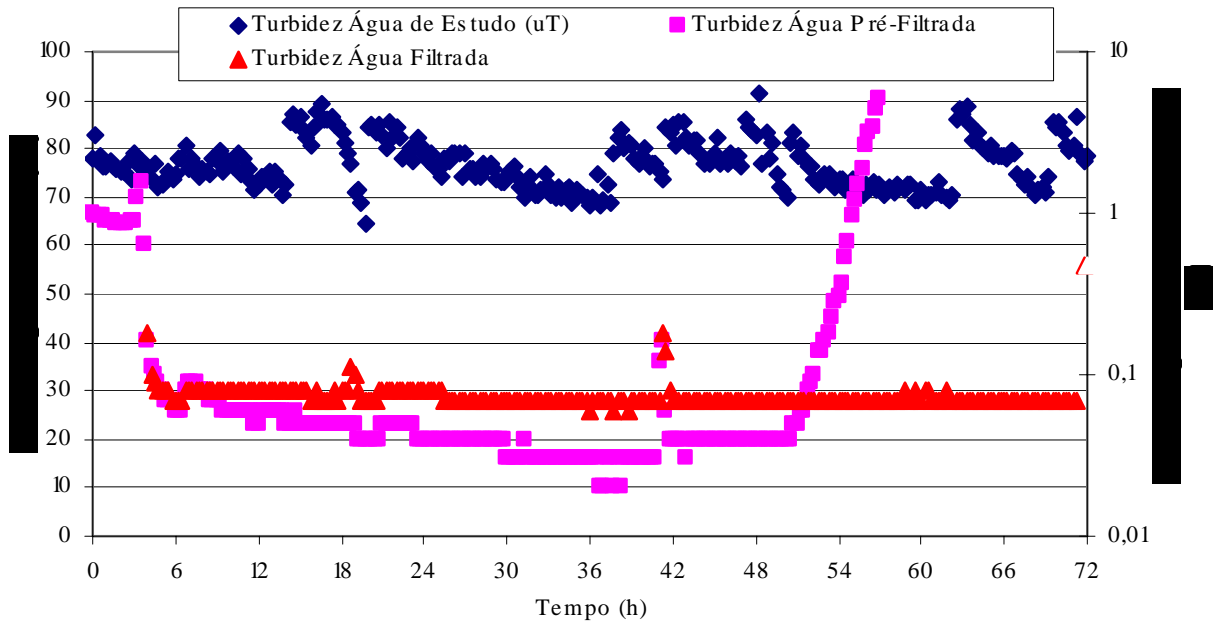

Figura C1.1 - Variação da turbidez das águas de estudo, pré-filtrada e filtrada no ensaio 1 Turbidímetros de Escoamento Contínuo 


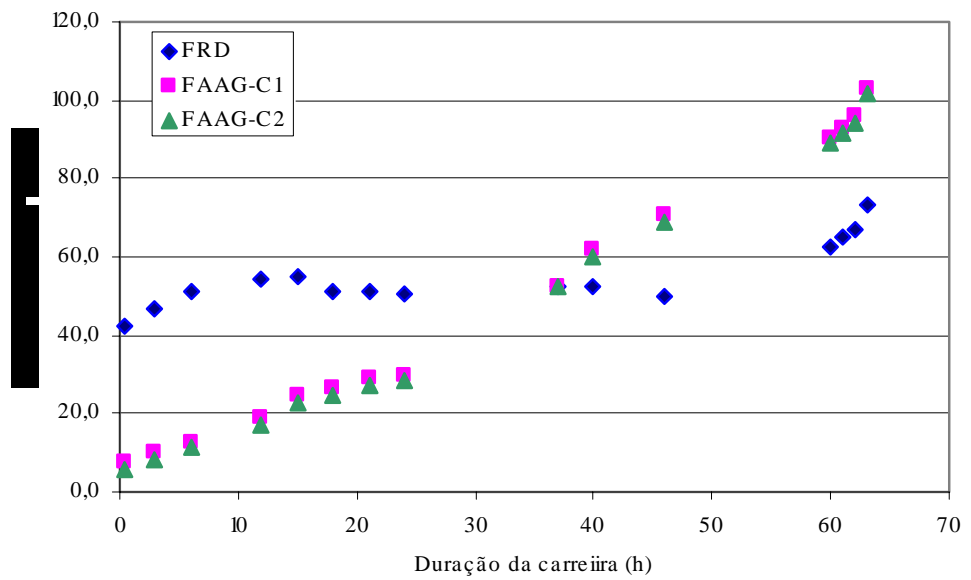

Figura C1.2 - Perda de carga nos filtros ascendente de areia grossa (duas câmaras de filtração) e descendente durante o ensaio 1 de dupla filtração

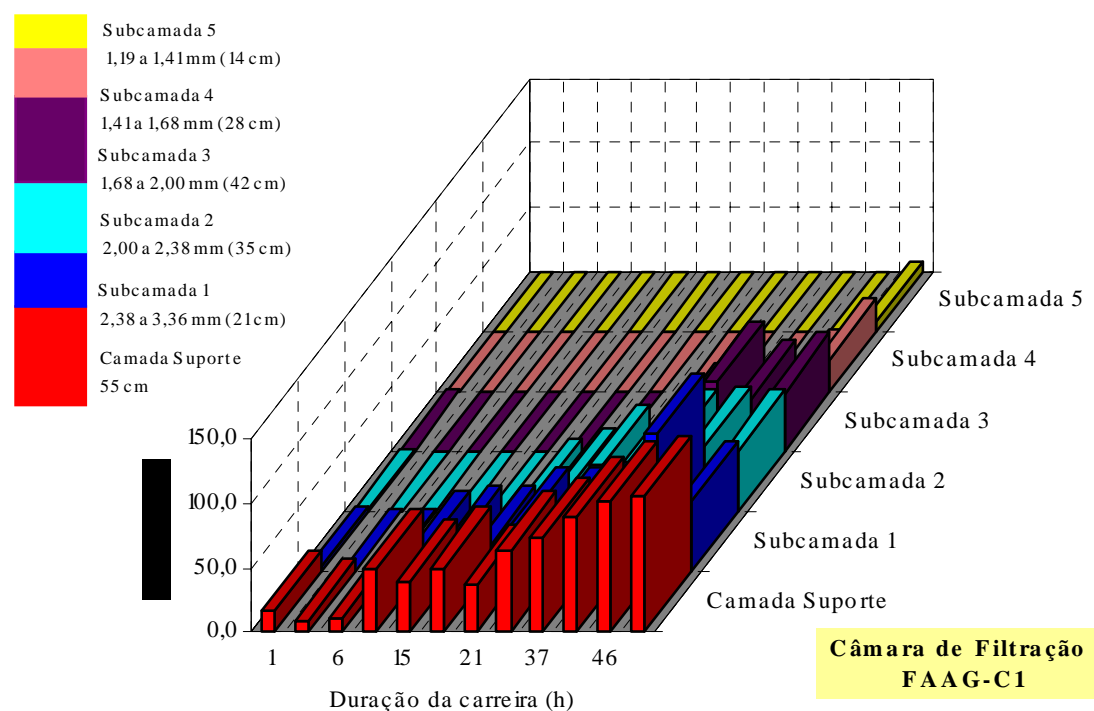

Figura C1.3 - Turbidez ao longo do meio filtrante da câmara de filtração 1 do FAAG durante o ensaio 1 de dupla filtração 


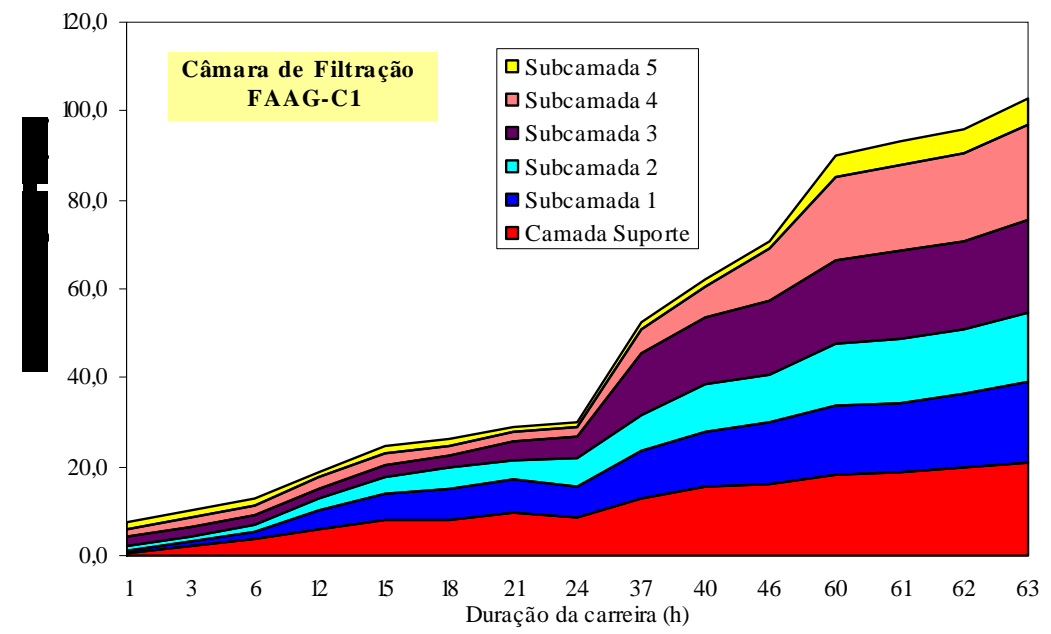

Figura C1.4 - Perda de carga ao longo do meio filtrante da câmara de filtração 1 do FAAG durante o ensaio 1 de dupla filtração

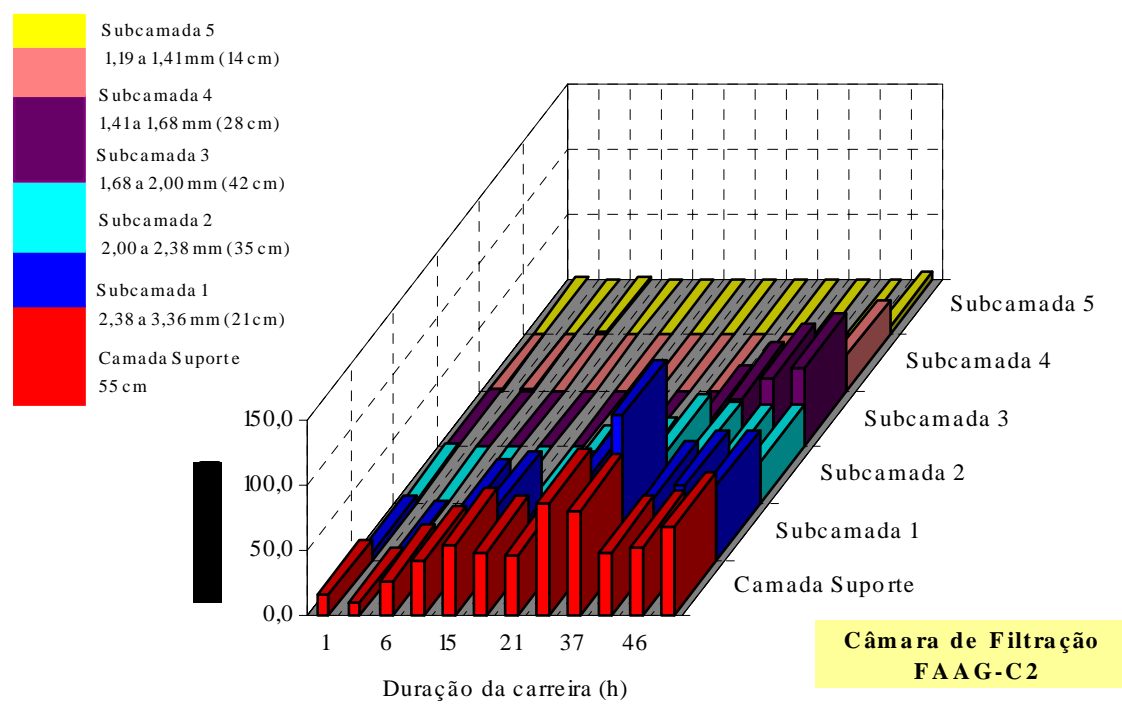

Figura C1.5 - Turbidez ao longo do meio filtrante da câmara de filtração 2 do FAAG durante o ensaio 1 de dupla filtração 


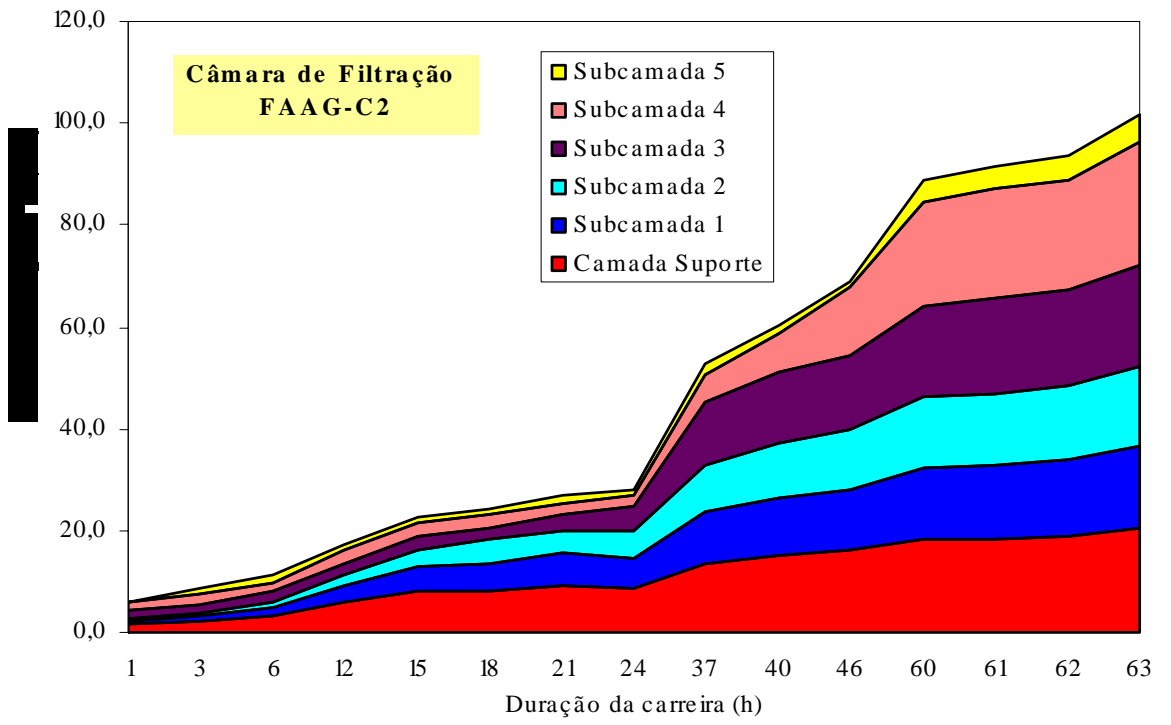

Figura C1.6 - Perda de carga ao longo do meio filtrante da câmara de filtração 2 do FAAG durante o ensaio 1 de dupla filtração 


\section{ENSAIO 2 DE DUPLA FILTRAÇÃO}

Tabela C2.1 - Condições do ensaio 2 de dupla filtração - Sistema 1 e Água de estudo Tipo I

\begin{tabular}{|c|c|c|}
\hline \multicolumn{3}{|c|}{ Água de Estudo } \\
\hline \multicolumn{2}{|l|}{ Turbidez (uT) } & 95,2 a 102 \\
\hline \multicolumn{2}{|l|}{$\mathrm{pH}$} & 7,56 a 7,70 \\
\hline \multicolumn{2}{|l|}{ Alcalinidade $\left(\mathrm{mg} / \mathrm{L} \mathrm{CaCO}_{3}\right)$} & 25,2 \\
\hline \multicolumn{2}{|l|}{ Temperatura $\left({ }^{\circ} \mathrm{C}\right)$} & 23,0 a 27,0 \\
\hline \multicolumn{2}{|l|}{ Potencial Zeta (mV) } & - \\
\hline \multicolumn{3}{|c|}{ Coagulação } \\
\hline \multicolumn{2}{|l|}{ Dosagem sulfato de alumínio (mg/L AL) } & 1,05 \\
\hline \multicolumn{2}{|c|}{ Dosagem sulfato de alumínio (mg/L produto comercial líquido) } & 27,5 \\
\hline \multicolumn{2}{|l|}{ pH de coagulação } & 6,98 a 7,10 \\
\hline \multicolumn{2}{|l|}{ Potencial Zeta (mV) } & - \\
\hline \multicolumn{2}{|l|}{ FLA (areia tipo 2) - Turbidez após 30 min de filtração } & 0,48 \\
\hline \multicolumn{2}{|l|}{ Gradiente de velocidade na mistura rápida $\left(\mathrm{s}^{-1}\right)$} & 400 \\
\hline \multicolumn{3}{|c|}{ Taxas de Filtração } \\
\hline CAP com orifício de & média & desvio padrão \\
\hline Vazão Total (L/h) - medidor eletromagnético & 127,6 & 0,84 \\
\hline Taxa de Filtração FAAG $\left(\mathrm{m}^{3} / \mathrm{m}^{2} . \mathrm{d}\right)$ & 235,6 & 1,6 \\
\hline Vazão FRD (L/h) - rotâmetro & 98,1 & - \\
\hline Taxa de Filtração FRD $\left(\mathrm{m}^{3} / \mathrm{m}^{2} . \mathrm{d}\right)$ & 362,2 & - \\
\hline
\end{tabular}


Tabela C2.2 - Resultados do ensaio 2 de dupla filtração - Sistema 1 e Água de estudo Tipo I

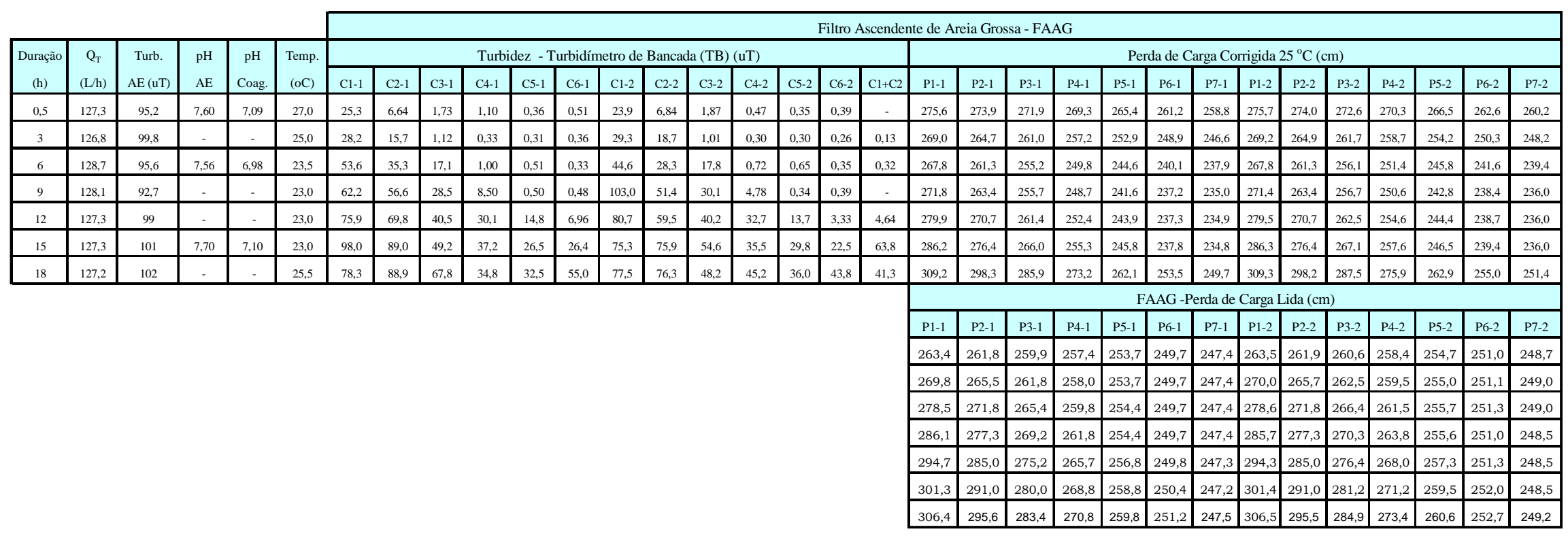

$\mathrm{Q}_{\mathrm{T}}$ : vazão total afluente ao Sistema de Dupla Filtração (medidor de vazão eletromagnético);

Turb. AE: turbidez da água de estudo (turbidímetro de bancada);

pH AE: pH da água de estudo;

pH Coag.: pH de coagulação;

Ci-1: amostra coletada no final da subcamada i do meio filtrante da câmara de filtração 1 do FAAG;

Ci-2: amostra coletada no final da subcamada i do meio filtrante da câmara de filtração 2 do FAAG;

C1+C2: amostra de água pré-filtrada global (efluentes das câmaras de filtração 1 e 2 da FAAG);

Pi-1: piezômetro i localizado na câmara de filtração 1 do FAAG;

Pi-2: piezômetro i localizado na câmara de filtração 2 do FAAG; 
Tabela C2.2 - Continuação

\begin{tabular}{|c|c|c|c|c|c|}
\hline \multirow{3}{*}{$\begin{array}{c}\text { Duração } \\
\text { (h) }\end{array}$} & \multirow{3}{*}{$\begin{array}{l}\text { Temp. } \\
\text { (oC) } \\
\end{array}$} & \multicolumn{4}{|c|}{ Filtro Rápido Descendente - FRD } \\
\hline & & \multirow{2}{*}{$\begin{array}{l}\text { Qfd } \\
(\mathrm{L} / \mathrm{h}) \\
\end{array}$} & \multirow{2}{*}{$\begin{array}{c}\text { Turbidez - TB (uT) } \\
\mathrm{AF}\end{array}$} & \multicolumn{2}{|c|}{ Perda de Carga Corrigida $25^{\circ} \mathrm{C}(\mathrm{cm})$} \\
\hline & & & & P1 & P2 \\
\hline 0,5 & 27,0 & 98,0 & 0,13 & 26,6 & 125,0 \\
\hline 3 & 25,0 & 98,0 & 0,16 & 25,2 & 123,7 \\
\hline 6 & 23,5 & 98,0 & 0,25 & 24,4 & 127,0 \\
\hline 9 & 23,0 & 99,0 & 0,26 & 23,7 & 128,2 \\
\hline 12 & 23,0 & 98,0 & 0,20 & 23,7 & 134,9 \\
\hline 15 & 23,0 & 98,0 & 0,23 & 23,7 & 145,8 \\
\hline \multirow[t]{10}{*}{18} & 25,5 & 99,0 & 0,53 & 25,2 & 176,6 \\
\hline & & & & \multicolumn{2}{|c|}{ Perda de Carga Lida (cm) } \\
\hline & & & & P1 & P2 \\
\hline & & & & 25,4 & 119,5 \\
\hline & & & & 25,3 & 124,1 \\
\hline & & & & 25,4 & 132,1 \\
\hline & & & & 25,0 & 135,0 \\
\hline & & & & 25,0 & 142,0 \\
\hline & & & & 25,0 & 153,5 \\
\hline & & & & 25,0 & 175,0 \\
\hline
\end{tabular}

$\mathrm{Q}_{\mathrm{fd}}$ : vazão afluente ao FRD (rotâmetro);

Turb. AF: turbidez da água filtrada (turbidímetro de bancada);

P1 e P2: piezômetros localizados no início e no final do FRD, respectivamente.

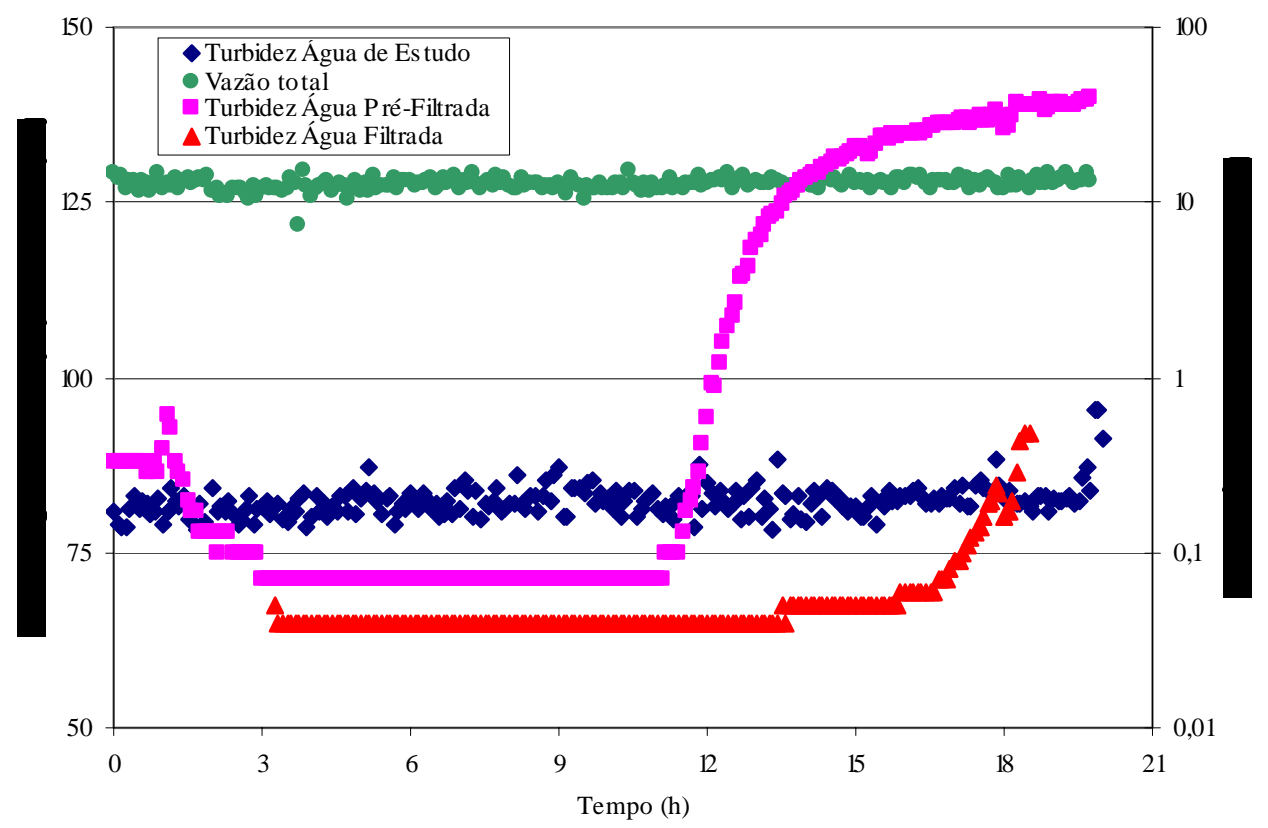

Figura C2.1 - Variações da vazão total afluente ao sistema de dupla filtraçào e da turbidez das águas de estudo, pré-filtrada e filtrada no ensaio 2 - Turbidímetros de Escoamento Contínuo 


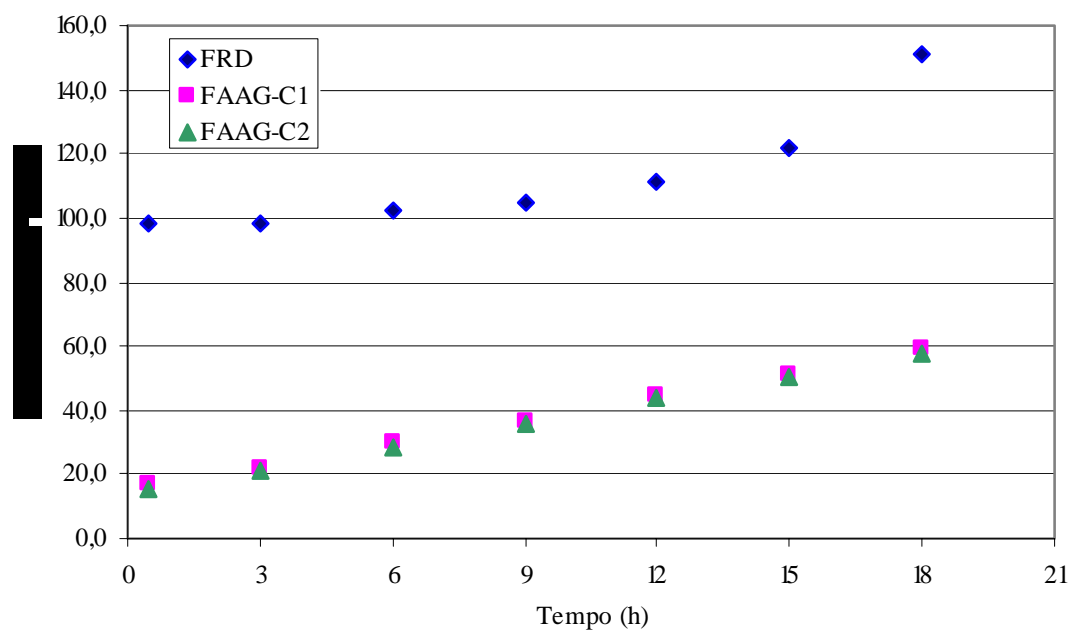

Figura C2.2 - Perda de carga nos filtros ascendente de areia grossa (duas câmaras de filtração) e descendente durante o ensaio 1 de dupla filtração

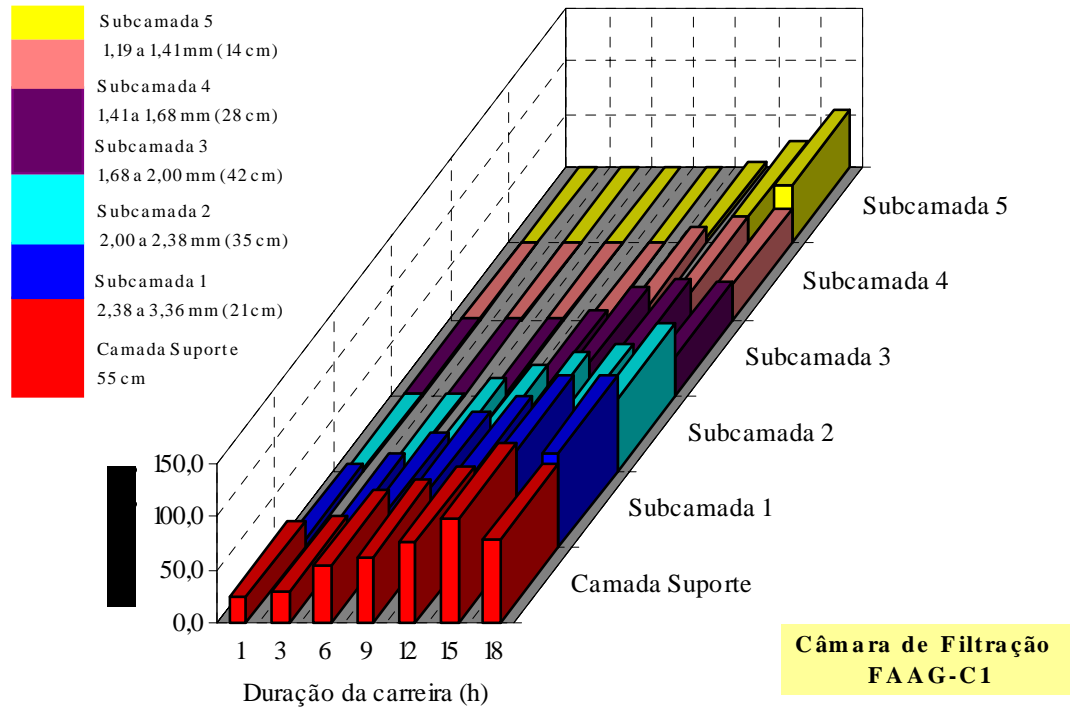

Figura C2.3 - Turbidez ao longo do meio filtrante da câmara de filtração 2 do FAAG durante o ensaio 1 de dupla filtração 


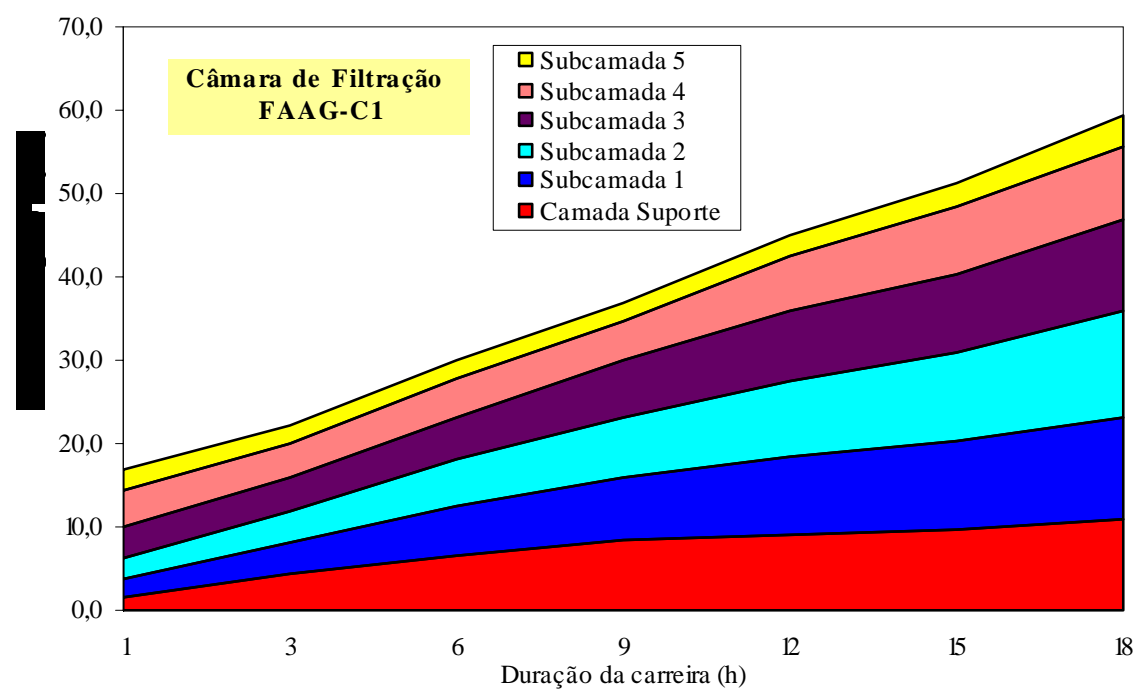

Figura C2.4 - Perda de carga ao longo do meio filtrante da câmara de filtração 1 do FAAG durante o ensaio 2 de dupla filtração

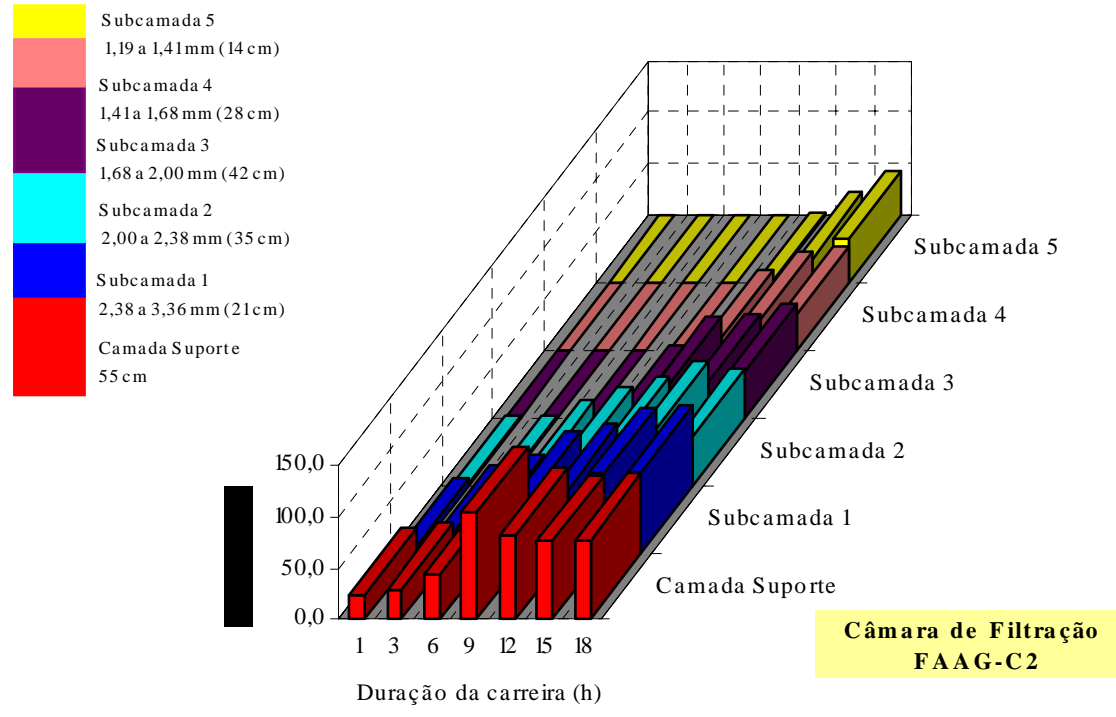

Figura C2.5 - Turbidez ao longo do meio filtrante da câmara de filtração 2 do FAAG durante o ensaio 2 de dupla filtração 


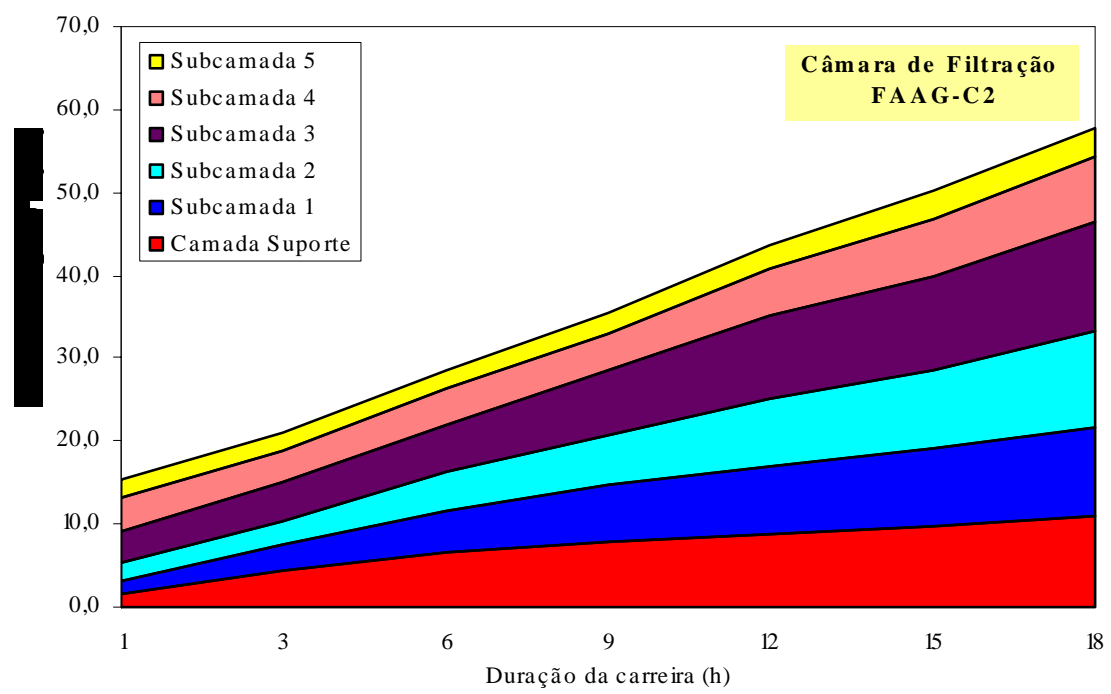

Figura C2.6 - Perda de carga ao longo do meio filtrante da câmara de filtração 2 do FAAG durante o ensaio 2 de dupla filtração 


\section{ENSAIO 3 DE DUPLA FILTRAÇÃO}

Tabela C3.1 - Condições do ensaio 3 de dupla filtração - Sistema 1 e Água de estudo Tipo I

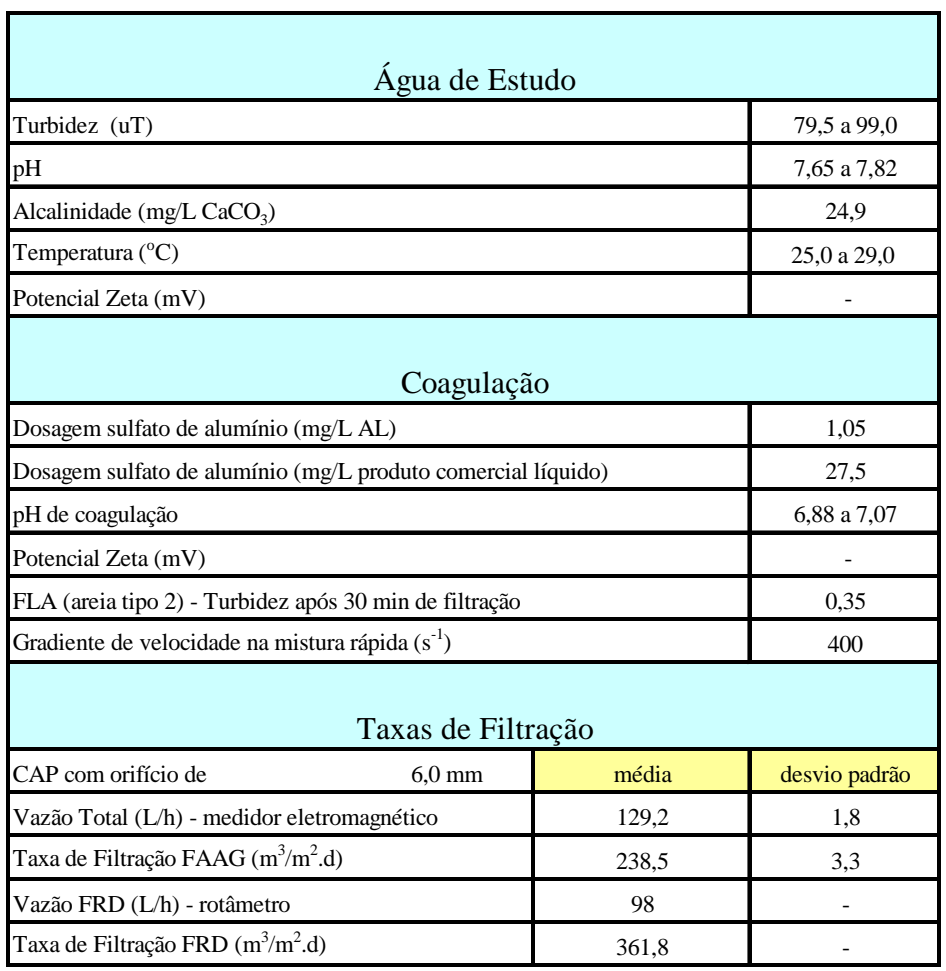


Tabela C3.2 - Resultados do ensaio 3 de dupla filtração - Sistema 1 e Água de estudo Tipo I

\begin{tabular}{|c|c|c|c|c|c|c|c|c|c|c|c|c|c|c|c|c|c|c|c|c|c|c|c|c|c|c|c|c|c|c|c|c|}
\hline \multirow{3}{*}{\begin{tabular}{|c} 
Duração \\
(1) \\
\end{tabular}} & \multirow{3}{*}{$\begin{array}{c}\mathrm{Q}_{\mathrm{T}} \\
(\mathrm{L} / \mathrm{h})\end{array}$} & \multirow{3}{*}{$\begin{array}{c}\text { Turb. } \\
\mathrm{AE}(\mathrm{UT})\end{array}$} & \multirow{3}{*}{$\begin{array}{l}\mathrm{pH} \\
\mathrm{AE} \\
\end{array}$} & \multirow{3}{*}{$\begin{array}{c}\text { pH } \\
\text { Coag. }\end{array}$} & \multirow{3}{*}{$\begin{array}{l}\text { Temp. } \\
\text { (oC) }\end{array}$} & \multicolumn{27}{|c|}{ Filtro Ascendente de Areia Grossa - FAAG } \\
\hline & & & & & & \multicolumn{13}{|c|}{ Turbidez - Turbidimetro de Bancada (TB) (uT) } & \multicolumn{14}{|c|}{ Perda de Carga Corrigida $25^{\circ} \mathrm{C}(\mathrm{cm})$} \\
\hline & & & & & & C1-1 & -1 & C3-1 & C4-1 & $\mathrm{Cs}-1$ & $66-1$ & $\mathrm{Cl}-2$ & $\mathrm{C2}-2$ & C3-2 & $\mathrm{C4} 42$ & C5-2 & $\mathrm{CG-2}$ & $\mathrm{C1+ \textrm {C } 2}$ & P1-1 & P2-1 & P3-1 & $\mathrm{P4} 4$ & 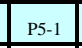 & \begin{tabular}{|l|l}
$\mathrm{P} 6-1$ \\
\end{tabular} & \begin{tabular}{|l|l} 
P7-1 \\
\end{tabular} & P1-2 & P2-2 & P3-2 & $\mathrm{P4} 42$ & 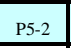 & $\frac{P 6-2}{2}$ & $1-2$ \\
\hline 0,5 & 130,0 & 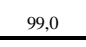 & 7,70 & 7,07 & 29,0 & 27,6 & 65 & 2,02 & 0,68 & 0,40 & 0,48 & 27,8 & 8,42 & 2,52 & 0,53 & 0,56 & 0,43 & 0,36 & 290,4 & 288,9 & 287,4 & 284,7 & 280,0 & 275,4 & 271,6 & 290,7 & \begin{tabular}{|l|l}
289,3 & 2 \\
2
\end{tabular} & 287,8 & 285,7 & 281,2 & 276,7 & 273,0 \\
\hline 3,0 & 129,3 & & & & 9,0 & 34,0 & 4,5 & 1,32 & 0,88 & 0,27 & 0,10 & 32,9 & 14,9 & 0,96 & 0,80 & 0,48 & 0,31 & 0,1 & 296,4 & 292,0 & 288,2 & 283,9 & 279,0 & 274,5 & 271,6 & 296,7 & \begin{tabular}{|l|l}
292,6 & 2 \\
\end{tabular} & 289,8 & 288,5 & 0,5 & 276,5 & 273,4 \\
\hline 6,0 & & & & & & & & & & & 0,20 & 37,8 & 28,60 & 17,80 & 0,42 & 0,16 & 0,16 & 0,19 & 296,9 & & 284,3 & 278,2 & & 267,8 & 265,1 & 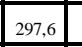 & \begin{tabular}{l|l}
291,3 & 2 \\
2
\end{tabular} & 285,6 & 279,7 & & & 0,5 \\
\hline 6,5 & & & & & & & & 2,08 & 0,58 & 0,31 & 0,39 & 27,2 & 8,53 & 1,89 & 0,50 & 0,31 & 0,23 & 0,26 & 278,5 & 277,1 & 275,5 & 273,0 & 268,7 & 264,6 & \begin{tabular}{|l|l}
262,0 \\
\end{tabular} & \begin{tabular}{|l}
278,5 \\
\end{tabular} & \begin{tabular}{ll|}
277,2 & 2
\end{tabular} & 275,8 & 273,6 & 269,5 & 65,9 & 263,1 \\
\hline 9,0 & 30,0 & & & & 27,0 & 40,8 & 13,8 & 1,93 & 0,80 & 1,02 & 0,24 & 32,2 & 15,4 & $\begin{array}{l}1,16 \\
\end{array}$ & 0,32 & 0,26 & 0,22 & 1,60 & 282,5 & 278,3 & 274,7 & 270,8 & 265,7 & 2661,4 & 258,7 & 282,4 & \begin{tabular}{|l|l|}
278,6 & 2 \\
\end{tabular} & 275,3 & 27 & 266,7 & 62,8 & 260,0 \\
\hline 12,0 & 128,7 & & & & 26,0 & 54,6 & 27,3 & 14,8 & 0,34 & $0,33^{2}$ & 0,19 & 47,6 & 27,2 & 14,7 & 0,58 & 0,27 & 0,18 & 0,18 & 282,9 & 276,8 & 271,3 & 265,5 & 259,7 & 255,1 & 252,5 & 283,0 & 277,22 & 272,1 & 266 & 260,5 & 56,4 & 253,8 \\
\hline 13,0 & & & & & & & 16,8 & 2 & 0,800 & 0, & 1,15 & 32,1 & 10,0 & 2,95 & 0,31 & 0,69 & 0,55 & & 1,3 & 269,9 & 268,0 & 265,1 & $=$ & 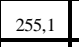 & 25. & 271,7 & $2 \pi$ & 268,5 & & 260,7 & - & 254,5 \\
\hline 15,0 & & & & & & & & & & & & & & & & & & 0,3 & 4,1 & 269,3 & 265,5 & 261,5 & \begin{tabular}{l|l}
254,6 \\
\end{tabular} & 249,1 & \begin{tabular}{|l|l}
246,7 \\
\end{tabular} & 274,4 & 270,42 & 266,5 & 263,0 & 254,0 & 250,4 & 248,2 \\
\hline 18,0 & 29,7 & & & & 25,0 & 64,7 & 54,0 & 25,8 & 16. & 0,75 & 0,39 & 49,3 & 29,5 & 23,80 & 12,1 & 3,21 & 0,29 & 0,68 & 283,1 & 276 & 27,0 & 263,2 & $5,8,8$ & 249,2 & 246,7 & 283,1 & 276,6 & 270,7 & $26=$ & 255,2 & 50,4 & 248, \\
\hline 19,0 & 129,9 & & & & 25,0 & 38,4 & 14,7 & 4,81 & 2,00 & 3,62 & 4,00 & 39,0 & 14,3 & 6,21 & 1,20 & 0,69 & 0,78 & 30,6 & 273,1 & 270,2 & 268,2 & 264,2 & \begin{tabular}{|l|}
257,5 \\
\end{tabular} & \begin{tabular}{|l|}
250,2 \\
\end{tabular} & 244,7 & $3,1]=$ & 270,52 & 268,2 & - & 255,6 & 0 & 248,2 \\
\hline . 2,0 & 129 & & & 7, & 25,0 & 52,4 & 30,3 & 14,9 & 9,53 & 4,96 & 4,14 & 46,4 & 30,5 & 12,5 & 6,50 & 0,31 & 0,38 & 6,39 & 280,9 & 275,3 & 271,2 & 265,7 & 258,2 & 250,2 & \begin{tabular}{|l|}
246,7 \\
\end{tabular} & $280,9=$ & 276,12 & 271,2 & 265,2 & 256,2 & 50,2 & 248,2 \\
\hline 24,0 & $122^{-}$ & 93 & & & & 50,8 & & - & 21,3 & 16,8 & 12,6 & \begin{tabular}{l|l|}
64,6 \\
\end{tabular} & 43,6 & 32 & 23,30 & 4,83 & 0.57 & 5,53 & 2911 & 283,1 & 276,1 & 268,2 & 89,2 & 250,7 & 246,7 & 291,1 & 284,12 & 276,8 & 268,2 & 257,2 & 50,7 & 248, \\
\hline 25,0 & & & & & 26,0 & 40,3 & 5,8 & \begin{tabular}{|l}
6,80 \\
\end{tabular} & 6,05 & 2,60 & 4,98 & 35,2 & 16,9 & 5,40 & \begin{tabular}{ll|}
1,86 \\
\end{tabular} & 1,63 & 1,57 & .28 & 278,8 & 277,0 & 274,7 & 270,6 & 8,0 & 256,8 & \begin{tabular}{|l}
252,8 \\
\end{tabular} & 8.8 & \begin{tabular}{|l|l|}
277,3 & 2 \\
\end{tabular} & 274,9 & 270,8 & 263,0 & 56,8 & $25,3,3$ \\
\hline 27,0 & $130, \mathrm{C}$ & & & & 26,5 & & & & & & & & & & & & & & 291,5 & 287,4 & 281,9 & 275,5 & 267,7 & 260,0 & \begin{tabular}{|l|l|}
255,8 \\
\end{tabular} & 291,8 & 28878 & 282,6 & 27 & 266,7 & 260,5 & 257,4 \\
\hline 30,4 & 130, & & & & & & 49 & 20,3 & 27,4 & 18,60 & 14,1 & 55,6 & 46,0 & 32, & 23,8 & 15,3 & 9,93 & 19, & 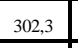 & 295,0 & 286,6 & 277,7 & 8,7 & 260,1 & \begin{tabular}{|l}
2255,8 \\
\end{tabular} & 302,7 & \begin{tabular}{l|l|l}
6,0 & 2 \\
\end{tabular} & 288,4 & 27. & 268,1 & 0,8 & 257,4 \\
\hline & & & & & 26,5 & 34,9 & 12,2 & \begin{tabular}{|l}
2,89 \\
\end{tabular} & 1,13 & 0,7 & 1,08 & 39,9 & 15,4 & 4,62 & \begin{tabular}{ll|}
0,98 \\
\end{tabular} & 1,54 & 5,08 & 11,3 & 0,1 & 277,8 & 275,2 & 271,0 & \begin{tabular}{|l|l|}
265,2 \\
\end{tabular} & 259,2 & \begin{tabular}{|l|}
255,8 \\
\end{tabular} & 280,1 & 278,12 & 275,6 & 27 & 265,5 & 260,2 & 257 \\
\hline & 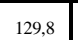 & & & & 2,0 & 4,3 & 20,3 & 8,45 & 3,22 & 1,57 & 1,62 & 37,5 & 21,2 & 9,98 & 3,33 &, 26 & 1,31 & 2,72 & 289,8 & 285,6 & 280,8 & 275,4 & \begin{tabular}{|l|}
268,9 \\
\end{tabular} & 262,4 & 258,9 & $289,8]$ & \begin{tabular}{|l|l|}
285,4 & 2 \\
\end{tabular} & 281,4 & 276,7 & 269,1 & 63,3 & 2 260,0 \\
\hline
\end{tabular}


Tabela C3.2 - Continuação

\begin{tabular}{|c|c|c|c|c|c|c|c|c|c|c|c|c|c|c|}
\hline \multirow{2}{*}{$\begin{array}{c}\text { Duração } \\
\text { (h) }\end{array}$} & \multicolumn{14}{|c|}{ FAAG -Perda de Carga Lida (cm) } \\
\hline & P1-1 & P2-1 & P3-1 & P4-1 & P5-1 & P6-1 & P7-1 & P1-2 & P2-2 & P3-2 & P4-2 & P5-2 & P6-2 & P7-2 \\
\hline 0,5 & 264,5 & 263,1 & 261,8 & 259,3 & 255,0 & 250,8 & 247,4 & 264,8 & 263,5 & 262,1 & 260,2 & 256,1 & 252,0 & 248,7 \\
\hline 3,0 & 270,0 & 266,0 & 262,5 & 258,6 & 254,1 & 250,0 & 247,4 & 270,2 & 266,5 & 264,0 & 260,0 & 255,5 & 251,8 & 249,0 \\
\hline 6,0 & 277,0 & 271,0 & 265,3 & 259,6 & 254,1 & 249,9 & 247,4 & 277,7 & 271,8 & 266,5 & 261,0 & 255,2 & 251,4 & 249,0 \\
\hline 6,5 & 263,0 & 261,7 & 260,2 & 257,8 & 253,8 & 249,9 & 247,4 & 263,0 & 261,8 & 260,5 & 258,4 & 254,5 & 251,1 & 248,5 \\
\hline 9,0 & 270,0 & 266,0 & 262,6 & 258,8 & 254,0 & 249,9 & 247,3 & 269,9 & 266,3 & 263,1 & 259,5 & 254,9 & 251,2 & 248,5 \\
\hline 12,0 & 277,0 & 271,0 & 265,7 & 260,0 & 254,3 & 249,8 & 247,2 & 277,1 & 271,4 & 266,4 & 261,1 & 255,1 & 251,1 & 248,5 \\
\hline 13,0 & 265,7 & 264,3 & 262,4 & 259,6 & 254,8 & 249,8 & 247,5 & 266,0 & 264,5 & 262,9 & 260,8 & 255,3 & 251,2 & 249,2 \\
\hline 15,0 & 275,0 & 270,1 & 266,3 & 262,3 & 255,4 & 249,9 & 247,5 & 275,3 & 271,2 & 267,3 & 263,8 & 254,8 & 251,2 & 249,0 \\
\hline 18,0 & 284,0 & 277,0 & 270,8 & 264 & 256,6 & 250,0 & 247,5 & 284,0 & 277,5 & 271,5 & 265,0 & 256,0 & 251,2 & 249,0 \\
\hline 19,0 & 274,0 & 271,0 & 269 & 265 & 258,3 & 251,0 & 247,5 & 274,0 & 271,3 & 269,0 & 264,5 & 256,4 & 251,2 & 249,0 \\
\hline 21,0 & 281,8 & 276,2 & 272 & 266,5 & 259,0 & 251,0 & 247,5 & 281,8 & 277,0 & 272,0 & 266,0 & 257,0 & 251,0 & 249,0 \\
\hline 24,0 & 292,0 & 284,0 & 277 & 269 & 260,0 & 251,5 & 247,5 & 292,0 & 285,0 & 277,7 & 269,0 & 258,0 & 251,5 & 249,0 \\
\hline 25,0 & 273,0 & 271,2 & 269 & 265 & 258,5 & 251,5 & 247,5 & 273,0 & 271,5 & 269,2 & 265,2 & 257,5 & 251,5 & 249,0 \\
\hline 27,0 & 282,0 & 278,0 & 272,7 & 266,5 & 259,0 & 251,5 & 247,5 & 282,3 & 278,4 & 273,4 & 267,2 & 258,0 & 252,0 & 249,0 \\
\hline 30,0 & 292,5 & 285,4 & 277,3 & 268,7 & 260,0 & 251,6 & 247,5 & 292,8 & 286,4 & 279,0 & 270,2 & 259,4 & 252,3 & 249,0 \\
\hline 31,0 & 271,0 & 268,8 & 266,2 & 262,2 & 256,6 & 250,8 & 247,5 & 271,0 & 269,0 & 266,6 & 263,2 & 256,9 & 251,7 & 249,0 \\
\hline 33,0 & 277,0 & 273,0 & 268,4 & 263,2 & 257,0 & 250,8 & 247,5 & 277,0 & 272,8 & 269,0 & 264,5 & 257,2 & 251,7 & 249,0 \\
\hline
\end{tabular}

QT: vazão total afluente ao Sistema de Dupla Filtração (medidor de vazão eletromagnético);

Turb. AE: turbidez da água de estudo (turbidímetro de bancada);

pH AE: pH da água de estudo;

pH Coag.: pH de coagulação;

Ci-1: amostra coletada no final da subcamada i do meio filtrante da câmara de filtração 1 do FAAG;

Ci-2: amostra coletada no final da subcamada i do meio filtrante da câmara de filtração 2 do FAAG;

C1+C2: amostra de água pré-filtrada global (efluentes das câmaras de filtração 1 e 2 da FAAG);

Pi-1: piezômetro i localizado na câmara de filtração 1 do FAAG;

Pi-2: piezômetro i localizado na câmara de filtração 2 do FAAG;
Execução de DFI nas duas câmaras de filtração do FAAG; 
Tabela C3.2 - Continuação

\begin{tabular}{|c|c|c|c|c|c|}
\hline \multirow{3}{*}{$\begin{array}{c}\text { Duração } \\
\text { (h) }\end{array}$} & \multirow{3}{*}{$\begin{array}{l}\text { Temp. } \\
\text { (oC) }\end{array}$} & \multicolumn{4}{|c|}{ Filtro Rápido Descendente - FRD } \\
\hline & & \multirow{2}{*}{$\begin{array}{l}\text { Qfd } \\
(\mathrm{L} / \mathrm{h})\end{array}$} & \multirow{2}{*}{$\begin{array}{c}\text { Turbidez - TB (uT) } \\
\text { AF } \\
\end{array}$} & \multicolumn{2}{|c|}{ Perda de Carga Corrigida $25^{\circ} \mathrm{C}(\mathrm{cm})$} \\
\hline & & & & $\mathrm{P} 1$ & P2 \\
\hline 0,5 & 29,0 & 98,0 & 0,32 & 28,4 & 135,9 \\
\hline 3,0 & 29,0 & 98,0 & 0,10 & 28,4 & 135,0 \\
\hline 6,0 & 28,0 & 98,0 & 0,10 & 27,8 & 133,5 \\
\hline 6,5 & 27,5 & 98,0 & 0,16 & 27,4 & 131,6 \\
\hline 9,0 & 27,0 & 98,0 & 0,18 & 27,1 & 138,4 \\
\hline 12,0 & 26,0 & 98,0 & 0,15 & 26,5 & 139,2 \\
\hline 13,0 & 26,0 & 98,0 & 0,24 & 26,5 & 141,4 \\
\hline 15,0 & 25,0 & 98,0 & 0,18 & 25,8 & 140,9 \\
\hline 18,0 & 25,0 & 98,0 & 0,22 & 25,8 & 144,0 \\
\hline 19,0 & 25,0 & 98,0 & 0,17 & 25,8 & 153,5 \\
\hline 21,0 & 25,0 & 98,0 & 0,18 & 25,8 & 156,2 \\
\hline 24,0 & 25,0 & 98,0 & 0,25 & 25,8 & 161,8 \\
\hline 25,0 & 26,0 & 98,0 & 0,45 & 26,5 & 171,6 \\
\hline 27,0 & 26,5 & 98,0 & & 26,8 & 184,8 \\
\hline 30,0 & 26,5 & 98,0 & 0,84 & 26,8 & 191,5 \\
\hline 31,0 & 26,5 & 98,0 & 1,06 & 26,8 & 198,1 \\
\hline \multirow[t]{20}{*}{33,0} & 27,0 & 98,0 & 0,43 & 27,1 & 207,1 \\
\hline & & & & \multicolumn{2}{|c|}{ Perda de Carga Lida (cm) } \\
\hline & & & & P1 & $\mathrm{P} 2$ \\
\hline & & & & 25,9 & 123,8 \\
\hline & & & & 25,9 & 123,0 \\
\hline & & & & 25,9 & 124,6 \\
\hline & & & & 25,9 & 124,3 \\
\hline & & & & 25,9 & 132,3 \\
\hline & & & & 25,9 & 136,3 \\
\hline & & & & 25,9 & 138,5 \\
\hline & & & & 25,9 & 141,3 \\
\hline & & & & 25,9 & 144,4 \\
\hline & & & & 25,9 & 154,0 \\
\hline & & & & 25,9 & 156,7 \\
\hline & & & & 25,9 & 162,3 \\
\hline & & & & 25,9 & 168,0 \\
\hline & & & & 25,9 & 178,8 \\
\hline & & & & 25,9 & 185,3 \\
\hline & & & & 25,9 & 191,7 \\
\hline & & & & 25,9 & 198,0 \\
\hline
\end{tabular}

$\mathrm{Q}_{\mathrm{fd}}$ : vazão afluente ao FRD (rotâmetro);

Turb. AF: turbidez da água filtrada (turbidímetro de bancada);

P1 e P2: piezômetros localizados no início e no final do FRD, respectivamente. 


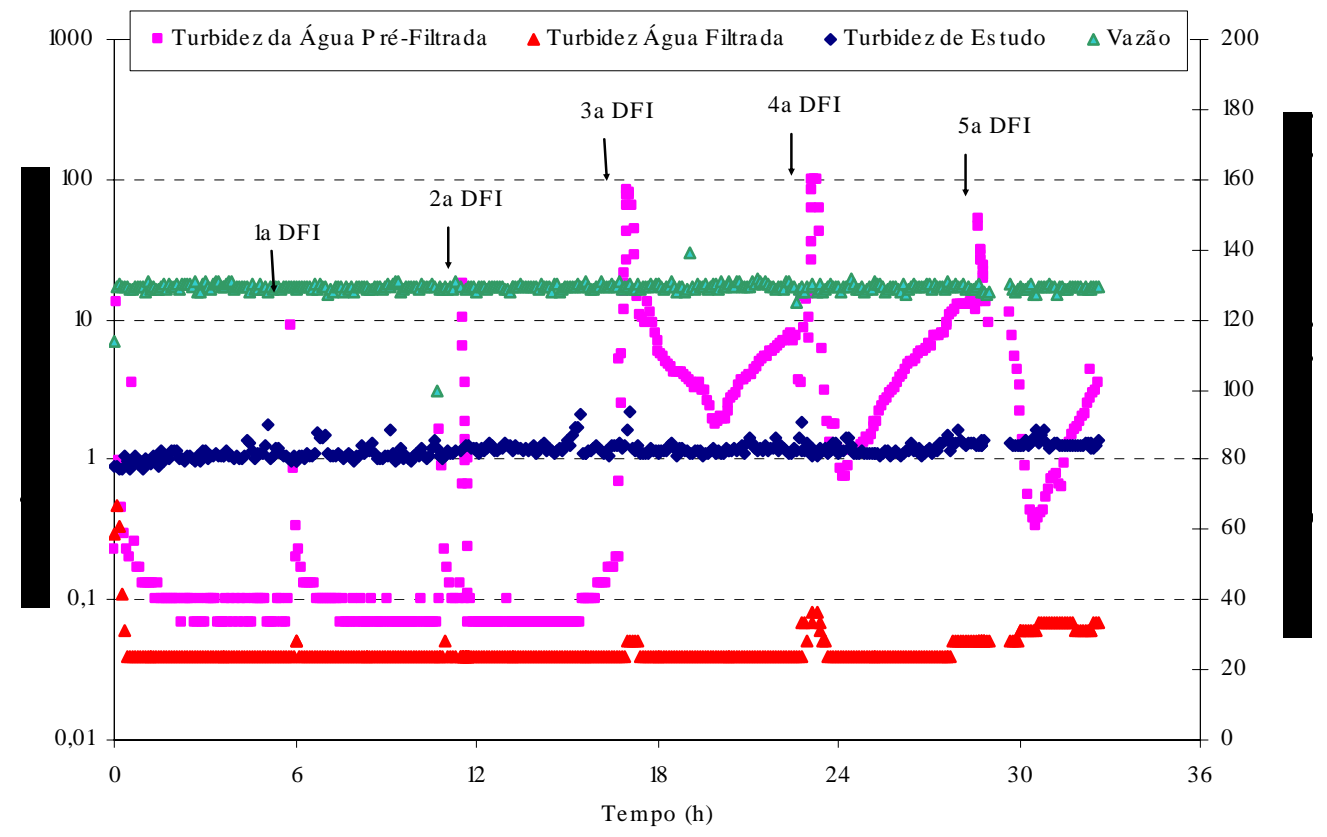

Figura C3.1 - Variações da vazão total afluente ao sistema de dupla filtraçào e da turbidez das águas de estudo, pré-filtrada e filtrada no ensaio 3 - Turbidímetros de Escoamento Contínuo

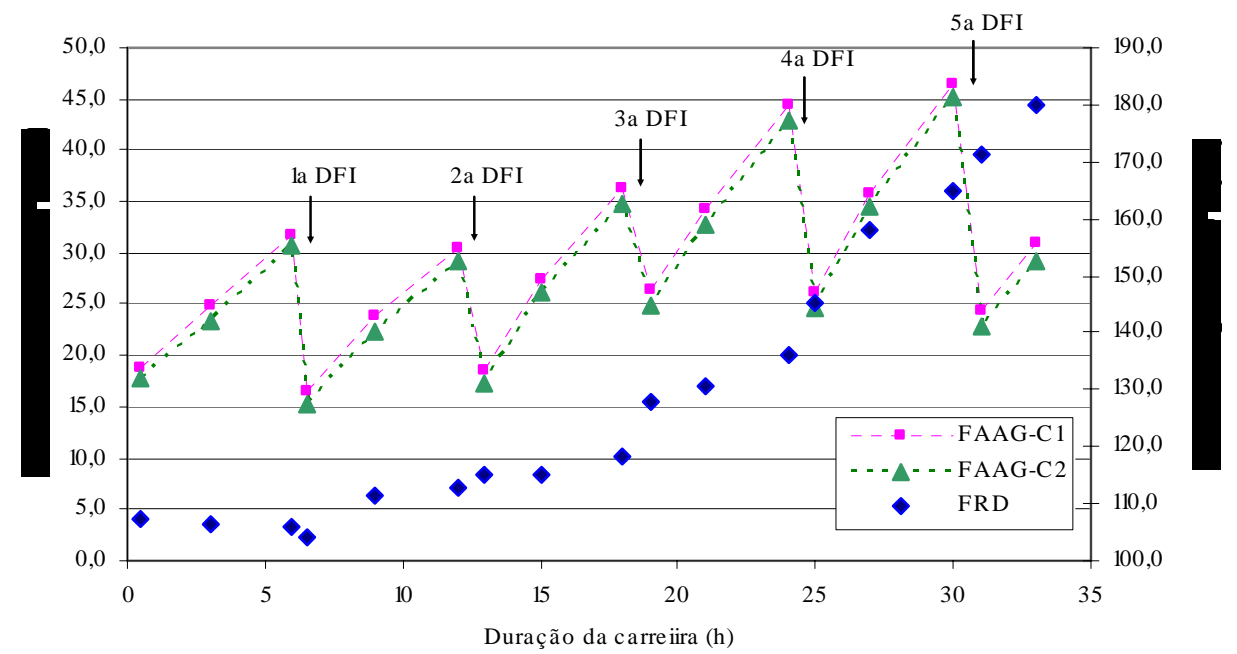

Figura C3.2 - Perda de carga nos filtros ascendente de areia grossa (duas câmaras de filtração) e descendente durante o ensaio 1 de dupla filtração 


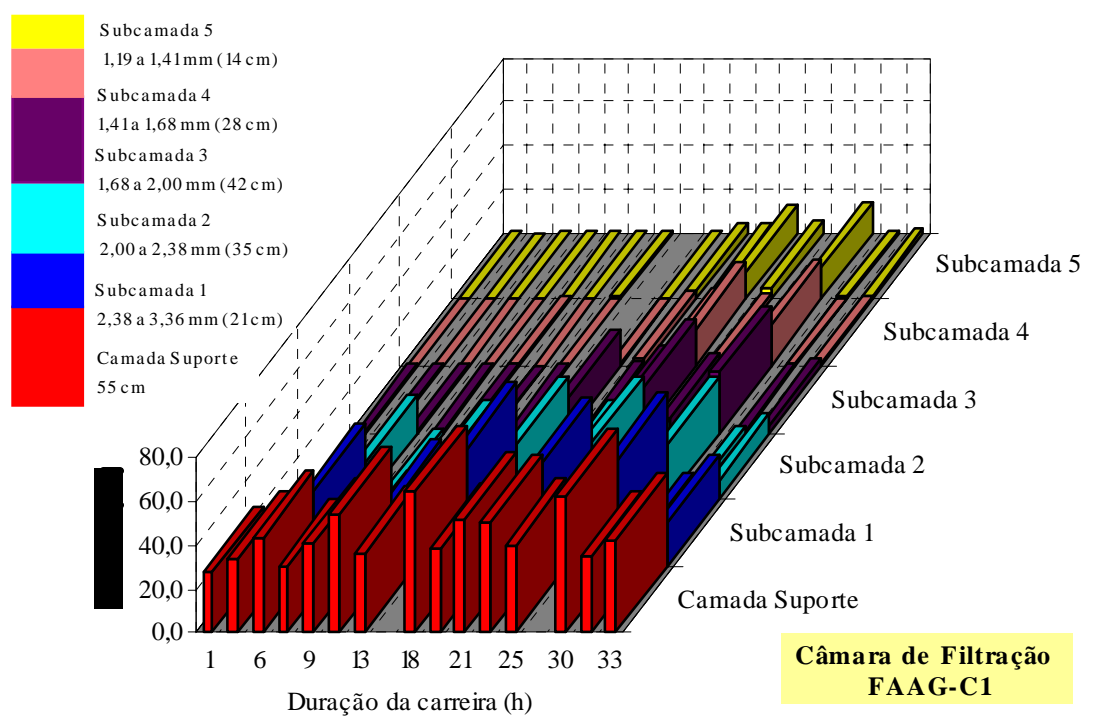

Figura C3.3 - Turbidez ao longo do meio filtrante da câmara de filtração 1 do FAAG durante o ensaio 1 de dupla filtração

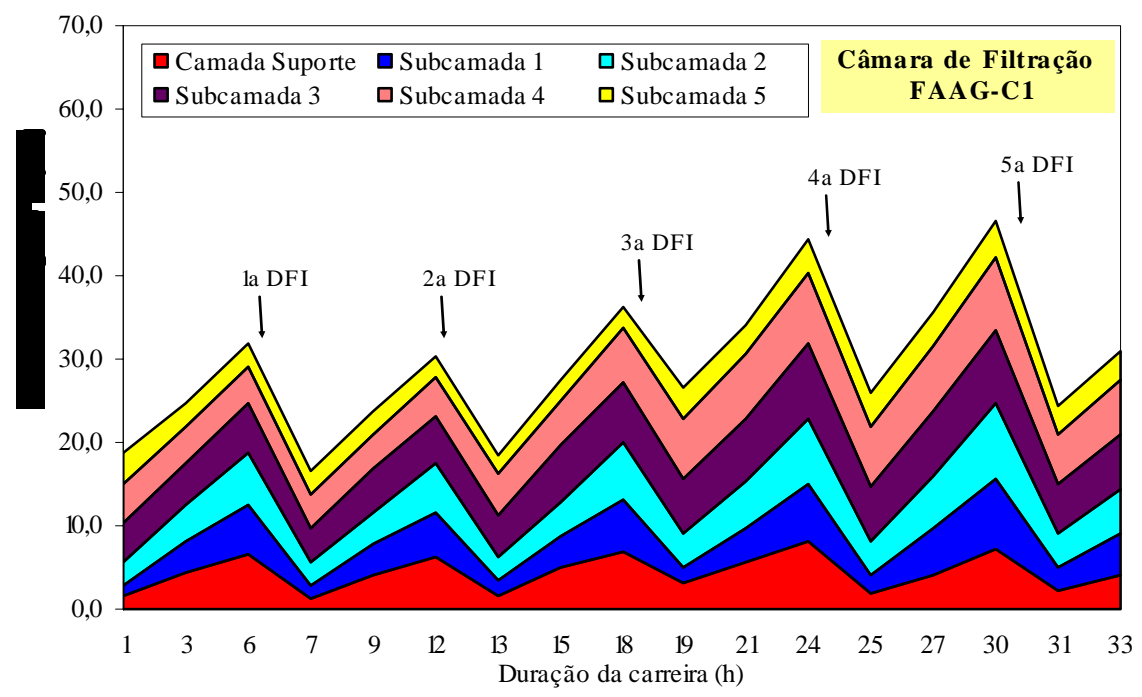

Figura C3.4 - Perda de carga ao longo do meio filtrante da câmara de filtração 1 do FAAG durante o ensaio 1 de dupla filtração 


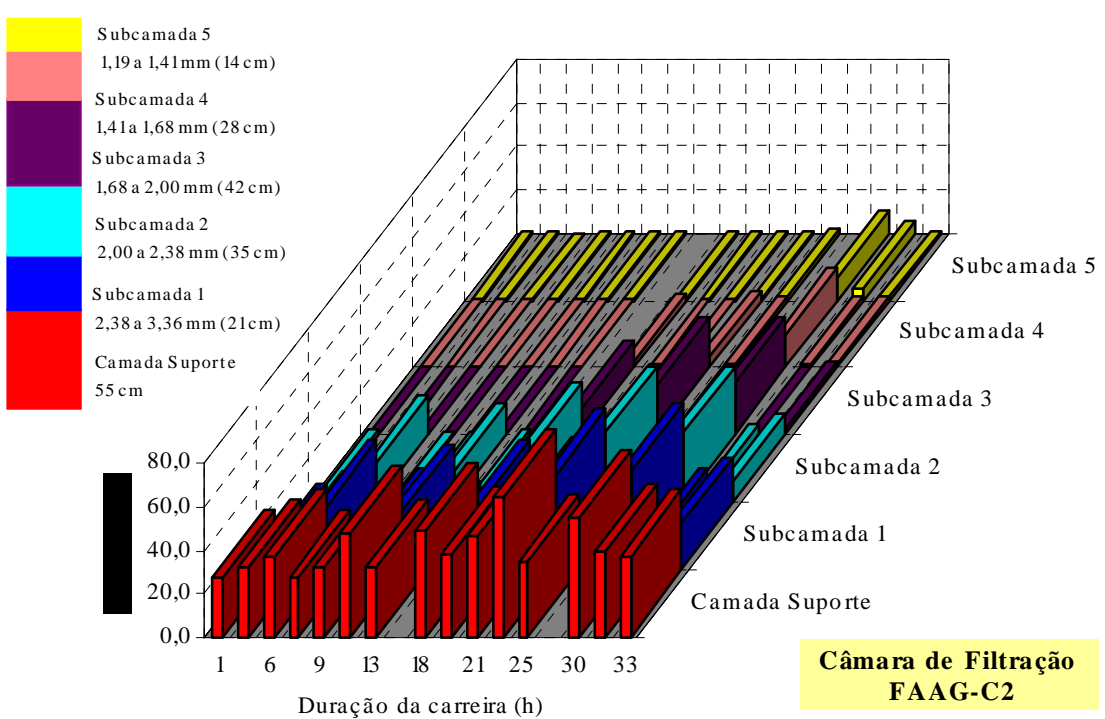

Figura C3.5 - Turbidez ao longo do meio filtrante da câmara de filtração 2 do FAAG durante o ensaio 1 de dupla filtração

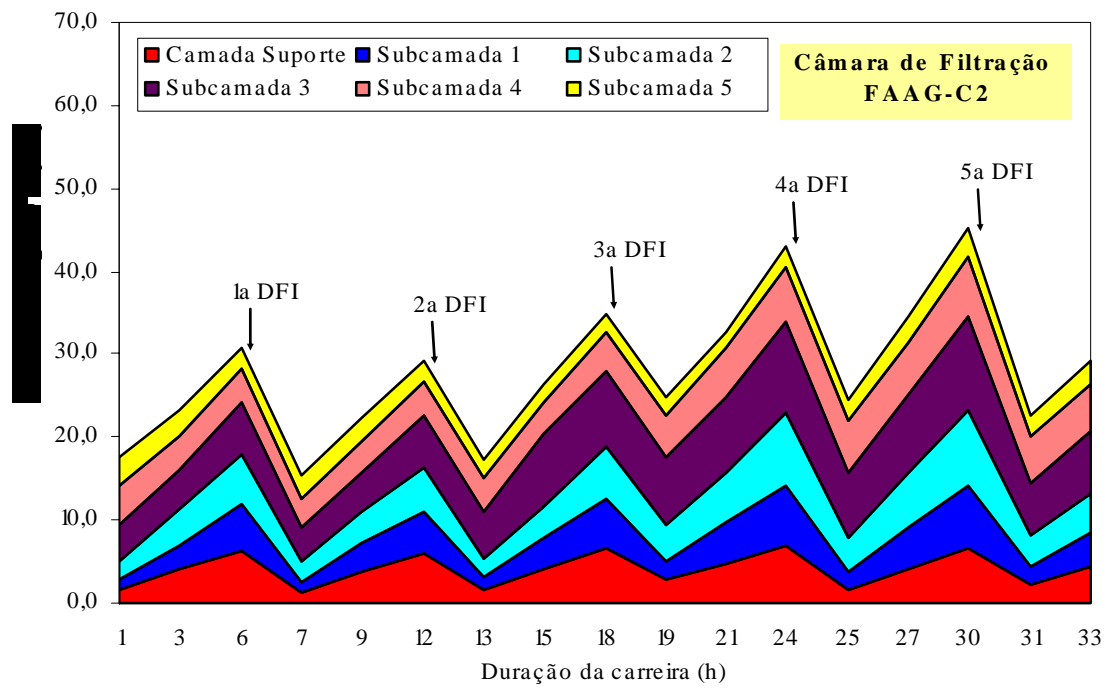

Figura C3.6 - Perda de carga ao longo do meio filtrante da câmara de filtração 2 do FAAG durante o ensaio 1 de dupla filtração 


\section{ENSAIO 4 DE DUPLA FILTRAÇÃO}

Tabela C4.1 - Condições do ensaio 4 de dupla filtração - Sistema 1 e Água de estudo Tipo I

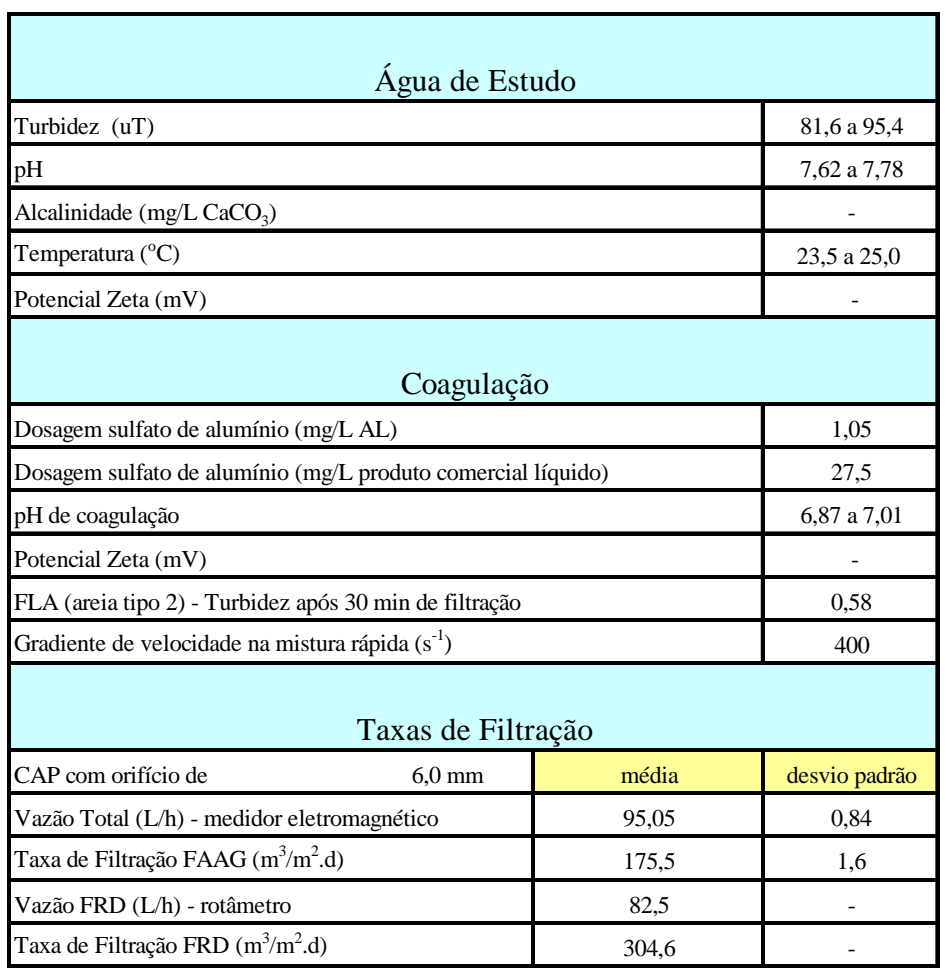


Tabela C4.2 - Resultados do ensaio 4 de dupla filtração - Sistema 1 e Água de estudo Tipo I

\begin{tabular}{|c|c|c|c|c|c|c|c|c|c|c|c|c|c|c|c|c|c|c|c|c|c|c|c|c|c|c|c|c|c|c|c|c|}
\hline \multirow{3}{*}{\begin{tabular}{|c} 
Duração \\
(h)
\end{tabular}} & \multirow{3}{*}{$\begin{array}{c}\mathrm{Q}_{\mathrm{T}} \\
(\mathrm{L} / \mathrm{h})\end{array}$} & \multirow{3}{*}{$\begin{array}{c}\text { Turb. } \\
\mathrm{AE}(\mathrm{uT})\end{array}$} & \multirow{3}{*}{$\begin{array}{l}\mathrm{pH} \\
\mathrm{AE} \\
\end{array}$} & \multirow{3}{*}{$\begin{array}{c}\mathrm{pH} \\
\text { Coag. }\end{array}$} & \multirow{3}{*}{$\begin{array}{l}\text { Temp. } \\
\text { (oC) }\end{array}$} & \multicolumn{27}{|c|}{ Filtro Ascendente de Areia Grossa - FAAG } \\
\hline & & & & & & \multicolumn{13}{|c|}{ Tubbidez - Turbidímetro de Bancada (TB) (uT) } & \multicolumn{14}{|c|}{ Perda de Carga Corrigida $25^{\circ} \mathrm{C}(\mathrm{cm})$} \\
\hline & & & & & & $\mathrm{Cl}-1$ & C2-1 & C3-1 & $\mathrm{C} 4-1$ & c5-1 & $66-1$ & $\mathrm{C1}-2$ & $\mathrm{C2}-2$ & $\mathrm{C} 3-2$ & $\mathrm{C4} 42$ & \begin{tabular}{|c|c|}
$C 5-2$ \\
\end{tabular} & $C 6-2$ & 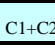 & $1-1$ & \begin{tabular}{|l|l|}
$\mathrm{P} 2-1$ & \\
\end{tabular} & P3-1 & P4-1 & \begin{tabular}{|l|} 
P5-1 \\
\end{tabular} & $\mathrm{P} 6-1$ & \begin{tabular}{|l|l} 
P7-1 \\
\end{tabular} & $\mathrm{P} 1-2$ & \begin{tabular}{|l|l} 
P2-2 \\
\end{tabular} & P3-2 & \begin{tabular}{|l|l|l|}
$\mathrm{P} 42$ & $\mathrm{l}$ \\
\end{tabular} & P5-2 & $P 6-2$ & $\mathrm{P} 7-2$ \\
\hline 0,5 & 96,93 & 87,0 & 7,62 & 6,87 & 25,0 & 38,2 & 3,0 & 4,41 & 1,01 & 0,92 & 0,96 & 33,6 & 13,4 & 2,63 & 1,02 & 0,95 & 1,09 & 0,75 & 259,2 & \begin{tabular}{|l|l}
258,2 \\
\end{tabular} & 257,3 & 255,5 & 251,4 & 248,6 & 244,5 & 259,2 & \begin{tabular}{|l|l}
258,5 \\
\end{tabular} & 258,0 & \begin{tabular}{|l|l|}
256,3 \\
\end{tabular} & 253,0 & 250,0 & 248,2 \\
\hline 3,0 & 96,2 & & & & 25,0 & 30,1 & & 4,46 & 0,89 & 0,89 & 0,90 & 28,7 & 8,04 & 5,37 & 1,04 & $\overline{1,82}$ & 2,40 & 5 & 262,2 & 260,4 & 258,6 & 255,8 & 252,0 & 248,7 & 244,5 & 262,3 & 266,7 & 259,4 & 257,1 & 253,2 & 250,1 & 248,2 \\
\hline 6,0 & & & & & 25,0 & 44,3 & 21,3 & 8,26 & 76 & 0,80 & 0,49 & 40,5 & 28,8 & 1,63 & 0,57 & 1,32 & 0,64 & 0,34 & 6,5 & 263,0 & 260,0 & 256,4 & 252,0 & 248,6 & \begin{tabular}{|l|l|}
246,7 \\
\end{tabular} & 266,6 & \begin{tabular}{|l|}
263,4 \\
\end{tabular} & 261,2 & 257,9 & 253,5 & 250,2 & 248,2 \\
\hline 9,0 & 96,29 & 89, & & & 24,0 & 51,4 & 39,8 & 23,1 & 1,64 & 1,02 & 0,54 & 49,9 & 54,5 & 17,6 & 1,87 & \begin{tabular}{|l|l}
1,54 \\
\end{tabular} & 0,51 & 0,39 & 266,9 & \begin{tabular}{|l|}
261,8 \\
\end{tabular} & 257,1 & 252,0 & 244,0 & 242,7 & 244,7 & 267,0 & 262,0 & 258,2 & 253,5 & 247,7 & 244,2 & 241,8 \\
\hline 12,0 & 95,65 & 95,0 & & & 24,0 & 48,9 & 34,6 & 20,1 & 0,84 & 0,77 & 0,74 & 66,7 & 52,8 & 27,5 & 0,74 & \begin{tabular}{|l}
2,59 \\
\end{tabular} & 0,80 & 0,65 & .5 & \begin{tabular}{|l|}
266,1 \\
\end{tabular} & 259,8 & 254,0 & 246,2 & 242,7 & 244,6 & 270,5 & 265,7 & 261,8 & \begin{tabular}{|l|}
255,4 \\
\end{tabular} & 48,1 & 4,2 & 244,3 \\
\hline 15,0 & 94,69 & 95,4 & 7,78 & 7,01 & 23,5 & 58,0 & 40,0 & 117,6 & 7,26 & 2,17 & 0,81 & 64,6 & 41,1 & 23,5 & 2,11 & \begin{tabular}{|l|l|}
0,81 \\
\end{tabular} & 1,00 & 0,78 & 5,2 & 268,4 & 261,5 & 254,2 & 244,2 & 239,4 & 237,7 & 275,7 & 269,0 & 263,8 & 255,7 & 245,9 & 241,3 & 239,4 \\
\hline 19,0 & 94,37 & 92. & & & 5 & 5 & 1,6 & 25,3 & 16,1 & 5,11 & 0,63 & 52,6 & 50,9 & 32,1 & 16,2 & \begin{tabular}{|l|l}
1,26 \\
\end{tabular} & 0,33 & 0,28 & 1,5 & \begin{tabular}{|l|}
2828,2 \\
\end{tabular} & 273,8 & 264,9 & 251,2 & 244,3 & \begin{tabular}{|l|l|}
2438 \\
\end{tabular} & 291,5 & \begin{tabular}{|l|}
282,7 \\
\end{tabular} & \begin{tabular}{|l|l|}
276,3 \\
\end{tabular} & 265,9 & 251,6 & 47,2 & 245,2 \\
\hline 22,0 & 95,65 & 86. & & & 25,0 & 57,8 & 5,4 & 23,7 & 16,8 & 13,1 & 4,91 & 68,0 & 45,7 & 32,3 & 20,5 & \begin{tabular}{|l}
8,34 \\
\end{tabular} & 0,96 & 414 & 299,8 & \begin{tabular}{|l|}
289,9 \\
\end{tabular} & 280,6 & 270,2 & 255,2 & 249,1 & 244,7 & 299,8 & 290,5 & 288,1 & 271,9 & 255,6 & 250,5 & 248,2 \\
\hline 23,5 & 7 & & & & 25,0 & & & & & & & & & & & & & & \begin{tabular}{|l|l|l} 
\\
\end{tabular} & \begin{tabular}{|l|}
291,9 \\
\end{tabular} & 282,1 & 271,3 & 255,7 & 249,0 & 246,7 & 302,2 & 292,5 & 284,8 & 272,9 & 257,4 & 51,0 & 248,2 \\
\hline 25,0 & 95,01 & 81. & 7,67 & 6,89 & 25,0 & 55,4 & 77,5 & 31,3 & 23,8 & 18,2 & 16,0 & 83,3 & 52,0 & 44,6 & 27,1 & \begin{tabular}{|l|l|}
25,4 \\
\end{tabular} & 111,7 & 13,1 & \begin{tabular}{|l|}
304,3 \\
\end{tabular} & 293,8 & 283,8 & 272,4 & 256,4 & 249,3 & 244,7 & 304,3 & 294,5 & 286,6 & 274,1 & 258,0 & 2551,2 & 248 \\
\hline 26,5 & 95,97 & & & & & & & & & & & & & & & & & & 307,0 & \begin{tabular}{|l|}
296,1 \\
\end{tabular} & 285,6 & 273,5 & 257,0 & 249,5 & 246,7 & 307,1 & 296,8 & 288,5 & 275,5 & 88,7 & 51,4 & 248,2 \\
\hline 28,0 & 95,33 & 84. & & & 24,0 & 83,5 & 54,8 & 32,1 & 27,3 & 27,3 & 31,0 & 64,7 & $\begin{array}{ll}43,4 \\
\end{array}$ & 38,8 & 30,9 & \begin{tabular}{|l|}
25,6 \\
\end{tabular} & 20,7 & 58,1 & 302,1 & 291,2 & 280,4 & 273,0 & 251,4 & 243,8 & 240,8 & \begin{tabular}{|l|l|}
303,1 \\
\end{tabular} & 291,8 & 2883,4 & 275,0 & 253,0 & 245,6 & 242,3 \\
\hline 29,5 & 94,05 & & & & 24,5 & & & & & & & & & & & & & & \begin{tabular}{|l}
307,6 \\
\end{tabular} & 296,5 & 285,2 & 272,3 & \begin{tabular}{|l|l}
254,7 \\
\end{tabular} & 247,1 & \begin{tabular}{|l|l|}
243,8 \\
\end{tabular} & 307,8 & \begin{tabular}{|l|l|}
297,0 \\
\end{tabular} & 288,2 & 274,1 & 256,4 & 248,7 & 245,2 \\
\hline 31,6 & $94,0$. & 89 & & & 24,5 & & & & & 27,4 & & & 45,7 & & 27 & 24,8 & & & \begin{tabular}{|l|l|l} 
\\
\end{tabular} & 298,2 & 286,7 & 273,2 & 255,1 & 247,2 & 243,6 & 310,2 & 299,0 & 2889,9 & 275,6 & 256,9 & 248,9 & 245,2 \\
\hline 33,0 & 95,01 & & & & & & & & & & & & & & & & & & 313,2 & \begin{tabular}{|l|}
300,4 \\
\end{tabular} & 288,6 & 274,2 & 255,1 & 247,2 & \begin{tabular}{|l|l|}
2439 \\
\end{tabular} & 313,2 & \begin{tabular}{|l|}
31,4 \\
\end{tabular} & 292,0 & 277,3 & 257,6 & 50,2 & 245. \\
\hline
\end{tabular}


Tabela C4.2 - Continuação

\begin{tabular}{|c|c|c|c|c|c|c|c|c|c|c|c|c|c|c|}
\hline \multirow{2}{*}{$\begin{array}{l}\text { Duração } \\
\text { (h) }\end{array}$} & \multicolumn{14}{|c|}{ FAAG -Perda de Carga Lida $(\mathrm{cm})$} \\
\hline & P1-1 & P2-1 & P3-1 & P4-1 & P5-1 & P6-1 & P7-1 & P1-2 & P2-2 & Р3-2 & P4-2 & P5-2 & P6-2 & P7-2 \\
\hline 0,5 & 260,0 & 259,0 & 258,1 & 256,3 & 252,2 & 249,4 & 247,3 & 260,0 & 259,3 & 258,8 & 257,1 & 253,8 & 250,8 & 249,0 \\
\hline 3,0 & 263,0 & 261,2 & 259,4 & 256,6 & 252,8 & 249,5 & 247,3 & 263,1 & 261,5 & 260,2 & 257,9 & 254,0 & 250,9 & 249,0 \\
\hline 6,0 & 267,3 & 263,8 & 260,8 & 257,2 & 252,8 & 249,4 & 247,5 & 267,4 & 264,2 & 262,0 & 258,7 & 254,3 & 251,0 & 249,0 \\
\hline 9,0 & 274,3 & 269,0 & 264,2 & 259,0 & 252,8 & 249,4 & 247,4 & 274,4 & 269,2 & 265,3 & 260,5 & 254,5 & 251,0 & 248,5 \\
\hline 12,0 & 279,0 & 273,5 & 267,0 & 261,0 & 253,0 & 249,4 & 247,3 & 278,0 & 273,0 & 269,0 & 262,5 & 255,0 & 251,0 & 249,0 \\
\hline 15,0 & 286,2 & 279,2 & 272,0 & 264,4 & 254,0 & 249,0 & 247,2 & 286,8 & 279,8 & 274,4 & 266,0 & 255,8 & 251,0 & 249,0 \\
\hline 19,0 & 296,0 & 286,5 & 278,0 & 269,0 & 255,0 & 248,0 & 247,5 & 296,0 & 287,0 & 280,5 & 270,0 & 255,5 & 251,0 & 249,0 \\
\hline 22,0 & 300,7 & 290,8 & 281,5 & 271 & 256,0 & 249,9 & 247,5 & 300,7 & 291,4 & 284,0 & 272,8 & 257,4 & 251,3 & 249,0 \\
\hline 23,5 & 302,3 & 292,8 & 283 & 272,1 & 256,5 & 249,8 & 247,5 & \begin{tabular}{|}
303,1 \\
\end{tabular} & 293,4 & 285,7 & 273,8 & $\begin{array}{r}258,2 \\
\end{array}$ & 251,8 & 249,0 \\
\hline 25,0 & 305,3 & 294,7 & 284,7 & 273,3 & 257,2 & 250,1 & 247,5 & 305,3 & 295,4 & 287,5 & 275,0 & 258,8 & 252,0 & 249,0 \\
\hline 26,5 & 308,0 & 297,0 & 286,5 & 274,4 & 257,8 & 250,3 & 247,5 & 308,1 & 297,7 & 289,4 & 276,4 & 259,5 & 252,2 & 249,0 \\
\hline 28,0 & 310,5 & 299,2 & 288,2 & 280,5 & 258,3 & 250,5 & 247,5 & 311,5 & 299,9 & 291,2 & 282,6 & 260,0 & 252,4 & 249,0 \\
\hline 29,5 & 312,3 & 301,0 & 289,6 & 276,5 & 258,6 & 250,9 & 247,5 & 312,5 & 301,5 & 292,6 & 278,3 & 260,3 & 252,5 & 249,0 \\
\hline 31,0 & 314,7 & 302,8 & 291,1 & 277,4 & 259,0 & 251,0 & 247,3 & 314,9 & 303,6 & 294,3 & 279,8 & 260,8 & 252,7 & 249,0 \\
\hline 33,0 & 318,0 & 305,0 & 293,0 & 278,4 & 259,0 & 251,0 & 247,6 & 318,0 & 306,0 & 296,5 & 281,5 & 261,5 & 254,0 & 249,0 \\
\hline
\end{tabular}

QT: vazão total afluente ao Sistema de Dupla Filtração (medidor de vazão eletromagnético);

Turb. AE: turbidez da água de estudo (turbidímetro de bancada);

pH AE: pH da água de estudo;

pH Coag.: pH de coagulação;

Ci-1: amostra coletada no final da subcamada i do meio filtrante da câmara de filtração 1 do FAAG;

Ci-2: amostra coletada no final da subcamada i do meio filtrante da câmara de filtração 2 do FAAG;

C1+C2: amostra de água pré-filtrada global (efluentes das câmaras de filtração 1 e 2 da FAAG)

Pi-1: piezômetro i localizado na câmara de filtração 1 do FAAG;

Pi-2: piezômetro i localizado na câmara de filtração 2 do FAAG; 
Tabela C4.2 - Continuação

\begin{tabular}{|c|c|c|c|c|c|}
\hline \multirow{3}{*}{$\begin{array}{c}\text { Duração } \\
\text { (h) }\end{array}$} & \multirow{3}{*}{$\begin{array}{l}\text { Temp. } \\
\text { (oC) }\end{array}$} & \multicolumn{4}{|c|}{ Filtro Rápido Descendente - FRD } \\
\hline & & Qfd & Turbidez - TB (uT) & Perda & ${ }^{\circ} \mathrm{C}(\mathrm{cm})$ \\
\hline & & $(\mathrm{L} / \mathrm{h})$ & $\mathrm{AF}$ & P1 & P2 \\
\hline 0,5 & 25,0 & 82,5 & 0,69 & 26,1 & 113,8 \\
\hline 3,0 & 25,0 & 82,5 & 0,33 & 26,1 & 113,6 \\
\hline 6,0 & 25,0 & 82,5 & 0,33 & 26,1 & 114,3 \\
\hline 9,0 & 24,0 & 82,5 & 0,34 & 25,5 & 111,9 \\
\hline 12,0 & 24,0 & 82,5 & 0,60 & 25,5 & 114,3 \\
\hline 15,0 & 23,5 & 82,5 & 0,52 & 25,2 & 115,4 \\
\hline 19,0 & 24,5 & 82,5 & 0,28 & 25,8 & 119,0 \\
\hline 22,0 & 25,0 & 82,5 & 0,55 & 26,1 & 120,8 \\
\hline 23,5 & 25,0 & 82,5 & 0,40 & 26,1 & 122,3 \\
\hline 25,0 & 25,0 & 82,5 & 0,20 & 26,1 & 123,8 \\
\hline 26,5 & 25,0 & 82,5 & 0,35 & 26,1 & 128,2 \\
\hline 28,0 & 24,0 & 82,5 & 0,24 & 25,5 & 129,5 \\
\hline 29,5 & 24,5 & 82,5 & 0,21 & 25,8 & 137,7 \\
\hline 31,0 & 24,5 & 82,5 & 0,89 & 25,8 & 145,8 \\
\hline \multirow[t]{18}{*}{33,0} & 24,5 & 82,5 & 1,78 & 25,8 & 157,6 \\
\hline & & & & \multicolumn{2}{|c|}{ Perda de Carga Lida (cm) } \\
\hline & & & & P1 & P2 \\
\hline & & & & 26,2 & 114,2 \\
\hline & & & & 26,2 & 114,0 \\
\hline & & & & 26,2 & 114,7 \\
\hline & & & & 26,2 & 115,0 \\
\hline & & & & 26,2 & 117,5 \\
\hline & & & & 26,2 & 120,0 \\
\hline & & & & 26,2 & 120,8 \\
\hline & & & & 26,2 & 121,2 \\
\hline & & & & 26,2 & 122,7 \\
\hline & & & & 26,2 & 124,2 \\
\hline & & & & 26,2 & 128,6 \\
\hline & & & & 26,2 & 133,1 \\
\hline & & & & 26,2 & 139,8 \\
\hline & & & & 26,2 & 148,0 \\
\hline & & & & 26,2 & 160,0 \\
\hline
\end{tabular}

$\mathrm{Q}_{\mathrm{fd}}$ : vazão afluente ao FRD (rotâmetro);

Turb. AF: turbidez da água filtrada (turbidímetro de bancada);

P1 e P2: piezômetros localizados no início e no final do FRD, respectivamente. 


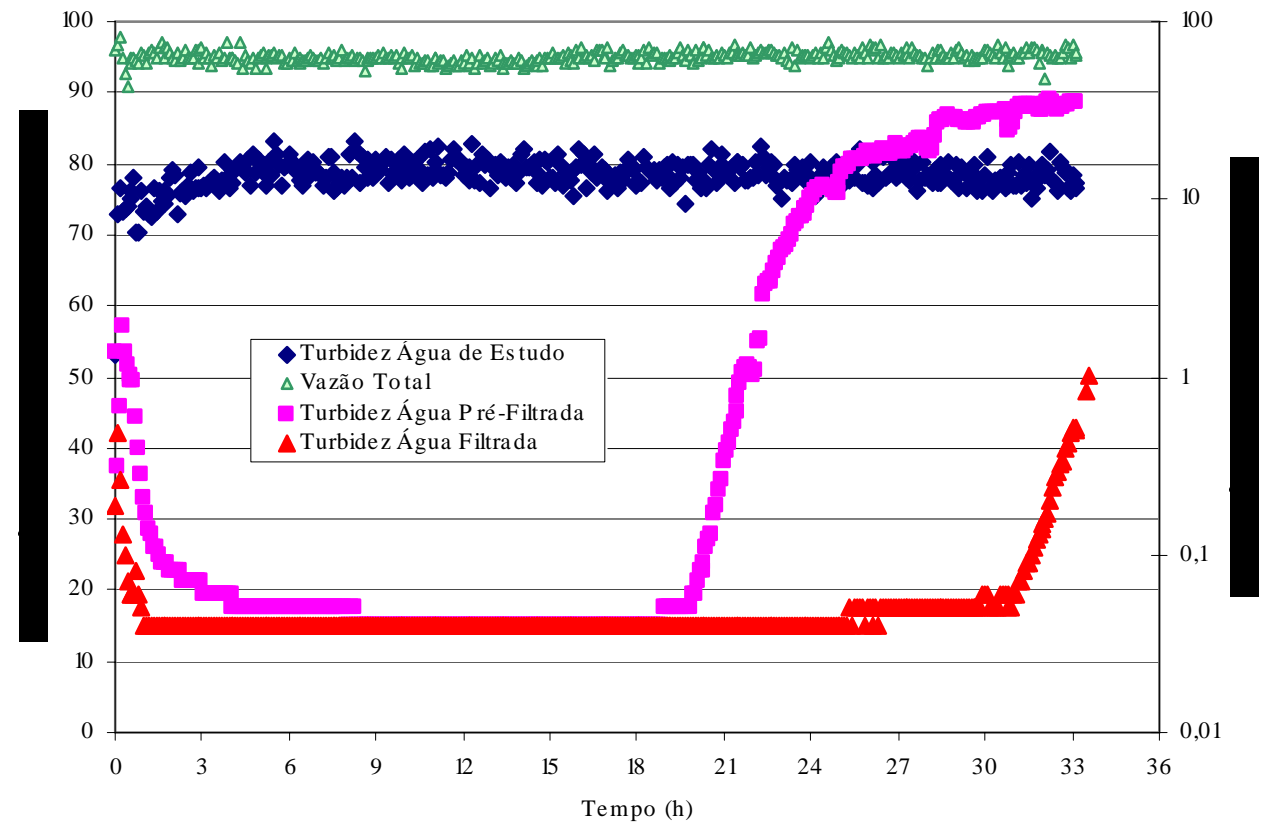

Figura C4.1 - Variações da vazão total afluente ao sistema de dupla filtraçào e da turbidez das águas de estudo, pré-filtrada e filtrada no ensaio 4 - Turbidímetros de Escoamento Contínuo

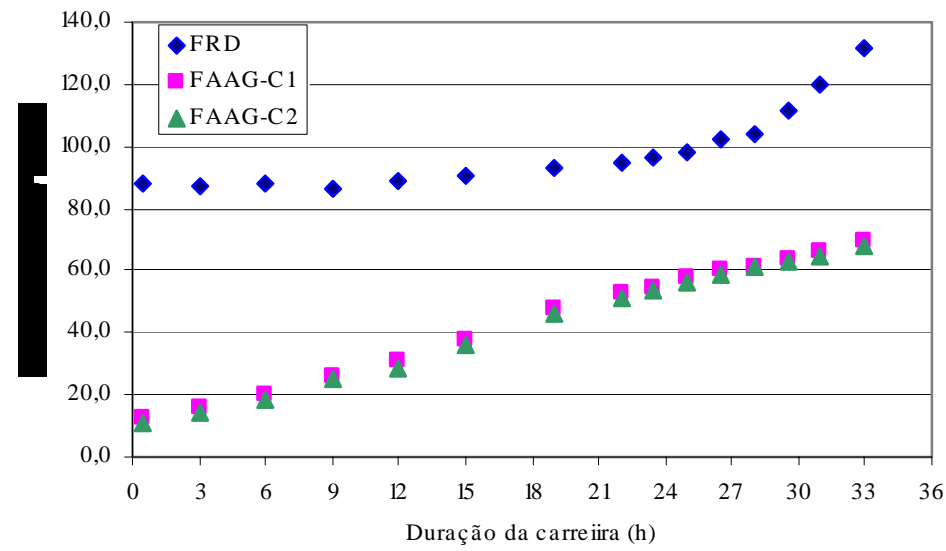

Figura C4.2 - Perda de carga nos filtros ascendente de areia grossa (duas câmaras de filtração) e descendente durante o ensaio 4 de dupla filtração 


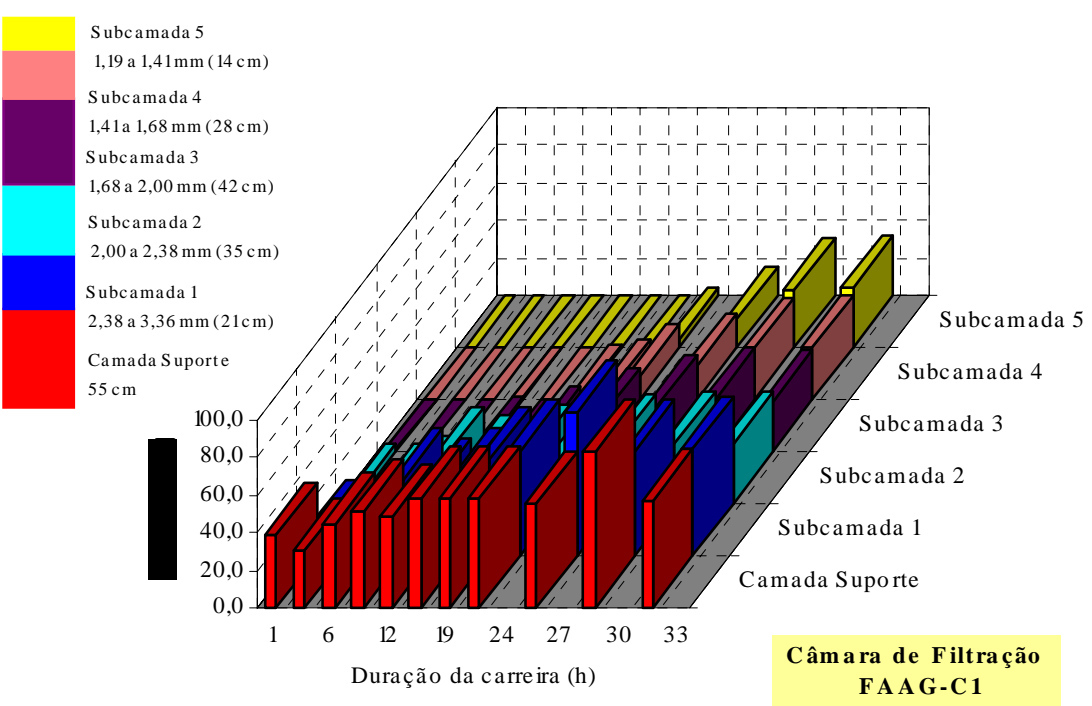

Figura C4.3 - Turbidez ao longo do meio filtrante da câmara de filtração 1 do FAAG durante o ensaio 4 de dupla filtração

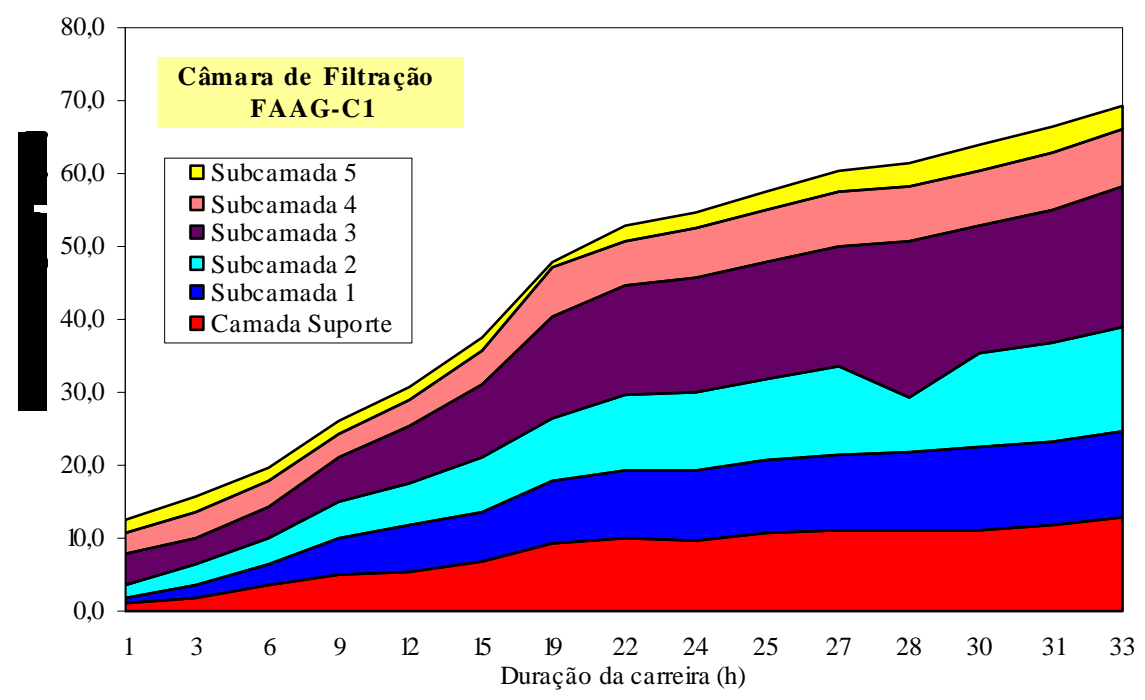

Figura C4.4 - Perda de carga ao longo do meio filtrante da câmara de filtração 1 do FAAG durante o ensaio 4 de dupla filtração 


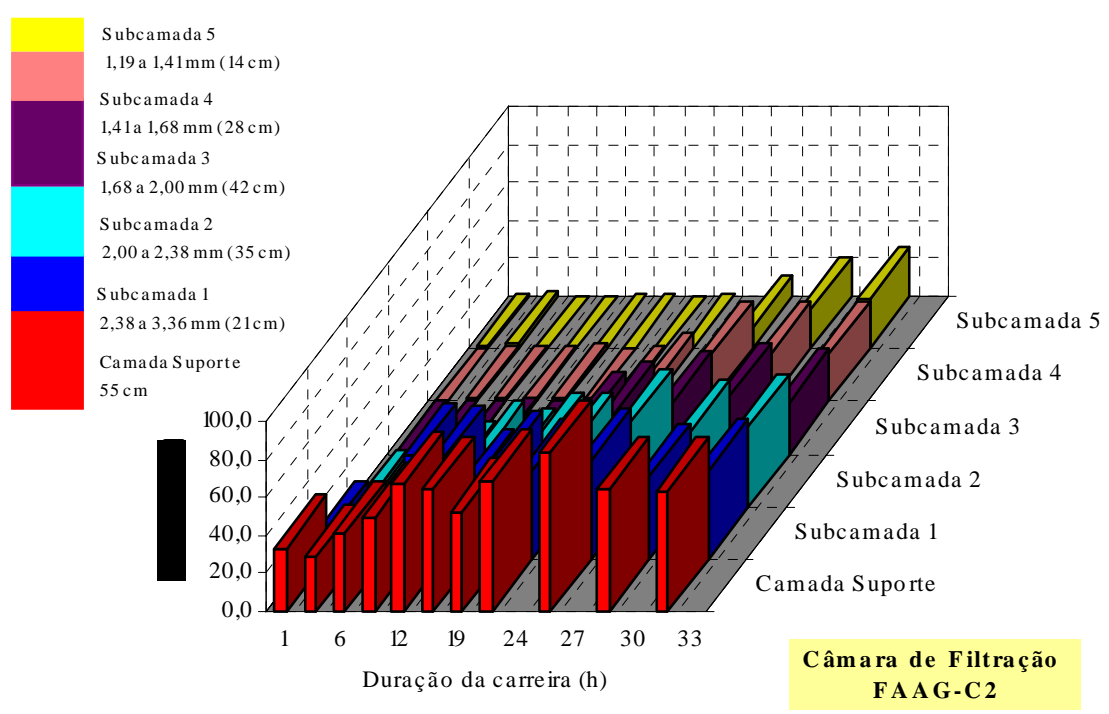

Figura C4.5 - Turbidez ao longo do meio filtrante da câmara de filtração 2 do FAAG durante o ensaio 4 de dupla filtração

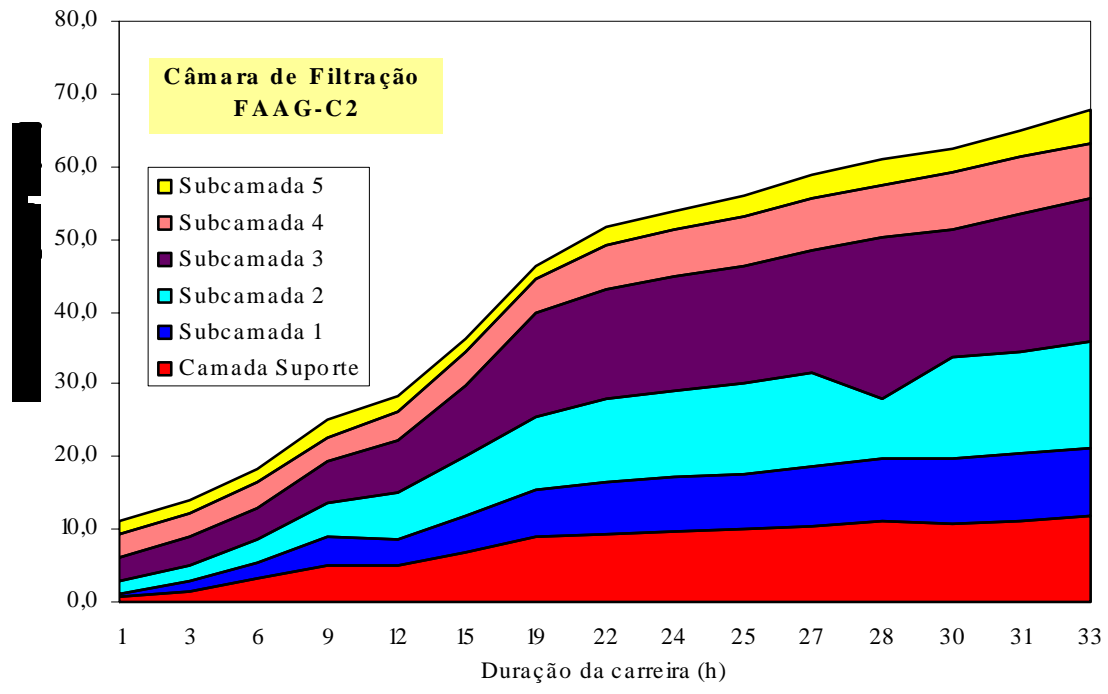

Figura C4.6 - Perda de carga ao longo do meio filtrante da câmara de filtração 2 do FAAG durante o ensaio 4 de dupla filtração 


\section{ENSAIO 5 DE DUPLA FILTRAÇÃO}

Tabela C5.1 - Condições do ensaio 5 de dupla filtração - Sistema 1 e Água de estudo Tipo I

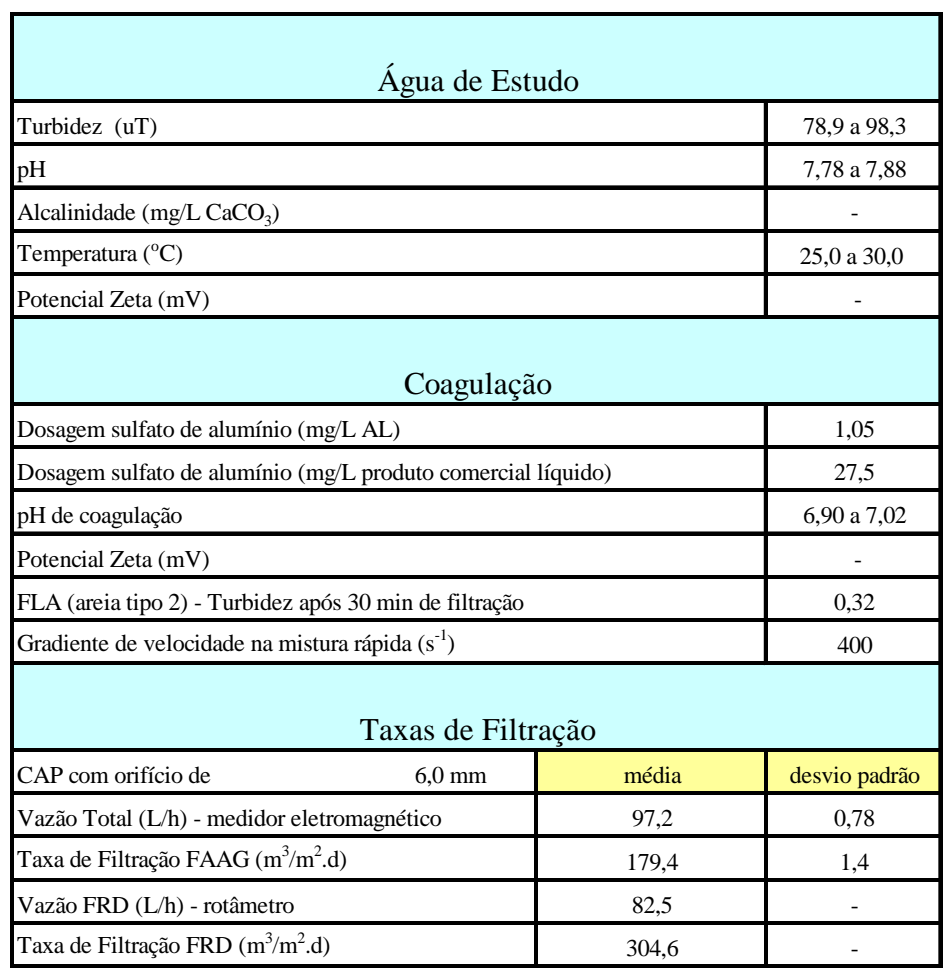


Tabela C5.2 - Resultados do ensaio 5 de dupla filtração - Sistema 1 e Água de estudo Tipo I

\begin{tabular}{|c|c|c|c|c|c|c|c|c|c|c|c|c|c|c|c|c|c|c|c|c|c|c|c|c|c|c|c|c|c|c|c|c|}
\hline \multirow{3}{*}{$\begin{array}{l}\text { Duraçăa } \\
\text { (h) }\end{array}$} & \multirow{3}{*}{\begin{tabular}{|c}
$Q_{1}$ \\
$(L / 1)$ \\
\end{tabular}} & \multirow{3}{*}{$\begin{array}{c}\text { Turb. } \\
\text { AE (UT) }\end{array}$} & \multirow{3}{*}{\begin{tabular}{|l|}
$\mathrm{pH}$ \\
$\mathrm{AE}$ \\
\end{tabular}} & \multirow{3}{*}{\begin{tabular}{|c|}
$\mathrm{pH}$ \\
Coag.
\end{tabular}} & \multirow{3}{*}{$\begin{array}{l}\text { Temp. } \\
\text { (oC) }\end{array}$} & \multicolumn{27}{|c|}{ Filtro Ascendente de Areia Grossa - FAAG } \\
\hline & & & & & & \multicolumn{13}{|c|}{ Turbidez - Turbidímetro de Bancada (TB) (UT) } & \multicolumn{14}{|c|}{ Perda de Carga Corrigida $25^{\circ} \mathrm{C}(\mathrm{cm})$} \\
\hline & & & & & & 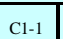 & $\mathrm{C2} 2-1$ & C3-1 & $\mathrm{C} 4-1$ & 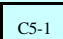 & \begin{tabular}{|c|c|}
$\mathrm{C}-1$ \\
\end{tabular} & $\mathrm{C1}-2$ & C2-2 & C3-2 & 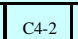 & Cs-2 & \begin{tabular}{|c|}
$66-2$ \\
\end{tabular} & $\mathrm{C} 1+\mathrm{C} 2$ & $\mathrm{P} 1-1_{1}$ & P2-1 & \begin{tabular}{|l} 
P3-1 \\
-1
\end{tabular} & P4-1 & P5-1 & $\overline{P 6-1}$ & p7-1 & P1-2 & P2-2 & P3-2 & P42 & P5-2 & P6-2 & $\overline{\mathrm{P} 7-2}$ \\
\hline 0,3 & 96,612 & 88,8 & 7,88 & 7,00 & 28,0 & & & & & & & & & & & & & & 278,7 & 277,6 & 276,5 & 274,0 & 270,3 & \begin{tabular}{|l|l|}
267,4 \\
\end{tabular} & 265,8 & 278,9 & 27,7 & 276,5 & 274,9 & 277,1 & 268,8 & 267,1 \\
\hline 1,0 & 96 & 91,3 & & 6,97 & 28,0 & & & & & & & & & & & & & & 280,8 & 278,4 & 276,5 & 273,8 & 270,4 & \begin{tabular}{|l|l|}
267,4 \\
\end{tabular} & 265,8 (1) & 280,8 & 278,7 & 277,3 & 275,0 & 271,5 & 269,0 & 267,1 \\
\hline 3,0 & 96,29 & 91,3 & & 6,97 & 28,0 & 30,7 & 7,14 & 1,00 & 0,89 & 0,87 & 1,02 & 21,0 & 6,1 & 0,86 & 0,73 & 0,58 & 0,76 & & 283,4 & 279,8 & 276,9 & 274,0 & 270,4 & 267,3 & 265,8 & 283,5 & 280,4 & 277,9 & 275,4 & 271,9 & 268,9 & 266,9 \\
\hline 6,0 & 98,22 & 96,1 & & & 28,0 & 38,1 & 24,60 & 1,40 & 0,52 & 0,50 & 1,23 & \begin{tabular}{|l|l|}
53,8 \\
\end{tabular} & 20,40 & \begin{tabular}{|l|l|}
0,76 \\
\end{tabular} & \begin{tabular}{|l|l} 
\\
\end{tabular} & \begin{tabular}{|l|}
0,53 \\
\end{tabular} & \begin{tabular}{|l|l|}
0,81 \\
\end{tabular} & & 287,8 & \begin{tabular}{|l|}
282,6 \\
\end{tabular} & 278,1 & 274,4 & 270,4 & \begin{tabular}{|l|l}
267,3 \\
\end{tabular} & 265,6 & \begin{tabular}{|l|l|}
287,9 \\
\end{tabular} & 283,0 & 279,2 & \begin{tabular}{|l|l|}
25,7 \\
\end{tabular} & 277,9 & 268,9 & 266,9 \\
\hline 6,5 & \begin{tabular}{|l}
96,93 \\
\end{tabular} & 92,5 & & & 27,5 & 24,6 & \begin{tabular}{|l|}
7,34 \\
\end{tabular} & \begin{tabular}{|l|l}
1,27 \\
\end{tabular} & \begin{tabular}{|l|l}
0,56 \\
\end{tabular} & \begin{tabular}{|l|l}
0,84 \\
\end{tabular} & \begin{tabular}{|l|l|}
0,64 \\
\end{tabular} & \begin{tabular}{|l|}
25,1 \\
\end{tabular} & \begin{tabular}{|l|}
8,30 \\
\end{tabular} & 1,20 & \begin{tabular}{|l|l|}
0,61 \\
\end{tabular} & \begin{tabular}{|l|l|}
0,46 \\
\end{tabular} & \begin{tabular}{|l|}
0,70 \\
\end{tabular} & & 278,3 & \begin{tabular}{|l}
276,7 \\
\end{tabular} & \begin{tabular}{|l|}
273,0 \\
\end{tabular} & 271,0 & 267,1 & \begin{tabular}{|l|}
264,1 \\
\end{tabular} & 262,4 & \begin{tabular}{|l|}
278,3 \\
\end{tabular} & 276,8 & \begin{tabular}{|l|l|}
274,8 \\
\end{tabular} & 272,3 & 268,6 & 265,7 & \begin{tabular}{|l|l}
263,9 \\
\end{tabular} \\
\hline 9,0 & \begin{tabular}{|l|l}
8,22 \\
\end{tabular} & 87,2 & & & 27,0 & 31,2 & \begin{tabular}{|l}
13,30 \\
\end{tabular} & 2,79 & \begin{tabular}{|l}
0,51 \\
\end{tabular} & \begin{tabular}{|l}
0,45 \\
\end{tabular} & 0,55 & \begin{tabular}{|l|}
34,4 \\
\end{tabular} & 27,60 & $\begin{array}{ll}0,83 \\
\end{array}$ & 0,48 & \begin{tabular}{|l|l|}
0,47 \\
\end{tabular} & \begin{tabular}{|l|l}
0,43 \\
\end{tabular} & & 281,2 & 277,2 & $\begin{array}{ll}272,4 \\
\end{array}$ & 268,1 & 263,8 & \begin{tabular}{|l|}
260,7 \\
\end{tabular} & 258,7 & \begin{tabular}{|l|l|}
281,2 \\
\end{tabular} & 277,2 & \begin{tabular}{|l|l|}
273,4 \\
\end{tabular} & \begin{tabular}{|l|}
269,5 \\
\end{tabular} & 265,5 & 262,4 & 2660,7 \\
\hline 12,0 & \begin{tabular}{|l|}
9,93 \\
\end{tabular} & 98,2 & 7,78 & \begin{tabular}{|l|l}
6,91 \\
\end{tabular} & 27,0 & 40,0 & 266,70 & \begin{tabular}{|l}
10,20 \\
\end{tabular} & \begin{tabular}{|l}
0,45 \\
\end{tabular} & \begin{tabular}{|l}
0,75 \\
\end{tabular} & \begin{tabular}{|l}
0,48 \\
\end{tabular} & \begin{tabular}{|l|}
53,3 \\
\end{tabular} & 28,60 & \begin{tabular}{l|}
7,91 \\
\end{tabular} & 0,73 & \begin{tabular}{|l|}
0,49 \\
\end{tabular} & \begin{tabular}{|l|}
0,55 \\
\end{tabular} & & 286,7 & \begin{tabular}{|l}
280,9 \\
\end{tabular} & 275,1 & 268,7 & 264,2 & \begin{tabular}{|l|l|}
261,0 \\
\end{tabular} & 258,7 & \begin{tabular}{|l|}
286,7 \\
\end{tabular} & 281,4 & 276,0 & 2609,8 & 265,7 & \begin{tabular}{|l|l|}
262,6 \\
\end{tabular} & 2660,7 \\
\hline 12,5 & \begin{tabular}{|l|}
96,93 \\
\end{tabular} & 82,1 & & & 26,0 & 34,3 & 13,20 & \begin{tabular}{|l|}
3,12 \\
\end{tabular} & \begin{tabular}{|l}
1,12 \\
\end{tabular} & \begin{tabular}{|l|l}
0,52 \\
\end{tabular} & 0,52 & \begin{tabular}{|l}
28,9 \\
\end{tabular} & \begin{tabular}{|l|}
8,62 \\
\end{tabular} & 2,29 & 1,11 & \begin{tabular}{|l|}
0,56 \\
\end{tabular} & \begin{tabular}{|l|}
0,76 \\
\end{tabular} & & 266,5 & 265,5 & 263,5 & \begin{tabular}{|l|l|}
261,4 \\
\end{tabular} & 258,4 & \begin{tabular}{|l|}
254,8 \\
\end{tabular} & 252,6 & $26,56,5$ & 265,7 & 264,5 & \begin{tabular}{|l|l|}
262,5 \\
\end{tabular} & \begin{tabular}{|l|}
259,4 \\
\end{tabular} & 256,0 & 254,5 \\
\hline 15,0 & \begin{tabular}{|l|l}
97,25 \\
\end{tabular} & 82,8 & & & 25,0 & 54,3 & 22,00 & \begin{tabular}{|l|}
8,54 \\
\end{tabular} & \begin{tabular}{|l|}
2,01 \\
\end{tabular} & \begin{tabular}{|l|}
0,51 \\
\end{tabular} & \begin{tabular}{|l|l}
0,50 \\
\end{tabular} & 51,0 & 18,50 & \begin{tabular}{|l|l}
5,14 \\
\end{tabular} & 1,72 & \begin{tabular}{|l|l|}
0,48 \\
\end{tabular} & \begin{tabular}{|l|}
0,70 \\
\end{tabular} & & 265,4 & 262,2 & 259,0 & 255,7 & 251,5 & 248,7 & 246,5 & 20 & 262,5 & 255,8 & \begin{tabular}{|l|l|}
256,7 \\
\end{tabular} & \begin{tabular}{|l|}
253,2 \\
\end{tabular} & 250,2 & 248,4 \\
\hline 18,0 & \begin{tabular}{|l|l}
97,57 \\
\end{tabular} & 98,3 & & & 25,0 & \begin{tabular}{c|}
65,0 \\
\end{tabular} & 36,70 & 21,10 & 0,8 & \begin{tabular}{|l}
0,77 \\
\end{tabular} & $\begin{array}{ll}1,27 \\
\end{array}$ & \begin{tabular}{|l|l}
68,0 \\
\end{tabular} & 25,40 & \begin{tabular}{l|l}
7,46 \\
\end{tabular} & 1,7 & \begin{tabular}{|l|l|}
0,84 \\
\end{tabular} & \begin{tabular}{|l|l|}
0,91 \\
\end{tabular} & & 273,1 & 2667,2 & 263,2 & 256,7 & 251,5 & \begin{tabular}{|l|}
248,7 \\
\end{tabular} & 246,5 & 273,1 & 267,2 & \begin{tabular}{|l|l|}
263,2 \\
\end{tabular} & \begin{tabular}{|l|}
258,2 \\
\end{tabular} & 254,2 & 250,2 & 248,4 \\
\hline 18,5 & \begin{tabular}{|l|l}
96,29 \\
\end{tabular} & 84,7 & & & 25,0 & 27,4 & \begin{tabular}{|l|l}
11,40 \\
\end{tabular} & \begin{tabular}{|l|}
2,70 \\
\end{tabular} & \begin{tabular}{|l|l}
0,73 \\
\end{tabular} & \begin{tabular}{|l|}
0,58 \\
\end{tabular} & \begin{tabular}{|l|l|}
0,83 \\
\end{tabular} & \begin{tabular}{|l|}
26,1 \\
\end{tabular} & \begin{tabular}{|l|l|}
9,31 \\
\end{tabular} & 1,95 & \begin{tabular}{|l|l|}
0,71 \\
\end{tabular} & \begin{tabular}{|l|}
0,56 \\
\end{tabular} & \begin{tabular}{|l|l|}
0,52 \\
\end{tabular} & & 261,2 & 260,0 & 258,2 & 256,0 & 251,7 & \begin{tabular}{|l|}
248,7 \\
\end{tabular} & 246,5 & 2 & 260,1 & \begin{tabular}{|l|}
258,7 \\
\end{tabular} & \begin{tabular}{|l|l|}
256,7 \\
\end{tabular} & \begin{tabular}{|l|l|}
253,2 \\
\end{tabular} & 250,2 & 248,4 \\
\hline 21,0 & \begin{tabular}{|l|l}
96,29 \\
\end{tabular} & 89,3 & & & 27,0 & \begin{tabular}{|l|}
30,3 \\
\end{tabular} & \begin{tabular}{|l|l}
11,80 \\
\end{tabular} & 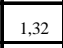 & \begin{tabular}{|l|}
2,83 \\
\end{tabular} & \begin{tabular}{|l|l}
0,70 \\
\end{tabular} & \begin{tabular}{|l|}
0,76 \\
\end{tabular} & \begin{tabular}{|l|l}
30,0 \\
\end{tabular} & \begin{tabular}{|l|l}
12,50 \\
\end{tabular} & \begin{tabular}{l|l}
0,96 \\
\end{tabular} & \begin{tabular}{ll|}
1,95 \\
\end{tabular} & \begin{tabular}{|l|}
0,53 \\
\end{tabular} & \begin{tabular}{|l|}
0,49 \\
\end{tabular} & & 279,9 & 276,2 & 272,5 & 268,9 & 266,4 & \begin{tabular}{|l|}
260,9 \\
\end{tabular} & \begin{tabular}{|l|l|}
258,7 \\
\end{tabular} & \begin{tabular}{|l|l|}
279,9 \\
\end{tabular} & \begin{tabular}{|l|l|}
27,6 \\
\end{tabular} & \begin{tabular}{|l|l|}
273,4 \\
\end{tabular} & \begin{tabular}{|l|l}
270,0 \\
\end{tabular} & 265,7 & 262,6 & 266,7 \\
\hline 24,0 & 95,65 & 89,3 & 7,80 & \begin{tabular}{|l}
6,95 \\
\end{tabular} & 30,0 & \begin{tabular}{l|l}
27,0 \\
\end{tabular} & \begin{tabular}{|l}
26,70 \\
\end{tabular} & \begin{tabular}{|l|}
9,70 \\
\end{tabular} & \begin{tabular}{|l|l}
0,50 \\
\end{tabular} & \begin{tabular}{|l|}
0,40 \\
\end{tabular} & $\begin{array}{ll}0,57 \\
\end{array}$ & \begin{tabular}{|l}
38,8 \\
\end{tabular} & 27,000 & \begin{tabular}{|l|}
5,26 \\
\end{tabular} & \begin{tabular}{ll|}
1,30 \\
\end{tabular} & \begin{tabular}{|l|l|}
0,49 \\
\end{tabular} & \begin{tabular}{|l|}
0,37 \\
\end{tabular} & & 307,2 & \begin{tabular}{|l|l}
301,1 \\
\end{tabular} & 296,5 & 289,9 & 285,2 & \begin{tabular}{|l|}
280,6 \\
\end{tabular} & \begin{tabular}{|l|l|}
278,1 \\
\end{tabular} & \begin{tabular}{|l|l|}
307,3 \\
\end{tabular} & \begin{tabular}{|l|l|}
301,4 \\
\end{tabular} & \begin{tabular}{|l|l|}
296,2 \\
\end{tabular} & \begin{tabular}{|l|l|}
20,8 \\
\end{tabular} & 285,7 & \begin{tabular}{|l}
282,5 \\
\end{tabular} & 288,3 \\
\hline 24,5 & \begin{tabular}{|l|}
97,90 \\
\end{tabular} & 86,3 & & & 30,0 & 21,7 & \begin{tabular}{|l|}
5,66 \\
\end{tabular} & \begin{tabular}{|l|}
1,56 \\
\end{tabular} & \begin{tabular}{|l}
0,58 \\
\end{tabular} & \begin{tabular}{|l|}
0,51 \\
\end{tabular} & \begin{tabular}{|l|}
2,70 \\
\end{tabular} & \begin{tabular}{|l|l|}
18,8 \\
\end{tabular} & \begin{tabular}{|l|l|}
5,60 \\
\end{tabular} & \begin{tabular}{l|l}
1,34 \\
\end{tabular} & 0,64 & \begin{tabular}{|l|}
0,56 \\
\end{tabular} & \begin{tabular}{|l|}
0,46 \\
\end{tabular} & & 298,5 & \begin{tabular}{|l|}
295,8 \\
\end{tabular} & \begin{tabular}{|l|l}
293,3 \\
\end{tabular} & 290,1 & 284,9 & \begin{tabular}{|l|}
280,9 \\
\end{tabular} & \begin{tabular}{|l|l|}
278,1 \\
\end{tabular} & \begin{tabular}{|l|l|}
298,6 \\
\end{tabular} & 296,4 & \begin{tabular}{|l|l|}
294,7 \\
\end{tabular} & \begin{tabular}{|l|l|}
291,6 \\
\end{tabular} & 288,6 & 282,3 & 288,3 \\
\hline 27,0 & \begin{tabular}{|l|}
97,90 \\
\end{tabular} & 87,1 & & & 30,0 & 30,8 & \begin{tabular}{|l|l}
10,10 \\
\end{tabular} & \begin{tabular}{|l|l}
0,73 \\
\end{tabular} & \begin{tabular}{|l|l|}
0,46 \\
\end{tabular} & \begin{tabular}{|l|l|}
0,45 \\
\end{tabular} & 1,81 & \begin{tabular}{|l|l|}
27,1 \\
\end{tabular} & 12,4 & 0,85 & \begin{tabular}{|l|}
0,73 \\
\end{tabular} & \begin{tabular}{|l|l|}
0,44 \\
\end{tabular} & \begin{tabular}{|l|}
0,45 \\
\end{tabular} & & 302,0 & 2997,1 & 293,0 & 289,2 & 284,3 & \begin{tabular}{|l|}
280,6 \\
\end{tabular} & 278,1 & \begin{tabular}{|l|}
302,2 \\
\end{tabular} & 298,0 & \begin{tabular}{|l|}
294,8 \\
\end{tabular} & \begin{tabular}{|l|l|}
291,0 \\
\end{tabular} & 288,0 & 282,3 & 288,3 \\
\hline 30,0 & \begin{tabular}{|l|}
97,25 \\
\end{tabular} & $\begin{array}{l}97,4 \\
\end{array}$ & & & 30,0 & 32,5 & $\begin{array}{l}30,70 \\
\end{array}$ & \begin{tabular}{|l|l}
9,85 \\
\end{tabular} & \begin{tabular}{|l|}
0,40 \\
\end{tabular} & \begin{tabular}{|l|l}
0,47 \\
\end{tabular} & 4,80 & 42,5 & \begin{tabular}{|l|l|}
45,90 \\
\end{tabular} & \begin{tabular}{l|l}
6,29 \\
\end{tabular} & 0,55 & \begin{tabular}{|l|}
0,48 \\
\end{tabular} & \begin{tabular}{|l|l|}
4,82 \\
\end{tabular} & & 309,0 & 302,0 & 295,7 & 290,2 & 284,2 & \begin{tabular}{|l|}
280,6 \\
\end{tabular} & 278,1 & \begin{tabular}{|l|}
309,3 \\
\end{tabular} & \begin{tabular}{|l|l|}
303,0 \\
\end{tabular} & 299,5 & \begin{tabular}{|l|l|}
292,2 \\
\end{tabular} & 2886,1 & 282,3 & 2880,3 \\
\hline 30,5 & \begin{tabular}{|l}
97,90 \\
\end{tabular} & 88,2 & & & 29,0 & 21,8 & \begin{tabular}{|l|}
5,80 \\
\end{tabular} & \begin{tabular}{|l|l}
2,32 \\
\end{tabular} & \begin{tabular}{|l|l}
0,90 \\
\end{tabular} & \begin{tabular}{|l|l}
0,92 \\
\end{tabular} & \begin{tabular}{|l|l|}
0,89 \\
\end{tabular} & 21,0 & \begin{tabular}{|c|c|}
6,2 \\
\end{tabular} & \begin{tabular}{|l|}
5,03 \\
\end{tabular} & \begin{tabular}{|l|l|}
0 \\
\end{tabular} & \begin{tabular}{|l|}
0,98 \\
\end{tabular} & \begin{tabular}{|l|l|}
0,46 \\
\end{tabular} & & 290,4 & 2888,2 & 286,0 & 283,3 & 278,6 & \begin{tabular}{|l|}
274,5 \\
\end{tabular} & 271,5 & 200,4 & 288,5 & \begin{tabular}{|l|l|}
286,8 \\
\end{tabular} & \begin{tabular}{|l|l|}
284,4 \\
\end{tabular} & \begin{tabular}{|l|l|}
279,4 \\
\end{tabular} & 2725,6 & \begin{tabular}{|l}
273,6 \\
\end{tabular} \\
\hline 33,0 & \begin{tabular}{|l}
96,93 \\
\end{tabular} & 92,1 & & & 28,0 & 37,4 & \begin{tabular}{|l|l}
16,20 \\
\end{tabular} & \begin{tabular}{|l|l|}
1,64 \\
\end{tabular} & \begin{tabular}{|l}
0,75 \\
\end{tabular} & \begin{tabular}{|l|}
0,38 \\
\end{tabular} & \begin{tabular}{|l|l|}
0,96 \\
\end{tabular} & \begin{tabular}{|l|}
33,7 \\
\end{tabular} & 12,90 & 2,28 & \begin{tabular}{|l|l|} 
\\
\end{tabular} & \begin{tabular}{|l|}
0,59 \\
\end{tabular} & \begin{tabular}{|l|}
0,39 \\
\end{tabular} & & 2899,4 & \begin{tabular}{|l|}
284,9 \\
\end{tabular} & 2881,2 & 277,6 & 272,2 & \begin{tabular}{|l|}
267,9 \\
\end{tabular} & 265,0 & \begin{tabular}{|l|}
299,6 \\
\end{tabular} & 285,3 & 281,9 & \begin{tabular}{|l|l|}
278,7 \\
\end{tabular} & 2773,3 & 269,2 & 26671 \\
\hline 36,0 & \begin{tabular}{|l}
96,61 \\
\end{tabular} & 95,2 & & & 27,0 & 48,0 & \begin{tabular}{|l|}
28,40 \\
\end{tabular} & \begin{tabular}{|l|l|}
8,13 \\
\end{tabular} & 0,8 & \begin{tabular}{|l}
0,48 \\
\end{tabular} & \begin{tabular}{|l|}
0,68 \\
\end{tabular} & \begin{tabular}{|l|l}
41,2 \\
\end{tabular} & 21,20 & \begin{tabular}{|c|} 
\\
\end{tabular} & \begin{tabular}{ll|}
0,8 \\
\end{tabular} & \begin{tabular}{|l|}
0,65 \\
\end{tabular} & \begin{tabular}{|l|}
0,42 \\
\end{tabular} & & 291,9 & \begin{tabular}{|l|}
284,0 \\
\end{tabular} & \begin{tabular}{|l|}
278,1 \\
\end{tabular} & 272,8 & 265,7 & \begin{tabular}{|l|}
261,5 \\
\end{tabular} & 258,7 & \begin{tabular}{|l|}
291,4 \\
\end{tabular} & 285,1 & 279,9 & 274,6 & \begin{tabular}{|l|l|}
26,8 \\
\end{tabular} & 262,6 & \begin{tabular}{|l}
260,7 \\
\end{tabular} \\
\hline 36,5 & \begin{tabular}{|l}
97,90 \\
\end{tabular} & 91,7 & & & 27,0 & 29,4 & \begin{tabular}{|l|}
19,30 \\
\end{tabular} & $\begin{array}{l}3,45 \\
\end{array}$ & \begin{tabular}{|l}
0,98 \\
\end{tabular} & \begin{tabular}{|l|l}
0,57 \\
\end{tabular} & 1,13 & \begin{tabular}{|l|}
37,3 \\
\end{tabular} & 15,20 & 2,13 & \begin{tabular}{|l|}
0,98 \\
\end{tabular} & \begin{tabular}{|l|l|}
0,81 \\
\end{tabular} & \begin{tabular}{|l|l|}
0,41 \\
\end{tabular} & & 276,2 & \begin{tabular}{|l|}
274,6 \\
\end{tabular} & 272,5 & 269,9 & 265,5 & \begin{tabular}{|l|}
261,3 \\
\end{tabular} & 258,7 & \begin{tabular}{|l|l|}
276,2 \\
\end{tabular} & 274,9 & \begin{tabular}{|l|}
273,1 \\
\end{tabular} & \begin{tabular}{|l}
271,0 \\
\end{tabular} & 266,3 & 262,6 & 260,7 \\
\hline 39,0 & \begin{tabular}{|l|l}
97,57 \\
\end{tabular} & 90,6 & & & 25,0 & 52,8 & 22,40 & \begin{tabular}{|l|l|}
11,01 \\
\end{tabular} & \begin{tabular}{|l}
5,14 \\
\end{tabular} & \begin{tabular}{|l|}
3,61 \\
\end{tabular} & $\begin{array}{ll}1,05 \\
\end{array}$ & \begin{tabular}{|l|l}
41,4 \\
\end{tabular} & 30,20 & \begin{tabular}{|l|l|l|}
50 \\
\end{tabular} & \begin{tabular}{|l|}
0,99 \\
\end{tabular} & \begin{tabular}{|l|l|}
0,88 \\
\end{tabular} & \begin{tabular}{|l|}
0,48 \\
\end{tabular} & & 271,6 & 267,7 & 263,7 & 259,2 & 253,2 & \begin{tabular}{|l|}
249,2 \\
\end{tabular} & 246,5 & 271,2 & 268,2 & 264,2 & 260,2 & \begin{tabular}{|l|}
2540 \\
\end{tabular} & 250,2 & \begin{tabular}{|l|l}
248,4 \\
\end{tabular} \\
\hline 42,0 & \begin{tabular}{|l|}
97,57 \\
\end{tabular} & 95,1 & 7,80 & 7,02 & 25,0 & \begin{tabular}{ll|}
78,2 \\
\end{tabular} & \begin{tabular}{|l}
35,90 \\
\end{tabular} & 25,00 & \begin{tabular}{|l}
8,53 \\
\end{tabular} & \begin{tabular}{|l}
6,35 \\
\end{tabular} & 1,06 & \begin{tabular}{|l}
68,8 \\
\end{tabular} & 43,40 & 23,20 & \begin{tabular}{|l|l|}
2,66 \\
\end{tabular} & \begin{tabular}{|l|l|}
0,95 \\
\end{tabular} & \begin{tabular}{|l|}
0,78 \\
\end{tabular} & & 280,1 & \begin{tabular}{|l}
273,6 \\
\end{tabular} & 267,7 & 262,2 & 253,7 & \begin{tabular}{|l|}
249,2 \\
\end{tabular} & 246,5 & 280,1 & 274,1 & 268,2 & 262,2 & \begin{tabular}{|l|l|}
254,2 \\
\end{tabular} & \begin{tabular}{|l|}
250,2 \\
\end{tabular} & 248,4 \\
\hline 42,5 & \begin{tabular}{|l|l|}
97,57 \\
\end{tabular} & 78,6 & & & 25,0 & 28,1 & \begin{tabular}{|l}
7,58 \\
\end{tabular} & \begin{tabular}{|l|l}
1,87 \\
\end{tabular} & \begin{tabular}{|l|l}
0,84 \\
\end{tabular} & \begin{tabular}{|l|}
0,95 \\
\end{tabular} & \begin{tabular}{ll|}
1,03 \\
\end{tabular} & \begin{tabular}{|l|}
26,3 \\
\end{tabular} & \begin{tabular}{|l|l}
8,17 \\
\end{tabular} & \begin{tabular}{ll|}
1,53 \\
\end{tabular} & \begin{tabular}{|l|}
0,76 \\
\end{tabular} & \begin{tabular}{|l|l|}
0,70 \\
\end{tabular} & \begin{tabular}{|l|}
0,49 \\
\end{tabular} & & 265,2 & \begin{tabular}{|l|}
263,4 \\
\end{tabular} & 261,7 & 259,0 & 253,5 & \begin{tabular}{|l|}
249,2 \\
\end{tabular} & 246,5 & \begin{tabular}{|l|l|}
265,2 \\
\end{tabular} & 263,7 & 262,2 & \begin{tabular}{|l|l|}
259,4 \\
\end{tabular} & \begin{tabular}{|l|}
254,4 \\
\end{tabular} & 250,2 & 2448,4 \\
\hline 45,0 & \begin{tabular}{|l|l}
97,25 \\
\end{tabular} & 95,1 & & & 27,0 & \begin{tabular}{|l|}
30,4 \\
\end{tabular} & \begin{tabular}{|l|l}
10,20 \\
\end{tabular} & \begin{tabular}{|l|}
2,72 \\
\end{tabular} & \begin{tabular}{|l|l}
0,86 \\
\end{tabular} & \begin{tabular}{|l}
0,63 \\
\end{tabular} & $\begin{array}{l}0,55 \\
\end{array}$ & \begin{tabular}{|l|l}
30,1 \\
\end{tabular} & \begin{tabular}{|l|l}
11,4 \\
\end{tabular} & \begin{tabular}{ll|l}
1,67 \\
\end{tabular} & 0,57 & \begin{tabular}{|l|}
0,53 \\
\end{tabular} & \begin{tabular}{|l|}
0,53 \\
\end{tabular} & & 282,5 & 278,8 & 275,6 & 271,9 & 265,9 & 261,5 & 258,7 & \begin{tabular}{|l|l|}
228,5 \\
\end{tabular} & \begin{tabular}{ll|}
278,3 \\
\end{tabular} & \begin{tabular}{|l|l}
276,2 \\
\end{tabular} & 272,5 & 267,1 & 262,6 & 266,7 \\
\hline 48,0 & \begin{tabular}{|l|l}
97,90 \\
\end{tabular} & $\begin{array}{l}88,8 \\
\end{array}$ & & & 299,0 & \begin{tabular}{|l|}
39,4 \\
\end{tabular} & 36,20 & 25,60 & \begin{tabular}{|l}
5,34 \\
\end{tabular} & \begin{tabular}{|l|l|}
1,94 \\
\end{tabular} & $\begin{array}{ll}0,78 \\
\end{array}$ & \begin{tabular}{|l}
66,1 \\
\end{tabular} & \begin{tabular}{|l|l}
45,20 \\
\end{tabular} & 13,40 & \begin{tabular}{|l|l|}
3,12 \\
\end{tabular} & \begin{tabular}{|l|l|}
0,72 \\
\end{tabular} & \begin{tabular}{|l|}
0,37 \\
\end{tabular} & & 305,2 & 299,1 & 293,2 & \begin{tabular}{|l|l}
28,0 \\
\end{tabular} & 279,4 & 274,5 & 27,5 & \begin{tabular}{|l|l|}
305,8 \\
\end{tabular} & \begin{tabular}{|l|l|}
300,8 \\
\end{tabular} & \begin{tabular}{|l|l|}
294,2 \\
\end{tabular} & \begin{tabular}{|l|l|}
289,6 \\
\end{tabular} & 288,3 & 275,6 & \begin{tabular}{|l}
273,6 \\
\end{tabular} \\
\hline 48,5 & \begin{tabular}{|l|}
97,90 \\
\end{tabular} & & & & 29,0 & 21,8 & \begin{tabular}{|l|}
6,90 \\
\end{tabular} & \begin{tabular}{|l|l}
1,18 \\
\end{tabular} & \begin{tabular}{|l}
1,00 \\
\end{tabular} & \begin{tabular}{|l|l|}
0,83 \\
\end{tabular} & \begin{tabular}{|l|}
0,99 \\
\end{tabular} & \begin{tabular}{|l|l}
20,9 \\
\end{tabular} & \begin{tabular}{|l|l|}
5,56 \\
\end{tabular} & 1,38 & 1,25 & \begin{tabular}{|l|l|}
0,72 \\
\end{tabular} & \begin{tabular}{|l|}
0,93 \\
\end{tabular} & & 290,3 & \begin{tabular}{|l|}
288,4 \\
\end{tabular} & 286,6 & 284,0 & 278,9 & \begin{tabular}{|l|}
274,5 \\
\end{tabular} & 271,5 & \begin{tabular}{|l|}
290,2 \\
\end{tabular} & 288,7 & 2887,2 & \begin{tabular}{|l|l|}
284,7 \\
\end{tabular} & 280,0 & 275,6 & 273,6 \\
\hline 51,0 & \begin{tabular}{|l|l}
96,61 \\
\end{tabular} & 84,2 & & & 30,0 & 28,7 & \begin{tabular}{|l|l}
14,20 \\
\end{tabular} & \begin{tabular}{|l|l}
4,11 \\
\end{tabular} & \begin{tabular}{|l|l}
0,73 \\
\end{tabular} & \begin{tabular}{|l|}
0,50 \\
\end{tabular} & \begin{tabular}{|l|l|}
0,89 \\
\end{tabular} & \begin{tabular}{|l|}
32,5 \\
\end{tabular} & \begin{tabular}{|l|l}
16,10 \\
\end{tabular} & $\begin{array}{ll}1,48 \\
\end{array}$ & \begin{tabular}{|c|}
0,69 \\
\end{tabular} & \begin{tabular}{|l|}
0,48 \\
\end{tabular} & \begin{tabular}{|l|}
0,48 \\
\end{tabular} & & 303,1 & 298,6 & 294,9 & \begin{tabular}{|l|l|}
291,2 \\
\end{tabular} & 285,3 & \begin{tabular}{|l|}
280,9 \\
\end{tabular} & 278,1 & \begin{tabular}{|l|l|}
303,2 \\
\end{tabular} & 2099,3 & \begin{tabular}{|l|l|}
295,9 \\
\end{tabular} & \begin{tabular}{|l|l|}
292,2 \\
\end{tabular} & \begin{tabular}{|l|l|}
28,7 \\
\end{tabular} & \begin{tabular}{|l|l|}
282,3 \\
\end{tabular} & 2880,3 \\
\hline 54,0 & \begin{tabular}{|l|}
97,57 \\
\end{tabular} & 83,9 & $\begin{array}{l}7,81 \\
\end{array}$ & \begin{tabular}{|l|l}
7,03 \\
\end{tabular} & 299,0 & \begin{tabular}{|l|}
37,9 \\
\end{tabular} & \begin{tabular}{|l|l}
30,90 \\
\end{tabular} & \begin{tabular}{|l|}
1,76 \\
\end{tabular} & \begin{tabular}{|l|}
1,76 \\
\end{tabular} & \begin{tabular}{|l|l}
1,04 \\
\end{tabular} & \begin{tabular}{|l|}
0,56 \\
\end{tabular} & \begin{tabular}{|l|l|}
93,1 \\
\end{tabular} & \begin{tabular}{|l|l|l|}
742 \\
\end{tabular} & \begin{tabular}{|l|}
9,95 \\
\end{tabular} & \begin{tabular}{ll|}
1,21 \\
\end{tabular} & \begin{tabular}{|l|}
0,56 \\
\end{tabular} & \begin{tabular}{|l|}
0,28 \\
\end{tabular} & & 304,4 & \begin{tabular}{|l}
297,8 \\
\end{tabular} & \begin{tabular}{|l|}
222,0 \\
\end{tabular} & 286,7 & 278,6 & \begin{tabular}{|l|}
274,3 \\
\end{tabular} & 271,5 & \begin{tabular}{|l|}
304,7 \\
\end{tabular} & 298,4 & \begin{tabular}{|l|l|}
293,1 \\
\end{tabular} & \begin{tabular}{|l|l|}
287,4 \\
\end{tabular} & 280,3 & 275,9 & 277,6 \\
\hline 54,5 & \begin{tabular}{|l|l}
95,97 \\
\end{tabular} & 83,1 & & & 28,0 & 23,4 & \begin{tabular}{|l|}
8,80 \\
\end{tabular} & \begin{tabular}{|l|}
1,06 \\
\end{tabular} & \begin{tabular}{|l|}
1,06 \\
\end{tabular} & \begin{tabular}{|l|}
1,69 \\
\end{tabular} & \begin{tabular}{|l|l|}
0,87 \\
\end{tabular} & \begin{tabular}{|l|}
27,2 \\
\end{tabular} & \begin{tabular}{|l|l|}
6,67 \\
\end{tabular} & 2,43 & 0,88 & \begin{tabular}{|l|l|}
1,28 \\
\end{tabular} & \begin{tabular}{|l|l|}
0,41 \\
\end{tabular} & & 281,9 & \begin{tabular}{|l|}
280,0 \\
\end{tabular} & 278,1 & 275,7 & 271,1 & \begin{tabular}{|l|}
267,4 \\
\end{tabular} & 265,0 & \begin{tabular}{|l|l|}
281,9 \\
\end{tabular} & \begin{tabular}{|l|l|}
280,6 \\
\end{tabular} & \begin{tabular}{|l|l|}
279,0 \\
\end{tabular} & \begin{tabular}{|l|}
27,5 \\
\end{tabular} & 272,2 & 2669,3 & 266,1 \\
\hline 57,0 & \begin{tabular}{|l|l}
97,5 \\
\end{tabular} & 78,9 & & & 26,0 & 31,5 & \begin{tabular}{|l|}
16,30 \\
\end{tabular} & \begin{tabular}{|l|}
5,94 \\
\end{tabular} & \begin{tabular}{|l|}
2,01 \\
\end{tabular} & \begin{tabular}{|l|l|}
2,13 \\
\end{tabular} & \begin{tabular}{|l|l|}
0,63 \\
\end{tabular} & \begin{tabular}{|l|l}
53,5 \\
\end{tabular} & \begin{tabular}{|l|l|}
12,5 \\
\end{tabular} & \begin{tabular}{|l|l|}
6,01 \\
\end{tabular} & 1,56 & \begin{tabular}{|l|}
1,98 \\
\end{tabular} & \begin{tabular}{|l|}
0,58 \\
\end{tabular} & & 274,7 & \begin{tabular}{|l|}
271,1 \\
\end{tabular} & 268,6 & 263,5 & 258,4 & \begin{tabular}{|l|}
254,8 \\
\end{tabular} & 252,6 & 2725, & 271,7 & 268,1 & 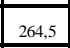 & 2559,9 & 25,8 & 254,5 \\
\hline 58,5 & \begin{tabular}{|l|l}
96,61 \\
\end{tabular} & & & & 26 & & & & & & & & & & & & & & 279,8 & \begin{tabular}{|l|}
273,7 \\
\end{tabular} & 2699,1 & 264,5 & 259,4 & 2 & \begin{tabular}{|l|l|}
252,6 \\
\end{tabular} & \begin{tabular}{|l|}
279,3 \\
\end{tabular} & \begin{tabular}{|l|l|}
274,5 \\
\end{tabular} & \begin{tabular}{|l|l|}
270,4 \\
\end{tabular} & \begin{tabular}{|l|l|}
265,5 \\
\end{tabular} & \begin{tabular}{|l|l|}
260,4 \\
\end{tabular} & 25,8 & 254,5 \\
\hline 60,0 & \begin{tabular}{|l}
97,90 \\
\end{tabular} & 82,3 & & & 26,0 & \begin{tabular}{|c|}
51,5 \\
\end{tabular} & \begin{tabular}{|l|}
31,90 \\
\end{tabular} & \begin{tabular}{|l}
22,30 \\
\end{tabular} & 3,15 & \begin{tabular}{|l|l}
1,58 \\
\end{tabular} & 1,58 & \begin{tabular}{|l|l}
62,5 \\
\end{tabular} & \begin{tabular}{|l|}
30,50 \\
\end{tabular} & 15,30 & \begin{tabular}{l|l}
2,98 \\
\end{tabular} & \begin{tabular}{|l|}
1,95 \\
\end{tabular} & \begin{tabular}{|l|l|}
0,98 \\
\end{tabular} & & 2885,4 & \begin{tabular}{|l|l|}
277,3 \\
\end{tabular} & 2270,7 & 26,5 & 25999 & \begin{tabular}{|l|}
255,8 \\
\end{tabular} & \begin{tabular}{|l|l|}
252,6 \\
\end{tabular} & \begin{tabular}{|l|}
285,4 \\
\end{tabular} & 277,4 & 271,7 & \begin{tabular}{|l|l|}
267, \\
\end{tabular} & 260,9 & 25,8 & 254,5 \\
\hline 60,9 & \begin{tabular}{|l|l}
8,22 \\
\end{tabular} & & & & 26 & & & & & & & & & & & & & & 287,2 & \begin{tabular}{|l}
280,1 \\
\end{tabular} & 271,1 & 267,6 & 260,1 & \begin{tabular}{|l|l|}
255,8 \\
\end{tabular} & 252,6 & \begin{tabular}{|l|l|}
287,2 \\
\end{tabular} & 280,4 & & 2688,1 & 261,2 & 256,8 & 254,5 \\
\hline
\end{tabular}


Tabela C5.2 - Continuação

\begin{tabular}{|c|c|c|c|c|c|c|c|c|c|c|c|c|c|c|}
\hline \multirow{2}{*}{$\begin{array}{c}\text { Duração } \\
\text { (h) }\end{array}$} & \multicolumn{14}{|c|}{ FAAG -Perda de Carga Lida (cm) } \\
\hline & P1-1 & P2-1 & P3-1 & P4-1 & P5-1 & P6-1 & P7-1 & P1-2 & P2-2 & P3-2 & P4-2 & P5-2 & P6-2 & P7-2 \\
\hline 0,3 & 260,0 & 259,0 & 258,0 & 255,7 & 252,2 & 249,5 & 248,0 & 260,2 & 259,1 & 258,0 & 256,5 & 253,0 & 250,8 & 249,2 \\
\hline 1,0 & 262,0 & 259,8 & 258,0 & 255,5 & 252,3 & 249,5 & 248,0 & 262,0 & 260,0 & 258,7 & 256,6 & 253,3 & 251,0 & 249,2 \\
\hline 3,0 & 264,4 & 261,1 & 258,4 & 255,7 & 252,3 & 249,4 & 248,0 & 264,5 & 261,6 & 259,3 & 257,0 & 253,7 & 250,9 & 249,0 \\
\hline 6,0 & 268,5 & 263,7 & 259,5 & 256,0 & 252,3 & 249,4 & 247,8 & 268,6 & 264,1 & 260,5 & 257,2 & 253,7 & 250,9 & 249,0 \\
\hline 6,5 & 262,8 & 261,3 & 257,8 & 255,9 & 252,2 & 249,4 & 247,8 & 262,8 & 261,4 & 259,5 & 257,2 & 253,7 & 250,9 & 249,2 \\
\hline 9,0 & 268,8 & 265,0 & 260,4 & 256,3 & 252,2 & 249,2 & 247,3 & 268,8 & 265,0 & 261,3 & 257,6 & 253,8 & 250,8 & 249,2 \\
\hline 12,0 & 274,0 & 268,5 & 263,0 & 256,8 & 252,5 & 249,5 & 247,3 & 274,0 & 269,0 & 263,8 & 257,9 & 254,0 & 251,0 & 249,2 \\
\hline 12,5 & 261,0 & 260,0 & 258,0 & 256,0 & 253,0 & 249,5 & 247,3 & 261,0 & 260,2 & 259,0 & 257,0 & 254,0 & 250,7 & 249,2 \\
\hline 15,0 & 266,2 & 263,0 & 259,8 & 256,5 & 252,3 & 249,5 & 247,3 & 266,3 & 263,3 & 260,6 & 257,5 & 254,0 & 251,0 & 249,2 \\
\hline 18,0 & 274,0 & 268,0 & 264,0 & 257,5 & 252,3 & 249,5 & 247,3 & 274,0 & 268,0 & 264,0 & 259,0 & 255,0 & 251,0 & 249,2 \\
\hline 18,5 & 262,0 & 260,8 & 259,0 & 256,8 & 252,5 & 249,5 & 247,3 & 262,0 & 260,9 & 259,5 & 257,5 & 254,0 & 251,0 & 249,2 \\
\hline 21,0 & 267,5 & 264,0 & 260,5 & 257,0 & 252,7 & 249,4 & 247,3 & 267,5 & 264,4 & 261,3 & 258,1 & 254,0 & 251,0 & 249,2 \\
\hline 24,0 & 273,1 & 267,7 & 263,6 & 257,8 & 253,6 & 249,5 & 247,3 & 273,2 & 268,0 & 263,4 & 258,6 & 254,0 & 251,2 & 249,2 \\
\hline 24,5 & 265,4 & 263,0 & 260,8 & 257,9 & 253,3 & 249,8 & 247,3 & 265,5 & 263,5 & 262,0 & 259,3 & 254,8 & 251,0 & 249,2 \\
\hline 27,0 & 268,5 & 264,2 & 260,5 & 257,1 & 252,8 & 249,5 & 247,3 & 268,7 & 265,0 & 262,1 & 258,7 & 254,3 & 251,0 & 249,2 \\
\hline 30,0 & 274,7 & 268,5 & 262,9 & 258,0 & 252,7 & 249,5 & 247,3 & 275,0 & 269,4 & 264,5 & 259,8 & 254,4 & 251,0 & 249,2 \\
\hline 30,5 & 264,5 & 262,5 & 260,5 & 258,0 & 253,8 & 250,0 & 247,3 & 264,5 & 262,8 & 261,2 & 259,0 & 254,5 & 251,0 & 249,2 \\
\hline 33,0 & 270,0 & 265,8 & 262,4 & 259,0 & 254,0 & 250,0 & 247,3 & 270,2 & 266,2 & 263,0 & 260,0 & 255,0 & 251,2 & 249,2 \\
\hline 36,0 & 279,0 & 271,5 & 265,8 & 260,8 & 254,0 & 250,0 & 247,3 & 278,5 & 272,5 & 267,5 & 262,5 & 255,0 & 251,0 & 249,2 \\
\hline 36,5 & 264,0 & 262,5 & 260,5 & 258,0 & 253,8 & 249,8 & 247,3 & 264,0 & 262,8 & 261,0 & 259,0 & 254,5 & 251,0 & 249,2 \\
\hline 39,0 & 272,4 & 268,5 & 264,5 & 260,0 & 254,0 & 250,0 & 247,3 & 272,0 & 269,0 & 265,0 & 261,0 & 254,8 & 251,0 & 249,2 \\
\hline 42,0 & 281,0 & 274,5 & 268,5 & 263,0 & 254,5 & 250,0 & 247,3 & 281,0 & 275,0 & 269,0 & 263,0 & 255,0 & 251,0 & 249,2 \\
\hline 42,5 & 266,0 & 264,2 & 262,5 & 259,8 & 254,3 & 250,0 & 247,3 & 266,0 & 264,5 & 263,0 & 260,2 & 255,2 & 251,0 & 249,2 \\
\hline 45,0 & 270,0 & 266,5 & 263,4 & 259,9 & 254,2 & 250,0 & 247,3 & 270,0 & 266,0 & 264,0 & 260,5 & 255,3 & 251,0 & 249,2 \\
\hline 48,0 & 278,0 & 272,4 & 267,1 & 262,3 & 254,5 & 250,0 & 247,3 & 278,5 & 274,0 & 268,0 & 263,8 & 255,3 & 251,0 & 249,2 \\
\hline 48,5 & 264,4 & 262,7 & 261,0 & 258,7 & 254,0 & 250,0 & 247,3 & 264,3 & 263,0 & 261,6 & 259,3 & 255,0 & 251,0 & 249,2 \\
\hline 51,0 & 269,5 & 265,5 & 262,2 & 258,9 & 253,7 & 249,8 & 247,3 & 269,6 & 266,1 & 263,1 & 259,8 & 254,9 & 251,0 & 249,2 \\
\hline 54,0 & 277,3 & 271,2 & 266,0 & 261,1 & 253,8 & 249,8 & 247,3 & 277,5 & 271,8 & 267,0 & 261,8 & 255,3 & 251,3 & 249,2 \\
\hline 54,5 & 263,0 & 261,3 & 259,5 & 257,2 & 253,0 & 249,5 & 247,3 & 263,0 & 261,8 & 260,3 & 258,0 & 254,0 & 251,3 & 249,2 \\
\hline 57,0 & 269,0 & 265,5 & 263,0 & 258,0 & 253,0 & 249,5 & 247,3 & 270,0 & 266,0 & 262,5 & 259,0 & 254,5 & 251,5 & 249,2 \\
\hline 58,5 & 274,0 & 268,0 & 263,5 & 259,0 & 254,0 & 250,0 & 247,3 & 273,5 & 268,8 & 264,8 & 260,0 & 255,0 & 251,5 & 249,2 \\
\hline 60,0 & 279,5 & 271,5 & 265,1 & 261,0 & 254,5 & 250,5 & 247,3 & 279,5 & 271,6 & 266,0 & 262,1 & 255,5 & 251,5 & 249,2 \\
\hline 60,9 & 281,2 & 274,3 & 265,5 & 262,0 & 254,7 & 250,5 & 247,3 & 281,2 & 274,6 & 266,5 & 262,5 & 255,8 & 251,5 & 249,2 \\
\hline
\end{tabular}

$\mathrm{Q}_{\mathrm{T}}$ : vazão total afluente ao Sistema de Dupla Filtração (medidor de vazão eletromagnético);

Turb. AE: turbidez da água de estudo (turbidímetro de bancada);

pH AE: pH da água de estudo;

pH Coag.: pH de coagulação;

Ci-1: amostra coletada no final da subcamada i do meio filtrante da câmara de filtração 1 do FAAG;

Ci-2: amostra coletada no final da subcamada i do meio filtrante da câmara de filtração 2 do FAAG;

C1+C2: amostra de água pré-filtrada global (efluentes das câmaras de filtração 1 e 2 da FAAG) - neste ensaio coleta de amostras não foi realizada;

Pi-1: piezômetro i localizado na câmara de filtração 1 do FAAG;

Pi-2: piezômetro i localizado na câmara de filtração 2 do FAAG;

: execução de DFI nas duas câmaras do FAAG; 
Tabela C5.2 - Continuação

\begin{tabular}{|c|c|c|c|c|c|c|c|}
\hline \multirow{3}{*}{$\begin{array}{c}\text { Duração } \\
\text { (h) }\end{array}$} & \multirow{3}{*}{$\begin{array}{l}\text { Temp. } \\
\text { (oC) }\end{array}$} & \multicolumn{6}{|c|}{ Filtro Rápido Descendente - FRD } \\
\hline & & \multirow{2}{*}{$\begin{array}{l}\text { Qfd } \\
(\mathrm{L} / \mathrm{h})\end{array}$} & \multirow{2}{*}{$\begin{array}{c}\text { Turbidez - TB (uT) } \\
\text { AF }\end{array}$} & \multicolumn{2}{|c|}{ Perda de Carga Corrigida $25^{\circ} \mathrm{C}(\mathrm{cm})$} & \multicolumn{2}{|c|}{ Perda de Carga Lida $(\mathrm{cm})$} \\
\hline & & & & $\mathrm{P} 1$ & P2 & $\mathrm{P} 1$ & $\mathrm{P} 2$ \\
\hline 0,3 & 28,0 & 82,5 & & 28,1 & 111,5 & 26,2 & 104,0 \\
\hline 1,0 & 28,0 & 82,5 & & 28,1 & 111,9 & 26,2 & 104, \\
\hline 3,0 & 28,0 & 82,5 & 0,35 & 28,0 & 113,3 & 26,1 & 105,7 \\
\hline 6,0 & 28,0 & 82,5 & 0,36 & 27,7 & 114,6 & 25,8 & 106,9 \\
\hline 6,5 & 27,5 & 82,5 & 0,37 & 27,5 & 116,1 & 26,0 & 109,6 \\
\hline 9,0 & 27,0 & 82,5 & 0,34 & 27,2 & 117,7 & 26,0 & 112,5 \\
\hline 12,0 & 27,0 & 82,5 & 0,42 & 27,2 & 120,6 & 26,0 & 115,3 \\
\hline 12,5 & 26,0 & 82,5 & 0,50 & 26,6 & 119,5 & 26,0 & 117,0 \\
\hline 15,0 & 25,0 & 82,5 & 0,48 & 25,9 & 118,6 & 26,0 & 119,0 \\
\hline 18,0 & 25,0 & 82,5 & 1,02 & 25,9 & 120,6 & 26,0 & 121,0 \\
\hline 18,5 & 25,0 & 82,5 & 0,50 & 25,9 & 125,8 & 26,0 & 126,2 \\
\hline 21,0 & 27,0 & 82,5 & 0,43 & 27,2 & 128,7 & 26,0 & 123,0 \\
\hline 24,0 & 30,0 & 82,5 & 0,37 & 29,2 & 139,6 & 26,0 & 124, \\
\hline 24,5 & 30,0 & 82,5 & 0,38 & 29,2 & 140,6 & 26,0 & 125,0 \\
\hline 27,0 & 30,0 & 82,5 & 0,35 & 29,2 & 142,2 & 26,0 & 126,4 \\
\hline 30,0 & 30,0 & 82,5 & 0,37 & 29,2 & 142,8 & 26,0 & 127,0 \\
\hline 30,5 & 29,0 & 82,5 & 0,19 & 28,5 & 147,1 & 26,0 & 134,0 \\
\hline 33,0 & 28,0 & 82,5 & 0,17 & 27,9 & 144,7 & 26,0 & 135,0 \\
\hline 36,0 & 27,0 & 82,5 & 0,22 & 27,2 & 143,9 & 26,0 & 137,5 \\
\hline 36,5 & 27,0 & 82,5 & 0,30 & 27,2 & 147,5 & 26,0 & 141,0 \\
\hline 39,0 & 25,0 & 82,5 & 0,21 & 25,9 & 145,7 & 26,0 & 146,2 \\
\hline 42,0 & 25,0 & 82,5 & 0,15 & 25,9 & 151,3 & 26,0 & 151,8 \\
\hline 42,5 & 25,0 & 82,5 & 0,43 & 25,9 & 154,0 & 26,0 & 154,5 \\
\hline 45,0 & 27,0 & 82,5 & 0,40 & 27,2 & 166,3 & 26,0 & 159,0 \\
\hline 48,0 & 29,0 & 82,5 & 0,28 & 28,5 & 176,8 & 26,0 & 161,0 \\
\hline 48,5 & 29,0 & 82,5 & 0,16 & 28,5 & 181,2 & 26,0 & 165,0 \\
\hline 51,0 & 30,0 & 82,5 & 0,48 & 29,2 & 193,8 & 26,0 & 172,3 \\
\hline 54,0 & 29,0 & 82,5 & 0,35 & 28,5 & 199,8 & 26,0 & 182,0 \\
\hline 54,5 & 28,0 & 82,5 & 0,19 & 27,9 & 202,1 & 26,0 & 188,6 \\
\hline 57,0 & 26,0 & 82,5 & 0,22 & 26,6 & 196,1 & 26,0 & 192,0 \\
\hline 58,5 & 26 & & & 26,6 & 202,3 & 26,0 & 198,1 \\
\hline 60,0 & 26,0 & 82,5 & 0,33 & 26,6 & 205,3 & 26,0 & 201,0 \\
\hline 60,9 & 26 & & & 26,6 & 207,8 & 26,0 & 203,5 \\
\hline
\end{tabular}

$\mathrm{Q}_{\mathrm{fd}}$ : vazão afluente ao FRD (rotâmetro);

Turb. AF: turbidez da água filtrada (turbidímetro de bancada);

P1 e P2: piezômetros localizados no início e no final do FRD, respectivamente. 


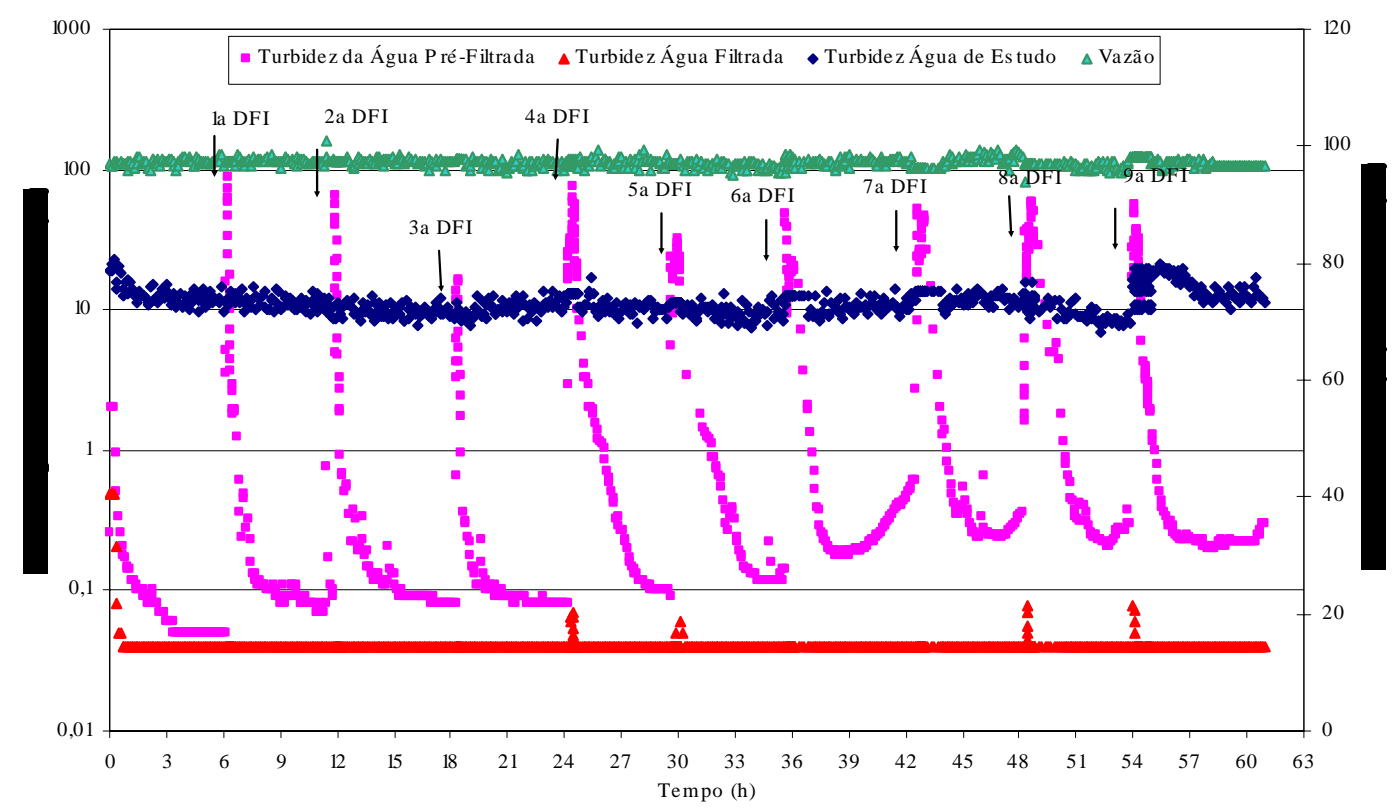

Figura C5.1 - Variações da vazão total afluente ao sistema de dupla filtração e da turbidez das águas de estudo, pré-filtrada e filtrada no ensaio 5 - Turbidímetros de Escoamento Contínuo

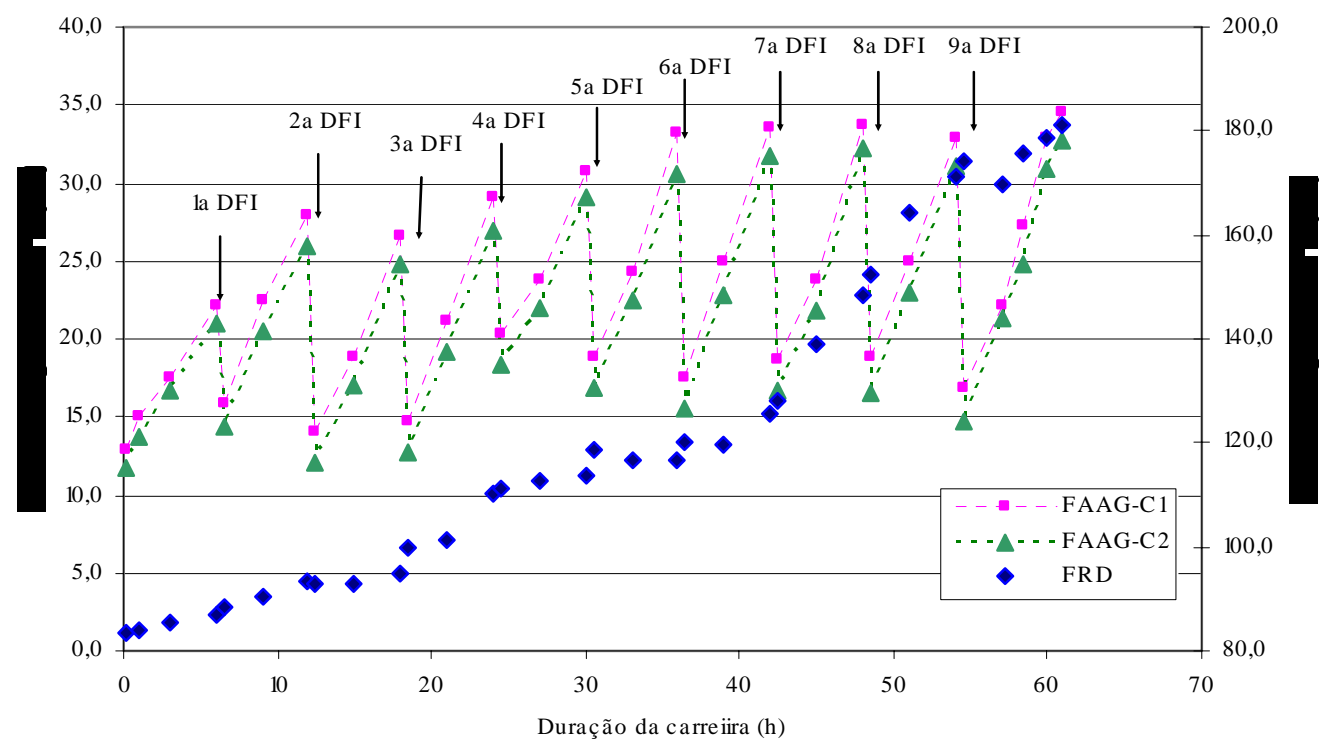

Figura C5.2 - Perda de carga nos filtros ascendente de areia grossa (duas câmaras de filtração) e descendente durante o ensaio 5 de dupla filtração 


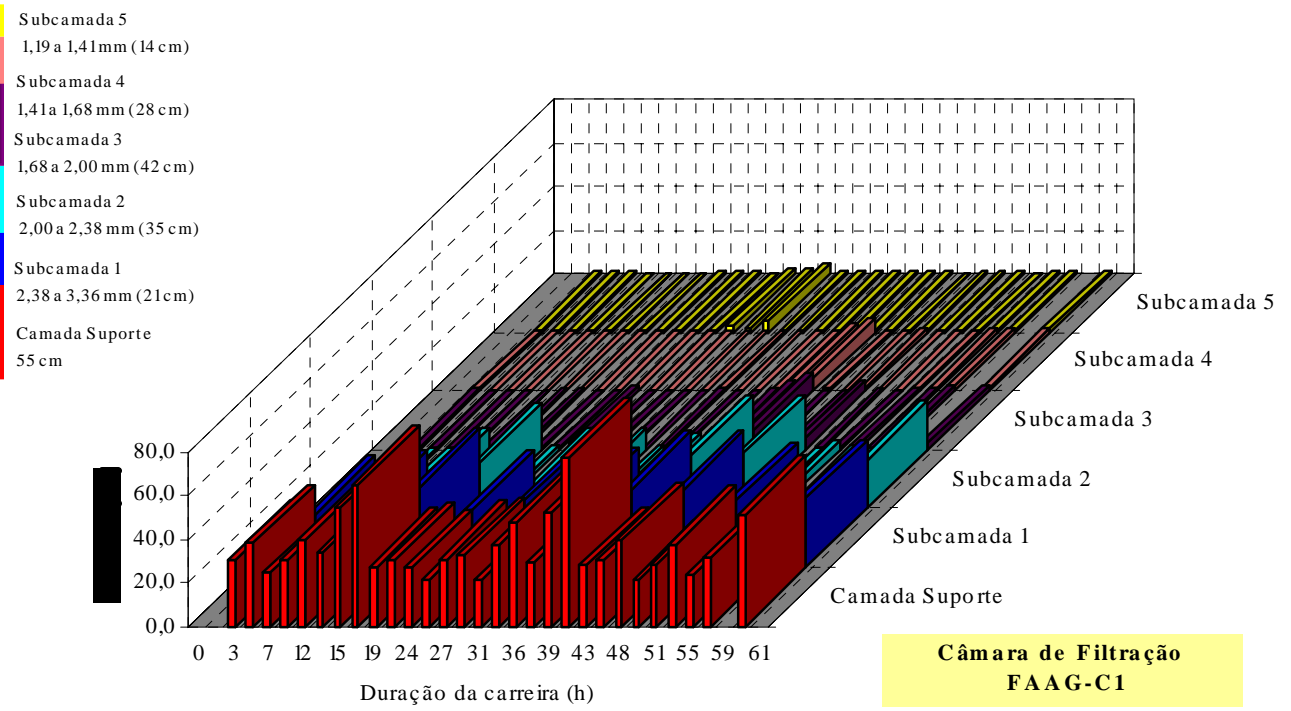

Figura C5.3 - Turbidez ao longo do meio filtrante da câmara de filtração 1 do FAAG durante o ensaio 5 de dupla filtração

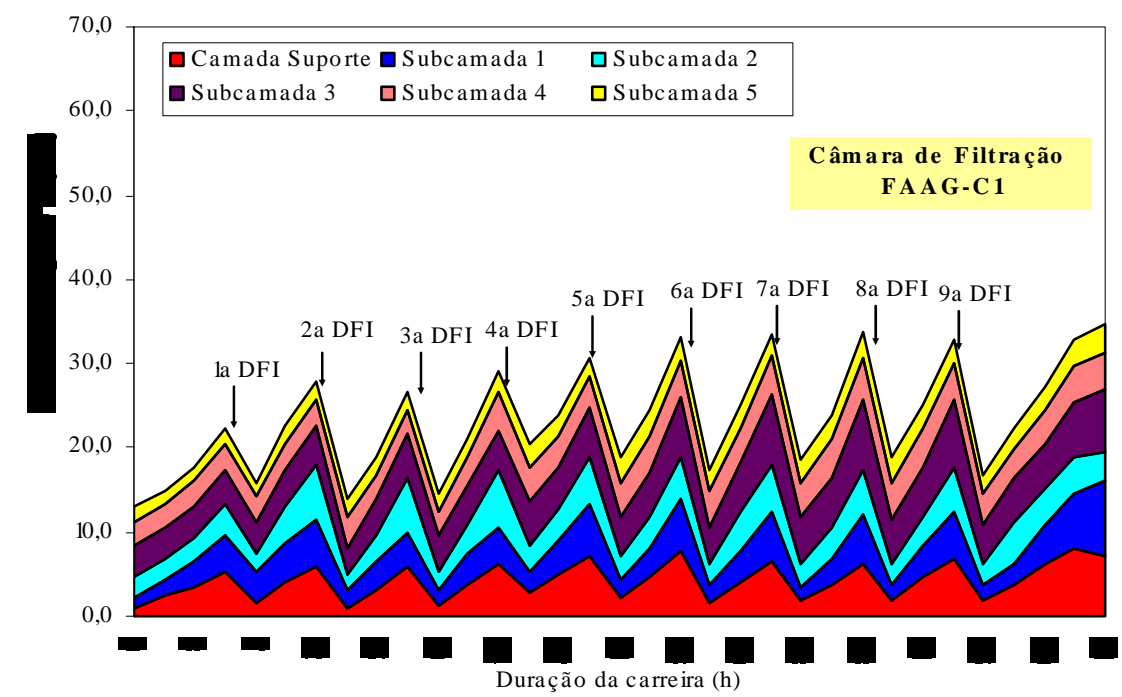

Figura C5.4 - Perda de carga ao longo do meio filtrante da câmara de filtração 1 do FAAG durante o ensaio 5 de dupla filtração 


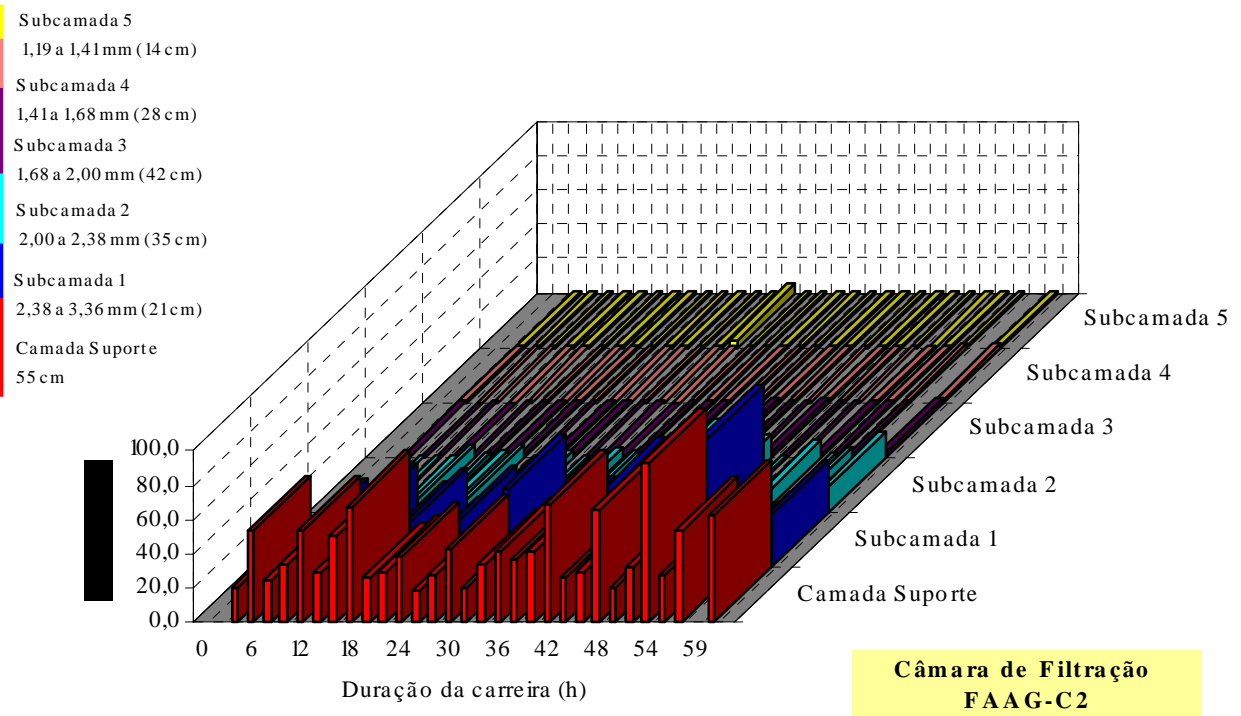

Figura C5.5 - Turbidez ao longo do meio filtrante da câmara de filtração 2 do FAAG durante o ensaio 5 de dupla filtração

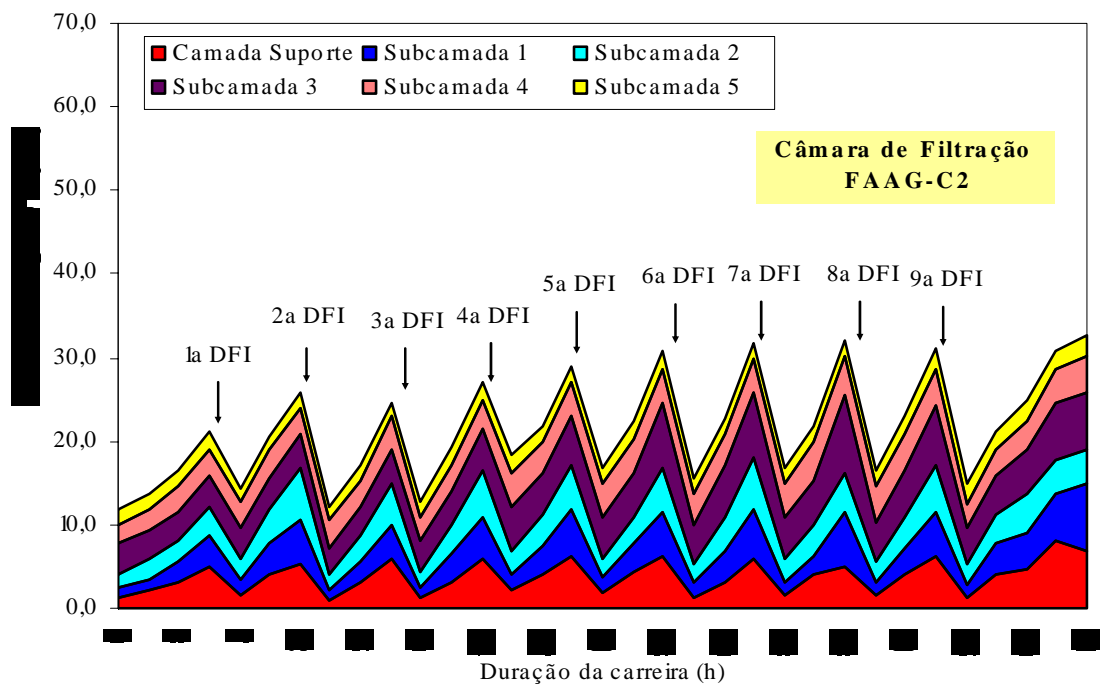

Figura C5.6 - Perda de carga ao longo do meio filtrante da câmara de filtração 2 do FAAG durante o ensaio 5 de dupla filtração 


\section{ENSAIO 6 DE DUPLA FILTRAÇÃO}

Tabela C6.1 - Condições do ensaio 6 de dupla filtração - Sistema 1 e Água de estudo Tipo II

\begin{tabular}{|c|c|c|}
\hline \multicolumn{3}{|c|}{ Água de Estudo } \\
\hline \multicolumn{2}{|l|}{ Turbidez (uT) } & 270 a 296 \\
\hline \multicolumn{2}{|l|}{$\mathrm{pH}$} & 7,63 a 7,91 \\
\hline \multicolumn{2}{|l|}{ Alcalinidade $\left(\mathrm{mg} / \mathrm{L} \mathrm{CaCO}_{3}\right)$} & 25,3 \\
\hline \multicolumn{2}{|l|}{ Temperatura $\left({ }^{\circ} \mathrm{C}\right)$} & 24,0 a 25,0 \\
\hline \multicolumn{2}{|l|}{ Potencial Zeta (mV) } & $-20,3 \pm 0,4$ \\
\hline \multicolumn{3}{|c|}{ Coagulação } \\
\hline \multicolumn{2}{|l|}{ Dosagem sulfato de alumínio (mg/L AL) } & 2,10 \\
\hline \multicolumn{2}{|c|}{ Dosagem sulfato de alumínio (mg/L produto comercial líquido) } & 55 \\
\hline \multicolumn{2}{|l|}{ pH de coagulação } & 6,52 a 6,80 \\
\hline \multicolumn{2}{|l|}{ Potencial Zeta (mV) } & $-0,2 \pm 0,2$ \\
\hline \multicolumn{2}{|l|}{ FLA (areia tipo 3) - Turbidez após 30 min de filtração } & 0,81 \\
\hline \multicolumn{2}{|l|}{ Gradiente de velocidade na mistura rápida $\left(\mathrm{s}^{-1}\right)$} & 600 \\
\hline \multicolumn{3}{|c|}{ Taxas de Filtração } \\
\hline CAP com orifício de & média & desvio padrão \\
\hline Vazão Total (L/h) - medidor eletromagnético & 96,9 & 1,00 \\
\hline Taxa de Filtração FAAG $\left(\mathrm{m}^{3} / \mathrm{m}^{2} . \mathrm{d}\right)$ & 178,9 & 1,8 \\
\hline Vazão FRD (L/h) - rotâmetro & 82,5 & - \\
\hline Taxa de Filtração FRD $\left(\mathrm{m}^{3} / \mathrm{m}^{2}\right.$. d) & 304,6 & - \\
\hline
\end{tabular}


Tabela C6.2 - Resultados do ensaio 6 de dupla filtração - Sistema 1 e Água de estudo Tipo II

\begin{tabular}{|c|c|c|c|c|c|c|c|c|c|c|c|c|c|c|c|c|c|c|}
\hline & & & & & & \multirow{2}{*}{\multicolumn{13}{|c|}{ Turbidez - Turbidimetro de Bancada (TB) (uT) }} \\
\hline \multirow{2}{*}{$\begin{array}{l}\text { Duraçã } \\
\text { (1) }\end{array}$} & \multirow{2}{*}{\begin{tabular}{c|}
$\mathrm{Q}_{\mathrm{T}}$ \\
$(\mathrm{Lhh})$
\end{tabular}} & \multirow{2}{*}{$\begin{array}{c}\text { Turb. } \\
\text { AE (uT) }\end{array}$} & \multirow{2}{*}{$\begin{array}{l}\mathrm{pH} \\
\mathrm{AE}\end{array}$} & \multirow{2}{*}{$\begin{array}{c}\mathrm{pH} \\
\text { Coag. }\end{array}$} & \multirow{2}{*}{$\begin{array}{l}\text { Temp. } \\
\text { (oC) }\end{array}$} & & & & & & & & & & & & & \\
\hline & & & & & & C1-1 & C2-1 & C3-1 & $\mathrm{C4}-1$ & C5-1 & $c 6-1$ & $\mathrm{Cl}-2$ & C2-2 & C3-2 & $\mathrm{CA} 42 \mathrm{C}$ & C5-2 & C6-2 & 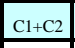 \\
\hline 0,5 & 97,57 & 270 & 7,88 & 6,75 & 25,0 & 74,2 & 10,1 & 3,17 & 1,25 & 1,98 & \begin{tabular}{l|l}
0,83 \\
\end{tabular} & 53,9 & 9,51 & 4,20 & 2,96 & 2,18 & 1,28 & \\
\hline 3,0 & 96,93 & 288 & & 6,78 & 25,5 & 0 & 78,1 & 5,53 & 1,26 & 2,01 & 0,54 & 111,0 & 52,3 & 2,20 & 1,89 & 1,75 & 0,49 & \\
\hline 6,0 & 97,90 & 296 & 7.91 & 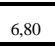 & 25,0 & $\frac{183,0}{}$ & 122,0 & 112,00 & 3,41 & 0,76 & 0,44 & 185,0 & 130,0 & 98,8 & 0,81 & 1,54 & 0,64 & \\
\hline 8,0 & 96,61 & & 7,67 & 6,60 & 25,0 & & & & & & & & & & & & & \\
\hline 9,0 & 95,97 & 283 & 7,6 & 6,60 & 25,0 & 283,0 & 108,0 & 69,2 & 45,30 & 0,56 & 0,58 & 260,0 & \begin{tabular}{l|l|l|}
141,0 \\
\end{tabular} & 78,1 & 199,3 & 0,98 & 0,62 & \\
\hline 10,5 & 96,29 & & 7,65 & 6,60 & 24,0 & & & & & & & & & & & & & \\
\hline 12,0 & 96,61 & 278 & & 6,55 & 24,0 & 0. & 158,0 & 97,4 & 50,40 & 17,80 & 2,02 & 18,0 & 152,0 & 90,9 & 35,1 &, 71 & 1,72 & \\
\hline 13,5 & 96,4 & & & - & 24,5 & & & & & & & & & & & & & \\
\hline 15,0 & 97,90 & 285 & 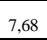 & 6,60 & 24,5 & 277,0 & 215,0 & 180,0 & 109,0 & 84,80 & 131,0 & 234,0 & 215,0 & 164,0 & 145,0 & \begin{tabular}{|l|l|}
44 \\
\end{tabular} & \begin{tabular}{|l|l}
66,3 \\
\end{tabular} & \\
\hline 18,5 & 96,61 & & 7,66 & 6,52 & 24,5 & & & & & & & & & & & & & \\
\hline 20,5 & 97,90 & 287 & & 6,77 & 24,5 & 214,0 & 217,0 & 160,0 & 1110,0 & 112,0 & 88,9 & 231,0 & 224,0 & 1770,0 & 111,0 & \begin{tabular}{|l|l|l}
101,0 \\
\end{tabular} & 150,2 & \\
\hline
\end{tabular}

A

Perda de Carga Corrigida $25^{\circ} \mathrm{C}(\mathrm{cm})$

\begin{tabular}{|l|l|l|l|l|l|l|l|l|l|l|}
\hline 1 & P5-1 & P6-1 & P7-1 & P1-2 & P2-2 & P3-2 & P4-2 & P5-2 & P6-2 & P7-2 \\
\hline
\end{tabular} \begin{tabular}{|l|l|l|l|l|l|l|l|l|l|l|l|l|l|}
259,7 & 258,2 & 256,5 & 254,6 & 251,3 & 24,6 & 247,0 & 26,0 & 258,4 & 25,7 & 255,2 & 252,2 & 249,4 & 24,3 \\
\hline
\end{tabular} \begin{tabular}{|l|l|l|l|l|l|l|l|l|l|l|l|l|l|}
227,4 & 265,4 & 261,3 & 258,3 & 254,6 & 251,6 & 250,1 & 270,4 & 265,9 & 262,1 & 259,1 & 255,5 & 253,1 & 251,4 \\
\hline
\end{tabular}

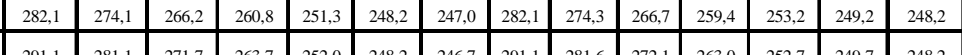

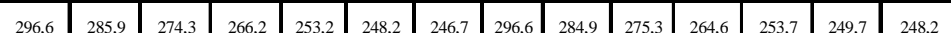
\begin{tabular}{|l|l|l|l|l|l|l|l|l|l|l|l|l|l|}
224,3 & 281,6 & 271,7 & 261,9 & 247,7 & 242,3 & 240,8 & 244,3 & 282,4 & 227,6 & 26,1 & 248,1 & 243,8 & 242,3 \\
\hline
\end{tabular} \begin{tabular}{llllllllllll|l|l|l|l|l|l|l|}
299,7 & 287,3 & 274,4 & 264,0 & 248,3 & 242,8 & 240,8 & 299,7 & 287,5 & 275,4 & 262,9 & 248,9 & 243,8 & 242,3 \\
\hline
\end{tabular} \begin{tabular}{lllllllllllllllll}
310,5 & 296,9 & 283,1 & 269,9 & 25,9 & 24,8 & 243,8 & 310,5 & 29,9 & 283,8 & 269,3 & 253,2 & 247,0 & 24,2 \\
\hline
\end{tabular} \begin{tabular}{|llllllllllll|l|l|l|l|}
3317,1 & 303,4 & 287,0 & 273,2 & 25,9 & 246,0 & 243,8 & 317,4 & 303,2 & 288,1 & 27,6 & 255,1 & 247,2 & 245,2 \\
\hline
\end{tabular} \begin{tabular}{|llllllllllllllllllll}
329,9 & 314,0 & 296,0 & 279,7 & 25,3 & 246,4 & 243,8 & 329,9 & 314,2 & 296,7 & 27,5 & 256,3 & 247,4 & 24,2 \\
\hline
\end{tabular} \begin{tabular}{|l|l|l|l|l|l|l|l|l|l|l|l|l|l|l|l|l|}
332,9 & 316,4 & 298,2 & 281,0 & 25,3 & 24,3 & 243,8 & 32,9 & 316,5 & 288,6 & 278,7 & 257,1 & 248,3 & 245,2 \\
\hline
\end{tabular} FAAG -Perda de Carga Lida (cm)

\begin{tabular}{|l|l|l|l|l|l|l|l|l|l|l|l|l|l|}
\hline P1-1 & P2-1 & P3-1 & P4-1 & P5-1 & P6-1 & P7-1 & P1-2 & P2-2 & P3-2 & P4-2 & P5-2 & P6-2 & P7-2 \\
\hline
\end{tabular} \begin{tabular}{|l|l|l|l|l|l|l|l|l|l|l|l|l|l|}
\hline 26,5 & 259,0 & 257,3 & 25,4 & 252,1 & 249,4 & 247,8 & 26,8 & 25,2 & 25,0 & 256,0 & 25,0 & 25,2 & 24,2 \\
\hline
\end{tabular}

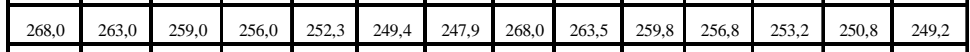
\begin{tabular}{llllllllllllllllll}
283,0 & 275,0 & 267,0 & 26,6 & 252,1 & 249,0 & 247,8 & 283,0 & 27,2 & 267,5 & 260,2 & 25,4 & 250,0 & 249,0 \\
\hline
\end{tabular}

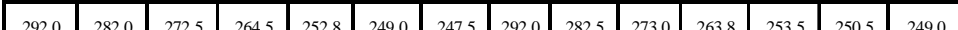

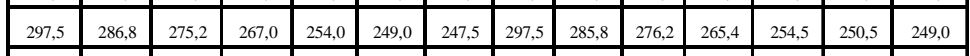

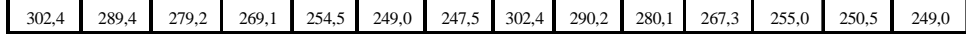
\begin{tabular}{|l|l|l|l|l|l|l|lll|l|l|l|l|}
\hline 308,0 & 295,2 & 282,0 & 271,3 & 255,2 & 249,5 & 247,5 & 308,0 & 29,4 & 23,0 & 270,2 & 25,8 & 250,5 & 249,0 \\
\hline
\end{tabular}

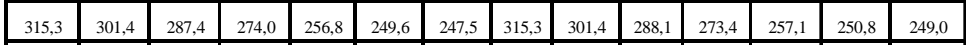

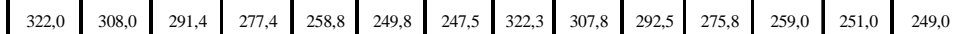

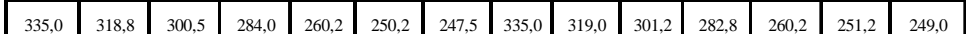
\begin{tabular}{|l|l|l|l|l|l|l|l|l|l|l|l|l|l|}
\hline 338,0 & 321,2 & 302,8 & 285,3 & 261,2 & 251,1 & 247,5 & 338,0 & 321,3 & 303,2 & 283,0 & 261,0 & 25,1, & 249,0 \\
\hline
\end{tabular} 
Tabela C6.2 - Continuação

\begin{tabular}{|c|c|c|c|c|c|}
\hline \multirow{3}{*}{$\begin{array}{l}\text { Duração } \\
\text { (h) }\end{array}$} & \multirow{3}{*}{$\begin{array}{l}\text { Temp. } \\
\text { (oC) }\end{array}$} & \multicolumn{4}{|c|}{ Filtro Rápido Descendente - FRD } \\
\hline & & Qfd & Turbidez - TB (uT) & Perda $\mathrm{d}$ & ${ }^{\circ} \mathrm{C}(\mathrm{cm})$ \\
\hline & & $(\mathrm{L} / \mathrm{h})$ & $\mathrm{AF}$ & P1 & P2 \\
\hline 0,5 & 25,0 & 82,5 & 0,18 & 24,7 & 105,7 \\
\hline 3,0 & 25,5 & 82,5 & 0,34 & 25,0 & 109,2 \\
\hline 6,0 & 25,0 & 82,5 & 0,24 & 24,7 & 116,9 \\
\hline 8,0 & 25,0 & 82,5 & & 24,7 & 120,0 \\
\hline 9,0 & 25,0 & 82,5 & 0,11 & 24,7 & 121,6 \\
\hline 10,5 & 24,0 & 82,5 & & 24,1 & 120,4 \\
\hline 12,0 & 24,0 & 82,5 & 0,12 & 24,1 & 121,8 \\
\hline 13,5 & 24,5 & 82,5 & & 24,4 & 132,4 \\
\hline 15,0 & 24,5 & 82,5 & 0,22 & 24,4 & 141,2 \\
\hline 18,5 & 24,5 & 82,5 & & 24,4 & 177,6 \\
\hline \multirow[t]{14}{*}{20,5} & 24,5 & 82,5 & 0,47 & 24,4 & 197,4 \\
\hline & & & & \multicolumn{2}{|c|}{ Perda de Carga Lida $(\mathrm{cm})$} \\
\hline & & & & P1 & P2 \\
\hline & & & & 24,8 & 106,0 \\
\hline & & & & 24,8 & 108,2 \\
\hline & & & & 24,8 & 117,3 \\
\hline & & & & 24,8 & 120,4 \\
\hline & & & & 24,8 & 122,0 \\
\hline & & & & 24,8 & 123,7 \\
\hline & & & & 24,8 & 125,2 \\
\hline & & & & 24,8 & 134,4 \\
\hline & & & & 24,8 & 143,4 \\
\hline & & & & 24,8 & 180,3 \\
\hline & & & & 24,8 & 200,4 \\
\hline
\end{tabular}

QT: vazão total afluente ao Sistema de Dupla Filtração (medidor de vazão eletromagnético);

Turb. AE: turbidez da água de estudo (turbidímetro de bancada);

pH AE: pH da água de estudo;

pH Coag.: pH de coagulação;

Ci-1: amostra coletada no final da subcamada i do meio filtrante da câmara de filtração 1 do FAAG;

Ci-2: amostra coletada no final da subcamada i do meio filtrante da câmara de filtração 2 do FAAG;

C1+C2: amostra de água pré-filtrada global (efluentes das câmaras de filtração 1 e 2 da FAAG);

Pi-1: piezômetro i localizado na câmara de filtração 1 do FAAG;

Pi-2: piezômetro i localizado na câmara de filtração 2 do FAAG;

$\mathrm{Q}_{\mathrm{fd}}$ : vazão afluente ao FRD (rotâmetro);

Turb. AF: turbidez da água filtrada (turbidímetro de bancada);

P1 e P2: piezômetros localizados no início e no final do FRD, respectivamente. 


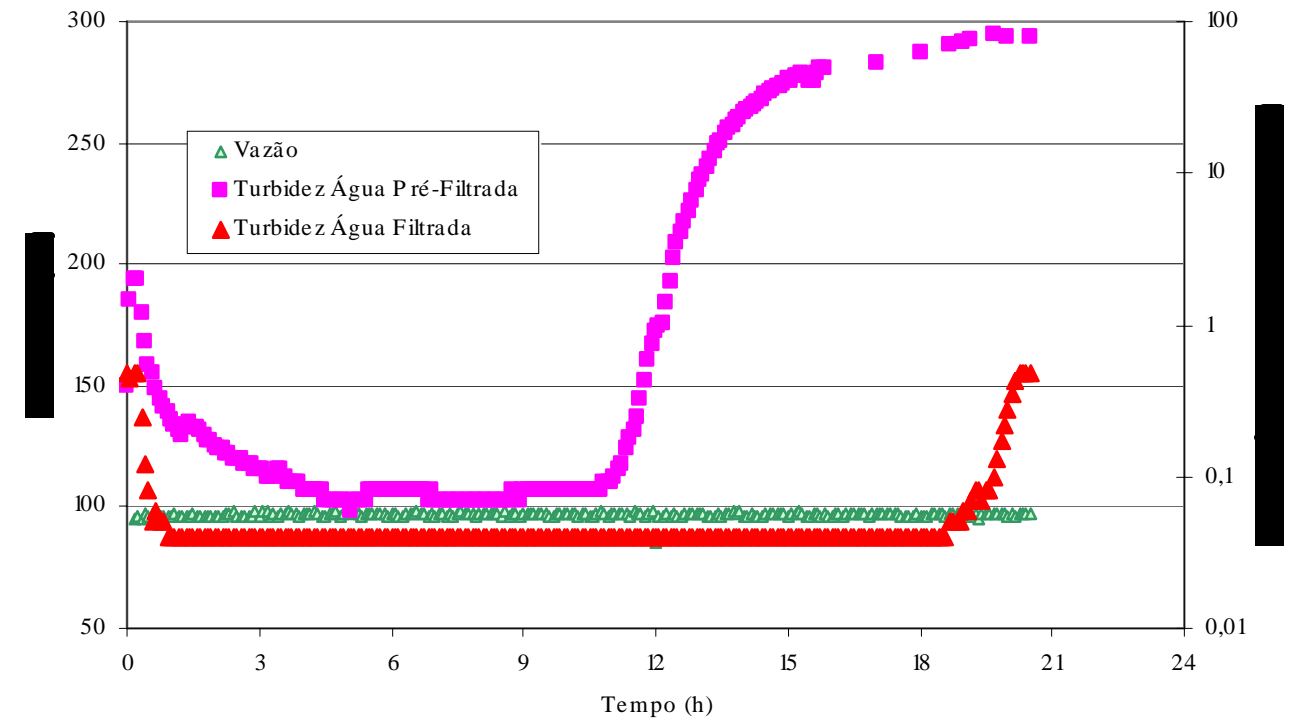

Figura C6.1 - Variações da vazão total afluente ao sistema de dupla filtração e da turbidez das águas pré-filtrada e filtrada no ensaio 6 - Turbidímetros de Escoamento Contínuo

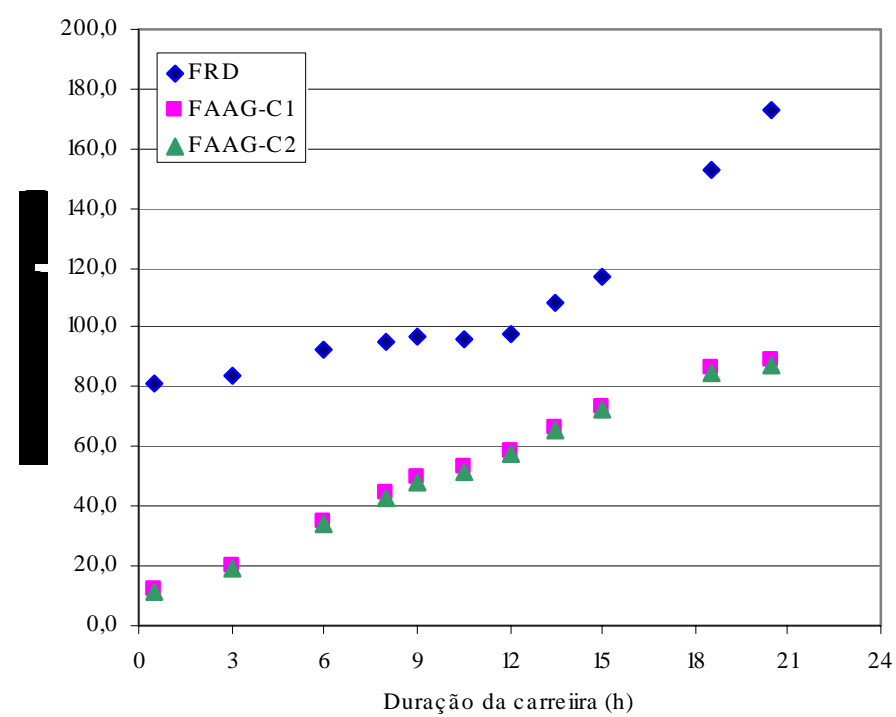

Figura C6.2 - Perda de carga nos filtros ascendente de areia grossa (duas câmaras de filtração) e descendente durante o ensaio 6 de dupla filtração 


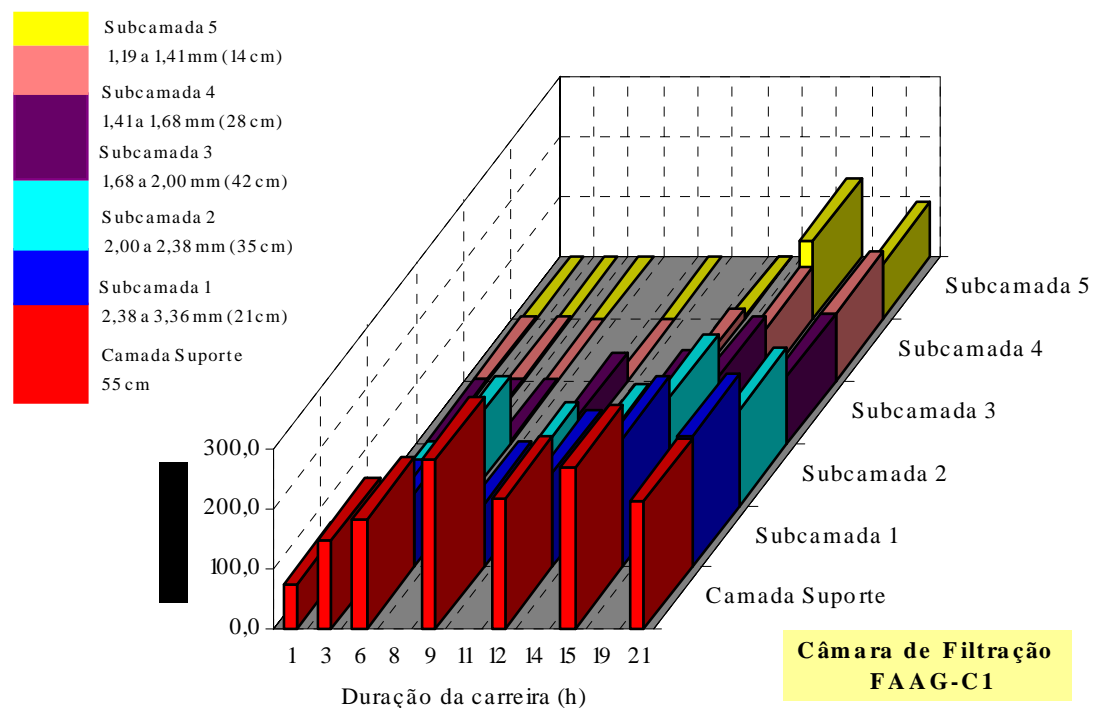

Figura C6.3 - Turbidez ao longo do meio filtrante da câmara de filtração 1 do FAAG durante o ensaio 6 de dupla filtração

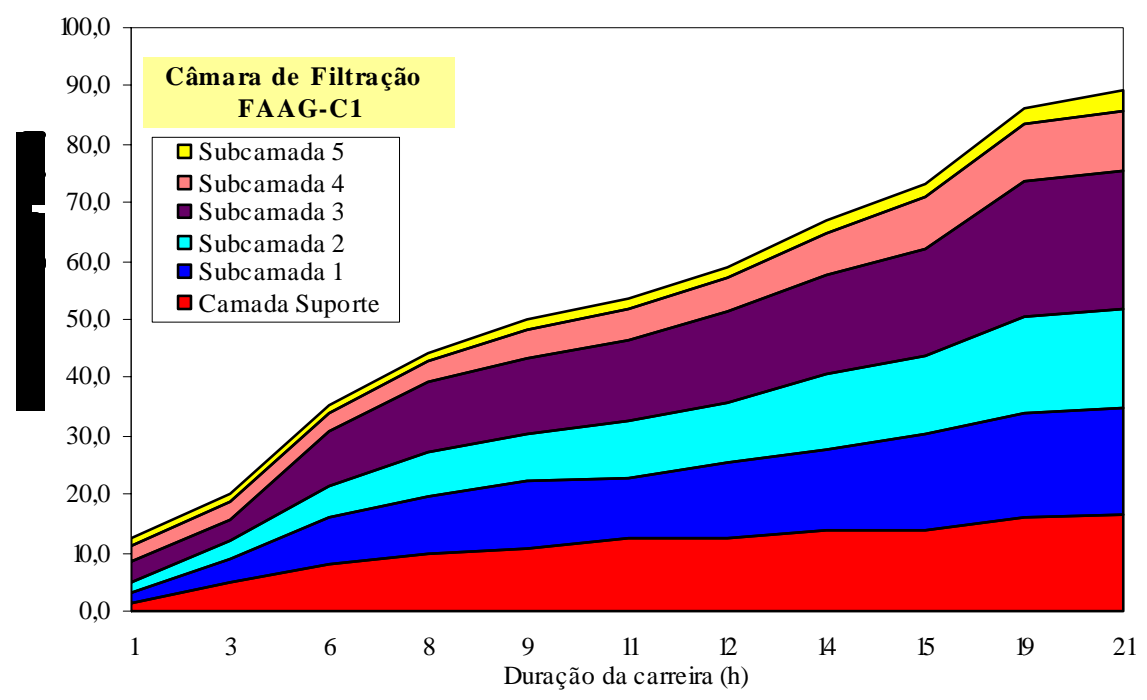

Figura C6.4 - Perda de carga ao longo do meio filtrante da câmara de filtração 1 do FAAG durante o ensaio 6 de dupla filtração 


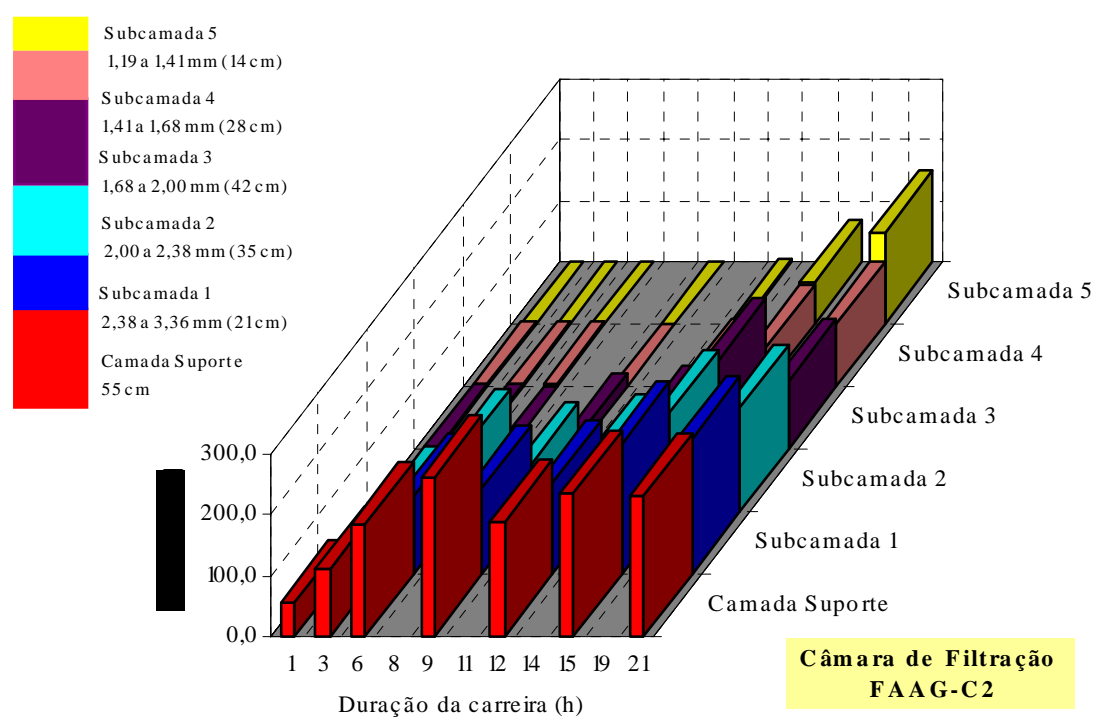

Figura C6.5 - Turbidez ao longo do meio filtrante da câmara de filtração 2 do FAAG durante o ensaio 6 de dupla filtração

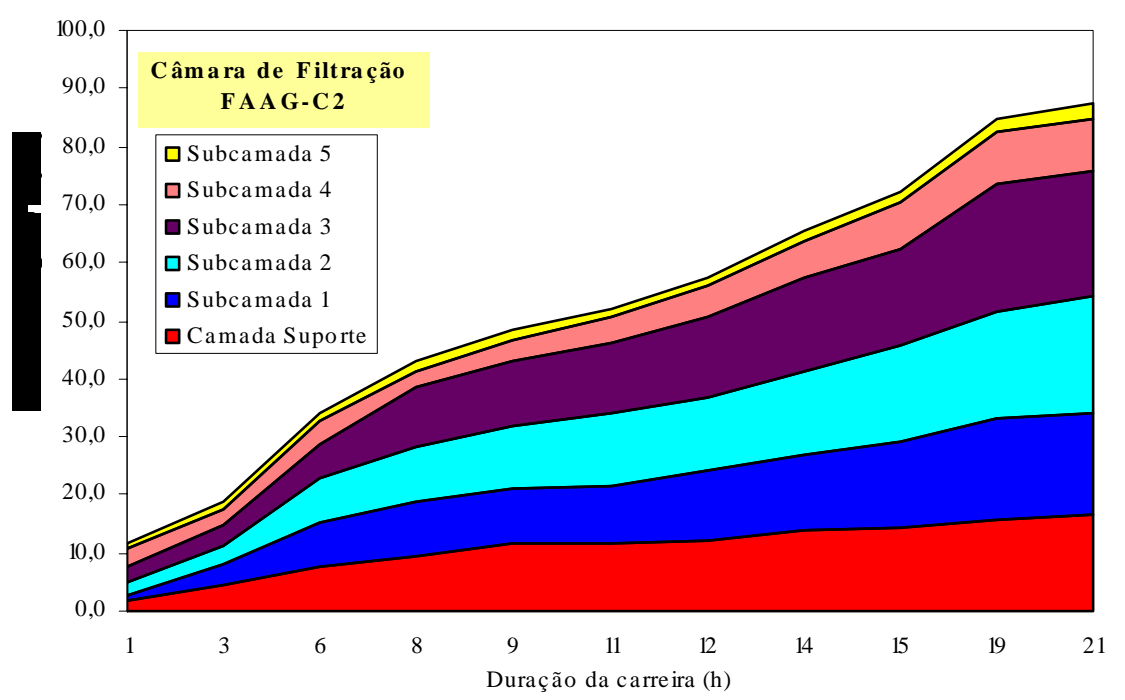

Figura C6.6 - Perda de carga ao longo do meio filtrante da câmara de filtração 2 do FAAG durante o ensaio 6 de dupla filtração 


\section{ENSAIO 7 DE DUPLA FILTRAÇÃO}

Tabela C7.1 - Condições do ensaio 7 de dupla filtração - Sistema 1 e Água de estudo Tipo II

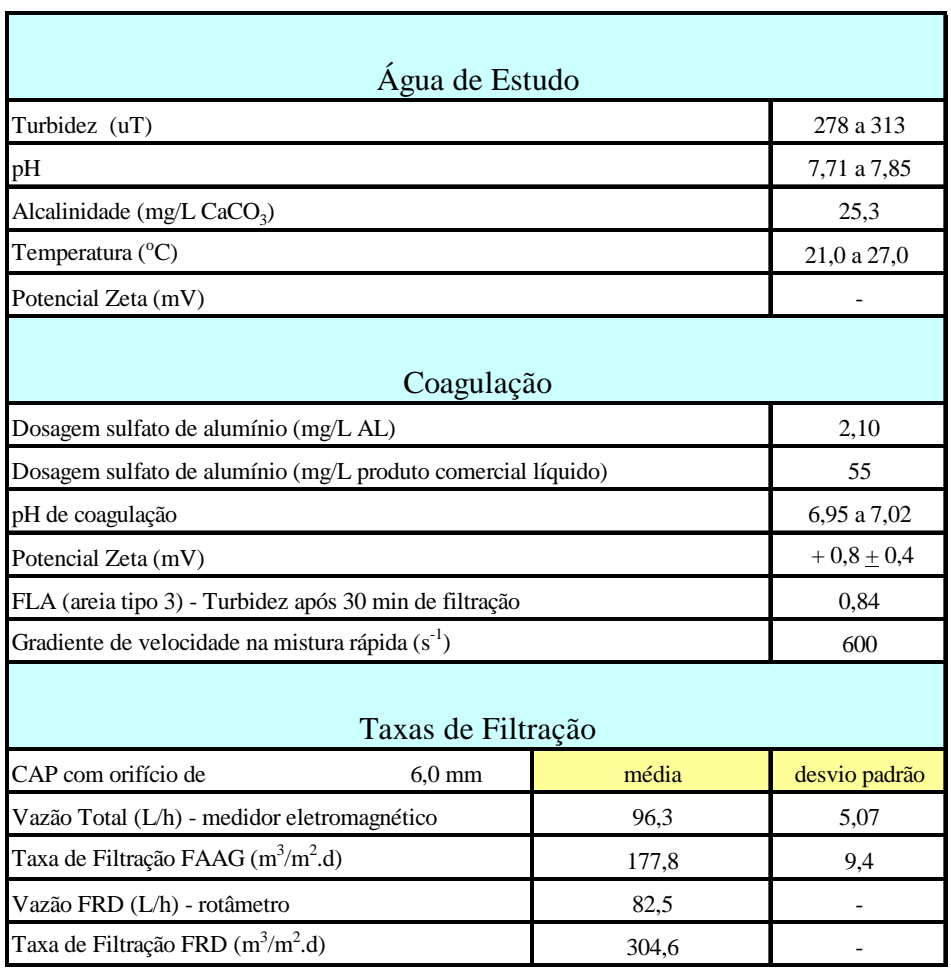


Tabela C7.2 - Resultados do ensaio 7 de dupla filtração - Sistema 1 e Água de estudo Tipo II

\begin{tabular}{|c|c|c|c|c|c|c|c|c|c|c|c|c|c|c|c|c|c|c|c|c|c|c|c|c|c|c|c|c|c|c|c|c|}
\hline & & & & & & \\
\hline \multirow{3}{*}{\begin{tabular}{|c|c} 
Duração \\
(h) \\
\end{tabular}} & \multirow{3}{*}{$\begin{array}{c}\mathrm{Q}_{\mathrm{T}} \\
\mathrm{L} / \mathrm{h})\end{array}$} & \multirow{3}{*}{$\begin{array}{c}\text { Turb. } \\
\mathrm{AE}(\mathrm{uT})\end{array}$} & \multirow{3}{*}{$\begin{array}{l}\mathrm{pH} \\
\mathrm{AE} \\
\end{array}$} & \multirow{3}{*}{$\begin{array}{c}\text { pH } \\
\text { Coag. } \\
\end{array}$} & \multirow{3}{*}{\begin{tabular}{|c} 
Temp. \\
$(\mathrm{OC})$ \\
\end{tabular}} & & & & & & & & & & & & & & & & & & & & & & & & & & & \\
\hline & & & & & & \multicolumn{13}{|c|}{ Turbidez - Turbidímetro de Bancada (TB) (uT) } & \multicolumn{14}{|c|}{ Perda de Carga Corrigida $25^{\circ} \mathrm{C}(\mathrm{cm})$} \\
\hline & & & & & & C1-1 & C2-1 & C3-1 & $\mathrm{C} 4-1$ & \begin{tabular}{|c|c|c|} 
C5-1 & \\
\end{tabular} & C6-1 & $\mathrm{Cl}-2$ & C2-2 & 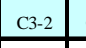 & $\mathrm{C} 42$ & \begin{tabular}{|c|c|} 
C5-2 \\
\end{tabular} & \begin{tabular}{c|c}
$C 6-2$ & $c$ \\
$C$
\end{tabular} & $\mathrm{C} 1+\mathrm{C} 2$ & P1-1 & P2-1 & P3-1 & $\mathrm{P} 4-1$ & \begin{tabular}{|l|ll} 
P5-1 & \\
\end{tabular} & $\mathrm{P} 6-1$ & p7-1 & \begin{tabular}{l|l}
$\mathrm{P} 1-2$ & $\mathrm{P}$ \\
$\mathrm{P}$
\end{tabular} & \begin{tabular}{l|llllll} 
&
\end{tabular} & P3-2 & \begin{tabular}{l|l} 
P42 & $: 1$ \\
\end{tabular} & P5-2 & \begin{tabular}{|l|l|l|}
$\mathrm{P} 6-2$ & -10 \\
\end{tabular} & P7-2 \\
\hline & \begin{tabular}{|l|l|}
96,93 \\
\end{tabular} & & 7,75 & 6,95 & 25,0 & & & & & & & & & & & & & & 2,2 & 259,2 & 256,7 & 254,2 & 251,2 & 248,2 & 247,0 & 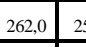 & $259,5 \quad 2$ & 258,2 & & 253,0 & 249,9 & 248,2 \\
\hline 3 & 97,25 & 313 & 7,70 & ,01 & 27.0 & 144 & & 6,58 & & 1,10 & 3 & 136 & 68,3 & 4,80 & 0,63 & \begin{tabular}{|l|l|}
1,45 \\
\end{tabular} & 1,1 & 0,35 & 79,3 & 274,6 & 270,4 & 266,8 & 263,6 & 260,5 & 258,8 & \begin{tabular}{l|l}
279,3 & 27 \\
27
\end{tabular} & 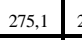 & 272,4 & \begin{tabular}{l|l}
268,9 & 2 \\
2
\end{tabular} & 265,7 & 262,3 & 260,5 \\
\hline 4,5 & 96,29 & & & & 26,8 & & & & & & & & & & & & & & 27,8 & 270,9 & 265,5 & 261,2 & 257,4 & 254,3 & 252,7 & $276,8 \quad 2$ & $271,3=2$ & 268,6 & \begin{tabular}{l|l}
264,0 & 2 \\
2
\end{tabular} & 259,4 & 256,0 & 254,3 \\
\hline 5,0 & 10,6 & & & 7,02 & 24,5 & & & & & & & & & & & & & & 56,3 & 255,1 & 253,6 & 251,2 & 248,2 & 245,2 & 243,7 & $\begin{array}{ll}256,3 & 2 \\
\end{array}$ & $255,3.32$ & 254,3 & 253,1 & 249,7 & 246,7 & 245,2 \\
\hline 6,0 & 97,25 & 2911 & & & 24,0 & 111 & 8 & $\begin{array}{r}3,44 \\
\end{array}$ & 0,79 & 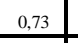 & 0,89 & 181 & 15,9 & $\begin{array}{r}3,55 \\
\end{array}$ & 0,7 & \begin{tabular}{|l|}
0,66 \\
\end{tabular} & 0,25 & 0,55 & 256,9 & 254,5 & \begin{tabular}{|l|}
251,1 \\
\end{tabular} & 248,3 & \begin{tabular}{|l|}
245,2 \\
\end{tabular} & 242,4 & 240,7 & \begin{tabular}{|l|l|}
255,7 & 2 \\
\end{tabular} & \begin{tabular}{l|l}
254,5 & 2 \\
\end{tabular} & 253,0 & \begin{tabular}{l|l}
250,6 & $=$ \\
\end{tabular} & 247,2 & \begin{tabular}{|l|}
243,8 \\
\end{tabular} & 242,3 \\
\hline 9,0 & 96,93 & 34 & & & -2 & 211 & 4 & \begin{tabular}{|l|}
105 \\
\end{tabular} & 0,56 & \begin{tabular}{|l}
0,42 \\
\end{tabular} & 0,95 & 268 & 18,4 & 96,9 & 2,33 & \begin{tabular}{|l|}
0,73 \\
\end{tabular} & 0,4 & $\begin{array}{l}0,24 \\
\end{array}$ & 0,1 & 254,4 & \begin{tabular}{|l|}
248,9 \\
\end{tabular} & 244,1 & \begin{tabular}{|l|}
239,4 \\
\end{tabular} & 236,5 & 235,0 & 259,6 & \begin{tabular}{l|l}
254,6 & 2 \\
\end{tabular} & 250,8 & \begin{tabular}{ll|l}
244,0 & $=$
\end{tabular} & 241,6 & \begin{tabular}{|l|}
238,2 \\
\end{tabular} & 236,5 \\
\hline 9,5 & \begin{tabular}{|l}
7,90 \\
\end{tabular} & & & & 23,0 & & & & & & & & & & & & & & 249,6 & 248,2 & 246,4 & 243,6 & \begin{tabular}{|l|}
2399,7 \\
2
\end{tabular} & 236,6 & 235,0 & 249,8 & $248,7=$ & 247,4 & 245,4 & 241,3 & 238,1 & 236,5 \\
\hline 12 & \begin{tabular}{|l}
97,90 \\
\end{tabular} & 299 & 7,8 & 7,01 & 22,0 & 192 & & 39,7 & 4,24 & 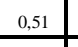 & 0,85 & 182 & 72,9 & 41,2 & 0,47 & 0,47 & 0,79 & 0,7 & 253,1 & 248,9 & \begin{tabular}{|l|l|}
243,8 \\
\end{tabular} & 239,5 & 234,1 & 231,3 & 229,4 & 253,6 & $248,9=2$ & 246,1 & 241,9 & 236,0 & 232,4 & 230,9 \\
\hline 13,5 & \begin{tabular}{|l|}
97,25 \\
\end{tabular} & & & & 21,5 & & & & & & & & & & & & & & 57,9 & 252,3 & \begin{tabular}{|l}
2455,1 \\
\end{tabular} & 239,3 & \begin{tabular}{|l|l|}
232,0 \\
\end{tabular} & 228,6 & 226,6 & 258,3 & \begin{tabular}{l|l}
252,5 & 2 \\
\end{tabular} & 247,7 & 241,8 & 233,5 & 229,7 & 228,1 \\
\hline 14,0 & \begin{tabular}{|l|}
97,25 \\
\end{tabular} & & & & 21,0 & & & & & & & & & & & & & & 238,7 & 237,4 & \begin{tabular}{|l|}
235,4 \\
\end{tabular} & 233,0 & \begin{tabular}{|l|l}
229,2 & 2 \\
2
\end{tabular} & 225,8 & 223,9 & \begin{tabular}{l|l|l}
238,6 & 2 \\
\end{tabular} & 237,6 & 236,7 & 234,4 & 230,3 & 227,0 & 225,4 \\
\hline 15 & \begin{tabular}{|l|}
97,25 \\
\end{tabular} & - & & & 21,0 & 99,1 & - & 6,647 & 1,65 & \begin{tabular}{|l}
0,89 \\
\end{tabular} & 3,63 & 118 & 41,8 & 11 & 1,17 & 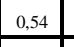 & 0,58 & 0,97 & 242,4 & 239,8 & \begin{tabular}{|l}
236,8 \\
\end{tabular} & 233,5 & \begin{tabular}{|l|l}
229,2 & \\
2
\end{tabular} & 225,8 & 223,9 & \begin{tabular}{l|l}
242,3 & 2 \\
\end{tabular} & 240,2 & 238,5 & 235,6 & $\begin{array}{r}230,8 \\
2\end{array}$ & 227,0 & 225,4 \\
\hline 18 & \begin{tabular}{|l|}
97,57 \\
\end{tabular} & 27 & & & 24,0 & 122 & B6,8 & 600,7 & 13,4 & 0,35 & $\begin{array}{l}0,30 \\
\end{array}$ & 168 & 89,2 & 57,7 & 10,3 & $\begin{array}{l}0,38 \\
\end{array}$ & 0,25 & 0,47 & 276,8 & 270,0 & \begin{tabular}{|l|}
261,8 \\
2
\end{tabular} & 254,8 & 247,2 & 243,3 & 240,7 & \begin{tabular}{|l|l|l}
27,8 & 2 \\
\end{tabular} & 270,5 & 265,5 & \begin{tabular}{l|l|l}
258,4 & $=$ \\
\end{tabular} & 249,1 & 244,0 & 242,3 \\
\hline 18,5 & \begin{tabular}{|l|}
95,65 \\
\end{tabular} & & & $\begin{array}{r}6,99 \\
\end{array}$ & 24,0 & & & & & & & & & & & & & & 260,8 & 258,8 & \begin{tabular}{|l|}
256,9 \\
\end{tabular} & 253,8 & \begin{tabular}{|l|l|}
248,1 & 2 \\
2
\end{tabular} & 243,3 & 240,7 & \begin{tabular}{|l|l|}
26,8 & 2 \\
\end{tabular} & 258,4 & 257,9 & $\begin{array}{ll}255,0 \\
25\end{array}$ & 249,1 & 244,2 & 242,3 \\
\hline 21 & \begin{tabular}{|l|}
97,57 \\
\end{tabular} & 29 & & & 24,3 & 163 & $\begin{array}{r}82,0 \\
\end{array}$ & 61,2 & 50,4 & , & 4,09 & 161 & 76,8 & 44,7 & 14,9 & \begin{tabular}{|l}
3,68 \\
\end{tabular} & 5,15 & 33,9 & 278,7 & 273,3 & \begin{tabular}{|l|}
266,9 \\
\end{tabular} & 261,0 & \begin{tabular}{|l|l|}
253,1 & 2 \\
\end{tabular} & 247,0 & 243,7 & \begin{tabular}{l|l}
279,5 & 2 \\
\end{tabular} & 273,3 & 269,7 & \begin{tabular}{l|l}
264,0 & $=$
\end{tabular} & 254,3 & \begin{tabular}{|l|}
247,0 \\
\end{tabular} & 245,2 \\
\hline 22,5 & \begin{tabular}{|l}
96,93 \\
\end{tabular} & & & & 24,5 & & & & & & & & & & & & & & 284,6 & 277,6 & \begin{tabular}{|l|}
269,7 \\
2
\end{tabular} & 263,0 & \begin{tabular}{|l|l|}
254,3 & 2 \\
\end{tabular} & 247,2 & 243,7 & \begin{tabular}{|l|}
284,8 \\
\end{tabular} & 277,9 & 273,1 & 266,3 & 256,1 & 247,4 & 45,2, \\
\hline 23,0 & \begin{tabular}{|l}
97,25 \\
\end{tabular} & & & & 24,5 & & & & & & & & & & & & & & 264,9 & 263,2 & \begin{tabular}{|l|}
261,0 \\
\end{tabular} & 258,0 & \begin{tabular}{|l|l|}
251,9 \\
\end{tabular} & 246,5 & 243,7 & \begin{tabular}{|l|l}
265,3 \\
\end{tabular} & 263,8 & 262,2 & 259,8 & 253,6 & \begin{tabular}{|l}
247,6 \\
\end{tabular} & 245,2 \\
\hline 24 & \begin{tabular}{|l|}
97,25 \\
\end{tabular} & 36 & & & 26,0 & & 48,3 & 32,4 & 40,4 & \begin{tabular}{|l}
20,0 \\
\end{tabular} & 85,0 & 90,4 & 55 & 31,4 & 51,9 & \begin{tabular}{|l}
23,0 \\
\end{tabular} & 108,0 & 31,9 & 280,3 & 276,6 & \begin{tabular}{|l|}
272,2 \\
\end{tabular} & 268,1 & \begin{tabular}{|l|l|}
261,4 & 2 \\
\end{tabular} & 255,8 & 252,7 & \begin{tabular}{|l|}
280,3 \\
\end{tabular} & 277,0 & 274,2 & 270,6 & 263,5 & \begin{tabular}{|l|}
257,4 \\
\end{tabular} & 254,3 \\
\hline 27,0 & \begin{tabular}{|l|}
97,25 \\
\end{tabular} & 30 & 7 & & 25,5 & & $\begin{array}{r}150,1 \\
\end{array}$ & 80,7 & 78,8 & 5 & 88,4 & 213,4 & 118 & 1 & 62,4 & $\begin{array}{r}41,8 \\
\end{array}$ & 80,4 & $\begin{array}{r}38,9 \\
\end{array}$ & 293,1 & 285,0 & \begin{tabular}{|l|}
277,0 \\
\end{tabular} & 269,9 & \begin{tabular}{|l|l|}
260,5 & 2 \\
\end{tabular} & 253,3 & 249,6 & 293,1 & 286,0 & 280,7 & 274,4 & 263,3 & 254,8 & 251,2 \\
\hline 27,5 & \begin{tabular}{|l}
98,01 \\
\end{tabular} & & & & 25,5 & & & & & & & & & & & & & & 276,5 & 274,2 & 271,2 & 267,4 & 260,8 & 253,5 & 249,6 & 276,5 & 274,4 & 272,9 & 269,4 & 262,3 & 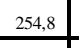 & 251,2 \\
\hline & \begin{tabular}{|l|l|}
97,25 \\
\end{tabular} & & & & $2,0,0$ & & & & & & & & & & & & & & 293,9 & 285,3 & \begin{tabular}{|l|}
277,3 \\
\end{tabular} & 270,3 & \begin{tabular}{|l|l|}
260,9 \\
\end{tabular} & 253,7 & 249,6 & & 286,4 & 281,7 & 274,7 & 263,6 & 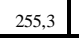 & 251,2 \\
\hline
\end{tabular}


Tabela C7.2 - Continuação

\begin{tabular}{|c|c|c|c|c|c|c|c|c|c|c|c|c|c|c|}
\hline \multirow{2}{*}{$\begin{array}{c}\text { Duração } \\
\text { (h) }\end{array}$} & \multicolumn{14}{|c|}{ FAAG -Perda de Carga Lida (cm) } \\
\hline & P1-1 & P2-1 & P3-1 & P4-1 & P5-1 & P6-1 & P7-1 & P1-2 & P2-2 & P3-2 & P4-2 & P5-2 & P6-2 & P7-2 \\
\hline 1 & 263,0 & 260,0 & 257,5 & 255,0 & 252,0 & 249,0 & 247,8 & 262,8 & 260,3 & 259,0 & 257,0 & 253,8 & 250,7 & 249,0 \\
\hline 3 & 267,0 & 262,5 & 258,5 & 255,0 & 252,0 & 249,0 & 247,4 & 267,0 & 263,0 & 260,4 & 257,0 & 254,0 & 250,7 & 249,0 \\
\hline 4,5 & 271,0 & 265,3 & 260,0 & 255,8 & 252,0 & 249,0 & 247,4 & 271,0 & 265,7 & 263,0 & 258,5 & 254,0 & 250,7 & 249,0 \\
\hline 5,0 & 260,2 & 259,0 & 257,5 & 255,0 & 252,0 & 249,0 & 247,4 & 260,2 & 259,2 & 258,2 & 257,0 & 253,5 & 250,5 & 249,0 \\
\hline 6,0 & 264,0 & 261,5 & 258,0 & 255,2 & 252,0 & 249,1 & 247,4 & 264,8 & 261,5 & 260,0 & 257,5 & 254,0 & 250,5 & 249,0 \\
\hline 9,0 & 273,8 & 267,8 & 262,0 & 257,0 & 252,0 & 249,0 & 247,4 & 273,3 & 268,0 & 264,0 & 259,0 & 254,3 & 250,8 & 249,0 \\
\hline 9,5 & 262,8 & 261,3 & 259,4 & 256,5 & 252,4 & 249,1 & 247,4 & 263,0 & 261,8 & 260,5 & 258,3 & 254,0 & 250,7 & 249,0 \\
\hline 12 & 273,0 & 268,4 & 263,0 & 258,3 & 252,5 & 249,5 & 247,4 & 273,5 & 268,5 & 265,4 & 260,9 & 254,5 & 250,7 & 249,0 \\
\hline 13,5 & 281,5 & 275,4 & 267,6 & 261,2 & 253,3 & 249,5 & 247,4 & 282,0 & 275,6 & 270,4 & 264,0 & 254,9 & 250,7 & 249,0 \\
\hline 14,0 & 263,8 & 262,3 & 260,1 & 257,4 & 253,3 & 249,5 & 247,4 & 263,6 & 262,5 & 261,5 & 259,0 & 254,5 & 250,8 & 249,0 \\
\hline 15 & 267,8 & 265,0 & 261,6 & 258,0 & 253,2 & 249,5 & 247,4 & 267,7 & 265,4 & 263,5 & 260,3 & 255,0 & 250,8 & 249,0 \\
\hline 18 & 284,5 & 277,5 & 269,0 & 261,8 & 254,0 & 250,0 & 247,4 & 284,5 & 278,0 & 272,8 & 265,5 & 256,0 & 250,7 & 249,0 \\
\hline 18,5 & 268,0 & 266,0 & 264,0 & 260,8 & 255,0 & 250,0 & 247,4 & 268,0 & 265,5 & 265,0 & 262,0 & 256,0 & 251,0 & 249,0 \\
\hline 21 & 283,0 & 277,5 & 271,0 & 265,0 & 257,0 & 250,8 & 247,4 & 283,8 & 277,5 & 273,8 & 268,0 & 258,2 & 250,8 & 249,0 \\
\hline 22,5 & 289,0 & 281,8 & 273,8 & 267,0 & 258,2 & 251,0 & 247,4 & 289,2 & 282,2 & 277,3 & 270,4 & 260,0 & 251,2 & 249,0 \\
\hline 23,0 & 269,0 & 267,2 & 265,0 & 262,0 & 255,8 & 250,3 & 247,4 & 269,4 & 267,8 & 266,2 & 263,8 & 257,5 & 251,4 & 249,0 \\
\hline 24 & 274,5 & 270,8 & 266,5 & 262,5 & 256,0 & 250,5 & 247,4 & 274,5 & 271,2 & 268,5 & 265,0 & 258,0 & 252,0 & 249,0 \\
\hline 27,0 & 290,5 & 282,5 & 274,5 & 267,5 & 258,2 & 251,0 & 247,4 & 290,5 & 283,5 & 278,2 & 272,0 & 261,0 & 252,5 & 249,0 \\
\hline 27,5 & 274,0 & 271,8 & 268,8 & 265,0 & 258,5 & 251,2 & 247,4 & 274,0 & 272,0 & 270,5 & 267,0 & 260,0 & 252,5 & 249,0 \\
\hline 30 & 291,3 & 282,8 & 274,8 & 267,9 & 258,6 & 251,4 & 247,4 & 291,3 & 283,8 & 279,2 & 272,3 & 261,3 & 253,0 & 249,0 \\
\hline
\end{tabular}

$\mathrm{Q}_{\mathrm{T}}$ : vazão total afluente ao Sistema de Dupla Filtração (medidor de vazão eletromagnético);

Turb. AE: turbidez da água de estudo (turbidímetro de bancada);

pH AE: pH da água de estudo;

pH Coag.: pH de coagulação;

Ci-1: amostra coletada no final da subcamada i do meio filtrante da câmara de filtração 1 do FAAG;

Ci-2: amostra coletada no final da subcamada i do meio filtrante da câmara de filtração 2 do FAAG;

C1+C2: amostra de água pré-filtrada global (efluentes das câmaras de filtração 1 e 2 da FAAG);

Pi-1: piezômetro i localizado na câmara de filtração 1 do FAAG;

Pi-2: piezômetro i localizado na câmara de filtração 2 do FAAG;

$\square$ : execução de DFI nas duas câmaras do FAAG; 
Tabela C7.2 - Continuação

\begin{tabular}{|c|c|c|c|c|c|c|c|}
\hline \multirow{3}{*}{$\begin{array}{l}\text { Duração } \\
\text { (h) }\end{array}$} & \multirow{3}{*}{$\begin{array}{l}\text { Temp. } \\
\text { (oC) }\end{array}$} & \multicolumn{6}{|c|}{ Filtro Rápido Descendente - FRD } \\
\hline & & \multirow{2}{*}{$\begin{array}{l}\text { Qfd } \\
(\mathrm{L} / \mathrm{h})\end{array}$} & \multirow{2}{*}{$\begin{array}{c}\text { Turbidez - TB (uT) } \\
\text { AF }\end{array}$} & \multicolumn{2}{|c|}{ Perda de Carga Corrigida $25^{\circ} \mathrm{C}(\mathrm{cm})$} & \multicolumn{2}{|c|}{ Perda de Carga Lida (cm) } \\
\hline & & & & P1 & P2 & P1 & P2 \\
\hline 1 & 25,0 & 82,5 & & 25,3 & 107,9 & 25,4 & 108,2 \\
\hline 3 & 27,0 & 82,5 & 0,14 & 26,6 & 116,1 & 25,4 & 111,0 \\
\hline 4,5 & 26,0 & 82,5 & & 25,9 & 116,2 & 25,4 & 113,8 \\
\hline 5,0 & 24,5 & 82,5 & & 25,0 & 112,3 & 25,4 & 114,0 \\
\hline 6,0 & 24,0 & 82,5 & 0,20 & 24,7 & 114,8 & 25,4 & 118,0 \\
\hline 9,0 & 23,0 & 82,5 & 0,14 & 24,1 & 115,0 & 25,4 & 121,1 \\
\hline 9,5 & 23,0 & 82,5 & & 24,1 & 114,5 & 25,4 & 120,5 \\
\hline 12 & 22,0 & 82,5 & 0,22 & 23,6 & 118,8 & 25,4 & 128,1 \\
\hline 13,5 & 21,5 & 82,5 & & 23,3 & 120,0 & 25,4 & 131,0 \\
\hline 14,0 & 21,0 & 82,5 & & 23,0 & 120,7 & 25,4 & 133,4 \\
\hline 15 & 21,0 & 82,5 & 0,23 & 23,0 & 125,1 & 25,4 & 138,2 \\
\hline 18 & 24,0 & 82,5 & 0,19 & 24,7 & 141,1 & 25,4 & 145,0 \\
\hline 18,5 & 24,0 & 82,5 & & 24,7 & 143,0 & 25,4 & 146,5 \\
\hline 21 & 24,5 & 82,5 & 0,51 & 25,0 & 148,2 & 25,4 & 147,5 \\
\hline 22,5 & 24,5 & 82,5 & & 25,0 & 154,0 & 25,4 & 148,0 \\
\hline 23,0 & 24,5 & 82,5 & & 25,0 & 155,0 & 25,4 & 149,0 \\
\hline 24 & 26,0 & 82,5 & 0,24 & 25,9 & 162,0 & 25,4 & 165,0 \\
\hline 27,0 & 25,5 & 82,5 & 0,23 & 25,6 & 175,0 & 25,4 & 172,5 \\
\hline 27,5 & 25,5 & 82,5 & & 25,6 & 180,0 & 25,4 & 177,0 \\
\hline 30 & 25,5 & 82,5 & & 25,6 & 200,5 & 25,4 & 192,5 \\
\hline
\end{tabular}

$\mathrm{Q}_{\mathrm{fd}}$ : vazão afluente ao FRD (rotâmetro);

Turb. AF: turbidez da água filtrada (turbidímetro de bancada);

P1 e P2: piezômetros localizados no início e no final do FRD, respectivamente. 


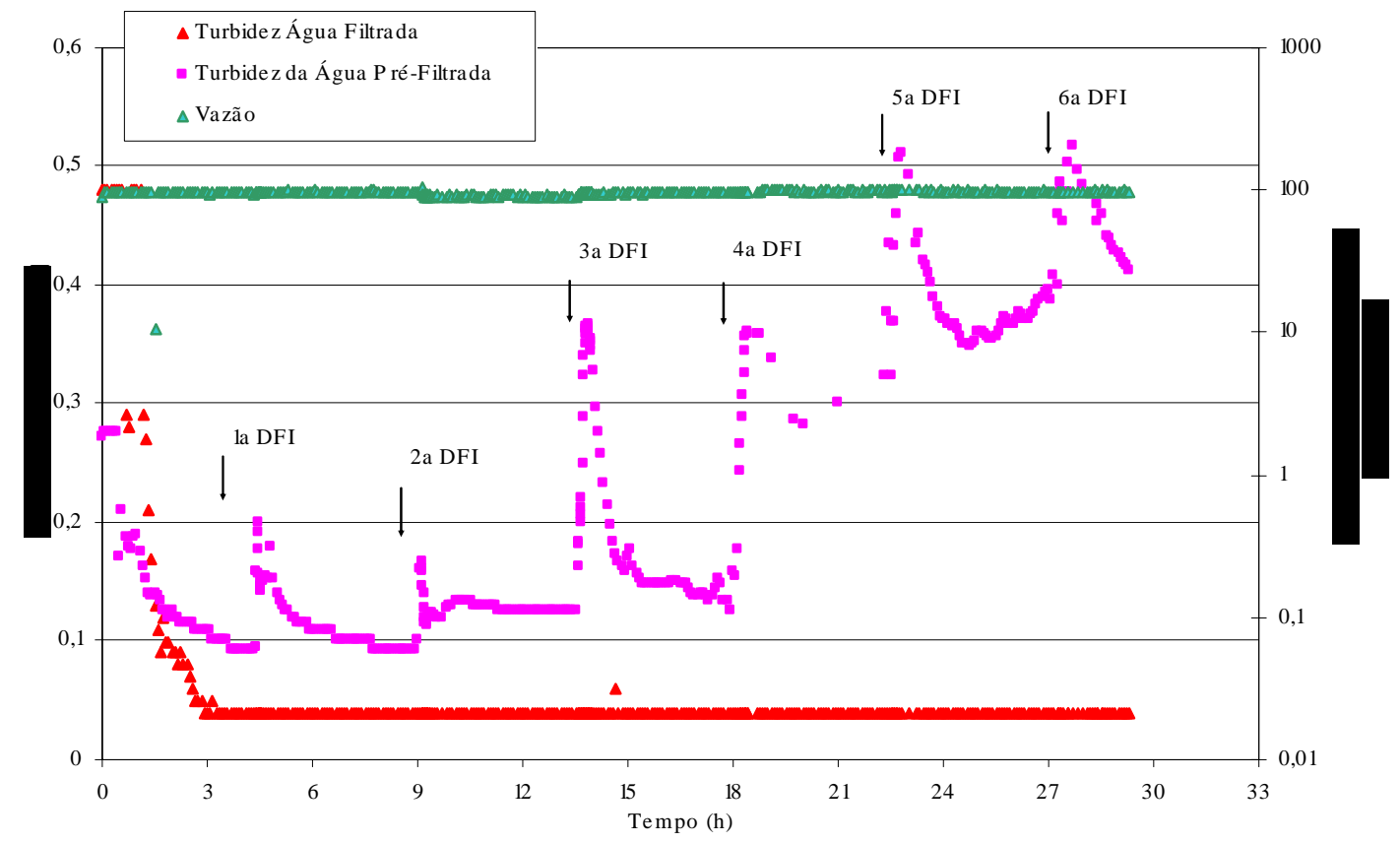

Figura C7.1 - Variações da vazão total afluente ao sistema de dupla filtração e da turbidez das águas pré-filtrada e filtrada no ensaio 7 - Turbidímetros de Escoamento Contínuo

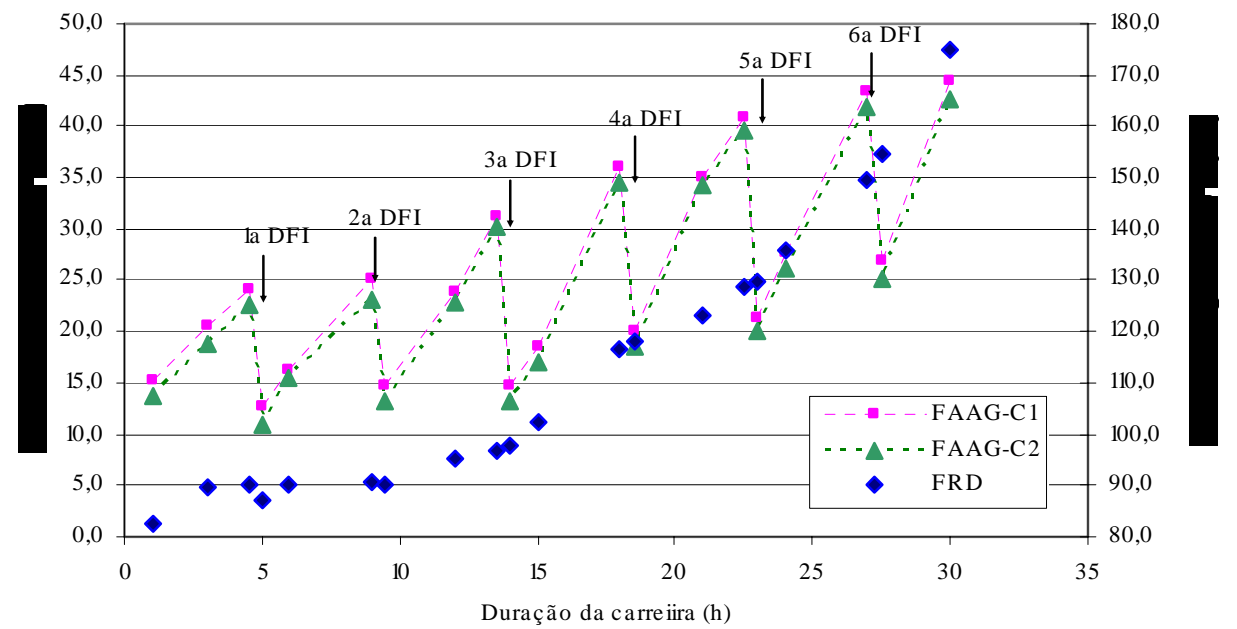

Figura C7.2 - Perda de carga nos filtros ascendente de areia grossa (duas câmaras de filtração) e descendente durante o ensaio 7 de dupla filtração 


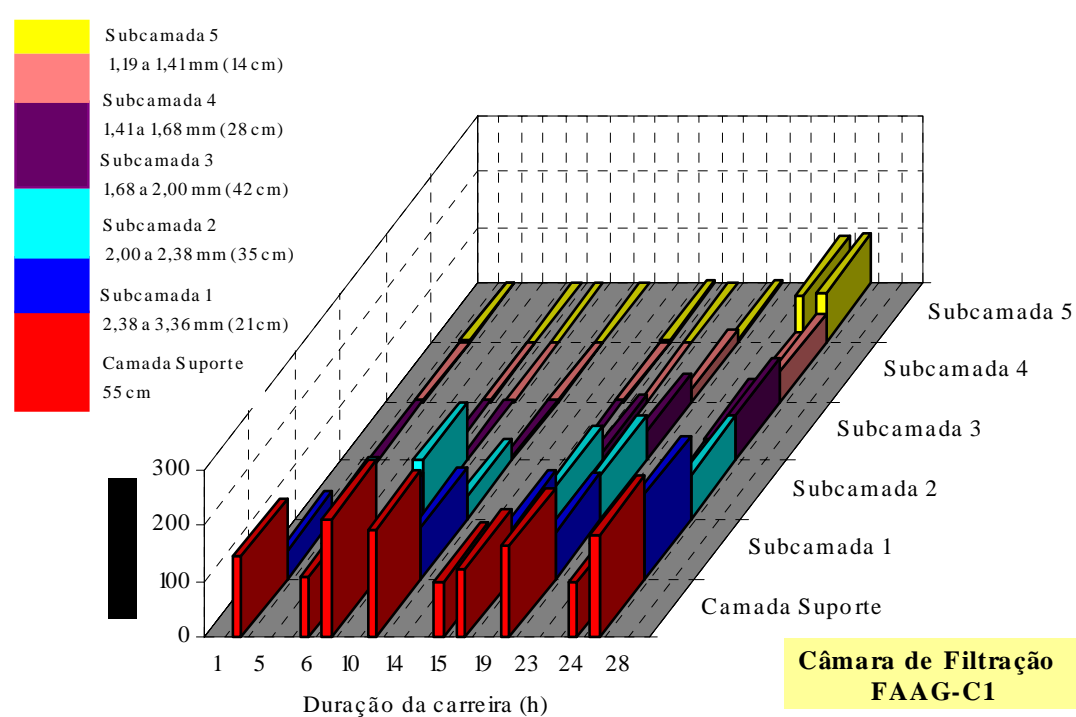

Figura C7.3 - Turbidez ao longo do meio filtrante da câmara de filtração 1 do FAAG durante o ensaio 7 de dupla filtração

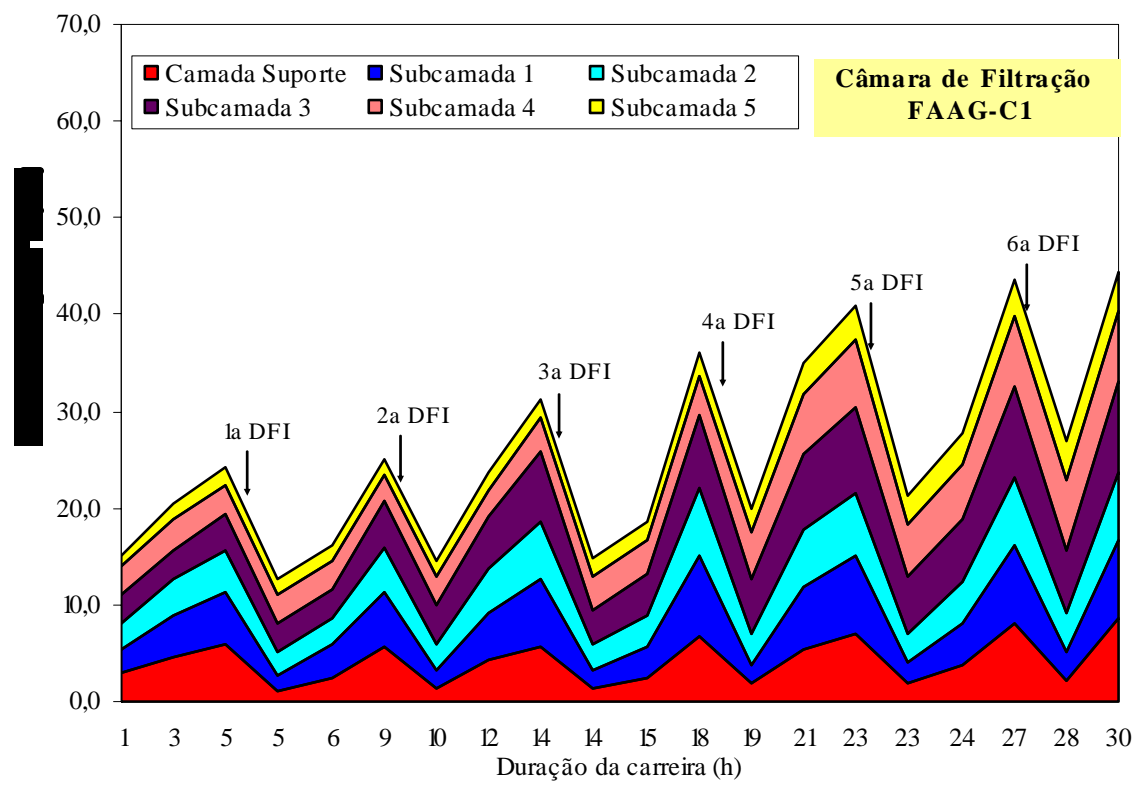

Figura C7.4 - Perda de carga ao longo do meio filtrante da câmara de filtração 1 do FAAG durante o ensaio 7 de dupla filtração 


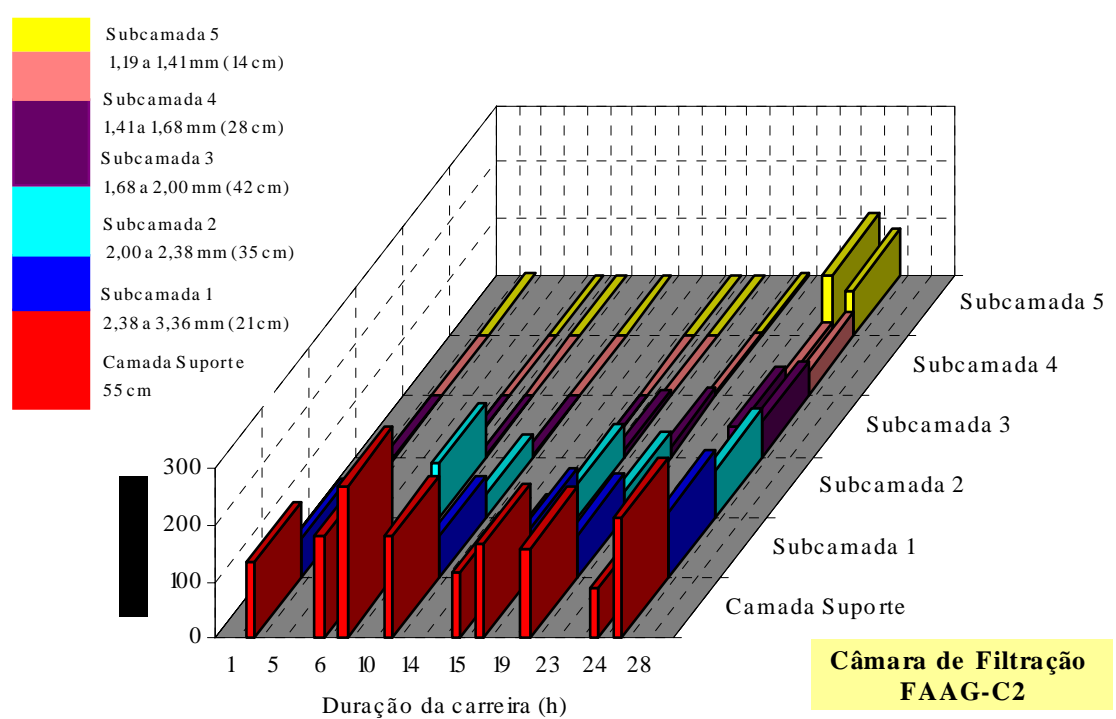

Figura C7.5 - Turbidez ao longo do meio filtrante da câmara de filtração 2 do FAAG durante o ensaio 7 de dupla filtração

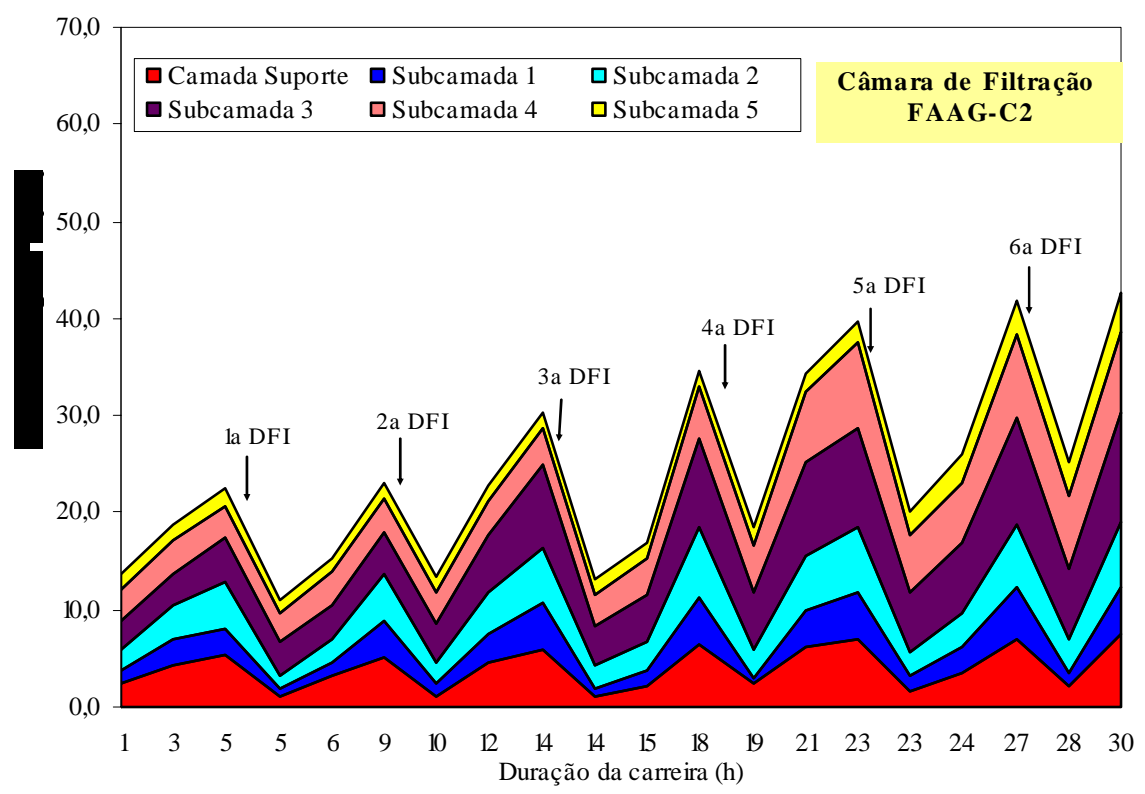

Figura C7.6 - Perda de carga ao longo do meio filtrante da câmara de filtração 2 do FAAG durante o ensaio 7 de dupla filtração 


\section{ENSAIO 8 DE DUPLA FILTRAÇÃO}

Tabela C8.1 - Condições do ensaio 8 de dupla filtração - Sistema 1 e Água de estudo Tipo II

\begin{tabular}{|c|c|c|}
\hline \multicolumn{3}{|c|}{ Água de Estudo } \\
\hline \multicolumn{2}{|l|}{ Turbidez (uT) } & 287 a 302 \\
\hline \multicolumn{2}{|l|}{$\mathrm{pH}$} & 7,67 a 7,80 \\
\hline \multicolumn{2}{|l|}{ Alcalinidade $\left(\mathrm{mg} / \mathrm{L} \mathrm{CaCO}_{3}\right)$} & 26,8 \\
\hline \multicolumn{2}{|l|}{ Temperatura $\left({ }^{\circ} \mathrm{C}\right)$} & 21,0 a 27,0 \\
\hline \multicolumn{2}{|l|}{ Potencial Zeta (mV) } & - \\
\hline \multicolumn{3}{|c|}{ Coagulação } \\
\hline \multicolumn{2}{|l|}{ Dosagem sulfato de alumínio (mg/L AL) } & 2,29 \\
\hline \multicolumn{2}{|c|}{ Dosagem sulfato de alumínio (mg/L produto comercial líquido) } & 60 \\
\hline \multicolumn{2}{|l|}{ pH de coagulação } & 6,81 a 6,96 \\
\hline \multicolumn{2}{|l|}{ Potencial Zeta $(\mathrm{mV})$} & $+0,4 \pm 0,3$ \\
\hline \multicolumn{2}{|l|}{ FLA (areia tipo 3) - Turbidez após 30 min de filtração } & 0,91 \\
\hline \multicolumn{2}{|l|}{ Gradiente de velocidade na mistura rápida $\left(\mathrm{s}^{-1}\right)$} & 600 \\
\hline \multicolumn{3}{|c|}{ Taxas de Filtração } \\
\hline CAP com orifício de & média & desvio padrão \\
\hline Vazão Total (L/h) - medidor eletromagnético & 68,07 & 1,24 \\
\hline Taxa de Filtração FAAG $\left(\mathrm{m}^{3} / \mathrm{m}^{2} . \mathrm{d}\right)$ & 125,7 & 2,3 \\
\hline Vazão FRD (L/h) - rotâmetro & 48,5 & - \\
\hline Taxa de Filtração FRD $\left(\mathrm{m}^{3} / \mathrm{m}^{2} . \mathrm{d}\right)$ & 179,1 & - \\
\hline
\end{tabular}


Tabela C8.2 - Resultados do ensaio 8 de dupla filtração - Sistema 1 e Água de estudo Tipo II

\begin{tabular}{|c|c|c|c|c|c|c|c|c|c|c|c|c|c|c|c|c|c|c|}
\hline & & & \multirow{3}{*}{\begin{tabular}{|l|}
$\mathrm{pH}$ \\
$\mathrm{AE}$
\end{tabular}} & \multirow{3}{*}{$\begin{array}{c}\mathrm{pH} \\
\text { Coag. }\end{array}$} & \multirow{3}{*}{$\begin{array}{l}\text { Temp. } \\
\text { (OC) }\end{array}$} & \multirow{2}{*}{\multicolumn{13}{|c|}{ Turbidez - Turbidímetro de Bancada (TB) (uT) }} \\
\hline \multirow{2}{*}{$\begin{array}{c}\text { Duração } \\
\text { (h) }\end{array}$} & \multirow{2}{*}{$\begin{array}{c}Q_{\mathrm{T}} \\
(\mathrm{Lh})\end{array}$} & \multirow{2}{*}{$\begin{array}{c}\text { Turb. } \\
\text { AE (uT) }\end{array}$} & & & & & & & & & & & & & & & & \\
\hline & & & & & & $\mathrm{Cl1}-1$ & $\mathrm{C} 2-1_{1}$ & c3-1 & $\mathrm{C4}-1$ & c5-1 & $\mathrm{C6} 6$ & $\mathrm{Cl}-2$ & 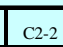 & $\mathrm{C} 32-2_{2}$ & $\mathrm{C} 42$ & $\mathrm{C} 5-2$ & $c 6-2$ & $\mathrm{Cl}+\mathrm{C}$ \\
\hline 1,0 & 67,42 & 297 & 7,80 & 6,96 & 27,0 & & & & & & & & & & & & & \\
\hline 3,0 & 68,02 & 285 & 7,70 & 6,91 & 27,0 & 104 & 35,2 & 1,90 & 0,63 & 0,54 & 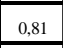 & 83,1 & 25,4 & 1,65 & 0,67 & 1,45 & 0,86 & 0,38 \\
\hline 6,0 & 69,70 & 284 & & & 25,5 & 219 & 137 & 21,1 & 0,77 & 0,87 & 0,72 & 179 & 101 & 5,75 & 0,71 & 0,67 & 0,52 & 0,89 \\
\hline 9,0 & 67,10 & 291 & & 6,88 & 24,0 & 271 & 159 & 74,2 & 0,57 & 0,73 & 0,80 & 301 & 164 & 142 & 0,52 & 1,13 & 0,36 & 0,42 \\
\hline 15,0 & 67,94 & 302 & & 6,81 & 23,0 & 233 & 209 & 129 & 129 & 79,8 & 11,8 & 290 & 217 & 131 & 84,7 & 45,5 & 0,48 & 1,21 \\
\hline 18,0 & 68,98 & 287 & & & 22,0 & 238 & 208 & 147 & 127 & 97,5 & $*$ & 213 & 184 & 155 & 111 & 92,2 & $*$ & \\
\hline 21,0 & 67,74 & 294 & 7,76 & 6,92 & 25,0 & & & & & & & & & & & & & \\
\hline 24,0 & 67,42 & 296 & & & 27,0 & 157 & 167 & \begin{tabular}{|l}
118 \\
\end{tabular} & 111 & 90,7 & $*$ & \begin{tabular}{|l}
221 \\
\end{tabular} & 150 & 183 & \begin{tabular}{|l}
119 \\
\end{tabular} & \begin{tabular}{|l|l}
148 \\
\end{tabular} & $*$ & \\
\hline 27,0 & 67,10 & 301 & & & 27,0 & & & & & & & & & & & & & \\
\hline 30,0 & 68,06 & 300 & 7,67 & 6,91 & 25,0 & & & & & & & & & & & & & \\
\hline 36,0 & 67,41 & 301 & & & 23,0 & & & & & & & & & & & & & \\
\hline
\end{tabular}
(De Areia Grossa - FAAG

Perda de Carga Corrigida $25^{\circ} \mathrm{C}(\mathrm{cm})$

\begin{tabular}{|l|l|l|l|l|l|l|l|l|l|l|l|l|l|l|}
\hline & P1-1 & P2-1 & P3-1 & P4-1 & P5-1 & P6-1 & P7-1 & P1-2 & P2-2 & P3-2 & P4-2 & P5-2 & P6-2 & P7-2 \\
\hline
\end{tabular} \begin{tabular}{|llllllllll|l|l|l|l|l|l|l|l|}
270,5 & 269,4 & 266,1 & 266,6 & 266,3 & 261,9 & 260,3 & 270,4 & 269,2 & 26,2 & 266,9 & 264,4 & 262,3 & 260,5 \\
\hline
\end{tabular}

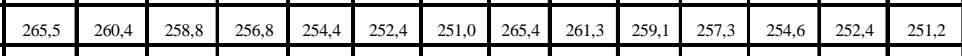

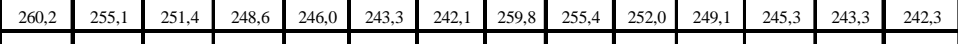
\begin{tabular}{|l|l|l|l|l|l|l|l|l|l|l|l|l|l|l|}
265,3 & 258,2 & 252,9 & 24,2 & 241,7 & 237,5 & 23,3 & 265,0 & 25,6 & 25,3 & 24,5 & 241,7 & 237,5 & 23,5 \\
\hline
\end{tabular} \begin{tabular}{llll|l|l|l|l|l|l|l|l|l|l|l|l|l|}
263,3 & 255,0 & 251,1 & 24,6 & 23,5 & 23,5 & 230,7 & 26,3 & 25,4 & 251,8 & 245,3 & 23,7 & 232,8 & 230,9 \\
\hline
\end{tabular} \begin{tabular}{|l|l|l|l|l|l|l|l|l|l|l|l|l|l|l|l|}
\hline 2878,1 & 278,1 & 271,2 & 264,7 & 256,4 & 251,0 & 248,0 & 288,1 & 279,1 & 27,1 & 265,7 & 256,8 & 251,2 & 248,2 \\
\hline
\end{tabular} \begin{tabular}{|lll|l|l|l|l|l|l|l|l|l|l|l|l|l|l|}
307,6 & 296,1 & 287,2 & 27,3 & 270,1 & 263,6 & 260,3 & 307,6 & 297,1 & 288,7 & 280,6 & 271,0 & 264,0 & 260,5 \\
\hline
\end{tabular} \begin{tabular}{llllllllllllll|l|l|l|l|l|l|}
3113,3 & 300,3 & 200,3 & 281,2 & 271,5 & 264,2 & 260,3 & 313,3 & 301,3 & 221,9 & 282,5 & 272,0 & 264,7 & 260,5 \\
\hline
\end{tabular} \begin{tabular}{|l|l|l|l|l|l|l|l|l|l|l|l|l|l|l|l|l|}
229,9 & 286,2 & 27,3 & 269,4 & 259,5 & 251,9 & 248,0 & 29,9 & 287,7 & 27,9 & 27,5 & 259,8 & 25,4 & 248,2 \\
\hline
\end{tabular} \begin{tabular}{|l|l|l|l|l|l|l|l|l|l|l|l|l|l|}
224,6 & 280,2 & 269,3 & 258,8 & 24,9 & 240,3 & 286,3 & 294,5 & 28,2 & 27,9 & 26,1 & 248,4 & 24,1 & 236,5 \\
\hline
\end{tabular} FAAG -Perda de Carga Lida (cm)

\begin{tabular}{|l|l|l|l|l|l|l|l|l|l|l|l|l|l|}
\hline P1-1 & P2-1 & P3-1 & P4-1 & P5-1 & P6-1 & P7-1 & P1-2 & P2-2 & P3-2 & P4-2 & P5-2 & P6-2 & P7-2 \\
\hline
\end{tabular} \begin{tabular}{l|l|l|l|l|l|l|l|l|l|l|l|l|l|}
\hline 258,6 & 25,5 & 256,3 & $25,4,8$ & 252,6 & 250,3 & 24,8 & 258,5 & 257,3 & 256,4 & 255,1 & 252,7 & 250,7 & 24,0 \\
\hline
\end{tabular}

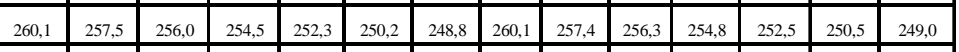

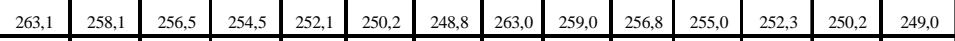
\begin{tabular}{|l|l|l|l|l|l|l|l|l|l|l|l|l|l|}
\hline 267,4 & 262,2 & 25,4 & 255,5 & 252,8 & 250,0 & 248,8 & 267,0 & 262,5 & 259,0 & 256,0 & 252,1 & 250,0 & 249,0 \\
\hline
\end{tabular} \begin{tabular}{|l|l|l|l|l|l|l|l|l|l|l|l|l|l|}
\hline 279,3 & $27,1,8$ & 266,2 & 261,3 & 254,5 & 250,0 & 248,8 & 279,0 & 272,3 & 266,7 & 261,6 & 25,5 & 250,0 & 249,0 \\
\hline
\end{tabular}

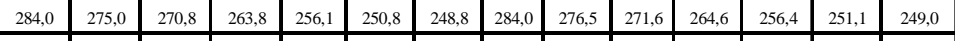

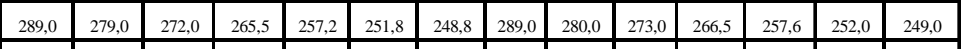

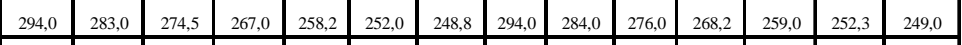
\begin{tabular}{|l|l|l|l|l|l|l|l|l|l|l|l|l|l|}
229,5 & 287,0 & 27,5 & 268,8 & 259,5 & 252,5 & 248,8 & 29,5 & 288,0 & 279,0 & 27,0 & 260,0 & 253,0 & 249,0 \\
\hline
\end{tabular} \begin{tabular}{|l|l|l|l|l|l|l|l|l|l|l|l|l|l|}
\hline 300,8 & 287,1 & 27,2 & 270,2 & 260,3 & 252,7 & 248,8 & 300,8 & 288,6 & 279,8 & 271,3 & 260,6 & 253,2 & 249,0 \\
\hline
\end{tabular} \begin{tabular}{|l|l|l|l|l|l|l|l|l|l|l|l|l|l|l|}
\hline 310,2 & 295,0 & 283,5 & 272,5 & 261,0 & 253,0 & 248,8 & 310,0 & 285,2 & 27,8 & 261,5 & $25,3,8$ & 249,0 \\
\hline
\end{tabular} 
Tabela C8.2 - Continuação

\begin{tabular}{|c|c|c|c|c|c|}
\hline \multirow{3}{*}{$\begin{array}{c}\text { Duração } \\
\text { (h) }\end{array}$} & \multirow{3}{*}{$\begin{array}{l}\text { Temp. } \\
(\mathrm{oC})\end{array}$} & \multicolumn{4}{|c|}{ Filtro Rápido Descendente - FRD } \\
\hline & & Qfd & Turbidez - TB (uT) & Perda c & $5^{\circ} \mathrm{C}(\mathrm{cm})$ \\
\hline & & $(\mathrm{L} / \mathrm{h})$ & $\mathrm{AF}$ & P1 & P2 \\
\hline 1,0 & 27,0 & 49,0 & 0,16 & 25,4 & 75,3 \\
\hline 3,0 & 27,0 & 49,5 & 0,28 & 25,4 & 75,8 \\
\hline 6,0 & 25,5 & 49,0 & 0,21 & 24,5 & 78,2 \\
\hline 9,0 & 24,0 & 49,0 & 0,27 & 23,6 & 77,1 \\
\hline 15,0 & 23,0 & 49,0 & 0,23 & 23,1 & 77,7 \\
\hline 18,0 & 22,0 & 48,0 & 0,24 & 22,5 & 76,0 \\
\hline 21,0 & 25,0 & 48,0 & 0,17 & 24,2 & 83,2 \\
\hline 24,0 & 27,0 & 48,0 & 0,29 & 25,4 & 88,9 \\
\hline 27,0 & 27,0 & 48,0 & 0,21 & 25,4 & 91,0 \\
\hline 30,0 & 25,0 & 48,0 & 0,20 & 24,2 & 93,4 \\
\hline \multirow[t]{14}{*}{36,0} & 23,0 & 48,0 & 0,18 & 23,1 & 107,3 \\
\hline & & & & \multicolumn{2}{|c|}{ Perda de Carga Lida (cm) } \\
\hline & & & & P1 & P2 \\
\hline & & & & 24,3 & 72,0 \\
\hline & & & & 24,3 & 72,5 \\
\hline & & & & 24,3 & 77,5 \\
\hline & & & & 24,3 & 79,2 \\
\hline & & & & 24,3 & 81,8 \\
\hline & & & & 24,3 & 82,0 \\
\hline & & & & 24,3 & 83,5 \\
\hline & & & & 24,3 & 85,0 \\
\hline & & & & 24,3 & 87,0 \\
\hline & & & & 24,3 & 93,7 \\
\hline & & & & 24,3 & 113,0 \\
\hline
\end{tabular}

$\mathrm{Q}_{\mathrm{T}}$ : vazão total afluente ao Sistema de Dupla Filtração (medidor de vazão eletromagnético);

Turb. AE: turbidez da água de estudo (turbidímetro de bancada);

pH AE: pH da água de estudo;

pH Coag.: pH de coagulação;

Ci-1: amostra coletada no final da subcamada i do meio filtrante da câmara de filtração 1 do FAAG;

Ci-2: amostra coletada no final da subcamada i do meio filtrante da câmara de filtração 2 do FAAG;

C1+C2: amostra de água pré-filtrada global (efluentes das câmaras de filtração 1 e 2 da FAAG);

Pi-1: piezômetro i localizado na câmara de filtração 1 do FAAG;

Pi-2: piezômetro i localizado na câmara de filtração 2 do FAAG;

*: comprometimento das coletas localizadas na última subcamada do FAAG devido a formação do manto de lodo; Q

Turb. AF: turbidez da água filtrada (turbidímetro de bancada);

P1 e P2: piezômetros localizados no início e no final do FRD, respectivamente. 


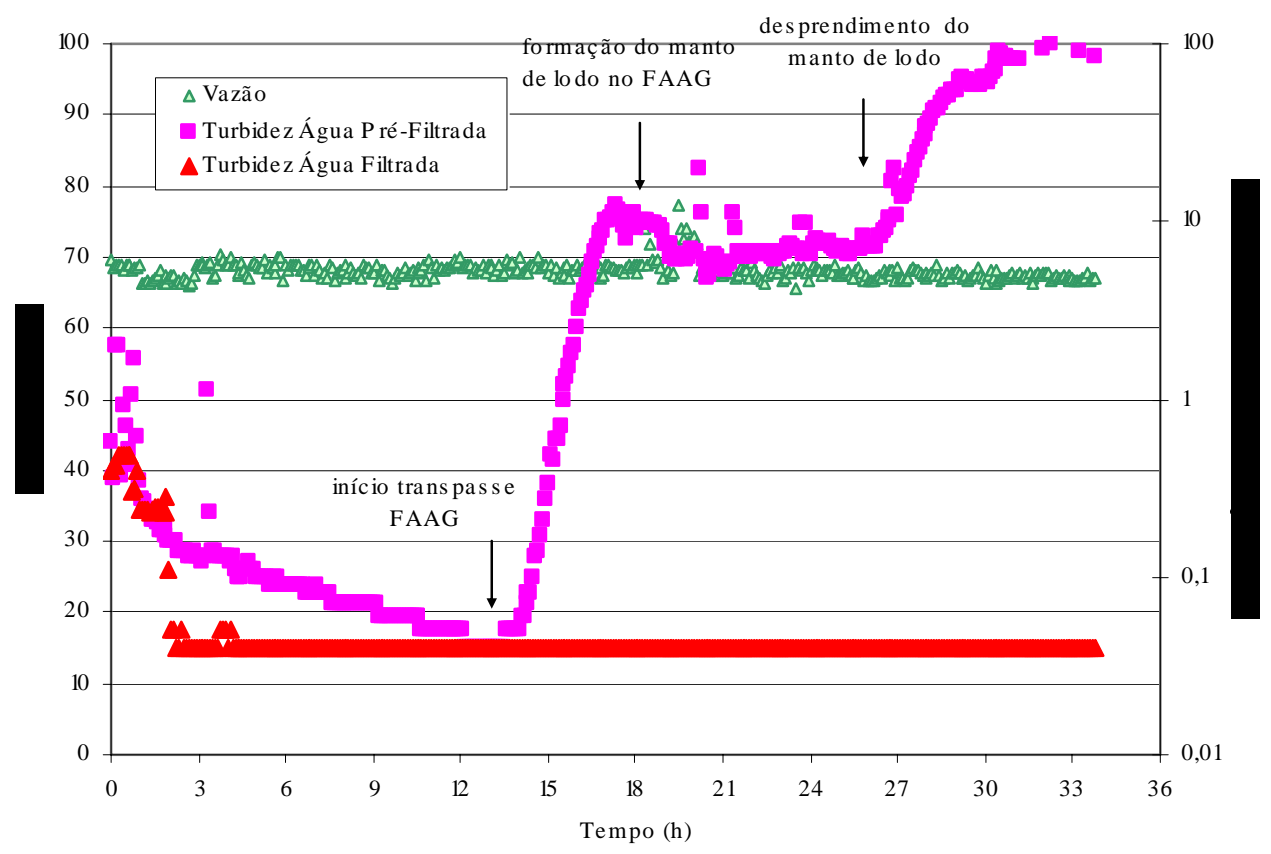

Figura C8.1 - Variações da vazão total afluente ao sistema de dupla filtraçào e da turbidez das águas pré-filtrada e filtrada no ensaio 8 - Turbidímetros de Escoamento Contínuo

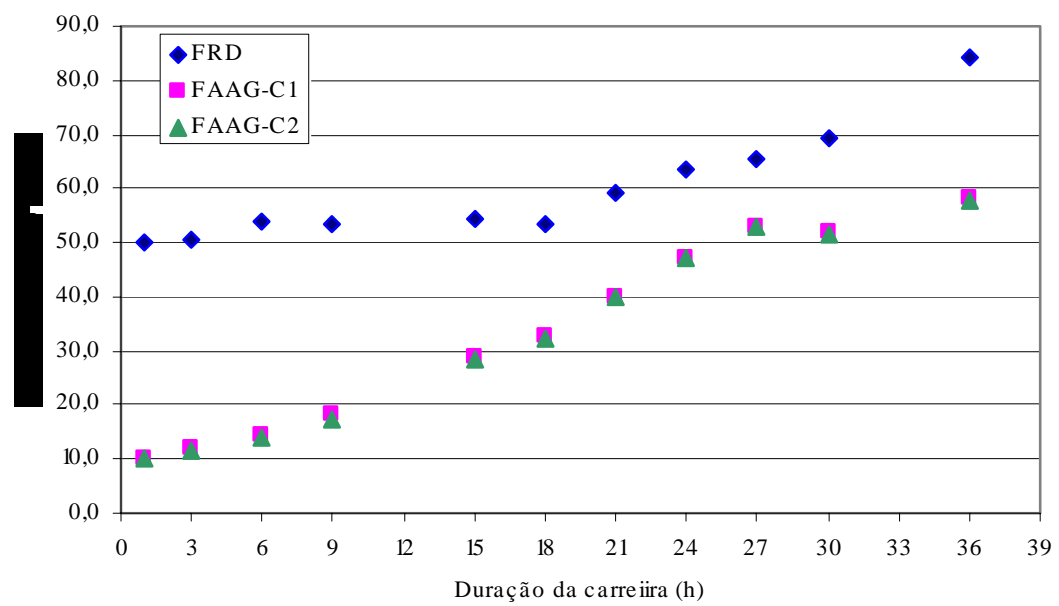

Figura C8.2 - Perda de carga nos filtros ascendente de areia grossa (duas câmaras de filtração) e descendente durante o ensaio 8 de dupla filtração 


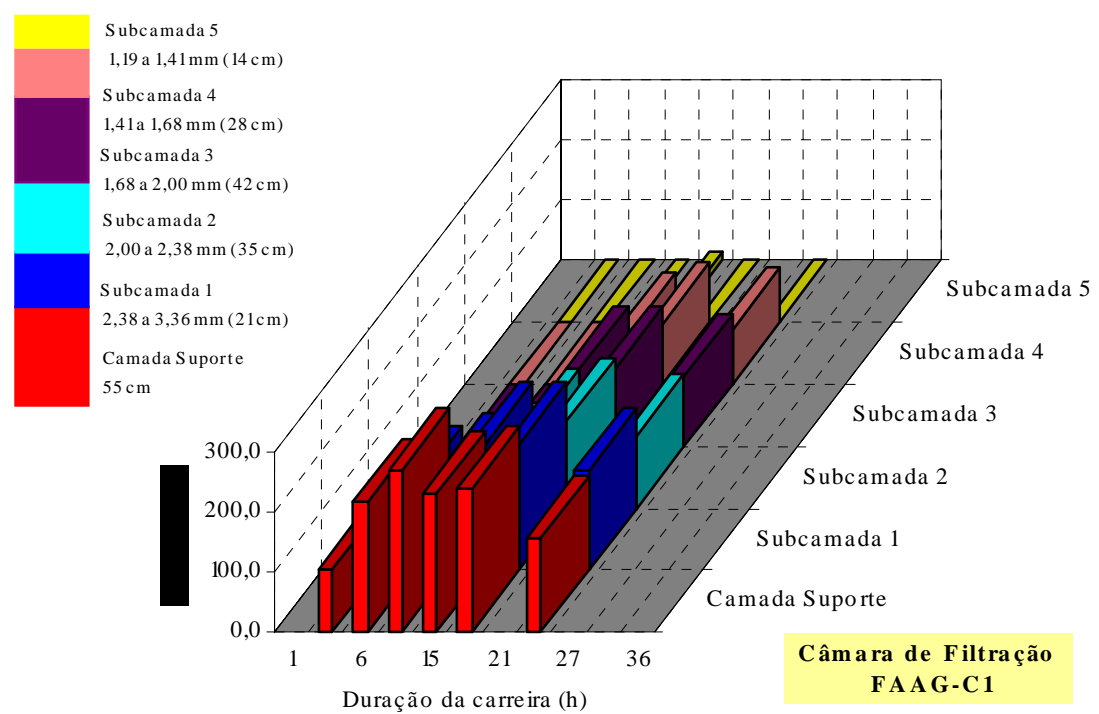

Figura C8.3 - Turbidez ao longo do meio filtrante da câmara de filtração 1 do FAAG durante o ensaio 8 de dupla filtração

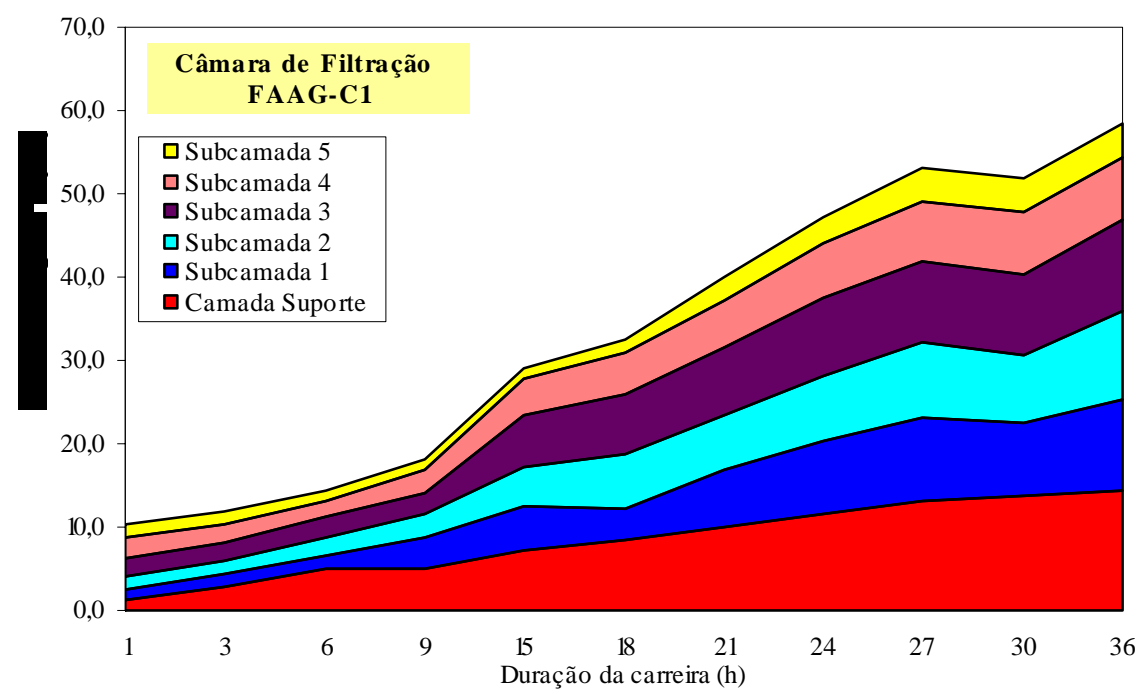

Figura C8.4 - Perda de carga ao longo do meio filtrante da câmara de filtração 1 do FAAG durante o ensaio 8 de dupla filtração 


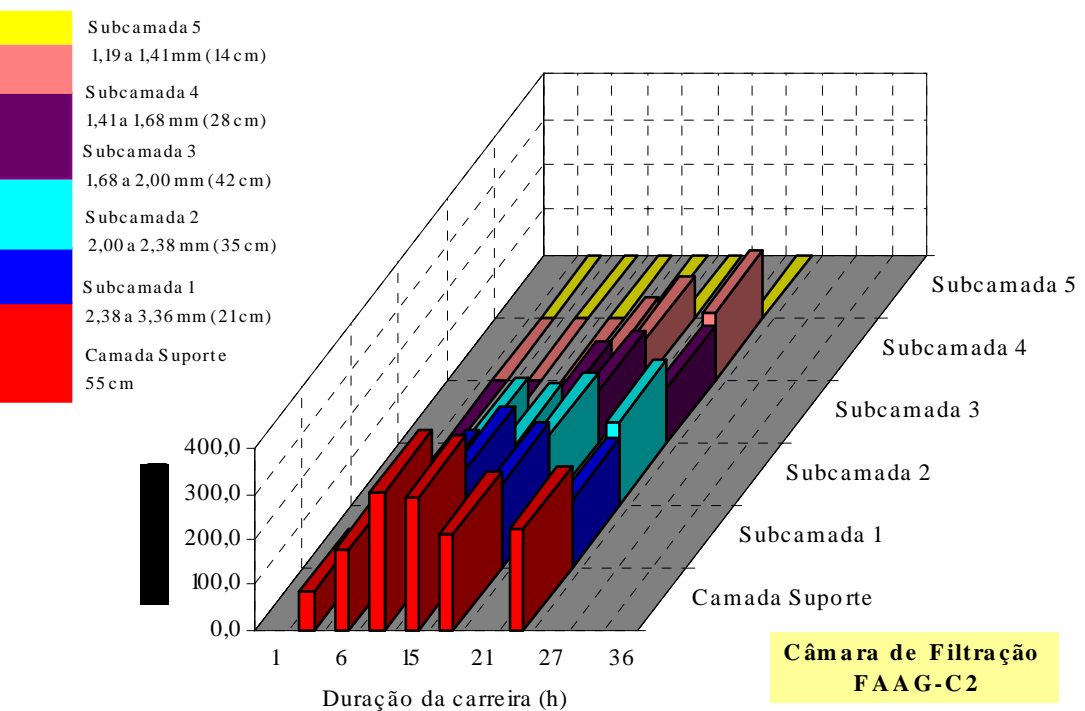

Figura C8.5 - Turbidez ao longo do meio filtrante da câmara de filtração 2 do FAAG durante o ensaio 8 de dupla filtração

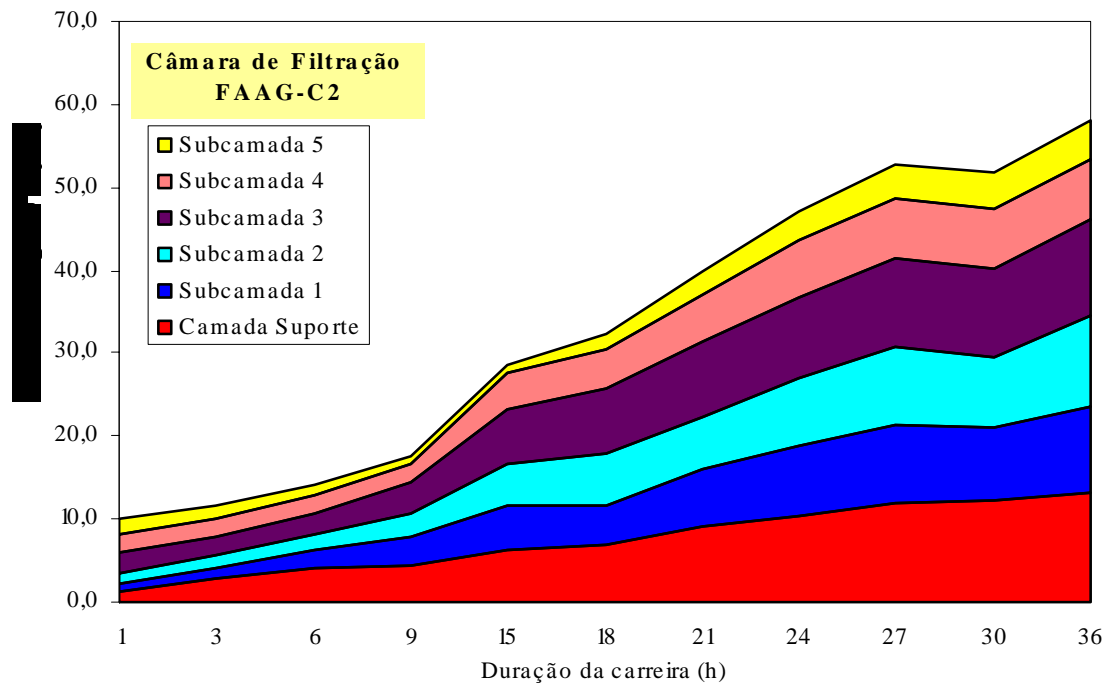

Figura C8.6 - Perda de carga ao longo do meio filtrante da câmara de filtração 2 do FAAG durante o ensaio 8 de dupla filtração 


\section{ENSAIO 9 DE DUPLA FILTRAÇÃO}

Tabela C9.1 - Condições do ensaio 9 de dupla filtração - Sistema 1 e Água de estudo Tipo II

\begin{tabular}{|c|c|c|}
\hline \multicolumn{3}{|c|}{ Água de Estudo } \\
\hline \multicolumn{2}{|l|}{ Turbidez (uT) } & 289 a 302 \\
\hline \multicolumn{2}{|l|}{$\mathrm{pH}$} & 7,74 a 7,91 \\
\hline \multicolumn{2}{|l|}{ Alcalinidade $(\mathrm{mg} / \mathrm{L} \mathrm{CaCO}$ ) } & 26,2 \\
\hline \multicolumn{2}{|l|}{ Temperatura $\left({ }^{\circ} \mathrm{C}\right)$} & 24,0 a 28,0 \\
\hline \multicolumn{2}{|l|}{ Potencial Zeta (mV) } & - \\
\hline \multicolumn{3}{|c|}{ Coagulação } \\
\hline \multicolumn{2}{|l|}{ Dosagem sulfato de alumínio (mg/L AL) } & 2,29 \\
\hline \multicolumn{2}{|c|}{ Dosagem sulfato de alumínio (mg/L produto comercial líquido) } & 60 \\
\hline \multicolumn{2}{|l|}{ pH de coagulação } & 6,91 a 7,02 \\
\hline \multicolumn{2}{|l|}{ Potencial Zeta (mV) } & $-0,3 \pm 0,2$ \\
\hline \multicolumn{2}{|l|}{ FLA (areia tipo 3) - Turbidez após 30 min de filtração } & 0,75 \\
\hline \multicolumn{2}{|l|}{ Gradiente de velocidade na mistura rápida $\left(\mathrm{s}^{-1}\right)$} & 600 \\
\hline \multicolumn{3}{|c|}{ Taxas de Filtração } \\
\hline CAP com orifício de & média & desvio padrão \\
\hline Vazão Total (L/h) - medidor eletromagnético & 66,55 & 1,54 \\
\hline Taxa de Filtração FAAG $\left(\mathrm{m}^{3} / \mathrm{m}^{2} . \mathrm{d}\right)$ & 122,9 & 2,8 \\
\hline Vazão FRD (L/h) - rotâmetro & 49,3 & - \\
\hline Taxa de Filtração FRD $\left(\mathrm{m}^{3} / \mathrm{m}^{2} . \mathrm{d}\right)$ & 182,0 & - \\
\hline
\end{tabular}


Tabela C9.2 - Resultados do ensaio 9 de dupla filtração - Sistema 1 e Água de estudo Tipo II

\begin{tabular}{|c|c|c|c|c|c|c|c|c|c|c|c|c|c|c|c|c|c|c|c|c|c|c|c|c|c|c|c|c|c|c|c|c|}
\hline & & & & & & \\
\hline \multirow{3}{*}{\begin{tabular}{|c|c} 
Duraçã \\
(h) \\
\end{tabular}} & \multirow{3}{*}{$\begin{array}{c}\mathrm{Q}_{\mathrm{T}} \\
\mathrm{L} / \mathrm{h})\end{array}$} & \multirow{3}{*}{$\begin{array}{c}\text { Turb. } \\
\mathrm{AE}(\mathrm{uT})\end{array}$} & & \multirow{3}{*}{$\begin{array}{c}\mathrm{pH} \\
\text { Coag. }\end{array}$} & \multirow{3}{*}{\begin{tabular}{|c} 
Temp. \\
$(\mathrm{OC})$ \\
\end{tabular}} & & & & & & & & & & & & & & & & & & & & & & & & & & & \\
\hline & & & & & & \multicolumn{13}{|c|}{ Turbidez - Turbidímetro de Bancada (TB) (uT) } & \multicolumn{14}{|c|}{ Perda de Carga Corrigida $25^{\circ} \mathrm{C}(\mathrm{cm})$} \\
\hline & & & & & & $\mathrm{Cl}-1$ & -1 & C3-1 & $\mathrm{CA}_{4}$ & $\mathrm{C5}-1^{-1}$ & C6-1 & $\mathrm{C1} 1-2$ & C2-2 & C3-2 & $\mathrm{C} 4-2$ & \begin{tabular}{|c|}
$\mathrm{C5}-2$ \\
\end{tabular} & $C 6-2$ & $\mathrm{Cl}+\mathrm{C} 2$ & P1-1-1 & P2-1 & \begin{tabular}{|l|l|l} 
P3-1 \\
\end{tabular} & $\mathrm{P} 4-1$ & \begin{tabular}{|l|l|l|l|l|} 
P5-1 \\
\end{tabular} & $\mathrm{P} 6-1$ & \begin{tabular}{l|l}
$\mathrm{p} 7-1$ \\
\end{tabular} & \begin{tabular}{|l}
$\mathrm{P} 1-2$ \\
\end{tabular} & \begin{tabular}{l|l} 
P2-2 & P \\
\end{tabular} & P3-2 & $\mathrm{P4} 2$ & P5-2 & $\mathrm{P} 6-2$ & P7-2 \\
\hline & \begin{tabular}{|c|}
67,42 \\
\end{tabular} & 298 & 7,74 & 6,91 & 27,0 & & & & & & & & & & & & & 0,50 & 59,5 & 268,0 & 266,9 & 265,7 & 263,6 & 261,8 & 260,5 & 269,4 & 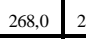 & & 265,8 & & 261,7 & 260,5 \\
\hline 3,0 & 5,82 & 299 & & & 28,0 & 86,4 & & 1,19 & 0,79 & \begin{tabular}{|l}
0,51 \\
\end{tabular} & 0,48 & 85,6 & 6,9 & 1,29 & 0,49 & \begin{tabular}{|l|l|l|l|}
0,84 \\
\end{tabular} & 0,60 & 0,33 & 78,1 & 275,4 & 273,5 & 272,2 & 270,1 & 268,1 & 266,9 & 277,8 & \begin{tabular}{l|l}
275,4 & 2 \\
\end{tabular} & 273,7 & 272,4 & 270,1 & 268,0 & 266,9 \\
\hline 4,5 & \begin{tabular}{|l|l}
68,38 \\
\end{tabular} & & & & 28,0 & & & & & & & & & & & & & & 30,3 & 276,0 & 273,8 & 272,2 & \begin{tabular}{|l|l|l|}
270,1 & & 0
\end{tabular} & 267,9 & 266,9 & \begin{tabular}{|l|l|}
279,5 & \\
\end{tabular} & \begin{tabular}{l|l}
276,2 & 2 \\
\end{tabular} & 274,0 & 272,4 & 270,1 & \begin{tabular}{|l|r|}
268,0 \\
\end{tabular} & 266,9 \\
\hline 5,0 & 66,7 & & & & 28,0 & & & & & & & & & & & & & & 5,4 & 274,4 & 273,4 & 272,2 & 270,1 & 268,0 & 266,9 & 275,2 & $\begin{array}{ll}274,4 & 2 \\
2\end{array}$ & 273,5 & 272,2 & 270,1 & 267,9 & 266,9 \\
\hline 6,0 & 67,10 & 301 & 7,86 & 6,95 & 28,0 & 56 & 7,88 & 2,25 & 0,88 & \begin{tabular}{|l}
0,41 \\
\end{tabular} & $\begin{array}{r}0,82 \\
\end{array}$ & \begin{tabular}{|l}
79,9 \\
\end{tabular} & 9,34 & $\begin{array}{r}2,25 \\
\end{array}$ & $0,0,50$ & \begin{tabular}{|l|l|}
0,90 \\
\end{tabular} & 0,40 & 0,33 & 277,2 & 275,1 & \begin{tabular}{|l}
273,9 \\
\end{tabular} & 272,4 & 270,1 & 268,4 & 266,9 & \begin{tabular}{|l|}
277,0 \\
\end{tabular} & 275,2 & 273,8 & 272,4 & 270,1 & 267,9 & 266,9 \\
\hline 9,0 & 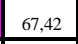 & 299 & & & 25,0 & 137 & 4,5 & 2,43 & 0,87 & 0,69 & $\begin{array}{r}0,89 \\
\end{array}$ & 126 & 88,6 & $\begin{array}{r}2,93 \\
\end{array}$ & 0,65 & \begin{tabular}{|l|l|}
1,60 \\
\end{tabular} & 0,70 & $\begin{array}{r}0,25 \\
\end{array}$ & 261,4 & 258,0 & \begin{tabular}{|l}
255,3 \\
\end{tabular} & 253,4 & 251,7 & 249,2 & 248,2 & 261,7 & 257,2 & 255,7 & 253,5 & 251,6 & 249,2 & 248,2 \\
\hline 9,5 & \begin{tabular}{|l|}
65,49 \\
\end{tabular} & & & & 25,0 & & & & & & & & & & & & & & 256,7 & 255,7 & \begin{tabular}{|l}
254,7 \\
25
\end{tabular} & 253,3 & 251,2 & 249,2 & 248,2 & \begin{tabular}{|l}
256,7 \\
\end{tabular} & 255,7 & 254,2 & 253,5 & 251,3 & 249,2 & 248,2 \\
\hline 12,0 & \begin{tabular}{|l}
66,71 \\
\end{tabular} & 289 & & & 24,0 & 118 & 8,9 & $\begin{array}{r}3,42 \\
\end{array}$ & 88 & 0,88 & 0,68 & 101 & 47,8 & 0,98 & 0,88 & \begin{tabular}{|l|l|}
0,58 \\
\end{tabular} & 0,65 & 0,31 & 253,8 & 251,1 & \begin{tabular}{|l}
2499,1 \\
\end{tabular} & 247,7 & 245,2 & 243,3 & 242,3 & 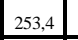 & $\begin{array}{ll}251,1 & 2 \\
2\end{array}$ & 249,3 & 247,7 & 245,4 & 243,3 & 242,3 \\
\hline 13,5 & 5,62, & & & & 24 & & & & & & & & & & & & & & 255,3 & 252,0 & \begin{tabular}{|l|}
249,6 \\
\end{tabular} & 247,7 & \begin{tabular}{|l|}
245,2 \\
2
\end{tabular} & 243,3 & 242,3 & 255,4 & $252,5=2$ & 250,1 & 247,9 & 245,7 & 243,3 & 242,3 \\
\hline 14,0 & \begin{tabular}{|l}
66,78 \\
\end{tabular} & & & & 24,0 & & & & & & & & & & & & & & 251,1 & 250,1 & \begin{tabular}{|l|}
249,1 \\
\end{tabular} & 247,7 & \begin{tabular}{|l|}
245,2 \\
\end{tabular} & 243,3 & 242,3 & 251,1 & $250,1=2$ & 249,6 & 247,7 & 245,7 & 243,3 & 242,3 \\
\hline 18,0 & 5,49 & 30 & 7,91 & 6,98 & $\begin{array}{r}24,0 \\
\end{array}$ & $\begin{array}{r}199 \\
\end{array}$ & & 8,67 & 0,54 & 0,61 & 0,25 & \begin{tabular}{|l}
193 \\
\end{tabular} & & 1,67 & 0,30 & 0,42 & 0,62 & 0,20 & 257,4 & 253,8 & \begin{tabular}{|l|l}
250,6 \\
\end{tabular} & 248,1 & $245,4 \mid$ & 243,3 & 242,3 & 257,4 & 253,8 & 250,9 & 247,7 & 245,4 & 243,3 & 242,3 \\
\hline 18,5 & \begin{tabular}{|l}
66,78 \\
\end{tabular} & & & & 24,0 & & & & & & & & & & & & & & 251,1 & 250,3 & \begin{tabular}{|l}
249,4 \\
\end{tabular} & 247,9 & 245,4 & 243,3 & 242,3 & 1,2 & $\begin{array}{r}250,3 \\
22\end{array}$ & 249,4 & 248,0 & 245,4 & 243,3 & 242,3 \\
\hline 21,0 & \begin{tabular}{|l}
66,12 \\
\end{tabular} & 30 & & &, 0 & 92,8 & 18,4 & \begin{tabular}{|l}
1,02 \\
\end{tabular} & 0,33 & $\begin{array}{r}0,32 \\
\end{array}$ & 0,65 & 84,5 & 37,3 & $\begin{array}{r}0,93 \\
\end{array}$ & 0,28 & \begin{tabular}{|l}
0,18 \\
\end{tabular} & 0,26 & $\begin{array}{l}0,27 \\
\end{array}$ & 259,7 & 258,5 & \begin{tabular}{|l|}
256,0 \\
\end{tabular} & 254,0 & \begin{tabular}{|l|}
251,4 \\
\end{tabular} & 249,2 & 248,2 & \begin{tabular}{l|l}
9,7 \\
\end{tabular} & $257,5=2$ & 256,1 & 254,2 & 251,4 & 249,2 & 248,2 \\
\hline 22,5 & \begin{tabular}{|l}
65,82 \\
\end{tabular} & & & & 26,0 & & & & & & & & & & & & & & 269,4 & 265,5 & 262,5 & 260,2 & \begin{tabular}{|l|}
257,6 \\
\end{tabular} & 255,3 & 254,3, & 269,1 & 265,7 & 263,0 & 260,4 & 257,6 & 255,3 & 254,3 \\
\hline 23,0 & \begin{tabular}{|l}
65,49 \\
\end{tabular} & & & & 26, & & & & & & & & & & & & & & 263,7 & 262,5 & \begin{tabular}{|l|}
261,8 \\
\end{tabular} & 260,3 & \begin{tabular}{|l|}
257,7 \\
\end{tabular} & 255,5 & 254,3 & \begin{tabular}{|l|}
263,5 \\
\end{tabular} & 262,8 & 261,9 & 260,4 & 257,6 & 255,3 & 254,3 \\
\hline 24,0 & \begin{tabular}{|l|}
66,7 \\
\end{tabular} & 296 & & & 27,5 & & & & & & & & & & & & & & 275,4 & 273,2 & \begin{tabular}{|l|}
271,6 \\
\end{tabular} & 270,0 & \begin{tabular}{|l|}
267,2 \\
\end{tabular} & 264,9 & 263,7 & 275,4 & $27,0=2$ & 271,7 & 270,0 & 267,1 & \begin{tabular}{|l|}
264,7 \\
\end{tabular} & 263,7 \\
\hline 27,0 & 65,17 & & & & & 197 & & 0 & 0 & 1 & 0,48 & 176 & $9=$ & 53 & 0,52 & 0,45 & $\begin{array}{l}0,50 \\
\end{array}$ & 0,39 & 282,9 & 279,1 & \begin{tabular}{|l|}
276,0 \\
\end{tabular} & 273,3 & \begin{tabular}{|l|}
270,4 \\
\end{tabular} & 268,1 & 266,9 & \begin{tabular}{|l|}
282,9 \\
\end{tabular} & $279,12_{2}^{2}$ & 276,3 & 3,3 & 0,3 & 268,0 & 266,9 \\
\hline 27,5 & \begin{tabular}{|l|}
65, \\
\end{tabular} & & & & 28. & & & & & & & & & & & & & & 277,0 & 275,4 & \begin{tabular}{|l|}
274,9 \\
\end{tabular} & 273,1 & 270,6 & 268,1 & 266,9 & 6,5 & 275,4 & 274,9 & 273,3 & 270,3 & 268,0 & 266,9 \\
\hline 30,0 & \begin{tabular}{|l}
65,62 \\
\end{tabular} & 29 & 7,4 & 7,02 & \begin{tabular}{|l}
28,0 \\
\end{tabular} & 86 & 00,1 & \begin{tabular}{|l|}
0,62 \\
0
\end{tabular} & 0,35 & \begin{tabular}{|l}
0,28 \\
\end{tabular} & $0,0,6$ & 74,8 & 70,2 & 0,04 & 0,29 & $0,0,23$ & 0,24 & 0,18 & 281,3 & 277,9 & \begin{tabular}{|l|}
275,4 \\
\end{tabular} & 273,3 & \begin{tabular}{|l|}
270,6 \\
\end{tabular} & 268,1 & 266,9 & 281,3 & 278,1 & 275,8 & 273,3 & 270,3 & \begin{tabular}{|l|}
268,0 \\
26
\end{tabular} & 266,9 \\
\hline 31,5 & 6 & & & & 26 & & & & & & & & & & & & & & 273,9 & 269,9 & \begin{tabular}{|l|}
266,7 \\
\end{tabular} & 263,6 & \begin{tabular}{|l|}
261,0 \\
\end{tabular} & 258,5 & 257,4 & \begin{tabular}{|l|}
273,9 \\
\end{tabular} & 270,0 & 267,0 & 263,8 & 260,7 & 258,5 & 257,4 \\
\hline 32,0 & \begin{tabular}{|l}
65 \\
\end{tabular} & & & & 2 & & & & & & & & & & & & & & 261,5 & 260,1 & 259,1 & 257,3 & 254,7 & 252,3 & 251,2 & 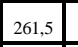 & 260,1 & 259,1 & 25,4 & 254,5 & 252,2 & 251,2 \\
\hline 33,0 & \begin{tabular}{|l}
66,71 \\
\end{tabular} & 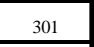 & & & \begin{tabular}{|l|}
25,5 \\
\end{tabular} & 103 & 15,0 & \begin{tabular}{|l|}
0,87 \\
\end{tabular} & 0,30 & $\begin{array}{l}0,45 \\
\end{array}$ & 0,54 & 91,7 & 22,3 & 0,88 & 0,40 & $\begin{array}{ll}0,23 \\
\end{array}$ & 0,24 & 0,20 & 263,0 & 260,8 & \begin{tabular}{|l|}
259,3 \\
\end{tabular} & 257,4 & 254,7 & 252,3 & 251,2 & \begin{tabular}{|l|}
262,8 \\
\end{tabular} & 266,1 & 259,5 & 257,5 & 254,5 & 252,2 & 251,2 \\
\hline 年 & \begin{tabular}{|l}
65,12 \\
\end{tabular} & & & & \begin{tabular}{|l|l|}
24,5 \\
\end{tabular} & 155 & 113 & \begin{tabular}{|l|}
26,5 \\
\end{tabular} & 0,27 & 0,22 & 0,068 & 140 & 106 & 24,8 & 0,23 & \begin{tabular}{|l|}
0,23 \\
\end{tabular} & 0,21 & 0,22 & 261,7 & 257,8 & \begin{tabular}{|l|l|}
254,6 \\
\end{tabular} & 251,6 & \begin{tabular}{|l|}
248,7 \\
\end{tabular} & \begin{tabular}{|l|l}
246,3 \\
\end{tabular} & 245,2 & \begin{tabular}{|l|}
261,8 \\
\end{tabular} & 258,0 & 255,2 & 251,9 & 248,4 & 246,2 & 24, \\
\hline
\end{tabular}


Tabela C9.2 - Continuação

\begin{tabular}{|c|c|c|c|c|c|c|c|c|c|c|c|c|c|c|}
\hline \multirow{2}{*}{$\begin{array}{c}\text { Duração } \\
\text { (h) }\end{array}$} & \multicolumn{14}{|c|}{ FAAG -Perda de Carga Lida (cm) } \\
\hline & P1-1 & $\mathrm{P} 2-1$ & P3-1 & P4-1 & P5-1 & P6-1 & P7-1 & P1-2 & P2-2 & P3-2 & P4-2 & P5-2 & P6-2 & P7-2 \\
\hline 1,0 & 257,6 & 256,2 & 255,1 & 254,0 & 252,0 & 250,2 & 249,0 & 257,5 & 256,2 & 255,3 & 254,1 & 252,0 & 250,1 & 249,0 \\
\hline 3,0 & 259,5 & 257,0 & 255,2 & 254,0 & 252,0 & 250,2 & 249,0 & 259,2 & 257,0 & 255,4 & 254,2 & 252,0 & 250,1 & 249,0 \\
\hline 4,5 & 261,5 & 257,5 & 255,5 & 254,0 & 252,0 & 250,0 & 249,0 & 260,8 & 257,7 & 255,7 & 254,2 & 252,0 & 250,1 & 249,0 \\
\hline 5,0 & 257,0 & 256,0 & 255,1 & 254,0 & 252,0 & 250,1 & 249,0 & 256,8 & 256,0 & 255,2 & 254,0 & 252,0 & 250,0 & 249,0 \\
\hline 6,0 & 258,6 & 256,7 & 255,6 & 254,2 & 252,0 & 250,4 & 249,0 & 258,5 & 256,8 & 255,5 & 254,2 & 252,0 & 250,0 & 249,0 \\
\hline 9,0 & 262,2 & 258,8 & 256,1 & 254,2 & 252,5 & 250,0 & 249,0 & 262,5 & 258,0 & 256,5 & 254,3 & 252,4 & 250,0 & 249,0 \\
\hline 9,5 & 257,5 & 256,5 & 255,5 & 254,1 & 252,0 & 250,0 & 249,0 & 257,5 & 256,5 & 255,0 & 254,3 & 252,1 & 250,0 & 249,0 \\
\hline 12,0 & 260,8 & 258,0 & 256,0 & 254,5 & 252,0 & 250,0 & 249,0 & 260,4 & 258,0 & 256,2 & 254,5 & 252,2 & 250,0 & 249,0 \\
\hline 13,5 & 262,4 & 259,0 & 256,5 & 254,5 & 252,0 & 250,0 & 249,0 & 262,5 & 259,5 & 257,0 & 254,8 & 252,5 & 250,0 & 249,0 \\
\hline 14,0 & 258,0 & 257,0 & 256,0 & 254,5 & 252,0 & 250,0 & 249,0 & 258,0 & 257,0 & 256,5 & 254,5 & 252,5 & 250,0 & 249,0 \\
\hline 18,0 & 264,5 & 260,8 & 257,5 & 255,0 & 252,2 & 250,0 & 249,0 & 264,5 & 260,8 & 257,8 & 254,5 & 252,2 & 250,0 & 249,0 \\
\hline 18,5 & 258,0 & 257,2 & 256,3 & 254,8 & 252,2 & 250,0 & 249,0 & 258,1 & 257,2 & 256,3 & 254,9 & 252,2 & 250,0 & 249,0 \\
\hline 21,0 & 260,5 & 259,3 & 256,8 & 254,8 & 252,2 & 250,0 & 249,0 & 260,5 & 258,3 & 256,9 & 255,0 & 252,2 & 250,0 & 249,0 \\
\hline 22,5 & 263,8 & 260,0 & 257,0 & 254,8 & 252,2 & 250,0 & 249,0 & 263,5 & 260,2 & 257,5 & 255,0 & 252,2 & 250,0 & 249,0 \\
\hline 23,0 & 258,2 & 257,0 & 256,4 & 254,9 & 252,3 & 250,2 & 249,0 & 258,0 & 257,3 & 256,5 & 255,0 & 252,2 & 250,0 & 249,0 \\
\hline 24,0 & 260,1 & 258,0 & 256,5 & 255,0 & 252,3 & 250,2 & 249,0 & 260,1 & 258,8 & 256,6 & 255,0 & 252,2 & 250,0 & 249,0 \\
\hline 27,0 & 264,0 & 260,4 & 257,5 & 255,0 & 252,3 & 250,2 & 249,0 & 264,0 & 260,4 & 257,8 & 255,0 & 252,2 & 250,1 & 249,0 \\
\hline 27,5 & 258,5 & 257,0 & 256,5 & 254,8 & 252,5 & 250,2 & 249,0 & 258,0 & 257,0 & 256,5 & 255,0 & 252,2 & 250,1 & 249,0 \\
\hline 30,0 & 262,5 & 259,3 & 257,0 & 255,0 & 252,5 & 250,2 & 249,0 & 262,5 & 259,5 & 257,3 & 255,0 & 252,2 & 250,1 & 249,0 \\
\hline 31,5 & 265,0 & 261,1 & 258,0 & 255,0 & 252,5 & 250,1 & 249,0 & 265,0 & 261,2 & 258,3 & 255,2 & 252,2 & 250,1 & 249,0 \\
\hline 32,0 & 259,2 & 257,8 & 256,8 & 255,0 & 252,4 & 250,1 & 249,0 & 259,2 & 257,8 & 256,8 & 255,1 & 252,2 & 250,0 & 249,0 \\
\hline 33,0 & 260,7 & 258,5 & 257,0 & 255,1 & 252,4 & 250,1 & 249,0 & 260,5 & 258,8 & 257,2 & 255,2 & 252,2 & 250,0 & 249,0 \\
\hline 36,0 & 265,7 & 261,7 & 258,5 & 255,5 & 252,5 & 250,1 & 249,0 & 265,8 & 262,0 & 259,1 & 255,8 & 252,2 & 250,0 & 249,0 \\
\hline
\end{tabular}

QT: vazão total afluente ao Sistema de Dupla Filtração (medidor de vazão eletromagnético);

Turb. AE: turbidez da água de estudo (turbidímetro de bancada);

pH AE: pH da água de estudo;

pH Coag.: pH de coagulação;

Ci-1: amostra coletada no final da subcamada i do meio filtrante da câmara de filtração 1 do FAAG;

Ci-2: amostra coletada no final da subcamada i do meio filtrante da câmara de filtração 2 do FAAG;

C1+C2: amostra de água pré-filtrada global (efluentes das câmaras de filtração 1 e 2 da FAAG);

Pi-1: piezômetro i localizado na câmara de filtração 1 do FAAG;

Pi-2: piezômetro i localizado na câmara de filtração 2 do FAAG;

: execução de DFI nas duas câmaras do FAAG; 
Tabela C9.2 - Continuação

\begin{tabular}{|c|c|c|c|c|c|c|c|}
\hline \multirow{3}{*}{$\begin{array}{l}\text { Duração } \\
\text { (h) }\end{array}$} & \multirow{3}{*}{$\begin{array}{l}\text { Temp. } \\
\text { (oC) }\end{array}$} & \multicolumn{6}{|c|}{ Filtro Rápido Descendente - FRD } \\
\hline & & \multirow{2}{*}{$\begin{array}{l}\text { Qfd } \\
(\mathrm{L} / \mathrm{h})\end{array}$} & \multirow{2}{*}{$\begin{array}{c}\text { Turbidez - TB (uT) } \\
\text { AF }\end{array}$} & \multicolumn{2}{|c|}{ Perda de Carga Corrigida $25^{\circ} \mathrm{C}(\mathrm{cm})$} & \multicolumn{2}{|c|}{ Perda de Carga Lida (cm) } \\
\hline & & & & P1 & P2 & P1 & P2 \\
\hline 1,0 & 27,0 & 50,0 & 0,14 & 27,2 & 76,2 & 26,0 & 72,8 \\
\hline 3,0 & 28,0 & 50,0 & 0,2 & 27,9 & 78,8 & 26,0 & 73,5 \\
\hline 4,5 & 28,0 & 50,0 & & 27,9 & 78,2 & 26,0 & 73,0 \\
\hline 5,0 & 28,0 & 50,0 & & 27,9 & 76,1 & 26,0 & 71,0 \\
\hline 6,0 & 28,0 & 50,0 & 0,24 & 27,9 & 77,2 & 26,0 & 72,0 \\
\hline 9,0 & 25,0 & 49,0 & 0,16 & 25,9 & 73,7 & 26,0 & 73,9 \\
\hline 9,5 & 25,0 & 50,0 & & 25,9 & 75,8 & 26,0 & 76,0 \\
\hline 12,0 & 24,0 & 49,0 & 0,13 & 25,3 & 74,9 & 26,0 & 77,0 \\
\hline 13,5 & 24,0 & 49,0 & & 25,3 & 75,9 & 26,0 & 78,0 \\
\hline 14,0 & 24,0 & 49,0 & & 25,3 & 76,1 & 26,0 & 78,2 \\
\hline 18,0 & 24,0 & 49,0 & 0,2 & 25,3 & 76,1 & 26,0 & 78,2 \\
\hline 18,5 & 24,0 & 49,0 & & 25,3 & 77,8 & 26,0 & 80,0 \\
\hline 21,0 & 25,0 & 49,0 & 0,15 & 25,9 & 80,0 & 26,0 & 80,2 \\
\hline 22,5 & 26,0 & 49,0 & & 26,6 & 82,7 & 26,0 & 81,0 \\
\hline 23,0 & 26,0 & 49,0 & & 26,6 & 83,5 & 26,0 & 81,8 \\
\hline 24,0 & 27,5 & 49,0 & & 27,5 & 88,6 & 26,0 & 83,7 \\
\hline 27,0 & 28,0 & 49,0 & 0,29 & 27,9 & 90,6 & 26,0 & 84,5 \\
\hline 27,5 & 28,0 & 49,0 & & 27,9 & 91,7 & 26,0 & 85,6 \\
\hline 30,0 & 28,0 & 49,0 & 0,17 & 27,9 & 94,3 & 26,0 & 88,0 \\
\hline 31,5 & 26,5 & 49,0 & & 26,9 & 92,0 & 26,0 & 89,0 \\
\hline 32,0 & 25,5 & 49,0 & & 26,2 & 92,0 & 26,0 & 91,2 \\
\hline 33,0 & 25,5 & 49,0 & 0,18 & 26,2 & 93,1 & 26,0 & 92,3 \\
\hline 36,0 & 24,5 & 49,0 & 0,21 & 25,6 & 92,6 & 26,0 & 94,0 \\
\hline
\end{tabular}

$\mathrm{Q}_{\mathrm{fd}}$ : vazão afluente ao FRD (rotâmetro);

Turb. AF: turbidez da água filtrada (turbidímetro de bancada);

P1 e P2: piezômetros localizados no início e no final do FRD, respectivamente.

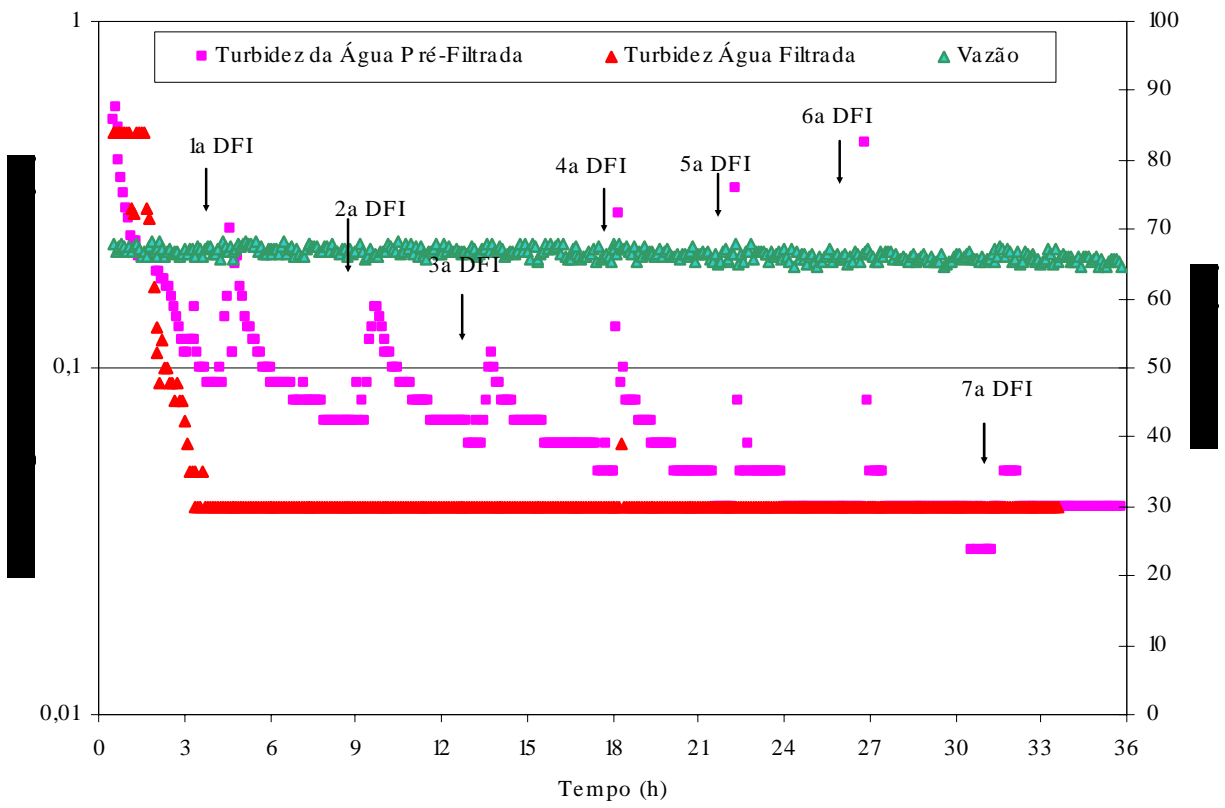

Figura C9.1 - Variações da vazão total afluente ao sistema de dupla filtração e da turbidez das águas pré-filtrada e filtrada no ensaio 9 - Turbidímetros de Escoamento Contínuo 


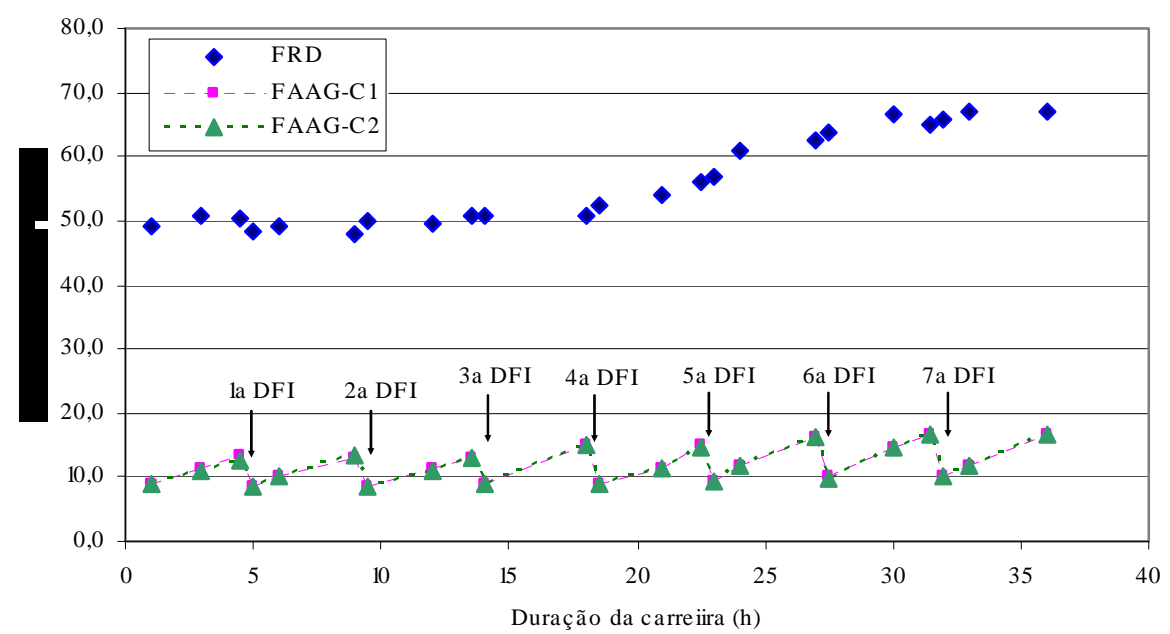

Figura C9.2 - Perda de carga nos filtros ascendente de areia grossa (duas câmaras de filtração) e descendente durante o ensaio 9 de dupla filtração

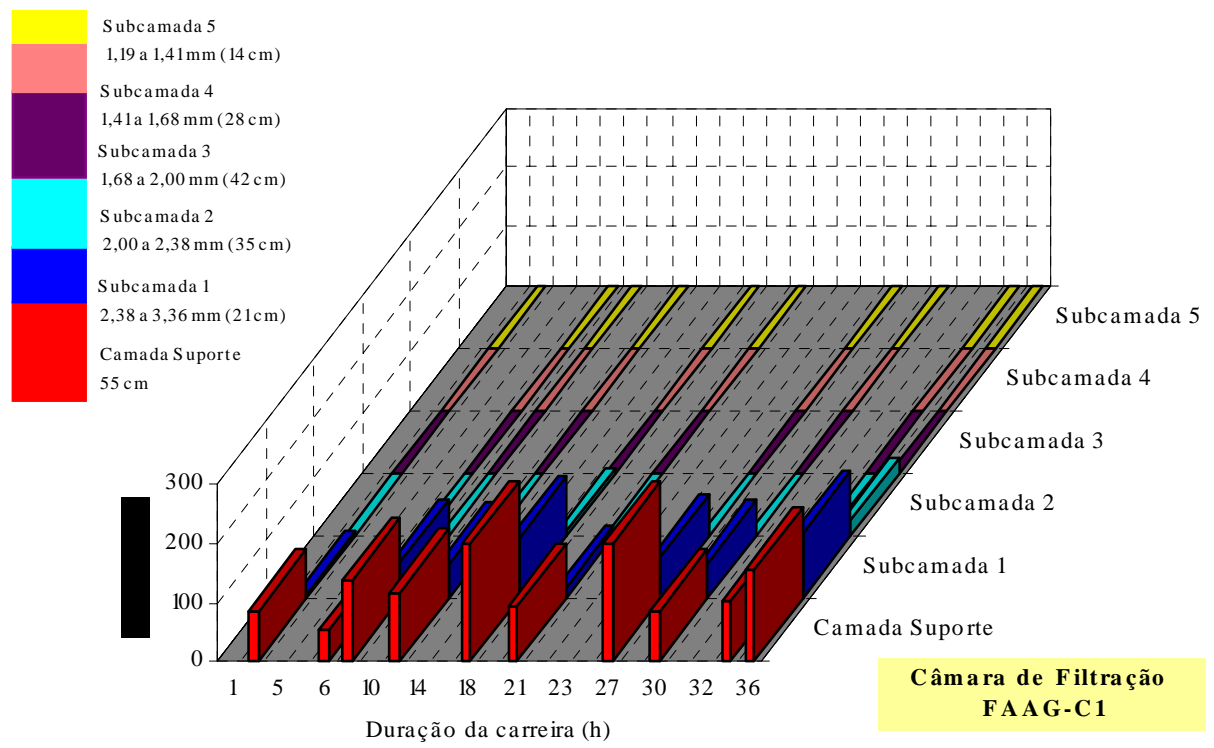

Figura C9.3 - Turbidez ao longo do meio filtrante da câmara de filtração 1 do FAAG durante o ensaio 9 de dupla filtração 


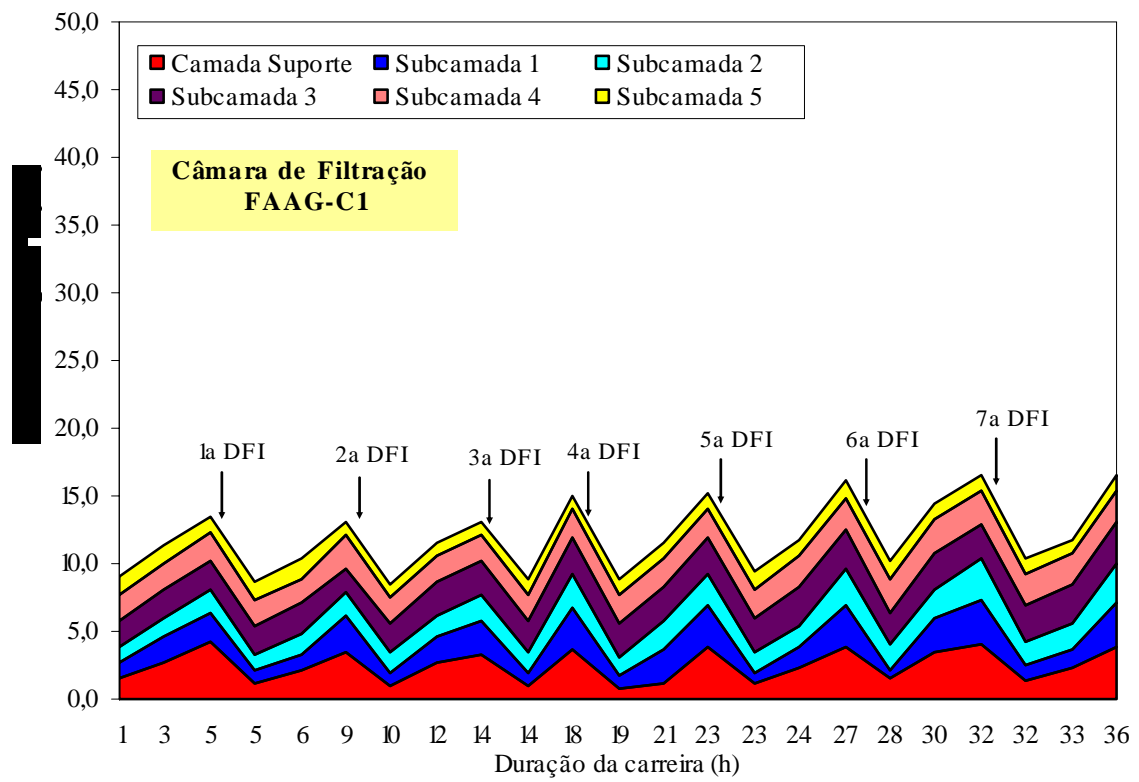

Figura C9.4 - Perda de carga ao longo do meio filtrante da câmara de filtração 1 do FAAG durante o ensaio 9 de dupla filtração

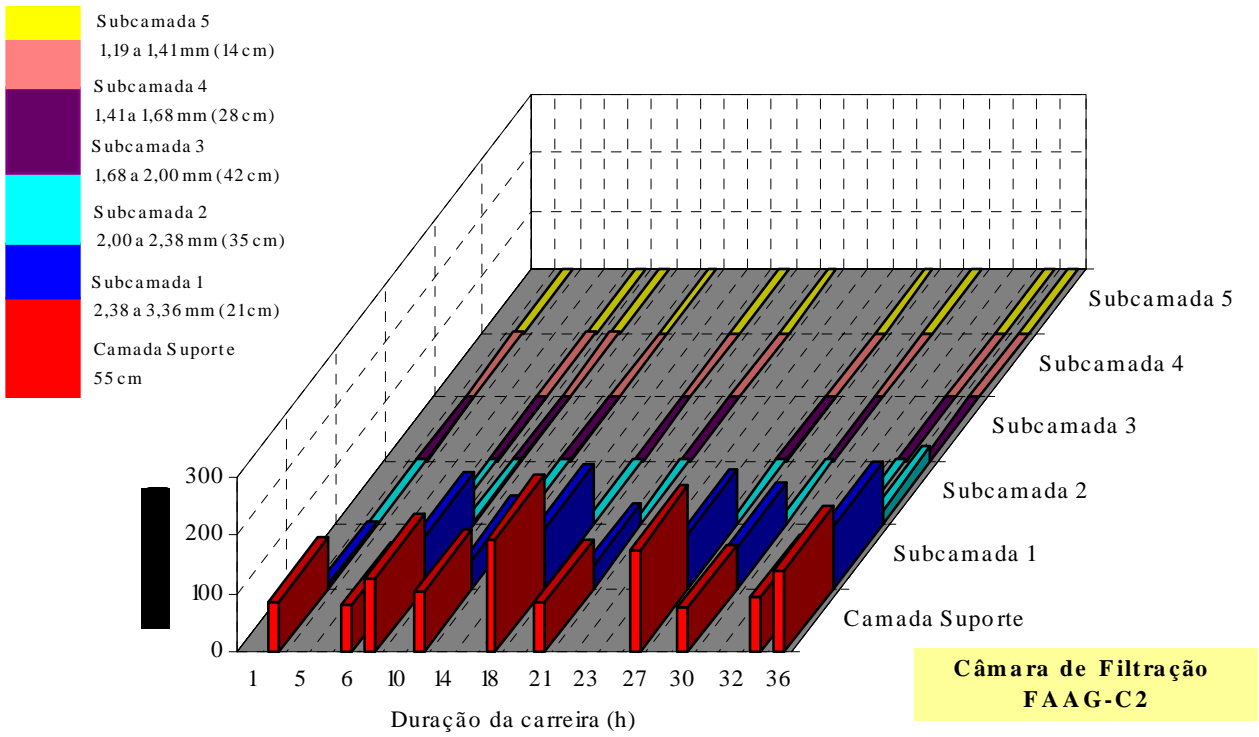

Figura C9.5 - Turbidez ao longo do meio filtrante da câmara de filtração 2 do FAAG durante o ensaio 9 de dupla filtração 


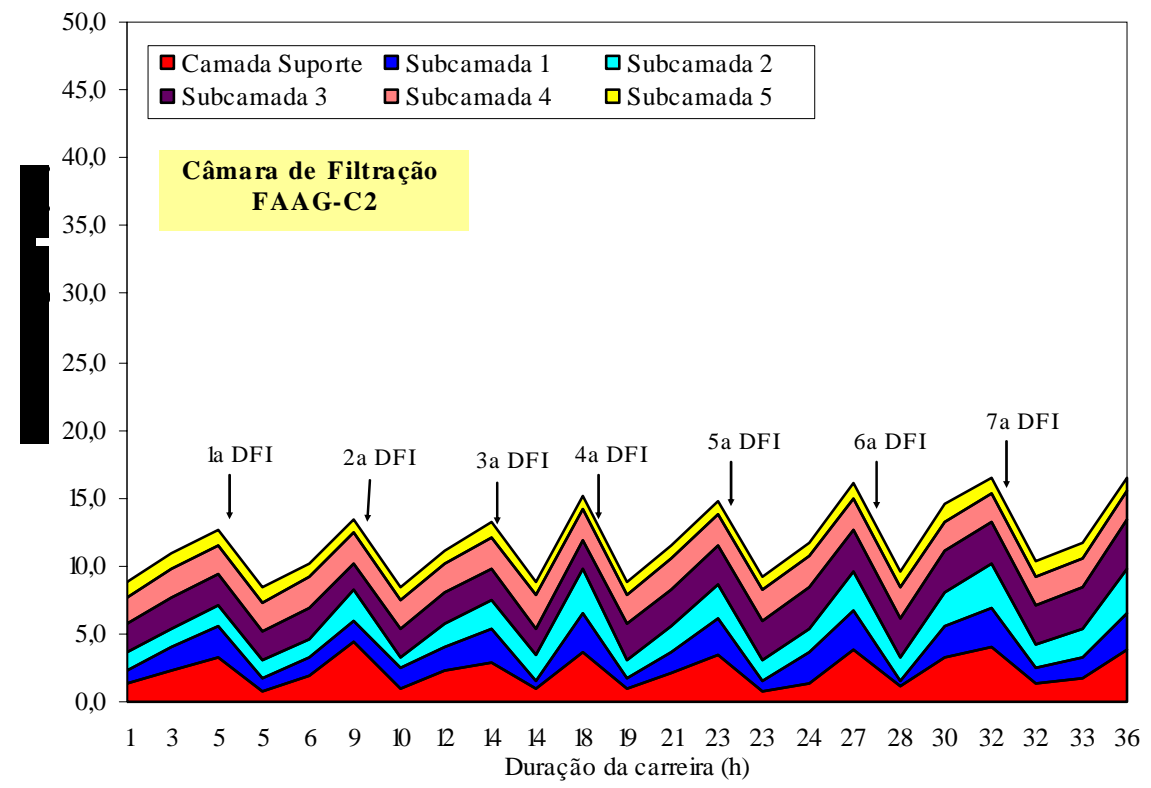

Figura C9.6 - Perda de carga ao longo do meio filtrante da câmara de filtração 2 do FAAG durante o ensaio 9 de dupla filtração 


\section{ENSAIO 10 DE DUPLA FILTRAÇÃO}

Tabela C10.1 - Condições do ensaio 10 de dupla filtração - Sistema 2 e Água de estudo Tipo I

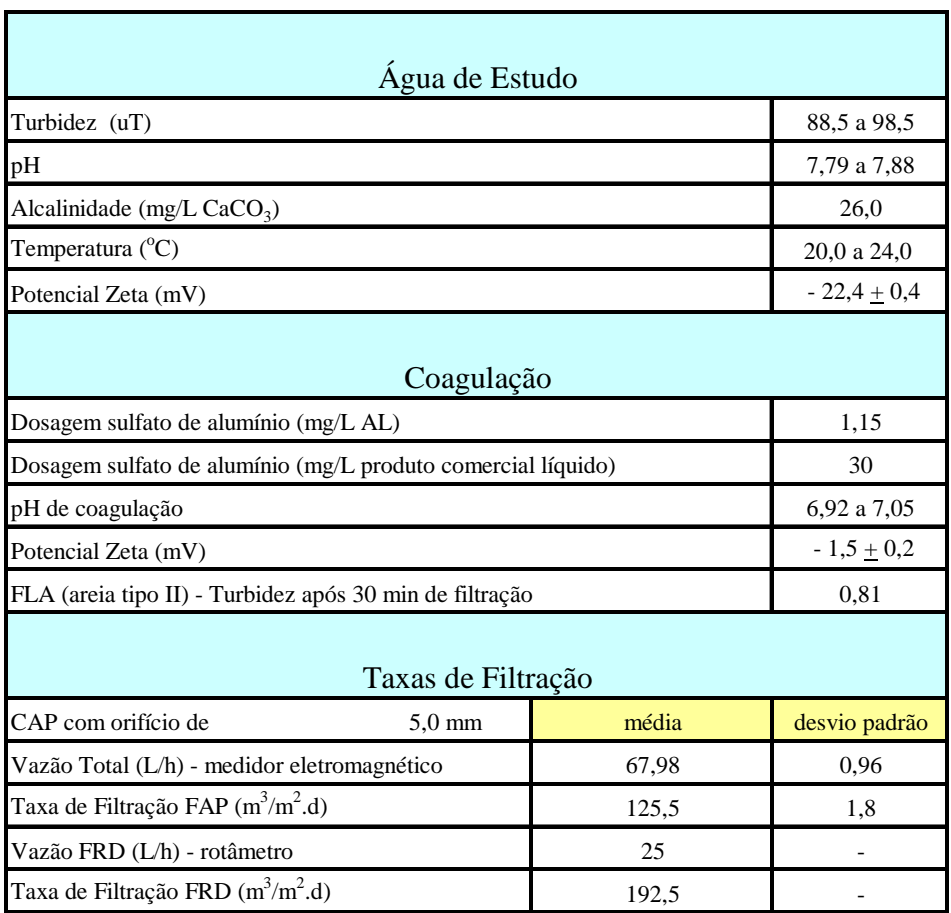


Tabela C10.2 - Resultados do ensaio 10 de dupla filtração - Sistema 2 e Água de estudo Tipo I

\begin{tabular}{|c|c|c|c|c|c|c|c|c|c|c|c|c|c|c|c|c|c|c|c|c|c|c|c|c|}
\hline \multirow{3}{*}{$\begin{array}{l}\text { Duração } \\
\text { (h) }\end{array}$} & \multirow{3}{*}{$\begin{array}{c}\mathrm{Q}_{\mathrm{T}} \\
(\mathrm{L} / \mathrm{h}) \\
\end{array}$} & \multirow{3}{*}{$\begin{array}{l}\text { Turb. } \\
\mathrm{AE}(\mathrm{uT})\end{array}$} & \multirow{3}{*}{$\begin{array}{l}\mathrm{pH} \\
\mathrm{AE}\end{array}$} & \multirow{3}{*}{$\begin{array}{c}\mathrm{pH} \\
\text { Coag. }\end{array}$} & \multirow{3}{*}{$\begin{array}{l}\text { Temp. } \\
\text { (oC) }\end{array}$} & \multicolumn{19}{|c|}{ Filtro Ascendente de Pedregulho - FAP } \\
\hline & & & & & & \multicolumn{9}{|c|}{ Turbidez - Turbidímetro de Bancada (TB) (uT) } & \multicolumn{10}{|c|}{ Perda de Carga Corrigida $25^{\circ} \mathrm{C}(\mathrm{cm})$} \\
\hline & & & & & & $\mathrm{Cl}-1$ & C2-1 & C3-1 & $\mathrm{C} 4-1$ & $\mathrm{Cl}-2$ & C2-2 & $\mathrm{C} 3-2$ & $\mathrm{C4-2}$ & $\mathrm{C} 1+\mathrm{C} 2$ & P1-1 & P2-1 & P3-1 & $\mathrm{P} 41$ & P5-1 & $\mathrm{P} 1-2$ & P2-2 & P3-2 & $\mathrm{P} 42$ & P5-2 \\
\hline 0,5 & 69,02 & 91,8 & 7,79 & 7,05 & 23,0 & 65,1 & 35,8 & 9,84 & 1,15 & 60,2 & 40,2 & 10,2 & 1,18 & 0,78 & 233,4 & 233,3 & 233,2 & 232,7 & 230,8 & 233,4 & 233,2 & 233,1 & 232,7 & 230,9 \\
\hline 3,0 & 68,38 & 90,5 & 7,84 & 6,92 & 24,0 & 68,9 & 49,6 & 12,60 & 1,14 & 68,0 & 47,30 & 13,2 & 1,50 & 1,03 & 240,5 & 240,4 & 240,3 & 239,4 & 236,5 & 240,5 & 240,4 & 240,2 & 239,5 & 236,6 \\
\hline 6,0 & 67,10 & 88,5 & & & 24,0 & 67,8 & 70,4 & 16,50 & 2,62 & 69,2 & 42,5 & 15,7 & 1,78 & 0,91 & 241,7 & 241,5 & 241,1 & 240,1 & 236,5 & 241,5 & 241,3 & 241,1 & 240,2 & 236,6 \\
\hline 9,0 & 69,12 & 89,0 & & & 23,0 & 70,8 & 48,2 & 26,4 & 1,35 & 66,7 & 47,6 & 21,0 & 1,08 & 1,12 & 236,3 & 236,2 & 235,8 & 235,1 & 230,8 & 236,1 & 236,0 & 235,6 & 235,1 & 230,9 \\
\hline 12,0 & 67,48 & 98,5 & & & 22,0 & 69,4 & 40,9 & 79,8 & 2,60 & 62,5 & 40,6 & 19,5 & 1,72 & $\begin{array}{l}1,29 \\
\end{array}$ & 233,2 & 233,1 & 232,7 & 230,9 & 225,3 & 233,1 & 233,0 & 232,5 & 230,9 & 225,4 \\
\hline 15,0 & 68,06 & 96,3 & 7,85 & 7,01 & 21,0 & 65,8 & 39,2 & 39,5 & 6,48 & 70,3 & 6990 & 23,2 & 6,33 & 6,92 & 229,0 & 228,8 & 228,5 & 226,5 & 219,9 & 229,0 & 228,8 & 228,5 & 226,5 & 222,0 \\
\hline 18,0 & 67,74 & 94,1 & & & 20,0 & 68,7 & 46,4 & 24,9 & 14,8 & 82,3 & 50,1 & 33,0 & 14,6 & 10,90 & 225,5 & 225,3 & 224,8 & 222,4 & 214,7 & 225,3 & 225,0 & 224,6 & 222,4 & 214,8 \\
\hline 21,0 & 68,10 & 91,5 & & & 21,0 & 74,4 & 49,7 & 21,8 & 30,2 & 65,7 & 66,2 & 26,0 & 23,1 & 7,24 & 232,4 & 232,1 & 231,7 & 229,0 & 219,9 & 232,1 & 232,0 & 231,3 & 228,9 & 220,0 \\
\hline 24,0 & 67,74 & 97,5 & & & 23,0 & 64,8 & 61,3 & 58,3 & $\begin{array}{r}15,9 \\
\end{array}$ & 78,9 & 69,8 & 37,5 & 12,8 & $\begin{array}{r}15,70 \\
\end{array}$ & 245,5 & 245,1 & 244,5 & 241,7 & 230,8 & 245,2 & 245,1 & 244,6 & 244,3 & 230,9 \\
\hline 27,0 & 67,74 & 97,5 & $\begin{array}{r}7,88 \\
\end{array}$ & 7,02 & 24,0 & 66,3 & 71,6 & 44,5 & 15,3 & 73,4 & 68,2 & 54,7 & 15,3 & 16,3 & $\begin{array}{r}252,8 \\
\end{array}$ & 252,5 & 251,4 & 248,1 & 236,5 & 252,7 & 252,3 & 251,4 & 248,1 & 236,6 \\
\hline 30,0 & 66,52 & 98,5 & & & 23,0 & 71,5 & 70,6 & 39,6 & 27,8 & 80,1 & 71,3 & 62,8 & 21,6 & 18,5 & 248,1 & 247,2 & 244,1 & 243,2 & 230,8 & 247,9 & 247,0 & 246,0 & 243,3 & 230,9 \\
\hline \multirow[t]{15}{*}{34,5} & 66,46 & 99,0 & & & 24,0 & & & & & & & & & & 255,9 & 255,4 & 254,8 & 250,3 & 236,5 & 256,0 & 255,0 & 253,5 & 250,6 & 236,6 \\
\hline & & & & & & & & & & & & & & & \multicolumn{10}{|c|}{ Perda de Carga Lida (cm) } \\
\hline & & & & & & & & & & & & & & & P1-1 & P2-1 & P3-1 & P4-1 & P5-1 & P1-2 & P2-2 & P3-2 & $\mathrm{P} 4-2$ & P5-2 \\
\hline & & & & & & & & & & & & & & & 245,7 & 245,6 & 245,5 & 245,0 & 243,0 & 245,7 & 245,5 & 245,4 & 245,0 & 243,1 \\
\hline & & & & & & & & & & & & & & & 247,2 & 247,0 & 24,9 & 246,0 & 243,0 & 247,1 & 247,0 & 246,8 & 246,1 & 243,1 \\
\hline & & & & & & & & & & & & & & & 248,4 & 248,2 & 247,8 & 246,7 & 243,0 & 248,2 & 248,0 & 247,8 & 246,8 & 243,1 \\
\hline & & & & & & & & & & & & & & & 248,8 & 248,7 & 248,2 & 247,5 & 243,0 & 248,6 & 248,5 & 248,0 & 247,5 & 243,1 \\
\hline & & & & & & & & & & & & & & & 251,5 & 251,4 & 251,0 & 249,0 & 243,0 & 251,4 & 251,3 & 250,8 & 249,0 & 243,1 \\
\hline & & & & & & & & & & & & & & & 253,0 & 252,8 & 252,5 & 250,3 & 243,0 & 253,0 & 252,8 & 252,5 & 250,3 & 243,1 \\
\hline & & & & & & & & & & & & & & & 255,3 & 255,0 & 254,5 & 251,8 & 243,0 & 255,0 & 254,7 & 254,2 & 251,7 & 243,1 \\
\hline & & & & & & & & & & & & & & & 256,8 & 256,5 & 256 & 253 & 243,0 & 256,5 & 256,3 & 255,6 & 252,9 & 243,1 \\
\hline & & & & & & & & & & & & & & & 258,5 & 258,0 & 257,4 & 254,5 & 243,0 & 258,1 & 258,0 & 257,5 & 254,0 & 243,1 \\
\hline & & & & & & & & & & & & & & & 259,8 & 259,5 & 258,4 & 255 & 243,0 & 259,7 & 259,3 & 258,4 & 255,0 & 243,1 \\
\hline & & & & & & & & & & & & & & & 261,2 & 260,3 & 259,1 & 256 & 243,0 & 261,0 & 260,0 & 259,0 & 256,1 & 243,1 \\
\hline & & & & & & & & & & & & & & & 263,0 & 262,5 & 261,8 & 257,2 & 243,0 & 263,1 & 262,1 & 260,5 & 257,5 & 243,1 \\
\hline
\end{tabular}


Tabela C10.2 - Continuação

\begin{tabular}{|c|c|c|c|c|c|}
\hline \multirow{3}{*}{$\begin{array}{c}\text { Duração } \\
\text { (h) }\end{array}$} & \multirow{3}{*}{$\begin{array}{l}\text { Temp. } \\
\text { (oC) } \\
\end{array}$} & \multicolumn{4}{|c|}{ Filtro Rápido Descendente - FRD } \\
\hline & & \multirow{2}{*}{$\begin{array}{l}\text { Qfd } \\
(\mathrm{L} / \mathrm{h}) \\
\end{array}$} & \multirow{2}{*}{$\begin{array}{c}\text { Turbidez - TB (uT) } \\
\text { AF } \\
\end{array}$} & \multicolumn{2}{|c|}{ Perda de Carga Corrigida $25^{\circ} \mathrm{C}(\mathrm{cm}$} \\
\hline & & & & P1 & $\mathrm{P} 2$ \\
\hline 0,5 & 23,0 & 25,0 & 0,32 & 34,0 & 87,3 \\
\hline 3,0 & 24,0 & 25,0 & 0,25 & 34,8 & 98,5 \\
\hline 6,0 & 24,0 & 25,0 & 0,32 & 34,8 & 102,7 \\
\hline 9,0 & 23,0 & 25,0 & 0,18 & 34,0 & 104,7 \\
\hline 12,0 & 22,0 & 25,0 & 0,46 & 33,2 & 109,4 \\
\hline 15,0 & 21,0 & 25,0 & 0,37 & 32,4 & 118,7 \\
\hline 18,0 & 20,0 & 25,0 & 0,34 & 31,6 & 123,9 \\
\hline 21,0 & 21,0 & 25,0 & 0,40 & 32,4 & 128,8 \\
\hline 24,0 & 23,0 & 25,0 & 0,27 & 34,0 & 141,7 \\
\hline 27,0 & 24,0 & 25,0 & 0,28 & 34,8 & 154,7 \\
\hline 30,0 & 23,0 & 25,0 & 0,38 & 34,0 & 162,9 \\
\hline \multirow[t]{15}{*}{34,5} & 24,0 & 25,0 & 0,21 & 34,8 & 207,7 \\
\hline & & & & \multicolumn{2}{|c|}{ Perda de Carga Lida $(\mathrm{cm})$} \\
\hline & & & & P1 & $\mathrm{P} 2$ \\
\hline & & & & 35,8 & 91,9 \\
\hline & & & & 35,8 & 101,2 \\
\hline & & & & 35,8 & 105,6 \\
\hline & & & & 35,8 & 110,2 \\
\hline & & & & 35,8 & 118,0 \\
\hline & & & & 35,8 & 131,2 \\
\hline & & & & 35,8 & 140,2 \\
\hline & & & & 35,8 & 142,3 \\
\hline & & & & 35,8 & 149,2 \\
\hline & & & & 35,8 & 159,0 \\
\hline & & & & 35,8 & 171,5 \\
\hline & & & & 35,8 & 213,4 \\
\hline
\end{tabular}

$\mathrm{Q}_{\mathrm{T}}$ : vazão total afluente ao Sistema de Dupla Filtração (medidor de vazão eletromagnético);

Turb. AE: turbidez da água de estudo (turbidímetro de bancada);

pH AE: pH da água de estudo;

pH Coag.: pH de coagulação;

Ci-1: amostra coletada no final da subcamada i do meio filtrante da câmara de filtração 1 do FAP;

Ci-2: amostra coletada no final da subcamada i do meio filtrante da câmara de filtração 2 do FAP;

C1+C2: amostra de água pré-filtrada global (efluentes das câmaras de filtração 1 e 2 da FAP);

Pi-1: piezômetro i localizado na câmara de filtração 1 do FAP;

Pi-2: piezômetro i localizado na câmara de filtração 2 do FAP;

$\mathrm{Q}_{\mathrm{fd}}$ : vazão afluente ao FRD (rotâmetro);

Turb. AF: turbidez da água filtrada (turbidímetro de bancada);

P1 e P2: piezômetros localizados no início e no final do FRD, respectivamente. 


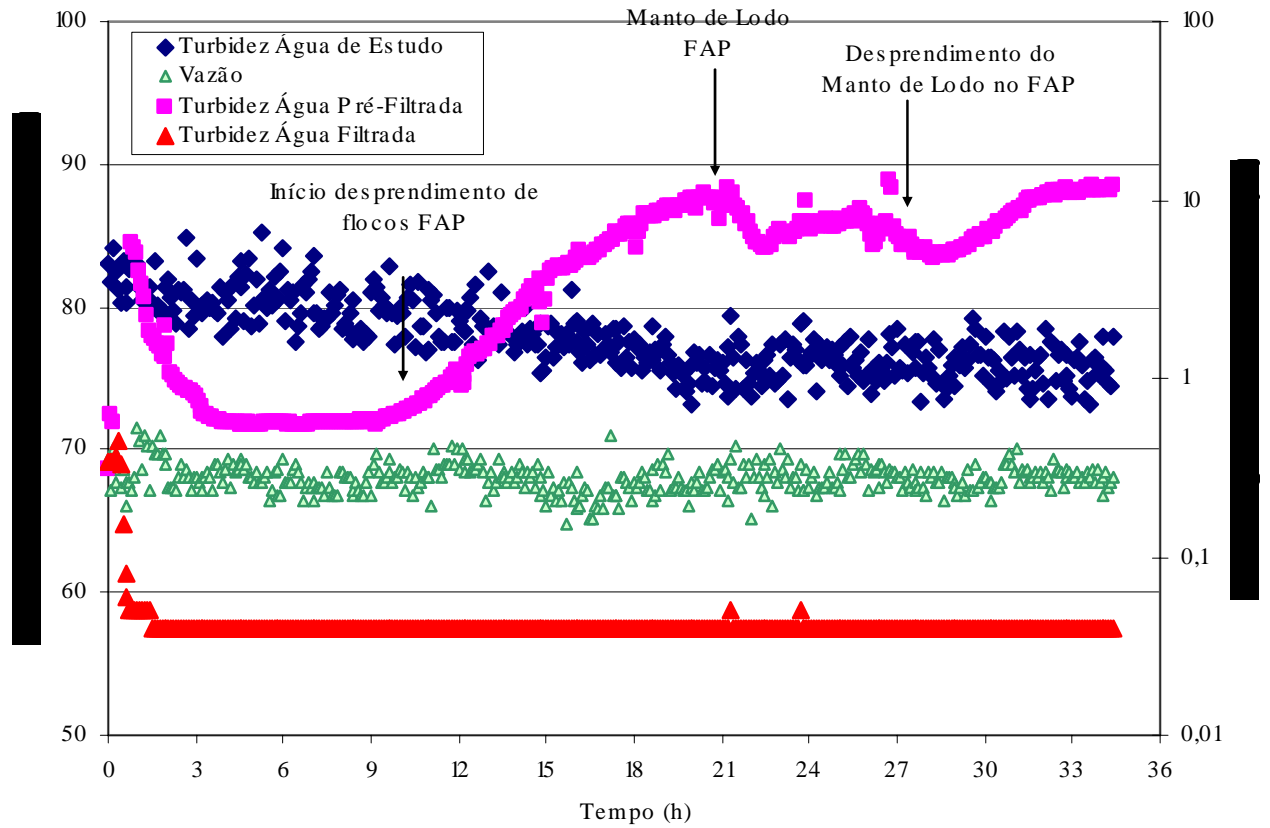

Figura C10.1 - Variações da vazão total afluente ao sistema de dupla filtração e da turbidez das águas de estudo, pré-filtrada e filtrada no ensaio 10 - Turbidímetros de Escoamento Contínuo

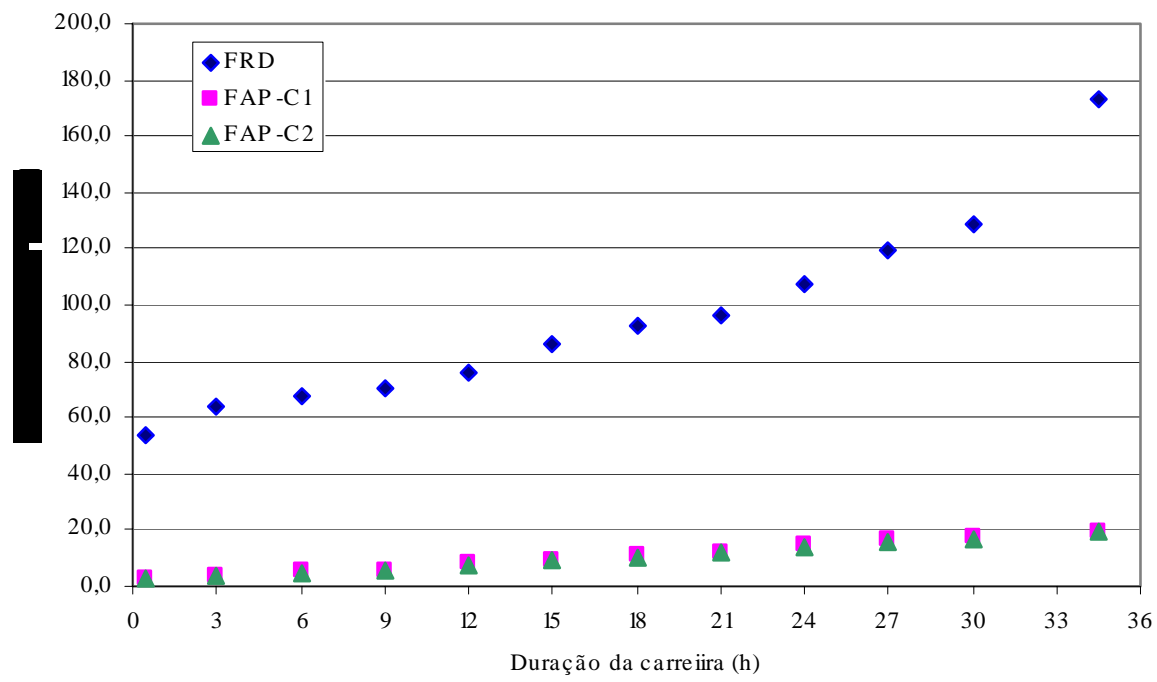

Figura C10.2 - Perda de carga nos filtros ascendente de pedregulho (duas câmaras de filtração) e descendente durante o ensaio 10 de dupla filtração 


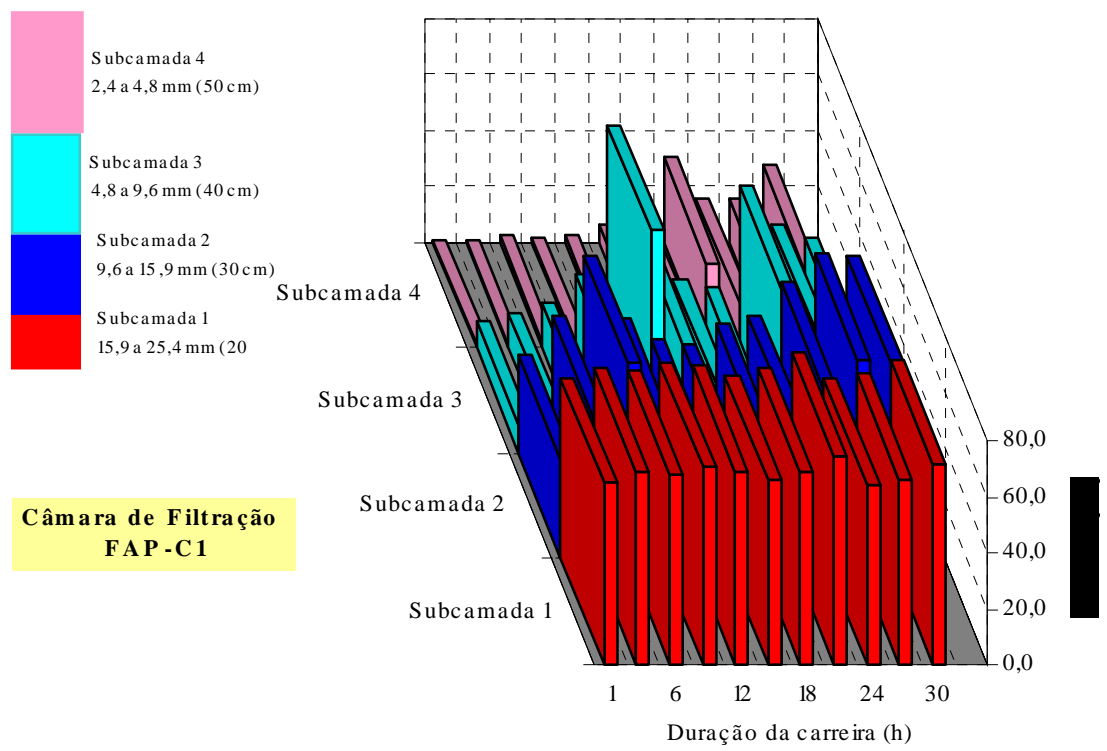

Figura C10.3 - Turbidez ao longo do meio filtrante da câmara de filtração 1 do FAP durante o ensaio 10 de dupla filtração

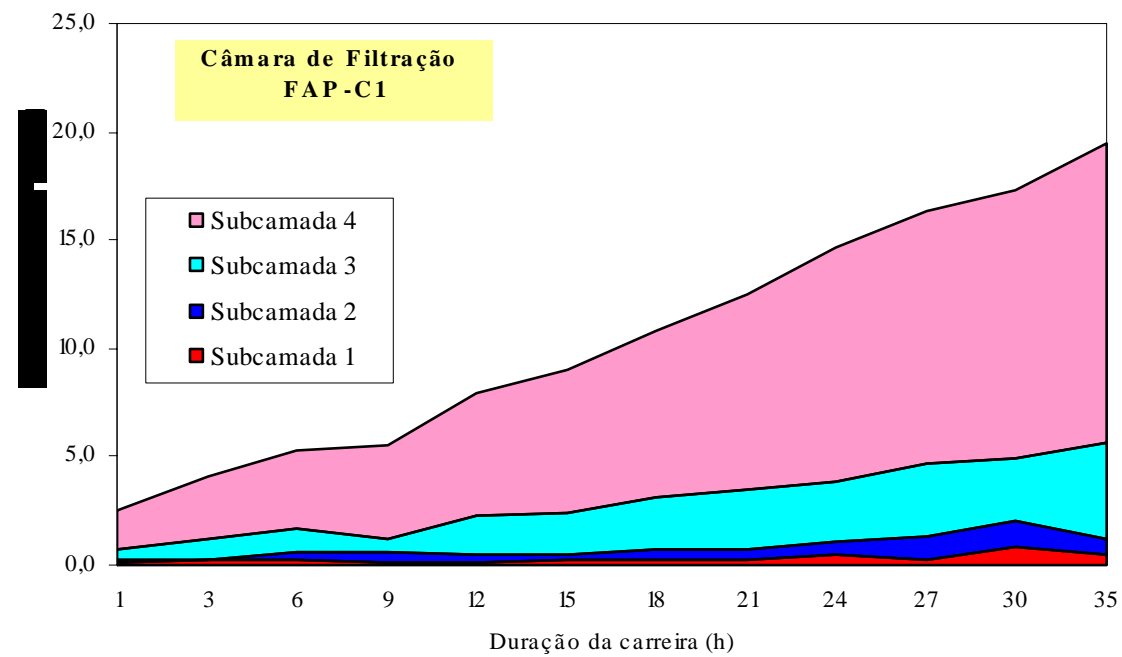

Figura C10.4 - Perda de carga ao longo do meio filtrante da câmara de filtração 1 do FAP durante o ensaio 10 de dupla filtração 


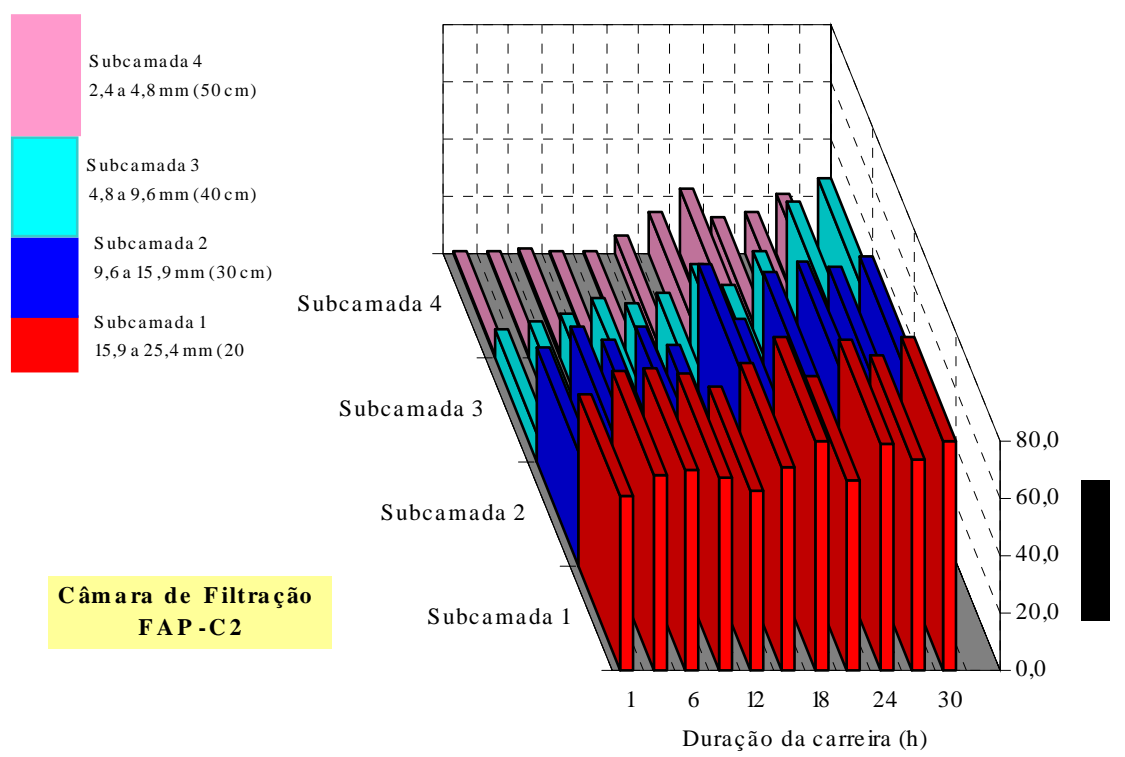

Figura C10.5 - Turbidez ao longo do meio filtrante da câmara de filtração 2 do FAP durante o ensaio 10 de dupla filtração

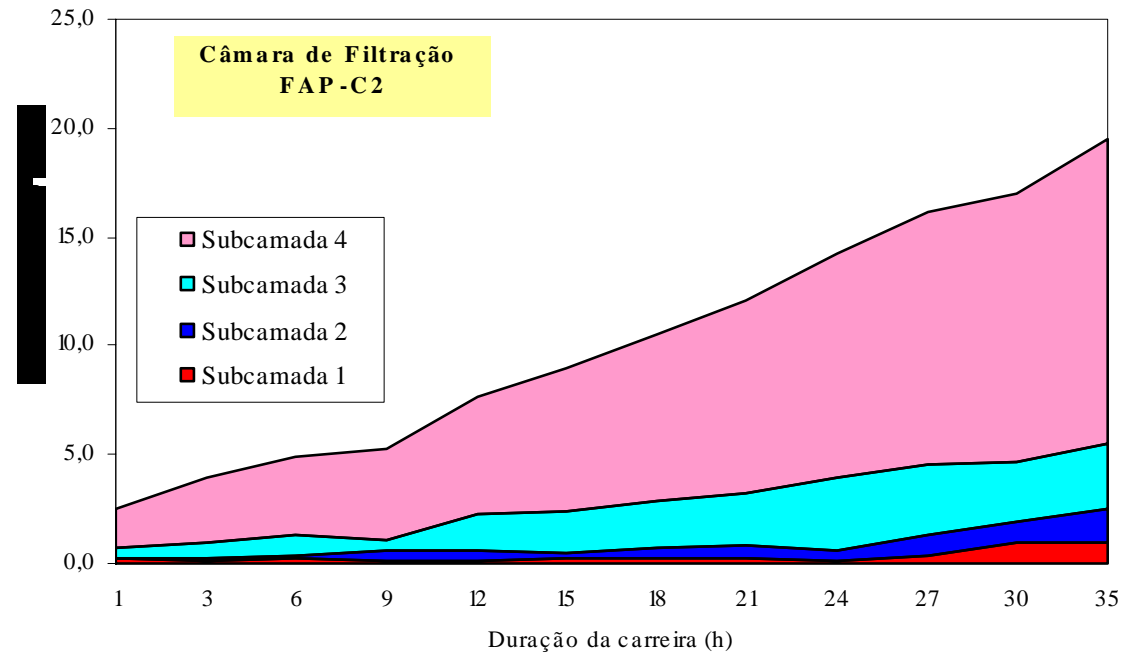

Figura C10.6 - Perda de carga ao longo do meio filtrante da câmara de filtração 2 do FAP durante o ensaio 10 de dupla filtração 


\section{ENSAIO 11 DE DUPLA FILTRAÇÃO}

Tabela C11.1 - Condições do ensaio 11 de dupla filtração - Sistema 2 e Água de estudo Tipo I

\begin{tabular}{|c|c|c|}
\hline \multicolumn{3}{|c|}{ Água de Estudo } \\
\hline \multicolumn{2}{|l|}{ Turbidez (uT) } & 90,4 a 101 \\
\hline \multicolumn{2}{|l|}{$\mathrm{pH}$} & 7,85 a 7,94 \\
\hline \multicolumn{2}{|l|}{ Alcalinidade $(\mathrm{mg} / \mathrm{L} \mathrm{CaCO})_{3}$} & 26,0 \\
\hline \multicolumn{2}{|l|}{ Temperatura $\left({ }^{\circ} \mathrm{C}\right)$} & 19,5 a 25,0 \\
\hline \multicolumn{2}{|l|}{ Potencial Zeta (mV) } & - \\
\hline \multicolumn{3}{|c|}{ Coagulação } \\
\hline \multicolumn{2}{|l|}{ Dosagem sulfato de alumínio (mg/L AL) } & 1,15 \\
\hline \multicolumn{2}{|c|}{ Dosagem sulfato de alumínio (mg/L produto comercial líquido) } & 30 \\
\hline \multicolumn{2}{|l|}{ pH de coagulação } & 7,06 a 7,15 \\
\hline \multicolumn{2}{|l|}{ Potencial Zeta (mV) } & $+1,3 \pm 0,4$ \\
\hline \multicolumn{2}{|l|}{ FLA (areia tipo II) - Turbidez após 30 min de filtração } & 0,64 \\
\hline \multicolumn{3}{|c|}{ Taxas de Filtração } \\
\hline CAP com orifício de & média & desvio padrão \\
\hline Vazão Total (L/h) - medidor eletromagnético & 68,04 & 1,10 \\
\hline Taxa de Filtração FAP $\left(\mathrm{m}^{3} / \mathrm{m}^{2} . \mathrm{d}\right)$ & 125,6 & 2,0 \\
\hline Vazão FRD (L/h) - rotâmetro & 25 & - \\
\hline Taxa de Filtração FRD $\left(\mathrm{m}^{3} / \mathrm{m}^{2}\right.$. d) & 192,5 & - \\
\hline
\end{tabular}


Tabela C11.2 - Resultados do ensaio 11 de dupla filtração - Sistema 2 e Água de estudo Tipo I

\begin{tabular}{|c|c|c|c|c|c|c|c|c|c|c|c|c|c|c|c|c|c|c|c|c|c|c|c|c|c|}
\hline \multirow{3}{*}{$\begin{array}{c}\text { Duração } \\
\text { (h) }\end{array}$} & \multirow{3}{*}{$\begin{array}{c}\mathrm{Q}_{\mathrm{T}} \\
(\mathrm{L} / \mathrm{h})\end{array}$} & \multirow{3}{*}{$\begin{array}{c}\text { Turb. } \\
\mathrm{AE}(\mathrm{uT})\end{array}$} & \multirow{3}{*}{$\begin{array}{l}\mathrm{pH} \\
\mathrm{AE} \\
\end{array}$} & \multirow{3}{*}{$\begin{array}{c}\mathrm{pH}^{\mathrm{pH}} \\
\text { Coag. }\end{array}$} & \multirow{3}{*}{$\begin{array}{l}\text { Temp. } \\
\text { (oC) }\end{array}$} & \multicolumn{20}{|c|}{ Filtro Ascendente de Pedregulho - FAP } \\
\hline & & & & & & \multicolumn{10}{|c|}{ Turbidez - Turbidímetro de Bancada (TB) (uT) } & \multicolumn{10}{|c|}{ Perda de Carga Corrigida $25^{\circ} \mathrm{C}(\mathrm{cm})$} \\
\hline & & & & & & C1-1 & C2-1 & C3-1 & C4-1 & $\mathrm{C1}-2$ & 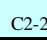 & $\mathrm{C} 3$ & & & $\mathrm{C} 1+\mathrm{C} 2$ & P1-1 & P2-1 & Р3-1 & P4-1 & P5-1 & $\mathrm{P} 1-2$ & P2-2 & P3-2 & $\mathrm{P} 4-2$ & P5-2 \\
\hline 0,5 & 68,98 & 95,4 & 7,90 & 7,12 & 25,0 & 68,6 & 21,2 & 6,89 & 1,15 & 60,2 & 25,2 & 10, & & & 1,02 & 244,7 & 244,5 & 244,4 & 244,0 & 242,2 & 244,5 & 244,4 & 244,3 & 244,0 & 242,3 \\
\hline 3,0 & 67,14 & 90,4 & 7,91 & 7,15 & 25,0 & 65,4 & 38,7 & 13,2 & 1,84 & 62,8 & 40,5 & 10 & & & 2,05 & 246,2 & 246,0 & 245,8 & 244,9 & 242,2 & 246,1 & 246,0 & 245,7 & 244,9 & 242,3 \\
\hline 6,0 & 68,98 & 98,2 & 7,88 & 7,10 & 24,0 & 79,3 & 47,8 & 17,6 & 2,25 & 67,9 & 46,3 & 14 & & & 5,76 & 241,5 & 241,2 & 241,0 & 239,8 & 236,5 & 241,3 & 241,1 & 240,9 & 239,8 & 236,6 \\
\hline 6,5 & 67,06 & & & & 24,0 & & & & & & & & & & & 239,2 & 239,0 & 238,9 & 238,4 & 236,5 & 238,9 & 238,8 & 238,7 & 237,6 & 236,6 \\
\hline 9,0 & 67,74 & 91,7 & & & $\begin{array}{r}23,0 \\
\end{array}$ & 63,1 & 42,0 & 13,5 & 3,44 & 60,8 & 39,4 & 10 & & & 4,78 & 234,8 & 234,5 & 234,3 & 233,5 & 230,8 & 234,6 & 234,4 & 234,3 & 232,9 & $\begin{array}{r}230,9 \\
2\end{array}$ \\
\hline 12,0 & 68,13 & 94,3 & 7,855 & 7,06 & 21,5 & 66,3 & 43,5 & 14,2 & 1,26 & 65,0 & 44,4 & 14 & & & 0,83 & 227,6 & 227,5 & $\begin{array}{r}227,2 \\
\end{array}$ & 226,1 & 222,6 & 227,5 & 227,5 & 227,2 & 225,3 & 222,7 \\
\hline 12,5 & 66,14 & & & & 21,0 & & & & & & & & & & & 222,2 & 222,0 & $\begin{array}{r}221,9 \\
\end{array}$ & 221,7 & 219,9 & 2222,1 & $\begin{array}{r}222,0 \\
\end{array}$ & 221,9 & 221,7 & $\begin{array}{r}220,0 \\
\end{array}$ \\
\hline 15,0 & 67,42 & 101 & & & 20,0 & 71,5 & 51,8 & 14,8 & 1,44 & 76,4 & 50,8 & 15 & & & 1,22 & 218,5 & 218,2 & 218,0 & 217,3 & 214,7 & 218,3 & 218,2 & 218,1 & 217,3 & 214,8 \\
\hline 18,0 & 68,08 & 100 & & & 20,0 & 73,6 & 47,4 & $\begin{array}{r}13,2 \\
\end{array}$ & 0,86 & 70,4 & 46,9 & 15 & & & 1,45 & 220,1 & 219,8 & 219,5 & 218,4 & 214,7 & 219,9 & 219,8 & 219,6 & 218,4 & 214,8 \\
\hline 18,5 & 69,69 & & & & 19,5 & & & & & & & & & & & 214,5 & 214,4 & 214,2 & 213,8 & 212,1 & 214,4 & 214,3 & 214,2 & 213,9 & 212,2 \\
\hline 21,0 & 69,69 & 97,5 & 7,919 & 7,08 & 20,0 & 79,5 & 56,4 & 18,1 & 1,16 & 75,2 & 56,8 & 16 & & & 1,40 & 218,6 & 218,5 & 218,2 & 217,5 & 214,7 & 218,5 & 218,3 & 218,2 & 217,6 & 214,8 \\
\hline 24,0 & 68,70 & 99,2 & & & 23,0 & 80,5 & 65,3 & 25,8 & 2,71 & 80,5 & 78,1 & 31 & & & 1,08 & 237,0 & 236,5 & 236,3 & 234,9 & 230,8 & 236,7 & 236,5 & 236,3 & 234,9 & $\begin{array}{r}230,9 \\
\end{array}$ \\
\hline 24,5 & 67,74 & & & & $\begin{array}{r}23,0 \\
23\end{array}$ & & & & & & & & & & & 233,5 & 233,4 & 233,1 & 232,7 & 230,8 & 233,4 & 233,2 & 233,1 & 232,8 & $\begin{array}{r}230,9 \\
\end{array}$ \\
\hline 27,0 & 68,21 & 101 & & & 24,0 & 80,1 & 69,4 & $\begin{array}{r}30,9 \\
\end{array}$ & 1,98 & 82,2 & 68,4 & 35 & & & 1,54 & 240,8 & 240,5 & 240,4 & 239,4 & 236,5 & 240,8 & 240,4 & 240,3 & 239,4 & 236,6 \\
\hline 30,0 & 67,22 & 93,6 & 7,94 & 7,10 & 23,0 & 88,4 & 71,3 & 39,7 & 1,34 & $\begin{array}{l}80,7 \\
\end{array}$ & 70,8 & 42 & & & 1,50 & 237,0 & 236,5 & 236,0 & 234,6 & $\begin{array}{r}230,8 \\
\end{array}$ & 236,7 & 236,5 & 236,0 & 234,6 & 230,9 \\
\hline 30,5 & 68,06 & & & & $\begin{array}{r}23,0 \\
\end{array}$ & & & & & & & & & & & 233,7 & 233,5 & 233,3 & 232,9 & 230,8 & 233,6 & 233,4 & 233,3 & 232,9 & 230,9 \\
\hline 33,0 & 67,48 & 99,7 & & & 22,0 & 91,2 & 82,5 & 42,5 & 1,17 & 87,5 & 80,7 & 48 & & & 1,89 & 229,5 & 228,8 & $\begin{array}{r}228,6 \\
\end{array}$ & 228,1 & 225,3 & 229,3 & 228,7 & 228,4 & 228,1 & 225,4 \\
\hline 35,5 & 68,70 & & & & 21,0 & & & & & & & & & & & 225,5 & 224,7 & 223,7 & 223,4 & 219,9 & 225,4 & 224,4 & 223,6 & 223,4 & 220,0 \\
\hline
\end{tabular}


Tabela C11.2 - Continuação

\begin{tabular}{|c|c|c|c|c|c|c|c|c|c|c|}
\hline \multirow{2}{*}{$\begin{array}{c}\text { Duração } \\
\text { (h) }\end{array}$} & \multicolumn{10}{|c|}{ FAP -Perda de Carga Lida (cm) } \\
\cline { 2 - 11 } & P1-1 & P2-1 & P3-1 & P4-1 & P5-1 & P1-2 & P2-2 & P3-2 & P4-2 & P5-2 \\
\hline 0,5 & 245,5 & 245,3 & 245,2 & 244,8 & 243,0 & 245,3 & 245,2 & 245,1 & 244,8 & 243,1 \\
\hline 3,0 & 247,0 & 246,8 & 246,6 & 245,7 & 243,0 & 246,9 & 246,8 & 246,5 & 245,7 & 243,1 \\
\hline 6,0 & 248,2 & 247,9 & 247,7 & 246,4 & 243,0 & 248,0 & 247,8 & 247,6 & 246,4 & 243,1 \\
\hline 6,5 & 245,8 & 245,6 & 245,5 & 245,0 & 243,0 & 245,5 & 245,4 & 245,3 & 244,2 & 243,1 \\
\hline 9,0 & 247,2 & 246,9 & 246,7 & 245,8 & 243,0 & 247,0 & 246,8 & 246,7 & 245,2 & 243,1 \\
\hline 12,0 & 248,5 & 248,3 & 248,0 & 246,8 & 243,0 & 248,4 & 248,3 & 248,0 & 246,0 & 243,1 \\
\hline 12,5 & 245,5 & 245,3 & 245,2 & 245,0 & 243,0 & 245,4 & 245,3 & 245,2 & 245,0 & 243,1 \\
\hline 15,0 & 247,3 & 247,0 & 246,8 & 246,0 & 243,0 & 247,1 & 247,0 & 246,9 & 246,0 & 243,1 \\
\hline 18,0 & 249,2 & 248,8 & 248,5 & 247,2 & 243,0 & 248,9 & 248,8 & 248,6 & 247,2 & 243,1 \\
\hline 18,5 & 245,8 & 245,7 & 245,4 & 245,0 & 243,0 & 245,7 & 245,5 & 245,4 & 245,1 & 243,1 \\
\hline 21,0 & 247,5 & 247,3 & 247,0 & 246,2 & 243,0 & 247,3 & 247,1 & 247,0 & 246,3 & 243,1 \\
\hline 24,0 & 249,5 & 249,0 & 248,8 & 247,3 & 243,0 & 249,2 & 249,0 & 248,8 & 247,3 & 243,1 \\
\hline 24,5 & 245,8 & 245,7 & 245,4 & 245,0 & 243,0 & 245,7 & 245,5 & 245,4 & 245,1 & 243,1 \\
\hline 27,0 & 247,5 & 247,2 & 247,0 & 246,0 & 243,0 & 247,5 & 247,0 & 246,9 & 246,0 & 243,1 \\
\hline 30,0 & 249,5 & 249,0 & 248,5 & 247,0 & 243,0 & 249,2 & 249,0 & 248,5 & 247,0 & 243,1 \\
\hline 30,5 & 246,0 & 245,8 & 245,6 & 245,2 & 243,0 & 245,9 & 245,7 & 245,6 & 245,2 & 243,1 \\
\hline 33,0 & 247,5 & 246,8 & 246,5 & 246,0 & 243,0 & 247,3 & 246,7 & 246,3 & 246,0 & 243,1 \\
\hline 35,5 & 249,2 & 248,3 & 247,2 & 246,8 & 243,0 & 249,0 & 248,0 & 247,1 & 246,8 & 243,1 \\
\hline
\end{tabular}

$\mathrm{Q}_{\mathrm{T}}$ : vazão total afluente ao Sistema de Dupla Filtração (medidor de vazão eletromagnético);

Turb. AE: turbidez da água de estudo (turbidímetro de bancada);

pH AE: pH da água de estudo;

pH Coag.: pH de coagulação;

Ci-1: amostra coletada no final da subcamada i do meio filtrante da câmara de filtração 1 do FAP;

Ci-2: amostra coletada no final da subcamada i do meio filtrante da câmara de filtração 2 do FAP;

C1+C2: amostra de água pré-filtrada global (efluentes das câmaras de filtração 1 e 2 da FAP);

Pi-1: piezômetro i localizado na câmara de filtração 1 do FAP;

Pi-2: piezômetro i localizado na câmara de filtração 2 do FAP;

: execução de DFI nas duas câmaras do FAP; 
Tabela C11.2 - Continuação

\begin{tabular}{|c|c|c|c|c|c|c|c|}
\hline \multirow{3}{*}{$\begin{array}{c}\text { Duração } \\
\text { (h) }\end{array}$} & \multirow{3}{*}{$\begin{array}{l}\text { Temp. } \\
\text { (oC) }\end{array}$} & \multicolumn{6}{|c|}{ Filtro Rápido Descendente - FRD } \\
\hline & & \multirow{2}{*}{$\begin{array}{l}\text { Qfd } \\
(\mathrm{L} / \mathrm{h})\end{array}$} & \multirow{2}{*}{$\begin{array}{c}\text { Turbidez - TB (uT) } \\
\text { AF }\end{array}$} & \multicolumn{2}{|c|}{ Perda de Carga Corrigida $25^{\circ} \mathrm{C}(\mathrm{cm})$} & \multicolumn{2}{|c|}{ Perda de Carga Lida $(\mathrm{cm})$} \\
\hline & & & & P1 & $\mathrm{P} 2$ & P1 & P2 \\
\hline 0,5 & 25,0 & 25,0 & 0,22 & 35,9 & 100,2 & 36,0 & 100,5 \\
\hline 3,0 & 25,0 & 25,0 & 0,20 & 35,9 & 104,7 & 36,0 & 105,0 \\
\hline 6,0 & 24,0 & 25,0 & 0,18 & 35,0 & 106,3 & 36,0 & 109,2 \\
\hline 6,5 & 24,0 & 25,0 & & 35,0 & 112,4 & 36,0 & 115,5 \\
\hline 9,0 & 23,0 & 25,0 & 0,24 & 34,2 & 115,4 & 36,0 & 121,5 \\
\hline 12,0 & 21,5 & 25,0 & 0,67 & 33,0 & 117,7 & 36,0 & 128,5 \\
\hline 12,5 & 21,0 & 25,0 & & 32,6 & 118,0 & 36,0 & 130,4 \\
\hline 15,0 & 20,0 & 25,0 & 0,21 & 31,8 & 126,5 & 36,0 & 143,2 \\
\hline 18,0 & 20,0 & 25,0 & 0,23 & 31,8 & 134,1 & 36,0 & 151,8 \\
\hline 18,5 & 19,5 & 25,0 & & 31,4 & 135,6 & 36,0 & 155,4 \\
\hline 21,0 & 20,0 & 25,0 & 0,21 & 31,8 & 141,9 & 36,0 & 160,6 \\
\hline 24,0 & 23,0 & 25,0 & 0,20 & 34,2 & 156,7 & 36,0 & 165,0 \\
\hline 24,5 & 23,0 & 25,0 & & 34,2 & 159,6 & 36,0 & 168,0 \\
\hline 27,0 & 24,0 & 25,0 & 0,20 & 35,0 & 175,2 & 36,0 & 180,0 \\
\hline 30,0 & 23,0 & 25,0 & 0,18 & 34,2 & 184,3 & 36,0 & 194,0 \\
\hline 30,5 & 23,0 & 25,0 & & 34,2 & 188,1 & 36,0 & 198,0 \\
\hline 33,0 & 22,0 & 25,0 & 0,18 & 33,4 & 198,2 & 36,0 & 213,8 \\
\hline 35,5 & 21,0 & 25,0 & 0,17 & 32,6 & 206,8 & 36,0 & 228,5 \\
\hline
\end{tabular}

$\mathrm{Q}_{\mathrm{fd}}$ : vazão afluente ao FRD (rotâmetro);

Turb. AF: turbidez da água filtrada (turbidímetro de bancada);

P1 e P2: piezômetros localizados no início e no final do FRD, respectivamente.

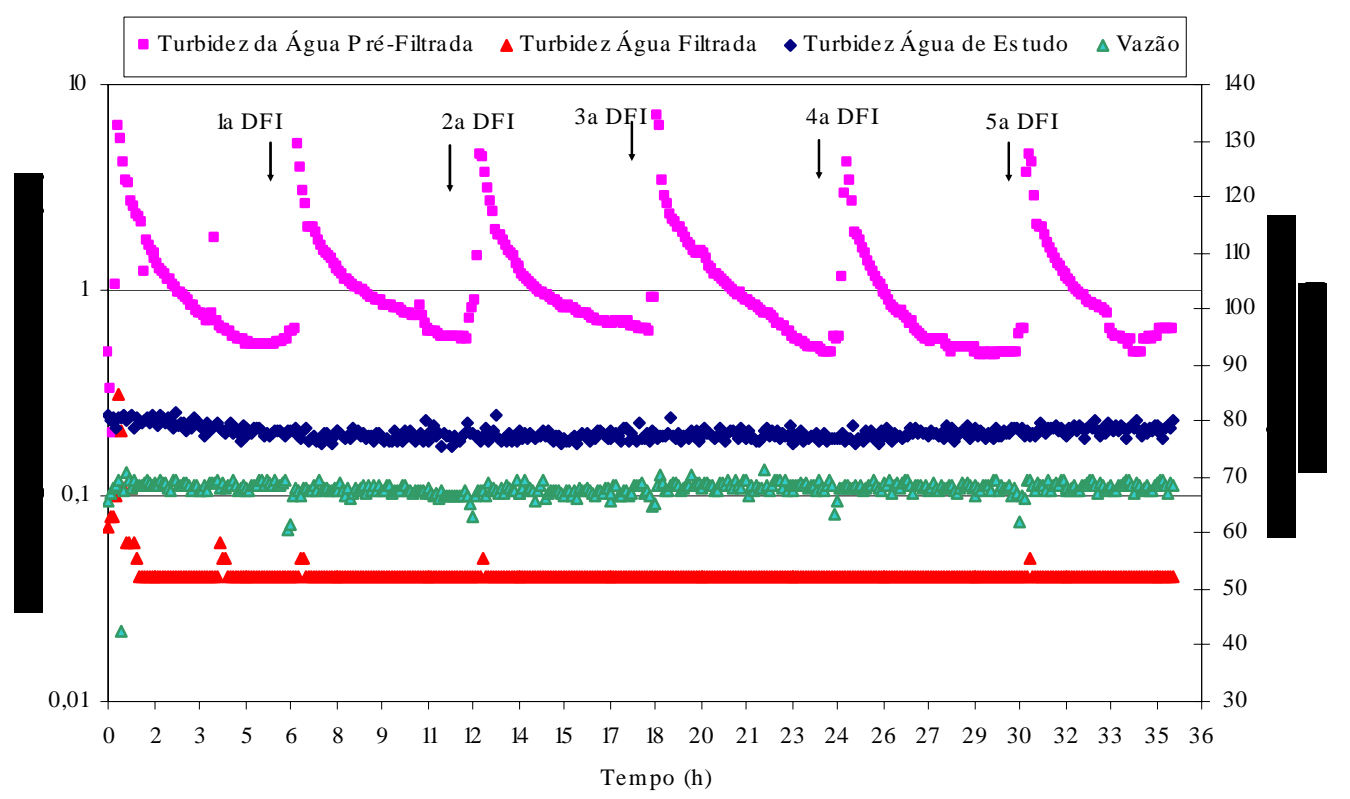

Figura C11.1 - Variações da vazão total afluente ao sistema de dupla filtração e da turbidez das águas de estudo, pré-filtrada e filtrada no ensaio 11 - Turbidímetros de Escoamento Contínuo 


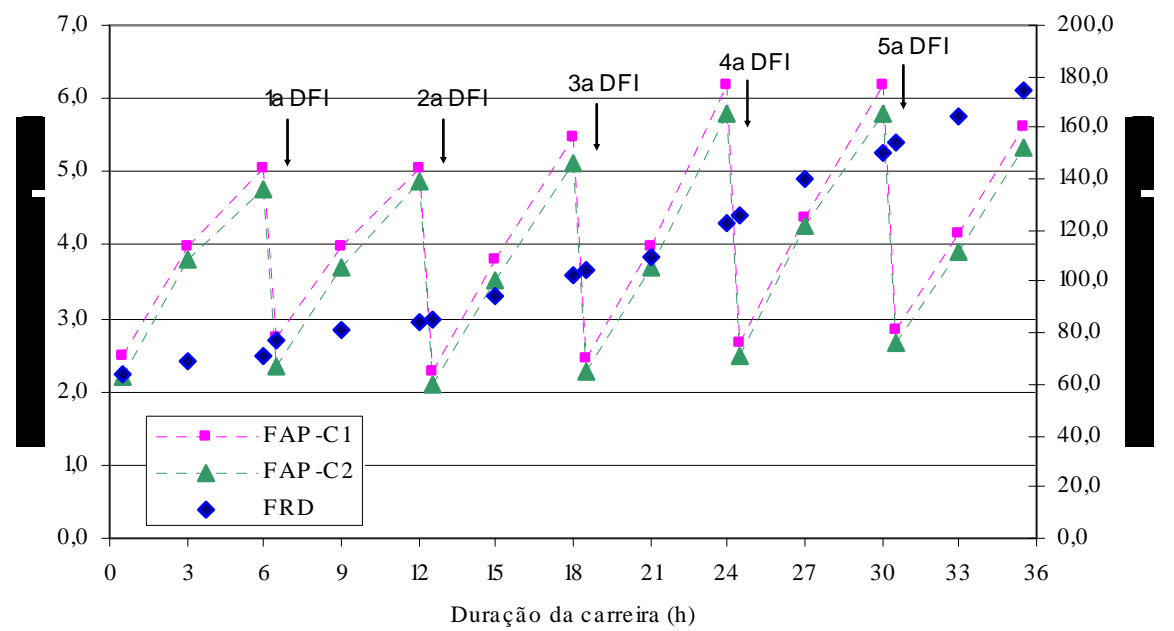

Figura C11.2 - Perda de carga nos filtros ascendente de pedregulho (duas câmaras de filtração) e descendente durante o ensaio 11 de dupla filtração

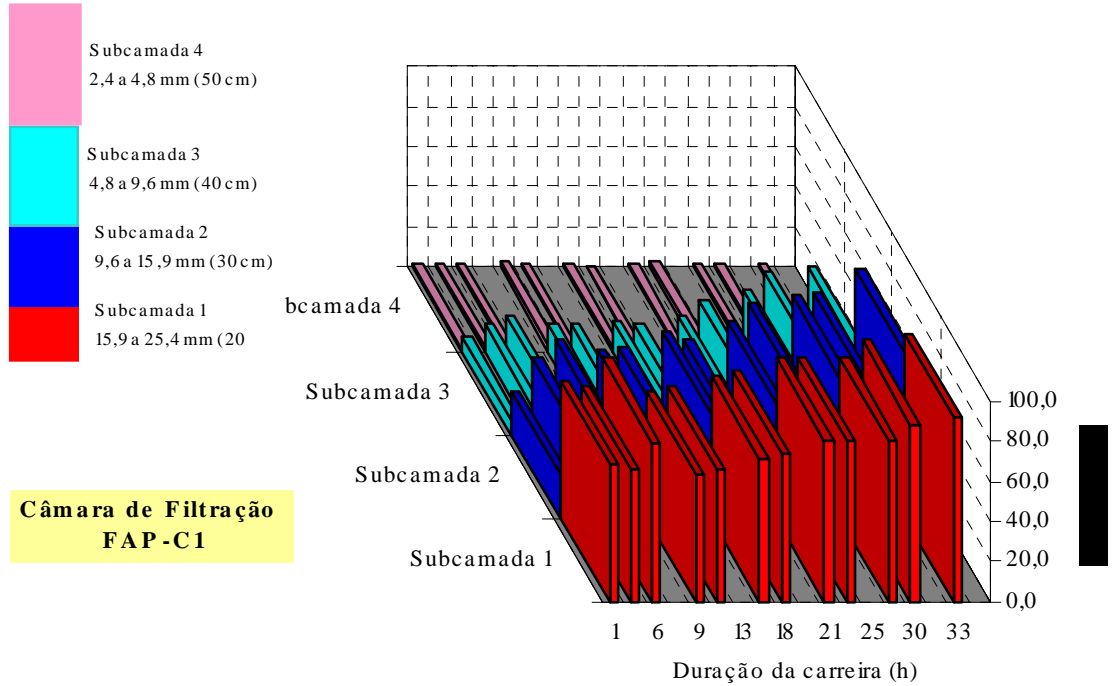

Figura C11.3 - Turbidez ao longo do meio filtrante da câmara de filtração 1 do FAP durante o ensaio 11 de dupla filtração 


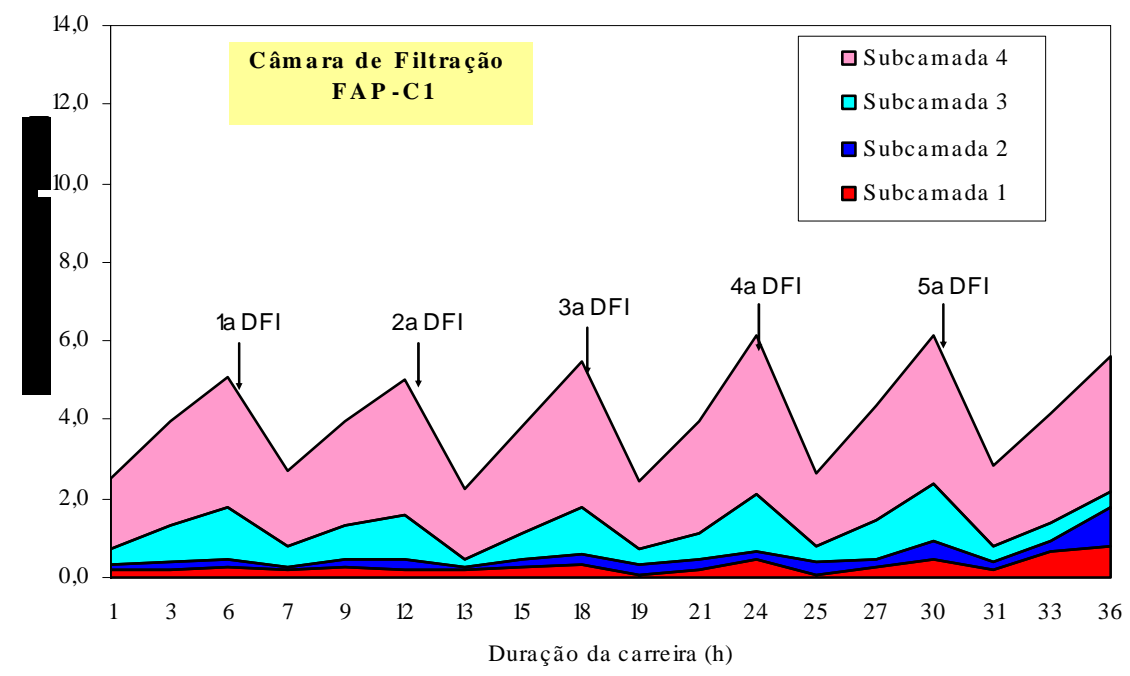

Figura C11.4 - Perda de carga ao longo do meio filtrante da câmara de filtração 1 do FAP durante o ensaio 11 de dupla filtração

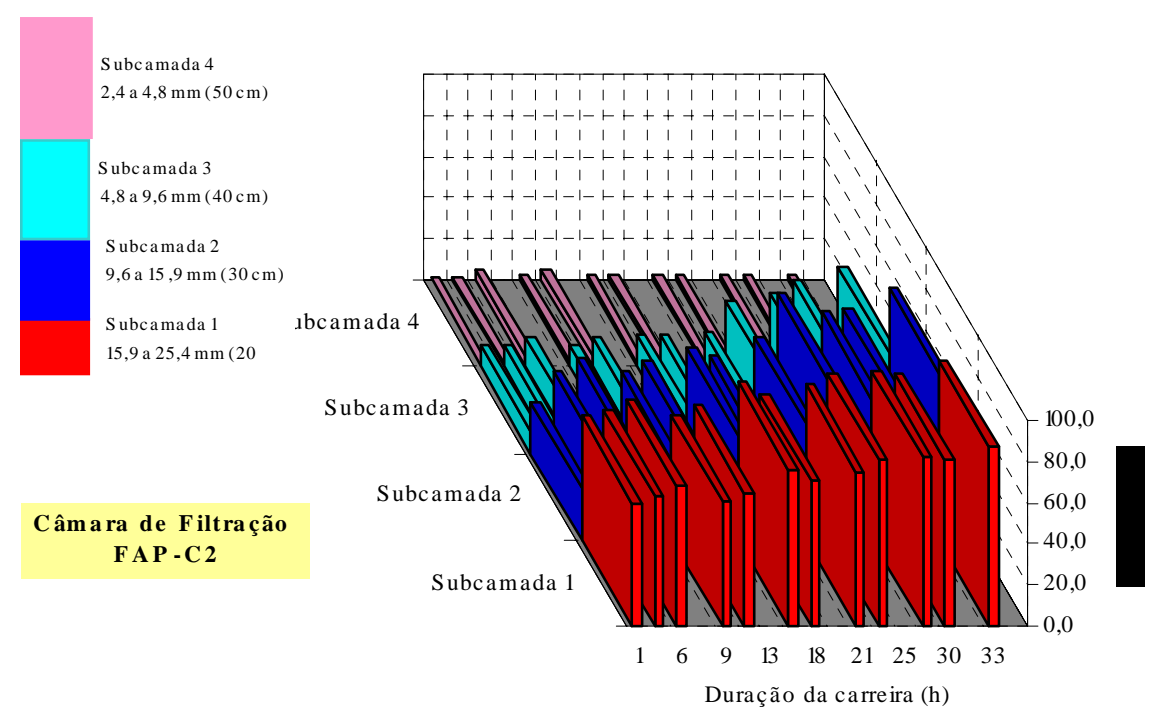

Figura C11.5 - Turbidez ao longo do meio filtrante da câmara de filtração 2 do FAP durante o ensaio 11 de dupla filtração 


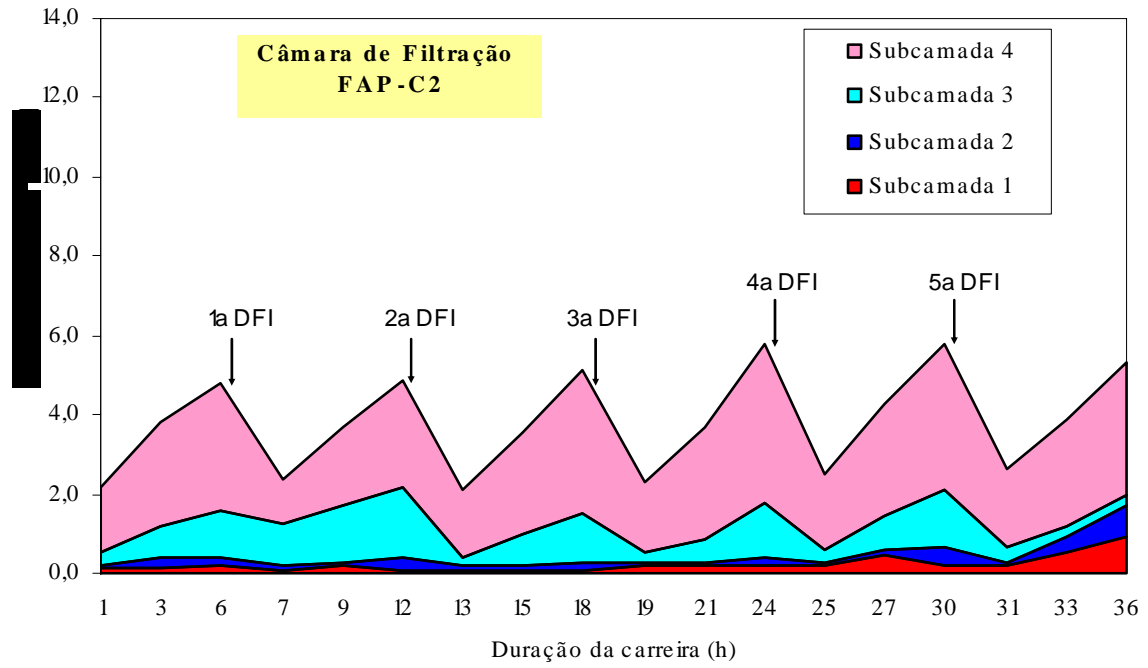

Figura C11.6 - Perda de carga ao longo do meio filtrante da câmara de filtração 2 do FAP durante o ensaio 11 de dupla filtração 


\section{ENSAIO 12 DE DUPLA FILTRAÇÃO}

Tabela C12.1 - Condições do ensaio 12 de dupla filtração - Sistema 2 e Água de estudo Tipo I

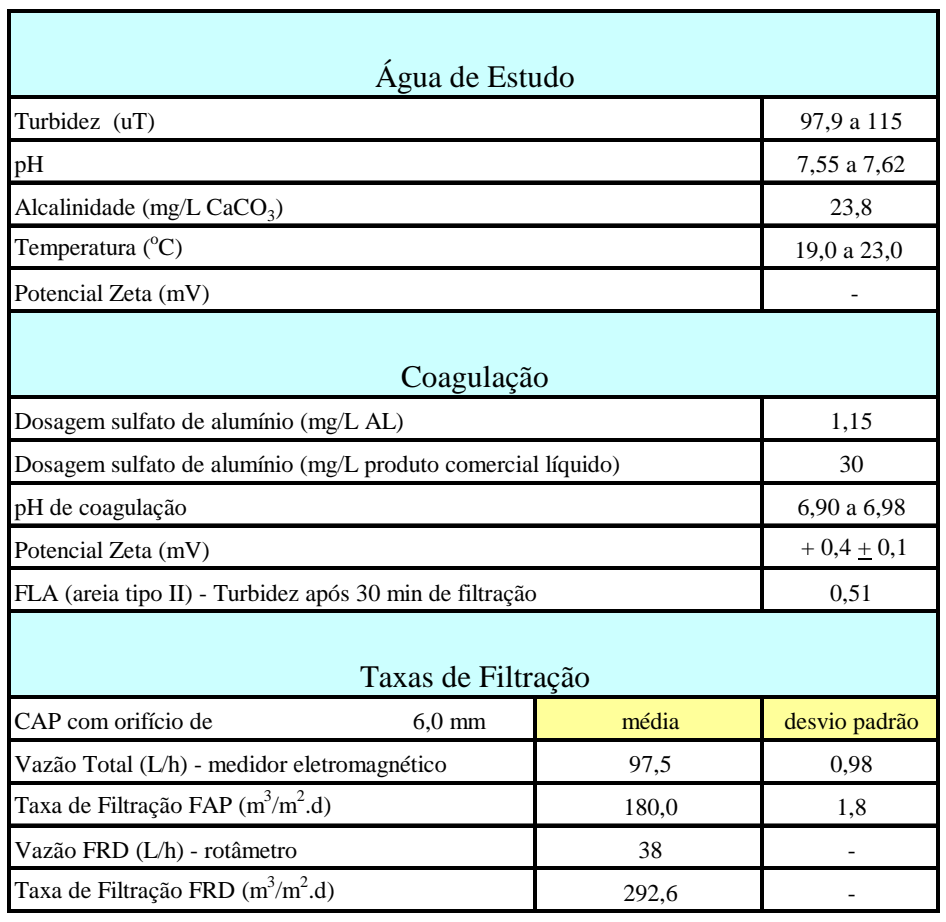


Tabela C12.2 - Resultados do ensaio 12 de dupla filtração - Sistema 2 e Água de estudo Tipo I

\begin{tabular}{|c|c|c|c|c|c|c|c|c|c|c|c|c|c|c|c|c|c|c|c|c|c|c|c|c|}
\hline \multirow{3}{*}{$\begin{array}{c}\text { Duração } \\
\text { (h) }\end{array}$} & \multirow{3}{*}{$\begin{array}{c}\mathrm{Q}_{\mathrm{T}} \\
(\mathrm{L} / \mathrm{h})\end{array}$} & \multirow{3}{*}{$\begin{array}{c}\text { Turb. } \\
\mathrm{AE}(\mathrm{uT})\end{array}$} & \multirow{3}{*}{$\begin{array}{l}\mathrm{pH} \\
\mathrm{AE} \\
\end{array}$} & \multirow{3}{*}{$\begin{array}{c}\mathrm{pH} \\
\text { Coag. }\end{array}$} & \multirow{3}{*}{$\begin{array}{l}\text { Temp. } \\
(\mathrm{oC})\end{array}$} & \multicolumn{19}{|c|}{ Filtro Ascendente de Pedregulho - FAP } \\
\hline & & & & & & \multicolumn{9}{|c|}{ Turbidez - Turbidímetro de Bancada (TB) (uT) } & \multicolumn{10}{|c|}{ Perda de Carga Corrigida $25^{\circ} \mathrm{C}(\mathrm{cm})$} \\
\hline & & & & & & C1-1 & C2-1 & C3-1 & $\mathrm{C} 4$ & & $\mathrm{C} 2-2$ & C3-2 & $\mathrm{C} 4-2$ & $\mathrm{C} 1+\mathrm{C} 2$ & $\mathrm{P} 1-1$ & P2-1 & P3-1 & P4-1 & P5-1 & $\mathrm{P} 1-2$ & P2-2 & Р3-2 & $\mathrm{P} 4-2$ & P5-2 \\
\hline 0,5 & 98,54 & 104 & 7,60 & 6,90 & 22,0 & 87,1 & 68,1 & 21,1 & 1, & & 67,5 & 19,5 & 1,18 & 1,57 & 229,1 & 229,0 & 228,8 & 228,2 & 225,3 & 229,0 & 228,8 & 228,7 & 228,1 & 225,4 \\
\hline 3,0 & 98,66 & 101 & 7,55 & 6,98 & 23,0 & 85,2 & 61,1 & 23,0 & 1,8 & & 61,50 & 21,0 & 2,41 & 1,94 & 236,6 & 236,5 & 236,3 & 235,1 & 230,8 & 236,6 & 236,5 & 236,3 & 235,1 & 230,9 \\
\hline 6,0 & 99,10 & 97,9 & & & 23,0 & 81,1 & 58,9 & 26,5 & 3, & & 63,1 & 30,7 & 3,36 & 2,94 & 238,8 & 238,6 & 238,2 & 236,6 & 230,8 & 238,7 & 238,6 & 238,2 & 236,6 & 230,9 \\
\hline 9,0 & 97,10 & 98,4 & & & 21,0 & 89,2 & 68,7 & 33,5 & 8,9 & & 65,3 & 45,7 & 9,45 & 7,31 & 229,7 & 229,4 & 229,0 & 227,0 & 219,9 & 229,5 & 229,4 & 228,8 & 226,7 & 220,0 \\
\hline 12,0 & 97,13 & 115 & 7,62 & 6,94 & 20,0 & 81,2 & 64,1 & 42,8 & 22 & & 69,6 & 46,9 & 20,5 & 16,30 & 226,0 & 225,7 & 225,1 & 222,4 & 214,7 & 225,8 & 225,6 & 225,1 & 222,5 & 214,8 \\
\hline \multirow[t]{9}{*}{13,0} & 97,90 & 107 & & & 19,0 & & & & & & & & & & 221,4 & 221,3 & 220,6 & 218,2 & 209,5 & 221,4 & 221,2 & 220,7 & 218,2 & 209,6 \\
\hline & & & & & & & & & & & & & & & \multicolumn{10}{|c|}{ Perda de Carga Lida (cm) } \\
\hline & & & & & & & & & & & & & & & P1-1 & P2-1 & P3-1 & P4-1 & P5-1 & P1-2 & P2-2 & P3-2 & P4-2 & P5-2 \\
\hline & & & & & & & & & & & & & & & 247,1 & 247,0 & 246,8 & 246,1 & 243,0 & 247,0 & 246,8 & 246,7 & 246,0 & 243,1 \\
\hline & & & & & & & & & & & & & & & 249,1 & 249,0 & 248,8 & 247,5 & 243,0 & 249,1 & 249,0 & 248,8 & 247,5 & 243,1 \\
\hline & & & & & & & & & & & & & & & 251,4 & 251,2 & 250,8 & 249,1 & 243,0 & 251,3 & 251,2 & 250,8 & 249,1 & 243,1 \\
\hline & & & & & & & & & & & & & & & 253,8 & 253,5 & 253,0 & 250,8 & 243,0 & 253,6 & 253,5 & 252,8 & 250,5 & 243,1 \\
\hline & & & & & & & & & & & & & & & 255,8 & 255,5 & 254,8 & 251,8 & 243,0 & 255,6 & 255,4 & 254,8 & 251,9 & 243,1 \\
\hline & & & & & & & & & & & & & & & 256,8 & 256,6 & 255,8 & 253,0 & 243,0 & 256,8 & 256,5 & 256,0 & 253,0 & 243,1 \\
\hline
\end{tabular}

$\mathrm{Q}_{\mathrm{T}}$ : vazão total afluente ao Sistema de Dupla Filtração (medidor de vazão eletromagnético);

Turb. AE: turbidez da água de estudo (turbidímetro de bancada);

pH AE: pH da água de estudo;

pH Coag.: pH de coagulação;

Ci-1: amostra coletada no final da subcamada i do meio filtrante da câmara de filtração 1 do FAP;

Ci-2: amostra coletada no final da subcamada i do meio filtrante da câmara de filtração 2 do FAP;

C1+C2: amostra de água pré-filtrada global (efluentes das câmaras de filtração 1 e 2 da FAP);

Pi-1: piezômetro i localizado na câmara de filtração 1 do FAP;

Pi-2: piezômetro i localizado na câmara de filtração 2 do FAP; 
Tabela C12.2 - Continuação

\begin{tabular}{|c|c|c|c|c|c|}
\hline \multirow{3}{*}{$\begin{array}{l}\text { Duração } \\
\text { (h) }\end{array}$} & \multirow{3}{*}{$\begin{array}{l}\text { Temp. } \\
\text { (oC) }\end{array}$} & \multicolumn{4}{|c|}{ Filtro Rápido Descendente - FRD } \\
\hline & & Qfd & Turbidez - TB (uT) & \multicolumn{2}{|c|}{ Perda de Carga Corrigida $25^{\circ} \mathrm{C}(\mathrm{cm})$} \\
\hline & & $(\mathrm{L} / \mathrm{h})$ & $\mathrm{AF}$ & P1 & P2 \\
\hline 0,5 & 22,0 & 38,0 & 0,21 & 32,5 & 123,0 \\
\hline 3,0 & 23,0 & 38,0 & 0,51 & 33,3 & 138,7 \\
\hline 6,0 & 23,0 & 38,0 & 0,22 & 33,3 & 150,1 \\
\hline 9,0 & 22,0 & 38,0 & 0,38 & 32,5 & 169,9 \\
\hline 12,0 & 22,0 & 38,0 & 0,50 & 32,5 & 196,6 \\
\hline \multirow[t]{9}{*}{13,0} & 22,0 & 38,0 & 0,37 & 32,5 & 203,1 \\
\hline & & & & \multicolumn{2}{|c|}{ Perda de Carga Lida (cm) } \\
\hline & & & & P1 & P2 \\
\hline & & & & 35,1 & 132,7 \\
\hline & & & & 35,1 & 146,0 \\
\hline & & & & 35,1 & 158,0 \\
\hline & & & & 35,1 & 183,2 \\
\hline & & & & 35,1 & 212,0 \\
\hline & & & & 35,1 & 219,0 \\
\hline
\end{tabular}

$\mathrm{Q}_{\mathrm{fd}}$ : vazão afluente ao FRD (rotâmetro);

Turb. AF: turbidez da água filtrada (turbidímetro de bancada);

P1 e P2: piezômetros localizados no início e no final do FRD, respectivamente.

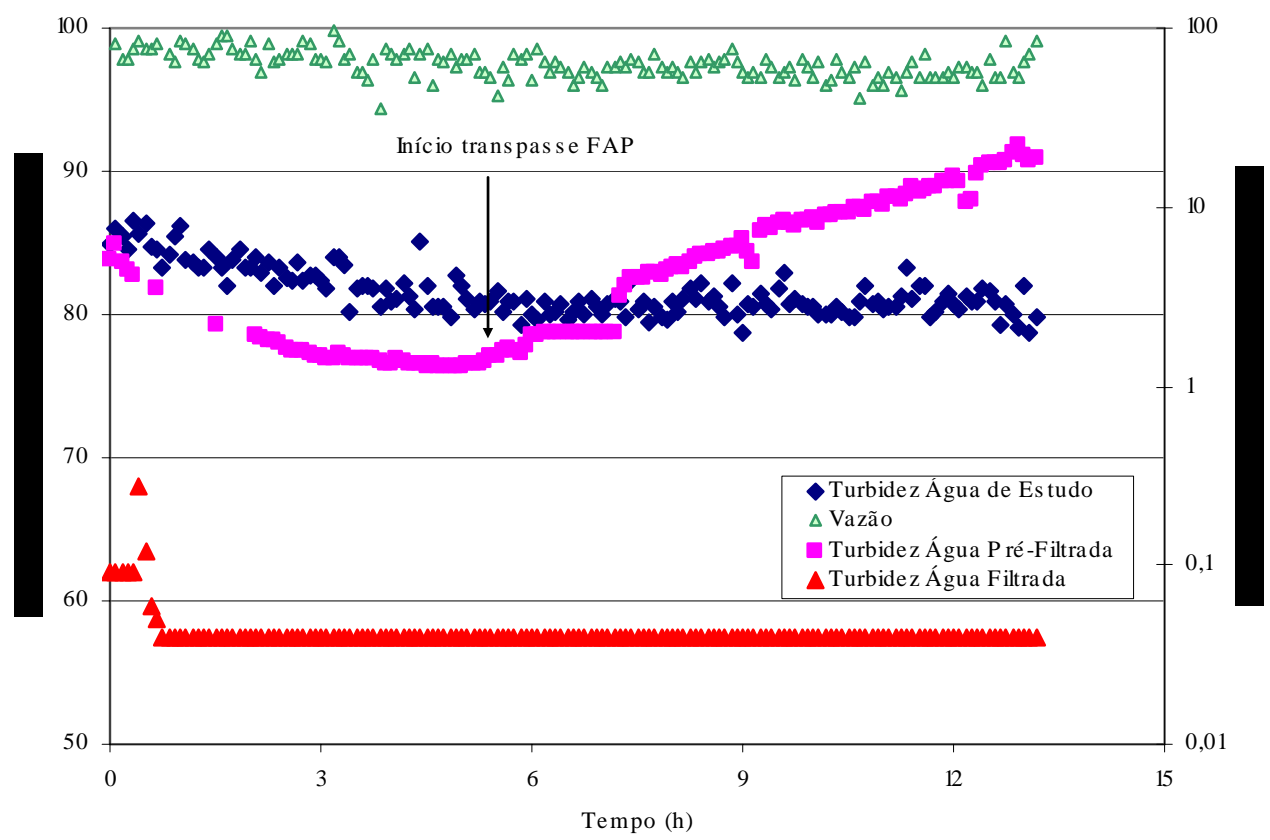

Figura C12.1 - Variações da vazão total afluente ao sistema de dupla filtraçào e da turbidez das águas de estudo, pré-filtrada e filtrada no ensaio 12 - Turbidímetros de Escoamento Contínuo 


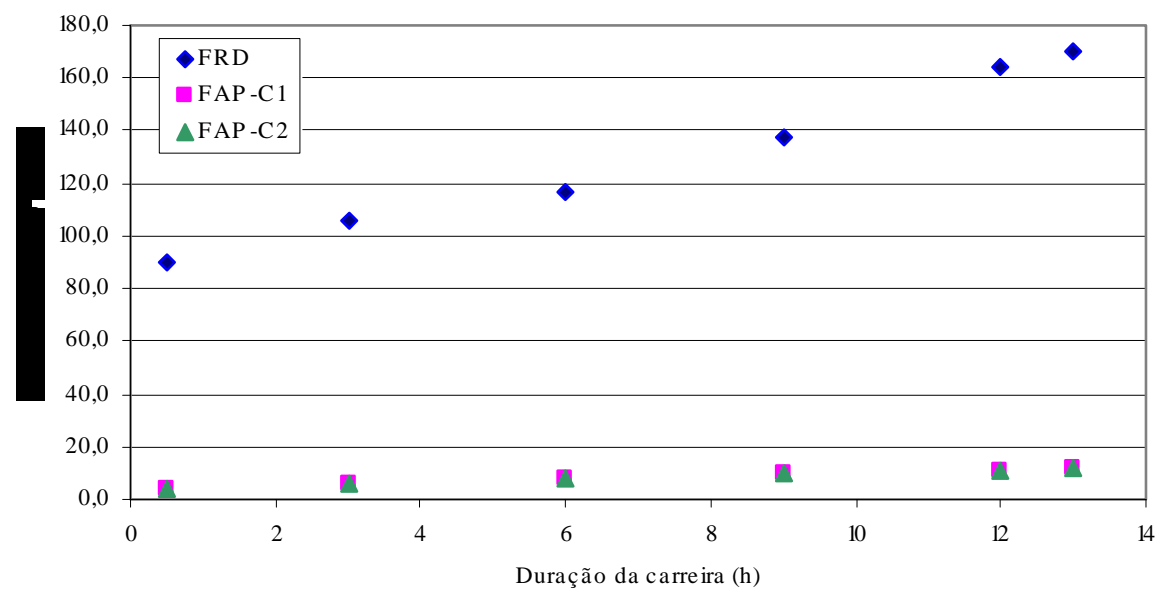

Figura C12.2 - Perda de carga nos filtros ascendente de pedregulho (duas câmaras de filtração) e descendente durante o ensaio 12 de dupla filtração

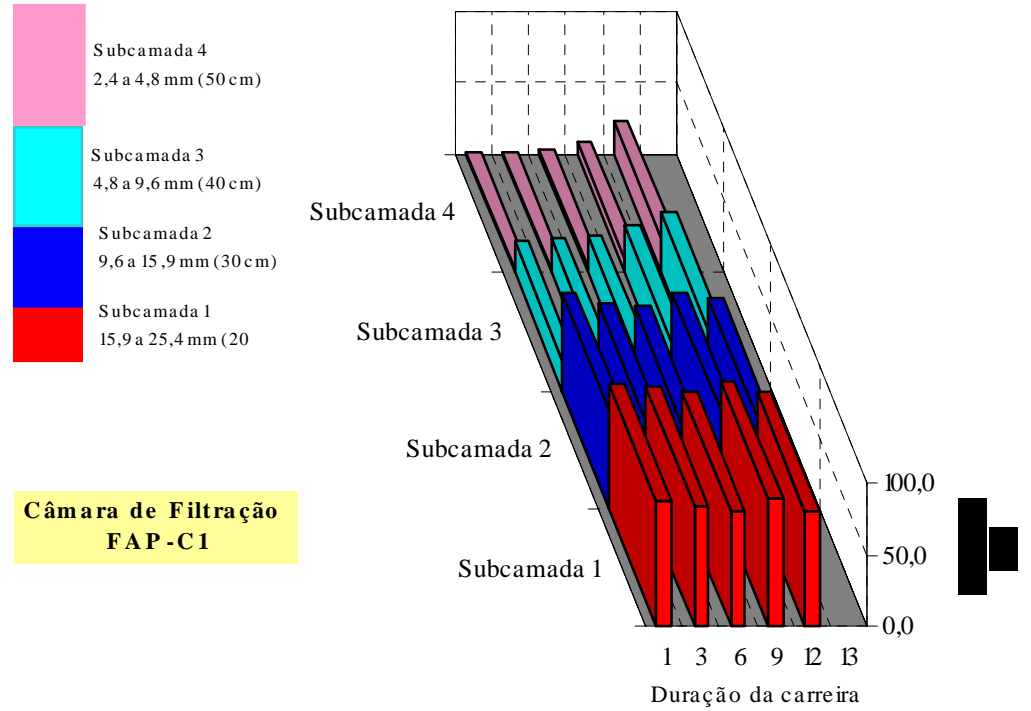

(h)

Figura C12.3 - Turbidez ao longo do meio filtrante da câmara de filtração 1 do FAP durante o ensaio 12 de dupla filtração 


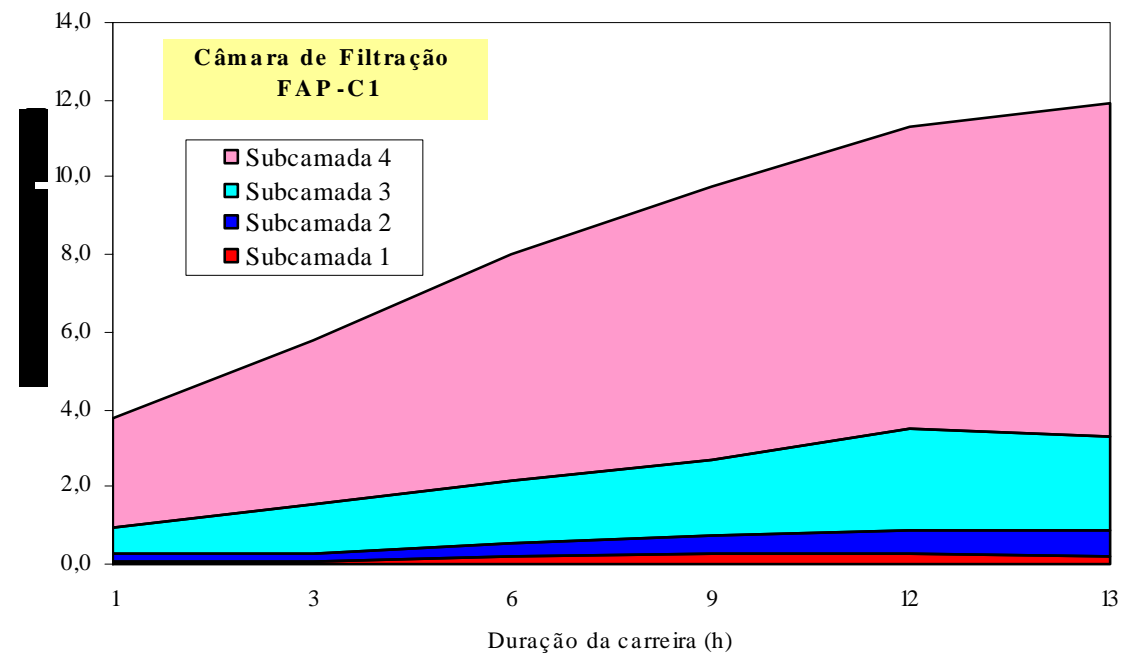

Figura C12.4 - Perda de carga ao longo do meio filtrante da câmara de filtração 1 do FAP durante o ensaio 11 de dupla filtração
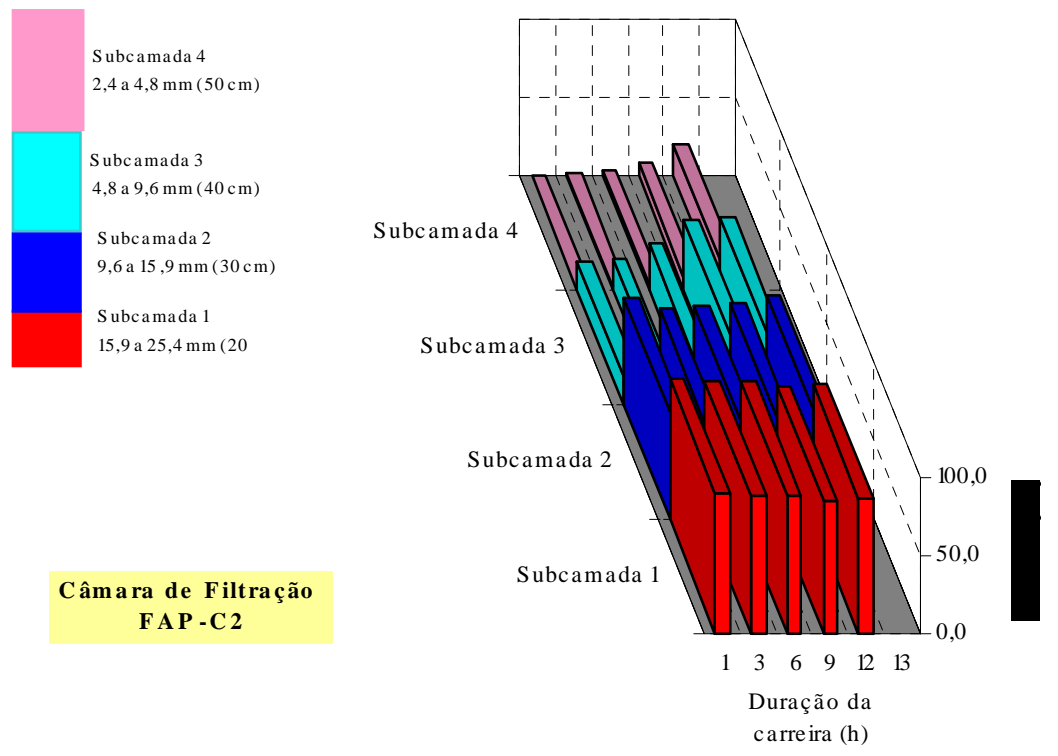

Figura C12.5 - Turbidez ao longo do meio filtrante da câmara de filtração 2 do FAP durante o ensaio 12 de dupla filtração 


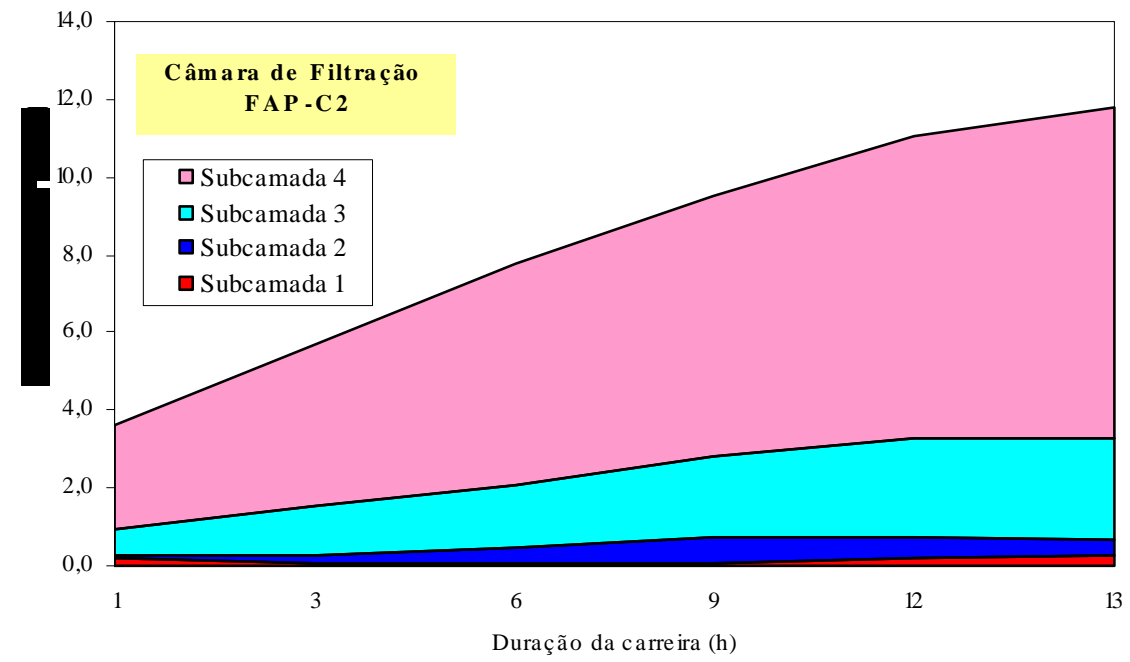

Figura C12.6 - Perda de carga ao longo do meio filtrante da câmara de filtração 2 do FAP durante o ensaio 12 de dupla filtração 


\section{ENSAIO 13 DE DUPLA FILTRAÇÃO}

Tabela C13.1 - Condições do ensaio 13 de dupla filtração - Sistema 2 e Água de estudo Tipo I

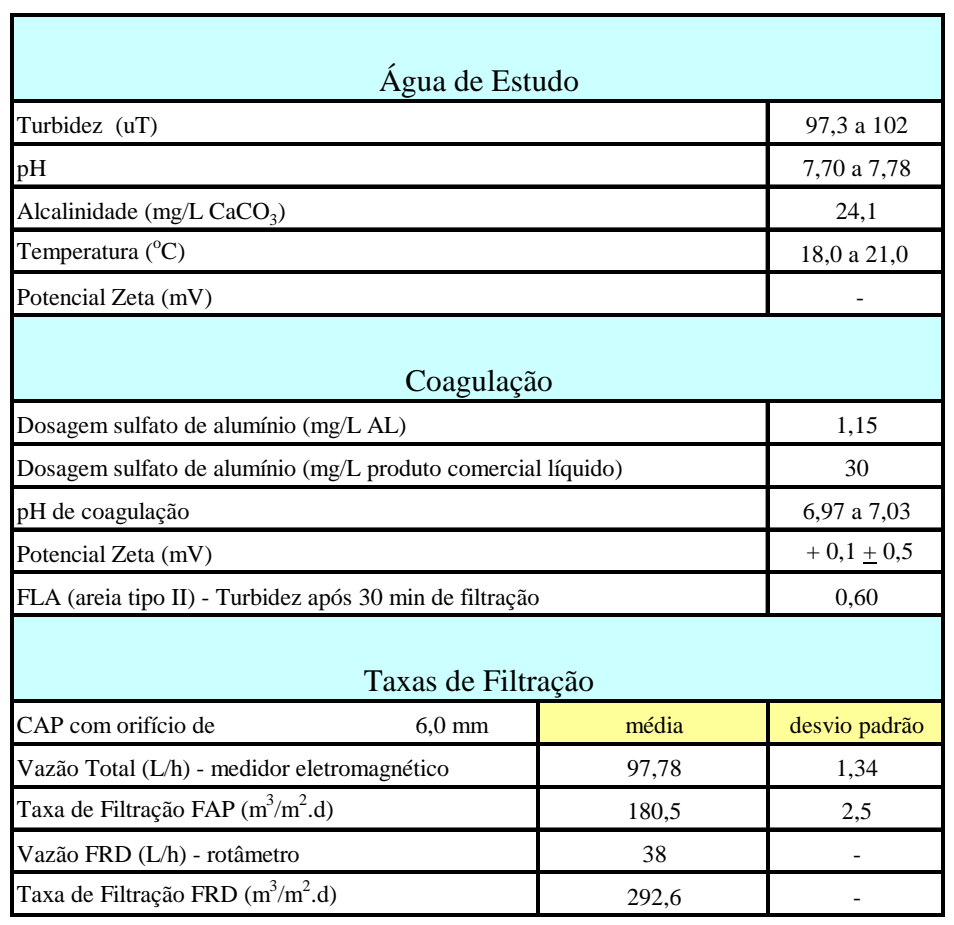


Tabela C13.2 - Resultados do ensaio 13 de dupla filtração - Sistema 2 e Água de estudo Tipo I

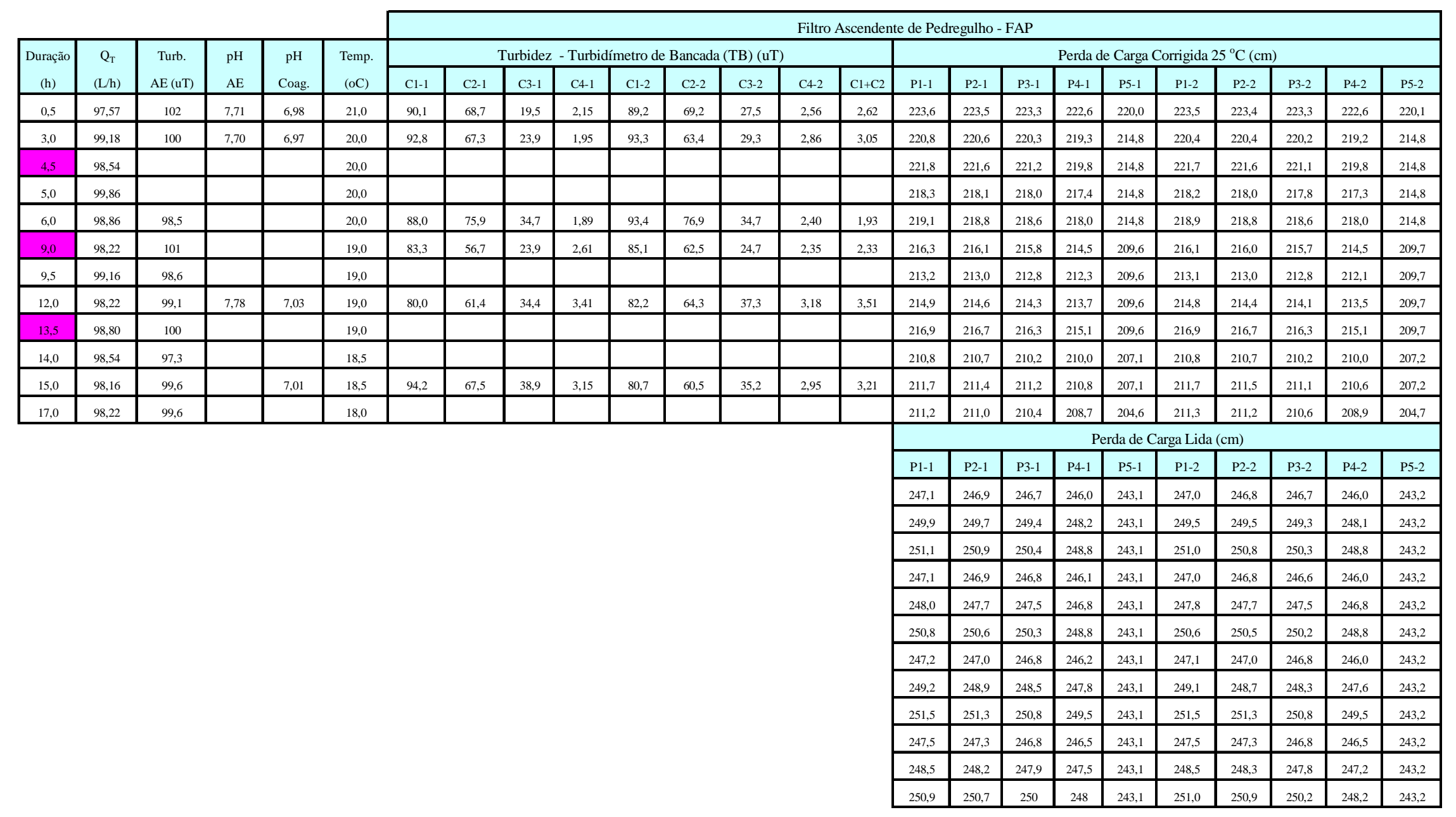


Tabela C13.2 - Continuação

\begin{tabular}{|c|c|c|c|c|c|c|c|}
\hline \multirow{3}{*}{$\begin{array}{l}\text { Duração } \\
\text { (h) }\end{array}$} & \multirow{3}{*}{$\begin{array}{l}\text { Temp. } \\
(\mathrm{oC})\end{array}$} & \multicolumn{6}{|c|}{ Filtro Rápido Descendente - FRD } \\
\hline & & \multirow{2}{*}{$\begin{array}{l}\text { Qfd } \\
(\mathrm{L} / \mathrm{h})\end{array}$} & \multirow{2}{*}{$\begin{array}{c}\text { Turbidez - TB (uT) } \\
\text { AF }\end{array}$} & \multicolumn{2}{|c|}{ Perda de Carga Corrigida $25^{\circ} \mathrm{C}(\mathrm{cm})$} & \multicolumn{2}{|c|}{ Perda de Carga Lida $(\mathrm{cm})$} \\
\hline & & & & P1 & P2 & P1 & P2 \\
\hline 0,5 & 21,0 & 38,0 & 0,19 & 33,8 & 121,6 & 37,3 & 134,4 \\
\hline 3,0 & 20,0 & 38,0 & 0,18 & 33,0 & 133,8 & 37,3 & 151,5 \\
\hline 4,5 & 20,0 & 38,0 & & 33,0 & 140,5 & 37,3 & 159,0 \\
\hline 5,0 & 20,0 & 38,0 & & 33,0 & 145,9 & 37,3 & 165,2 \\
\hline 6,0 & 20,0 & 38,0 & 0,12 & 33,0 & 150,8 & 37,3 & 170,7 \\
\hline 9,0 & 19,0 & 38,0 & 0,12 & 32,2 & 164,7 & 37,3 & 191,0 \\
\hline 9,5 & 19,0 & 38,0 & & 32,2 & 166,4 & 37,3 & 193,0 \\
\hline 12,0 & 19,0 & 38,0 & 0,21 & 32,2 & 170,7 & 37,3 & 198,0 \\
\hline 13,5 & 19,0 & 38,0 & & 32,2 & 175,9 & 37,3 & 204,0 \\
\hline 14,0 & 18,5 & 38,0 & & 31,8 & 179,8 & 37,3 & 211,0 \\
\hline 15,0 & 18,5 & 38,0 & 0,21 & 31,8 & 183,2 & 37,3 & 215,0 \\
\hline 17,0 & 18,0 & 38,0 & & 31,4 & 186,3 & 37,3 & 221,3 \\
\hline
\end{tabular}

$\mathrm{Q}_{\mathrm{T}}$ : vazão total afluente ao Sistema de Dupla Filtração (medidor de vazão eletromagnético);

Turb. AE: turbidez da água de estudo (turbidímetro de bancada);

pH AE: pH da água de estudo;

pH Coag.: $\mathrm{pH}$ de coagulação;

Ci-1: amostra coletada no final da subcamada i do meio filtrante da câmara de filtração 1 do FAP;

Ci-2: amostra coletada no final da subcamada i do meio filtrante da câmara de filtração 2 do FAP;

C1+C2: amostra de água pré-filtrada global (efluentes das câmaras de filtração 1 e 2 da FAP);

Pi-1: piezômetro i localizado na câmara de filtração 1 do FAP;

Pi-2: piezômetro i localizado na câmara de filtração 2 do FAP;

$\square$ : execução de DFI nas duas câmaras do FAP;

$\mathrm{Q}_{\mathrm{fd}}$ : vazão afluente ao FRD (rotâmetro);

Turb. AF: turbidez da água filtrada (turbidímetro de bancada);

P1 e P2: piezômetros localizados no início e no final do FRD, respectivamente.

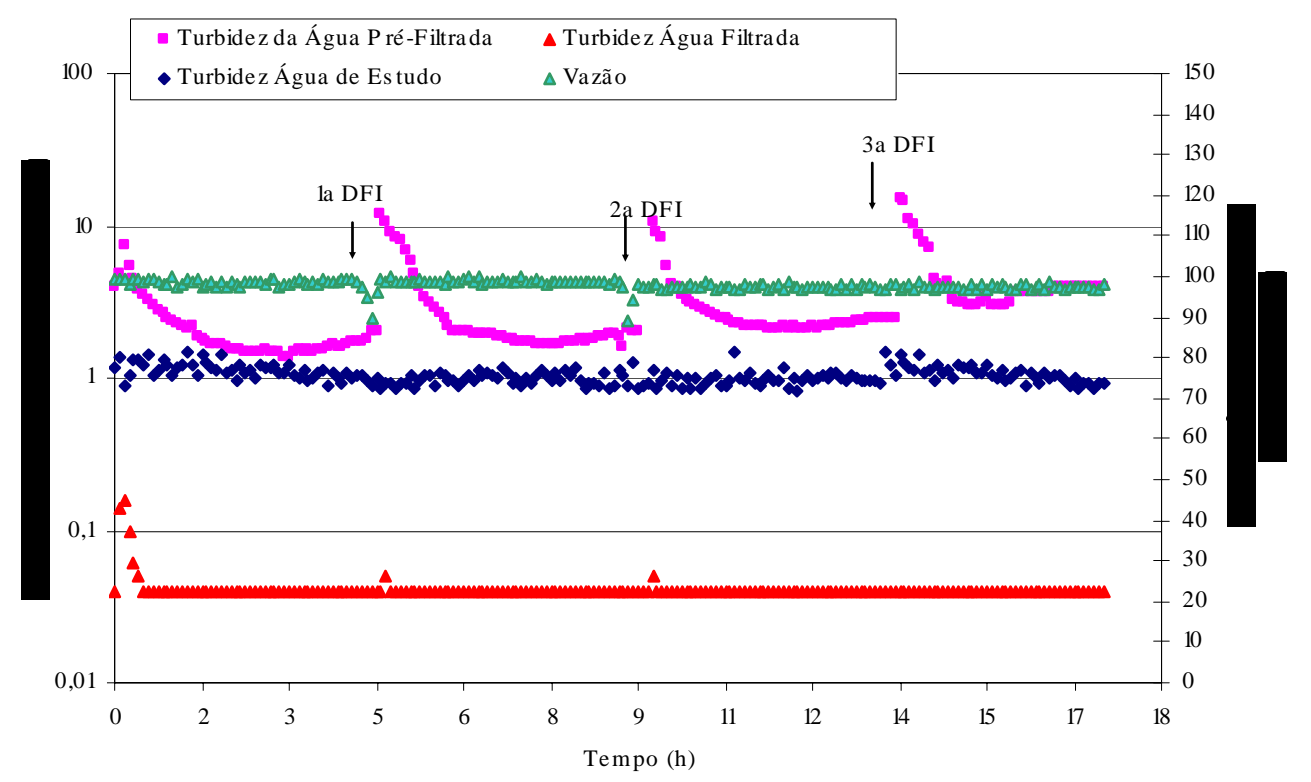

Figura C13.1 - Variações da vazão total afluente ao sistema de dupla filtração e da turbidez das águas de estudo, pré-filtrada e filtrada no ensaio 13 - Turbidímetros de Escoamento Contínuo 


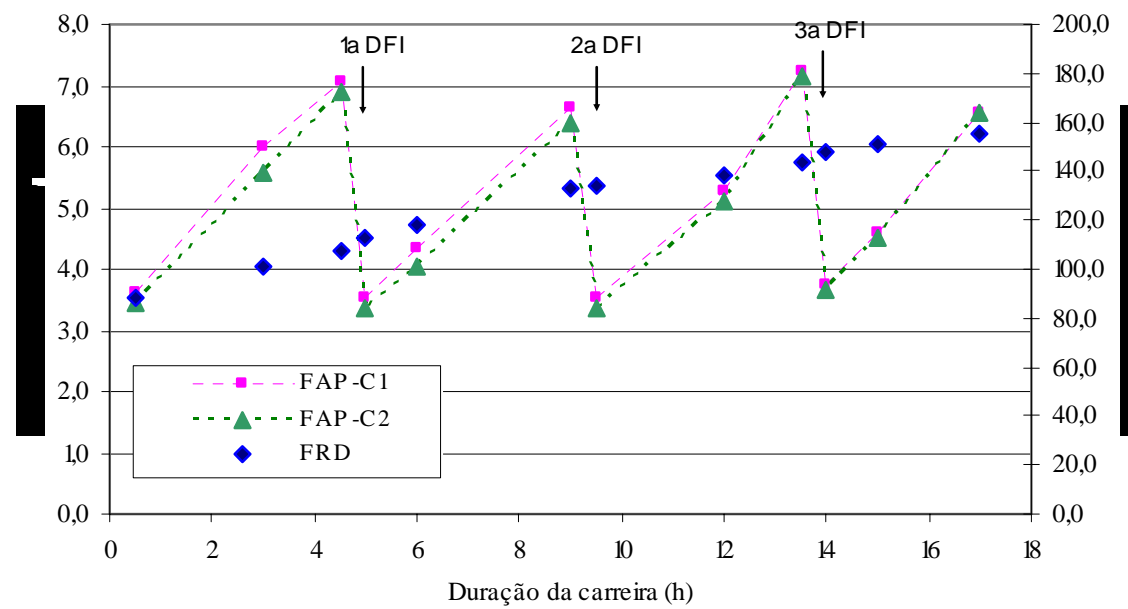

Figura C13.2 - Perda de carga nos filtros ascendente de pedregulho (duas câmaras de filtração) e descendente durante o ensaio 13 de dupla filtração

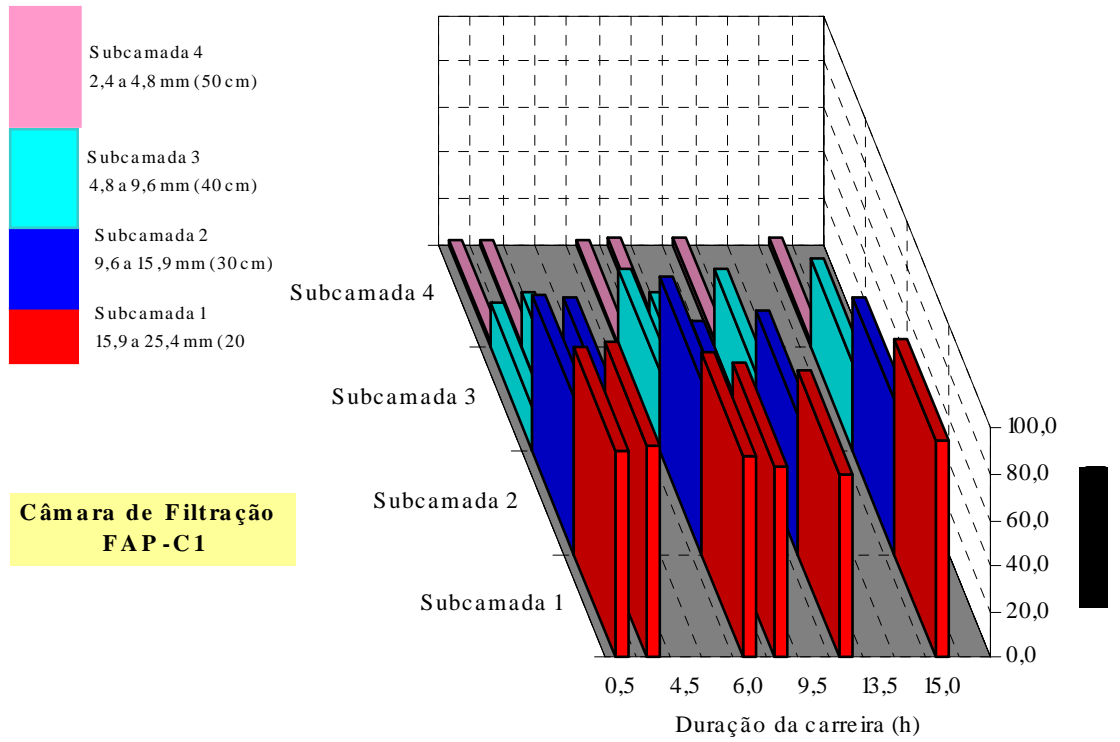

Figura C13.3 - Turbidez ao longo do meio filtrante da câmara de filtração 1 do FAP durante o ensaio 13 de dupla filtração 


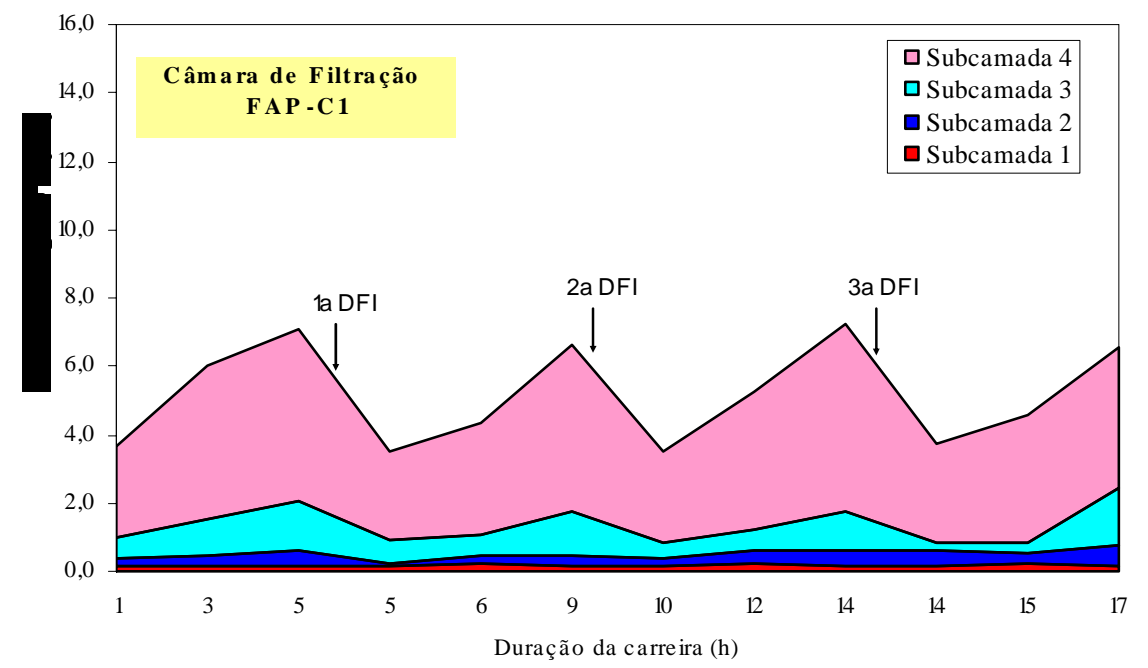

Figura C13.4 - Perda de carga ao longo do meio filtrante da câmara de filtração 1 do FAP durante o ensaio 13 de dupla filtração

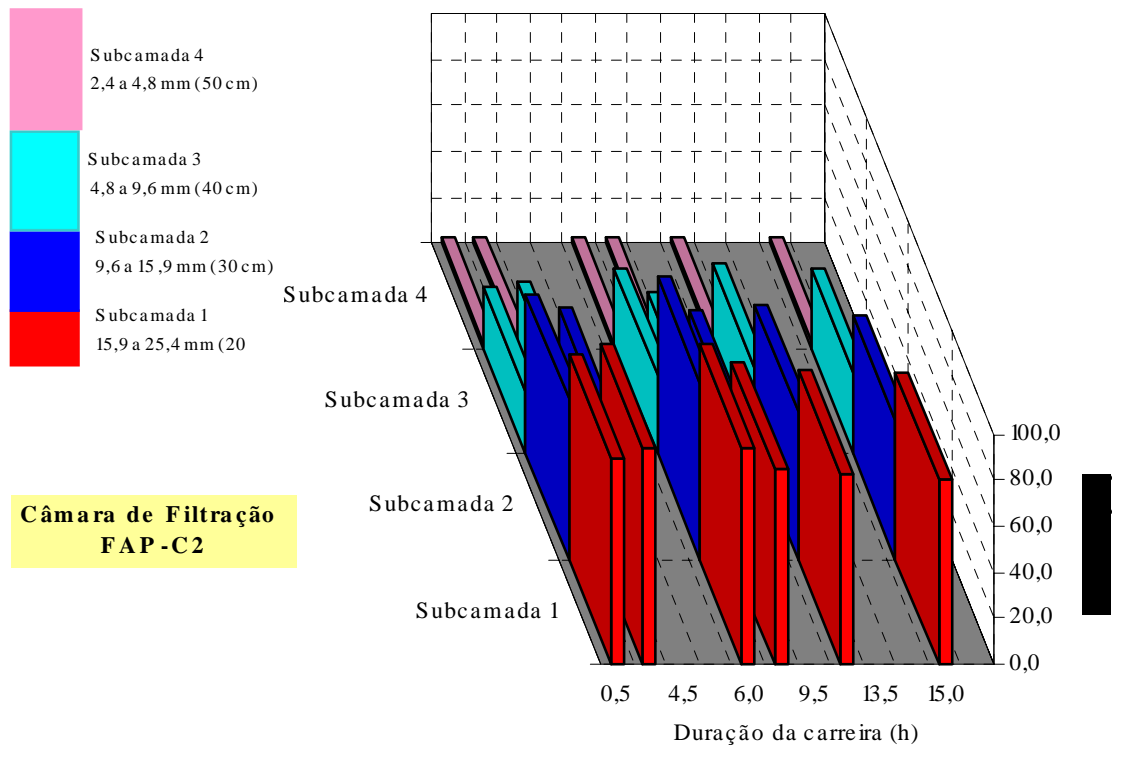

Figura C13.5 - Turbidez ao longo do meio filtrante da câmara de filtração 2 do FAP durante o ensaio 13 de dupla filtração 


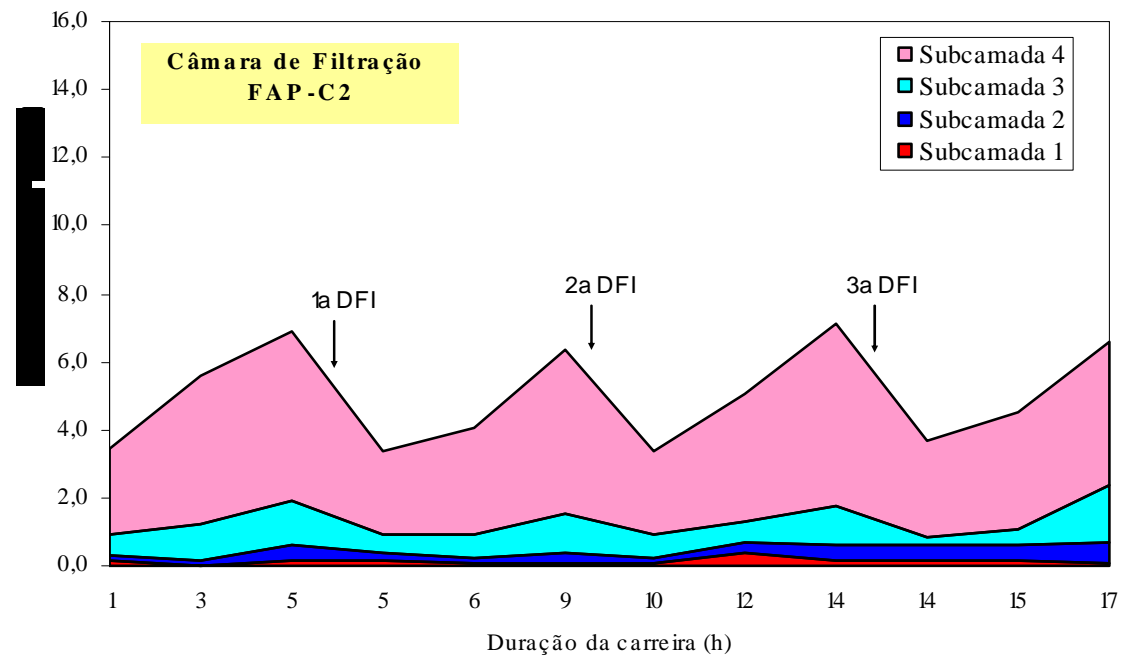

Figura C13.6 - Perda de carga ao longo do meio filtrante da câmara de filtração 2 do FAP durante o ensaio 13 de dupla filtração 


\section{ENSAIO 14 DE DUPLA FILTRAÇÃO}

Tabela C14.1 - Condições do ensaio 14 de dupla filtração - Sistema 2 e Água de estudo Tipo II

\begin{tabular}{|c|c|c|}
\hline \multicolumn{3}{|c|}{ Água de Estudo } \\
\hline \multicolumn{2}{|l|}{ Turbidez (uT) } & 290 а 315 \\
\hline \multicolumn{2}{|l|}{$\mathrm{pH}$} & 7,95 a 8,00 \\
\hline \multicolumn{2}{|l|}{ Alcalinidade $(\mathrm{mg} / \mathrm{L} \mathrm{CaCO})_{3}$} & 25,6 \\
\hline \multicolumn{2}{|l|}{ Temperatura $\left({ }^{\circ} \mathrm{C}\right)$} & 19,0 a 24,0 \\
\hline \multicolumn{2}{|l|}{ Potencial Zeta (mV) } & - \\
\hline \multicolumn{3}{|c|}{ Coagulação } \\
\hline \multicolumn{2}{|l|}{ Dosagem sulfato de alumínio (mg/L AL) } & 2,29 \\
\hline \multicolumn{2}{|c|}{ Dosagem sulfato de alumínio (mg/L produto comercial líquido) } & 60 \\
\hline \multicolumn{2}{|l|}{ pH de coagulação } & 6,91 а 6,98 \\
\hline \multicolumn{2}{|l|}{ Potencial Zeta (mV) } & $-1,4 \pm 0,2$ \\
\hline \multicolumn{2}{|l|}{ FLA (areia tipo III) - Turbidez após 30 min de filtração } & 0,94 \\
\hline \multicolumn{3}{|c|}{ Taxas de Filtração } \\
\hline CAP com orifício de & média & desvio padrão \\
\hline Vazão Total (L/h) - medidor eletromagnético & 96,35 & 0,51 \\
\hline Taxa de Filtração FAP $\left(\mathrm{m}^{3} / \mathrm{m}^{2} . \mathrm{d}\right)$ & 177,9 & 0,9 \\
\hline Vazão FRD (L/h) - rotâmetro & 24 & - \\
\hline Taxa de Filtração FRD $\left(\mathrm{m}^{3} / \mathrm{m}^{2} . \mathrm{d}\right)$ & 184,8 & - \\
\hline
\end{tabular}


Tabela C14.2 - Resultados do ensaio 14 de dupla filtração - Sistema 2 e Água de estudo Tipo II

\begin{tabular}{|c|c|c|c|c|c|c|c|c|c|c|c|c|c|c|c|c|c|c|c|c|c|c|c|c|}
\hline \multirow{3}{*}{$\begin{array}{c}\text { Duração } \\
\text { (h) }\end{array}$} & \multirow{3}{*}{$\begin{array}{c}\mathrm{Q}_{\mathrm{T}} \\
(\mathrm{L} / \mathrm{h})\end{array}$} & \multirow{3}{*}{$\begin{array}{c}\text { Turb. } \\
\mathrm{AE}(\mathrm{uT})\end{array}$} & \multirow{3}{*}{$\begin{array}{l}\mathrm{pH} \\
\mathrm{AE}\end{array}$} & \multirow{3}{*}{$\begin{array}{c}\mathrm{pH} \\
\text { Coag. }\end{array}$} & \multirow{3}{*}{$\begin{array}{c}\text { Temp. } \\
\text { (oC) }\end{array}$} & \multicolumn{19}{|c|}{ Filtro Ascendente de Pedregulho - FAP } \\
\hline & & & & & & \multicolumn{9}{|c|}{ Turbidez - Turbidímetro de Bancada (TB) (uT) } & \multicolumn{10}{|c|}{ Perda de Carga Corrigida $25^{\circ} \mathrm{C}(\mathrm{cm})$} \\
\hline & & & & & & C1-1 & C2-1 & C3-1 & C4-1 & $\mathrm{C} 1-2$ & $\mathrm{C} 2-2$ & С3-2 & $\mathrm{C} 4-2$ & $\mathrm{C} 1+\mathrm{C} 2$ & P1-1 & P2-1 & P3-1 & P4-1 & P5-1 & P1-2 & P2-2 & Р3-2 & P4-2 & P5-2 \\
\hline 1,0 & 96,61 & 299 & 8,00 & 6,94 & 23,0 & 236 & 165 & 44,3 & 3,42 & 244 & 160 & 52,1 & 4,54 & 3,37 & 235,9 & 235,6 & 235,4 & 234,5 & 231,1 & 235,7 & 235,6 & 235,4 & 234,5 & 231,1 \\
\hline 3,0 & 97,25 & 305 & 7,95 & 6,91 & 24,0 & 269 & 150 & 45,4 & 3,19 & 239 & 140 & 44,2 & 3,37 & 2,69 & 242,8 & 242,7 & 242,3 & 241,1 & 236,8 & 242,7 & 242,6 & 242,2 & 241,1 & 236,8 \\
\hline 6,0 & 97,57 & 290 & & & 23,0 & 222 & 158 & 69,5 & 10,80 & 236 & 149 & 67,5 & 15,70 & 5,92 & 239,4 & 239,1 & 238,6 & 236,7 & 231,1 & 239,2 & 239,1 & 238,4 & 236,8 & 231,1 \\
\hline 9,0 & 95,67 & 301 & & & 22,0 & 242 & 160 & 82,1 & 20,40 & 251 & 165 & 81,4 & 22,40 & 18,8 & 235,9 & 235,5 & 234,6 & 232,4 & 225,6 & 235,5 & 235,4 & 234,6 & 232,5 & 225,6 \\
\hline 12,0 & 95,67 & 301 & 7,98 & 6,98 & 20,5 & 271 & 203 & 115 & * & 277 & 187 & 127 & * & 84,4 & 230,2 & 229,8 & 228,7 & 226,2 & 217,5 & 230,0 & 229,8 & 228,7 & 226,2 & 217,5 \\
\hline 15,0 & 96,61 & 315 & & & 19,0 & 288 & 217 & 180 & $*$ & 301 & 208 & 194 & $*$ & 159 & 223,8 & 223,1 & 222,4 & 219,4 & 209,8 & 223,6 & 223,0 & 222,4 & 219,4 & 209,8 \\
\hline \multirow[t]{10}{*}{18,0} & 96,12 & 306 & & & 19,0 & 327 & 251 & 292 & * & 285 & 216 & 313 & $*$ & 131 & 225,1 & 224,8 & 224,0 & 220,7 & 209,8 & 225,1 & 224,9 & 223,8 & 220,7 & 209,8 \\
\hline & & & & & & & & & & & & & & & \multicolumn{10}{|c|}{ Perda de Carga Lida (cm) } \\
\hline & & & & & & & & & & & & & & & P1-1 & P2-1 & P3-1 & P4-1 & P5-1 & P1-2 & P2-2 & Р3-2 & P4-2 & P5-2 \\
\hline & & & & & & & & & & & & & & & 248,3 & 248,0 & 247,8 & 246,9 & 243,3 & 248,1 & 248,0 & 247,8 & 246,9 & 243,3 \\
\hline & & & & & & & & & & & & & & & 249,5 & 249,4 & 249,0 & 247,8 & 243,3 & 249,4 & 249,3 & 248,9 & 247,8 & 243,3 \\
\hline & & & & & & & & & & & & & & & 252,0 & 251,7 & 251,2 & 249,2 & 243,3 & 251,8 & 251,7 & 251,0 & 249,3 & 243,3 \\
\hline & & & & & & & & & & & & & & & 254,4 & 254,0 & 253,0 & 250,7 & 243,3 & 254,0 & 253,9 & 253,0 & 250,8 & 243,3 \\
\hline & & & & & & & & & & & & & & & 257,5 & 257,0 & 255,8 & 253,0 & 243,3 & 257,2 & 257,0 & 255,8 & 253,0 & 243,3 \\
\hline & & & & & & & & & & & & & & & 259,5 & 258,7 & 257,9 & 254,5 & 243,3 & 259,3 & 258,6 & 257,9 & 254,5 & 243,3 \\
\hline & & & & & & & & & & & & & & & 261,0 & 260,7 & 259,8 & 256,0 & 243,3 & 261,0 & 260,8 & 259,5 & 256,0 & 243,3 \\
\hline
\end{tabular}

QT: vazão total afluente ao Sistema de Dupla Filtração (medidor de vazão eletromagnético);

Turb. AE: turbidez da água de estudo (turbidímetro de bancada);

pH AE: pH da água de estudo;

pH Coag.: pH de coagulação;

Ci-1: amostra coletada no final da subcamada i do meio filtrante da câmara de filtração 1 do FAP; Ci-2: amostra coletada no final da subcamada i do meio filtrante da câmara de filtração 2 do FAP;

C1+C2: amostra de água pré-filtrada global (efluentes das câmaras de filtração 1 e 2 da FAP);

Pi-1: piezômetro i localizado na câmara de filtração 1 do FAP;

Pi-2: piezômetro i localizado na câmara de filtração 2 do FAP;

*: formação do manto de lodo na posição da coleta C6-1 e C6-2; 
Tabela C14.2 - Continuação

\begin{tabular}{|c|c|c|c|c|c|}
\hline \multirow{3}{*}{$\begin{array}{c}\text { Duração } \\
\text { (h) }\end{array}$} & \multirow{3}{*}{$\begin{array}{l}\text { Temp. } \\
\text { (oC) }\end{array}$} & \multicolumn{4}{|c|}{ Filtro Rápido Descendente - FRD } \\
\hline & & \multirow{2}{*}{$\begin{array}{l}\text { Qfd } \\
(\mathrm{L} / \mathrm{h})\end{array}$} & \multirow{2}{*}{$\begin{array}{c}\text { Turbidez - TB (uT) } \\
\text { AF }\end{array}$} & \multicolumn{2}{|c|}{ Perda de Carga Corrigida $25^{\circ} \mathrm{C}(\mathrm{cm})$} \\
\hline & & & & P1 & P2 \\
\hline 1,0 & 23,0 & 24,0 & 0,42 & 35,4 & 90,5 \\
\hline 3,0 & 24,0 & 24,0 & 0,33 & 36,3 & 96,4 \\
\hline 6,0 & 23,0 & 24,0 & 0,38 & 35,4 & 102,1 \\
\hline 9,0 & 22,0 & 24,0 & 0,21 & 34,6 & 109,9 \\
\hline 12,0 & 20,5 & 24,0 & 0,15 & 33,4 & 118,7 \\
\hline 15,0 & 19,0 & 24,0 & 0,18 & 32,2 & 132,9 \\
\hline \multirow[t]{10}{*}{18,0} & 18,5 & 24,0 & 0,59 & 31,8 & 156,9 \\
\hline & & & & \multicolumn{2}{|c|}{ Perda de Carga Lida (cm) } \\
\hline & & & & P1 & P2 \\
\hline & & & & 37,3 & 95,3 \\
\hline & & & & 37,3 & 99,1 \\
\hline & & & & 37,3 & 107,5 \\
\hline & & & & 37,3 & 118,5 \\
\hline & & & & 37,3 & 132,8 \\
\hline & & & & 37,3 & 154,1 \\
\hline & & & & 37,3 & 184,2 \\
\hline
\end{tabular}

$\mathrm{Q}_{\mathrm{fd}}$ : vazão afluente ao FRD (rotâmetro);

Turb. AF: turbidez da água filtrada (turbidímetro de bancada);

P1 e P2: piezômetros localizados no início e no final do FRD, respectivamente.

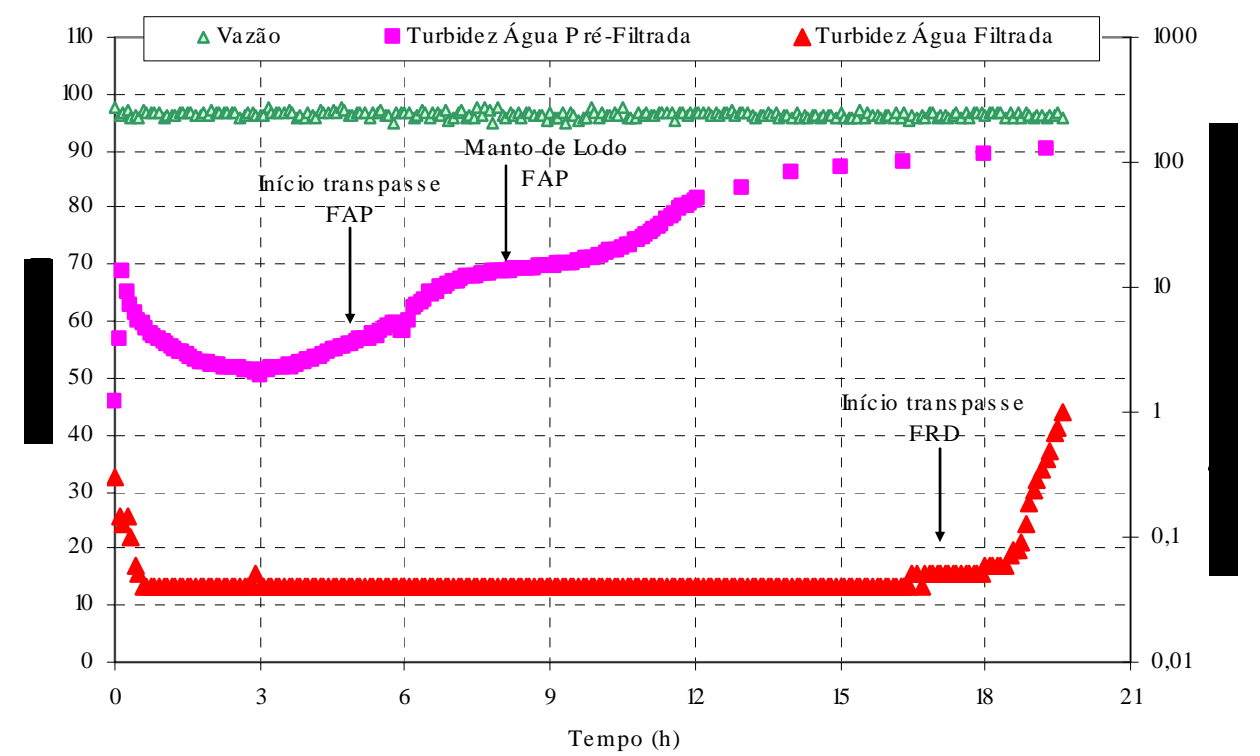

Figura C14.1 - Variações da vazão total afluente ao sistema de dupla filtração e da turbidez das águas pré-filtrada e filtrada no ensaio 14 - Turbidímetros de Escoamento Contínuo 


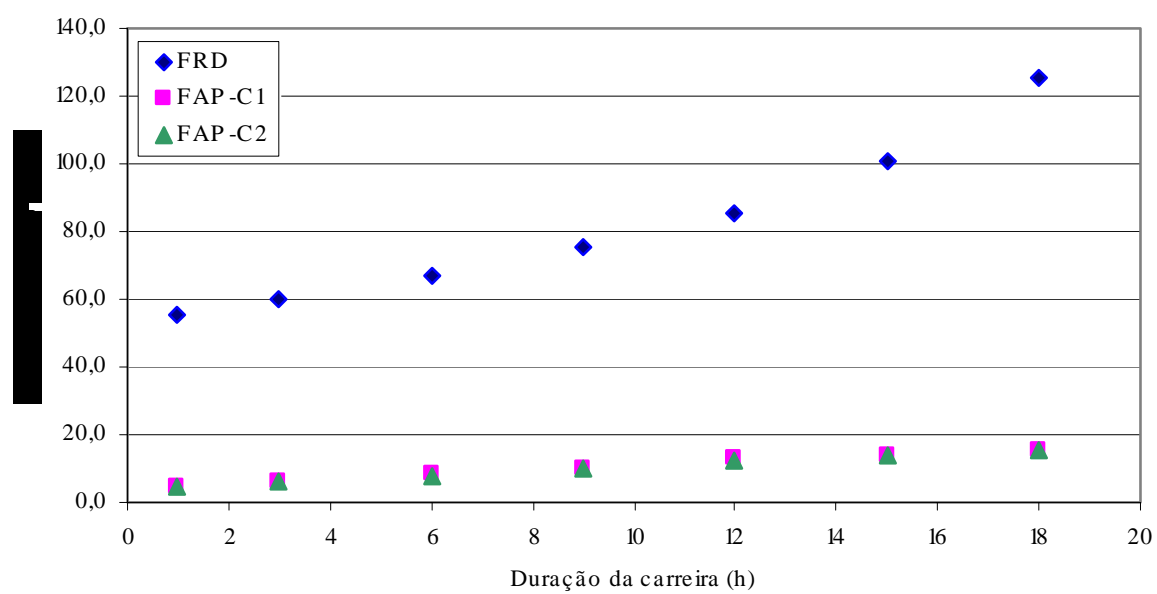

Figura C14.2 - Perda de carga nos filtros ascendente de pedregulho (duas câmaras de filtração) e descendente durante o ensaio 14 de dupla filtração

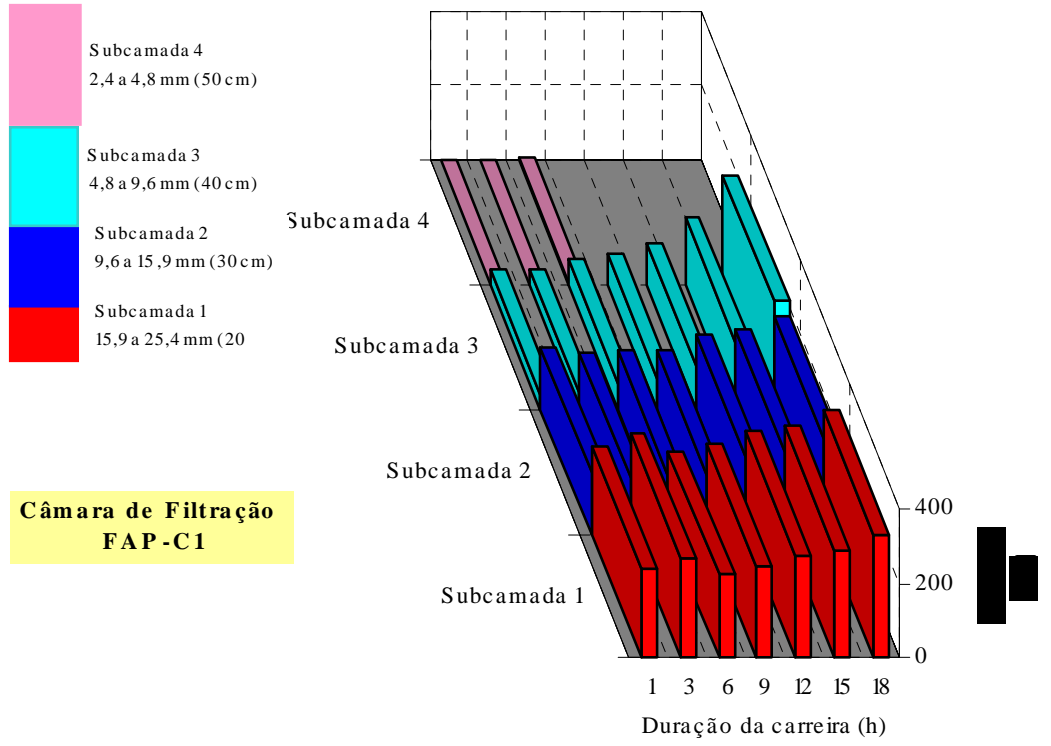

Figura C14.3 - Turbidez ao longo do meio filtrante da câmara de filtração 1 do FAP durante o ensaio 14 de dupla filtração 


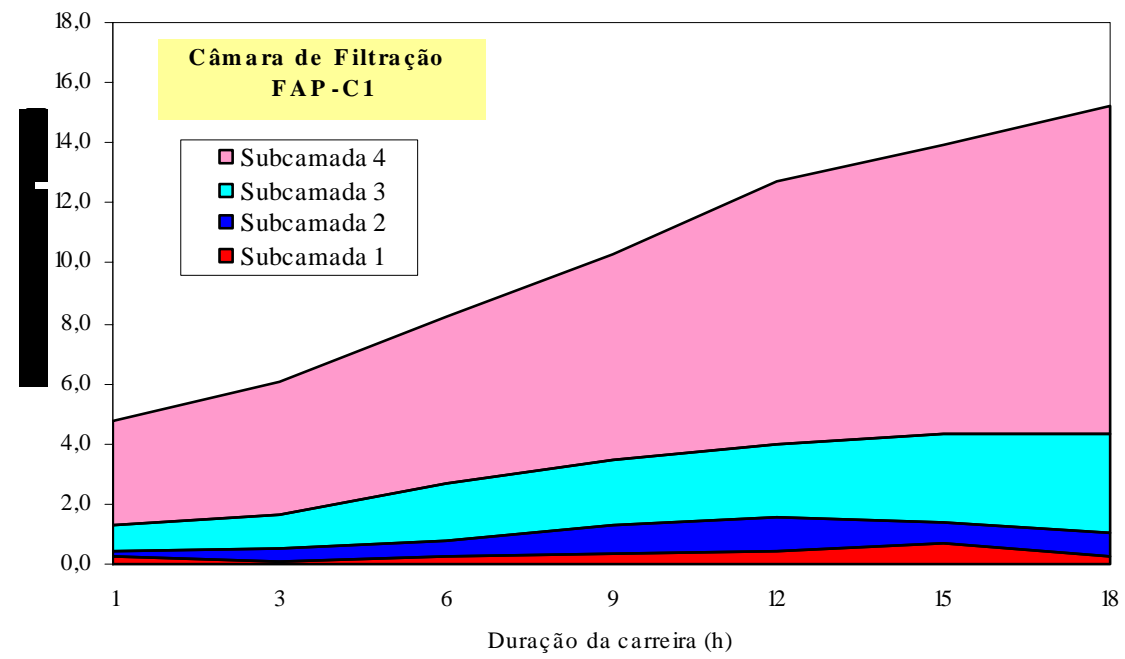

Figura C14.4 - Perda de carga ao longo do meio filtrante da câmara de filtração 1 do FAP durante o ensaio 14 de dupla filtração

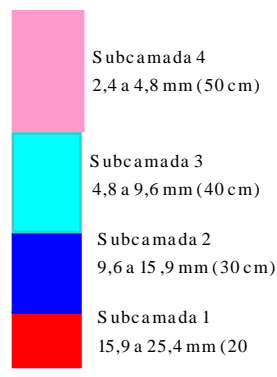

Câma ra de Filtração

$$
\text { F A P - C } 2
$$

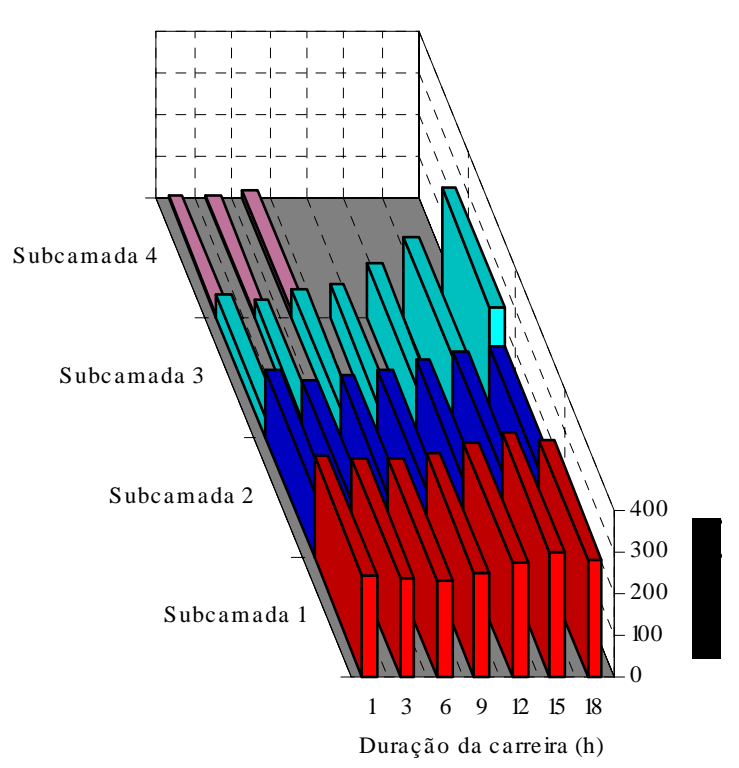

Figura C14.5 - Turbidez ao longo do meio filtrante da câmara de filtração 2 do FAP durante o ensaio 14 de dupla filtração 


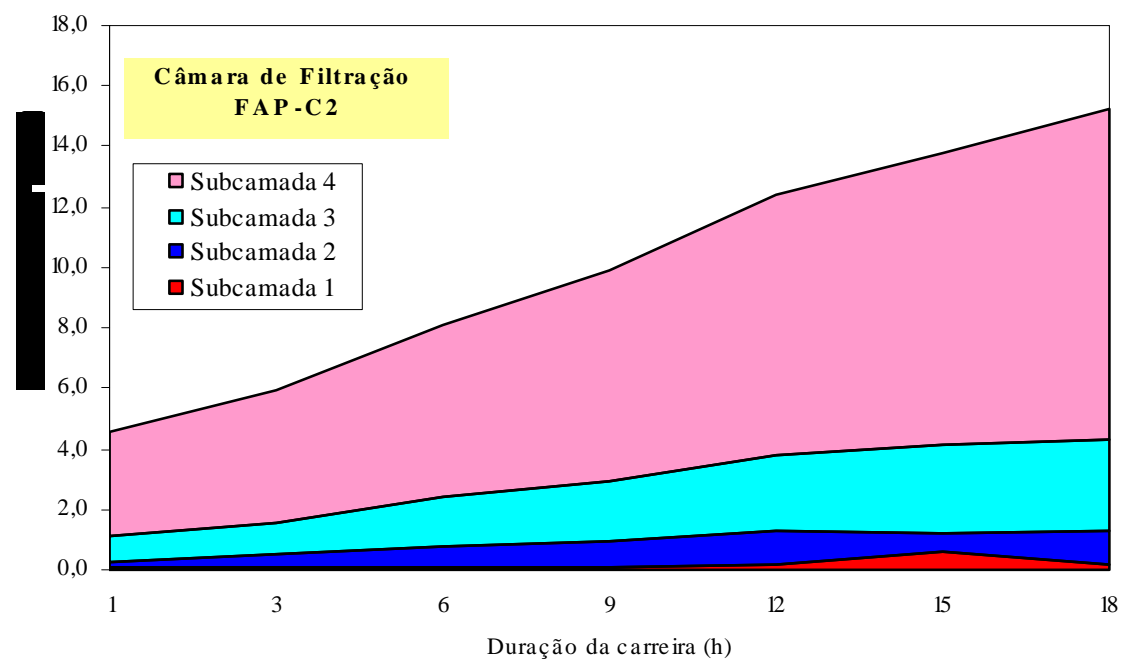

Figura C14.6 - Perda de carga ao longo do meio filtrante da câmara de filtração 2 do FAP durante o ensaio 14 de dupla filtração 


\section{ENSAIO 15 DE DUPLA FILTRAÇÃO}

Tabela C15.1 - Condições do ensaio 15 de dupla filtração - Sistema 2 e Água de estudo Tipo II

\begin{tabular}{|c|c|c|}
\hline \multicolumn{3}{|c|}{ Água de Estudo } \\
\hline \multicolumn{2}{|l|}{ Turbidez (uT) } & 299 a 315 \\
\hline \multicolumn{2}{|l|}{$\mathrm{pH}$} & 7,48 a 7,60 \\
\hline \multicolumn{2}{|l|}{ Alcalinidade $\left(\mathrm{mg} / \mathrm{L} \mathrm{CaCO}_{3}\right)$} & 25,0 \\
\hline \multicolumn{2}{|l|}{ Temperatura $\left({ }^{\circ} \mathrm{C}\right)$} & 19,0 a 24,5 \\
\hline \multicolumn{2}{|l|}{ Potencial Zeta (mV) } & - \\
\hline \multicolumn{3}{|c|}{ Coagulação } \\
\hline \multicolumn{2}{|l|}{ Dosagem sulfato de alumínio (mg/L AL) } & 2,29 \\
\hline \multicolumn{2}{|c|}{ Dosagem sulfato de alumínio (mg/L produto comercial líquido) } & 60 \\
\hline \multicolumn{2}{|l|}{ pH de coagulação } & 6,80 a 6,89 \\
\hline \multicolumn{2}{|l|}{ Potencial Zeta (mV) } & $-0,1 \pm 0,3$ \\
\hline \multicolumn{2}{|l|}{ FLA (areia tipo III) - Turbidez após 30 min de filtração } & 0,94 \\
\hline \multicolumn{3}{|c|}{ Taxas de Filtração } \\
\hline CAP com orifício de & média & desvio padrão \\
\hline Vazão Total (L/h) - medidor eletromagnético & 96,3 & 1,30 \\
\hline Taxa de Filtração FAP $\left(\mathrm{m}^{3} / \mathrm{m}^{2} . d\right)$ & 177,8 & 2,4 \\
\hline Vazão FRD (L/h) - rotâmetro & 24 & - \\
\hline Taxa de Filtração FRD $\left(\mathrm{m}^{3} / \mathrm{m}^{2} . \mathrm{d}\right)$ & 184,8 & - \\
\hline
\end{tabular}


Tabela C15.2 - Resultados do ensaio 15 de dupla filtração - Sistema 2 e Água de estudo Tipo II

\begin{tabular}{|c|c|c|c|c|c|c|c|c|c|c|c|c|c|c|c|c|c|c|c|c|c|c|c|c|c|}
\hline \multirow{3}{*}{$\begin{array}{c}\text { Duração } \\
\text { (h) }\end{array}$} & \multirow{3}{*}{$\begin{array}{c}\mathrm{Q}_{\mathrm{T}} \\
(\mathrm{L} / \mathrm{h})\end{array}$} & \multirow{3}{*}{$\begin{array}{c}\text { Turb. } \\
\mathrm{AE}(\mathrm{uT})\end{array}$} & \multirow{3}{*}{$\begin{array}{l}\mathrm{pH} \\
\mathrm{AE} \\
\end{array}$} & \multirow{3}{*}{$\begin{array}{c}\mathrm{pH}^{\mathrm{pH}} \\
\text { Coag. }\end{array}$} & \multirow{3}{*}{$\begin{array}{l}\text { Temp. } \\
\text { (oC) }\end{array}$} & \multicolumn{20}{|c|}{ Filtro Ascendente de Pedregulho - FAP } \\
\hline & & & & & & \multicolumn{10}{|c|}{ Turbidez - Turbidímetro de Bancada (TB) (uT) } & \multicolumn{10}{|c|}{ Perda de Carga Corrigida $25^{\circ} \mathrm{C}(\mathrm{cm})$} \\
\hline & & & & & & C1-1 & C2-1 & C3-1 & $\mathrm{C}-1$ & $\mathrm{C} 1-2$ & C2-2 & $\mathrm{C} 3-$ & & & $\mathrm{Cl}+\mathrm{C2}$ & P1-1 & P2-1 & Р3-1 & $\mathrm{P} 4-1$ & P5-1 & $\mathrm{P} 1-2$ & P2-2 & P3-2 & $\mathrm{P} 42$ & P5-2 \\
\hline 1,0 & 97,72 & 308 & 7,54 & 6,89 & 22,0 & 258 & 171 & 50,2 & 5,12 & 281 & 171 & 48, & & & 7,05 & 229,8 & 229,6 & 229,4 & 228,7 & 225,6 & 229,7 & 229,5 & 229,3 & 228,8 & 225,6 \\
\hline 3,0 & 96,29 & 312 & 7,51 & 6,87 & 24,5 & 272 & 174 & 52,8 & 7,14 & 282 & 162 & 45, & & & 8,18 & 245,9 & 245,7 & 245,4 & 244,2 & 239,6 & 245,6 & 245,5 & 245,2 & 244,3 & 239,6 \\
\hline 4,5 & 96,93 & & & & 24,5 & & & & & & & & & & & 246,6 & 246,5 & 246,2 & 245,3 & 239,6 & 246,4 & 246,3 & 246,2 & 245,3 & 239,6 \\
\hline 5,0 & 96,61 & & & & 24,0 & & & & & & & & & & & 241,3 & 240,8 & 240,5 & 240,2 & 236,8 & 240,8 & 240,6 & 240,5 & 239,5 & 236,8 \\
\hline 6,0 & 96,29 & 307 & & & 23,5 & 255 & 163 & $\begin{array}{r}38,2 \\
\end{array}$ & 21,4 & 267 & 149 & 68, & & & 7,29 & 239,3 & 238,9 & $\begin{array}{r}238,6 \\
\end{array}$ & 237,9 & 233,9 & 238,9 & 238,8 & 238,5 & 237,3 & 233,9 \\
\hline 9,0 & 95,97 & 315 & & & 22,0 & 231 & 149 & 96,8 & 21,5 & 239 & 167 & 60, & & & 11,4 & 232,3 & 232,1 & 231,8 & 230,4 & $\begin{array}{r}225,6 \\
\end{array}$ & $\begin{array}{r}232,1 \\
\end{array}$ & 231,9 & 231,7 & 229,9 & 225,6 \\
\hline 9,5 & 96,29 & & & & 21,5 & & & & & & & & & & & 227,4 & 227,1 & $\begin{array}{r}226,7 \\
\end{array}$ & 226,1 & $\begin{array}{r}222,9 \\
\end{array}$ & 227,0 & 226,9 & 226,7 & 225,8 & $\begin{array}{r}222,9 \\
2\end{array}$ \\
\hline 12,0 & 95,13 & 305 & 7,600 & 6,688 & 21,0 & 235 & 160 & 62,8 & 10,8 & 243 & 151 & 65, & & & 5,22 & 226,3 & 226,1 & 225,8 & 224,7 & 220,2 & 226,2 & 226,0 & 225,8 & 224,4 & 220,2 \\
\hline 13,5 & 95,97 & & & & 20,0 & & & & & & & & & & & 223,0 & 222,0 & 221,6 & 220,2 & 214,9 & 222,0 & 221,9 & 221,6 & 220,0 & 214,9 \\
\hline 14,0 & 95,44 & & & & 20,0 & & & & & & & & & & & 219,4 & 219,3 & $\begin{array}{r}219,1 \\
\end{array}$ & 218,4 & 214,9 & 219,3 & 219,3 & 219,2 & 218,2 & 214,9 \\
\hline 15,0 & 97,13 & 301 & & & 20,0 & 235 & 177 & 59,9 & 7,51 & 247 & 178 & 76, & & & 8,14 & 219,9 & 219,7 & 219,3 & 218,5 & 214,9 & 219,8 & 219,6 & 219,4 & 218,5 & 214,9 \\
\hline 18,0 & 96,93 & & 7,48 & 6,80 & 19,5 & 259 & 160 & 84,3 & 17,3 & 246 & 148 & 59, & & & 10,7 & 219,9 & 219,8 & 219,4 & 217,8 & 212,3 & 219,8 & 219,7 & 219,3 & 217,8 & 212,3 \\
\hline 18,5 & 97,95 & & & & 20,0 & & & & & & & & & & & 218,9 & 218,8 & 218,6 & 218,2 & 214,9 & 218,9 & 218,8 & 218,6 & 218,2 & 214,9 \\
\hline 21,0 & 97,72 & 300 & & & 19,0 & 248 & 160 & 67,5 & 8,10 & 264 & 163 & 60, & & & 7,47 & 216,2 & 216,0 & 215,7 & 214,5 & 209,8 & 216,0 & 215,9 & 215,7 & 214,7 & 209,8 \\
\hline 22,5 & 96,93 & & & & 20,0 & & & & & & & & & & & 223,0 & 222,8 & 222,4 & 220,8 & 214,9 & 222,8 & 222,7 & 222,3 & 220,8 & 214,9 \\
\hline 23,0 & 96,61 & & & & 21,5 & & & & & & & & & & & 227,5 & 227,0 & 226,8 & 226,1 & 222,9 & 227,0 & 226,9 & 226,8 & 226,3 & 222,9 \\
\hline 24,0 & 96,29 & 304 & 7,58 & 6,84 & 22,0 & 248 & 168 & 62,7 & 6,82 & 261 & 152 & 58, & & & 8,12 & 231,5 & 231,2 & 231,0 & 229,8 & 225,6 & 231,2 & 231,1 & 231,0 & 229,9 & $\begin{array}{r}225,6 \\
\end{array}$ \\
\hline 27,0 & 96,29 & 302 & & & 23,0 & 235 & 171 & $\begin{array}{r}6,8,8 \\
\end{array}$ & 7,13 & 247 & 163 & 61, & & & 9,12 & 239,8 & 239,6 & 239,1 & 237,3 & 231,1 & 239,6 & 239,5 & 239,0 & 237,4 & 231,1 \\
\hline 27,5 & 95,97 & & & & 23,5 & & & & & & & & & & & 238,4 & 238,1 & 237,9 & 237,3 & 233,9 & 238,0 & 237,9 & 237,9 & 237,3 & $\begin{array}{r}233,9 \\
\end{array}$ \\
\hline 30,0 & 95,13 & 299 & & & 24,0 & 241 & 178 & 66,5 & 8,13 & 258 & 161 & 68, & & & 9,11 & 243,8 & 243,5 & 243,2 & 241,7 & 236,8 & 243,5 & 243,3 & 243,2 & 241,8 & 236,8 \\
\hline 31,0 & 95,13 & & & & 24,0 & & & & & & & & & & & 244,2 & 244,1 & 243,6 & 242,1 & 236,8 & 244,1 & 243,9 & 243,5 & 243,2 & 236,8 \\
\hline
\end{tabular}


Tabela C15.2 - Continuação

\begin{tabular}{|c|c|c|c|c|c|c|c|c|c|c|}
\hline \multirow{2}{*}{$\begin{array}{c}\text { Duração } \\
\text { (h) }\end{array}$} & \multicolumn{10}{|c|}{ FAP - Perda de Carga Lida (cm) } \\
\cline { 2 - 11 } & P1-1 & P2-1 & P3-1 & P4-1 & P5-1 & P1-2 & P2-2 & P3-2 & P4-2 & P5-2 \\
\hline 1,0 & 247,8 & 247,6 & 247,4 & 246,7 & 243,3 & 247,7 & 247,5 & 247,3 & 246,8 & 243,3 \\
\hline 3,0 & 249,7 & 249,5 & 249,2 & 247,9 & 243,3 & 249,4 & 249,3 & 249,0 & 248,0 & 243,3 \\
\hline 4,5 & 250,4 & 250,3 & 250,0 & 249,1 & 243,3 & 250,2 & 250,1 & 250,0 & 249,1 & 243,3 \\
\hline 5,0 & 248,0 & 247,5 & 247,2 & 246,8 & 243,3 & 247,5 & 247,3 & 247,1 & 246,1 & 243,3 \\
\hline 6,0 & 248,9 & 248,5 & 248,2 & 247,5 & 243,3 & 248,5 & 248,4 & 248,1 & 246,8 & 243,3 \\
\hline 9,0 & 250,5 & 250,3 & 250,0 & 248,5 & 243,3 & 250,3 & 250,1 & 249,9 & 248,0 & 243,3 \\
\hline 9,5 & 248,2 & 247,9 & 247,5 & 246,8 & 243,3 & 247,8 & 247,7 & 247,5 & 246,5 & 243,3 \\
\hline 12,0 & 250,0 & 249,8 & 249,5 & 248,3 & 243,3 & 249,9 & 249,7 & 249,5 & 247,9 & 243,3 \\
\hline 13,5 & 252,4 & 251,3 & 250,9 & 249,3 & 243,3 & 251,3 & 251,2 & 250,8 & 249,0 & 243,3 \\
\hline 14,0 & 248,4 & 248,3 & 248,0 & 247,2 & 243,3 & 248,3 & 248,2 & 248,1 & 247,0 & 243,3 \\
\hline 15,0 & 248,9 & 248,7 & 248,3 & 247,3 & 243,3 & 248,8 & 248,6 & 248,4 & 247,3 & 243,3 \\
\hline 18,0 & 252,0 & 251,8 & 251,4 & 249,5 & 243,3 & 251,8 & 251,7 & 251,3 & 249,5 & 243,3 \\
\hline 18,5 & 247,8 & 247,7 & 247,5 & 247,0 & 243,3 & 247,8 & 247,7 & 247,5 & 247,0 & 243,3 \\
\hline 21,0 & 250,7 & 250,5 & 250,2 & 248,8 & 243,3 & 250,5 & 250,4 & 250,1 & 249,0 & 243,3 \\
\hline 22,5 & 252,4 & 252,2 & 251,7 & 249,9 & 243,3 & 252,2 & 252,1 & 251,6 & 250,0 & 243,3 \\
\hline 23,0 & 248,3 & 247,8 & 247,6 & 246,8 & 243,3 & 247,8 & 247,7 & 247,6 & 247,0 & 243,3 \\
\hline 24,0 & 249,7 & 249,4 & 249,1 & 247,9 & 243,3 & 249,4 & 249,2 & 249,1 & 248,0 & 243,3 \\
\hline 27,0 & 252,5 & 252,2 & 251,7 & 249,8 & 243,3 & 252,2 & 252,1 & 251,6 & 249,9 & 243,3 \\
\hline 27,5 & 248,0 & 247,7 & 247,5 & 246,8 & 243,3 & 247,6 & 247,4 & 247,5 & 246,8 & 243,3 \\
\hline 30,0 & 250,5 & 250,2 & 249,9 & 248,4 & 243,3 & 250,2 & 250,0 & 249,9 & 248,5 & 243,3 \\
\hline 31,0 & 251,0 & 250,8 & 250,3 & 248,8 & 243,3 & 250,8 & 250,6 & 250,2 & 249,9 & 243,3 \\
\hline & & & & & & & \\
\hline
\end{tabular}

$\mathrm{Q}_{\mathrm{T}}$ : vazão total afluente ao Sistema de Dupla Filtração (medidor de vazão eletromagnético);

Turb. AE: turbidez da água de estudo (turbidímetro de bancada);

pH AE: pH da água de estudo;

pH Coag.: pH de coagulação;

Ci-1: amostra coletada no final da subcamada i do meio filtrante da câmara de filtração 1 do FAP;

Ci-2: amostra coletada no final da subcamada i do meio filtrante da câmara de filtração 2 do FAP;

C1+C2: amostra de água pré-filtrada global (efluentes das câmaras de filtração 1 e 2 da FAP);

Pi-1: piezômetro i localizado na câmara de filtração 1 do FAP;

Pi-2: piezômetro i localizado na câmara de filtração 2 do FAP;

$\square$ : execução de DFI nas duas câmaras do FAP. 
Tabela C15.2 - Continuação

\begin{tabular}{|c|c|c|c|c|c|c|c|}
\hline \multirow{3}{*}{$\begin{array}{c}\text { Duração } \\
\text { (h) }\end{array}$} & \multirow{3}{*}{$\begin{array}{l}\text { Temp. } \\
\text { (oC) }\end{array}$} & \multicolumn{6}{|c|}{ Filtro Rápido Descendente - FRD } \\
\hline & & \multirow{2}{*}{$\begin{array}{l}\text { Qfd } \\
(\mathrm{L} / \mathrm{h})\end{array}$} & \multirow{2}{*}{$\begin{array}{c}\text { Turbidez - TB (uT) } \\
\text { AF }\end{array}$} & \multicolumn{2}{|c|}{ Perda de Carga Corrigida $25^{\circ} \mathrm{C}(\mathrm{cm})$} & \multicolumn{2}{|c|}{ Perda de Carga Lida (cm) } \\
\hline & & & & P1 & P2 & $\mathrm{P} 1$ & P2 \\
\hline 1,0 & 22,0 & 24,0 & 0,18 & 33,6 & 93,1 & 36,2 & 100,4 \\
\hline 3,0 & 24,5 & 24,0 & 0,24 & 35,7 & 102,0 & 36,2 & 103,6 \\
\hline 4,5 & 24,5 & 24,0 & & 35,7 & 103,9 & 36,2 & 105,5 \\
\hline 5,0 & 24,0 & 24,0 & & 35,2 & 107,0 & 36,2 & 110,0 \\
\hline 6,0 & 23,5 & 24,0 & 0,35 & 34,8 & 109,1 & 36,2 & 113,5 \\
\hline 9,0 & 22,0 & 24,0 & 0,28 & 33,6 & 115,9 & 36,2 & 125,0 \\
\hline 9,5 & 21,5 & 24,0 & & 33,2 & 120,0 & 36,2 & 131,0 \\
\hline 12,0 & 21,0 & 24,0 & 0,54 & 32,8 & 125,5 & 36,2 & 138,7 \\
\hline 13,5 & 20,0 & 24,0 & & 32,0 & 128,1 & 36,2 & 145,0 \\
\hline 14,0 & 20,0 & 24,0 & & 32,0 & 129,4 & 36,2 & 146,5 \\
\hline 15,0 & 20,0 & 24,0 & 0,34 & 32,0 & 130,7 & 36,2 & 148,0 \\
\hline 18,0 & 19,5 & 24,0 & 0,58 & 31,6 & 140,0 & 36,2 & 160,4 \\
\hline 18,5 & 20,0 & 24,0 & & 32,0 & 144,7 & 36,2 & 163,8 \\
\hline 21,0 & 19,0 & 24,0 & 0,28 & 31,2 & 149,6 & 36,2 & 173,5 \\
\hline 22,5 & 20,0 & 24,0 & & 32,0 & 155,5 & 36,2 & 176,0 \\
\hline 23,0 & 21,5 & 24,0 & & 33,2 & 164,0 & 36,2 & 179,0 \\
\hline 24,0 & 22,0 & 24,0 & 0,18 & 33,6 & 168,0 & 36,2 & 181,2 \\
\hline 27,0 & 23,0 & 24,0 & 0,20 & 34,4 & 183,3 & 36,2 & 193,0 \\
\hline 27,5 & 23,5 & 24,0 & & 34,8 & 196,6 & 36,2 & 204,5 \\
\hline 30,0 & 24,0 & 24,0 & 0,35 & 35,2 & 204,5 & 36,2 & 210,2 \\
\hline 31,0 & 24,0 & 24,0 & & 35,2 & 207,5 & 36,2 & 213,2 \\
\hline
\end{tabular}

$\mathrm{Q}_{\mathrm{fd}}$ : vazão afluente ao FRD (rotâmetro);

Turb. AF: turbidez da água filtrada (turbidímetro de bancada);

P1 e P2: piezômetros localizados no início e no final do FRD, respectivamente. 


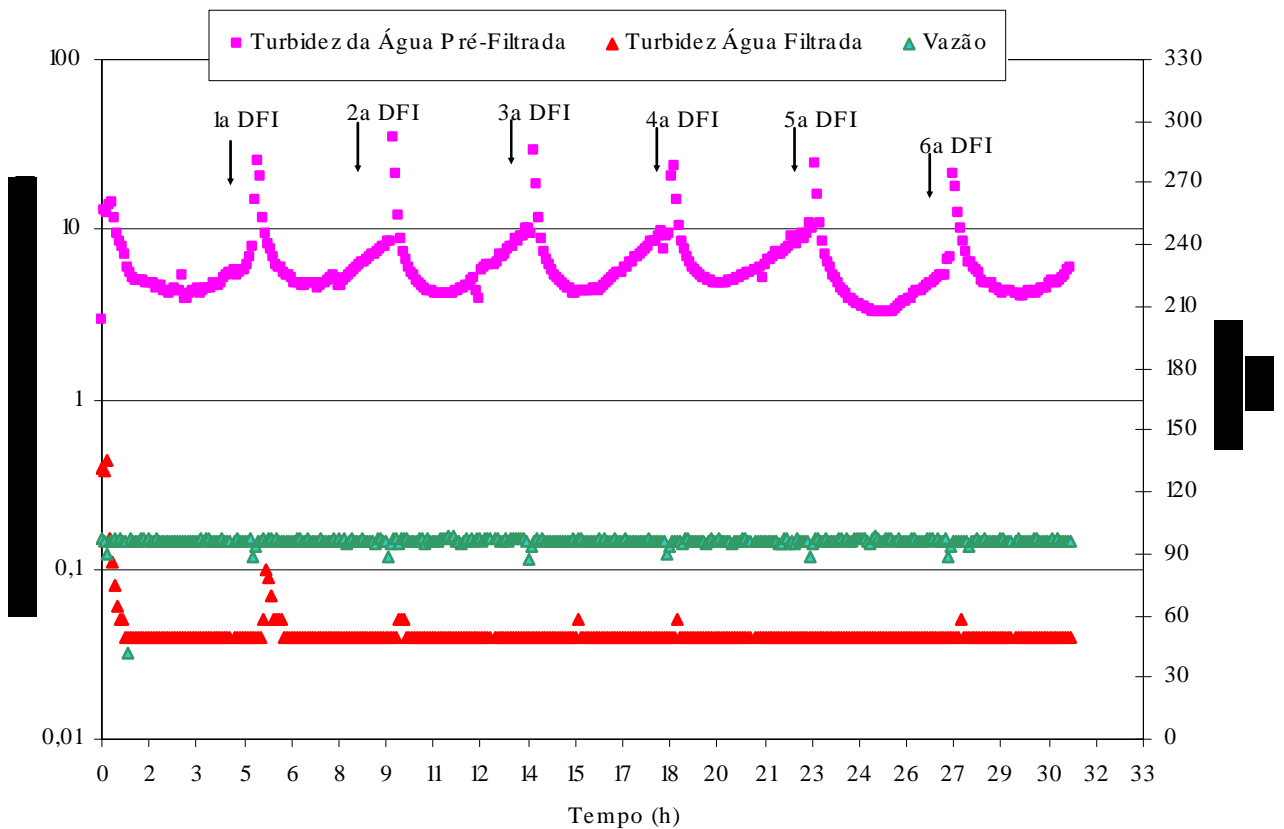

Figura C15.1 - Variações da vazão total afluente ao sistema de dupla filtração e da turbidez das águas de estudo, pré-filtrada e filtrada no ensaio 15 - Turbidímetros de Escoamento Contínuo

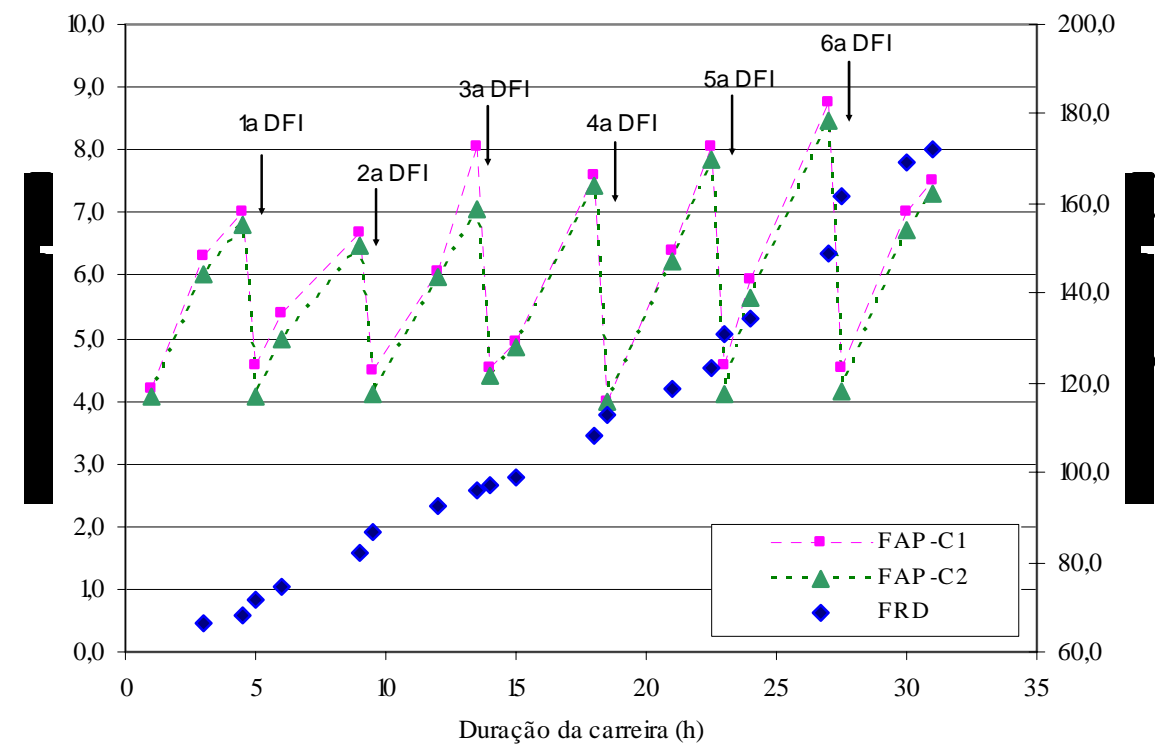

Figura C15.2 - Perda de carga nos filtros ascendente de pedregulho (duas câmaras de filtração) e descendente durante o ensaio 15 de dupla filtração 


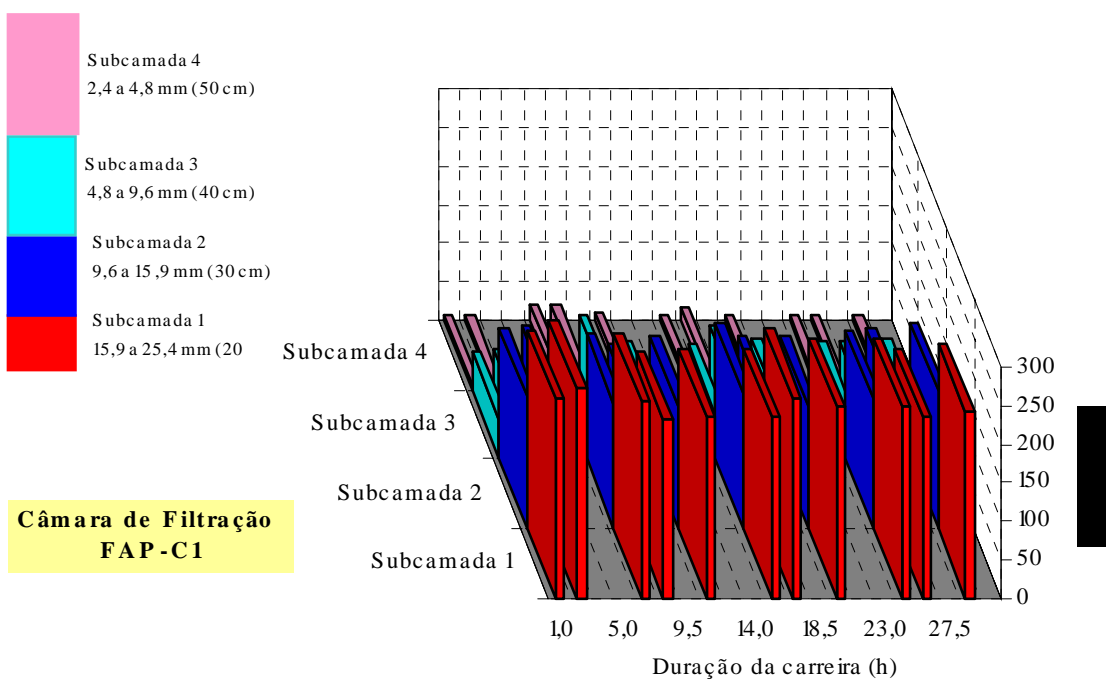

Figura C15.3 - Turbidez ao longo do meio filtrante da câmara de filtração 1 do FAP durante o ensaio 15 de dupla filtração

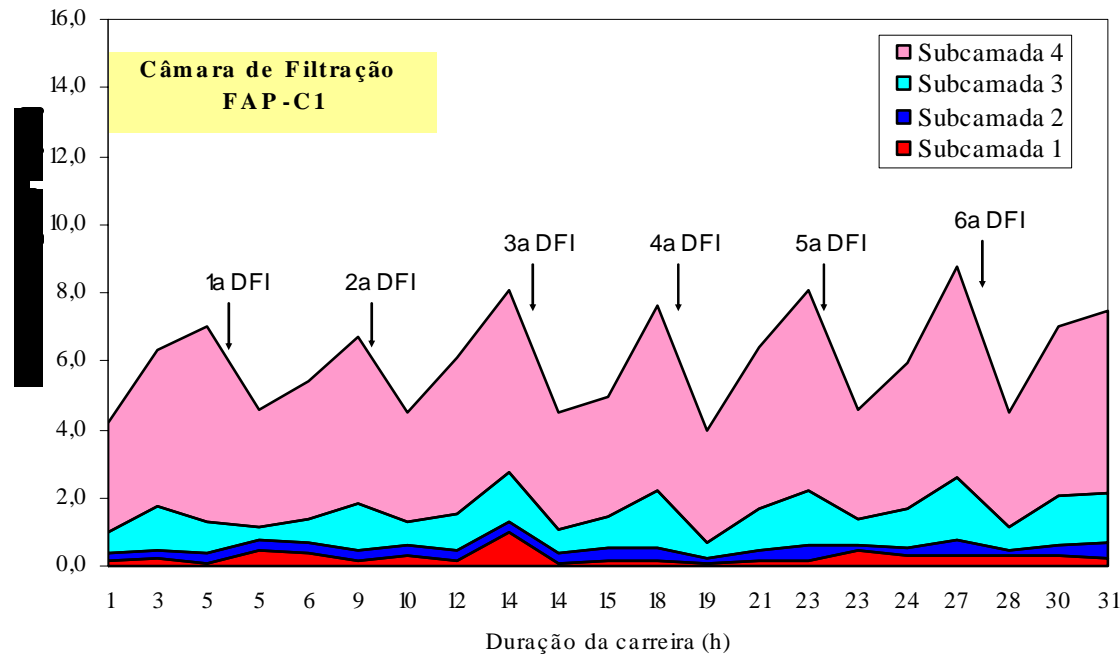

Figura C15.4 - Perda de carga ao longo do meio filtrante da câmara de filtração 1 do FAP durante o ensaio 15 de dupla filtração 


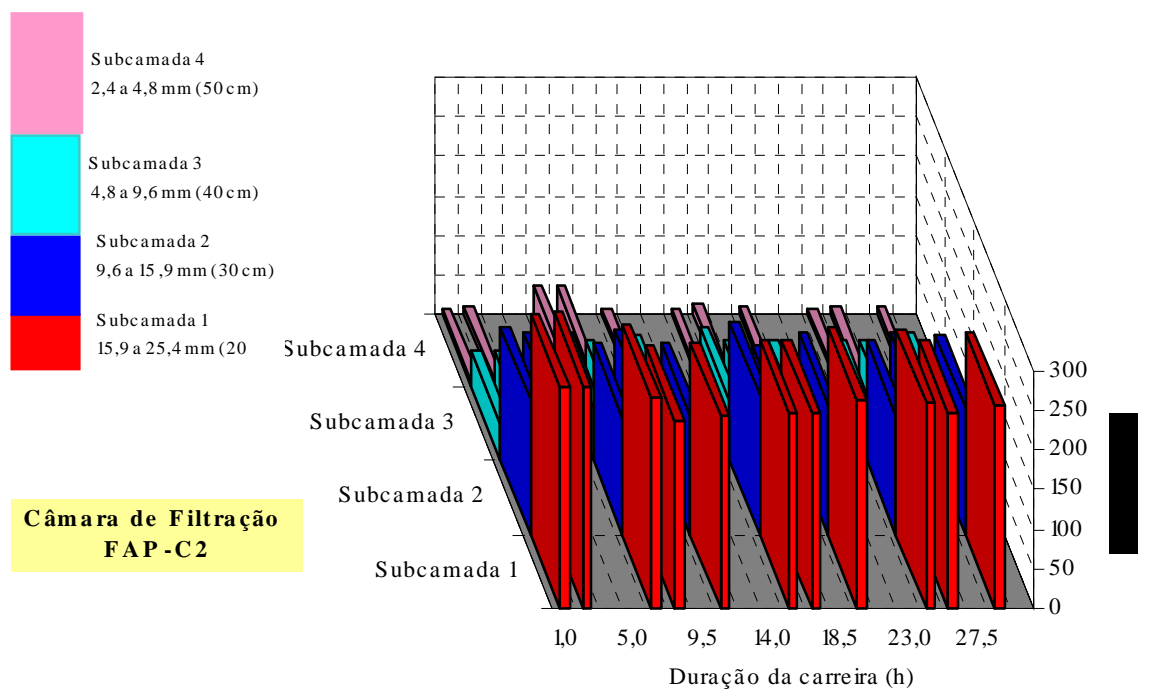

Figura C15.5 - Turbidez ao longo do meio filtrante da câmara de filtração 2 do FAP durante o ensaio 15 de dupla filtração

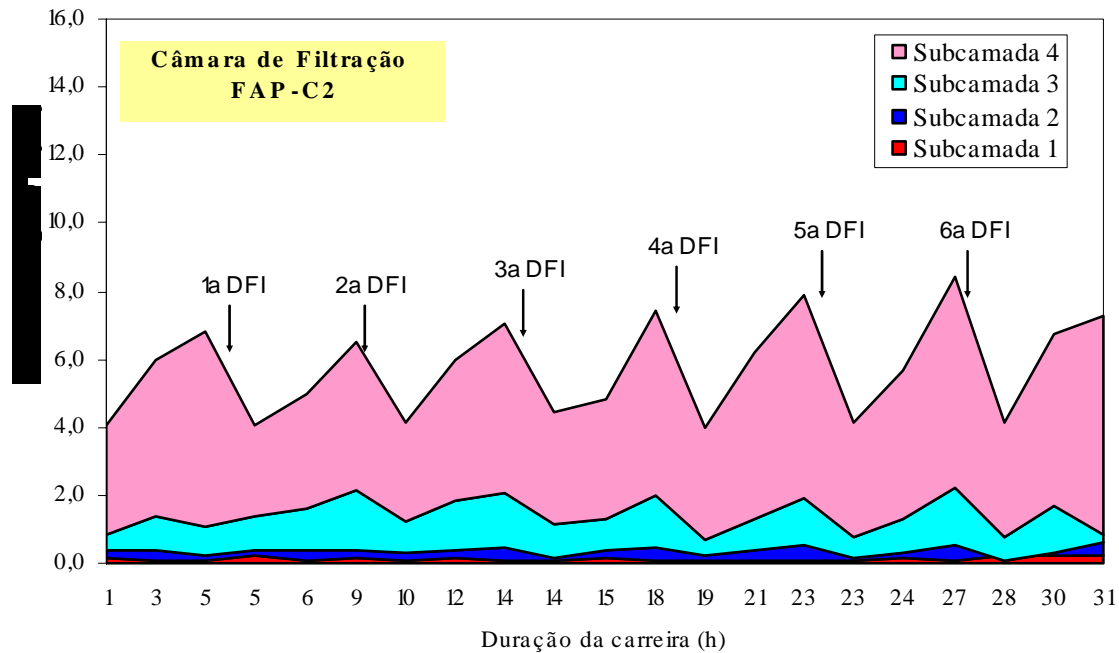

Figura C15.6 - Perda de carga ao longo do meio filtrante da câmara de filtração 2 do FAP durante o ensaio 15 de dupla filtração 
ANEXO D 


\section{Parte D1}

\section{CÁLCULO DA PRODUÇÃO EFETIVA NOS ENSAIOS DE DUPLA FILTRAÇÃO SISTEMA DE DUPLA FILTRAÇÃO 1}

\section{FILTRO ASCENDENTE DE AREIA GROSSA - FILTRO RÁPIDO DESCENDENTE}

Tabela D1.1 - Cálculo da produção efetiva de água no ensaio 1 de dupla filtração Sistema 1 e Água Tipo I

\begin{tabular}{|c|c|c|}
\hline Ensaio 1 & \multicolumn{2}{|c|}{ Encerramento } \\
\hline \multirow{2}{*}{$\begin{array}{l}\text { Produção efetiva de água calculada com base no item } 4.9 .4 \text { b.1) } \\
\text { (transpasse no FAAG após 50,5 h de ensaio) }\end{array}$} & \multicolumn{2}{|c|}{ Tempo de ensaio $=72 \mathrm{~h}$} \\
\hline & Símbolo & Valor \\
\hline Duração do ensaio (h) & $\mathrm{DF}$ & 72 \\
\hline Taxa de filtração FAAG $\left(\mathrm{m}^{3} / \mathrm{m}^{2} . \mathrm{d}\right)$ & $\mathrm{TF}$ & 120 \\
\hline Área total FAAG $\left(\mathrm{m}^{2}\right)$ & $\mathrm{A}_{\mathrm{FA}}$ & 0,013 \\
\hline Perda de carga prevista FAAG (m) & $\Delta \mathrm{H}_{\text {limite }} \mathrm{FA}$ & 1,20 \\
\hline Perda de carga final no FAAG $25^{\circ} \mathrm{C}(\mathrm{m})$ & $\Delta \mathrm{H}_{\text {final }} \mathrm{FA}$ & $<1,20$ \\
\hline Taxa de lavagem do FAAG - ar e água $\left(\mathrm{m}^{3} / \mathrm{m}^{2} . \mathrm{d}\right)$ & $\mathrm{TL}_{\mathrm{FA}}$ & 720 \\
\hline Duração da lavagem com ar e água (min) & $\mathrm{DL}_{\mathrm{FA}}$ & 5 \\
\hline Taxa de lavagem do FAAG - água $\left(\mathrm{m}^{3} / \mathrm{m}^{2} . \mathrm{d}\right)$ & $\mathrm{TL}_{\mathrm{FA}}$ & 2160 \\
\hline Duração da lavagem somente com água (min) & $\mathrm{DL}_{\mathrm{FA}}$ & 10 \\
\hline Taxa de DFF $\left(\mathrm{m}^{3} / \mathrm{m}^{2} . \mathrm{d}\right)$ & $\mathrm{T}_{\mathrm{DFF}}$ & 960 \\
\hline Duração da DFF (min) & $\mathrm{D}_{\mathrm{DFF}}$ & 1,5 \\
\hline Taxa de DFI $\left(\mathrm{m}^{3} / \mathrm{m}^{2} . \mathrm{d}\right)$ & $\mathrm{T}_{\mathrm{DFI}}$ & 0 \\
\hline Duração da DFI (min) & $\mathrm{D}_{\mathrm{DFI}}$ & 0 \\
\hline Número de DFI em 72 h & $\mathrm{N}_{\mathrm{DFI}}$ & 0 \\
\hline Taxa de filtração FRD $\left(\mathrm{m}^{3} / \mathrm{m}^{2} . \mathrm{d}\right)$ & $\mathrm{TF}_{\mathrm{FRD}}$ & 187,2 \\
\hline Área total FRD $\left(\mathrm{m}^{2}\right)$ & $A_{F R D}$ & 0,0065 \\
\hline Perda de carga prevista FRD (m) & $\Delta \mathrm{H}_{\text {limite }} \mathrm{FRD}$ & 1,80 \\
\hline Perda de carga final no FRD $25^{\circ} \mathrm{C}(\mathrm{m})$ & $\Delta \mathrm{H}_{\text {final }}$ FRD (estimada) & 1,00 \\
\hline Taxa de lavagem do FRD $\left(\mathrm{m}^{3} / \mathrm{m}^{2} . \mathrm{d}\right)$ & $\mathrm{TL}_{\mathrm{FRD}}$ & 1152 \\
\hline Duração da lavagem FRD (min) & $\mathrm{DL}_{\mathrm{FRD}}$ & 10 \\
\hline Produção efetiva de água $\left(\mathrm{m}^{3} / \mathrm{m}^{2}\right)$ & $\mathrm{PE}$ & 339,3 \\
\hline Produção total de água $\left(\mathrm{m}^{3} / \mathrm{m}^{2}\right)$ & PT & 360 \\
\hline Consumo de água para lavagem do FAAG $\left(\mathrm{m}^{3} / \mathrm{m}^{2}\right)$ & $\mathrm{L}_{\mathrm{FA}}$ & 17,5 \\
\hline Consumo de água na descarga de fundo final $\left(\mathrm{m}^{3} / \mathrm{m}^{2}\right)$ & DFF & 1,0 \\
\hline Consumo de água nas descargas de fundo intermediárias $\left(\mathrm{m}^{3} / \mathrm{m}^{2}\right)$ & DFI & 0 \\
\hline Consumo de água para lavagem do filtro descendente $\left(\mathrm{m}^{3} / \mathrm{m}^{2}\right)$ & $\mathrm{L}_{\mathrm{FRD}}$ & 2,2 \\
\hline Porcentagem de água perdida (\%) & $P$ & 5,8 \\
\hline Eficiência na produção de água filtrada (\%) & $\mathrm{E}$ & 94,2 \\
\hline
\end{tabular}


Tabela D1.2 - Cálculo da produção efetiva de água no ensaio 2 de dupla filtração Sistema 1 e Água Tipo I

\begin{tabular}{|c|c|c|}
\hline Ensaio 2 & \multicolumn{2}{|c|}{ Encerramento } \\
\hline \multirow{2}{*}{$\begin{array}{l}\text { Produção efetiva de água calculada com base no item } 4.9 .4 \text { a) } \\
\text { (transpasse no FAAG após } 11 \text { h de ensaio) }\end{array}$} & \multicolumn{2}{|c|}{ Transpasse no FRD } \\
\hline & Símbolo & Valor \\
\hline Duração do ensaio (h) & $\mathrm{DF}$ & 19 \\
\hline Taxa de filtração FAAG $\left(\mathrm{m}^{3} / \mathrm{m}^{2} . \mathrm{d}\right)$ & $\mathrm{TF}$ & 235,6 \\
\hline Área total FAAG $\left(\mathrm{m}^{2}\right)$ & $\mathrm{A}_{\mathrm{FA}}$ & 0,013 \\
\hline Perda de carga prevista FAAG (m) & $\Delta \mathrm{H}_{\text {limite }} \mathrm{FA}$ & 1,20 \\
\hline Perda de carga final no FAAG $25^{\circ} \mathrm{C}(\mathrm{m})$ & $\Delta \mathrm{H}_{\text {final }} \mathrm{FA}$ & 0,60 \\
\hline Taxa de lavagem do FAAG - ar e água $\left(\mathrm{m}^{3} / \mathrm{m}^{2} . \mathrm{d}\right)$ & $\mathrm{TL}_{\mathrm{FA}}$ & 720 \\
\hline Duração da lavagem com ar e água (min) & $\mathrm{DL}_{\mathrm{FA}}$ & 5 \\
\hline Taxa de lavagem do FAAG - água $\left(\mathrm{m}^{3} / \mathrm{m}^{2} . \mathrm{d}\right)$ & $\mathrm{TL}_{\mathrm{FA}}$ & 2160 \\
\hline Duração da lavagem somente com água (min) & $\mathrm{DL}_{\mathrm{FA}}$ & 10 \\
\hline Taxa de DFF $\left(\mathrm{m}^{3} / \mathrm{m}^{2} . \mathrm{d}\right)$ & $\mathrm{T}_{\mathrm{DFF}}$ & 960 \\
\hline Duração da DFF (min) & $\mathrm{D}_{\mathrm{DFF}}$ & 1,5 \\
\hline Taxa de DFI $\left(\mathrm{m}^{3} / \mathrm{m}^{2} . \mathrm{d}\right)$ & $\mathrm{T}_{\mathrm{DFI}}$ & 0 \\
\hline Duração da DFI (min) & $\mathrm{D}_{\mathrm{DFI}}$ & 0 \\
\hline Número de DFI em 72 h & $\mathrm{N}_{\text {DFI }}$ & 0 \\
\hline Taxa de filtração FRD $\left(\mathrm{m}^{3} / \mathrm{m}^{2} . \mathrm{d}\right)$ & $\mathrm{TF}_{\mathrm{FRD}}$ & 362,2 \\
\hline Área total FRD $\left(\mathrm{m}^{2}\right)$ & $A_{F R D}$ & 0,0065 \\
\hline Perda de carga prevista FRD (m) & $\Delta \mathrm{H}_{\text {limite }} \mathrm{FRD}$ & 1,80 \\
\hline Perda de carga final no FRD $25^{\circ} \mathrm{C}(\mathrm{m})$ & $\Delta \mathrm{H}_{\text {final }} \mathrm{FRD}$ & 1,55 \\
\hline Taxa de lavagem do FRD $\left(\mathrm{m}^{3} / \mathrm{m}^{2} . \mathrm{d}\right)$ & $\mathrm{TL}_{\mathrm{FRD}}$ & 1152 \\
\hline Duração da lavagem FRD (min) & $\mathrm{DL}_{\mathrm{FRD}}$ & 10 \\
\hline Produção efetiva de água $\left(\mathrm{m}^{3} / \mathrm{m}^{2}\right)$ & $\mathrm{PE}$ & 621,5 \\
\hline Produção total de água $\left(\mathrm{m}^{3} / \mathrm{m}^{2}\right)$ & PT & 706,8 \\
\hline Consumo de água para lavagem do FAAG $\left(\mathrm{m}^{3} / \mathrm{m}^{2}\right)$ & $\mathrm{L}_{\mathrm{FA}}$ & 66,3 \\
\hline Consumo de água na descarga de fundo final $\left(\mathrm{m}^{3} / \mathrm{m}^{2}\right)$ & DFF & 3,8 \\
\hline Consumo de água nas descargas de fundo intermediárias $\left(\mathrm{m}^{3} / \mathrm{m}^{2}\right)$ & DFI & 0 \\
\hline Consumo de água para lavagem do filtro descendente $\left(\mathrm{m}^{3} / \mathrm{m}^{2}\right)$ & $\mathrm{L}_{\mathrm{FRD}}$ & 15,2 \\
\hline Porcentagem de água perdida (\%) & $\bar{P}$ & 12,1 \\
\hline Eficiência na produção de água filtrada (\%) & $\mathrm{E}$ & 87,9 \\
\hline
\end{tabular}


Tabela D1.3 - Cálculo da produção efetiva de água no ensaio 3 de dupla filtração Sistema 1 e Água Tipo I

\begin{tabular}{|c|c|c|}
\hline Ensaio 3 & \multicolumn{2}{|c|}{ Encerramento } \\
\hline \multirow{2}{*}{$\begin{array}{l}\text { Produção efetiva de água calculada com base no item 4.9.4 c.1) } \\
\text { (transpasse no FAAG após } 18 \text { h de ensaio) }\end{array}$} & \multicolumn{2}{|c|}{ Perda de carga limite no FRD } \\
\hline & Símbolo & Valor \\
\hline Duração do ensaio (h) & $\mathrm{DF}$ & 33 \\
\hline Taxa de filtração FAAG $\left(\mathrm{m}^{3} / \mathrm{m}^{2} . \mathrm{d}\right)$ & $\mathrm{TF}$ & 238,5 \\
\hline Área total FAAG $\left(\mathrm{m}^{2}\right)$ & $\mathrm{A}_{\mathrm{FA}}$ & 0,013 \\
\hline Perda de carga prevista FAAG (m) & $\Delta \mathrm{H}_{\text {limite }} \mathrm{FA}$ & 1,20 \\
\hline Perda de carga final no FAAG $25^{\circ} \mathrm{C}(\mathrm{m})$ & $\Delta \mathrm{H}_{\text {final }} \mathrm{FA}$ & 0,29 \\
\hline Taxa de lavagem do FAAG - ar e água $\left(\mathrm{m}^{3} / \mathrm{m}^{2} . \mathrm{d}\right)$ & $\mathrm{TL}_{\mathrm{FA}}$ & 720 \\
\hline Duração da lavagem com ar e água (min) & $\mathrm{DL}_{\mathrm{FA}}$ & 5 \\
\hline Taxa de lavagem do FAAG - água $\left(\mathrm{m}^{3} / \mathrm{m}^{2} . \mathrm{d}\right)$ & $\mathrm{TL}_{\mathrm{FA}}$ & 2160 \\
\hline Duração da lavagem somente com água (min) & $\mathrm{DL}_{\mathrm{FA}}$ & 10 \\
\hline Taxa de DFF $\left(\mathrm{m}^{3} / \mathrm{m}^{2} . \mathrm{d}\right)$ & $\mathrm{T}_{\mathrm{DFF}}$ & 960 \\
\hline Duração da DFF (min) & $\mathrm{D}_{\mathrm{DFF}}$ & 1,5 \\
\hline Taxa de DFI $\left(\mathrm{m}^{3} / \mathrm{m}^{2} . \mathrm{d}\right)$ & $\mathrm{T}_{\mathrm{DFI}}$ & 800 \\
\hline Duração da DFI (min) & $\mathrm{D}_{\mathrm{DFI}}$ & 2 \\
\hline Número de DFI em 72 h & $\mathrm{N}_{\mathrm{DFI}}$ & 11 \\
\hline Taxa de filtração FRD $\left(\mathrm{m}^{3} / \mathrm{m}^{2} . \mathrm{d}\right)$ & $\mathrm{TF}_{\mathrm{FRD}}$ & 361,8 \\
\hline Área total FRD $\left(\mathrm{m}^{2}\right)$ & $A_{F R D}$ & 0,0065 \\
\hline Perda de carga prevista FRD (m) & $\Delta \mathrm{H}_{\text {limite }} \mathrm{FRD}$ & 1,80 \\
\hline Perda de carga final no FRD $25^{\circ} \mathrm{C}(\mathrm{m})$ & $\Delta \mathrm{H}_{\text {final }} \mathrm{FRD}$ & 1,80 \\
\hline Taxa de lavagem do FRD $\left(\mathrm{m}^{3} / \mathrm{m}^{2} . \mathrm{d}\right)$ & $\mathrm{TL}_{\mathrm{FRD}}$ & 1152 \\
\hline Duração da lavagem FRD (min) & $\mathrm{DL}_{\mathrm{FRD}}$ & 10 \\
\hline Produção efetiva de água $\left(\mathrm{m}^{3} / \mathrm{m}^{2}\right)$ & $\mathrm{PE}$ & 654,2 \\
\hline Produção total de água $\left(\mathrm{m}^{3} / \mathrm{m}^{2}\right)$ & PT & 715,5 \\
\hline Consumo de água para lavagem do FAAG $\left(\mathrm{m}^{3} / \mathrm{m}^{2}\right)$ & $\mathrm{L}_{\mathrm{FA}}$ & 38,2 \\
\hline Consumo de água na descarga de fundo final $\left(\mathrm{m}^{3} / \mathrm{m}^{2}\right)$ & DFF & 2,2 \\
\hline Consumo de água nas descargas de fundo intermediárias $\left(\mathrm{m}^{3} / \mathrm{m}^{2}\right)$ & DFI & 12,2 \\
\hline Consumo de água para lavagem do filtro descendente $\left(\mathrm{m}^{3} / \mathrm{m}^{2}\right)$ & $\mathrm{L}_{\mathrm{FRD}}$ & 8,7 \\
\hline Porcentagem de água perdida (\%) & $\bar{P}$ & 8,6 \\
\hline Eficiência na produção de água filtrada (\%) & $\mathrm{E}$ & 91,4 \\
\hline
\end{tabular}


Tabela D1.4 - Cálculo da produção efetiva de água no ensaio 4 de dupla filtração Sistema 1 e Água Tipo I

\begin{tabular}{|c|c|c|}
\hline Ensaio 4 & \multicolumn{2}{|c|}{ Encerramento } \\
\hline \multirow{2}{*}{$\begin{array}{l}\text { Produção efetiva de água calculada com base no item } 4.9 .4 \text { a) } \\
\text { (transpasse no FAAG após 19,5 h de ensaio) }\end{array}$} & \multicolumn{2}{|c|}{ Transpasse no FRD } \\
\hline & Símbolo & Valor \\
\hline Duração do ensaio (h) & $\mathrm{DF}$ & 33,5 \\
\hline Taxa de filtração FAAG $\left(\mathrm{m}^{3} / \mathrm{m}^{2} . \mathrm{d}\right)$ & $\mathrm{TF}$ & 175,5 \\
\hline Área total FAAG $\left(\mathrm{m}^{2}\right)$ & $\mathrm{A}_{\mathrm{FA}}$ & 0,013 \\
\hline Perda de carga prevista FAAG (m) & $\Delta \mathrm{H}_{\text {limite }} \mathrm{FA}$ & 1,20 \\
\hline Perda de carga final no FAAG $25^{\circ} \mathrm{C}(\mathrm{m})$ & $\Delta \mathrm{H}_{\text {final }} \mathrm{FA}$ & 0,68 \\
\hline Taxa de lavagem do FAAG - ar e água $\left(\mathrm{m}^{3} / \mathrm{m}^{2} . \mathrm{d}\right)$ & $\mathrm{TL}_{\mathrm{FA}}$ & 720 \\
\hline Duração da lavagem com ar e água (min) & $\mathrm{DL}_{\mathrm{FA}}$ & 5 \\
\hline Taxa de lavagem do FAAG - água $\left(\mathrm{m}^{3} / \mathrm{m}^{2} . \mathrm{d}\right)$ & $\mathrm{TL}_{\mathrm{FA}}$ & 2160 \\
\hline Duração da lavagem somente com água (min) & $\mathrm{DL}_{\mathrm{FA}}$ & 10 \\
\hline Taxa de DFF $\left(\mathrm{m}^{3} / \mathrm{m}^{2} . \mathrm{d}\right)$ & $\mathrm{T}_{\mathrm{DFF}}$ & 960 \\
\hline Duração da DFF (min) & $\mathrm{D}_{\mathrm{DFF}}$ & 1,5 \\
\hline Taxa de DFI $\left(\mathrm{m}^{3} / \mathrm{m}^{2} . \mathrm{d}\right)$ & $\mathrm{T}_{\mathrm{DFI}}$ & 0 \\
\hline Duração da DFI (min) & $\mathrm{D}_{\mathrm{DFI}}$ & 0 \\
\hline Número de DFI em 72 h & $\mathrm{N}_{\mathrm{DFI}}$ & 0 \\
\hline Taxa de filtração FRD $\left(\mathrm{m}^{3} / \mathrm{m}^{2} . \mathrm{d}\right)$ & $\mathrm{TF}_{\mathrm{FRD}}$ & 304,6 \\
\hline Área total FRD $\left(\mathrm{m}^{2}\right)$ & $A_{F R D}$ & 0,0065 \\
\hline Perda de carga prevista FRD (m) & $\Delta \mathrm{H}_{\text {limite }} \mathrm{FRD}$ & 1,80 \\
\hline Perda de carga final no FRD $25^{\circ} \mathrm{C}(\mathrm{m})$ & $\Delta \mathrm{H}_{\text {final }} \mathrm{FRD}$ & 1,32 \\
\hline Taxa de lavagem do FRD $\left(\mathrm{m}^{3} / \mathrm{m}^{2} . \mathrm{d}\right)$ & $\mathrm{TL}_{\mathrm{FRD}}$ & 1152 \\
\hline Duração da lavagem FRD (min) & $\mathrm{DL}_{\mathrm{FRD}}$ & 10 \\
\hline Produção efetiva de água $\left(\mathrm{m}^{3} / \mathrm{m}^{2}\right)$ & $\mathrm{PE}$ & 478,1 \\
\hline Produção total de água $\left(\mathrm{m}^{3} / \mathrm{m}^{2}\right)$ & PT & 526,5 \\
\hline Consumo de água para lavagem do FAAG $\left(\mathrm{m}^{3} / \mathrm{m}^{2}\right)$ & $\mathrm{L}_{\mathrm{FA}}$ & 37,6 \\
\hline Consumo de água na descarga de fundo final $\left(\mathrm{m}^{3} / \mathrm{m}^{2}\right)$ & DFF & 2,1 \\
\hline Consumo de água nas descargas de fundo intermediárias $\left(\mathrm{m}^{3} / \mathrm{m}^{2}\right)$ & DFI & 0 \\
\hline Consumo de água para lavagem do filtro descendente $\left(\mathrm{m}^{3} / \mathrm{m}^{2}\right)$ & $\mathrm{L}_{\mathrm{FRD}}$ & 8,6 \\
\hline Porcentagem de água perdida (\%) & $\mathrm{P}$ & 9,2 \\
\hline Eficiência na produção de água filtrada (\%) & $\mathrm{E}$ & 90,8 \\
\hline
\end{tabular}


Tabela D1.5 - Cálculo da produção efetiva de água no ensaio 5 de dupla filtração Sistema 1 e Água Tipo I

\begin{tabular}{|c|c|c|}
\hline \multirow{3}{*}{$\begin{array}{c}\text { Ensaio } 5 \\
\text { Produção efetiva de água calculada com base no item 4.9.4 c.2) }\end{array}$} & \multicolumn{2}{|c|}{ Encerramento } \\
\hline & \multicolumn{2}{|c|}{ Perda de carga limite no FRD } \\
\hline & Símbolo & Valor \\
\hline Duração do ensaio (h) & $\mathrm{DF}$ & 61 \\
\hline Taxa de filtração FAAG $\left(\mathrm{m}^{3} / \mathrm{m}^{2} . \mathrm{d}\right)$ & $\mathrm{TF}$ & 179,4 \\
\hline Área total FAAG $\left(\mathrm{m}^{2}\right)$ & $\mathrm{A}_{\mathrm{FA}}$ & 0,013 \\
\hline Perda de carga prevista FAAG (m) & $\Delta \mathrm{H}_{\text {limite }} \mathrm{FA}$ & 1,20 \\
\hline Perda de carga final no FAAG $25^{\circ} \mathrm{C}(\mathrm{m})$ & $\Delta \mathrm{H}_{\text {final }} \mathrm{FA}$ & 0,35 \\
\hline Taxa de lavagem do FAAG - ar e água $\left(\mathrm{m}^{3} / \mathrm{m}^{2} . \mathrm{d}\right)$ & $\mathrm{TL}_{\mathrm{FA}}$ & 720 \\
\hline Duração da lavagem com ar e água (min) & $\mathrm{DL}_{\mathrm{FA}}$ & 5 \\
\hline Taxa de lavagem do FAAG - água $\left(\mathrm{m}^{3} / \mathrm{m}^{2} . \mathrm{d}\right)$ & $\mathrm{TL}_{\mathrm{FA}}$ & 2160 \\
\hline Duração da lavagem somente com água (min) & $\mathrm{DL}_{\mathrm{FA}}$ & 10 \\
\hline Taxa de DFF $\left(\mathrm{m}^{3} / \mathrm{m}^{2} . \mathrm{d}\right)$ & $\mathrm{T}_{\mathrm{DFF}}$ & 960 \\
\hline Duração da DFF (min) & $\mathrm{D}_{\mathrm{DFF}}$ & 1,5 \\
\hline Taxa de DFI $\left(\mathrm{m}^{3} / \mathrm{m}^{2} . \mathrm{d}\right)$ & $\mathrm{T}_{\mathrm{DFI}}$ & 800 \\
\hline Duração da DFI (min) & $\mathrm{D}_{\mathrm{DFI}}$ & 2 \\
\hline Número de DFI em 72 h & $\mathrm{N}_{\mathrm{DFI}}$ & 11 \\
\hline Taxa de filtração FRD $\left(\mathrm{m}^{3} / \mathrm{m}^{2} . \mathrm{d}\right)$ & $\mathrm{TF}_{\mathrm{FRD}}$ & 304,6 \\
\hline Área total FRD $\left(\mathrm{m}^{2}\right)$ & $A_{F R D}$ & 0,0065 \\
\hline Perda de carga prevista FRD (m) & $\Delta \mathrm{H}_{\text {limite }} \mathrm{FRD}$ & 1,80 \\
\hline Perda de carga final no FRD $25^{\circ} \mathrm{C}(\mathrm{m})$ & $\Delta \mathrm{H}_{\text {final }} \mathrm{FRD}$ & 1,80 \\
\hline Taxa de lavagem do FRD $\left(\mathrm{m}^{3} / \mathrm{m}^{2} . \mathrm{d}\right)$ & $\mathrm{TL}_{\mathrm{FRD}}$ & 1152 \\
\hline Duração da lavagem FRD (min) & $\mathrm{DL}_{\mathrm{FRD}}$ & 10 \\
\hline Produção efetiva de água $\left(\mathrm{m}^{3} / \mathrm{m}^{2}\right)$ & $\mathrm{PE}$ & 514,9 \\
\hline Produção total de água $\left(\mathrm{m}^{3} / \mathrm{m}^{2}\right)$ & PT & 538,2 \\
\hline Consumo de água para lavagem do FAAG $\left(\mathrm{m}^{3} / \mathrm{m}^{2}\right)$ & $\mathrm{L}_{\mathrm{FA}}$ & 6,0 \\
\hline Consumo de água na descarga de fundo final $\left(\mathrm{m}^{3} / \mathrm{m}^{2}\right)$ & DFF & 0,3 \\
\hline Consumo de água nas descargas de fundo intermediárias $\left(\mathrm{m}^{3} / \mathrm{m}^{2}\right)$ & DFI & 12,2 \\
\hline Consumo de água para lavagem do filtro descendente $\left(\mathrm{m}^{3} / \mathrm{m}^{2}\right)$ & $\mathrm{L}_{\mathrm{FRD}}$ & 4,7 \\
\hline Porcentagem de água perdida (\%) & $\mathrm{P}$ & 4,3 \\
\hline Eficiência na produção de água filtrada (\%) & E & 95,7 \\
\hline
\end{tabular}


Tabela D1.6 - Cálculo da produção efetiva de água no ensaio 6 de dupla filtração Sistema 1 e Água Tipo II

\begin{tabular}{|c|c|c|}
\hline Ensaio 6 & \multicolumn{2}{|c|}{ Encerramento } \\
\hline \multirow{2}{*}{$\begin{array}{l}\text { Produção efetiva de água calculada com base no item } 4.9 .4 \text { a) } \\
\text { (transpasse no FAAG após 10,8 h de ensaio) }\end{array}$} & \multicolumn{2}{|c|}{ Transpasse no FRD } \\
\hline & Símbolo & Valor \\
\hline Duração do ensaio (h) & $\overline{D F}$ & 20,5 \\
\hline Taxa de filtração FAAG $\left(\mathrm{m}^{3} / \mathrm{m}^{2} . \mathrm{d}\right)$ & $\mathrm{TF}$ & 178,9 \\
\hline Área total FAAG $\left(\mathrm{m}^{2}\right)$ & $\mathrm{A}_{\mathrm{FA}}$ & 0,013 \\
\hline Perda de carga prevista FAAG (m) & $\Delta \mathrm{H}_{\text {limite }} \mathrm{FA}$ & 1,20 \\
\hline Perda de carga final no FAAG $25^{\circ} \mathrm{C}(\mathrm{m})$ & $\Delta \mathrm{H}_{\text {final }} \mathrm{FA}$ & 0,88 \\
\hline Taxa de lavagem do FAAG - ar e água $\left(\mathrm{m}^{3} / \mathrm{m}^{2} . \mathrm{d}\right)$ & $\mathrm{TL}_{\mathrm{FA}}$ & 720 \\
\hline Duração da lavagem com ar e água (min) & $\mathrm{DL}_{\mathrm{FA}}$ & 5 \\
\hline Taxa de lavagem do FAAG - água $\left(\mathrm{m}^{3} / \mathrm{m}^{2} . \mathrm{d}\right)$ & $\mathrm{TL}_{\mathrm{FA}}$ & 2160 \\
\hline Duração da lavagem somente com água (min) & $\mathrm{DL}_{\mathrm{FA}}$ & 10 \\
\hline Taxa de DFF $\left(\mathrm{m}^{3} / \mathrm{m}^{2} . \mathrm{d}\right)$ & $\mathrm{T}_{\mathrm{DFF}}$ & 960 \\
\hline Duração da DFF (min) & $\mathrm{D}_{\mathrm{DFF}}$ & 1,5 \\
\hline Taxa de DFI $\left(\mathrm{m}^{3} / \mathrm{m}^{2} . \mathrm{d}\right)$ & $\mathrm{T}_{\mathrm{DFI}}$ & 0 \\
\hline Duração da DFI (min) & $\mathrm{D}_{\mathrm{DFI}}$ & 0 \\
\hline Número de DFI em 72 h & $\mathrm{N}_{\mathrm{DFI}}$ & 0 \\
\hline Taxa de filtração FRD $\left(\mathrm{m}^{3} / \mathrm{m}^{2} . \mathrm{d}\right)$ & $\mathrm{TF}_{\mathrm{FRD}}$ & 304,6 \\
\hline Área total FRD $\left(\mathrm{m}^{2}\right)$ & $A_{F R D}$ & 0,0065 \\
\hline Perda de carga prevista FRD (m) & $\Delta \mathrm{H}_{\text {limite }} \mathrm{FRD}$ & 1,80 \\
\hline Perda de carga final no FRD $25^{\circ} \mathrm{C}(\mathrm{m})$ & $\Delta \mathrm{H}_{\text {final }} \mathrm{FRD}$ & 1,73 \\
\hline Taxa de lavagem do FRD $\left(\mathrm{m}^{3} / \mathrm{m}^{2} . \mathrm{d}\right)$ & $\mathrm{TL}_{\mathrm{FRD}}$ & 1152 \\
\hline Duração da lavagem FRD (min) & $\mathrm{DL}_{\mathrm{FRD}}$ & 10 \\
\hline Produção efetiva de água $\left(\mathrm{m}^{3} / \mathrm{m}^{2}\right)$ & $\mathrm{PE}$ & 457,7 \\
\hline Produção total de água $\left(\mathrm{m}^{3} / \mathrm{m}^{2}\right)$ & PT & 536,7 \\
\hline Consumo de água para lavagem do FAAG $\left(\mathrm{m}^{3} / \mathrm{m}^{2}\right)$ & $\mathrm{L}_{\mathrm{FA}}$ & 61,5 \\
\hline Consumo de água na descarga de fundo final $\left(\mathrm{m}^{3} / \mathrm{m}^{2}\right)$ & DFF & 3,5 \\
\hline Consumo de água nas descargas de fundo intermediárias $\left(\mathrm{m}^{3} / \mathrm{m}^{2}\right)$ & DFI & 0 \\
\hline Consumo de água para lavagem do filtro descendente $\left(\mathrm{m}^{3} / \mathrm{m}^{2}\right)$ & $\mathrm{L}_{\mathrm{FRD}}$ & 14,0 \\
\hline Porcentagem de água perdida (\%) & $\mathrm{P}$ & 14,7 \\
\hline Eficiência na produção de água filtrada (\%) & $\mathrm{E}$ & 85,3 \\
\hline
\end{tabular}


Tabela D1.7 - Cálculo da produção efetiva de água no ensaio 7 de dupla filtração Sistema 1 e Água Tipo II

\begin{tabular}{|c|c|c|}
\hline \multirow{3}{*}{$\begin{array}{c}\text { Ensaio 7 } \\
\text { Produção efetiva de água calculada com base no item 4.9.4 c.1) } \\
\text { (transpasse no FAAG após aproximadamente } 15 \text { h de ensaio) }\end{array}$} & \multicolumn{2}{|c|}{ Encerramento } \\
\hline & \multicolumn{2}{|c|}{ Perda de carga limite no FRD } \\
\hline & Símbolo & Valor \\
\hline Duração do ensaio (h) & $\mathrm{DF}$ & 30 \\
\hline Taxa de filtração FAAG $\left(\mathrm{m}^{3} / \mathrm{m}^{2} . \mathrm{d}\right)$ & $\mathrm{TF}$ & 177,8 \\
\hline Área total FAAG $\left(\mathrm{m}^{2}\right)$ & $\mathrm{A}_{\mathrm{FA}}$ & 0,013 \\
\hline Perda de carga prevista FAAG (m) & $\Delta \mathrm{H}_{\text {limite }} \mathrm{FA}$ & 1,20 \\
\hline Perda de carga final no FAAG $25^{\circ} \mathrm{C}(\mathrm{m})$ & $\Delta \mathrm{H}_{\text {final }} \mathrm{FA}$ & 0,43 \\
\hline Taxa de lavagem do FAAG - ar e água $\left(\mathrm{m}^{3} / \mathrm{m}^{2} . \mathrm{d}\right)$ & $\mathrm{TL}_{\mathrm{FA}}$ & 720 \\
\hline Duração da lavagem com ar e água (min) & $\mathrm{DL}_{\mathrm{FA}}$ & 5 \\
\hline Taxa de lavagem do FAAG - água $\left(\mathrm{m}^{3} / \mathrm{m}^{2} . \mathrm{d}\right)$ & $\mathrm{TL}_{\mathrm{FA}}$ & 2160 \\
\hline Duração da lavagem somente com água (min) & $\mathrm{DL}_{\mathrm{FA}}$ & 10 \\
\hline Taxa de DFF $\left(\mathrm{m}^{3} / \mathrm{m}^{2} . \mathrm{d}\right)$ & $\mathrm{T}_{\mathrm{DFF}}$ & 960 \\
\hline Duração da DFF (min) & $\mathrm{D}_{\mathrm{DFF}}$ & 1,5 \\
\hline Taxa de DFI $\left(\mathrm{m}^{3} / \mathrm{m}^{2} . \mathrm{d}\right)$ & $\mathrm{T}_{\mathrm{DFI}}$ & 800 \\
\hline Duração da DFI (min) & $\mathrm{D}_{\mathrm{DFI}}$ & 2 \\
\hline Número de DFI em 72 h & $\mathrm{N}_{\mathrm{DFI}}$ & 15 \\
\hline Taxa de filtração FRD $\left(\mathrm{m}^{3} / \mathrm{m}^{2} . \mathrm{d}\right)$ & $\mathrm{TF}_{\mathrm{FRD}}$ & 304,6 \\
\hline Área total FRD $\left(\mathrm{m}^{2}\right)$ & $A_{F R D}$ & 0,0065 \\
\hline Perda de carga prevista FRD (m) & $\Delta \mathrm{H}_{\text {limite }} \mathrm{FRD}$ & 1,80 \\
\hline Perda de carga final no FRD $25^{\circ} \mathrm{C}(\mathrm{m})$ & $\Delta \mathrm{H}_{\text {final }} \mathrm{FRD}$ & 1,75 \\
\hline Taxa de lavagem do FRD $\left(\mathrm{m}^{3} / \mathrm{m}^{2} . \mathrm{d}\right)$ & $\mathrm{TL}_{\mathrm{FRD}}$ & 1152 \\
\hline Duração da lavagem FRD (min) & $\mathrm{DL}_{\mathrm{FRD}}$ & 10 \\
\hline Produção efetiva de água $\left(\mathrm{m}^{3} / \mathrm{m}^{2}\right)$ & $\mathrm{PE}$ & 462,7 \\
\hline Produção total de água $\left(\mathrm{m}^{3} / \mathrm{m}^{2}\right)$ & PT & 533,4 \\
\hline Consumo de água para lavagem do FAAG $\left(\mathrm{m}^{3} / \mathrm{m}^{2}\right)$ & $\mathrm{L}_{\mathrm{FA}}$ & 42,0 \\
\hline Consumo de água na descarga de fundo final $\left(\mathrm{m}^{3} / \mathrm{m}^{2}\right)$ & DFF & 2,4 \\
\hline Consumo de água nas descargas de fundo intermediárias $\left(\mathrm{m}^{3} / \mathrm{m}^{2}\right)$ & DFI & 16,7 \\
\hline Consumo de água para lavagem do filtro descendente $\left(\mathrm{m}^{3} / \mathrm{m}^{2}\right)$ & $\mathrm{L}_{\mathrm{FRD}}$ & 9,6 \\
\hline Porcentagem de água perdida (\%) & $\mathrm{P}$ & 13,2 \\
\hline Eficiência na produção de água filtrada (\%) & $\mathrm{E}$ & 86,8 \\
\hline
\end{tabular}


Tabela D1.8 - Cálculo da produção efetiva de água no ensaio 8 de dupla filtração Sistema 1 e Água Tipo II

\begin{tabular}{|c|c|c|}
\hline Ensaio 8 & \multicolumn{2}{|c|}{ Encerramento } \\
\hline \multirow{2}{*}{$\begin{array}{l}\text { Formação do manto de lodo no topo do FAAG após } 17 \text { h de ensaio } \\
\text { Não foi calculada a produção efetiva }\end{array}$} & \multicolumn{2}{|c|}{ Tempo de ensaio $=36 \mathrm{~h}$} \\
\hline & Símbolo & Valor \\
\hline Duração do ensaio (h) & DF & 36 \\
\hline Taxa de filtração FAAG $\left(\mathrm{m}^{3} / \mathrm{m}^{2} . \mathrm{d}\right)$ & TF & 125,7 \\
\hline Área total FAAG $\left(\mathrm{m}^{2}\right)$ & $\mathrm{A}_{\mathrm{FA}}$ & 0,013 \\
\hline Perda de carga prevista FAAG (m) & $\Delta \mathrm{H}_{\text {limite }} \mathrm{FA}$ & 1,20 \\
\hline Perda de carga final no FAAG $25^{\circ} \mathrm{C}(\mathrm{m})$ & $\Delta \mathrm{H}_{\text {final }} \mathrm{FA}$ & 0,58 \\
\hline Taxa de lavagem do FAAG - ar e água $\left(\mathrm{m}^{3} / \mathrm{m}^{2} . \mathrm{d}\right)$ & $\mathrm{TL}_{\mathrm{FA}}$ & 720 \\
\hline Duração da lavagem com ar e água (min) & $\mathrm{DL}_{\mathrm{FA}}$ & 5 \\
\hline Taxa de lavagem do FAAG - água $\left(\mathrm{m}^{3} / \mathrm{m}^{2} . \mathrm{d}\right)$ & $\mathrm{TL}_{\mathrm{FA}}$ & 2160 \\
\hline Duração da lavagem somente com água (min) & $\mathrm{DL}_{\mathrm{FA}}$ & 10 \\
\hline Taxa de DFF $\left(\mathrm{m}^{3} / \mathrm{m}^{2} . \mathrm{d}\right)$ & $\mathrm{T}_{\mathrm{DFF}}$ & 960 \\
\hline Duração da DFF (min) & $\mathrm{D}_{\mathrm{DFF}}$ & 1,5 \\
\hline Taxa de DFI $\left(\mathrm{m}^{3} / \mathrm{m}^{2} . \mathrm{d}\right)$ & $\mathrm{T}_{\mathrm{DFI}}$ & 0 \\
\hline Duração da DFI (min) & $\mathrm{D}_{\mathrm{DFI}}$ & 0 \\
\hline Número de DFI em 72 h & $\mathrm{N}_{\mathrm{DFI}}$ & 0 \\
\hline Taxa de filtração FRD $\left(\mathrm{m}^{3} / \mathrm{m}^{2} . \mathrm{d}\right)$ & $\mathrm{TF}_{\mathrm{FRD}}$ & 179,1 \\
\hline Área total FRD $\left(m^{2}\right)$ & $A_{F R D}$ & 0,0065 \\
\hline Perda de carga prevista FRD (m) & $\Delta \mathrm{H}_{\text {limite }} \mathrm{FRD}$ & 1,80 \\
\hline Perda de carga final no FRD $25^{\circ} \mathrm{C}(\mathrm{m})$ & $\Delta \mathrm{H}_{\text {final }} \mathrm{FRD}$ & 0,84 \\
\hline Taxa de lavagem do FRD $\left(\mathrm{m}^{3} / \mathrm{m}^{2} . \mathrm{d}\right)$ & $\mathrm{TL}_{\mathrm{FRD}}$ & 1152 \\
\hline Duração da lavagem FRD (min) & DLFRD $_{\text {FRD }}$ & 10 \\
\hline Produção efetiva de água $\left(\mathrm{m}^{3} / \mathrm{m}^{2}\right)$ & $\mathrm{PE}$ & - \\
\hline Produção total de água $\left(\mathrm{m}^{3} / \mathrm{m}^{2}\right)$ & PT & - \\
\hline Consumo de água para lavagem do FAAG $\left(\mathrm{m}^{3} / \mathrm{m}^{2}\right)$ & $\mathrm{L}_{\mathrm{FA}}$ & - \\
\hline Consumo de água na descarga de fundo final $\left(\mathrm{m}^{3} / \mathrm{m}^{2}\right)$ & DFF & - \\
\hline Consumo de água nas descargas de fundo intermediárias $\left(\mathrm{m}^{3} / \mathrm{m}^{2}\right)$ & DFI & - \\
\hline Consumo de água para lavagem do filtro descendente $\left(\mathrm{m}^{3} / \mathrm{m}^{2}\right)$ & $\mathrm{L}_{\mathrm{FRD}}$ & - \\
\hline Porcentagem de água perdida (\%) & $\bar{P}$ & - \\
\hline Eficiência na produção de água filtrada (\%) & $\mathrm{E}$ & - \\
\hline
\end{tabular}


Tabela D1.9 - Cálculo da produção efetiva de água no ensaio 9 de dupla filtração Sistema 1 e Água Tipo II

\begin{tabular}{|c|c|c|}
\hline Ensaio 9 & \multicolumn{2}{|c|}{ Encerramento } \\
\hline \multirow[t]{2}{*}{ Não foi calculada a produção efetiva de água } & \multicolumn{2}{|c|}{ Tempo de ensaio $=36 \mathrm{~h}$} \\
\hline & Símbolo & Valor \\
\hline Duração do ensaio (h) & DF & 36 \\
\hline Taxa de filtração FAAG $\left(\mathrm{m}^{3} / \mathrm{m}^{2} . \mathrm{d}\right)$ & $\mathrm{TF}$ & 122,9 \\
\hline Área total FAAG $\left(\mathrm{m}^{2}\right)$ & $\mathrm{A}_{\mathrm{FA}}$ & 0,013 \\
\hline Perda de carga prevista FAAG (m) & $\Delta \mathrm{H}_{\text {limite }} \mathrm{FA}$ & 1,20 \\
\hline Perda de carga final no FAAG $25^{\circ} \mathrm{C}(\mathrm{m})$ & $\Delta \mathrm{H}_{\text {final }} \mathrm{FA}$ & 0,17 \\
\hline Taxa de lavagem do FAAG - ar e água $\left(\mathrm{m}^{3} / \mathrm{m}^{2} . \mathrm{d}\right)$ & $\mathrm{TL}_{\mathrm{FA}}$ & 720 \\
\hline Duração da lavagem com ar e água (min) & $\mathrm{DL}_{\mathrm{FA}}$ & 5 \\
\hline Taxa de lavagem do FAAG - água $\left(\mathrm{m}^{3} / \mathrm{m}^{2} . \mathrm{d}\right)$ & $\mathrm{TL}_{\mathrm{FA}}$ & 2160 \\
\hline Duração da lavagem somente com água (min) & $\mathrm{DL}_{\mathrm{FA}}$ & 10 \\
\hline Taxa de DFF $\left(\mathrm{m}^{3} / \mathrm{m}^{2} . \mathrm{d}\right)$ & $\mathrm{T}_{\mathrm{DFF}}$ & 960 \\
\hline Duração da DFF (min) & $\mathrm{D}_{\mathrm{DFF}}$ & 1,5 \\
\hline Taxa de DFI $\left(\mathrm{m}^{3} / \mathrm{m}^{2} . \mathrm{d}\right)$ & $\mathrm{T}_{\mathrm{DFI}}$ & 800 \\
\hline Duração da DFI (min) & $\mathrm{D}_{\mathrm{DFI}}$ & 2 \\
\hline Número de DFI em 36 h & $\mathrm{N}_{\mathrm{DFI}}$ & 7 \\
\hline Taxa de filtração FRD $\left(\mathrm{m}^{3} / \mathrm{m}^{2} . \mathrm{d}\right)$ & $\mathrm{TF}_{\mathrm{FRD}}$ & 182 \\
\hline Área total FRD $\left(\mathrm{m}^{2}\right)$ & $A_{F R D}$ & 0,0065 \\
\hline Perda de carga prevista FRD (m) & $\Delta \mathrm{H}_{\text {limite }} \mathrm{FRD}$ & 1,80 \\
\hline Perda de carga final no FRD $25^{\circ} \mathrm{C}(\mathrm{m})$ & $\Delta \mathrm{H}_{\text {final }} \mathrm{FRD}$ & 0,67 \\
\hline Taxa de lavagem do FRD $\left(\mathrm{m}^{3} / \mathrm{m}^{2} . \mathrm{d}\right)$ & $\mathrm{TL}_{\mathrm{FRD}}$ & 1152 \\
\hline Duração da lavagem FRD (min) & $\mathrm{DL}_{\mathrm{FRD}}$ & 10 \\
\hline Produção efetiva de água $\left(\mathrm{m}^{3} / \mathrm{m}^{2}\right)$ & $\mathrm{PE}$ & - \\
\hline Produção total de água $\left(\mathrm{m}^{3} / \mathrm{m}^{2}\right)$ & PT & - \\
\hline Consumo de água para lavagem do FAAG $\left(\mathrm{m}^{3} / \mathrm{m}^{2}\right)$ & $\mathrm{L}_{\mathrm{FA}}$ & - \\
\hline Consumo de água na descarga de fundo final $\left(\mathrm{m}^{3} / \mathrm{m}^{2}\right)$ & DFF & - \\
\hline Consumo de água nas descargas de fundo intermediárias $\left(\mathrm{m}^{3} / \mathrm{m}^{2}\right)$ & DFI & - \\
\hline Consumo de água para lavagem do filtro descendente $\left(\mathrm{m}^{3} / \mathrm{m}^{2}\right)$ & $\mathrm{L}_{\mathrm{FRD}}$ & - \\
\hline Porcentagem de água perdida (\%) & $\mathrm{P}$ & - \\
\hline Eficiência na produção de água filtrada (\%) & $\mathrm{E}$ & - \\
\hline
\end{tabular}


Parte D2

CÁLCULO DA PRODUÇÃO EFETIVA NOS ENSAIOS DE DUPLA FILTRAÇÃO SISTEMA DE DUPLA FILTRAÇÃO 2

\section{FILTRO ASCENDENTE DE PEDREGULHO - FILTRO RÁPIDO DESCENDENTE}

Tabela D2.1 -Cálculo da produção efetiva de água no ensaio 10 de dupla filtração

Sistema 2 e Água Tipo I

\begin{tabular}{|c|c|c|}
\hline \multirow{3}{*}{$\begin{array}{c}\text { Ensaio 10 } \\
\text { Formação do manto de lodo no topo do FAP após 21 h de ensaio } \\
\text { Não foi calculada a produção efetiva }\end{array}$} & \multicolumn{2}{|c|}{ Encerramento } \\
\hline & \multicolumn{2}{|c|}{ Perda de carga limite no FRD } \\
\hline & Símbolo & Valor \\
\hline Duração do ensaio (h) & $\overline{\mathrm{DF}}$ & 34,5 \\
\hline Taxa de filtração FAP $\left(\mathrm{m}^{3} / \mathrm{m}^{2} . \mathrm{d}\right)$ & $\mathrm{TF}$ & 125,5 \\
\hline Área total FAP $\left(\mathrm{m}^{2}\right)$ & $\mathrm{A}_{\mathrm{FA}}$ & 0,013 \\
\hline Perda de carga prevista FAP (m) & $\Delta \mathrm{H}_{\text {limite }} \mathrm{FA}$ & 0,80 \\
\hline Perda de carga final no FAP $25^{\circ} \mathrm{C}(\mathrm{m})$ & $\Delta \mathrm{H}_{\text {final }} \mathrm{FA}$ & 0,20 \\
\hline Taxa de lavagem do FAP - ar e água $\left(\mathrm{m}^{3} / \mathrm{m}^{2} . \mathrm{d}\right)$ & $\mathrm{TL}_{\mathrm{FA}}$ & 720 \\
\hline Duração da lavagem com ar e água (min) & $\mathrm{DL}_{\mathrm{FA}}$ & 3 \\
\hline Taxa de lavagem do FAP - água $\left(\mathrm{m}^{3} / \mathrm{m}^{2} . \mathrm{d}\right)$ & $\mathrm{TL}_{\mathrm{FA}}$ & 2160 \\
\hline Duração da lavagem somente com água (min) & $\mathrm{DL}_{\mathrm{FA}}$ & 5 \\
\hline Taxa de DFF $\left(\mathrm{m}^{3} / \mathrm{m}^{2} . \mathrm{d}\right)$ & $\mathrm{T}_{\mathrm{DFF}}$ & 960 \\
\hline Duração da DFF (min) & $\mathrm{D}_{\mathrm{DFF}}$ & 1,5 \\
\hline Taxa de DFI $\left(\mathrm{m}^{3} / \mathrm{m}^{2} . \mathrm{d}\right)$ & $\mathrm{T}_{\mathrm{DFI}}$ & 0 \\
\hline Duração da DFI (min) & $\mathrm{D}_{\mathrm{DFI}}$ & 0 \\
\hline Número de DFI em 72 h & $\mathrm{N}_{\mathrm{DFI}}$ & 0 \\
\hline Taxa de filtração FRD $\left(\mathrm{m}^{3} / \mathrm{m}^{2} . \mathrm{d}\right)$ & $\mathrm{TF}_{\mathrm{FRD}}$ & 192,5 \\
\hline Área total FRD (m²) & $A_{F R D}$ & 0,0031 \\
\hline Perda de carga prevista FRD (m) & $\Delta \mathrm{H}_{\text {limite }} \mathrm{FRD}$ & 1,80 \\
\hline Perda de carga final no FRD $25^{\circ} \mathrm{C}(\mathrm{m})$ & $\Delta \mathrm{H}_{\text {final }} \mathrm{FRD}$ & 1,73 \\
\hline Taxa de lavagem do FRD $\left(\mathrm{m}^{3} / \mathrm{m}^{2} . \mathrm{d}\right)$ & $\mathrm{TL}_{\mathrm{FRD}}$ & 1152 \\
\hline Duração da lavagem FRD (min) & $\mathrm{DL}_{\mathrm{FRD}}$ & 10 \\
\hline Produção efetiva de água $\left(\mathrm{m}^{3} / \mathrm{m}^{2}\right)$ & PE & - \\
\hline Produção total de água $\left(\mathrm{m}^{3} / \mathrm{m}^{2}\right)$ & PT & - \\
\hline Consumo de água para lavagem do FAP $\left(\mathrm{m}^{3} / \mathrm{m}^{2}\right)$ & $\mathrm{L}_{\mathrm{FA}}$ & - \\
\hline Consumo de água na descarga de fundo final $\left(\mathrm{m}^{3} / \mathrm{m}^{2}\right)$ & DFF & - \\
\hline Consumo de água nas descargas de fundo intermediárias $\left(\mathrm{m}^{3} / \mathrm{m}^{2}\right)$ & DFI & - \\
\hline Consumo de água para lavagem do filtro descendente $\left(\mathrm{m}^{3} / \mathrm{m}^{2}\right)$ & $\mathrm{L}_{\mathrm{FRD}}$ & - \\
\hline Porcentagem de água perdida (\%) & $\mathrm{P}$ & - \\
\hline Eficiência na produção de água filtrada (\%) & E & - \\
\hline
\end{tabular}


Tabela D2.2 -Cálculo da produção efetiva de água no ensaio 11 de dupla filtração

Sistema 2 e Água Tipo I

\begin{tabular}{|c|c|c|}
\hline Ensaio 11 & \multicolumn{2}{|c|}{ Encerramento } \\
\hline \multirow[t]{2}{*}{ Produção efetiva de água calculada com base no item 4.9.4 c.2) } & \multicolumn{2}{|c|}{ Perda de carga limite no FRD } \\
\hline & Símbolo & Valor \\
\hline Duração do ensaio (h) & $\overline{\mathrm{DF}}$ & 35,5 \\
\hline Taxa de filtração FAP $\left(\mathrm{m}^{3} / \mathrm{m}^{2} . \mathrm{d}\right)$ & $\mathrm{TF}$ & 125,6 \\
\hline Área total FAP $\left(\mathrm{m}^{2}\right)$ & $\mathrm{A}_{\mathrm{FA}}$ & 0,013 \\
\hline Perda de carga prevista FAP (m) & $\Delta \mathrm{H}_{\text {limite }} \mathrm{FA}$ & 0,80 \\
\hline Perda de carga final no FAP $25^{\circ} \mathrm{C}(\mathrm{m})$ & $\Delta \mathrm{H}_{\text {final }} \mathrm{FA}$ & 0,06 \\
\hline Taxa de lavagem do FAP - ar e água $\left(\mathrm{m}^{3} / \mathrm{m}^{2} . \mathrm{d}\right)$ & $\mathrm{TL}_{\mathrm{FA}}$ & 720 \\
\hline Duração da lavagem com ar e água (min) & $\mathrm{DL}_{\mathrm{FA}}$ & 3 \\
\hline Taxa de lavagem do FAP - água $\left(\mathrm{m}^{3} / \mathrm{m}^{2} . \mathrm{d}\right)$ & $\mathrm{TL}_{\mathrm{FA}}$ & 2160 \\
\hline Duração da lavagem somente com água (min) & $\mathrm{DL}_{\mathrm{FA}}$ & 5 \\
\hline Taxa de DFF $\left(\mathrm{m}^{3} / \mathrm{m}^{2} . \mathrm{d}\right)$ & $\mathrm{T}_{\mathrm{DFF}}$ & 960 \\
\hline Duração da DFF (min) & $\mathrm{D}_{\mathrm{DFF}}$ & 1,5 \\
\hline Taxa de DFI $\left(\mathrm{m}^{3} / \mathrm{m}^{2} . \mathrm{d}\right)$ & $\mathrm{T}_{\mathrm{DFI}}$ & 700 \\
\hline Duração da DFI (min) & $\mathrm{D}_{\mathrm{DFI}}$ & 2 \\
\hline Número de DFI em 72 h & $\mathrm{N}_{\mathrm{DFI}}$ & 11 \\
\hline Taxa de filtração FRD $\left(\mathrm{m}^{3} / \mathrm{m}^{2} . \mathrm{d}\right)$ & $\mathrm{TF}_{\mathrm{FRD}}$ & 192,5 \\
\hline Área total FRD $\left(\mathrm{m}^{2}\right)$ & $\mathrm{A}_{\mathrm{FRD}}$ & 0,0031 \\
\hline Perda de carga prevista FRD (m) & $\Delta \mathrm{H}_{\text {limite }} \mathrm{FRD}$ & 1,80 \\
\hline Perda de carga final no FRD $25^{\circ} \mathrm{C}(\mathrm{m})$ & $\Delta \mathrm{H}_{\text {final }} \mathrm{FRD}$ & 1,74 \\
\hline Taxa de lavagem do FRD $\left(\mathrm{m}^{3} / \mathrm{m}^{2} . \mathrm{d}\right)$ & $\mathrm{TL}_{\mathrm{FRD}}$ & 1152 \\
\hline Duração da lavagem FRD (min) & $\mathrm{DL}_{\mathrm{FRD}}$ & 10 \\
\hline Produção efetiva de água $\left(\mathrm{m}^{3} / \mathrm{m}^{2}\right)$ & $\mathrm{PE}$ & 360,7 \\
\hline Produção total de água $\left(\mathrm{m}^{3} / \mathrm{m}^{2}\right)$ & PT & 376,8 \\
\hline Consumo de água para lavagem do FAP $\left(\mathrm{m}^{3} / \mathrm{m}^{2}\right)$ & $\mathrm{L}_{\mathrm{FA}}$ & 1,4 \\
\hline Consumo de água na descarga de fundo final $\left(\mathrm{m}^{3} / \mathrm{m}^{2}\right)$ & DFF & 0,2 \\
\hline Consumo de água nas descargas de fundo intermediárias $\left(\mathrm{m}^{3} / \mathrm{m}^{2}\right)$ & DFI & 10,7 \\
\hline Consumo de água para lavagem do filtro descendente $\left(\mathrm{m}^{3} / \mathrm{m}^{2}\right)$ & $\mathrm{L}_{\mathrm{FRD}}$ & 3,9 \\
\hline Porcentagem de água perdida (\%) & $\mathrm{P}$ & 4,3 \\
\hline Eficiência na produção de água filtrada (\%) & $\mathrm{E}$ & 95,7 \\
\hline
\end{tabular}


Tabela D2.3 -Cálculo da produção efetiva de água no ensaio 12 de dupla filtração

Sistema 2 e Água Tipo I

\begin{tabular}{|c|c|c|}
\hline Ensaio 12 & \multicolumn{2}{|c|}{ Encerramento } \\
\hline \multirow{2}{*}{$\begin{array}{l}\text { Produção efetiva de água calculada com base no item 4.9.4 c.1) } \\
\text { (transpasse no FAP após aproximadamente } 6 \text { h de ensaio) }\end{array}$} & \multicolumn{2}{|c|}{ Perda de carga limite no FRD } \\
\hline & Símbolo & Valor \\
\hline Duração do ensaio (h) & $\overline{\mathrm{DF}}$ & 13 \\
\hline Taxa de filtração FAP $\left(\mathrm{m}^{3} / \mathrm{m}^{2} . \mathrm{d}\right)$ & $\mathrm{TF}$ & 180 \\
\hline Área total FAP $\left(\mathrm{m}^{2}\right)$ & $\mathrm{A}_{\mathrm{FA}}$ & 0,013 \\
\hline Perda de carga prevista FAP (m) & $\Delta \mathrm{H}_{\text {limite }} \mathrm{FA}$ & 0,80 \\
\hline Perda de carga final no FAP $25^{\circ} \mathrm{C}(\mathrm{m})$ & $\Delta \mathrm{H}_{\text {final }} \mathrm{FA}$ & 0,12 \\
\hline Taxa de lavagem do FAP - ar e água $\left(\mathrm{m}^{3} / \mathrm{m}^{2} . \mathrm{d}\right)$ & $\mathrm{TL}_{\mathrm{FA}}$ & 720 \\
\hline Duração da lavagem com ar e água (min) & $\mathrm{DL}_{\mathrm{FA}}$ & 3 \\
\hline Taxa de lavagem do FAP - água $\left(\mathrm{m}^{3} / \mathrm{m}^{2} . \mathrm{d}\right)$ & $\mathrm{TL}_{\mathrm{FA}}$ & 2160 \\
\hline Duração da lavagem somente com água (min) & $\mathrm{DL}_{\mathrm{FA}}$ & 5 \\
\hline Taxa de DFF $\left(\mathrm{m}^{3} / \mathrm{m}^{2} . \mathrm{d}\right)$ & $\mathrm{T}_{\mathrm{DFF}}$ & 960 \\
\hline Duração da DFF (min) & $\mathrm{D}_{\mathrm{DFF}}$ & 1,5 \\
\hline Taxa de DFI $\left(\mathrm{m}^{3} / \mathrm{m}^{2} . \mathrm{d}\right)$ & $\mathrm{T}_{\mathrm{DFI}}$ & 0 \\
\hline Duração da DFI (min) & $\mathrm{D}_{\mathrm{DFI}}$ & 0 \\
\hline Número de DFI em 72 h & $\mathrm{N}_{\mathrm{DFI}}$ & 0 \\
\hline Taxa de filtração FRD $\left(\mathrm{m}^{3} / \mathrm{m}^{2} . \mathrm{d}\right)$ & $\mathrm{TF}_{\mathrm{FRD}}$ & 292,6 \\
\hline Área total FRD $\left(\mathrm{m}^{2}\right)$ & $\mathrm{A}_{\mathrm{FRD}}$ & 0,0031 \\
\hline Perda de carga prevista FRD (m) & $\Delta \mathrm{H}_{\text {limite }} \mathrm{FRD}$ & 1,80 \\
\hline Perda de carga final no FRD $25^{\circ} \mathrm{C}(\mathrm{m})$ & $\Delta \mathrm{H}_{\text {final }} \mathrm{FRD}$ & 1,71 \\
\hline Taxa de lavagem do FRD $\left(\mathrm{m}^{3} / \mathrm{m}^{2} . \mathrm{d}\right)$ & $\mathrm{TL}_{\mathrm{FRD}}$ & 1152 \\
\hline Duração da lavagem FRD (min) & $\mathrm{DL}_{\mathrm{FRD}}$ & 10 \\
\hline Produção efetiva de água $\left(\mathrm{m}^{3} / \mathrm{m}^{2}\right)$ & $\mathrm{PE}$ & 474,0 \\
\hline Produção total de água $\left(\mathrm{m}^{3} / \mathrm{m}^{2}\right)$ & PT & 540 \\
\hline Consumo de água para lavagem do FAP $\left(\mathrm{m}^{3} / \mathrm{m}^{2}\right)$ & $\mathrm{L}_{\mathrm{FA}}$ & 49,8 \\
\hline Consumo de água na descarga de fundo final $\left(\mathrm{m}^{3} / \mathrm{m}^{2}\right)$ & DFF & 5,5 \\
\hline Consumo de água nas descargas de fundo intermediárias $\left(\mathrm{m}^{3} / \mathrm{m}^{2}\right)$ & DFI & 0,0 \\
\hline Consumo de água para lavagem do filtro descendente $\left(\mathrm{m}^{3} / \mathrm{m}^{2}\right)$ & $\mathrm{L}_{\mathrm{FRD}}$ & 10,6 \\
\hline Porcentagem de água perdida (\%) & $\mathrm{P}$ & 12,2 \\
\hline Eficiência na produção de água filtrada (\%) & E & 87,8 \\
\hline
\end{tabular}


Tabela D2.4 -Cálculo da produção efetiva de água no ensaio 13 de dupla filtração

Sistema 2 e Água Tipo I

\begin{tabular}{|c|c|c|}
\hline Ensaio 13 & \multicolumn{2}{|c|}{ Encerramento } \\
\hline \multirow{2}{*}{$\begin{array}{l}\text { Produção efetiva de água calculada com base no item 4.9.4 c.1) } \\
\text { (transpasse no FAP após aproximadamente } 6 \text { h de ensaio) }\end{array}$} & \multicolumn{2}{|c|}{ Perda de carga limite no FRD } \\
\hline & Símbolo & Valor \\
\hline Duração do ensaio (h) & $\overline{\mathrm{DF}}$ & 17,5 \\
\hline Taxa de filtração FAP $\left(\mathrm{m}^{3} / \mathrm{m}^{2} . \mathrm{d}\right)$ & $\mathrm{TF}$ & 180,5 \\
\hline Área total FAP $\left(\mathrm{m}^{2}\right)$ & $\mathrm{A}_{\mathrm{FA}}$ & 0,013 \\
\hline Perda de carga prevista FAP (m) & $\Delta \mathrm{H}_{\text {limite }} \mathrm{FA}$ & 0,80 \\
\hline Perda de carga final no FAP $25^{\circ} \mathrm{C}(\mathrm{m})$ & $\Delta \mathrm{H}_{\text {final }} \mathrm{FA}$ & 0,12 \\
\hline Taxa de lavagem do FAP - ar e água $\left(\mathrm{m}^{3} / \mathrm{m}^{2} . \mathrm{d}\right)$ & $\mathrm{TL}_{\mathrm{FA}}$ & 720 \\
\hline Duração da lavagem com ar e água (min) & $\mathrm{DL}_{\mathrm{FA}}$ & 3 \\
\hline Taxa de lavagem do FAP - água $\left(\mathrm{m}^{3} / \mathrm{m}^{2} . \mathrm{d}\right)$ & $\mathrm{TL}_{\mathrm{FA}}$ & 2160 \\
\hline Duração da lavagem somente com água (min) & $\mathrm{DL}_{\mathrm{FA}}$ & 5 \\
\hline Taxa de DFF $\left(\mathrm{m}^{3} / \mathrm{m}^{2} . \mathrm{d}\right)$ & $\mathrm{T}_{\mathrm{DFF}}$ & 960 \\
\hline Duração da DFF (min) & $\mathrm{D}_{\mathrm{DFF}}$ & 1,5 \\
\hline Taxa de DFI $\left(\mathrm{m}^{3} / \mathrm{m}^{2} . \mathrm{d}\right)$ & $\mathrm{T}_{\mathrm{DFI}}$ & 700 \\
\hline Duração da DFI (min) & $\mathrm{D}_{\mathrm{DFI}}$ & 2 \\
\hline Número de DFI em 72 h & $\mathrm{N}_{\mathrm{DFI}}$ & 15 \\
\hline Taxa de filtração FRD $\left(\mathrm{m}^{3} / \mathrm{m}^{2} . \mathrm{d}\right)$ & $\mathrm{TF}_{\mathrm{FRD}}$ & 292,6 \\
\hline Área total FRD $\left(\mathrm{m}^{2}\right)$ & $\mathrm{A}_{\mathrm{FRD}}$ & 0,0031 \\
\hline Perda de carga prevista FRD (m) & $\Delta \mathrm{H}_{\text {limite }} \mathrm{FRD}$ & 1,80 \\
\hline Perda de carga final no FRD $25^{\circ} \mathrm{C}(\mathrm{m})$ & $\Delta \mathrm{H}_{\text {final }} \mathrm{FRD}$ & 1,71 \\
\hline Taxa de lavagem do FRD $\left(\mathrm{m}^{3} / \mathrm{m}^{2} . \mathrm{d}\right)$ & $\mathrm{TL}_{\mathrm{FRD}}$ & 1152 \\
\hline Duração da lavagem FRD (min) & $\mathrm{DL}_{\mathrm{FRD}}$ & 10 \\
\hline Produção efetiva de água $\left(\mathrm{m}^{3} / \mathrm{m}^{2}\right)$ & $\mathrm{PE}$ & 477,9 \\
\hline Produção total de água $\left(\mathrm{m}^{3} / \mathrm{m}^{2}\right)$ & PT & 541,5 \\
\hline Consumo de água para lavagem do FAP $\left(\mathrm{m}^{3} / \mathrm{m}^{2}\right)$ & $\mathrm{L}_{\mathrm{FA}}$ & 37,0 \\
\hline Consumo de água na descarga de fundo final $\left(\mathrm{m}^{3} / \mathrm{m}^{2}\right)$ & DFF & 4,1 \\
\hline Consumo de água nas descargas de fundo intermediárias $\left(\mathrm{m}^{3} / \mathrm{m}^{2}\right)$ & DFI & 14,6 \\
\hline Consumo de água para lavagem do filtro descendente $\left(\mathrm{m}^{3} / \mathrm{m}^{2}\right)$ & $\mathrm{L}_{\mathrm{FRD}}$ & 7,8 \\
\hline Porcentagem de água perdida (\%) & $\mathrm{P}$ & 11,7 \\
\hline Eficiência na produção de água filtrada (\%) & E & 88,3 \\
\hline
\end{tabular}


Tabela D2.5 -Cálculo da produção efetiva de água no ensaio 14 de dupla filtração

Sistema 2 e Água Tipo II

\begin{tabular}{|c|c|c|}
\hline Ensaio 14 & \multicolumn{2}{|c|}{ Encerramento } \\
\hline \multirow{2}{*}{$\begin{array}{l}\text { Formação do manto de lodo no topo do FAP após } 8 \text { h de ensaio } \\
\text { Não foi calculada a produção efetiva }\end{array}$} & \multicolumn{2}{|c|}{ Transpasse no FRD } \\
\hline & Símbolo & Valor \\
\hline Duração do ensaio (h) & $\overline{\mathrm{DF}}$ & 19,5 \\
\hline Taxa de filtração FAP $\left(\mathrm{m}^{3} / \mathrm{m}^{2} . \mathrm{d}\right)$ & $\mathrm{TF}$ & 177,9 \\
\hline Área total FAP (m²) & $\mathrm{A}_{\mathrm{FA}}$ & 0,013 \\
\hline Perda de carga prevista FAP (m) & $\Delta \mathrm{H}_{\text {limite }} \mathrm{FA}$ & 0,80 \\
\hline Perda de carga final no FAP $25^{\circ} \mathrm{C}(\mathrm{m})$ & $\Delta \mathrm{H}_{\text {final }} \mathrm{FA}$ & 0,16 \\
\hline Taxa de lavagem do FAP - ar e água $\left(\mathrm{m}^{3} / \mathrm{m}^{2} . \mathrm{d}\right)$ & $\mathrm{TL}_{\mathrm{FA}}$ & 720 \\
\hline Duração da lavagem com ar e água (min) & $\mathrm{DL}_{\mathrm{FA}}$ & 3 \\
\hline Taxa de lavagem do FAP - água $\left(\mathrm{m}^{3} / \mathrm{m}^{2} . \mathrm{d}\right)$ & $\mathrm{TL}_{\mathrm{FA}}$ & 2160 \\
\hline Duração da lavagem somente com água (min) & $\mathrm{DL}_{\mathrm{FA}}$ & 5 \\
\hline Taxa de DFF $\left(\mathrm{m}^{3} / \mathrm{m}^{2} . \mathrm{d}\right)$ & $\mathrm{T}_{\mathrm{DFF}}$ & 960 \\
\hline Duração da DFF (min) & $\mathrm{D}_{\mathrm{DFF}}$ & 1,5 \\
\hline Taxa de DFI $\left(\mathrm{m}^{3} / \mathrm{m}^{2} . \mathrm{d}\right)$ & $\mathrm{T}_{\mathrm{DFI}}$ & 0 \\
\hline Duração da DFI (min) & $\mathrm{D}_{\mathrm{DFI}}$ & 0 \\
\hline Número de DFI em 72 h & $\mathrm{N}_{\mathrm{DFI}}$ & 0 \\
\hline Taxa de filtração FRD $\left(\mathrm{m}^{3} / \mathrm{m}^{2} . \mathrm{d}\right)$ & $\mathrm{TF}_{\mathrm{FRD}}$ & 184,8 \\
\hline Área total FRD $\left(\mathrm{m}^{2}\right)$ & $A_{F R D}$ & 0,0031 \\
\hline Perda de carga prevista FRD (m) & $\Delta \mathrm{H}_{\text {limite }} \mathrm{FRD}$ & 1,80 \\
\hline Perda de carga final no FRD $25^{\circ} \mathrm{C}(\mathrm{m})$ & $\Delta \mathrm{H}_{\text {final }} \mathrm{FRD}$ & 1,30 \\
\hline Taxa de lavagem do FRD $\left(\mathrm{m}^{3} / \mathrm{m}^{2} . \mathrm{d}\right)$ & TLFRD & 1152 \\
\hline Duração da lavagem FRD (min) & DLFRD & 10 \\
\hline Produção efetiva de água $\left(\mathrm{m}^{3} / \mathrm{m}^{2}\right)$ & $\mathrm{PE}$ & - \\
\hline Produção total de água $\left(\mathrm{m}^{3} / \mathrm{m}^{2}\right)$ & PT & - \\
\hline Consumo de água para lavagem do FAP $\left(\mathrm{m}^{3} / \mathrm{m}^{2}\right)$ & $\mathrm{L}_{\mathrm{FA}}$ & - \\
\hline Consumo de água na descarga de fundo final $\left(\mathrm{m}^{3} / \mathrm{m}^{2}\right)$ & DFF & - \\
\hline Consumo de água nas descargas de fundo intermediárias $\left(\mathrm{m}^{3} / \mathrm{m}^{2}\right)$ & DFI & - \\
\hline Consumo de água para lavagem do filtro descendente $\left(\mathrm{m}^{3} / \mathrm{m}^{2}\right)$ & $\mathrm{L}_{\mathrm{FRD}}$ & - \\
\hline Porcentagem de água perdida (\%) & $\mathrm{P}$ & - \\
\hline Eficiência na produção de água filtrada (\%) & E & - \\
\hline
\end{tabular}


Tabela D2.6 -Cálculo da produção efetiva de água no ensaio 15 de dupla filtração

Sistema 2 e Água Tipo II

\begin{tabular}{|c|c|c|}
\hline Ensaio 15 & \multicolumn{2}{|c|}{ Encerramento } \\
\hline \multirow[t]{2}{*}{ Produção efetiva de água calculada com base no item 4.9.4 c.2) } & \multicolumn{2}{|c|}{ Perda de carga limite no FRD } \\
\hline & Símbolo & Valor \\
\hline Duração do ensaio (h) & $\overline{\mathrm{DF}}$ & 31 \\
\hline Taxa de filtração FAP $\left(\mathrm{m}^{3} / \mathrm{m}^{2} . \mathrm{d}\right)$ & $\mathrm{TF}$ & 177,8 \\
\hline Área total FAP $\left(\mathrm{m}^{2}\right)$ & $\mathrm{A}_{\mathrm{FA}}$ & 0,013 \\
\hline Perda de carga prevista FAP (m) & $\Delta \mathrm{H}_{\text {limite }} \mathrm{FA}$ & 0,80 \\
\hline Perda de carga final no FAP $25^{\circ} \mathrm{C}(\mathrm{m})$ & $\Delta \mathrm{H}_{\text {final }} \mathrm{FA}$ & 0,08 \\
\hline Taxa de lavagem do FAP - ar e água $\left(\mathrm{m}^{3} / \mathrm{m}^{2} . \mathrm{d}\right)$ & $\mathrm{TL}_{\mathrm{FA}}$ & 720 \\
\hline Duração da lavagem com ar e água (min) & $\mathrm{DL}_{\mathrm{FA}}$ & 3 \\
\hline Taxa de lavagem do FAP - água $\left(\mathrm{m}^{3} / \mathrm{m}^{2} . \mathrm{d}\right)$ & $\mathrm{TL}_{\mathrm{FA}}$ & 2160 \\
\hline Duração da lavagem somente com água (min) & $\mathrm{DL}_{\mathrm{FA}}$ & 5 \\
\hline Taxa de DFF $\left(\mathrm{m}^{3} / \mathrm{m}^{2} . \mathrm{d}\right)$ & $\mathrm{T}_{\mathrm{DFF}}$ & 960 \\
\hline Duração da DFF (min) & $\mathrm{D}_{\mathrm{DFF}}$ & 1,5 \\
\hline Taxa de DFI $\left(\mathrm{m}^{3} / \mathrm{m}^{2} . \mathrm{d}\right)$ & $\mathrm{T}_{\mathrm{DFI}}$ & 700 \\
\hline Duração da DFI (min) & $\mathrm{D}_{\mathrm{DFI}}$ & 2 \\
\hline Número de DFI em 72 h & $\mathrm{N}_{\mathrm{DFI}}$ & 15 \\
\hline Taxa de filtração FRD $\left(\mathrm{m}^{3} / \mathrm{m}^{2} . \mathrm{d}\right)$ & $\mathrm{TF}_{\mathrm{FRD}}$ & 184,8 \\
\hline Área total FRD $\left(\mathrm{m}^{2}\right)$ & $\mathrm{A}_{\mathrm{FRD}}$ & 0,0031 \\
\hline Perda de carga prevista FRD (m) & $\Delta \mathrm{H}_{\text {limite }} \mathrm{FRD}$ & 1,80 \\
\hline Perda de carga final no FRD $25^{\circ} \mathrm{C}(\mathrm{m})$ & $\Delta \mathrm{H}_{\text {final }} \mathrm{FRD}$ & 1,73 \\
\hline Taxa de lavagem do FRD $\left(\mathrm{m}^{3} / \mathrm{m}^{2} . \mathrm{d}\right)$ & $\mathrm{TL}_{\mathrm{FRD}}$ & 1152 \\
\hline Duração da lavagem FRD (min) & $\mathrm{DL}_{\mathrm{FRD}}$ & 10 \\
\hline Produção efetiva de água $\left(\mathrm{m}^{3} / \mathrm{m}^{2}\right)$ & $\mathrm{PE}$ & 512,1 \\
\hline Produção total de água $\left(\mathrm{m}^{3} / \mathrm{m}^{2}\right)$ & PT & 533,4 \\
\hline Consumo de água para lavagem do FAP $\left(\mathrm{m}^{3} / \mathrm{m}^{2}\right)$ & $\mathrm{L}_{\mathrm{FA}}$ & 2,1 \\
\hline Consumo de água na descarga de fundo final $\left(\mathrm{m}^{3} / \mathrm{m}^{2}\right)$ & DFF & 0,2 \\
\hline Consumo de água nas descargas de fundo intermediárias $\left(\mathrm{m}^{3} / \mathrm{m}^{2}\right)$ & DFI & 14,6 \\
\hline Consumo de água para lavagem do filtro descendente $\left(\mathrm{m}^{3} / \mathrm{m}^{2}\right)$ & $\mathrm{L}_{\mathrm{FRD}}$ & 4,4 \\
\hline Porcentagem de água perdida (\%) & $\mathrm{P}$ & 4,0 \\
\hline Eficiência na produção de água filtrada (\%) & $\mathrm{E}$ & 96,0 \\
\hline
\end{tabular}




\section{REFERÊNCIAS BIBLIOGRÁFICAS}

AHSAN, T. (1995). Process Analysis and Optimization of Direct Horizontal-flow Roughing Filtration. The Netherlands. 193p. PhD Dissertation submitted to Delft University of Technology.

AHSAN, T.; ALAERTS, G. J.; BUITEMAN, J. P. (1996a). Direct Horizontal-flow Roughing Filtration. Part I: optimization of process parameters. J Water SRT - Aqua, v.45, n.5, p. $262-271$.

AHSAN, T.; ALAERTS, G. J.; BUITEMAN, J. P. (1996b). Direct Horizontal-flow Roughing Filtration. Part II: performance, and operational guideline. J Water SRT Аqua, v.45, n.6, p. $281-291$.

AMARAL, S. F. et al. (2001). Filtração ascendente em pedregulho seguida de filtração descendente em areia (dupla filtração) aplicada ao tratamento de águas com presença de algas. /Apresentado ao $21^{\circ}$. Congresso Brasileiro de Engenharia Sanitária e Ambiental, João Pessoa, 2001/

AMIRTHARAJAH, A. (1989). The mechanisms of coagulation. In: SEMINÁRIO NACIONAL SOBRE COAGULAÇÃO E FILTRAÇÃO DIRETA, 1989, São Carlos, Anais. São Carlos: EESC-USP, 1989, v.1, p.1-19.

AMIRTHARAJAH, A.; MILLS, K.M. (1982). Rapid - mix design for mechanisms of alum coagulation. Journal of the American Water Works Association, v. 76, n. 4, p.210-216, Apr.

AMERICAN WATER WORKS ASSOCIATION (1990). AWWA - Water Quality and Treatment - A handbook of Community Water Suplies, 4.ed., USA, Mcgraw-Hill Inc.

AZEVEDO NETTO, J. M. (1973). Filtros de fluxo ascendente. São Paulo, CETESB. vol. 2, Cap. 8, p. 903 - 912: Técnicas de Abastecimento e Tratamento de Água.

BENINI,B. D. S. (2003). Remoção de substâncias húmicas na dupla filtração com filtro ascendente de pedregulho. São Carlos, 2003. 147 p. Dissertação (Mestrado) - Escola de Engenharia de São Carlos, Universidade de São Paulo.

BRASIL. Leis, etc. (2004). Ministério da Saúde. Portaria nº 518 de abril de 2004. Controle e Vigilância da Qualidade da Água para Consumo Humano e seu Padrão de Potabilidade. 
BLACK, A .P.; WILLEMS, D.G. (1961). Eletrophoretic Studies of Coagulation for Removal Organic Color. JAWWA. v.53, n..5, p.589-604, May, USA.

BLACK, A .P; HANNAH, S.A. (1961). Eletrophoretic Studies of Turbity Removal by Coagulation with Aluminum Sulphate. JAWWA. v.53, n..4, p.439-451, Apr., USA.

BLACK, A .P.; CHRISTMAN, R.F. (1963). Characteristics of Colored Surfaces Waters. JAWWA. v.55, n.6, p.753-770, Jun., USA.

CASTILLA MIRANDA, S. J. (1997). Influência da mistura dos grãos de areia no desempenho da filtração direta ascendente. São Carlos. 154 p. Dissertação (Mestrado). Escola de Engenharia de São Carlos, Universidade de São Paulo.

CEZAR, M.C.M.; CARVALHO, R.P.M.; BRANDÃO, C.C.S. (2000). Efeito da coagulação química na (pré) filtração em pedregulho de águas com presença de algas, e seu potencial como pré-tratamento para a filtração rápida descendente. / Apresentado ao $21^{\circ}$.Congresso Interamericano de Engenharia Sanitária e Ambiental, Porto Alegre, 2000 /

CRUZ VELEZ, C. H. (1993). Filtração direta ascendente com alta taxa. São Carlos. 220 p. Dissertação (Mestrado) - Escola de Engenharia de São Carlos, Universidade de São Paulo.

CRUZ VELEZ, C.H; GALVIS, G; VISSCHER, J.T; DI BERNARDO, L; ALAERTS, G (1998). Optimización de sistemas de potabilización com filtración rápida: La filtración gruesa dinámica y la clarificación con filtración gruesa ascendente, una alternativa factible. / Presentado à Conferencia Internacional Agua Y Sostenibilidad, Cali, 1998 /

DE PAUlA (2003), D. Avaliação da Dupla Filtração para Tratamento de Água de Superficial utilizando Filtro Ascendente de Areia Grossa. São Carlos, 2003. 117 p. Dissertação (Mestrado) - Escola de Engenharia de São Carlos, Universidade de São Paulo.

DI BERNARDO, A. S. (2000). Influência das condições de aplicação de polímeros catiônicos na eficiência da floculação. São Carlos, 2000. 207 p. Dissertação (Mestrado). Escola de Engenharia de São Carlos, Universidade de São Paulo.

DI BERNARDO, A. S. (2001). Some Fundamental and Practical Aspects of Particle Removal in Upflow Filtration. Georgia Institute of Technology; Report.

DI BERNARDO, L.; MOURA, R.M.P.; RAZABONI, J.D.; REZENDE, R.J. (1982). Estudo das influências das características hidráulicas e da camada de areia na filtração ascendente. Revista DAE, v. 42, n.131, p.94-102, dez. 
DI BERNARDO, L. (1983). Tratamento de águas de abastecimento de cor elevada. Revista DAE, ano XLII, n. 133, p: 61 -65, Jun.;

DI BERNARDO, L.; RAZABONI, J. D. (1984). Influência da realização de descargas de fundo durante a carreira de filtração no comportamento se sistemas de filtração direta ascendente. Revista DAE, São Paulo, v.44, n.139, p.340-345, Dez.;

DI BERNARDO, L. (1985). Comparação entre a filtração realizada em papel de filtro e em instalação piloto de filtração direta ascendente. Revista DAE., São Paulo.v.45, n.142, p.298-301.

DI BERNARDO, L.; GUIMARÃES, A.F.; MENDES, C.G.N. (1987) Coagulação, Floculação de Água com Turbidez ou Cor Elevada. Revista DAE. São Paulo. v.47, n.150, p.227-239.

DI BERNARDO, L. (1993a). Métodos e técnicas de tratamento de água. Rio de Janeiro, ABES.vol. 1.

DI BERNARDO, L. (1993b). Métodos e técnicas de tratamento de água. Rio de Janeiro, ABES.vol. 2.

DI BERNARDO, L.; PÁDUA, V. L.; DI BERNARDO, A S. (2000). Desenvolvimento de instalação de laboratório para determinação da dosagem de coagulante na filtração direta. Apresentado no IX Simpósio Luso-Brasileiro de Engenharia Sanitária e Ambiental, Porto Seguro, 2000/

DI BERNARDO, L.; ISAAC R. L. (2001). Upflow Direct Filtration - A Review. In: INTERNATIONAL CONFERENCE ON ADVANCES IN RAPID GRANULAR FILTRATION IN WATER AND WASTEWATER TREATMENT. London, 2001. Anais. UK

DI BERNARDO, L. , KURODA, E. K., DE PAULA, D. (2002a). Uso de filtros de laboratório de areia para determinação das condições de coagulação na filtração direta ascendente. In: VI SIBESA - Simpósio Ítalo-Brasileiro de Engenharia Sanitária e Ambiental, Vitória, ES, set.

DI BERNARDO, L.; DI BERNARDO, A. S., CENTURIONE FILHO, P.L. (2002b) Ensaios de Tratabilidade de Água e dos Resíduos Gerados em Estações de Tratamento de Água. 1 ed. São Carlos, RiMa. 
DI BERNARDO, L. (2003). Filtração Direta Ascendente e Descendente. Material didático da disciplina Tecnologias apropriadas para Tratamento de Água de Abastecimento, Prof. Luiz Di Bernardo, mar. 2003.

DI BERNARDO, L. coord. et al. (2003). Tratamento de Água para Abastecimento por Filtração Direta. Projeto Prosab, Rio de Janeiro, ABES, Rima.

FERNANDES, L.C. (1987). Influência das características da camada suporte e dos métodos de descargas de fundo intermediárias no desempenho de sistemas de filtração direta ascendente. São Carlos. 297p. Dissertação (Mestrado) - Escola de Engenharia de São Carlos, Universidade de São Paulo.

FAIR, M. G., GEYER, J. C., OKUN, D. A. (1968). Water and Wastewater Engineering. John Wiley and Sons, Inc. v. 2, USA.

FAUST, S.D.; ALY, O.M. (1998). Chemistry of Water Treatment. $2^{\text {nd }}$ edition. Lewis Publishers.

GUSMÃO, P. T. R. (2001). Utilização de Filtração direta ascendente como pré-tratamento para tratamento de água de abastecimento. São Carlos. 335 p. Tese (Doutorado). Escola de Engenharia de São Carlos, Universidade de São Paulo.

GUSMÃO, P. T. R.; DI BERNARDO, L. (2001). Utilização de filtração direta ascendente em areia como pré-tratamento à filtração rápida descendente para tratamento de águas para abastecimento./ Apresentado ao $21^{\circ}$. Congresso Brasileiro de Engenharia Sanitária e Ambiental, João Pessoa, 2001 /

HACH, C. C.; VANOUS, R. D. \& HEER, J. M. (1989). Understanding turbidity measurement, Techinal Information Series, n. 11, 1 ed., 11 p., Hach Company.

ISAAC, R. L (1997). Influência da disposição inicial dos grãos de areia na eficiência da filtração direta ascendente. São Carlos. 74 p. Tese de Doutorado.Escola de Engenharia de São Carlos, Universidade de São Paulo.

KURODA, E. K. (2002). Avaliação da filtração direta ascendente em pedregulho como prétratamento em sistemas de dupla filtração. São Carlos, 2002. 238 p. Dissertação (Mestrado). Escola de Engenharia de São Carlos, Universidade de São Paulo.

LANG, S.J. et al. (1993). Investigating Filter Performance as a Function of the Ratio of Filter Size to Media Size. JAWWA. v.88, n.8 p.122-130, Aug., USA. 
LARA PINTO, D.M.C. (1994). Influência das descargas de fundo intermediárias na filtração direta ascendente de alta taxa. São Carlos. 194p. Dissertação (Mestrado). Escola de Engenharia de São Carlos, Universidade de São Paulo.

LYKEMA, J. (1978). Surface Chemistry of Colloids in Connection with Stability . In: IVES, S.K (1978). The Scientific Basis Of Flocculation. p.3-36. The Netherlands, SIJHOFF \& NOORDHOFF.

MARINELli, P. S. (1999). Aplicação de Amidos Catiônicos de Milho como Auxiliares de Floculação no Tratamento de Água. São Carlos, v.1. Dissertação (Mestrado). Área Interunidades em “Ciência e Engenharia de Materias”, Universidade de São Paulo.

MEGDA, C. R. (1999). Filtração direta ascendente em pedregulho como pré-tratamento à filtração rápida descendente. São Carlos. 167p. Dissertação (Mestrado). Escola de Engenharia de São Carlos, Universidade de São Paulo.

MENDES, C.G.N. (1985). Estudo das influências das dosagens de produtos químicos na filtração direta ascendente. São Carlos. 117p. Dissertação (Mestrado). Escola de Engenharia de São Carlos, Universidade de São Paulo.

MENDES, C.G.N. (1989). Estudo de Coagulação e Floculação de Águas Sintéticas e Naturais com Turbidez e Cor variáveis. São Carlos. Tese (Doutorado). Escola de Engenharia de São Carlos, Universidade de São Paulo.

OLPHEN, V. H. (1977). Clay Colloid Chemistry. $2^{\text {nd }}$ ed. USA, Wiley- Interscience Publishers John Wiley \& Sons.

O’MELIA, C.R. (1978). Coagulation in Water Treatment. In: IVES, S.K (1978). The Scientific Basis Of Flocculation. p.209-265. The Netherlands, SIJHOFF \& NOORDHOFF.

PATERNIANI, J.E.S. (1986). Estudo da influência de descarga de fundo na eficiência da remoção de microrganismos em sistemas de filtração direta ascendente. São Carlos.139p. Dissertação (Mestrado). Escola de Engenharia de São Carlos, Universidade de São Paulo.

PAVANELLI, G. (2001). Eficiência de Diferentes Tipos de Coagulantes na Coagulação, Floculação e Sedimentação de Água com Cor ou Turbidez Elevada. São Carlos. 205 p. Dissertação (Mestrado). Escola de Engenharia de São Carlos, Universidade de São Paulo. 
RUBIN, A .J. (1974). Chemistry of Water Supply - Treatment and Distribuition, USA, Ann Arbor Science Publishers Inc.

SALDANHA, J.R. (2002). Avaliação do desempenho de uma Estação de Tratamento de Água com Sistema de Dupla Filtração, em escala real. São Carlos, 2002. 214 p. Dissertação (Mestrado) - Escola de Engenharia de São Carlos, Universidade de São Paulo.

STUMM, W. \& O’MELIA, C.R. (1968). Stoichiometriy of Coagulation. JAWWA. v.60, n..5, p.514-539, May, USA.

TAMBO, N. \& WATANABE, Y. (1979a). Physical Characteristics of Flocs I: The Floc Density Function and Alum Floc. Water Research, v.13, p.409, England.

TAMBO, N. \& WATANABE, Y. (1979b). Physical Aspects of Flocculation Process I: Fundamental Treatise. Water Research, v.13, p.441, England.

TAMBO, N. \& WATANABE, Y. (1979c). Physical Aspects of Flocculation Process II: Contact Flocculation. Water Research, v.13, p.441, England.

TAMBO, N. \& HOZUMI, H. (1979). Physical Characteristics of Flocs II: Strength of Floc. Water Research, v.13, p.421, England.

TEIXEIRA, B.A.N. (1986). Influência das características da camada suporte e da areia na eficiência da filtração direta ascendente. São Carlos. 194p. Dissertação (Mestrado).Escola de Engenharia de São Carlos, Universidade de São Paulo.

TEIXEIRA, A. R.; COSTA, E. P.; PÁDUA, V. L.; HELLER, L.; DI BERNARDO, L.; LIBÂNIO, M. (2004). A confiabilidade analítica dos valores de turbidez da água filtrada e seu efeito no cumprimento do padrão de potabilidade. Revista Engenharia Sanitária e Ambiental, Rio de Janeiro, ABES, v.9, n.1, p.65-72.

WAGNER, E.G.; HUDSON, JR.H.E. (1982). Low dosage high- rate direct filtration. Journal of the American Water Works Association, v.76, n.5, p.256-261, May.

WEGELIN, M.; INGALLINELLA, A. M; STECCA, L. M. (1996). Filtración gruesa ascendente en manto de grava - Rehabilitación de la etapa previa a los filtros lentos de la planta potabilizadora de Tarata, Bolivia. / Presentado à Conferencia Internacional Sobre Mejoramiento De La Calidad del Agua, Cali, 1996 /.

WIECHETECK, G.; DI BERNARDO, L. (2002) Influência da pré-oxidação com ozônio e peróxido de hidrogênio de água colorida na eficiência da dupla filtração, Relatório Prosab 1, dez/2002. 
WILLIAMS, R. L. (1965). Microeletrophoretic studies of coagulation with aluminum sulfate. JAWWA. v. 57, n. 6, p: 801 - 810, June.

WILLIAMS, R.A. (1994). Characterization of process dispersons. In: Colloid and surface engineering: application in the process industries. $2^{\text {nd }}$ ed. Oxford, ButterworthHeinemann Ltd.

YOKOSAWA, M. M. (2001). Polieletrólitos Sintéticos e Derivados de Polímeros Naturais na Estabilização de Suspensões Aquosas de Alumina. São Carlos. Tese de Doutorado. Instituto de Química de São Carlos, Universidade de São Paulo. 